UNIVERSIDAD NACIONAL DE LA PLATA

FACULTAD DE CIENCIAS NATURALES Y MUSEO

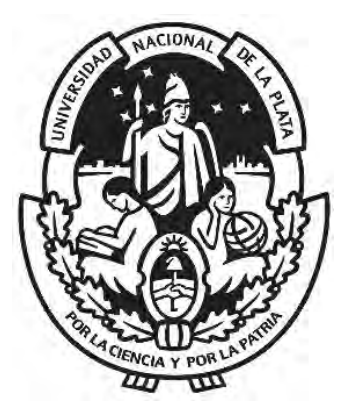

\title{
IDENTIFICACIÓN Y ESTUDIO DE LOS MINERALES CONTENIDOS EN LOS PLACERES MARINOS DE LA COSTA ATLÁNTICA DE TIERRA DEL FUEGO, ARGENTINA
}

\author{
Luis Santamaría Torres \\ Directores: \\ Dr. Raúl Ernesto de Barrio \\ Dr. Rogelio Daniel Acevedo
}

Tesis presentada para optar al título de Doctor en Ciencias Naturales, orientación Geología

2021

CONICET

C A D I C

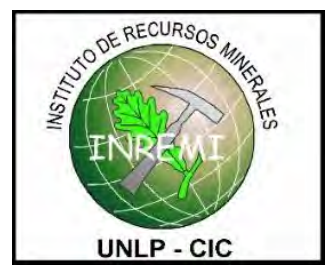


A mi familia y amigos 


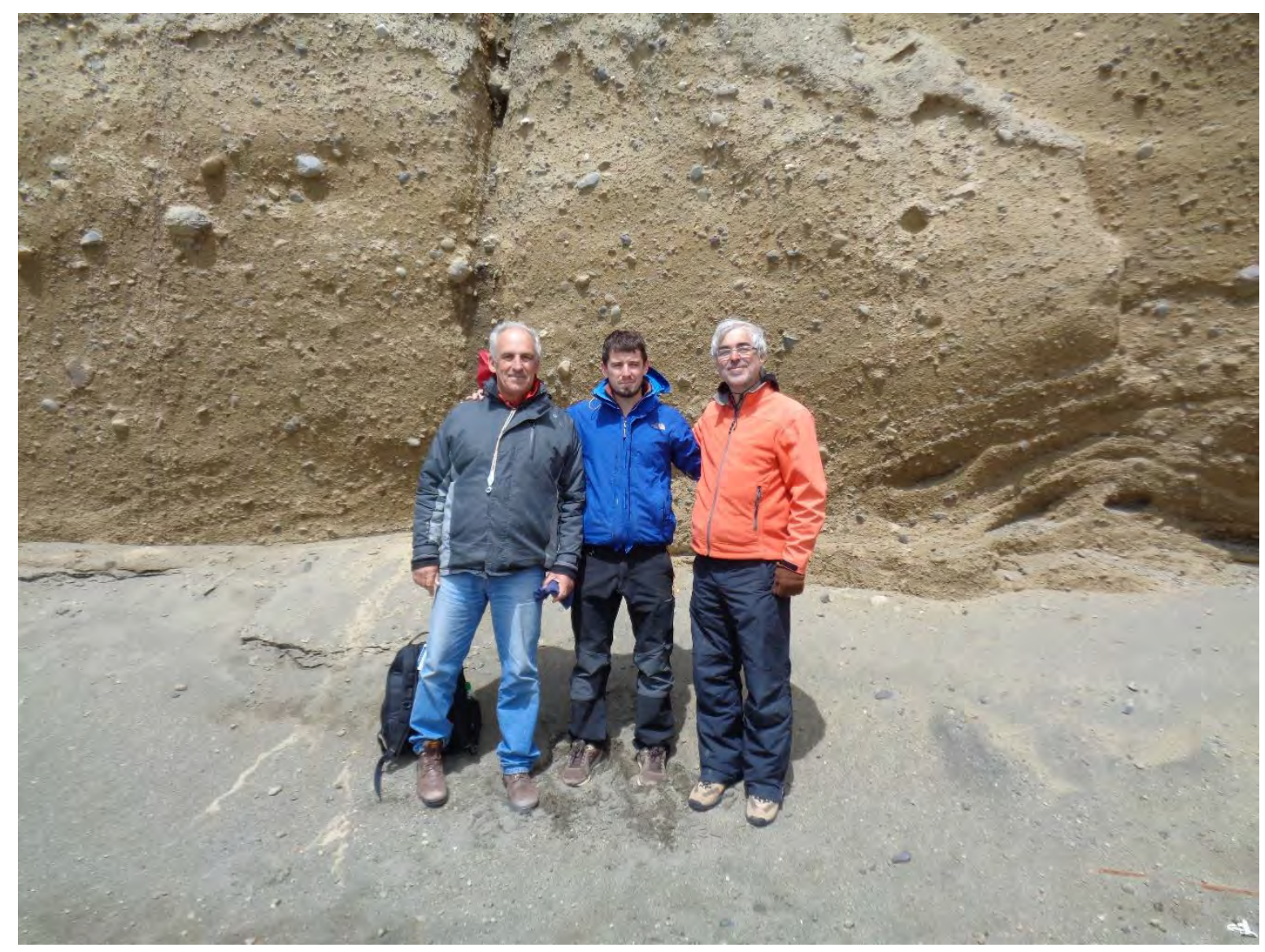




\section{ÍNDICE}

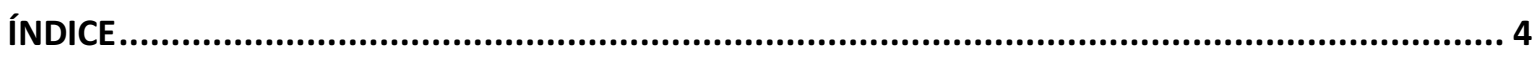

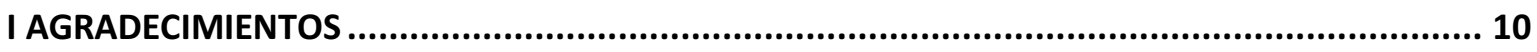

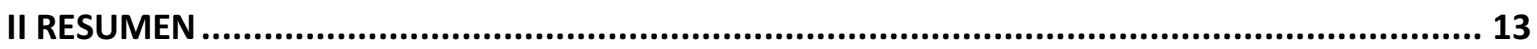

III ABSTRACT

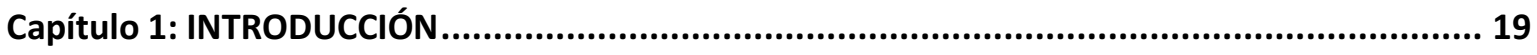

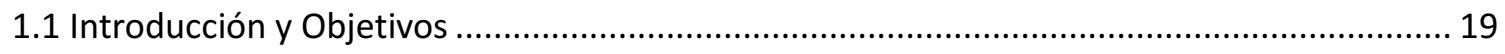

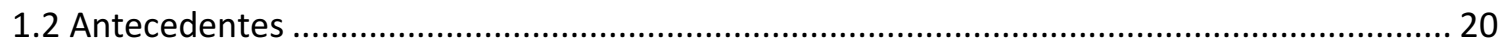

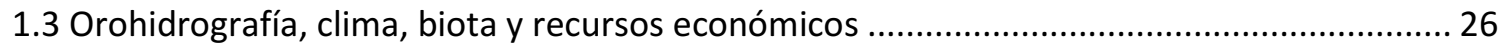

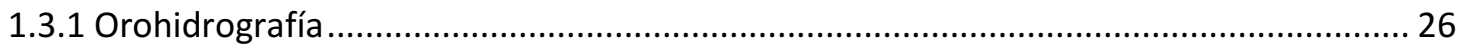

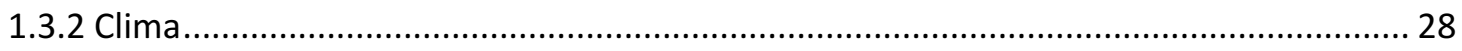

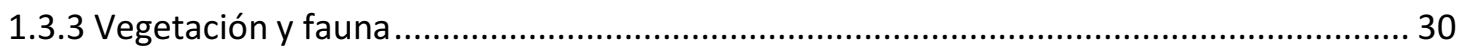

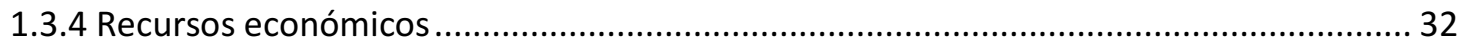

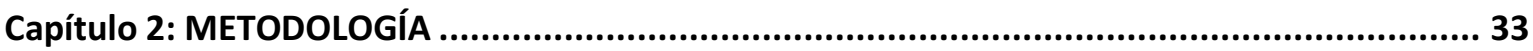

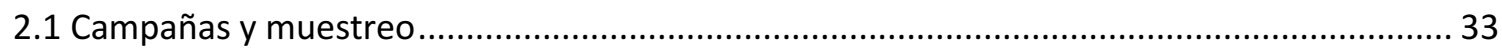

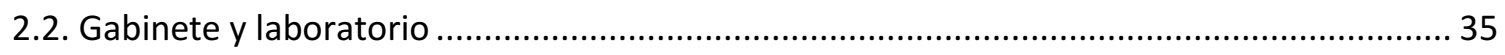

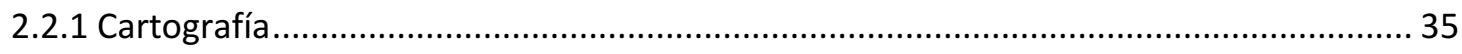

2.2.2 Estudios sedimentológicos. Análisis granulométricos .................................................... 35

2.2.3 Separación de minerales por métodos densimétricos.................................................. 37

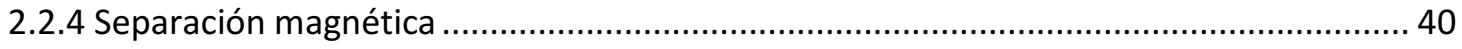

2.2.5 Lupa binocular, granulometría, microscopía de luz transmitida y reflejada.................... 41

2.2.6 Análisis por difracción de rayos X (DRX) ......................................................................... 42

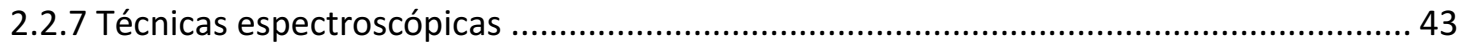

2.2.7.1. FE-SEM (Field Emision Scanning Electron Microscopy) con detector EDS (Energy

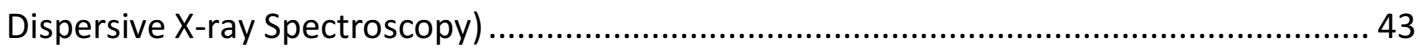

2.2.7.2. Microsonda Electrónica (EPMA, Electron Probe Micro Analyzer) ........................... 44

\section{Capítulo 3: GEOLOGÍA Y GEOMORFOLOGÍA DEL ÁREA DE ESTUDIO Y REGIONES ADYACENTES . 46}

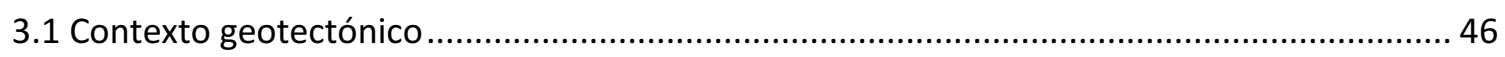

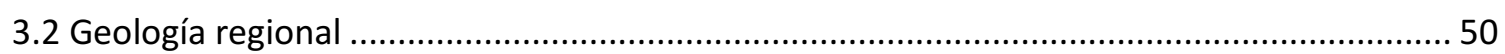


3.2.1 Estratigrafía del sector continental cordillerano 50

3.2.1.1 Rocas de basamento (Paleozoico superior-Jurásico medio) .................................... 51

3.2.1.2 Formación Tobífera o Lemaire (Jurásico superior). …………………………….... 52

3.2.1.3 Formación Hardy (Jurásico superior-Cretácico inferior)........................................ 53

3.2.1.4 Complejo Tortuga (Jurásico superior-Cretácico inferior)........................................ 53

3.2.1.5 Formación Yahgán (Jurásico superior-Cretácico inferior)....................................... 55

3.2.1.6 Formación Beauvoir (Cretácico inferior) .............................................................. 56

3.2.1.7 Batolito Patagónico e intrusiones satélites (Jurásico superior-Terciario)................. 57

3.2.1.7.1 Granitoides tipo S Cordillera Darwin (Jurásico superior).................................. 57

3.2.1.7.2 Plutones Calcoalcalinos de arco principal (Cretácico-Paleógeno). ..................... 58

3.2.1.7.3 Plutones Tierra del Fuego de trasarco (sector argentino). ................................ 59

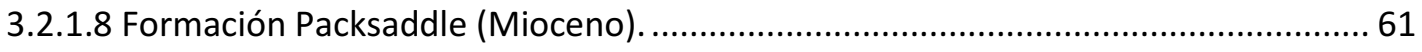

3.2.1.9 Campo Volcánico de Pali Aike (Plioceno-Cuaternario)............................................. 62

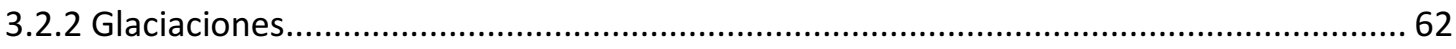

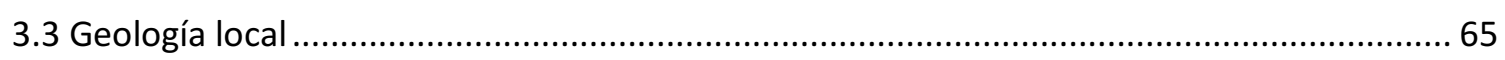

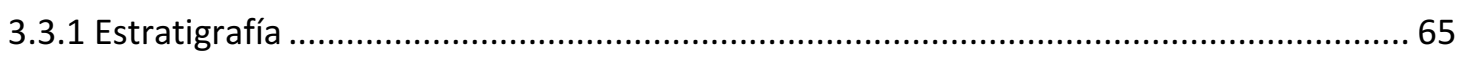

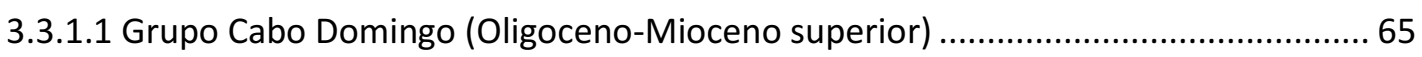

3.3.1.2 Fm. Punta Basílica (Mioceno superior-Plioceno inferior) ........................................ 67

3.3.1.3 Formación Cullen (Mioceno superior-Plioceno)...................................................... 69

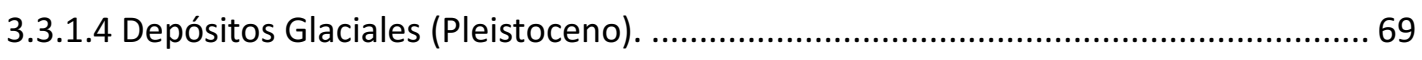

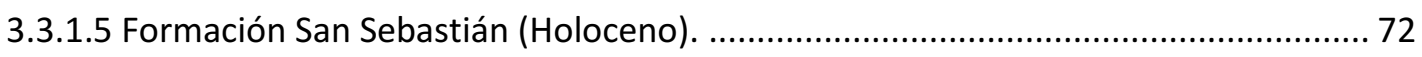

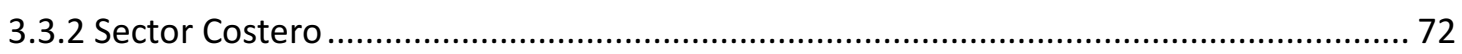

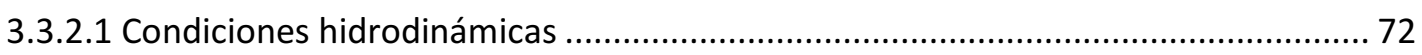

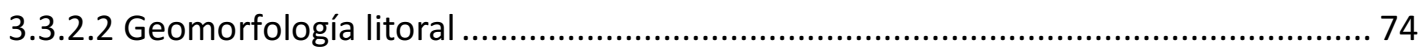

3.3.2.3 Estado morfodinámico de la playa actual............................................................ 77

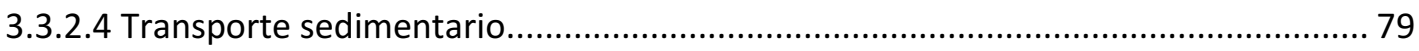

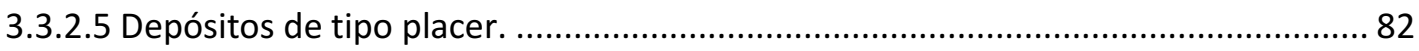

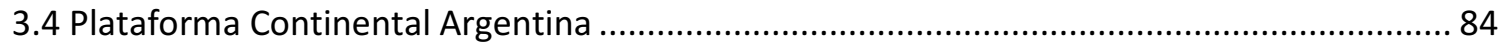

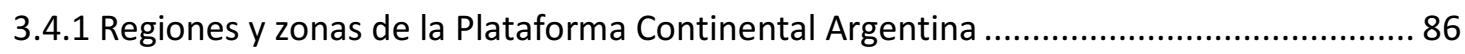

3.4.2 Plataforma Continental en el sector NE de Tierra del Fuego......................................... 88

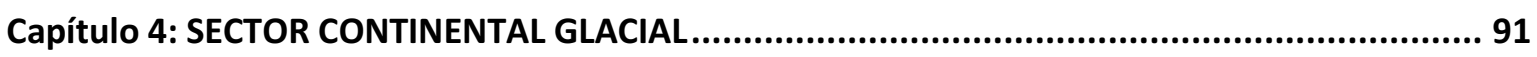

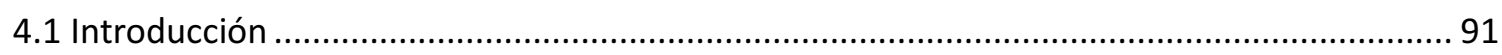




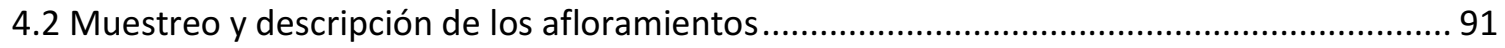

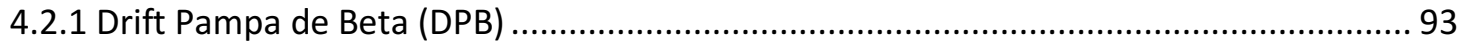

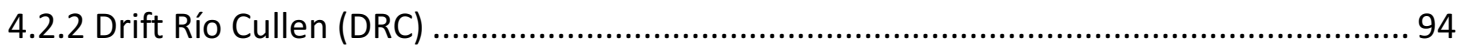

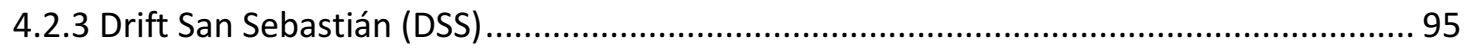

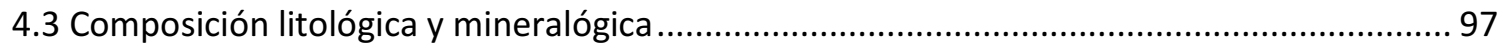

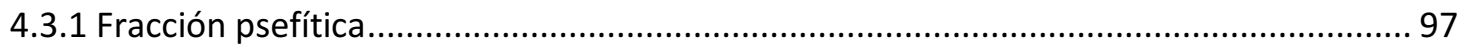

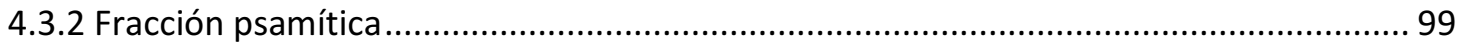

4.3.2.1 Descripción mineralógica de las arenas ............................................................... 102

4.3.2.1.1 Minerales y fragmentos líticos de la fracción pesada ...................................... 102

4.3.2.1.2 Minerales y fragmentos líticos de la fracción liviana ........................................ 105

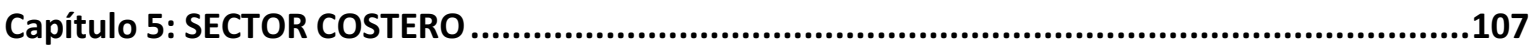

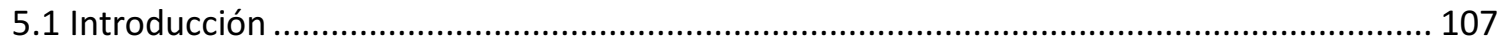

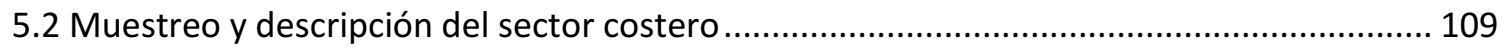

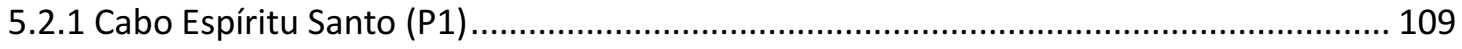

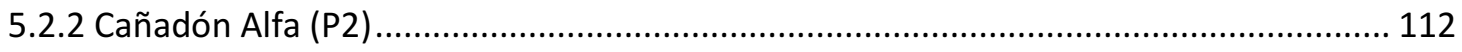

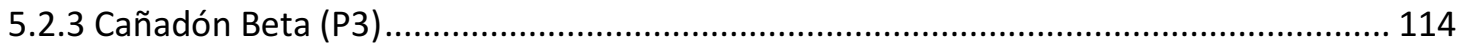

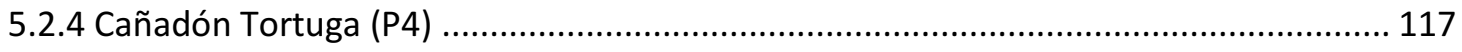

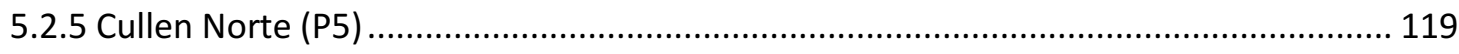

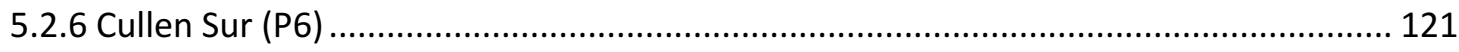

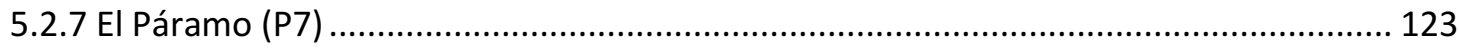

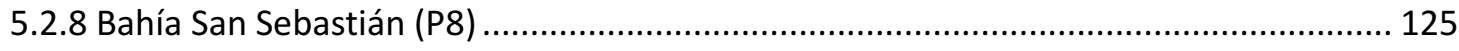

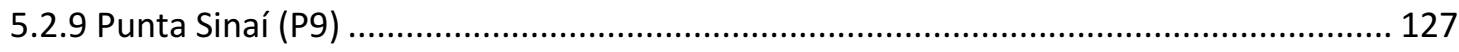

5.3 Morfología de las playas: Análisis granulométrico y perfiles ................................................. 129

5.4 Composición litológica y mineralógica de los depósitos detríticos de playa........................ 136

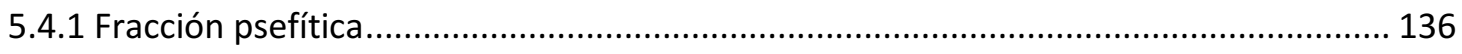

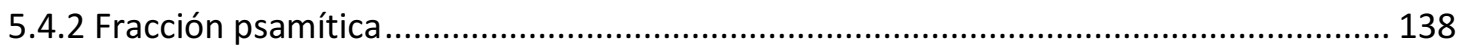

5.4.2.1 Descripción mineralógica de las arenas ............................................................. 141

5.4.2.1.1 Minerales y fragmentos líticos de la fracción pesada ..................................... 141

5.3.2.1.2 Minerales y fragmentos líticos de la fracción liviana ..................................... 146

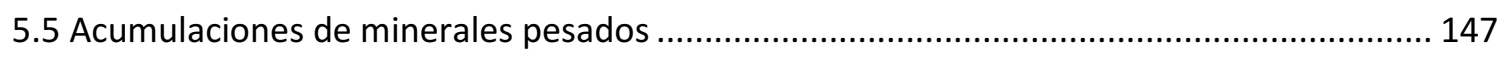

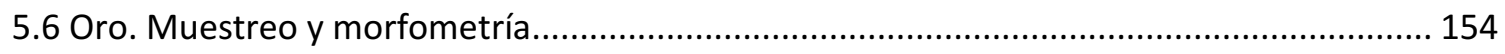

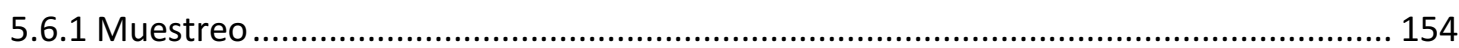


5.6.2 Estudio morfométrico 155

5.7 Sectores de punta Loyola, provincia de Santa Cruz y bahía Sloggett, sur de Tierra del Fuego

5.7.1 Minerales pesados en las playas del área de punta Loyola, Provincia de Santa Cruz .. 158

5.7.2 Minerales pesados en la playa de bahía Sloggett 160

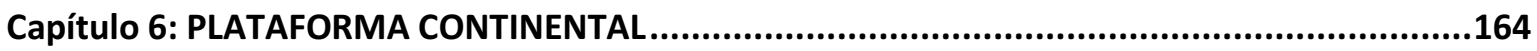

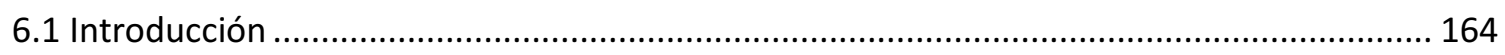

6.2 Muestreo y análisis granulométrico ................................................................... 164

6.3 Composición litológica y mineralógica de los depósitos detríticos .................................. 167

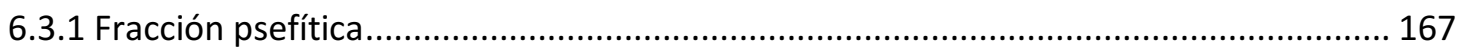

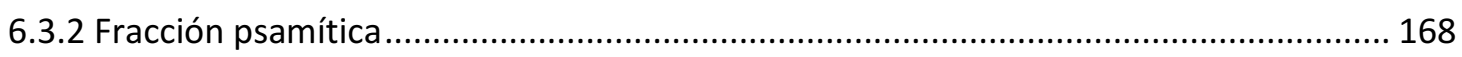

6.3.2.1 Descripción mineralógica de las arenas .................................................... 170

6.3.2.1.1 Minerales y fragmentos líticos de la fracción pesada ................................. 170

6.3.2.1.2 Minerales y fragmentos líticos de la fracción liviana ................................. 173

Capítulo 7: ANÁLISIS GEOQUíMICOS DE LOS MINERALES DE LOS DEPÓSITOS DETRÍTICOS........174

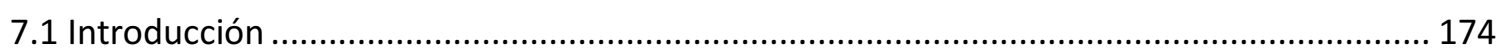

7.2 Composición química de las diferentes fases minerales................................................. 174

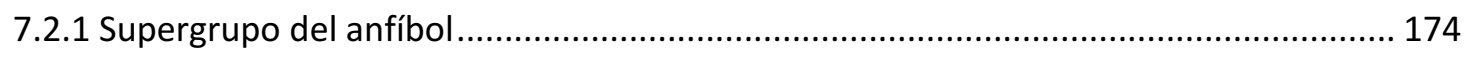

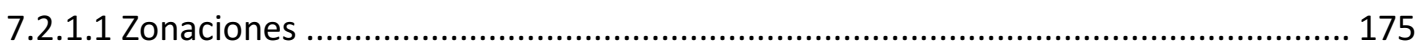

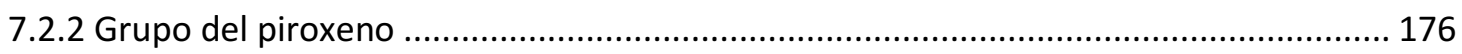

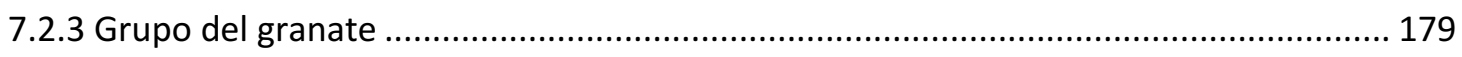

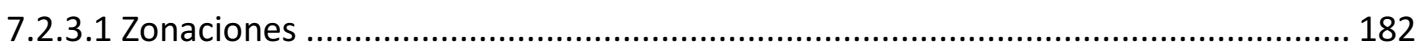

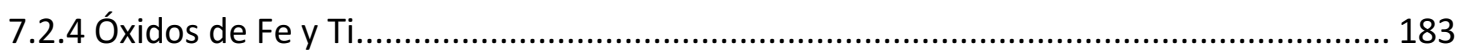

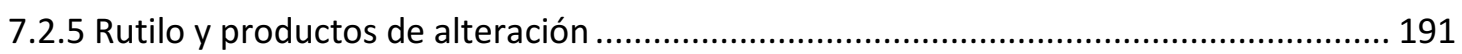

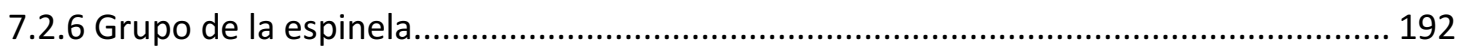

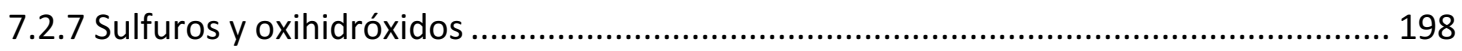

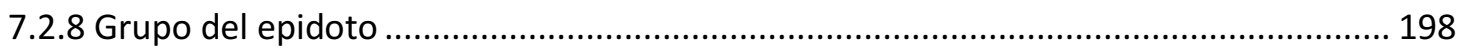

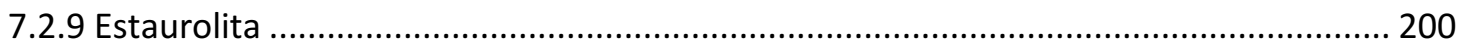

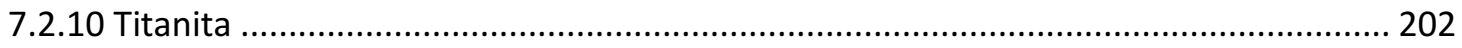

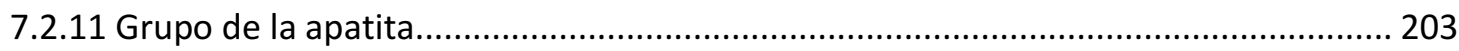

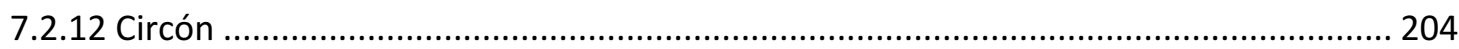




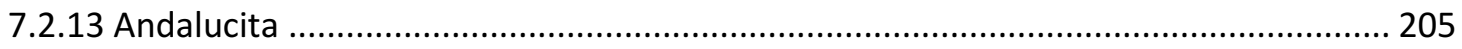

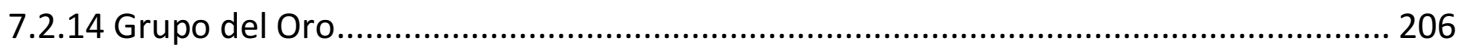

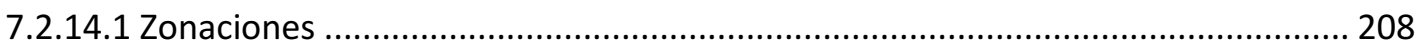

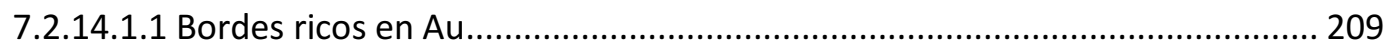

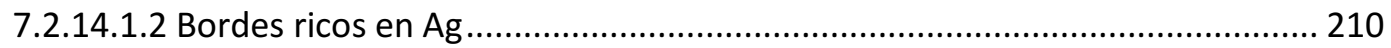

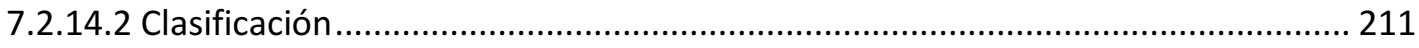

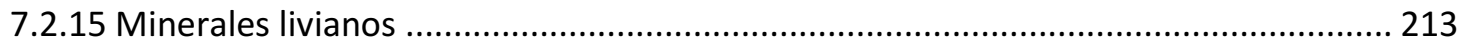

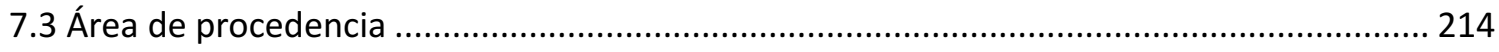

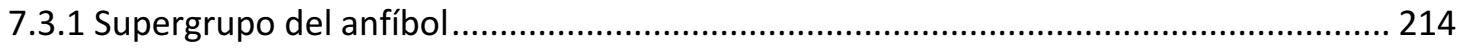

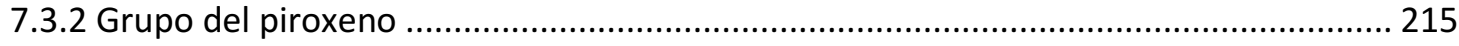

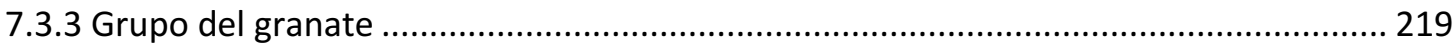

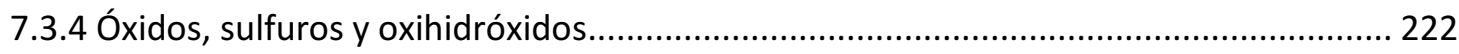

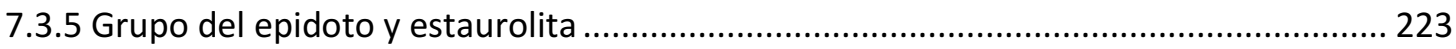

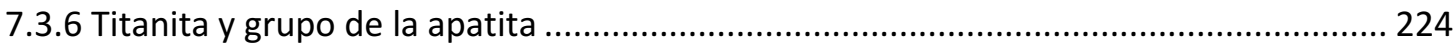

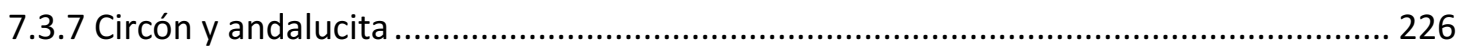

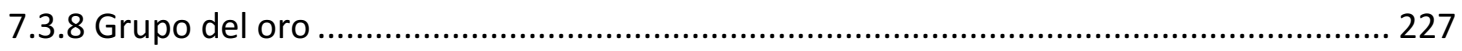

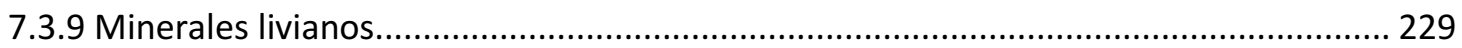

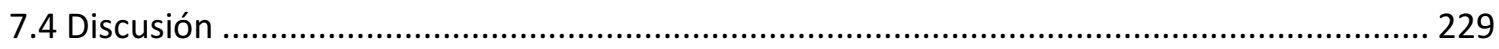

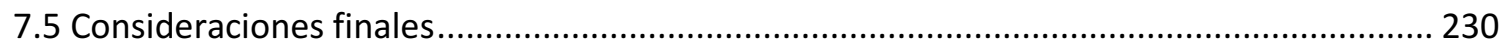

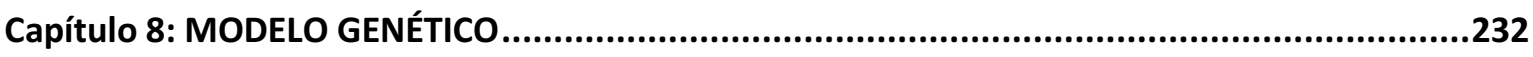

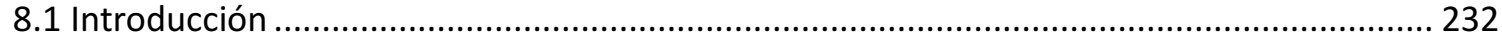

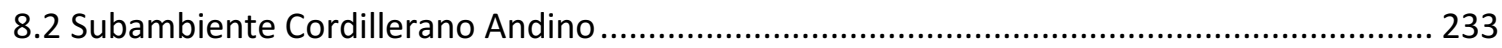

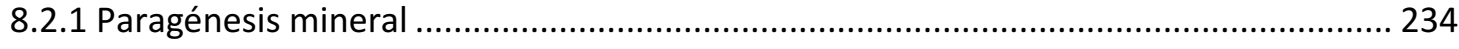

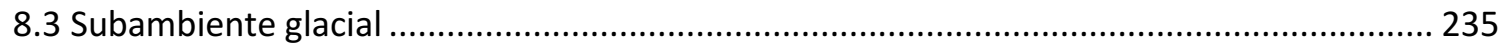

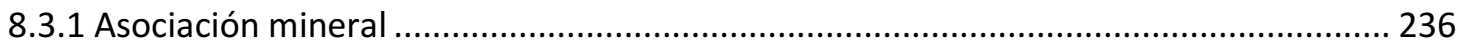

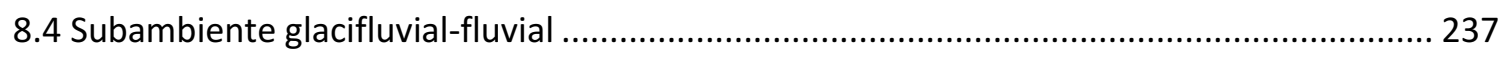

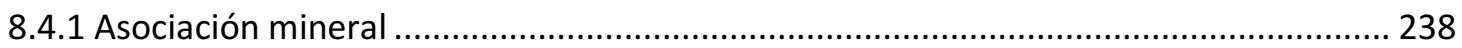

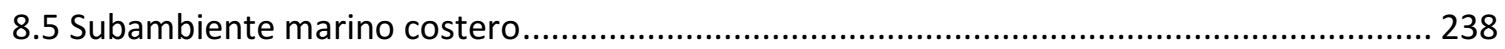

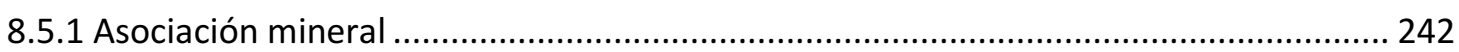

8.6 Subambiente marino de Plataforma Continental Argentina ........................................... 242

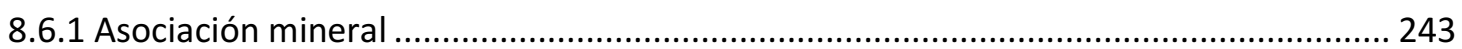

8.7 Concentración de minerales pesados según el subambiente de muestreo .......................... 245 
8.8 Discusión 246

8.8 Consideraciones finales.......

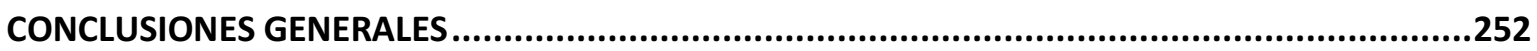

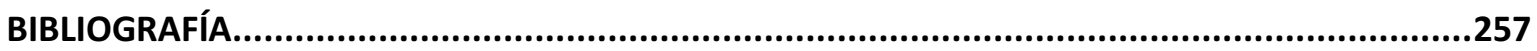

Anexo. TABLAS DE ANÁLISIS POR MICROSONDA ELECTRÓNICA............................................274

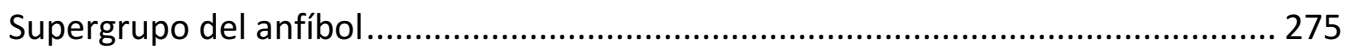

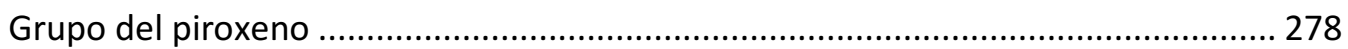

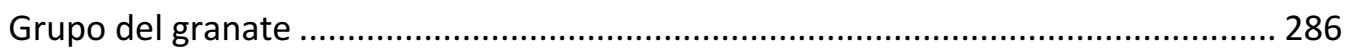

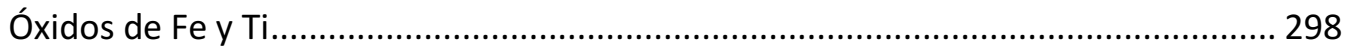

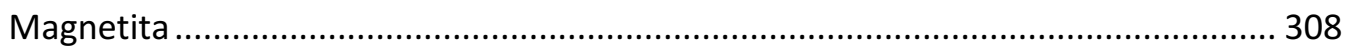

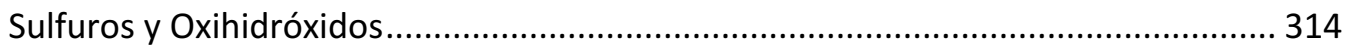

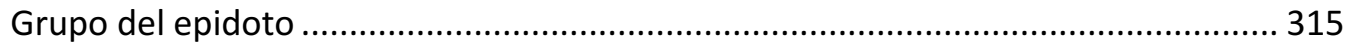

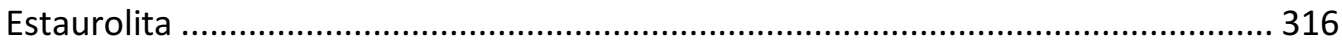

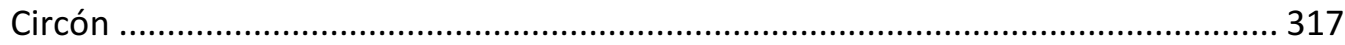

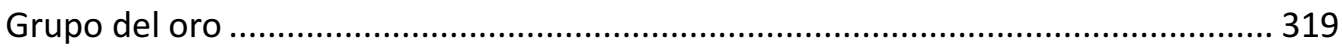




\section{AGRADECIMIENTOS}

En primer lugar, quiero agradecer a mis directores de tesis y de beca sin los cuales no se hubiera podido desarrollar esta investigación. A Rogelio Daniel Acevedo (CADICCONICET y UNTDF) le agradezco toda la confianza que depositó en mí desde el inicio hasta el final del proyecto, por haberme acompañado en cada una de las campañas y su apoyo moral y logístico durante ellas. También le agradezco su buena disposición a la hora de compartir sus conocimientos y experiencias, y apoyo económico para construir la canaleta para lavar oro. A Raúl Ernesto de Barrio (INREMI-FCNyM-UNLP) le agradezco su enorme apoyo y presencia en cada una de las diferentes fases de la investigación a pesar de la distancia, que no fue motivo para que decidiera incluso acompañarme en dos campañas. Le agradezco el haberme motivado a ampliar las áreas de muestreo enriqueciendo aún más la tesis, el apoyo económico para realizar láminas delgadas, probetas y análisis mediante microsonda electrónica, y el haberme animado en los momentos más críticos. A Isabel Fanlo (UNIZAR, España) le agradezco el haberme mostrado la posibilidad de realizar esta investigación, el apoyo económico que me brindó para hacer láminas delgadas y análisis mediante difracción de rayos $\mathrm{X}$, microscopio electrónico de barrido y microsonda electrónica, además de haberme abierto las puertas del laboratorio del Área de Cristalografía y Mineralogía de la Universidad de Zaragoza. En este párrafo también quiero incluir a Ignacio Subías (q.e.p.d.) quien me animó junto con Isabel a emprender la aventura de realizar una tesis en Tierra del Fuego.

Agradezco al Consejo Nacional de Investigaciones Científicas y Técnicas (CONICET) de la República Argentina por concederme la beca doctoral y al Centro Austral de Investigaciones Científicas (CADIC) por darme el lugar de trabajo durante el transcurso de la investigación. A la Facultad de Ciencias Naturales y Museo de la Universidad Nacional de la Plata (FCNyM-UNLP) por permitir la realización del Doctorado.

Del personal del CADIC quiero agradecer a Ignacio Magneres por acompañarme en todas las campañas siempre con buen ánimo y su gran ayuda en los trabajos de laboratorio. A Ramiro López y Alejandro Montes por instruirme en el manejo del GPS Diferencial y procesamiento de los datos. A Miguel Barbagallo por la elaboración de las láminas delgadas y a Rubén Rosales por la construcción de la canaleta para concentrar oro. A Mauricio González-Guillot, Andrea Coronato, Federico Ponce y Martín M. Vázquez por facilitarme bibliografía. También quiero agradecer a otros compañeros y 
amigos que me ayudaron en la ejecución de la tesis como Luis Díaz Balocchi, Sebastián Cao y Pau Montero.

También deseo agradecer a los pasantes que me ayudaron en las diferentes tareas de laboratorio y campo: Iñaki Gómez, Luis Ignacio Jara, Constanza Lobo y Lara Besada. A Iñaki le tengo que agradecer adicionalmente la proporción de la muestra de oro de bahía Sloggett.

Al Instituto de Recursos Minerales (INREMI-FCNyM-UNLP) por facilitar sus instalaciones y equipamientos. De esta institución quiero agradecer a José Luis Molina por la confección de láminas delgadas y secciones pulidas y a Carlos Ballivián por su apoyo en la realización de separación de minerales pesados mediante campos magnéticos y por instruirme en el uso de software gráfico geológico.

Del Centro de Investigaciones Geológicas (CIG-FCNyM-UNLP) agradezco a Ana María Sato por la supervisión en los trabajos de concentración de minerales pesados y a Eugenio Aragón por la dirección y supervisión de una pasantía.

A la empresa LCV S.R.L. por la realización de láminas delgadas y análisis difractométricos con rayos $X$.

Agradezco a José Luis Cavallotto y Roberto Violante del Servicio de Hidrografía Naval de la República Argentina por facilitar las muestras provenientes de la Plataforma Continental Argentina.

Por otra parte, quiero agradecer a los operadores de la microsonda electrónica, a Miguel Ángel Fernández en la Universidad de Oviedo (España) y a Manuel Demartis en la Universidad Nacional de Córdoba (UNC, Argentina) por la ayuda recibida en la realización de análisis mineraloquímicos. A Joaquín A. Proenza de la Universidad de Barcelona (España) y Agustín Martín-Izard de la Universidad de Oviedo (España) por facilitar la realización de análisis con microsonda electrónica.

De la Universidad de Oviedo también quiero agradecer a Germán Flor por su gran ayuda en temas de geología litoral, además de sus buenos consejos y apoyo moral.

Quiero añadir en el agradecimiento a Daniel Poiré (CIG-FCNyM-UNLP), Susana Conconi (UNLP-CETMIC-CIC) y Alberto Riveros (UNC, Argentina) por seleccionarme para realizar sus respectivos cursos de posgrado relacionados con la temática de la tesis y al MinCyT (Argentina) por la ayuda económica proporcionada.

Quiero agradecer a los jurados de la tesis Raúl Fernández, Raúl Lira y Jorge Coniglio por las observaciones y correcciones indicadas las cuales contribuyeron a la mejoría de la presente investigación. 
Agradezco a la empresa TOTAL AUSTRAL por facilitar las instalaciones de los campamentos Cañadón Alfa y Río Cullen y la retroexcavadora para la realización de los pozos y calicatas exploratorias y a la señora Ana Berbel, de esta empresa, por su amabilidad y su gestión para todos los trámites correspondientes a la logística de campo. Agradezco a la Armada Argentina por darnos alojamiento en el Puesto Hito 1 de cabo Espíritu Santo.

Finalmente, quiero agradecer muchísimo a mi pareja, Milena y a nuestros gatos, cuyo apoyo, paciencia infinita y amor fue fundamental durante toda la tesis. A Martín Castro y María Bagur por su amistad y el haberme acompañado en una de las campañas. También a mis padres Javier y Sara por su gran apoyo. 


\section{RESUMEN}

En las playas de la costa atlántica nororiental de la Isla Grande de Tierra del Fuego se encuentran acumulaciones de minerales pesados que constituyen yacimientos de tipo "placer" explotados principalmente entre finales del siglo XIX y principios del siglo XX para la extracción de oro. En la presente investigación se estudió la composición, procedencia y génesis de estos yacimientos, para lo cual se llevó a cabo un muestreo sistemático realizado tanto en las playas como en los depósitos glacigénicos continentales y sedimentos de la Plataforma Continental adyacente. En las playas se realizó el muestreo desde el cabo Espíritu Santo hasta punta Sinaí. En el sector continental se tomaron muestras de los diferentes depósitos de till y glacifluviales agrupados en los Drifts Pampa de Beta, Río Cullen y San Sebastián. Finalmente, en la Plataforma Continental se obtuvieron muestras de la cubierta superficial de la zona interna, media y externa. Adicionalmente, se dispusieron muestras de las playas al sur de Río Gallegos (Provincia de Santa Cruz) y de la bahía Sloggett (sureste de la Isla Grande de Tierra del Fuego), sectores donde se generan yacimientos de tipo placer de oro análogos a los presentes en la zona de trabajo.

El estudio geomorfológico y geológico del área de trabajo se realizó mediante imágenes satelitales y observaciones en campo. Los perfiles levantados en las playas se realizaron con GPS diferencial. Para la concentración de las diferentes fases de minerales pesados se aplicaron diversas técnicas granulométricas, densimétricas y magnéticas. El estudio de la naturaleza de los minerales se realizó con lupa binocular, microscopio petrocalcográfico, difractómetro de rayos $\mathrm{X}$, microscopio electrónico de barrido $\mathrm{y}$ microsonda electrónica.

Los resultados obtenidos permitieron corroborar la similitud petrológica y mineralógica de los depósitos detríticos presentes en los tres subambientes, reflejando por lo tanto una misma región de procedencia. Los sedimentos de las playas y la cubierta superficial de la Plataforma Continental derivan del retrabajo por la acción marina de los diferentes materiales glacigénicos presentes tanto en los acantilados activos como sumergidos en la Plataforma Continental.

En los tres subambientes se pudieron reconocer fragmentos detríticos de rocas volcánicas como riolitas, andesitas y basaltos; rocas plutónicas como dioritas, granodioritas 
y gabros, además de tonalitas y rocas ultramáficas en los depósitos glacigénicos y de playa; una amplia variedad de rocas metamórficas de grado bajo a medio y finalmente de algunas rocas sedimentarias y cuarzo de veta.

Dentro de la fracción pesada de las arenas de los diferentes subambientes muestreados se identificaron clinopiroxenos (augita y diópsido), ortopiroxenos (enstatita rica en Fe), clinoanfíboles, minerales del grupo del epidoto (epidoto s.s. y clinozoisita), óxidos de Fe y Ti (ilmenita, óxidos intermedios de Fe-Ti y hematita titanífera), magnetitas y minerales del grupo del granate (almandino y en los sedimentos de las playas también espessartina). Como minerales accesorios se identificaron circón y andalucita. En la fracción arenosa de los depósitos glacigénicos y en los sedimentos de las playas se reconocieron también estaurolita, minerales del grupo de la apatita, sulfuros (pirita y calcopirita), oxihidróxidos y titanita. En los niveles enriquecidos en minerales pesados de las playas, se identificaron, además rutilo, espinela s.s. y oro. La fracción liviana, dominante en todas las muestras salvo las derivadas de los niveles enriquecidos de las playas, está compuesta por cuarzo, plagioclasa y feldespato potásico, además de carbonato procedente de fragmentos de conchillas.

Las acumulaciones de minerales pesados están principalmente asociadas a eventos de oleaje de tormenta, siendo por lo tanto la zona supramareal y de batida del oleaje los lugares del perfil de la playa donde se producen las mayores acumulaciones.

Los depósitos glacifluviales, al haber sufrido procesos de selección y concentración de minerales pesados mayores que los de los depósitos de till, aportan la mayor cantidad de material a los niveles enriquecidos de las playas. A lo largo del litoral costero, los volúmenes más importantes en minerales pesados se dan en las playas al norte del río Cullen. En este sector se localiza el Drift Pampa de Beta, caracterizado por presentar grandes espesores de material glacifluvial. Como consecuencia de la fuerte deriva litoral hacia el sur, el material detrítico es distribuido por toda la costa, generando acumulaciones de minerales pesados más importantes en algunos sectores geodinámicamente propicios.

Los niveles enriquecidos de las playas pueden alcanzar hasta los $7 \mathrm{~cm}$ de espesor y una extensión lateral discontinua de hasta $3 \mathrm{~m}$. La composición mineral está dominada por minerales del grupo del granate (principalmente almandino) y minerales opacos (óxidos de Fe y Ti y magnetita), aumentando considerablemente el contenido de oro. Los granos de este mineral precioso se caracterizan por tener un tamaño promedio pequeño $(<1 \mathrm{~mm})$, clasificándose como chispas $\mathrm{y}$, en menor medida, polvo de oro. Presentan hábitos planares, tanto discoidales como alargados, en individuos principalmente subredondeados a redondeados, con marcas de martilleo en su superficie y bordes regulares pulidos con 
frecuencia plegados. Normalmente no presentan inclusiones y exhiben una coloración desde amarillo oscuro hasta amarillo claro, producto de la alta variación composicional que presentan respecto al contenido en $\mathrm{Ag}$. Las características morfológicas de los granos de oro, al igual que la presencia de granos con bordes enriquecidos en $\mathrm{Au}$, reflejan un intenso transporte, siendo esta última característica más notoria en las chispas tomadas en el sector más meridional.

A partir de los diagramas de discriminación tectónica y similitud composicional, se pudieron diferenciar minerales pesados procedentes de las rocas del Complejo Ofiolítico Tortuga, del Complejo Metamórfico Cordillera Darwin, asociados al Batolito Fueguino y también posiblemente a la Formación Lemaire. Todas estas unidades se encuentran en la Cordillera Darwin, lugar desde donde partieron los diferentes glaciares que afectaron a la isla.

El megamodelo genético de formación del yacimiento de tipo placer involucra una serie de eventos que se han ido sucediendo desde el Mesozoico hasta la actualidad: actividad ígnea y metamórfica en un ambiente de arco magmático que permitió la conformación de la Cordillera Darwin, erosión y transporte glacial de enormes cantidades de material desde la cordillera y finalmente retrabajo de estos materiales por la acción marina. Si bien la riqueza aurífera de estos depósitos es baja, ya que el oro está solamente concentrado en los niveles enriquecidos de la playa, su extensión es enorme, puesto que abarca como mínimo desde el sector costero austral de la provincia de Santa Cruz hasta el sur de Punta Sinaí, incluyendo el sector oriental del Canal Beagle. A esta colosal distribución hay que agregarle los depósitos detríticos del lecho de la Plataforma Continental los cuales permanecen aún inexplorados. 


\section{ABSTRACT}

On the beaches of the northeastern Atlantic coast of the Isla Grande of Tierra del Fuego there are accumulations of heavy minerals that constitute deposits of the "placer" type mainly exploited between the late 19th and early 20th centuries for the extraction of gold. In the present investigation, the composition, origin and genesis of these deposits was studied, for which a systematic sampling was carried out both on the beaches and in the continental glacigenic deposits and the adjacent Continental Shelf sediments. In the continental sector, samples were taken from the different till and glacifluvial deposits grouped in the Drifts Pampa de Beta (DPB), Río Cullen (DRC) and San Sebastián (DSS). Finally, in the Continental Shelf, samples of the surface cover of the inner, middle and outer zone were obtained. Additionally, samples were taken from the beaches south of Río Gallegos (Santa Cruz Province) and Sloggett Bay (southeast of the Isla Grande of Tierra del Fuego), sectors where deposits of the placer type of gold similar to those present in the work area.

The geomorphological and geological study of the work area was carried out through satellite images and field observations. The profiles made on the beaches were made with differential GPS. For the concentration of the different phases of heavy minerals, granulometric, densimetric and magnetic techniques were applied. The study of the composition of the minerals was carried out with a binocular magnifying glass, petrocalcographic microscope, X-ray diffractometer, scanning electron microscope and electron microprobe.

The results obtained allowed to corroborate the petrological and mineralogical similarity of the detrital deposits present in the three sub environments, this reflecting the same region of origin.

In the three subenvironments it was possible to recognize detrital fragments of volcanic rocks such as rhyolites, andesites and basalts; plutonic rocks such as diorites, granodiorites, and gabbros, as well as tonalites and ultramafic rocks in glacigenic and beach deposits; a wide variety of low to medium grade metamorphic rocks and finally some sedimentary rocks and vein quartz.

Clinopyroxenes (augite and diopside), orthopyroxenes (hypersthene), clinoamphiboles, epidote group minerals (epidote s.s. and clinozoisite), oxides of $\mathrm{Fe}$ and $\mathrm{Ti}$ (ilmenite, intermediate oxides of $\mathrm{Fe}-\mathrm{Ti}$ and $\mathrm{Ti}$-hematite), magnetite and garnet group minerals (almandine and in the sediments of the beaches also spessartine) were identified in the heavy fraction of the sands of the different sampled subenvironments. Zircon and 
andalusite were identified as accessory minerals. Staurolite, apatite group, sulfides (pyrite and chalcopyrite), oxyhydroxides and titanite were also recognized in the sand fraction of the glacigenic deposits and in the beach sediments. In the enriched beds of heavy minerals on the beaches, rutile, spinel s.s. and gold were also identified. The light fraction, dominant in all samples except those derived from the enriched beds of the beaches, is composed of quartz, plagioclase and potassium feldspar, in addition to carbonate from shell fragments.

The accumulations of heavy minerals are mainly associated with storm wave, therefore the supratidal and swash zones are the places on the beach profile where the greatest accumulations occur.

The glacifluvial deposits have been subjected to processes of selection and concentration of heavy minerals, greater than the deposits of till, therefore they contribute the greatest amount of material to the enriched beds of the beaches. Along the coastline, the largest volumes of heavy minerals occur on the beaches north of the Cullen River. The Drift Pampa de Beta is located in this sector, characterized by presenting large thicknesses of glacifluvial material. As a consequence of the strong coastal drift towards the south, the detrital material is distributed along the coast, generating accumulations of more important heavy minerals in some geodynamically favorable sectors.

The enriched beds of the beaches can reach up to $7 \mathrm{~cm}$ thick and a discontinuous lateral extension of up to $3 \mathrm{~m}$. The mineral composition is dominated by garnet group minerals (almandine) and opaque minerals (Fe and Ti oxides and magnetites), considerably increasing the gold content. The grains of this precious mineral are characterized by having a small average size $(<1 \mathrm{~mm})$, classified as moderately fine gold. They present planar habits, both discoidal and elongated, in individuals mainly sub-rounded to rounded, with hammer marks on their surface and regular polished edges that are frequently folded. Normally they do not present inclusions and exhibit a coloration from dark yellow to light yellow, a product of the high compositional variability that they present with respect to Ag content.

The morphological characteristics of the gold grains, as well as the presence of grains with Au-rich rims on gold grains, reflect an intense transport. This last characteristic is more notorious in the grains extracted from the southernmost sector. From the tectonic discrimination and compositional similarity diagrams, it was possible to differentiate heavy minerals from the rocks of the Tortuga Ophiolitic Complex, the Cordillera Darwin Metamorphic Complex, associated with the Fueguino batholith and possibly also with the Lemaire Formation. All these units are located in the Cordillera Darwin, the place from where departed the different glaciers that affected the island. 
The genetic megamodel of formation of the placer deposit involves a series of events that have occurred from the Mesozoic to the present: igneous and metamorphic activity in a magmatic arc environment that allowed the formation of the Cordillera Darwin, erosion and glacial transport of huge amounts of material from the range and finally reworking of these materials by marine action. Although the gold richness of the deposit is low, since the gold is only concentrated in the enriched beds of the beach, its extension is enormous, from the southern coastal sector of the province of Santa Cruz to the south of Punta Sinaí, including the eastern sector of the Beagle Channel. To this colossal distribution must be added the detrital deposits of the bed of the Continental Shelf which remain unexplored. 


\section{Capítulo 1: INTRODUCCIÓN}

\subsection{Introducción y Objetivos}

En el norte de la Isla Grande de Tierra del Fuego se localizan, en el sector costero de las playas atlánticas, acumulaciones de minerales pesados que constituyen yacimientos de tipo "placer" de playa, explotados intermitentemente desde fines del siglo XIX para la obtención de oro. Acompañando al metal precioso se identifica un conjunto de minerales pesados entre los que se destacan óxidos de Fe y Ti (ilmenita, óxidos intermedios de Fe y Ti y hematita titanífera), magnetitas (magnetita s.s. y magnetita titanífera) y especies del grupo del granate (almandino y en menor medida espessartina). Estas acumulaciones se originaron en las playas y actualmente continúan formándose debido a los efectos del oleaje y corrientes marinas que concentran y acumulan los minerales pesados en sectores morfodinámicamente propicios. Las mareas y los fuertes vientos pueden acentuar en algunos sitios el proceso de concentración de los minerales pesados, generando horizontes de mayor riqueza.

El objetivo principal de la presente investigación fue profundizar el conocimiento de la asociación mineral de los depósitos detríticos con especial énfasis en los minerales pesados distribuidos por la costa atlántica del noreste de la isla Grande de Tierra del Fuego, aplicando diversas y modernas técnicas, que pudieron aportar nueva información en este campo.

El trabajo de investigación se basó en dos hipótesis de partida:

I) Los minerales pesados provienen de la erosión de depósitos glacigénicos localizados en el sector continental y en la Plataforma Continental.

II) El área fuente primigenia de estos minerales se ubica en los materiales de las montañas de la Cordillera Darwin (Chile) situadas al oeste a más de $200 \mathrm{~km}$ de distancia.

Si la primera hipótesis era verdadera, entonces es de esperar que la acción marina esté retrabajando los depósitos glacigénicos y concentrando los minerales pesados en ciertos sectores de las playas. Los glaciares discurrieron desde Cordillera Darwin (Chile) por lo tanto el área fuente de estos minerales se correspondería con las rocas localizadas en dichas montañas, confirmando la segunda hipótesis. 


\subsection{Antecedentes}

Los primeros antecedentes sobre la existencia de minerales pesados se remontan al siglo XIX con el descubrimiento de oro en los depósitos detríticos fluviales del sector chileno de Tierra del Fuego. Las primeras explotaciones comenzaron en los ríos Santa María, Oro y Rosario, cercanos a la ciudad de Porvenir, en la porción noroccidental de la isla, a principios de 1881 (Vairo y Gatti 2000). Estos ríos fluyen por los Altos del Boquerón y el cordón Baquedano (Fig. 1.4). Para 1885, se calcula que el oro exportado fue de 209 $\mathrm{kg}$, aunque se cree que se pudo haber duplicado esa cantidad (Vairo y Gatti 2000). En 1907 existía más de una decena de dragas trabajando en la zona. Paralelamente a esta explotación, comenzó la explotación del oro tipo placer en la zona costera de Santa Cruz, Argentina, desde cabo Vírgenes hasta Río Gallegos. En esos sectores en cada explotación se llegó a obtener un beneficio de 160 gramos de oro por día (Vairo y Gatti 2000). Por otra parte, en el sur de Tierra del Fuego se descubrió oro en las playas de bahía Sloggett, extremo oriental del Canal Beagle, donde se instaló una gran draga perteneciente a la compañía The Argentina Tierra del Fuego Exploration Co. Ltd, cuyos restos oxidados se conservan actualmente. En esta zona el oro se localiza a una profundidad de 0,3 a 6 metros, en contacto con el "bed rock", donde se concentra junto con magnetita. En las islas ubicadas al sur del Canal Beagle, Picton, Lennox y Nueva también se encontró oro y se explotó, principalmente en las dos primeras (Vairo y Gatti 2000). En la costa atlántica de Tierra del Fuego, el interés por el oro se remonta a 1886, año en que el ingeniero de minas rumano Julius Popper comenzó a explotar placeres marinos mediante grandes aparatos con placas y rifles para la amalgamación que posteriormente fueron sustituidos por las denominadas "cosechadoras de oro" de su invención (Fig.1.1), lo que simplificó el proceso al permitir la recuperación del oro de forma directa sobre los lugares enriquecidos de la playa (Guevara 2004). Durante el periodo de 1887 a 1893, llegó a obtener un beneficio de $265 \mathrm{~kg}$ de oro en El Páramo (Fig.1.2) (Guevara 2016). A mediados del siglo XX, la fiebre del oro en la región decayó, quedando pequeños lavaderos artesanales. Actualmente el oro sigue siendo explotado en el cordón Baquedano (Chile) y de manera más discontinua en el arroyo Beta (costa atlántica del Tierra del Fuego) y bahía Sloggett (Fig.1.4). 


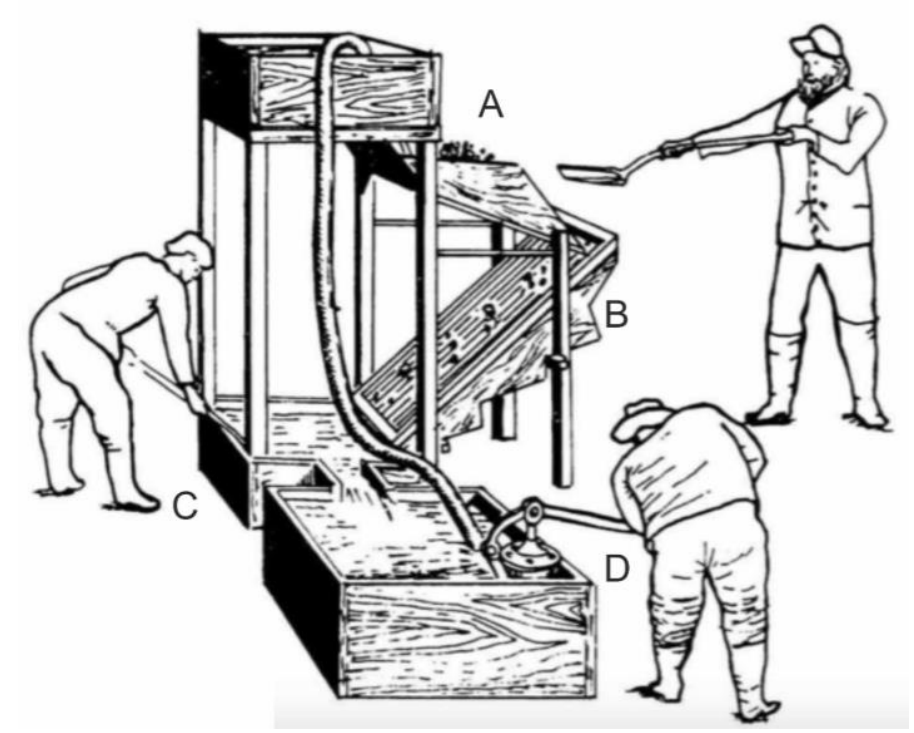

Fig.1.1. Cosechadora de oro de Popper. Las arenas auriferas eran arrastradas por una corriente de agua del cajón (A) hacia la canaleta (B) donde material más grueso era separado mediante una rejilla y el resto pasaba por unas placas corrugadas de cobre y mercurio. Finalmente, la arena lavada y el agua se depositaba en los cajones al pie de la cosechadora (C), donde el agua era de nuevo bombeada para repetir el proceso (D). Dibujo tomado de Vairo y Gatti (2000).

A
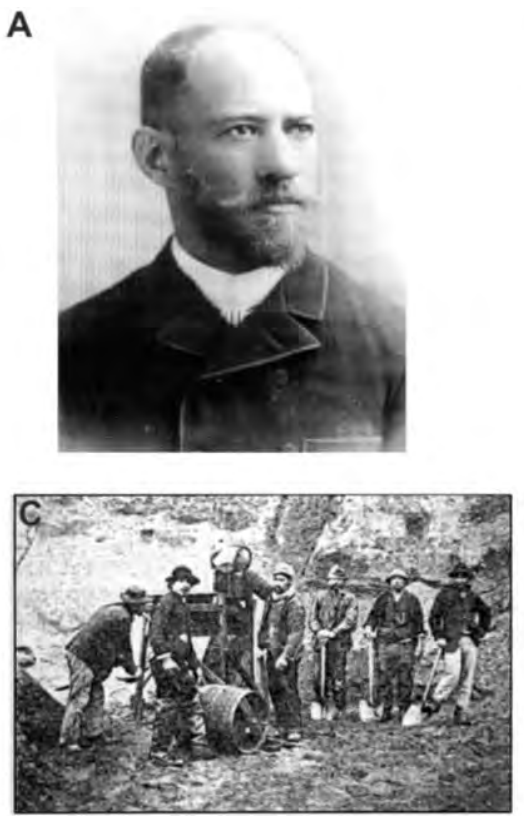

B
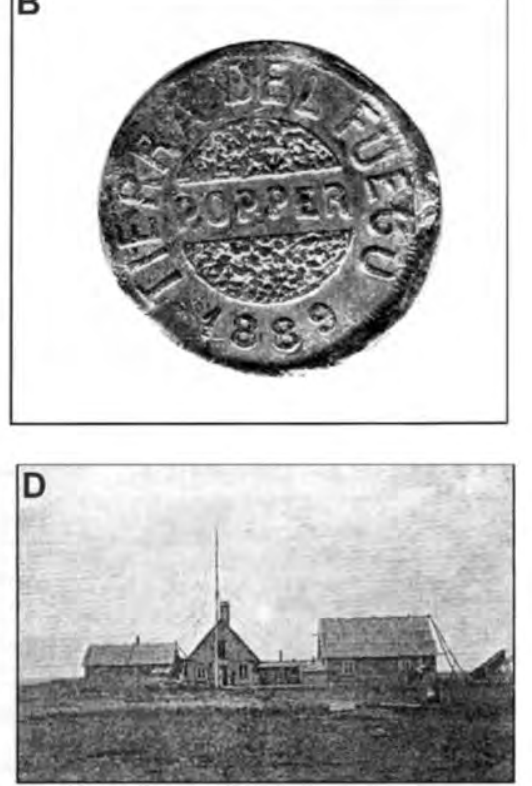

Fig.1.2. A) Julius Popper, B) moneda de un gramo de oro acuñada por Popper en 1889, C) mineros lavando oro, D) Establecimiento minero El Páramo. Imágenes tomadas de Guevara (2004).

Kyle (1890) analizó una muestra procedente de El Páramo, obsequiada por Popper, la cual arrojó, sorprendentemente, el siguiente resultado: 70,15\% de platino, 3\% de iridio, $1,75 \%$ de osmio-iridio, $0,8 \%$ de paladio, $0,4 \%$ de rodio, $0,2 \%$ de oro, $6,965 \%$ de hierro, $1,676 \%$ de cobre y $0,984 \%$ de osmio y pérdida por calcinación. Señoret (1893), desde su cargo de gobernador de Magallanes, publicó la información disponible sobre la búsqueda, 
descubrimiento y explotación de oro en algunos sitios de Tierra del Fuego entre 1886 y 1892.

Penrose (1908) fue uno de los primeros investigadores que estudió los placeres auríferos. Diferenció dos ambientes: el lecho de los arroyos o laderas y los sectores marinos. En estos últimos consideró que el oro se concentraba junto con magnetita y granate. Indicó que el oro era el resultado de la denudación de rocas auríferas y que, al hundirse el continente, éstas quedaron en parte bajo el mar. Una porción del oro de las playas provendría de la erosión de las partículas presentes en el lecho de los arroyos y laderas y otra transportada por el mar a partir de los depósitos sumergidos. Además, indicó que el oro se presenta normalmente como finas partículas con cobre y plata. Stappenbeck (1918) consideró que el oro fueguino es producto de la "lixiviación" marina sobre los sedimentos glaciales.

Sister (1948) en su tesis doctoral estudió los aluviones auríferos de Tierra del Fuego diferenciando depósitos morénicos (till), fluvioglaciales y costaneros o de playa. Realizó trabajos de prospección en el arroyo Beta y en las playas de Tortuga, en el sur del río Cullen y en El Páramo. Al sur de la bahía de San Sebastián trabajó en el sedimento morénico-glacifluvial que recorre el chorrillo del Oro y en las playas entre punta Carmen Silva y cabo San Sebastián (Fig. 1.4), donde se ubica el chorrillo Mercurio, el cual también muestreó. La concentración de oro alcanzó los valores más ricos en los depósitos de playa, donde la ley ronda $1 \mathrm{~g} / \mathrm{m}^{3}$ en los niveles ricos en magnetita, siendo un poco menor en las playas del sur de la bahía San Sebastián. En los depósitos de till la concentración de oro fue muy baja, aumentando un poco en los depósitos fluvioglaciales, con una ley de 0,052 $\mathrm{g} / \mathrm{m}^{3}$. Indica que el oro provendría de la cordillera, transportado por los hielos en la última glaciación y que posteriormente el mar erosionó los depósitos glacigénicos distribuyéndolos por la costa.

Petersen y Methol (1948) también señalaron que los depósitos marinos o de playa de la parte norte de Tierra del Fuego se originaron a partir de las acumulaciones glacifluviales y de till donde el oro se hallaba diseminado. A partir de la acción del mar, mediante un lavado y trabajo selectivo, se formaron zonas de concentración que se ponen de manifiesto en la superficie de las playas por la presencia de manchas de color azul acero debido al elevado tenor de magnetita. Señalaron que el oro se encuentra principalmente como fino polvo, hojuelas y pajuelas muchas veces imperceptibles a simple vista. Suele estar asociado a pirita y con frecuencia recubierto por una fina película de óxido de hierro. Con respecto al carácter mineralógico de estos depósitos, el mismo no sufre grandes variaciones, cualquiera sea la región donde se los examina. Se trata de típicas 
arenas negras (black sands) compuestas por magnetita, hematita, ilmenita, hornblenda (anfíbol cálcico), minerales del supergrupo de la turmalina, olivina, granate, cuarzo rosado, circón y pirita.

En un informe sobre los aluviones auríferos presentes entre el río Gamma y cabo Espíritu Santo (Methol y Sister 1949) se infiere, por lo visto en Isla Lennox, que el oro provendría de "pegmatitas auríferas" derivadas de granodioritas pertenecientes al Batolito Andino. Concluyen que los depósitos morénicos fueron retrabajados por el mar, "lixiviados" y concentrados sus minerales pesados, entre los que se encuentra el oro. El análisis de una pepita, beneficiada en la zona de cañadón Tortuga, reveló un contenido de $87,5 \%$ de $\mathrm{Au}, 11,28 \%$ de $\mathrm{Ag}$, vestigios de $\mathrm{Cu}$ y ausencia de platino. Respecto de la presencia de platino, en la desembocadura del arroyo Alfa y al sur de cañadón Tortuga, se menciona en el informe el hallazgo de partículas finísimas de color gris blanquecino, que se supone son de ese metal.

Etchichury y Tófalo (1981) publicaron un estudio sedimentológico y mineralógico entre cabo Espíritu Santo y Mina María, donde se menciona la presencia de oro. Otros minerales reconocidos entre los sedimentos costeros fueron augita, hipersteno (enstatita rica en $\mathrm{Fe}$ ), hornblenda, carbonatos, minerales del grupo del granate, circón, minerales del grupo de la turmalina, andalucita, rutilo, hematita, ilmenita, leucoxeno, biotita, minerales del grupo de la apatita, moscovita, minerales del grupo del epidoto (epidoto-zoisita) y estaurolita. Respecto a los minerales livianos aparecen litoclastos, plagioclasas y cuarzo principalmente, seguidos por feldespato potásico, vidrio volcánico, carbonatos y fosfatos como minerales accesorios. Concluyeron que las distintas especies integrantes derivan principalmente de la destrucción de rocas volcánicas, piroclásticas, metamórficas y sedimentarias silíceas, con un aporte más limitado de rocas ígneas plutónicas y componentes biogénicos, todas ellas provenientes de la Formación Cullen y Drift Tapera Sur. En el perfil de la playa, el nivel A (zona supramareal) constituye la capa más rica en minerales pesados, seguida en orden decreciente por el nivel B (intermareal alta) y C (intermareal baja).

Por su parte, Codignotto y Malumián (1981) analizaron la composición mineral del sedimento glacigénico identificando como minerales principales cuarzo, vidrio volcánico, hornblenda verde, plagioclasa, minerales opacos, piroxenos (augita e hipersteno) y restos de rocas volcánicas. Como minerales minoritarios aparecen circón y minerales del supergrupo de la turmalina.

Unos años después, Carrillo et al. (1989) realizaron un estudio sobre los depósitos aluvionales del río López y bahía Sloggett, en el extremo oriental de la Isla de Tierra del 
Fuego, confirmando la presencia de oro junto con otros minerales pesados como hornblenda, biotita, moscovita, epidoto, hipersteno, titanita, ilmenita y magnetita, aumentando la concentración de minerales pesados en la bahía. Concluyen que esta mayor concentración de pesados no está vinculada con la acción de los ríos sino a la dinámica marina local.

Greiner (1991), trabajando en los placeres detríticos del lado chileno, clasifica los depósitos glacigénicos auríferos del cordón Baquedano en cuatro grupos: a) oro asociado a morenas de fondo relacionadas con la primera glaciación, localizado en las mesetas remanentes en el cordón Baquedano, b) oro retrabajado y depositado durante la segunda glaciación ubicado en las suaves pendientes de los ríos, c) oro retrabajado por la actividad fluvial durante y posterior al retiro de la segunda glaciación y d) oro retrabajado durante la actividad interglacial cuyos depósitos no fueron cubiertos por la segunda glaciación. En cuanto a la potencialidad económica, localiza en estos dos últimos grupos los depósitos de mejor potencial en cuanto a volúmenes grandes y alta ley, y los localizados en las laderas de los ríos como depósitos pequeños e individualizados de alta ley. Con la exploración del $25 \%$ de territorio en ese momento, los recursos globales obtenidos fueron: como mineral de explotación en seco en $12.000 .000 \mathrm{~m}^{3}$ con alrededor de $700 \mathrm{mg} / \mathrm{m}^{3}$ de Au y como mineral dragable en $90.000 .000 \mathrm{~m}^{3}$ entre 200 y $300 \mathrm{mg} / \mathrm{m}^{3}$ de Au. Actualmente se sigue lavando oro en pequeñas explotaciones de manea artesanal (Fig.1.3).

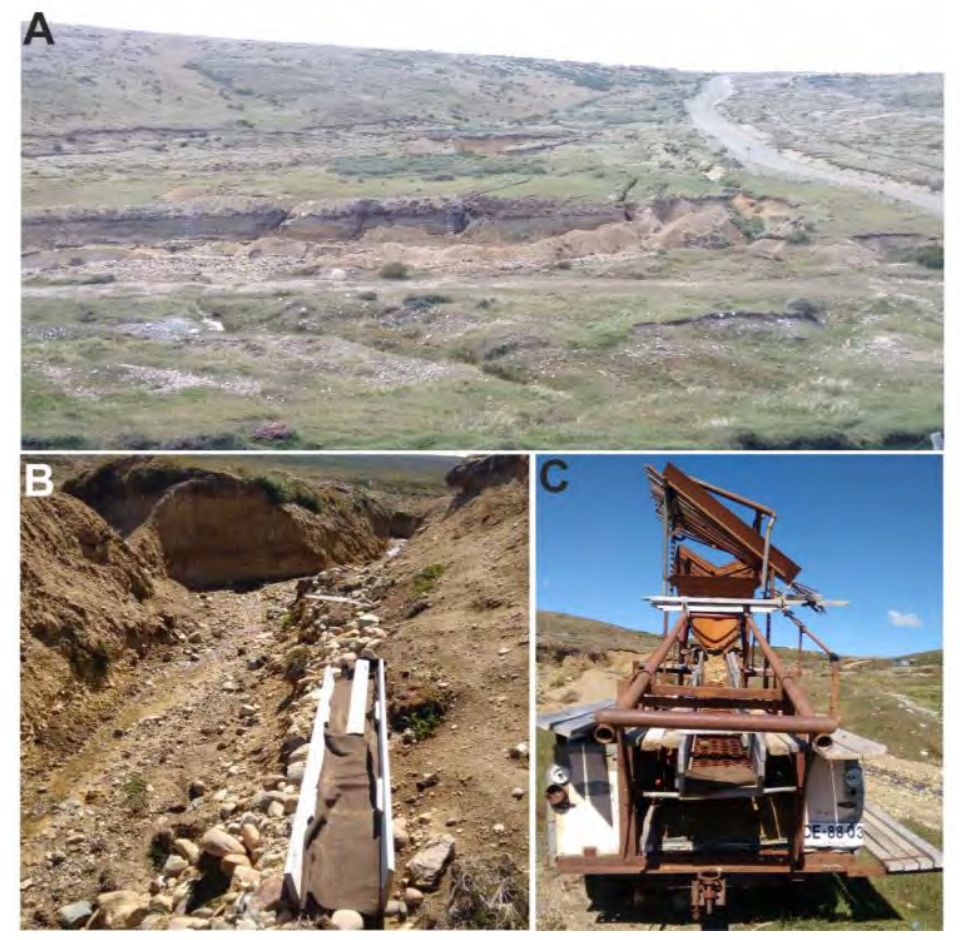

Fig.1.3. A) Lavadero de oro artesanal localizado en el cordón Baquedano. A partir del uso de canaletas (B y C) concentran el oro presente en los depósitos glacigénicos. 
En el sector costero localizado entre la localidad de Río Gallegos y punta Dungeness, al sur de la Provincia de Santa Cruz, Beros y Prez (1987) y Codignotto et al. (1992) estudiaron los depósitos auríferos presentes en las playas, obteniendo las leyes de oro más elevadas en las proximidades de los cañadones y en los niveles enriquecidos.

Posteriormente, Gagliardo (1994) realizó un estudio sobre los minerales pesados de las playas de la bahía de San Sebastián, entre Mina María y punta de Arenas, en la espiga de El Páramo. Muestreó tanto en la playa distal como en el borde superior de la playa frontal y borde inferior (supramareal, intermareal alta e intermareal baja). Los minerales identificados fueron andalucita, apatita, aragonita, augita-diópsido, hipersteno, circón, estaurolita, grupo de las cloritas, grupo del epidoto (clinozoisita y epidoto), grupo del granate (almandino), hematita, hornblenda, ilmenita, leucoxeno, nódulos fosfáticos, rutilo, sillimanita y minerales del supergrupo de la turmalina. De la mineralogía observada concluye un origen principalmente metamórfico y plutónico, seguido por rocas volcánicas y sedimentarias.

Gómez Peral y Martínez (1997) confeccionaron un estudio estadístico de las concentraciones de minerales pesados magnéticos y no magnéticos, con presencia de oro, muy escaso, en escamas muy finas, en el sector de playas entre los cabos San Sebastián y Domingo. Determinaron que la mayor concentración de minerales pesados se encuentra en la arena fina de la zona supramareal y en la arena muy fina de la zona intermareal alta y baja. Postulan que estos depósitos se deberían al transporte sedimentario fluvial y posteriormente a la deriva litoral.

En un informe inédito, Maleville (1998) presentó una prospección de oro, circón y titanio en los depósitos marinos de río Cullen, donde en un volumen de $1.538 .306 \mathrm{~m}^{3} \mathrm{de}$ arenas se calcularon reservas posibles de oro de $923 \mathrm{~kg}$ (ley de $0,6 \mathrm{~g} / \mathrm{m}^{3}$ o 0,3 g/t) y de plata de $20.614 \mathrm{~kg}\left(0,2 \mathrm{~g} / \mathrm{m}^{3} \circ 0,1 \mathrm{~g} / \mathrm{t}\right)$. Los análisis sobre la pureza del oro en cuatro muestras arrojaron una media de $\mathrm{Ag}$ de $18,94 \%$ en peso. La mayor pureza se obtuvo al sur de la desembocadura del río.

Zappetini et al. (2004), a partir del estudio de una muestra de playa del sector de cabo Nombre, identificaron inclusiones de platino en las titanomagnetitas presentes en la fracción arena fina. 


\subsection{Orohidrografía, clima, biota y recursos económicos}

\subsubsection{Orohidrografía}

El área de trabajo se ubica al noreste de la Isla Grande de Tierra del Fuego, en el sector argentino perteneciente a la provincia de Tierra del Fuego, Antártida e islas del Atlántico Sur, desde el cabo Espíritu Santo hasta punta Sinaí. Esta isla está compartida con Chile, región de Magallanes y Antártida Chilena (Región XII), separada por el meridiano $68^{\circ} 36^{\prime} \mathrm{O}$. Al norte limita con el Estrecho de Magallanes, al este con el océano Atlántico y al sur con el Canal Beagle.

La ciudad más próxima a nuestro sector es la localidad de Río Grande, situada al sur a una distancia de $80 \mathrm{~km}$ por la Ruta Nacional $\mathrm{N}^{\circ} 3$. La zona de trabajo incluye la población y puesto fronterizo de San Sebastián (fin de la ruta pavimentada) y las estancias Cullen al norte y Sara al sur, además de yacimientos petrolíferos de las empresas YPF y TOTAL Austral, un campamento de Vialidad Provincial y puestos de la Marina y Gendarmería. El acceso a los lugares de muestreo se realizó a través de caminos de ripio en general en muy buen estado de conservación y huellas que debido al escaso tránsito y mantenimiento se encuentran en regular estado (Fig.1.4).

La zona de trabajo presenta un relieve suave formado por rocas sedimentarias marinas terciarias sobre las que se asientan sedimentos glacigénicos cuaternarios, que comprenden un paisaje de morenas y planicies glacifluviales y glacilacustres. Los sectores más elevados se corresponden con las sierras de San Sebastián al norte, con una altura promedio que aumenta hacia el oeste hasta los 150 m s.n.m (sobre el nivel del mar) y Carmen Silva al sur, con una altura máxima de 250 m s.n.m hacia el oeste, separados por la depresión bahía Inútil-bahía de San Sebastián. Al norte de la sierra de San Sebastián y la depresión del río Cullen se localiza una suave planicie o llanura con una altura promedio de 90 m y máxima de 100 m s.n.m, comprendiendo las zonas denominadas Pampa de Beta y Pampa del Rincón. Estos depósitos conforman en la costa altos acantilados en retroceso al norte y sur de la bahía de San Sebastián como consecuencia de los procesos erosivos.

Frente a los acantilados se desarrolla una extensa playa rectilínea únicamente interrumpida por la bahía semicircular de San Sebastián (35 km x $25 \mathrm{~km})$, donde se puede diferenciar una espiga gravosa cerrando parcialmente la bahía, denominada península El Páramo con una longitud de $20 \mathrm{~km}$. En la bahía se pueden distinguir, cuando el nivel de marea está bajo, distintos ambientes como marismas, cordones litorales de gravas, cheniers compuestos por arenas y valvas de moluscos y planicies de marea (Bujalesky 1997). 


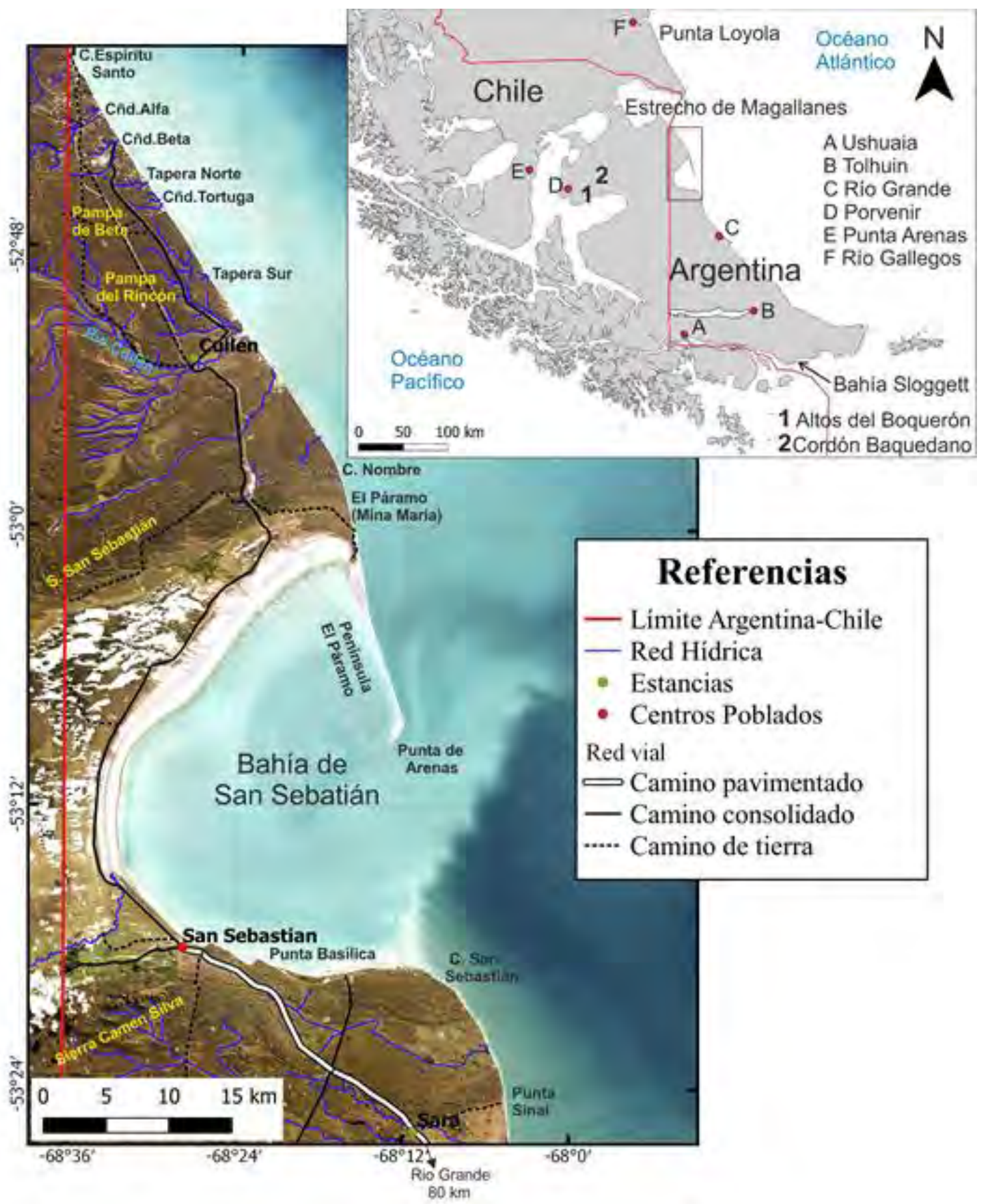

Fig.1.4. Mapa geográfico de la zona de trabajo. Cñd, cañadón; C, cabo.

Respecto a la hidrografía, el sector de trabajo se caracteriza por una red de drenaje poco desarrollada, escaso caudal y pendientes suaves (Iturraspe y Urciuolo 2007).

Se pueden diferenciar cursos efímeros y permanentes (Codignotto 1979), todos ellos con vertiente atlántica. Los primeros de norte a sur se corresponden con los cañadones Alfa, Tapera Norte, Tortuga (Fig.1.5 C1 y C2), Tapera Sur, Malanoche y de La Piedra. Los permanentes están representados por el cañadón Beta (Fig.1.5 B) y los ríos 
Cullen (Fig.1.5 A), al norte de la sierra de San Sebastián, y San Martín al norte de la sierra Carmen Silva con desembocadura en la bahía de San Sebastián. El río Cullen es el que presenta la mayor red de drenaje cuya naciente se localiza en las estribaciones de la sierra del Boquerón, en el sector chileno. Codignotto et al. (1981) distinguen cinco terrazas fluviales asociadas a este río situadas a $79 / 80 \mathrm{~m}, 50 \mathrm{~m}, 15 / 20 \mathrm{~m}, 10 \mathrm{~m}$ y $3 / 4 \mathrm{~m}$ de altura.
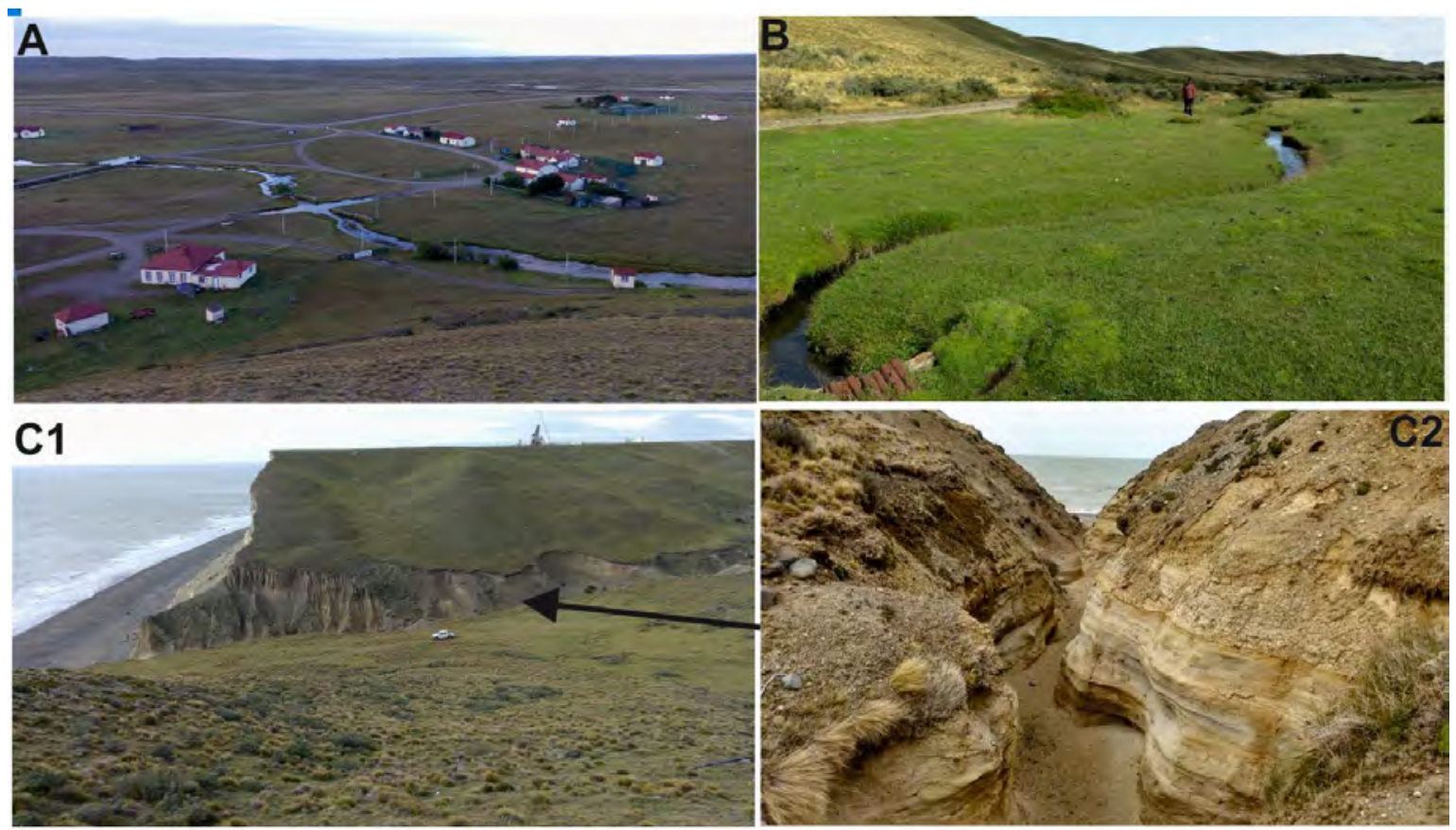

Fig.1.5. A) Río Cullen a su paso por la estancia homónima. B) Arroyo Beta que genera el cañadón de mismo nombre. C1 y C2) Cañadón Tortuga.

Son comunes las lagunas temporales de escasa profundidad y carácter salino, ubicadas en depresiones originadas principalmente por la acción erosiva del viento y el agua (Coronato et al. 2017). Se localizan principalmente en la depresión de la bahía Inútilbahía de San Sebastián observándose en algunas de ellas migración hacia el este como consecuencia de los fuertes vientos provenientes del oeste (Codignotto y Malumián 1981).

\subsubsection{Clima}

El clima está dominado por dos factores, un intenso viento del oeste y la barrera orográfica de la Cordillera de los Andes (Cogliati y Cuello 2007). Según la ubicación latitudinal toda la región de la Patagonia comprende la zona de circulación de los vientos del oeste del Hemisferio Sur (entre el cinturón de altas presiones subtropicales y la zona de bajas presiones subpolares) con la particularidad de que no hay otro continente que se interponga en el camino de estos vientos, por lo que alcanzan una gran intensidad y continuidad durante todo el año (Coronato et al. 2017). 
El sector de trabajo se caracteriza por tener un clima frío subhúmedo oceánico (Coronato et al. 2017). Presenta precipitaciones medias anuales de $300 \mathrm{~mm}$ al año, aumentando durante la estación de verano y disminuyendo en primavera, y temperatura media de $6,1^{\circ} \mathrm{C}$ alcanzando los valores más bajos en los meses de invierno y los máximos en verano (Kreps et al. 2012).

Como ya se ha indicado, en esta zona son muy comunes los fuertes vientos principalmente durante la primavera y el verano dificultando en algunas ocasiones el trabajo en las playas.

Según los datos para el año 2018 de la Estación Astronómica de Rio Grande, los vientos más fuertes provienen del O y OSO, con ráfagas que superan los $100 \mathrm{~km} / \mathrm{h}$ (viento sostenido máximo de $80,5 \mathrm{~km} / \mathrm{h}$ ). Estos vientos representan el $57 \%$ de los vientos anuales, con una velocidad promedio de $29,5 \mathrm{~km} / \mathrm{h}$ y $24,5 \mathrm{~km} / \mathrm{h}$, respectivamente. Se mantienen a lo largo de todo el año alcanzando las velocidades más altas en los meses de primavera. Le siguen en frecuencia los vientos del NO y NNO, con el 19,8\% y una velocidad media de $19 \mathrm{~km} / \mathrm{h}$ y $18,3 \mathrm{~km} / \mathrm{h}$, siendo más frecuentes los vientos de NO en los meses del otoño e invierno. Los vientos del N, NNE y NE representan el 7,5\% de los vientos anuales, con velocidades medias de $17,4 \mathrm{~km} / \mathrm{h}, 14,2 \mathrm{~km} / \mathrm{h}$ y $13,9 \mathrm{~km} / \mathrm{h}$, respectivamente (Tabla 1.1). La calma tiene una frecuencia media anual del $0,9 \%$, presentando la temporada más tranquila entre los meses de mayo y agosto.

\begin{tabular}{|c|c|c|c|c|c|c|c|c|c|c|c|c|c|c|c|}
\hline & 0 & OSO & so & SSO & $S$ & SSE & SE & ESE & $\mathbf{E}$ & NE & NNE & $\mathrm{N}$ & NNO & NO & Calma \\
\hline $\mathrm{Vm}(\mathrm{km} / \mathrm{h})$ & 29,5 & 24,5 & 12,3 & 10,2 & 11,2 & 12,1 & 12,1 & 15,2 & 13,9 & 14,2 & 13,9 & 17,4 & 18,3 & 19,0 & 0,0 \\
\hline $\operatorname{Max} V(\mathrm{Km} / \mathrm{h})$ & 80,5 & 80,5 & 64,4 & 41,8 & 32 & 31 & 34 & 40,2 & 35,4 & 33,8 & 40 & 40,2 & 45,1 & 56 & 0 \\
\hline Frecuencia (\%) & 22,1 & 34,9 & 4,4 & 1,9 & 1,2 & 1,3 & 1,8 & 2,6 & 1,5 & 0,9 & 2,4 & 4,2 & 6,9 & 12,9 & 0,9 \\
\hline
\end{tabular}

Tabla 1.1. Velocidad y frecuencia para vientos sostenidos tomados por la Estación Astronómica de Rio Grande en 2018. $V m$, velocidad promedio; Max $V$, velocidad máxima.

En la zona del río Cullen, los datos de la Compagnie de Recherches et d'Études Oceanographiques y Geomatter (1985) indican una dominancia de los vientos de sector oeste, con velocidades superiores a $55 \mathrm{~km} / \mathrm{h}$ todos los meses del año.

A partir de los datos para la zona marina realizados por IMCOS Marine (1978), vistos en Montes (2015), se extrae que la mayor parte de los vientos y los más fuertes provienen del sector SSO a NNO, sin embargo temporales con velocidades superiores a $87 \mathrm{~km} / \mathrm{h}$ pueden provenir de cualquier dirección.

Respecto a la nubosidad, se caracteriza por presentar generalmente un cielo parcialmente nublado, entre 4,1 y 5,5 octavos (Servicio Meteorológico Nacional 2018). 


\subsubsection{Vegetación y fauna}

El tipo de vegetación se corresponde con la región ecológica de la estepa magallánica o estepa graminosa cubierta principalmente por vegetación herbácea como el coirón (Festuca gracillima), murtillar (Empetrum rubrum) en las planicies más elevadas expuestas al viento y arbustos diseminados de mata verde (Lepidophyllum cupressiforme) y mata negra (Chiliotrichum diffusum) según Collado (2007) y Coronato et al. (2017). En el sector de la bahía de San Sebastián como consecuencia de la salinidad se encuentra la especie Salicornia ambigua (Codignotto, 1979). En los cañadones donde las condiciones ventosas no son tan extremas y en los cursos de agua donde la humedad es más alta se desarrollan las vegas compuestas por gramíneas de los géneros Hordeum, Alopecurus, Deschampsia y ciperáceas del género Carex (Collado 2007), reconociéndose en algunos sectores la hierba zapatito de la virgen (Calceolaria uniflora). Cerca de la costa se han identificado arbustos aislados de calafate (Berberis microphylla) junto con gramíneas (Fig.1.6 A-E).
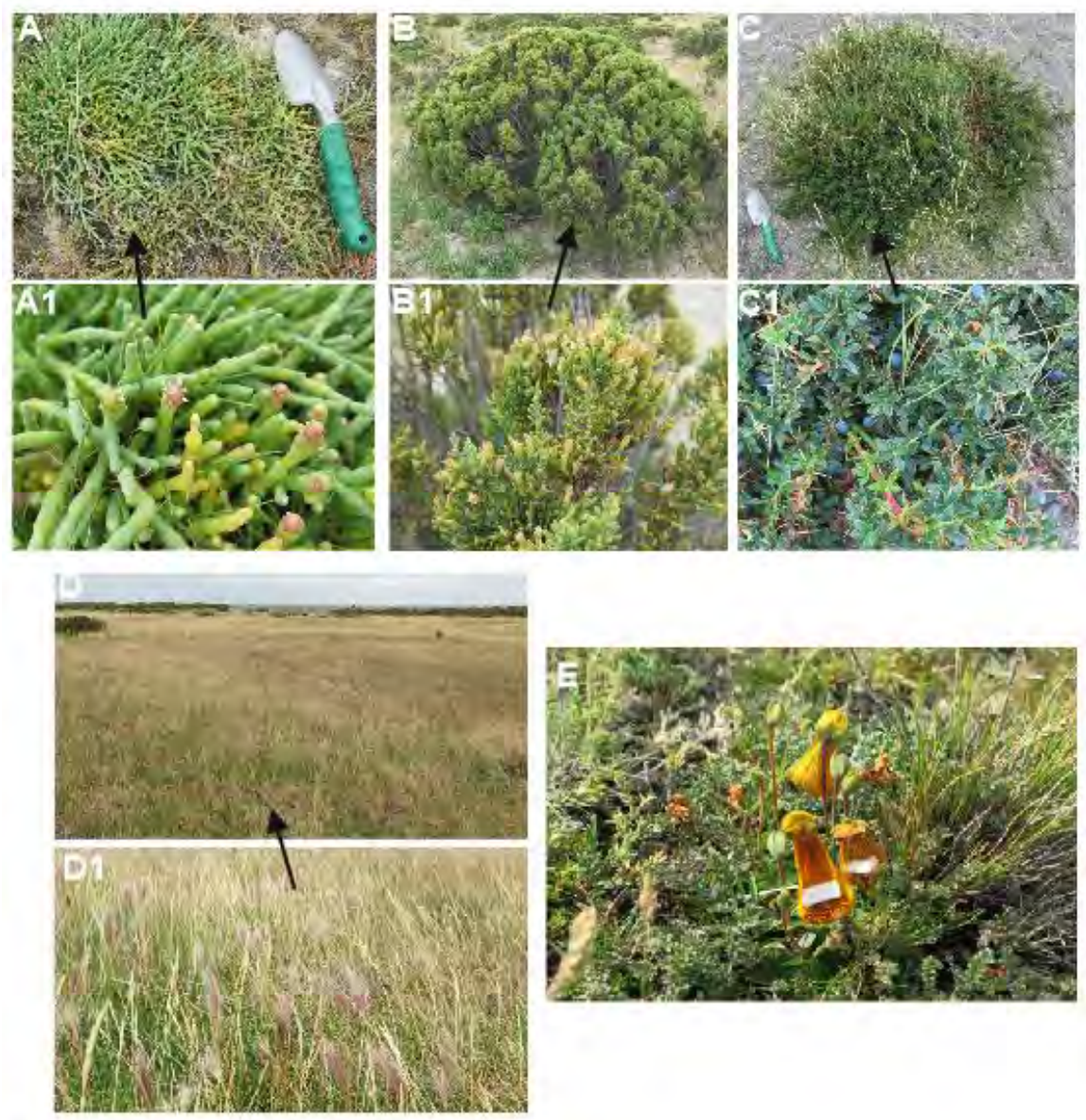

Fig.1.6. Vegetación presente en la zona esteparia del norte de Tierra del Fuego: A, salicornia; B, mata verde; $C$, gramíneas; $D$, calafate; $E$, zapatito de la virgen. $A 1, B 1, C 1$ y D1: detalles. 
Respecto a la fauna, en este sector es fácil encontrarse con el guanaco (Lama guanicoide) y el zorro gris (Lycalopex griseus), además de algún quirquincho o piche (Chaetophractus villosus) cruzando la ruta y cerca de los asentamientos humanos a la rata almizclera (Ondatra zibethicus). Estos mamíferos conviven con los animales pertenecientes a las estancias como las ovejas (Fig. 1.7).
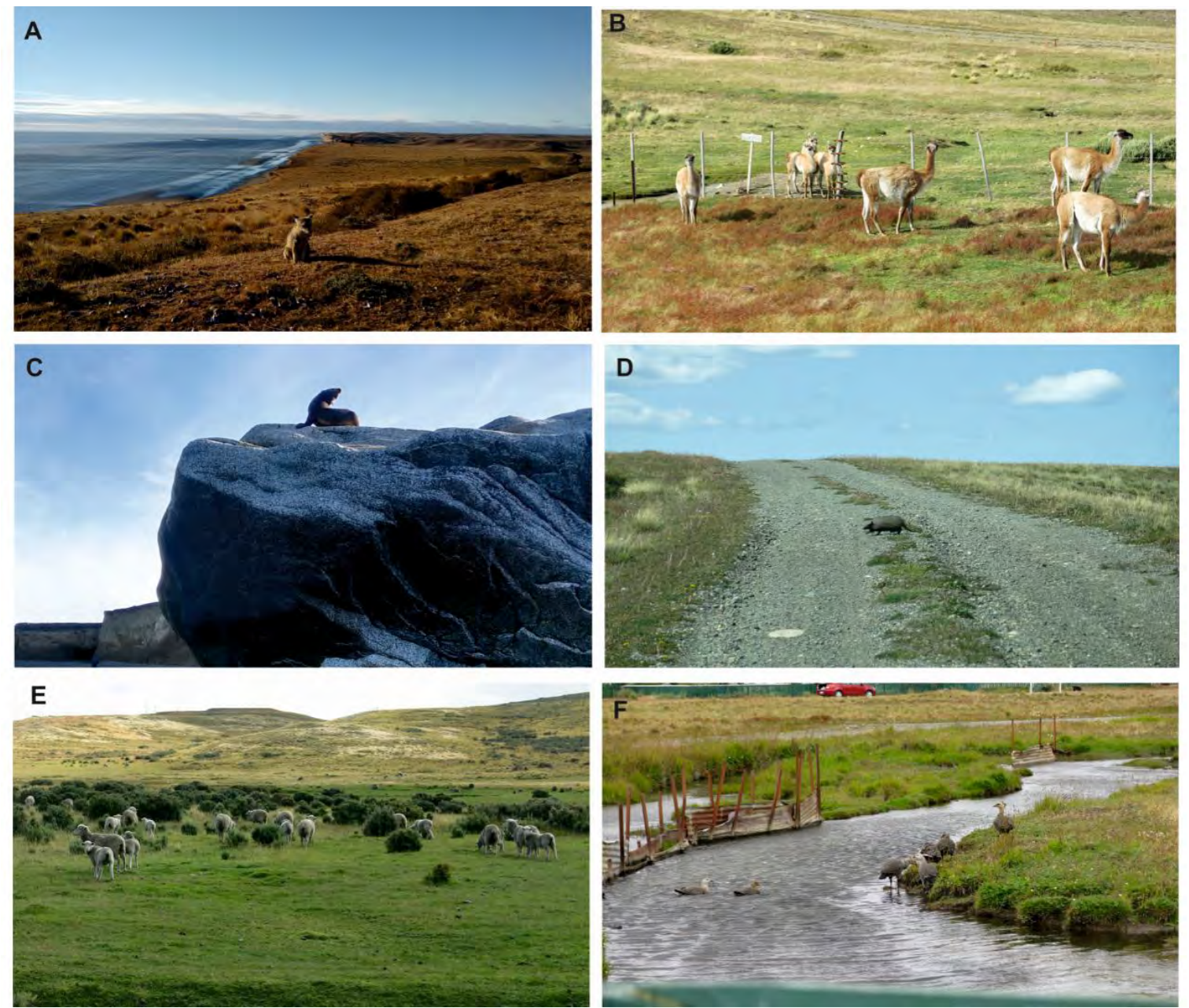

Fig.1.7. Fauna del norte de Tierra del Fuego: A, Zorro gris; B, guanacos; C, lobo marino de un pelo; $D$, quirquincho; $E$, ovejas; F, cauquén común.

La región desde el cabo Nombre hacia el sur pertenece a la Reserva Nacional Costa Atlántica (Ley Provincial 415), siendo su mayor riqueza la avifauna, destacándose las aves playeras migratorias provenientes del hemisferio norte. La bahía de San Sebastián representa el sector más importante ya que alberga $43 \%$ de la población mundial de becasa de mar (Limosa haemastica) e importantes concentraciones de chorlo rojizo (Calidris canutus) y playerito rabadilla blanca (Calidris fuscicollis) (Loekemeyer et al. 2005). Entre otros también se reconoce el gaviotín sudamericano (Sterna hirundinacea), la gaviota 
cocinera (Larus dominicanus), la bandurria austral (Theristicus melanopis), el flamenco austral (Phoenicopterus chilensis), el cauquén común (Chloephaga picta), la caraca o cauquén costero (Chloephaga hybrida), el cauquén real (Chloephaga poliocephala) y cauquén colorado (Chloephaga rubidiceps), siendo esta última una especie amenazada de extinción.

Costa afuera, el área marina constituye una zona de tránsito, migración y alimentación de diversas especies de aves y mamíferos marinos, como el pingüino de Magallanes (Spheniscus magellanicus), pingüino penacho amarillo (Eudyptes chrysocome), petrel gigante (Macronectes giganteus), observándose más de veintiocho especies de cetáceos, destacándose en abundancia la tonina overa (Cephalorhyncus commersonii) (Loekemeyer et al. 2005). También se han podido reconocer, encima de bloques erráticos durante la marea baja o en zonas cercanas a la costa, lobos marinos de un pelo (Otaria flavescens) (Fig.1.7C)

\subsubsection{Recursos económicos}

La actividad económica de la zona de trabajo se corresponde a la extracción de hidrocarburos por parte de las empresas YPF y TOTAL Austral, tanto en el continente como en la Plataforma Continental, y la ganadería ovina en las estancias Cullen al norte de la bahía de San Sebastián y Sara al sur de ésta. Respecto a la minería, únicamente en el cañadón Beta se continúa con el lavado oro de manera artesanal y esporádica por parte de la empresa minera EI Winchester (Fig.1.8).
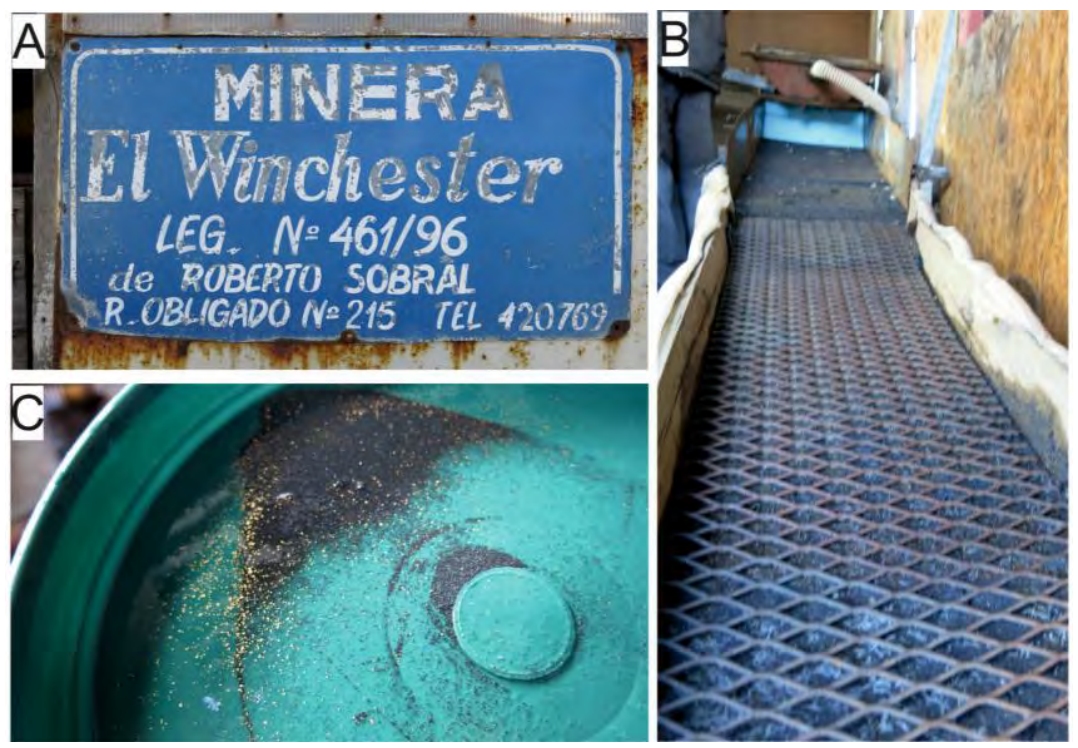

Fig.1.8. Minera El Winchester presente en el cañadón Beta donde concentran oro de manera artesanal mediante el uso de una canaleta (B) y posterior bateo (C). 


\section{Capítulo 2: METODOLOGÍA}

\subsection{Campañas y muestreo}

El área de trabajo se dividió en tres sectores: a) playas, b) depósitos glacigénicos continentales y c) plataforma continental.

\section{a) Playas}

Se dividió la zona en 9 lugares de muestreo, elegidos por cambios geomorfológicos (presencia de ríos, arroyos o cañadones, cabos o bahías), cambios en la litología de las unidades estratigráficas continentales y por los antecedentes mineros, de norte a sur: 1) cabo Espíritu Santo, 2) cañadón Alfa, 3) cañadón Beta, 4) cañadón Tortuga, 5) Cullen Norte, 6) Cullen Sur, 7) El Páramo, 8) bahía de San Sebastián y 9) punta Sinaí. En los nueve sectores se muestreó la zona supramareal e intermareal alta y baja en aquellos lugares donde la bajamar permitía acceder. Se realizaron calicatas en la zona supramareal para observar la presencia de niveles enriquecidos en minerales pesados, de manera manual y en el cañadón Beta se pudieron realizar calicatas mediante la utilización de una pala mecánica (retroexcavadora). Las muestras fueron sometidas a análisis granulométricos mediante tamizado y a estudios mineralógicos las provenientes de la zona supramareal.

En cada uno de los lugares mencionados se realizaron perfiles topográficos con GPS diferencial modelo Trimble R8S utilizando en el dispositivo móvil el software JunoT41 (Fig.2.1A y B). Los puntos se midieron con la proyección Posgar faja 2 y el modelo geoidal EGMO8-AR. Se midió desde el acantilado o cordón litoral hasta la zona intermareal baja en aquellos lugares donde era accesible. En total se realizaron 36 perfiles en tres estaciones distintas, primavera, verano y otoño. La campaña de primavera coincidió con marea de sicigia. En el laboratorio se descargaron los datos con el software Trimble Business y se incorporaron a una tabla Excel para su posterior análisis. 


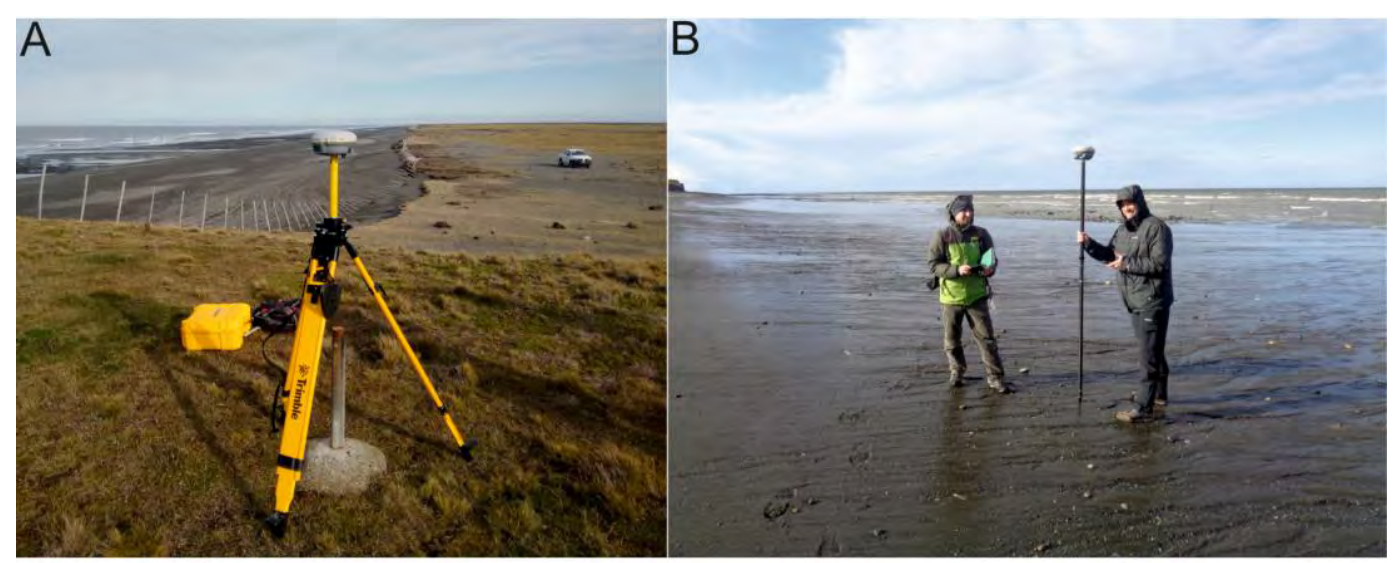

Fig.2.1. GPS diferencial. A) torre fija y B) antena móvil.

\section{b) Depósitos glacigénicos continentales}

Se muestreó en 17 puntos considerados representativos distribuidos por toda la zona de trabajo. Estos lugares se eligieron por cambios geomorfológicos y litológicos, ya sean sedimentos de till o glacifluviales y fluviales. Las muestras se tamizaron en el campo (Fig.2.2A y B) para separar la fracción grava, es decir mayor a $2 \mathrm{~mm}$, del resto de la muestra. Esta fracción gruesa se estudió mediante lupa de campo, realizando láminas delgadas en aquellas gravas en las que la identificación fue más dificultosa. El resto del material $(<2 \mathrm{~mm})$ se recogió para realizar tamizados y análisis mineralógicos posteriores.
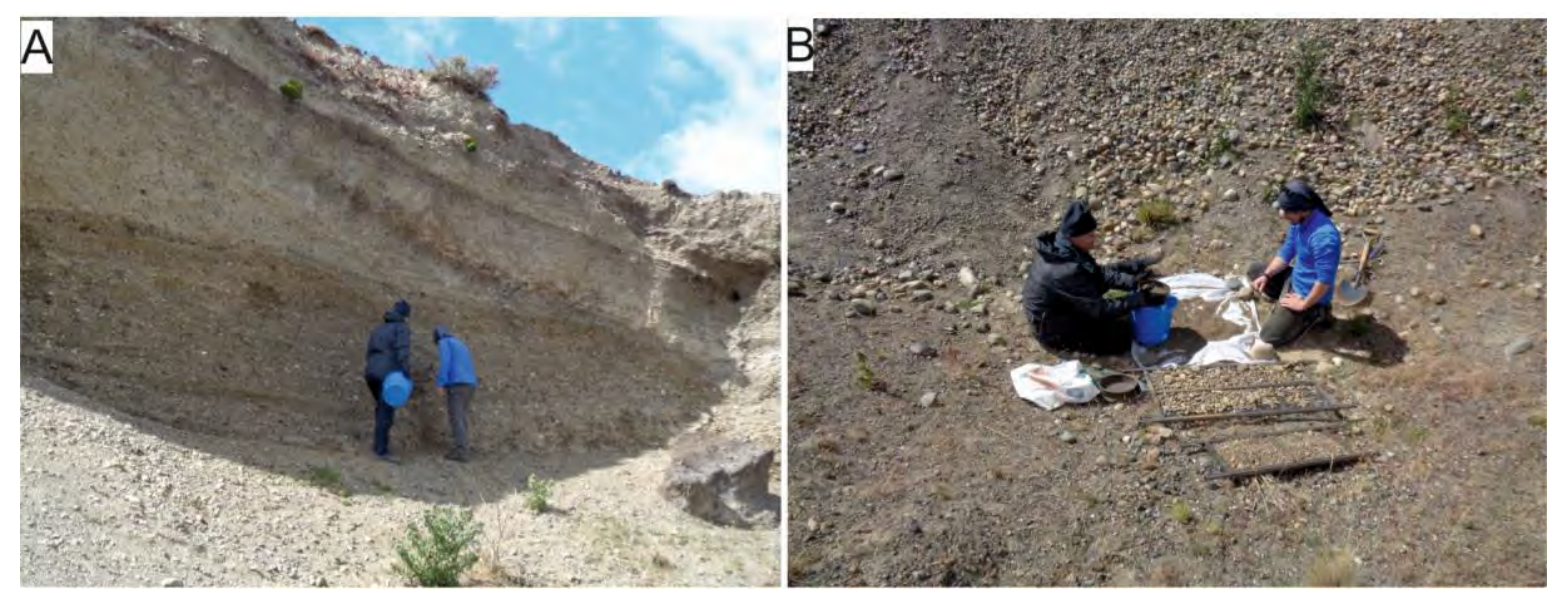

Fig.2.2. Muestreo depósitos glacigénicos: A, toma de muestra; B, tamizado en campo mediante diferentes tamices.

\section{c) Plataforma Continental}

A través del Servicio de Hidrografía Naval se tuvo acceso a un total de 65 muestras de fondos marinos distribuidas por la Plataforma Continental de la zona de trabajo e inmediaciones. El muestreo corresponde a 4 campañas entre 1970 y 1984 donde se tomaron muestras superficiales con una draga tipo Shipeck y testigos con un muestreador tipo Phleger (Fig.2.3A y B). Se seleccionaron 28 muestras, consideradas como más 
representativas y de mayor volumen, para realizar los análisis sedimentológicos y mineralógicos posteriores.
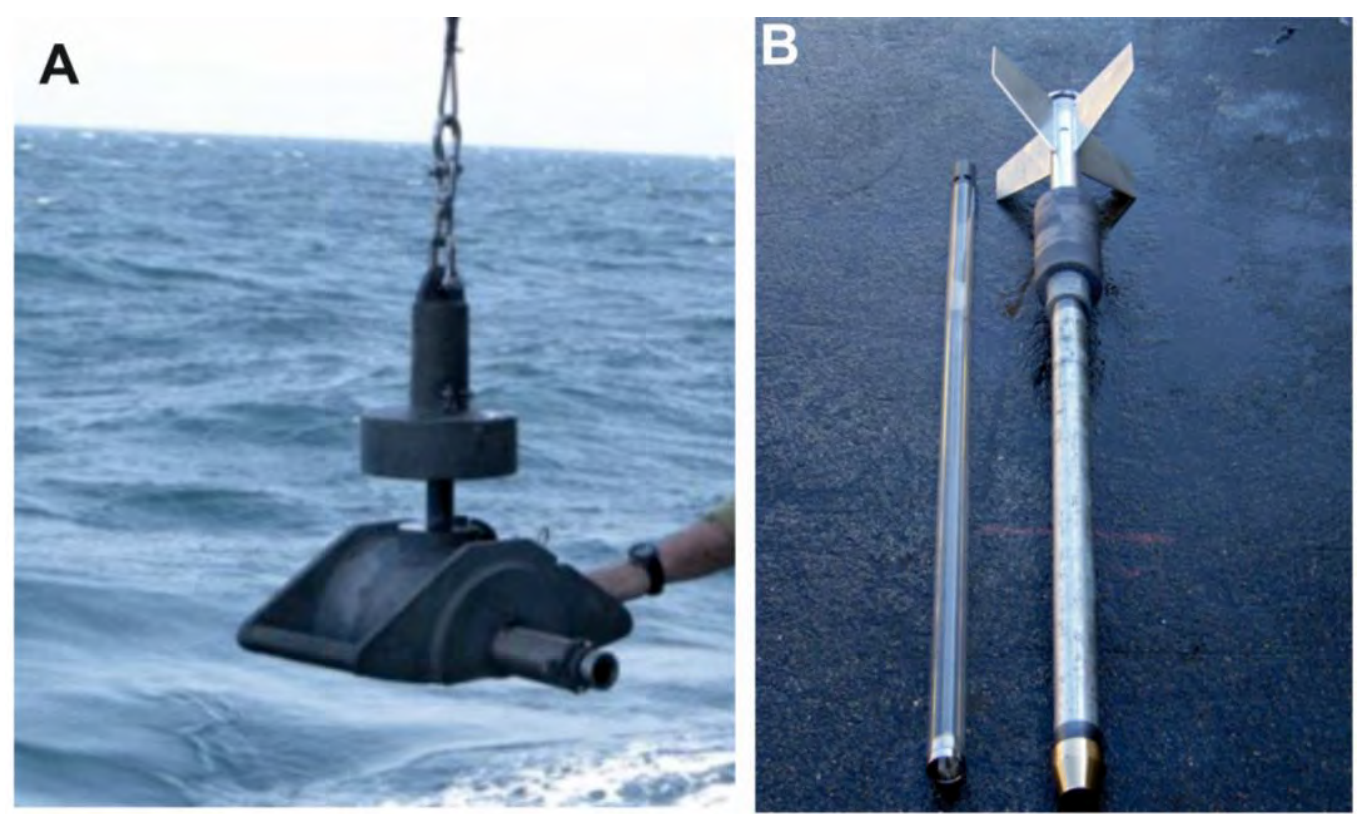

Fig.2.3. Muestreadores empleados: A) Draga Shipeck B) Muestreador Phleger.

\subsection{Gabinete y laboratorio}

\subsubsection{Cartografía}

Para la cartografía de la región de estudio se utilizaron los mapas geológicos y geomorfológicos presentes en la bibliografía geológica (Codignotto 1979; Codignotto y Malumián 1981; Agüero et al. 2003, Olivero et al. 2006 y Darvill et al. 2015b), las observaciones realizadas en campo y las imágenes satelitales LANDSAT 8 existentes del sector norte de la Isla Grande de Tierra del Fuego. El programa de computación utilizado para realizar la base cartográfica fue el QGIS.

Las imágenes satelitales LANDSAT 8 se descargaron a través de la página web de la Comisión Nacional de Actividades Espaciales (CONAE): LO82280962017142COA00, LO82280972015297COA00 y LO82270972017103COA00. La combinación de bandas utilizadas fue 432. Las ubicaciones de las localidades, asentamientos y carreteras se obtuvieron del Instituto Geográfico Nacional (IGN).

\subsubsection{Estudios sedimentológicos. Análisis granulométricos}

Una parte de las muestras de arenas de las playas y de la plataforma se destinó a realizar estudios sedimentológicos en el Laboratorio de Geología del CADIC (Centro Austral de Investigaciones Científicas). 
El estudio granulométrico se realizó mediante tamizado en seco. Previamente a este paso se purificaron las muestras lavándolas con agua destilada a fines de eliminar posibles contaminantes. La escala de clasificación utilizada fue la de Udden (1914) y Wentworth (1922), Tabla 2.1.

\begin{tabular}{|c|c|c|c|c|c|c|c|}
\hline & & & & & & \multirow{3}{*}{$\begin{array}{c}\text { grado phi } \\
-5\end{array}$} & \multirow{2}{*}{ no malla ASTM } \\
\hline & \multicolumn{2}{|c|}{\begin{tabular}{l|l|}
$\mathrm{mm}$ & $\mu \mathrm{m}$ \\
\end{tabular}} & & \\
\hline \multirow{5}{*}{ 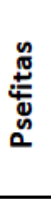 } & \multirow{5}{*}{ Gravas } & \multirow{5}{*}{$\begin{array}{l}\text { Muy grueso } \\
\text { Grueso } \\
\text { Medio } \\
\text { Fino } \\
\text { Muy fino } \\
\end{array}$} & \multirow{4}{*}{ Guijarro } & $>32$ & & & $11 / 4$ \\
\hline & & & & $32-16$ & & -4 & $5 / 8$ \\
\hline & & & & $16-8$ & & -3 & $5 / 16$ \\
\hline & & & & $8-4$ & & -2 & 5 \\
\hline & & & Gravilla & $4-2$ & & -1 & 10 \\
\hline \multirow{5}{*}{$\begin{array}{l}\frac{n}{0} \\
\stackrel{5}{E} \\
\frac{\pi}{\mathbb{E}} \\
0\end{array}$} & & Muy grueso & & $2-1$ & & 0 & 18 \\
\hline & & Grueso & & $1-0,5$ & & 1 & 35 \\
\hline & Arenas & Medio & & $0,5-0,25$ & & 2 & 60 \\
\hline & & Fino & & $0,25-0,125$ & & 3 & 120 \\
\hline & & Muy fino & & $0,125-0,063$ & & 4 & 230 \\
\hline \multirow{5}{*}{ 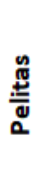 } & & Grueso & & & $63-31$ & 5 & \\
\hline & Limos & Medio & & & $31-15,6$ & 6 & \\
\hline & & Fino & & & $15,6-7,8$ & 7 & \\
\hline & & Muy fino & & & $7,8-3,9$ & 8 & \\
\hline & Arcillas & & & & $3,9-0,06$ & 14 & \\
\hline
\end{tabular}

Tabla 2.1. Clasificación granulométrica.

Las muestras de playa se tamizaron durante 5 minutos con una tamizadora marca ALEIN utilizando un juego de tamices de la misma marca con un $n^{\circ}$ de malla $1,1 / 4,5 / 8$, $5 / 16,5,10,18,35,60,120$ y 230 . En las muestras de la plataforma submarina, debido a la menor cantidad de muestra y la presencia de limos y arcillas, se utilizó un equipo Mastersizer 2000E para analizar la granulometría (Fig.2.4A-E).

Los datos granulométricos de las muestras tomadas en las playas durante la campaña de verano fueron procesados estadísticamente a través del programa GRADISTAT versión 8.0 (Blott y Pye 2001) siguiendo las fórmulas de Folk y Ward (1957) para la media $\left(\mathrm{M}_{\mathrm{z}}\right)$, desviación estándar $\left(\sigma_{1}\right)$, asimetría $\left(\mathrm{Sk}_{1}\right)$ y curtosis $\left(\mathrm{K}_{\mathrm{G}}\right)$. 


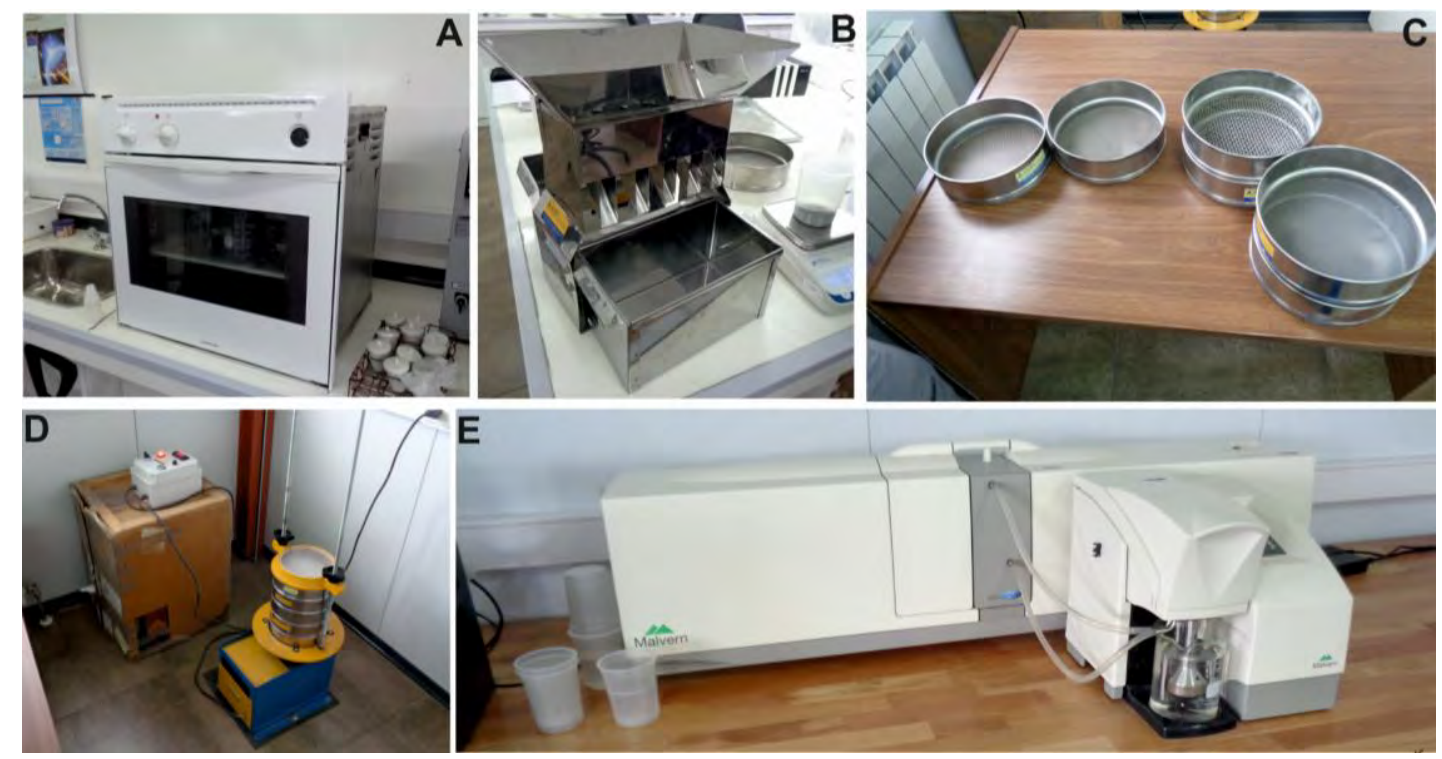

Fig.2.4. Material del laboratorio utilizado para el análisis granulométrico: A, horno; B, cuarteador; $C$, juego de tamices; D, tamizadora; E, analizador de tamaño de partículas Mastersizer.

\subsubsection{Separación de minerales por métodos densimétricos}

Se seleccionaron 26 muestras representativas para separar mediante líquidos densos: 12 muestras de las arenas de playas (8 de la zona supramareal y 4 de la zona intermareal baja), 6 muestras de la Plataforma Continental y 8 muestras de los depósitos glacigénicos continentales. A partir de la separación por flotación en un líquido denso se obtuvieron dos fracciones, una liviana constituida por minerales con una densidad inferior a $2,82 \mathrm{~g} / \mathrm{cm}^{3}$ (mayormente cuarzo, feldespatos o carbonatos) y otra pesada con minerales con una densidad superior a ese valor (magnetita, ilmenita, granate, circón, piroxenos, anfíboles, entre otros).

Previo a la separación hubo que efectuar la preparación de las muestras. Se reservó aproximadamente $0,5 \mathrm{~kg}$ de cada una para el análisis mineral. El primer paso que se efectuó fue disgregar la muestra de manera manual, con cuidado de no fracturar los minerales, y tamizarla para eliminar las fracciones de mayor tamaño: gravas gruesas y finas, y arenas muy gruesas retenidas por el tamiz malla ASTM n³5. La porción resultante fue sometida a lavado para eliminar la fracción arcillo-limosa, repitiendo esta operación varias veces hasta que el agua quedó limpia. Una vez secada la muestra, en estufa a $60^{\circ} \mathrm{C}$, el sedimento se tamizó con una malla 120, dejando una fracción final de 0,5-0,125 mm (arena mediana-arena fina) para su tratamiento con líquidos densos. De esta manera se llegó a obtener una granulometría apta para poderla tratar mediante líquidos densos permitiendo la separación de los minerales pesados y livianos. Siguiendo la metodología de Pérez Mateos (1965) las muestras no fueron atacadas mediante ácidos o agua 
oxigenada ya que no se observó que los minerales presentaran algún recubrimiento por oxidación o la presencia de materia orgánica. De esta manera se evitó eliminar minerales tales como los fosfatos.

Se eligió el tamaño de 0,5-0,125 mm porque en este intervalo de granulometría es donde se concentra los mayores porcentajes de minerales pesados, incluido el oro, y se facilita el montaje en las láminas delgadas al tener un tamaño de grano más restringido. Se observó que en las fracciones de arena entre 2 y 0,5 mm la mayor parte de los granos correspondió a fragmentos líticos lo que provocaba un error en la estimación de las proporciones de minerales pesados y livianos. En la fracción de arena muy fina, de 0,125 a 0,062 $\mathrm{mm}$, la cantidad de fases minerales se redujo, siendo las presentes las mismas que se identificaron en la fracción arena media-arena muy fina.

Para la separación mediante líquidos densos se siguió el método de asentamiento por gravedad (Parfenoff et al. 1970 y Mange y Maurer 1992). Se utilizó como líquido denso politungstato de sodio con un $80 \%$ de agua fabricado por la empresa Flukka Analytical. Esta solución presenta una densidad de 2,82 $\pm 0,02 \mathrm{~g} / \mathrm{ml}$. Los materiales utilizados para los ensayos fueron: vaso de precipitado, embudo, papel de filtro y decantador de $250 \mathrm{ml}$ (Fig.2.5A, B y C).

Pasos seguidos: 1) Llenado del decantador hasta la mitad con líquido denso y pesaje de la muestra con balanza de dos decimales. 2) A continuación se introdujo la muestra en el decantador y se dejó reposar durante una hora y media. 3) Una vez pasado este tiempo se abrió la válvula de paso hasta que todo el material pesado quedó retenido en el papel de filtro, pasando el politungstato de sodio a un vaso de precipitado. 4) Se lavó la muestra con abundante agua destilada y se puso otro papel para recuperar la fracción de minerales livianos y el líquido restante realizando el mismo proceso. 5) Finalmente, se limpiaron todos los instrumentos utilizados con agua destilada y jabón para dejar el sistema convenientemente preparado para la siguiente muestra. 

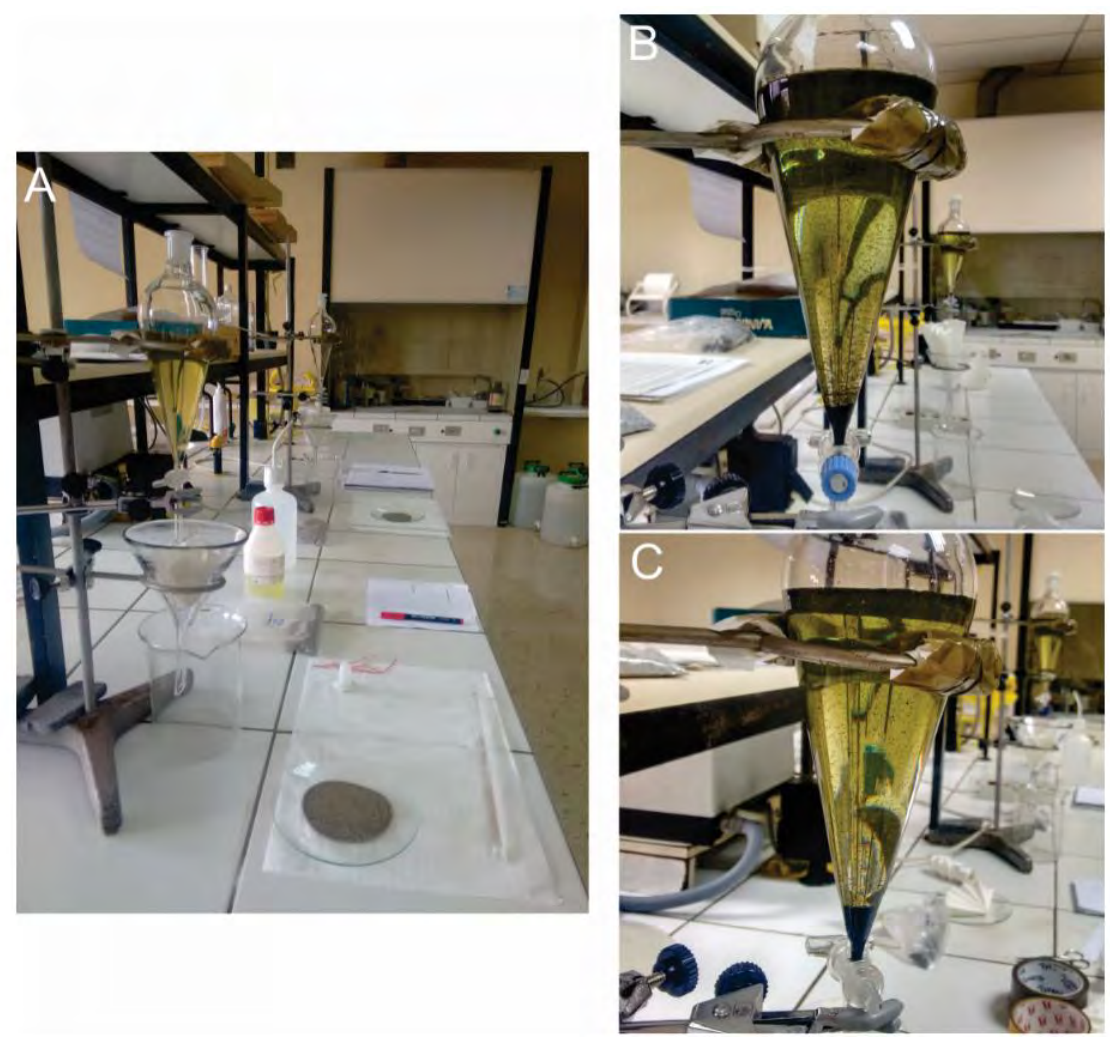

Fig.2.5. A) Montaje para la separación mediante líquidos densos. B) y C) Separación de los minerales después de 30 y 60 minutos, respectivamente.

Alternativamente a este método, para las muestras provenientes de la playa del sector sur de Río Gallegos, se utilizó otro método desarrollado en el Centro de Investigaciones Geológicas (FCNyM-UNLP). Consistió en la separación de los minerales pesados mediante bateo utilizando unos cuencos o ensaladeras (Fig.2.6A y B) con pequeñas irregularidades circulares en su interior a modo de diminutos rifles o costillas que permiten la retención de los minerales pesados. Para evitar la tensión superficial del agua se utilizó una gota de detergente lavaplatos. Esta técnica permite separar las arenas finas y muy finas.
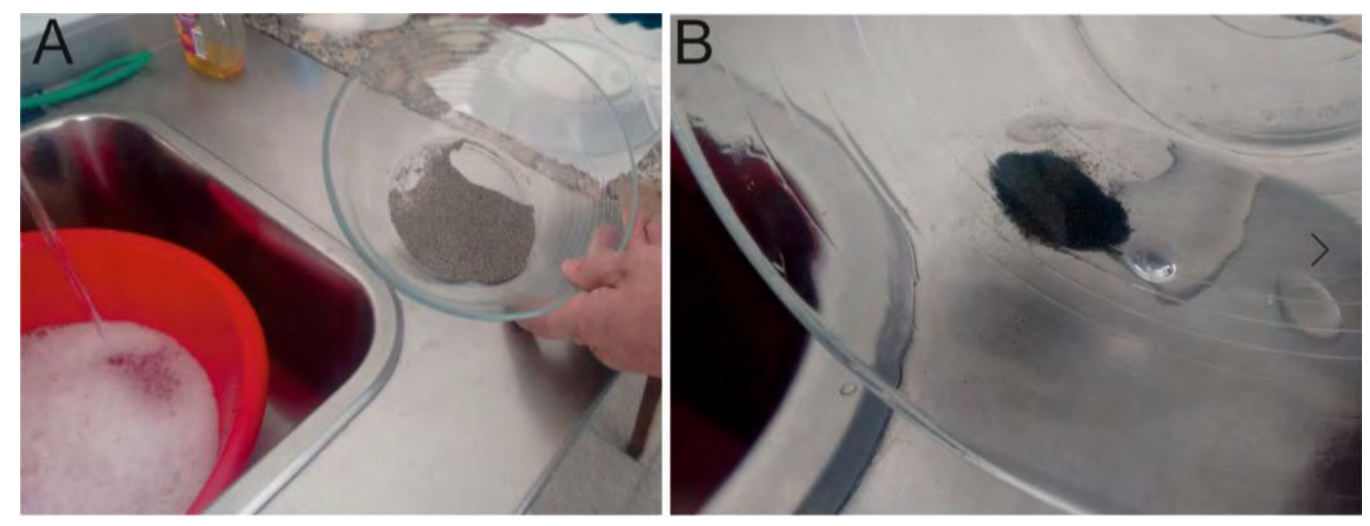

Fig.2.6. Separación de los minerales pesados mediante bateo: A, muestra inicial; B, concentrado de minerales pesados obtenido. 


\subsubsection{Separación magnética}

En el Centro de Investigaciones Geológicas (CIG, FCNyM-UNLP), se utilizó un separador magnético tipo FRANTZ (Fig.2.7A). La separación con el separador magnético permite concentrar minerales a partir de su susceptibilidad magnética, separándolos en función de su naturaleza y comportamiento en los siguientes grupos:

- $\quad$ Ferromagnéticos: minerales fuertemente atraídos por el imán, como puede ser la magnetita.

- Paramagnéticos: minerales con un magnetismo inferior al de los ferromagnéticos.

- Diamagnéticos: minerales no magnéticos

Se seleccionaron 4 muestras de niveles ricos encontrados en las arenas de los cañadones Alfa y Beta, El Páramo y punta Sinaí para su separación mediante susceptibilidad magnética.

Siguiendo las recomendaciones de Rosenblum y Brownfield (2000) se utilizó un tamaño de grano de 0,250-0,125 mm ya que de esta manera se optimiza la respuesta magnética de los minerales puesto que presentan menos posibilidades de contener inclusiones minerales y se minimiza la probabilidad de la existencia de fragmentos líticos. El separador magnético se configuró con una inclinación lateral (side slope) de $15^{\circ}$ y una inclinación frontal (forward slope) de $25^{\circ}$. Se seleccionaron rangos de amperaje de 0,2, 0,6 y $1 \mathrm{~A}$. La fracción más ferromagnética se separó previamente con un imán convencional debido a que los minerales de esta fracción se adhieren fácilmente a la superficie de los conductos metálicos del separador magnético produciéndose pérdidas de muestra.

En las muestras provenientes de las playas al sur de Río Gallegos, para facilitar la identificación de las diferentes fases se separaron magnéticamente utilizando primero un imán normal y después otros de neodimio (Fig.2.7B)
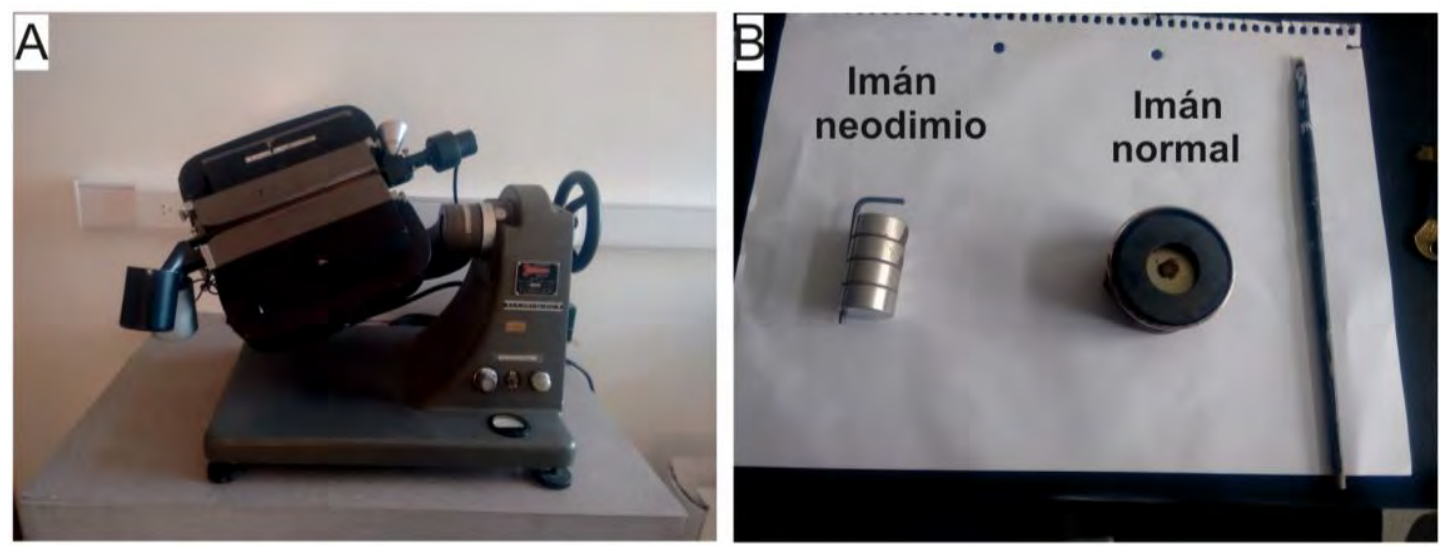

Fig.2.7. Separación magnética: A, separador Frantz; B, imanes normales y de neodimio utilizados. 


\subsubsection{Lupa binocular, granulometría, microscopía de luz transmitida y reflejada}

Las muestras obtenidas en los sectores costeros de las playas, Plataforma Continental y sedimentos glacigénicos continentales fueron estudiadas mediante lupa binocular modelo LEICA EZ4 (Fig.2.9) perteneciente al laboratorio de Recursos Geológicos del CADIC-CONICET para posteriormente seleccionar aquellas en las cuales se realizaron estudios mineralógicos. Las fotografías se hicieron mediante la lupa binocular modelo Leica S6D perteneciente al laboratorio ATMA (Análisis Tecno-Funcional de Materiales Arqueológicos) del CADIC-CONICET.

La confección de las láminas delgadas y probetas pulidas se realizó en el Laboratorio de Petrotomía del Instituto de Recursos Minerales (INREMI) de la Facultad de Ciencias Naturales y Museo de la Universidad Nacional de La Plata (Argentina) y en el Servicio General de Apoyo de la Investigación-SAI, perteneciente a la Universidad de Zaragoza (España). En este último, posteriormente se pulieron en el Área de Cristalografía y Mineralogía, con lijas al agua de tamaño de grano decreciente $(800,1000,1200,1500$, y 2000) puliéndolas al final con paños con pasta diamantada (3 y $1 \mu \mathrm{m}$ ). Este proceso tuvo que realizarse con mucho cuidado durante la preparación de las probetas con oro debido a su pequeño tamaño y forma aplanada. Para que quedaran los granos de oro en el mismo plano, se utilizó previamente una cinta con pegamento en ambas caras; una de ellas se pegó al fondo de la probeta (Fig.2.8) y en la otra los granos de oro uno a uno. Finalmente se embebieron en la resina.

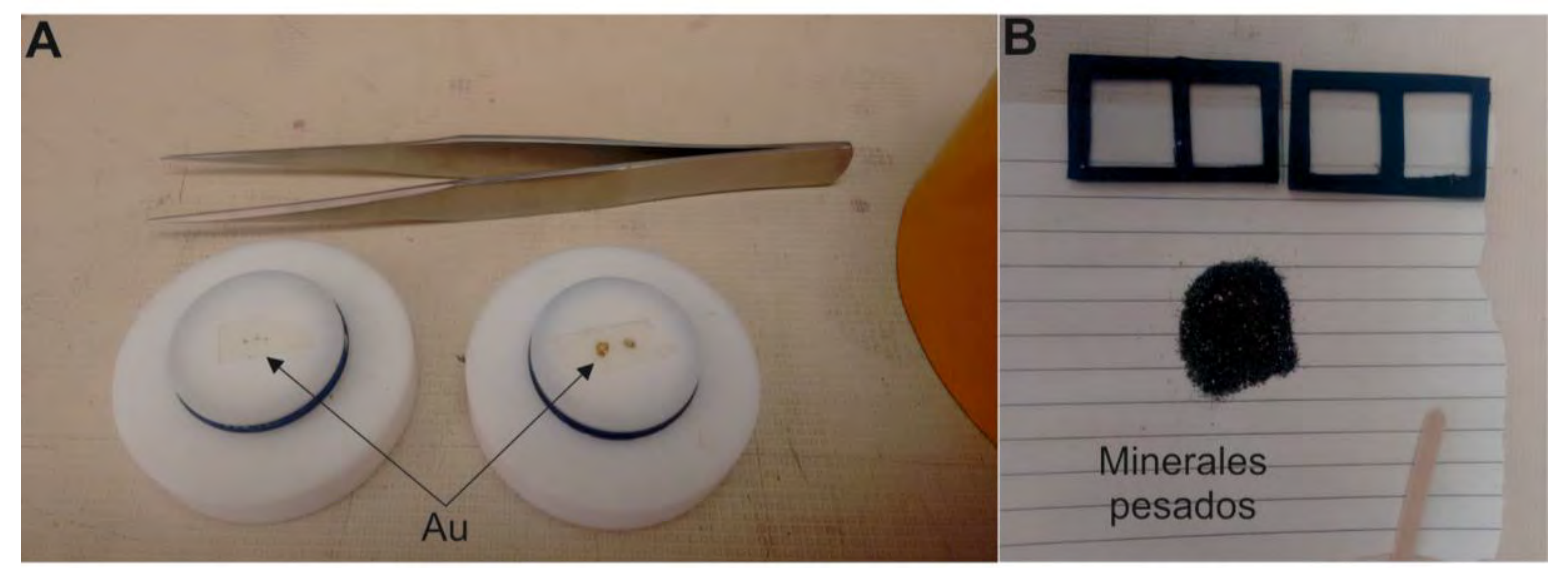

Fig.2.8. Preparación de los montajes antes de cubrirlos con la resina: A) Granos de oro en la base del molde pegados con una cinta. B) Separación de la lámina delgada en dos partes para poder preparar dos muestras por cada lámina.

Las láminas delgado-pulidas y probetas fueron analizadas bajo microscopio de luz transmitida y reflejada (Fig.2.9B) en el Centro Austral de Investigaciones Científicas (CADIC) de Ushuaia, perteneciente al CONICET y en los laboratorios del Área de 
Mineralogía y Cristalografía del Departamento de Ciencias de la Tierra de la Universidad de Zaragoza.

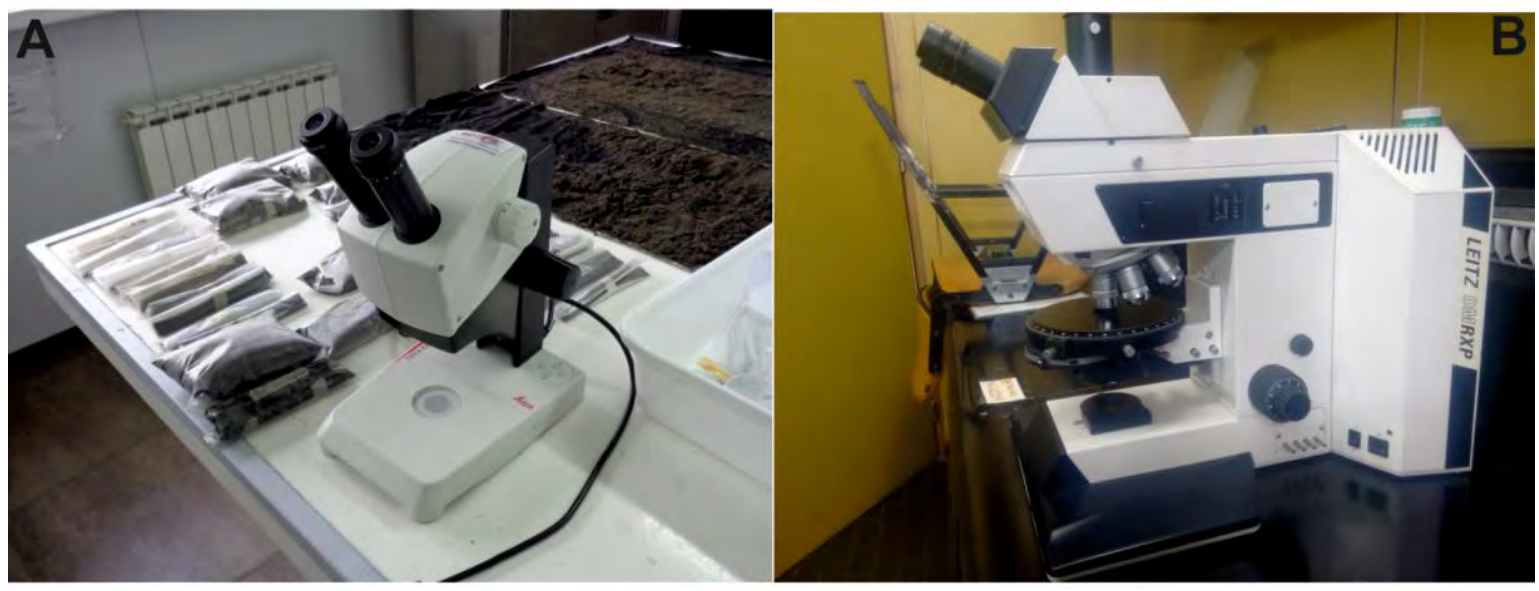

Fig.2.9. A) Lupa binocular. B) Microscopio petro-calcográfico.

La presencia de numerosas fases minerales dificultó el estudio mediante estimación visual, por lo que se realizó un conteo de granos siguiendo el método "line counting", consistente en realizar varias líneas de reconocimiento de minerales y contabilizándose todos los granos atravesados por esa línea (Pérez Mateos 1965; Mange y Maurer 1992). Para efectuar el conteo, la lámina se movió mediante un carro de movimiento de objetos que se encuentra fijado a la platina giratoria del microscopio. El número de granos contados superó los 300 en cada lámina. Posteriormente, se recalculó el número de granos al 100\% y la frecuencia cada mineral se expresó en porcentaje. Con esta técnica se analizaron 6 muestras de arena del sedimento glacigénico (till y glacifluvial), 3 de la plataforma continental, 8 de la zona supramareal de la playa y 4 de los niveles ricos presentes en la misma.

Las abreviaturas de minerales utilizadas en este documento son las indicadas por Whitney y Evans (2010).

\subsubsection{Análisis por difracción de rayos $X(D R X)$}

Los análisis por difracción de Rayos X fueron realizados con el difractómetro marca Philips 1710 con rendija automática y monocromador de grafito del Área de Cristalografía y Mineralogía de la Universidad de Zaragoza (España).

Mediante esta técnica se analizó tanto muestra total como muestra separada previamente mediante la utilización de imanes (normal y de neodimio) con el objetivo de realizar una primera identificación de los principales minerales pesados. 
La preparación de las muestras para el estudio de DRX consistió en su machaqueo a mano, seguido de una molienda en un molino de aros de acero. A continuación, se cuarteó cada muestra para obtener porciones representativas de las mismas. Estas partes alícuotas se tamizaron con un tamiz con luz de malla de $53 \mu \mathrm{m}$ para cargar el portamuestras de aluminio utilizado para el método del polvo cristalino (Fig. 2.10). Las condiciones de trabajo fueron $40 \mathrm{KV}, 30 \mathrm{~mA}$ y radiación $\mathrm{Ka}$ del $\mathrm{Cu}$. Los difractogramas de las muestras se obtuvieron a una velocidad de goniómetro de 0,0320/s y tiempo de integración de 0,5 s. El software de control empleado fue Xpowder (Martín Ramos 2007).
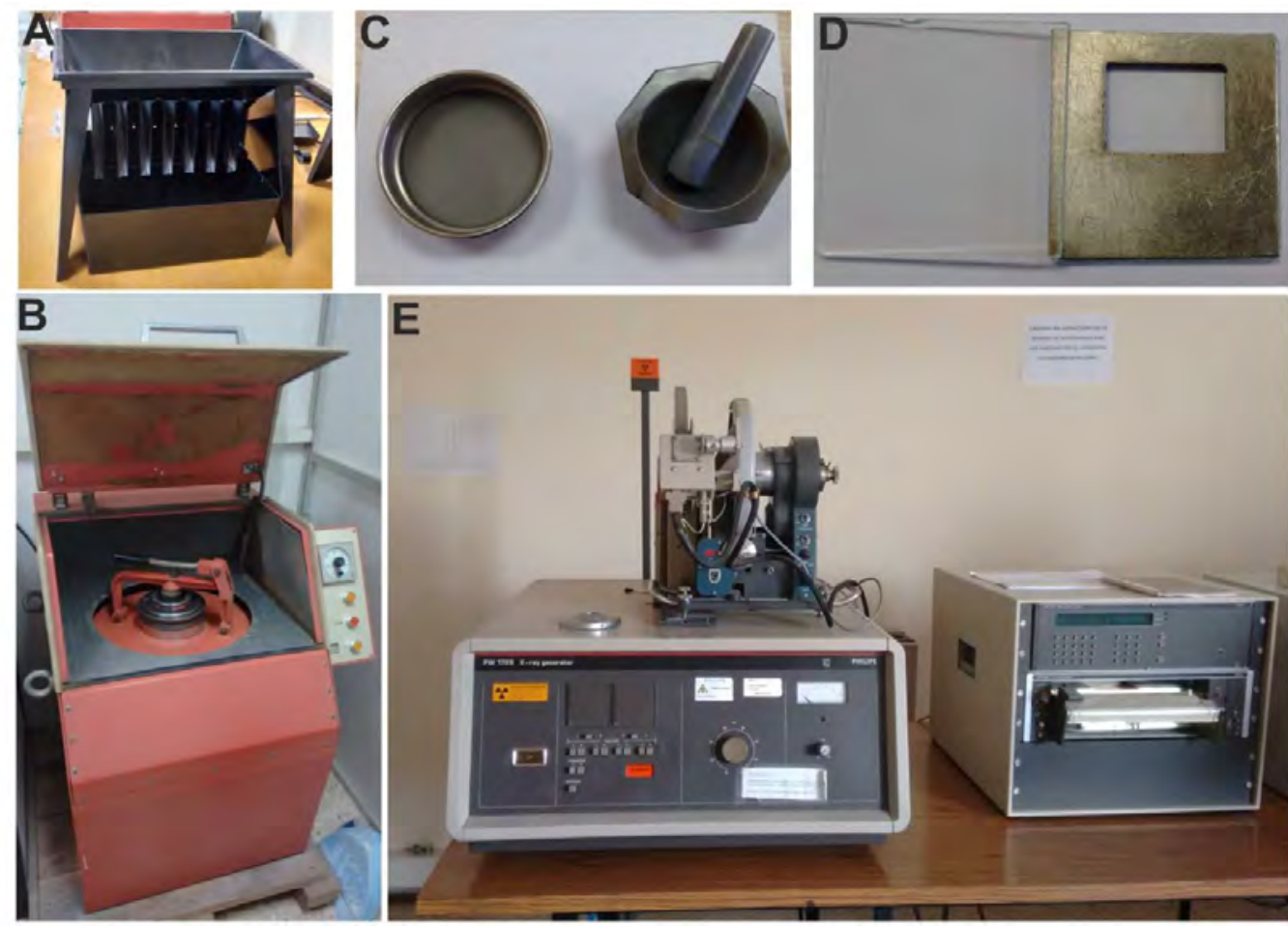

Fig.2.10. A) cuarteador, B) molino de aros para moler la muestra, C) mortero y tamiz de $56 \mu$, D) portamuestra y E) difractómetro del Área de Cristalografía y Mineralogía de la Universidad de Zaragoza.

\subsubsection{Técnicas espectroscópicas}

\subsubsection{FE-SEM (Field Emision Scanning Electron Microscopy) con detector EDS (Energy Dispersive X-ray Spectroscopy)}

El estudio de las inclusiones presentes en los distintos minerales pesados de las playas se realizó mediante microscopía electrónica de barrido. Se utilizó un equipo de emisión de campo (FESEM) Carl Zeiss MERLIN, con una resolución espacial de hasta 0,8 $\mathrm{nm}$, con voltajes de aceleración entre 0,02 y $30 \mathrm{Kv}$ del Servicio de Microscopía Electrónica de Material de la Universidad de Zaragoza (Fig. 2.11B). Este equipo lleva acoplado un sistema informatizado de Análisis de Energía Dispersiva de Rayos X (EDS) INCA 350 de 
Oxford Instruments con resolución en energía de $127 \mathrm{KeV}$ a 5,9 KeV. Las muestras fueron recubiertas con grafito para hacerlas conductoras. En las imágenes de electrones retrodispersados se utilizó una distancia de trabajo entre 5,9 y 6,1 $\mathrm{mm}$ y un voltaje de 15 kV. La composición química de las fases se obtuvo a partir de los rayos $\mathrm{X}$ generados por las mismas, recogidos y tratados mediante un detector EDS, cuyo límite de detección aproximado es de $0,1 \%$ y el error de cuantificación entre el $5 \%$ y el $10 \%$ dependiendo del mineral.

\subsubsection{Microsonda Electrónica (EPMA, Electron Probe Micro Analyzer)}

Los análisis químicos cuantitativos se efectuaron mediante tres microsondas electrónicas distintas: modelo CAMECA SX-100 de la Universidad de Oviedo (España), modelo JEOL JXA-8230 del CCiTUB, Universidad de Barcelona (España) y modelo JEOL JXA-8230 del LAMARX, Universidad Nacional de Córdoba (Argentina).

La microsonda CAMECA SX-100 de Oviedo está dotada con cinco espectrómetros dispersivos de longitud de onda (WDS), un espectrómetro de energía dispersiva (EDS) y detectores SE, BSE, ABS y catodoluminiscencia. Las rutinas analíticas para los silicatos, óxidos y fosfatos se realizaron con corriente de 15 y 30 nA, voltaje de aceleración de 15 $\mathrm{keV}, 2 \mu \mathrm{m}$ de tamaño del haz de electrones y tiempo de medición de entre 5 y 10 segundos por elemento. Para el circón se utilizó una rutina diferente con un voltaje de aceleración 25 keV, corriente de 100 nA y $2 \mu \mathrm{m}$ de tamaño del haz de electrones, con tiempos de medición entre 5 y 20 segundos por elemento. Las condiciones de medición para los sulfuros fueron con un voltaje de aceleración de $20 \mathrm{keV}$, corriente de $25 \mathrm{nA}, 2 \mu \mathrm{m}$ de tamaño del haz de electrones y tiempo de medición por elemento que varió de 5 a 30 segundos. Para el oro se realizaron dos rutinas analíticas con un voltaje de aceleración de $20 \mathrm{keV}$, tamaño del haz de electrones de $2 \mu \mathrm{m}$, tiempo de medición entre 10 y 60 segundos por elemento y corriente de $40 \mathrm{nA}$.

La microsonda de la Universidad de Barcelona consta de 5 espectrómetros WDS y un EDS. Se realizaron dos rutinas analíticas, una para silicatos y óxidos con un voltaje de aceleración de $20 \mathrm{keV}$. y una corriente de $6 \mathrm{nA}$. y otra para los granos de oro con un voltaje de aceleración de $20 \mathrm{keV}$. y una corriente de $20 \mathrm{nA}$. En ambas rutinas el conteo fue de 20 segundos por elemento y la corrección mediante el método XPP.

La microsonda electrónica JEOL JXA-8230 de la Universidad de Córdoba consta de 3 espectrómetros WDS y un EDS. Se realizaron dos rutinas analíticas, una para óxidos y otra para silicatos, con un voltaje de aceleración de $15 \mathrm{keV}$, una corriente de $20 \mathrm{nA}$ y un tiempo de medición de 10 segundos por elemento (Fig.2.11A). 
La calibración se realizó utilizando estándares naturales y sintéticos. Los principales estándares utilizados fueron: forsterita, ortosa, rodonita y wollastonita para $\mathrm{Si}$; hornblenda, ilmenita y $\mathrm{MnTiO}_{3}$ para $\mathrm{Ti} ; \mathrm{ZrO}_{2}$ y circón para $\mathrm{Zr}$; anortita y $\mathrm{Al}_{2} \mathrm{O}_{3}$ para $\mathrm{Al}$; cromita para $\mathrm{Cr}$; andradita, fayalita, hematita, pirita y magnetita para $\mathrm{Fe}$; rodonita y $\mathrm{MnTiO}_{3}$ para $\mathrm{Mn}$; niquelina y $\mathrm{NiO}$ para $\mathrm{Ni}$; ZnO para Zn; diópsido, MgO y forsterita para Mg; andradita, calcita, apatita y wollastonita para $\mathrm{Ca}$; albita y anortoclasa para $\mathrm{Na}$; ortosa para $\mathrm{K}$; willemita para el Zn; apatita para P; $\mathrm{YPO}_{4}$ para Y; pirita para S; V para el V, $\mathrm{Ag}_{2} \mathrm{Te}$ para Ag, Au, para Au, $\mathrm{Cu}$ para el $\mathrm{Cu}$, Bi para $\mathrm{Bi}$; topacio, LiF y apatito para $\mathrm{F}$; sodalita y vanadinita para $\mathrm{Cl}$; fosfatos de $\mathrm{Nd}$, Dy, Yb, Y y Er para las citadas tierras raras; $\mathrm{HfO}_{2}$ y circón para $\mathrm{Hf}$ y $\mathrm{ThO}_{2}$ para Th.

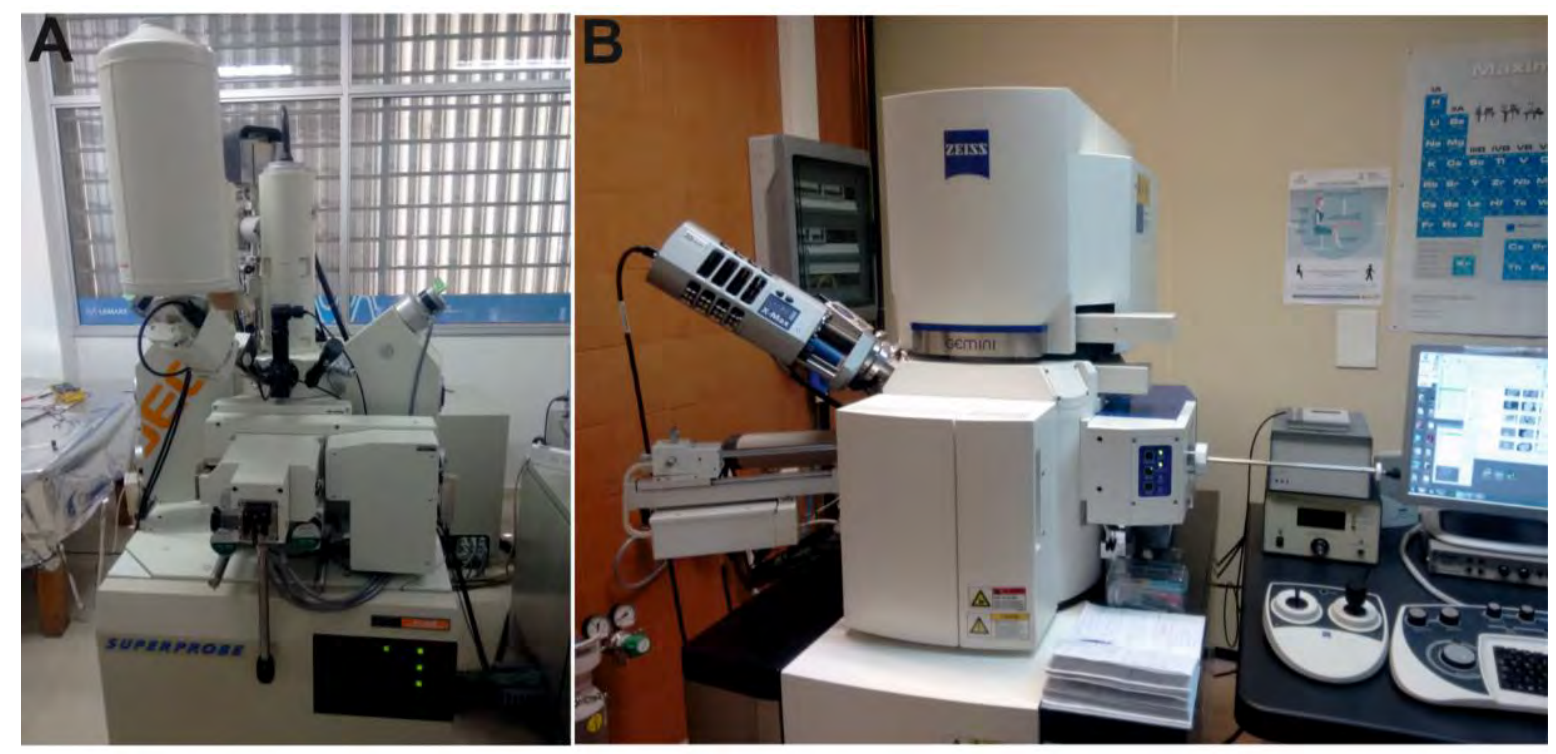

Fig.2.11. A) Microsonda electrónica de la Universidad de Córdoba (Argentina). B) Microscopio electrónico de barrido de la Universidad de Zaragoza (España). 


\section{Capítulo 3: GEOLOGÍA Y GEOMORFOLOGÍA DEL ÁREA DE ESTUDIO Y REGIONES ADYACENTES}

\subsection{Contexto geotectónico}

Actualmente la configuración geotectónica de la Isla Grande de Tierra del Fuego está asociada a la presencia e influencia de tres placas tectónicas mayores: la Placa Antártica (PA), la Placa Sudamericana (PSA), que es subducida por la anterior y la Placa de Scotia (PS), relacionada con la PSA a través de un límite transformante levógiro (Diraison et al. 2000) (Fig.3.1A).

Como resultado de la evolución tectónica se pueden diferenciar distintas regiones morfoestructurales (Klepeis 1994): a) Cuencas de antepaís Magallanes (CAM) y Malvinas (CM), b) Faja Corrida y Plegada (FCP), c) Complejo Metamórfico Cordillera Darwin (CMCD), d) Cuenca Marginal de Rocas Verdes (CMRV) y e) Batolito Patagónico (Fig.3.1B).

La zona de trabajo se ubica en el sector sur de la cuenca Magallánica o Austral, localizada en el extremo suroccidental de la placa Sudamericana. Esta cuenca compartida por Chile y Argentina limita hacia el oeste con los Andes Patagónico-Fueguinos, hacia el norte y este con el arco o dorsal Río Chico-Dungeness y hacia el sureste con la cuenca de Malvinas (Malumián et al. 2013).

La cuenca Austral presenta una superficie aproximada de $230.000 \mathrm{~km}^{2}$, con un relleno sedimentario de edad cretácico-cenozoico de más de $7 \mathrm{~km}$ de espesor (Malumián et al. 2013). Está asociada a la Faja Corrida y Plegada desarrollada entre los $51^{\circ}$ y $54^{\circ} \mathrm{S}$ constituyendo el margen activo de la cuenca de antepaís desarrollado entre el Cretácico superior y el Paleógeno (Ghiglione 2002 y referencias allí citadas).

La historia geológica de la zona austral de Sudamérica está relacionada con distintos regímenes tectónicos que provocaron el origen y cierre de la Cuenca Marginal de Rocas Verdes, el levantamiento de los Andes Fueguinos y la formación de las cuencas de antepaís de Magallanes y Malvinas.

Desde el Paleozoico superior y hasta el Jurásico inferior-medio existió un régimen de subducción compresivo en el margen Pacífico (Panthalásico) de Gondwana, cuyo prisma de acreción está bien expuesto en la Cordillera Darwin, en Chile (Mukasa y Daziel 1996), aflorando también en la bahía Lapataia, Argentina (Kranck 1932). Estas rocas que alcanzaron facies de alto grado metamórfico (asociación estaurolita-cianita-sillimanita) constituyen el basamento regional. 


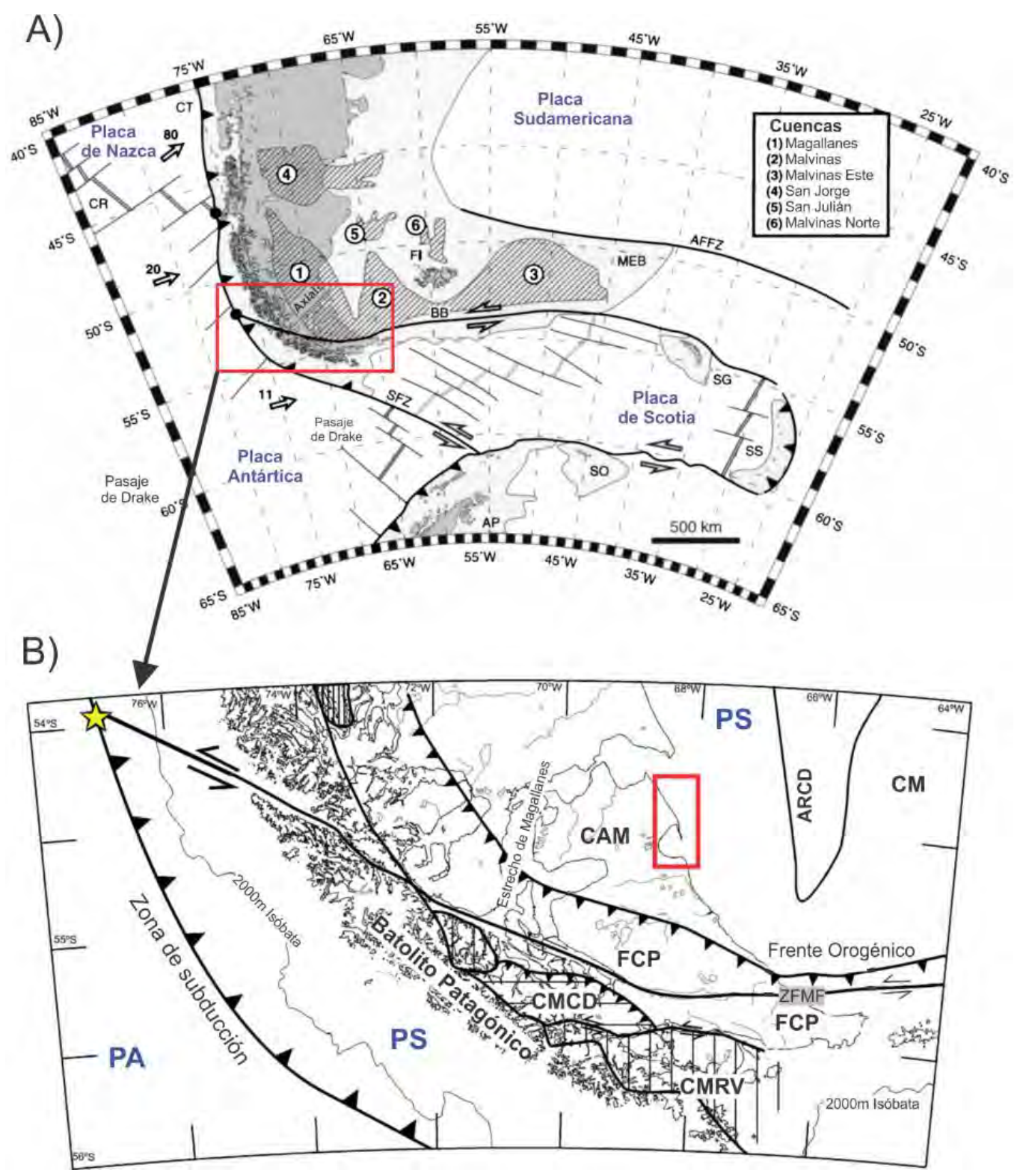

Fig.3.1. A) Contexto geotectónico regional. Tomado de Diraison et al. (2000). Abreviaturas: AFFZ, zona de fractura Agulhas-Malvinas; AP, península Antártica; BB, Banco Burdwood; CT, Fosa Chilena; Fl, Islas Malvinas; MEB, Banco Maurice-Ewing; SFZ, Zona de Fractura Shackleton; SG, Islas Georgias del Sur; SO, Islas Orcadas del Sur; SS; Islas Sándwich del Sur. El recuadro rojo corresponde con la zona ampliada debajo. B) Provincias morfoestructurales. Modificado de Ghiglione y Ramos (2005). Abreviaturas: ZFMF, Zona de Fallas Magallanes-Fagnano; FCP, Faja Corrida y Plegada; ARCD, Arco Río Chico-Dungeness. La estrella indica un punto triple entre las placas tectónicas y el recuadro rojo la ubicación de la zona de trabajo.

Según la revisión de Olivero y Malumián (2008) se pueden diferenciar desde el Mesozoico tres regímenes tectónicos distintos: a) extensional (Jurásico-Cretácico inferior), b) compresional (Cretácico superior-Paleógeno) y c) transcurrente (OligocenoCuaternario).

Durante el Jurásico se inició un régimen de extensión relacionado con el desmembramiento de Gondwana, generándose un gran campo volcánico riolítico en la 
Patagonia durante el Jurásico medio-superior (Hanson y Wilson 1991). Este volcanismo en el sur de Tierra del Fuego está representado por la Fm. Lemaire, relacionada con un rift marino profundo (Hanson y Wilson 1991, Olivero y Martinioni 1996). La continuación de este régimen durante el Jurásico superior-Cretácico inferior provocó la apertura de la cuenca marginal de tras arco Rocas Verdes, separada del mar abierto al sur por una cadena de islas volcánicas (Batolito Fueguino y Fm. Hardy), llegándose a desarrollar corteza oceánica (Complejo Ofiolítico Tortuga; Dalziel et al. 1974, Suárez et al. 1985). Sobre ella se depositó el relleno volcanoclástico relacionado con la fase de subsidencia térmica (Mpodozis et al. 2011), constituido por la Formación Yahgán cuyos depósitos detríticos andesíticos son similares a los del arco volcánico (Fm. Hardy; Suárez et al. 1985, Olivero y Martinioni 2001) y las sedimentitas marinas de la Formación Beauvoir (Olivero y Martinioni 1996).

La cadena de islas volcánicas dio origen a la Fm. Hardy, de afinidad calcoalcalina y en ella se emplazó gran parte de las rocas plutónicas del Complejo de Gabros y las plutonitas más antiguas de la suite Beagle.

A mediados del Cretácico estos esfuerzos cambiaron a un régimen compresivo que provocó el cierre de la cuenca marginal y el desplazamiento del arco volcánico hacia el continente (Dalziel et al. 1974). Como consecuencia de ello, una intensa deformación afectó al relleno de la cuenca, a las rocas plutónicas emplazadas en ella y, en menor medida, a las rocas del arco volcánico (Suárez et al. 1985). Según Hervé et al. (1984) la fase de deformación principal se produjo durante la evolución del Batolito Patagónico, alcanzándose el pico de metamorfismo (facies de anfibolita) entre los 100 y 90 Ma (Olivero y Malumián 2008 y referencias allí citadas). Los Andes Fueguinos se estructuraron durante el Cretácico tardío-Paleógeno a partir de esta intensa deformación y metamorfismo, además de corrimientos con vergencia hacia el NE-NNE, lo que provocó la subsidencia flexural por carga tectónica que dio origen a las cuencas de antepaís Austral y de Malvinas (Ghiglione et al. 2002 y referencias allí citadas).

La transición entre el cierre de la Cuenca de Rocas Verdes y el comienzo de la cuenca Austral está constituida por los depósitos marinos profundos (representados en el sector argentino por los Estratos de Buen Suceso, Turoniano-Campaniano inferior) asociados con ambientes de plataforma externa a talud (Olivero y Malumián 2008). El avance de esta deformación compresional provocó la migración progresiva de los depocentros hacia el norte desde el Cretácico tardío hasta el Mioceno, con algunas secuencias restringidas al sector adyacente al orógeno (Torres Carbonell et al. 2009).Tres depocentros (desde el Campaniano tardío hasta el Eoceno superior), constituidos por 
potentes secuencias marinas, se localizan dentro de la Faja Corrida y Plegada en el sector argentino (formaciones Bahía Thetis, Policarpo y Tres Amigos, Grupo Río Claro y Grupo La Despedida). Un cuarto depocentro (Oligoceno inferior-Mioceno medio) incluye rocas sedimentarias marinas y continentales al norte de la faja (Grupo Cabo Domingo), representando el último relleno de la cuenca remanente (“foredeep") asociado con la disminución de la deformación por compresión (Olivero y Malumián 2008). La formación de Calizas Río Bueno (Eoceno) y los depósitos fluviales de las formaciones Punta Cactus y Sloggett (Eoceno superior-Oligoceno inferior) se incluyen dentro de la faja (Olivero y Malumián 2008).

Como consecuencia del desplazamiento de las placas Sudamericana y Antártica, la apertura del pasaje Drake y la generación de la placa de Scotia, el régimen tectónico pasó a transcurrente (Ramos et al. 1986, Cunningham 1993, Cunningham et al.1995, Ghiglione 2003). Este régimen está asociado con la actividad del sistema de fallas sinistral Magallanes-Fagnano localizado en el límite de las placas Sudamericana y de Scotia. E cambio de un régimen compresivo a transcurrente en Tierra del Fuego ocurrió durante el Oligoceno y Mioceno (Klepeis y Austin 1997, Ghiglione 2002) desarrollándose en el sector argentino pequeñas cuencas de pull apart constituidas por los depósitos marinos Formación Irigoyen y Estratos de la María Luisa (Olivero y Malumián 2007 y referencias allí citadas). Asociada con un régimen transcurrente-transpresivo, en la costa Atlántica se produjo la intrusión de diques clásticos durante el Mioceno inferior (Ghiglione 2002). En la región cordillerana del sector chileno, durante el Mioceno, se desarrolló un vulcanismo calcoalcalino y alcalino (Fm. Packsaddle; Puig et al. 1984).

En el Neógeno se desarrolló un rift perpendicular al orógeno (NE-SO), responsable de la apertura del Estrecho de Magallanes y de la separación de Tierra del Fuego del continente, rellenándose durante el Cuaternario con depósitos glacígenos (Diraison et al. 1997, 2000). Ghiglione et al. (2012) relacionan el desarrollo de este rift con la reactivación extensional de fallas jurásicas de transferencia. Durante el Plioceno y Cuaternario se produjo una intensa actividad volcánica con la generación de basaltos alcalinos en el área de Pali Aike (al norte del Estrecho de Magallanes), donde la alineación de los volcanes indica un ascenso del magma a través de la reactivación de estas fallas jurásicas (Corbella et al. 1996, Mazzarini y D’Orazio 2003, Ghiglione et al. 2012). 


\subsection{Geología regional}

\subsubsection{Estratigrafía del sector continental cordillerano}

Para entender la composición mineralógica de los depósitos presentes en la costa noreste de Tierra del Fuego es necesario considerar la geología de la región cordillerana incluyendo el sector chileno donde afloran unidades que no tienen equivalencia, o todavía no se han identificado, en el sector argentino.

A continuación, se describen las distintas unidades que tienen interés bajo el punto de vista de la posible proveniencia de las fases minerales que se encuentran en los depósitos del NE de la Isla Grande de Tierra del Fuego. Siguiendo la dirección de las masas glaciales, el área fuente se correspondería con la Cordillera Darwin y zonas adyacentes (Fig.3.2)

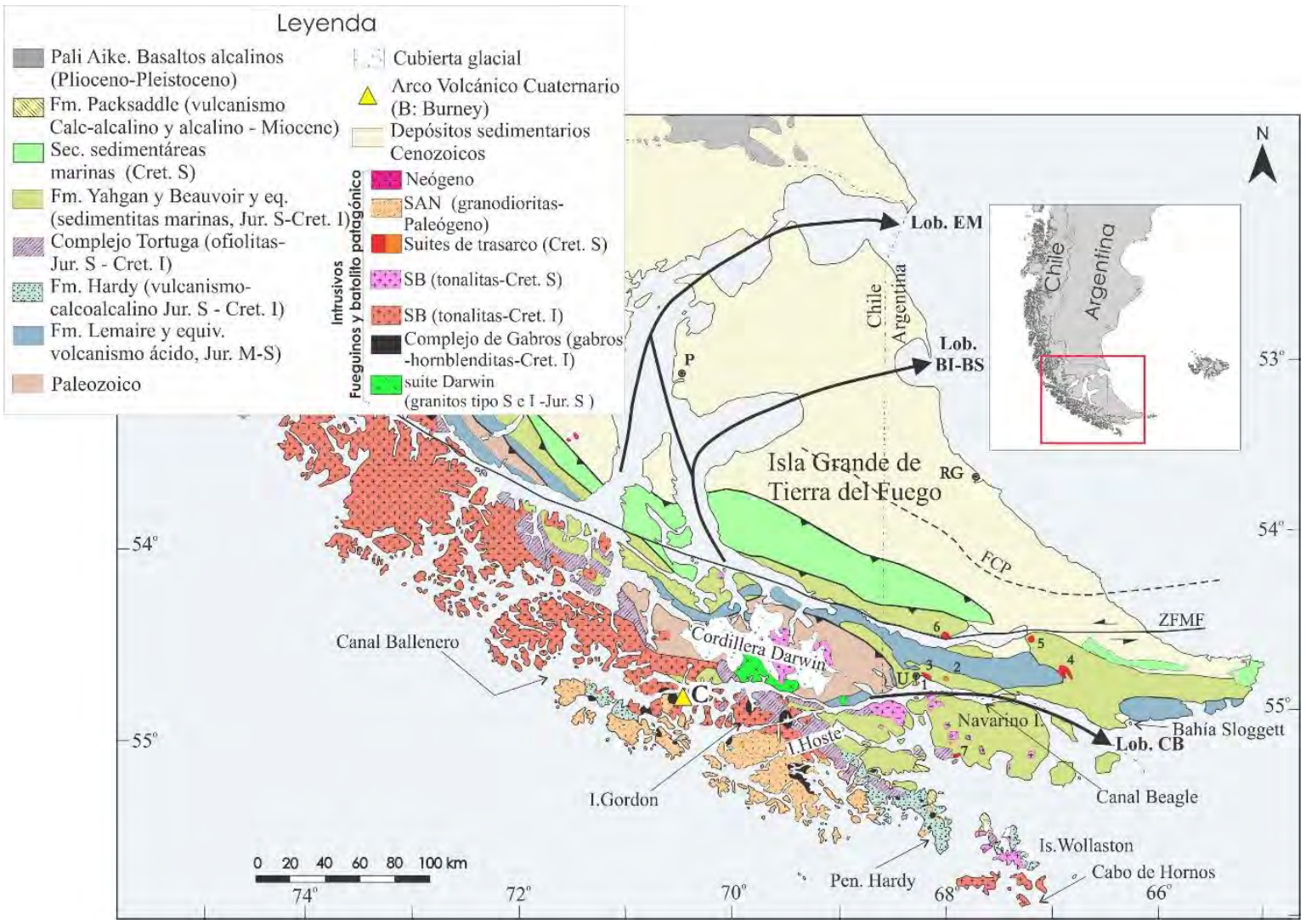

Fig.3.2. Mapa Geológico regional de Tierra del Fuego y sur de Santa Cruz (tomado de González-Guillot 2016). Abreviaturas: FCP Faja Corrida y Plegada, ZFMF Zona de Falla Magallanes-Fagnano, C Volcán Cook, U Ushuaia, RG Río Grande, PA Punta Arenas. Los números indican intrusiones de trasarco: 1 Península Ushuaia, 2 Cerro Trapecio, 3 Ushuaia, 4 Moat, 5 JeuJepén, 6 Kranck y el número 7 indica un plutón monzonítico correlacionado con estas intrusiones. Lob. EM lóbulo Estrecho de Magallanes, Lob.BI-BS lóbulo Bahía Inútil-Bahía San Sebastián y Lob. CB lóbulo Canal Beagle. SB suite Beagle y SAN suite Seno Año Nuevo. 
Las sedimentitas marinas y continentales presentes desde el Cretácico superior no se describen (a excepción de las presentes en la zona de trabajo, ver en 3.3 Geología Local) ya que carecen de interés para los objetivos de esta investigación. Se puede encontrar información de estas unidades en los trabajos de Olivero y Martinioni (2001) y Olivero y Malumián (2008).

\subsubsection{Rocas de basamento (Paleozoico superior-Jurásico medio)}

El basamento de la cordillera Fueguina está constituido por los High Metamorphic Schists denominados por Kranck (1932). Estas metamorfitas de grado medio a alto afloran en la Cordillera Darwin (Complejo Metamórfico Cordillera Darwin) y en el sector occidental del Canal Beagle argentino donde Borrello (1969) las denominó como Metamorfita Lapataia. Una discordancia separa el basamento de la Formación Lemaire (Caminos et al. 1981).

En el sector argentino, Caminos et al. (1981) describen estas rocas como filitas gris verdosas muy deformadas e inyectadas con venas de cuarzo. Mineralógicamente las rocas que conforman la Metamorfita Lapataia, según las descripciones de Kranck (1932) y Caminos (1980), están constituidas por cuarzo, albita y moscovita junto con calcita, epidoto y titanita en menor medida. En algunas zonas, intercaladas entre las filitas afloran cuerpos de rocas básicas metamorfizadas (metabasitas, esquistos verdes ofiolíticos y anfibolitas de bajo grado) compuestos por actinolita, clorita, epidoto y albita (Caminos et al.1981). Estos autores observaron también, menos frecuentemente, la asociación cuarzo-albita-actinolitamoscovita-titanita.

Por otra parte, Olivero et al. (1997) describen esquistos finos cuarzo-sericíticos con granate y una extensa cloritización en la bahía Ensenada y esquistos psamíticos con biotita al sur de la bahía Lapataia e Isla Redonda.

En la Cordillera Darwin, las rocas de basamento consisten en unidades metasedimentarias (metapelitas y metapsamitas) y metavolcánicas (gneisses) (Hervé et al. 2010) en las cuales se alcanza el grado metamórfico más elevado de la cordillera, observándose la asociación de minerales metamórficos de granate, estaurolita, cianita, sillimanita (Hervé et al. 2008). Presentan una cobertura mesozoica de rocas volcánicas riolíticas de la Formación Lemaire y metapelitas de la Formación Yahgán (Hervé et al. 1981). Todas estas rocas están intruidas por metagranitoides de la suite Darwin (transformados por el metamorfismo a ortogneises), intersectados por diques basálticos (transformados a anfibolitas) y por plutones no deformados de tonalita y granodiorita de la suite Beagle (Nelson et al. 1980). 
Según Kranck (1932) las rocas de Cordillera Darwin muestran un grado metamórfico desde esquistos verdes hasta anfibolitas. Este autor identificó en la bahía Plüschow, al oeste de la cordillera, esquistos con granate, glaucofano y minerales del supergrupo de la turmalina que se asocian a la influencia térmica relacionada con la intrusión de los granitoides. Hacia el este, en el sector de bahía Lapataia, el grado metamórfico se corresponde con el de la parte baja de los esquistos verdes (Caminos 1980).

\subsubsection{Formación Tobífera o Lemaire (Jurásico superior).}

Borrello (1969) designó con este nombre al conjunto volcánico sedimentario presente en la cordillera Fueguina, siendo equivalente con la Formación Tobífera de los Andes Patagónicos. Aflora constituyendo fajas discontinuas con orientación NO desde Isla de los Estados hasta el Seno Almirantazgo (Chile).

La Formación Tobífera conforma un complejo volcano-sedimentario submarino que incluye rocas epiclásticas (areniscas, conglomerados, chert, fangolitas negras con radiolarios y carbonáceas), rocas volcánicas ácidas y volcanoclásticas (lavas riolíticas, flujos piroclásticos, brechas, tobas y lapillis), pórfidos cuarzosos subvolcánicos y espilitas basálticas (Hanson y Wilson, 1991).

Olivero et al. (1997) describen las tobas o pórfidos de esta formación en la bahía Ensenada con textura blastoporfídica cataclástica-milonítica y composición riolítica, riodacítica y dacítica. La mineralogía está dominada por cristales de cuarzo, feldespato alcalino (albita) y en menor medida anfíbol. Como minerales accesorios describen titanita, circón, allanita y minerales opacos. Dentro de los minerales metamórficos identifican biotita-flogopita, estilpnomelano, sericita-moscovita y como mineral de alteración clorita. Estos mismos autores describen las areniscas tobáceas con una mineralogía similar dominada por cristales de cuarzo, feldespato y fragmentos líticos angulosos de volcanitas ácidas.

Las lavas y filones básicos están constituidos por plagioclasa con y sin clinopiroxeno (augita, $\mathrm{Wo}_{41,6} \mathrm{En}_{46,8} \mathrm{Fs}_{11,6}-\mathrm{Wo}_{39,5} \mathrm{En}_{48,3} \mathrm{Fs}_{12,2}$ ). También aparecen otros minerales primarios como pirrotina y titanita (Quartino et al. 1989, González Guillot et al. 2016).

El conjunto de la formación presenta un grado de metamorfismo muy bajo, facies prehnita-pumpellyíta (Caminos 1980), sin embargo, está fuertemente deformada y cortada por venas de cuarzo y en menor abundancia carbonatos, con un clivaje muy penetrativo que ha obliterado la estratificación en las facies de grano fino (Olivero et al. 1997).

El contacto con la Formación Yahgán es principalmente tectónico (Olivero y Malumián 2008). Las relaciones estratigráficas de esta formación con las ofiolitas del 
Complejo Tortuga y las rocas del arco volcánico (Fm. Hardy) no han sido precisadas todavía con claridad (Suárez et al. 1985, Miller et al. 1994).

\subsubsection{Formación Hardy (Jurásico superior-Cretácico inferior).}

La Formación Hardy fue definida por Suárez y Pettigrew (1976) para agrupar una secuencia de por lo menos 600 m de espesor (medido en la Península Hardy) de rocas volcanoclásticas (piroclásticas) y epiclásticas, con lavas riolíticas y basálticas (Suárez 1979). Aflora en la península Hardy (isla Hoste) y en otras islas del archipiélago chileno.

Las rocas piroclásticas incluyen tobas vítreas y en menor proporción líticas, tobas acrecionarias (Dott et al. 1977), cherts volcanogénicos, brechas riolíticas y andesíticas e ignimbritas alteradas (Suárez et al. 1985).

Las rocas epiclásticas están constituidas por areniscas y conglomerados, con contenido variable de material piroclástico. Poseen fauna marina fósil y presentan gradación normal (Suárez et al. 1985)

Las lavas basálticas se intercalan en la secuencia volcanoclástica en coladas normalmente con espesores inferiores a 1,5 m. Algunas muestran textura intergranular, compuesta por plagioclasas alteradas a cloritas y clinopiroxenos con abundantes minerales opacos. Otras poseen textura ofítica y están compuestas por plagioclasas y clinopiroxenos, clorita, leucoxeno y minerales opacos. Ocasionalmente se observan seudomorfos de posibles olivinas y las amígdalas están rellenas por clorita y ceolitas (Suárez et al. 1985).

Estas rocas alcanzaron el grado de metamorfismo de la facies ceolita y prehnitapumpellyíta (Suárez et al.1985).

La Formación Hardy representaría el arco volcánico existente en el Jurásico superior-Cretácico inferior (Suárez 1979, Miller et al. 1994). La alternancia de rocas piroclásticas y lavas se interpreta como evidencia de vulcanismo de estratovolcanes en un ambiente de deposición subaéreo y submarino (Suárez et al.1985).

Suárez et al. (1985) infieren que la Formación Hardy es previa a los basaltos del Complejo Tortuga, del Jurásico superior-Cretácico inferior, y que la actividad volcánica que dio origen a esta formación habría continuado durante el Cretácico inferior, interpretando también, que los niveles bajos podrían correlacionarse en parte con la Formación Lemaire o Tobífera.

\subsubsection{Complejo Tortuga (Jurásico superior-Cretácico inferior).}

Suárez et al. (1985) describen el Complejo Tortuga como una sucesión máfica pseudoestratificada, de base a techo: troctolitas, gabros, diabasas, basaltos y brechas 
almohadilladas. Aflora en el Cerro Tortuga, extremo SO de la Isla Navarino y en Isla Milne Edwards. Toda la secuencia está cortada por diques lamprofíricos (Avendaño 2008). La sucesión de rocas concuerda con la sección superior de una ofiolita, explicándose la ausencia del resto de la secuencia (rocas ultramáficas en los niveles inferiores) a causa de que el nivel de erosión es poco profundo ya que los gabros se encuentran al nivel del mar (Suárez et al. 1985).

Las troctolitas están constituidas por cristales de olivina y plagioclasa (normalmente labradorita-bitownita) y de manera subordinada clino y ortopiroxeno (Suárez et al. 1985). En los gabros la mineralogía predominante está constituida por plagioclasas (bitownita), clinopiroxenos (diópsido y augita) y de manera subordinada ortopiroxenos (hipersteno o enstatita rica en $\mathrm{Fe}$ ) y olivina (forsterita) y minerales opacos (pirrotina y calcopirita > cubanita, pirita, pseudomorfos de hematita, magnetita, oxi-hidróxidos de Fe y bornita) (Avendaño 2008, Coloma 2010). Son rocas de grano medio a grueso, cuya textura es maciza y bandeada, lo que es interpretado como cumulados magmáticos (Suárez 1976). Las diabasas forman niveles de cuerpos masivos y como enjambres de diques. La mineralogía primaria corresponde con plagioclasas (algunas de ellas con inclusiones de clinopiroxeno), clinopiroxenos, ortopiroxenos y minerales opacos (titanomagnetita con alteración a leucoxeno y pseudomorfos de hematita > pirrotina, calcopirita, pirita y oxihidróxidos de Fe) (Avendaño 2008, Coloma 2010). Los basaltos y brechas almohadilladas constituyen el techo del Complejo. Están compuestos por coladas de cuerpos masivos y basaltos almohadillados con diaclasamiento radial (Suárez et al. 1985). Mineralógicamente están constituidos principalmente por plagioclasa, clinopiroxeno, ortopiroxeno, olivina y minerales opacos (pirrotina y calcopirita >pirita, oxi-hidróxidos de Fe y magnetita) (Avendaño 2008, Coloma 2010). Los fenocristales de los lamprófidos están representados por hornblenda, plagioclasa, piroxeno y olivina.

La geoquímica de estas rocas máficas es tholeítica, asociada con los basaltos de fondo oceánico (Suárez 1976, Suárez 1977a, Avendaño 2008).

Presentan un metamorfismo desarrollado en condiciones estáticas de tipo térmico, sin desarrollo de foliación en donde Stern y Elthon (1979) describen 4 facies desde ceolitas hasta actinolita, a medida que se desciende en la columna estratigráfica, desapareciendo en los gabros frescos. Estos investigadores lo relacionan con el metamorfismo hidrotermal de fondo oceánico, asociado a celdas convectivas de agua marina en dorsales en expansión, que no habrían alcanzado los niveles inferiores de gabros. En algunos sectores al oeste del Canal Beagle, el metamorfismo alcanza la facies de esquistos verdes (Suárez et al.1985). 
Respecto a la relación estratigráfica, el Complejo Tortuga infrayace a la Fm. Yahgán y suprayace a las Formaciones Tobífera y Hardy (Suárez 1979).

\subsubsection{Formación Yahgán (Jurásico superior-Cretácico inferior).}

El nombre de esta Formación fue establecido por Kranck (1932) para agrupar un conjunto de sedimentitas débilmente metamorfizadas ocasionalmente intercaladas con rocas volcánicas básicas. Aflora desde Ushuaia hasta bahía Sloggett a largo de la costa norte del Canal Beagle, y en el sector chileno en las islas Hoste, Navarino, Nueva, Lennox y Picton (Dott et al. 1977, Winn 1978, Suárez et al. 1985).

La Formación Yahgán consiste en brechas y conglomerados, areniscas, tobas limolíticas negras y tufitas, intruidas por rocas basálticas (Olivero y Martinioni 2001) y gabros (Villar et al. 2007, González Guillot et al. 2016).

Caminos (1980) describió los afloramientos de los montes Martial y Olivia como pizarras bandeadas con alternancia de arenisca fina y limoarcilitas, con algunos niveles con arenisca gruesa y brechas con clastos lutíticos y matriz arcillo-lutítica. La fracción arcillosa esta recristalizada a cuarzo, sericita, epidoto, calcita, prehnita y óxidos de hierro. El bandeamiento composicional está fuertemente plegado y cortado por clivaje de plano axial.

En los basaltos alcalinos que se intercalan con las sedimentitas, Acevedo (2016) identificó xenocristales de anfíbol (kaersutita), feldespato alcalino, clinopiroxeno (augita) y ortopiroxeno (enstatita), espinela, magnetita-ulvoespinela, flogopita y olivina (forsterita). En la pasta pudo analizar olivina (forsterita), clinopiroxeno (augita), feldespato alcalino, apatita y minerales opacos. En un xenolito ultrabásico identificó granate (piropo), clinopiroxeno y bitownita.

Próximo al Parque Nacional de Tierra del Fuego, Villar et al. (2007) y más tarde González Guillot et al. (2016) analizaron los Gabros Puente Quemado que intruyen a la Fm. Yahgán. Identificaron como minerales primarios clinopiroxeno (diópsido-augita), plagioclasa, ilmenita, titanita, hornblenda (ferroedenita y en menor medida ferrohornblenda), apatita, intercrecimientos de cuarzo, ortopiroxeno y olivina (estas dos últimas fases no fueron detectadas por González Guillot et al. 2016). La paragénesis metamórfica está constituida por cuarzo, albita, clorita, epidoto, actinolita, ferroactinolita, titanita en agregados, sericita, carbonatos, pirita, pirrotina y estilpnomelano.

Según Caminos (1980) el grado de metamorfismo regional se corresponde con el de la facies prehnita-pumpellyíta. Sin embargo, para Olivero y Martinioni (2001) la presencia de clorita, sericita, cuarzo, albita y epidoto indica el grado de esquistos verdes. 
En algunos lugares se evidencia también metamorfismo de contacto con esquistos andalucíticos (Nordenskjöld 1905) y cornubianitas nodulosas con porfidoblastos de cordierita (Caminos 1980). En la zona Estancia Túnel, Acevedo et al. (1989) reconocieron granate, biotita y recristalización de moscovita en los esquistos de esta Formación como consecuencia del metamorfismo de contacto relacionado con una intrusión ultramáfica.

La Formación Yahgán rellena la Cuenca Marginal Rocas Verdes durante la fase de hundimiento térmico post-rift (Fig.3.3) y se interpreta como una cuña volcanoclástica adosada al arco volcánico (Formación Hardy; Olivero y Martinioni 2001).

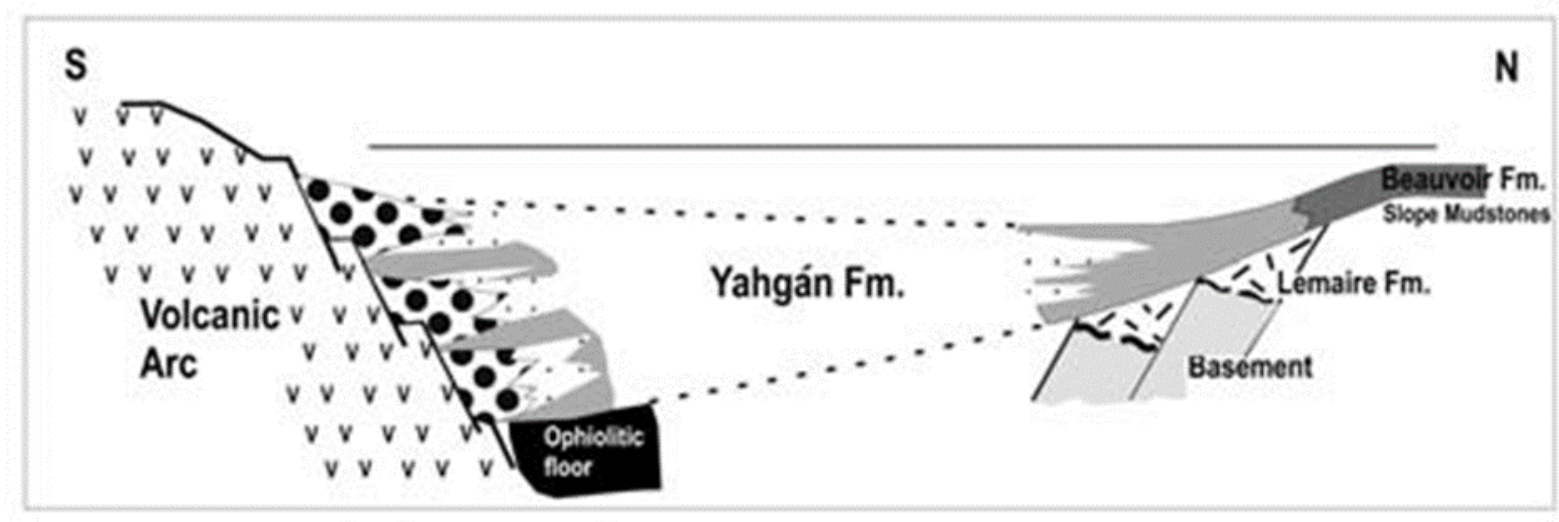

Fig.3.3. Configuración tectónica en el momento de la deposición de la Formación Yahgán (Jurásico superior-Cretácico inferior). Las sedimentitas de esta Formación están constituidas por conglomerados (puntos gruesos), areniscas (puntos finos) y lutitas (gris liso). Tomado de Olivero y Malumián (2008) a su vez modificado de Olivero y Martinioni (2001).

\subsubsection{Formación Beauvoir (Cretácico inferior).}

Denominada por Camacho (1948) como "Serie de Beauvoir" y más tarde por Furque (1966) como Formación Beauvoir, corresponde a un conjunto de sedimentitas que aflora en la sierra homónima, en el extremo noroccidental de la sierra Lucio López y desde la sierra Noguera hasta el extremo NE de la península Mitre (Petersen 1949). También se incluyen dentro de esta Formación las sedimentitas que afloran en la costa NE de la Isla de los Estados y las islas Año Nuevo (Caminos y Nullo 1979). Corresponden a esta unidad también los estratos del Hito XIX (Macellari 1979). Hacia el O, en Chile, los afloramientos de esta Formación se corresponden con las Formaciones La Paciencia y Vicuña (Natland, et al. 1974).

Está constituida por un conjunto homogéneo de pizarras gris oscuras, masivas a finamente laminadas y tobas de color gris claro, con escasas ritmitas de areniscas y limolitas. Los estratos suelen formar pliegues asimétricos, con clivaje subvertical de plano axial E-O (Olivero y Martinioni 2001). 
Las limolitas negras de la Formación Beauvoir constituyen una sedimentación de plataforma externa en el norte de Tierra del Fuego y un ambiente marino profundo, de talud y planicie abisal en el sur, donde grada lateralmente a la Formación Yahgán (Olivero y Martinioni 1996). Esta Formación es considerada también como la parte superior de la Fm. Yahgán, por lo que no se aconseja su separación como una entidad distinta (Acevedo 1988, 2019)

\subsubsection{Batolito Patagónico e intrusiones satélites (Jurásico superior- Terciario).}

El Batolito Patagónico de edad Jurásico superior a Terciario, se extiende a lo largo del margen continental andino de América del Sur, desde los $40^{\circ} \mathrm{S}$ hasta los $56^{\circ} \mathrm{S}$ de latitud, con un ancho que varía de 40 a $100 \mathrm{~km}$, dividiéndose en tres segmentos: Batolito Norpatagónico (al norte de los $47^{\circ} \mathrm{S}$ ), Batolito Surpatagónico $\left(47^{\circ}-53^{\circ} \mathrm{S}\right)$, y Batolito Fueguino (al sur de los $53^{\circ} \mathrm{S}$ ) (Hervé et al. 2007). El Batolito Patagónico es una intrusión múltiple, de composición calcoalcalina constituida principalmente por tonalitas y granodioritas y en menor proporción granitos, monzodioritas cuarcíferas, dioritas cuarcíferas, dioritas y gabros (Suárez 1977b, Suárez et al. 1985).

A continuación, se describirá más detalladamente el Batolito Fueguino (BF) ya que por las direcciones de las masas glaciales cuaternarias a través del Estrecho de Magallanes y de las bahías Inútil y San Sebastián, representa posibles áreas fuente de las rocas y minerales depositados en nuestro sector de trabajo.

El BF es una intrusión dominada por tonalitas y granodioritas (Hervé et al. 1984, Suárez et al. 1985, Nelson et al. 1988), pudiéndose dividir en: 1) granitoides tipo S de la Cordillera Darwin, 2) Plutones calcoalcalinos tipo I del arco principal y 3 ) intrusiones shoshoníticas y potásicas de trasarco "rear-arc" (Fig.3.4; González-Guillot 2016). A continuación, se describe cada uno de ellos.

\subsection{Granitoides tipo S Cordillera Darwin (Jurásico superior).}

Se agrupan en la suite Darwin y están dominados por ortogneises (protolito magmático deformado) intruidos en las rocas del basamento paleozoico y las secuencias mesozoicas, aflorando en el flanco continental del batolito en los Andes Fueguinos y Patagónicos (Nelson et al. 1980, Hervé et al. 2007). Los ortogneises derivan principalmente de granitos (leucogranitos) con biotita y granodioritas, con cantidades menores de granate, moscovita y anfíboles. También es común encontrar allanita y circón como minerales accesorios. La asociación de estas rocas con gabros les confiere una naturaleza bimodal 
(Hervé et al. 2007). Los gabros están compuestos principalmente por anfíboles (con hornblenda normalmente reemplazada por anfíboles secundarios, plagioclasas y sericita) y plagioclasa, identificando también menores cantidades de cuarzo, biotita, allanita, epidoto y titanita (Hervé et al. 2007).

Estas rocas están intruidas por diques máficos y por los granitoides no deformados de la suite Beagle (Nelson et al. 1980, Hervé et al. 2007).

De acuerdo con Suárez et al. (1990) estas rocas son algo intermedias entre granitos de tipo $S$ e I, generadas en un entorno extensional durante la fragmentación de Gondwana, adyacente a una zona de subducción. Los magmas que generaron estas rocas fueron contemporáneos con el final de la etapa extensiva con volcanismo riolítico (Fm. Lemaire) (Hervé et al. 2007).

\subsection{Plutones Calcoalcalinos de arco principal (Cretácico- Paleógeno).}

Al sur del Canal Beagle el Batolito Patagónico se divide en función de su petrografía, textura y fábrica estructural en tres unidades (Hervé et al. 1984, González-Guillot 2016): Complejo de Gabros (CG) (Cretácico inferior), suite Beagle (SB) (Cretácico inferiorsuperior) y suite Seno Año Nuevo (SAN) (Paleógeno).

Suárez et al. (1985), describen el Complejo de Gabros como gabros, gabronoritas, hornblenditas y dioritas, con variedades leuco y melanocráticas, dispuestas en afloramientos aislados distribuidos esporádicamente a lo largo del batolito. La composición modal media del CG corresponde a un gabro de hornblenda. Se caracteriza por presentar texturas cumulares, aunque también puede mostrar texturas ofíticas y granudas hipidiomórficas. La mineralogía consiste en diferentes proporciones de plagioclasas (normalmente labradorita), hornblenda, clinopiroxeno, ortopiroxeno y ocasionalmente olivina, biotita y cuarzo. Los minerales principales de alteración son anfíboles, clorita, calcita, titanita, epidoto y anhidrita.

Según Hervé et al. (1984), la suite Beagle domina el Batolito Fueguino y está constituida por tonalitas y granodioritas, aflorando también cuarzo-monzodioritas y cuarzodioritas en menor cantidad. Los granitoides presentan una foliación penetrativa sinmagmática formada probablemente en respuesta a diapirismo y/o a campos de esfuerzos regionales. Suárez et al. (1985) describen la mineralogía de estas rocas, constituidas por plagioclasas zonadas (andesina sódica a cálcica en los núcleos), feldespato alcalino (normalmente ortosa), cuarzo, hornblenda y biotita. El clinopiroxeno es muy escaso y aparece sólo como núcleos en anfíbol. Como minerales accesorios 
identifican apatita, titanita, minerales opacos y escasos circón y allanita. Según estos investigadores la composición modal promedio se corresponde con una tonalita.

Según Suárez et al. (1985) la suite Seno Año Nuevo está constituida principalmente por tonalitas y monzodioritas cuarcíferas, además de granitos y dioritas cuarcíferas. De acuerdo con la nomenclatura de Lameyre y Bowden (1982) muestra una tendencia calcoalcalina trondhjemítica de bajo potasio y otra calcoalcalina granodiorítica de contenido en potasio intermedio, correspondiendo el análisis modal con una granodiorita. La composición mineralógica es similar a la del Grupo Plutónico Canal Beagle. A diferencia de éste, no presenta una foliación penetrativa (Hervé et al. 1984) sin embargo la composición mineral es similar, variando el contenido de feldespato potásico que es mayor en el Grupo Seno Año Nuevo (Suárez et al. 1985).

\subsection{Plutones Tierra del Fuego de trasarco (sector argentino).}

En la zona de trasarco "rear Arc", en Tierra del Fuego, se identifican plutones aislados con una composición potásica ligeramente alcalina, el Magmatismo potásico fueguino (MPF) y otras intrusiones menores de composición calco-alcalina con alto contenido de K, las Andesitas de la Península de Ushuaia (APU) (González-Guillot 2009, 2016). Ambas suites aparecen como intrusiones dispersas al norte del Canal Beagle y este de la Cordillera Darwin, separadas del resto del batolito. A partir de los datos de GonzálezGuillot (2009) se describen ambas suites a continuación.

EI MPF es el más importante volumétricamente y contiene los plutones Hornblendita Ushuaia, Plutón Diorítico Moat, Intrusivo del Monte Kranck y Monzonita Jeu-Jepén. González Guillot (2009) estima su presencia en el subsuelo del Co. Trapecio e incluye también los diques básicos del Co. Rodríguez y otros en el sector chileno (islas Navarino y Gordon y península Barros). La composición de las rocas es muy variada: piroxenitas, hornblenditas, sienitas, sienitas alcalifeldespáticas, gabros, dioritas, monzograbros, monzodioritas, monzonitas y algunas variedades cuarzosas (monzogranitos y granitos alcalifeldespáticos). Respecto a la composición mineral, este autor identifica como componentes mayoritarios piroxeno (diópsido), hornblenda (magnesiohornblenda y magnesiohastingsita), biotita (rica en $\mathrm{MgO}$ ), plagioclasa y feldespato potásico. Otros constituyentes menores son cuarzo, apatita, titanita, epidoto, magnetita, ilmenita, ferroespinela y sulfuros (pirita, calcopirita, pirrotina). En las rocas ultramáficas, las mineralizaciones metalíferas, constituidas principalmente por óxidos a los que se les asocian sulfuros (fases minerales indicadas anteriormente), poseen además anomalías 
positivas de Pt y $\mathrm{Pd}$, compartiendo muchas características de los complejos tipo Alaska (González-Guillot y Schalamuk 2009).

Los plutones Ushuaia y Jeu-Jepén contienen también facies de borde de contacto compuestas por monzodioritas cuarzosas y tonalitas, caracterizadas por presentar biotita + granate \pm fibrolita \pm apatita (prismática y acicular) entre otros minerales, los que parecen ser el resultado de un híbrido entre magmas dioríticos o monzodioríticos (normales del MPF) y el fundido anatéctico originado por la fusión parcial de las metapelitas (Fm. Yahgán y Beauvoir; González-Guillot y Acevedo 2009, González-Guillot 2016).

Se caracterizan por su carácter potásico (alcalinidad media, serie shoshoníticamonzonítica). Presentan enriquecimiento en elementos incompatibles de alto radio iónico (LILE) y alta relación LILE/HFSE (elementos de alto potencial iónico) y LREE/HREE (elementos de las tierras raras livianas/ elementos de las tierras raras pesadas; González Guillot, 2009). Estos magmas son asociados por González-Guillot (2016) a un ambiente de arco volcánico, generados después del pico de metamorfismo. Asimismo, González-Guillot (2009) sugiere una fuente diferente para el BPA y MPF, en una misma cuña mantélica, pero con metasomatismo controlado por fluidos, derivados de la deshidratación de la losa subducida, de distinta composición (asociados a diferentes profundidades).

Por su parte, las Andesitas de la Península de Ushuaia (APU) afloran en la península homónima, mostrando también manifestaciones de este magmatismo en el Co. Trapecio, Plutón Diorítico Moat e Intrusivo del Monte Kranck. En la península de Ushuaia, considerada localidad tipo, están constituidas por melagabros cuarzosos, granodioritas y diques y filones andesíticos y dacíticos. Este magmatismo es post-tectónico debido a la falta de metamorfismo y deformación penetrativa, siendo anterior al MPF (González-Guillot 2016). Se diferencia de este último tanto por la mineralogía como por la geoquímica (González-Guillot 2009). Según este autor, la composición mineral de estas rocas está constituida principalmente por hornblenda, plagioclasa, feldespato alcalino, cuarzo y escasa biotita. También aparecen apatita, titanita, allanita y circón. Su carácter es calcoalcalino de alto potasio y el LILE y las relaciones LILE/HFSE y LREE/HREE son inferiores al MPF, pero superiores al BPA. Su origen lo relaciona con un ambiente de subducción, equivalente al batolito al sur del Canal Beagle, por fusión parcial de corteza oceánica (adakitas). 


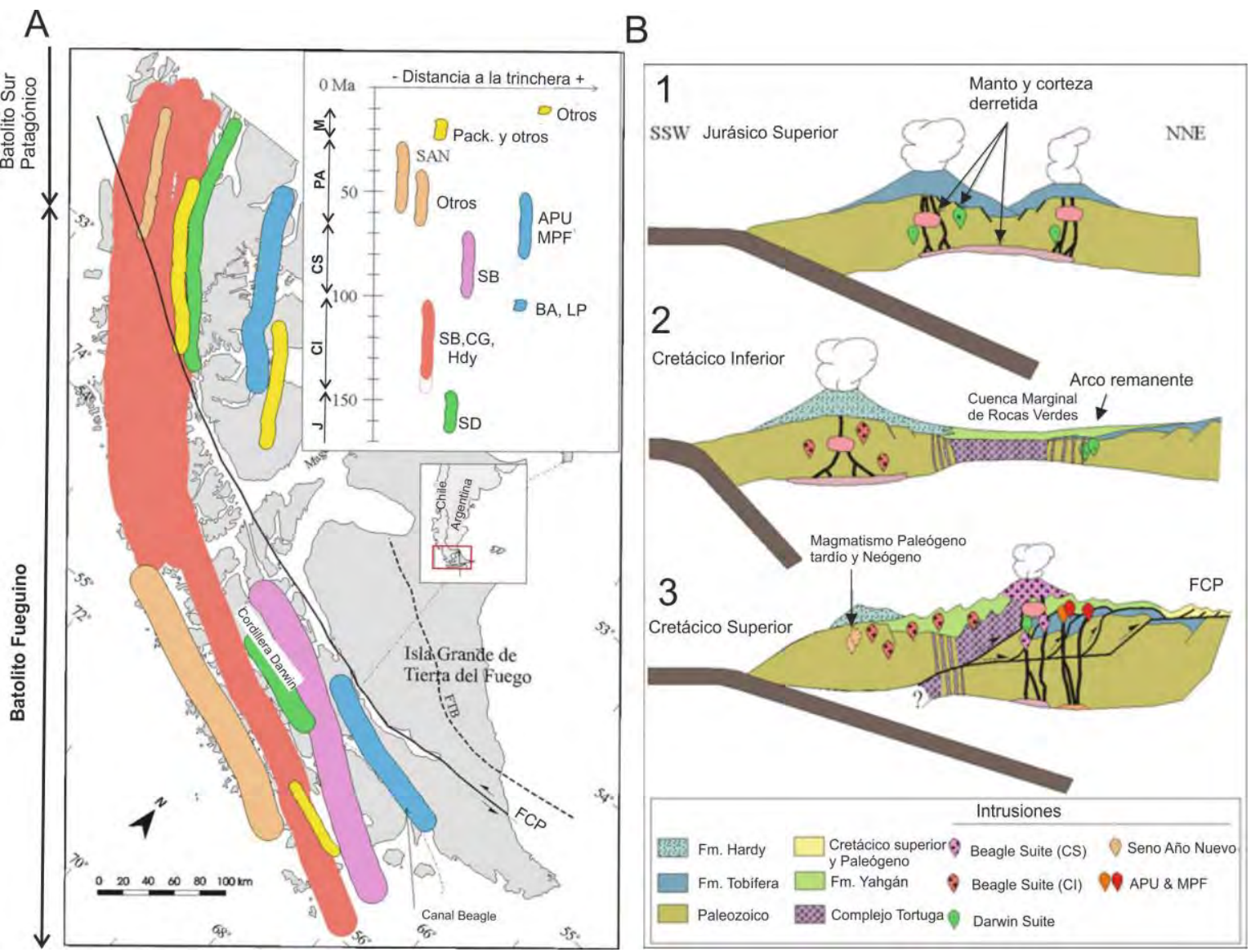

Fig. 3.4. Mapa y esquema tomado de González-Guillot et al. (2016). A) Mapa simplificado de las diferentes intrusiones ígneas sucedidas en Tierra del Fuego y sur de la Patagonia. Abreviaturas: SD, Suite Darwin; SB (Suite Beagle), CG (Complejo de Gabros); Hdy, Fm. Hardy; SAN, Suite Año Nuevo; Pack, Fm. Packsaddle. En relación al Batolito Sur Patagónico se indica: BA, Fm. Baros Arana; LP, Fm. La Pera y Otras a plutones sin nombre. B) Evolución tectonomagmática del margen Pacífico de Tierra del Fuego. 1) Subducción asociada con un magmatismo extensional de arco. Generación de la Suite Darwin y el volcanismo de la Fm. Tobífera 2) Verticalización y retroceso de la losa, extensión generalizada y desarrollo de la Cuenca Marginal de Rocas Verdes, permaneciendo la mayoría de los plutones de la Suite Darwin en el arco remanente, continuando el magmatismo alcalino en el arco frontal. 3) Horizontalización de la losa generada por la inversión de la cuenca marginal y acortamiento orogénico. El magmatismo se desplaza hacia el continente y se genera el magmatismo potásico de tras-arco. Abreviaturas: $\mathrm{Cl}$, Cretácico Inferior; CS, Cretácico superior; FCP, Faja Corrida y Plegada.

\subsubsection{Formación Packsaddle (Mioceno).}

Agrupa basaltos columnares alcalinos (18 Ma), lavas andesíticas y basálticas calcoalcalinas (21 Ma) (Puig et al. 1984). Estas rocas afloran en la Isla Packsaddle y en otros sectores insulares del territorio chileno (Suárez et al. 1985).

Los basaltos alcalinos presentan textura intergranular con fenocristales de olivina y labradorita en una matriz compuesta por microlitos de plagioclasa y gránulos de clinopiroxeno, junto con biotita y minerales opacos.

Las andesitas presentan textura intersertal, con fenocristales de andesina en una matriz constituida por microlitos de plagioclasa, agregados cuarzo-feldespáticos y vidrio subordinado. 
Los basaltos calcoalcalinos presentan textura traquítica, con fenocristales de olivina, clinopiroxeno, ortopiroxeno y labradorita, en una matriz de microlitos de plagioclasa y gránulos de clinopiroxeno y minerales opacos.

Se apoyan en discordancia angular sobre las Formaciones Yahgán, Hardy y sobre los granitoides del Batolito Patagónico (Suárez y Pettigrew 1976).

Las rocas calcoalcalinas se asocian a procesos de subducción (Suárez et al. 1985) y los basaltos alcalinos son resultado de procesos de extensión de tras-arco (Baker et al. 1981) o están asociados a la apertura del Pasaje de Drake (Barker y Burrel 1977).

\subsubsection{Campo Volcánico de Pali Aike (Plioceno-Cuaternario).}

Por su proximidad con la zona de trabajo, se describe también este vulcanismo más reciente presente al norte del Estrecho de Magallanes. Los afloramientos se encuentran intercalados y flanqueados al oeste y al sur por sedimentos glaciales (Skewes 1978, Corbella 2002).

Petrográficamente comprenden lavas desde nefelinitas y basanitas hasta basaltos alcalinos y subalcalinos y son portadores de enclaves ultramáficos que comprenden Iherzolitas, harzburgitas, piroxenitas, websteritas, wehrlitas y en menor medida granulitas gábricas (Skewes 1978, Skewes y Stern 1979, Stern et al. 1986, 1989). Según Corbella (2002), las lavas están constituidas por una pasta compuesta por microlitos de olivina, clinopiroxenos, plagioclasa, feldespato alcalino, titanomagnetita y vidrio. Los fenocristales principalmente se corresponden con olivina y en menor proporción augitas y $\mathrm{Cr}$-espinelas. Respecto a los xenolitos, predominan las Iherzolitas y harzburgitas constituidas por ortopiroxenos $\left(\mathrm{En}_{92-87}\right)$ y $\mathrm{Cr}$-diópsidos $\left(\mathrm{Cr}_{2} \mathrm{O}_{3}>1,2 \%\right)$, piropos cromíferos, espínelas, anfíbol pargasítico y flogopita.

Esta actividad volcánica es consecuencia de la tectónica particular del extremo sur de Sudamérica, debido a la cercanía del inestable punto triple entre las placas Sudamericana, Antártica y Escocia (Skewes 1978). Se considera este vulcanismo asociado con la reactivación de fallas jurásicas (Corbella et al. 1996, Mazzarini y D’Orazio 2003, Ghiglione et al. 2012).

\subsubsection{Glaciaciones}

Las glaciaciones del Plioceno y Cuaternario en la Patagonia y Tierra del Fuego han sido estudias por numerosos autores, siendo Caldenius (1932) el primero en realizar un estudio completo sobre las glaciaciónes del Pleistoceno de la Patagonia. 
Los Andes Patagónicos se cubrieron por un manto de hielo de montaña continuo durante por lo menos 5 glaciaciones mayores en más de 15 eventos fríos en el último millón de años (Rabassa et al. 2011). En la Isla Grande de Tierra del Fuego se han mapeado cinco glaciaciones principales en la zona norte, pero únicamente las dos últimas han sido reconocidas en la zona montañosa del sur (Fig.3.5).

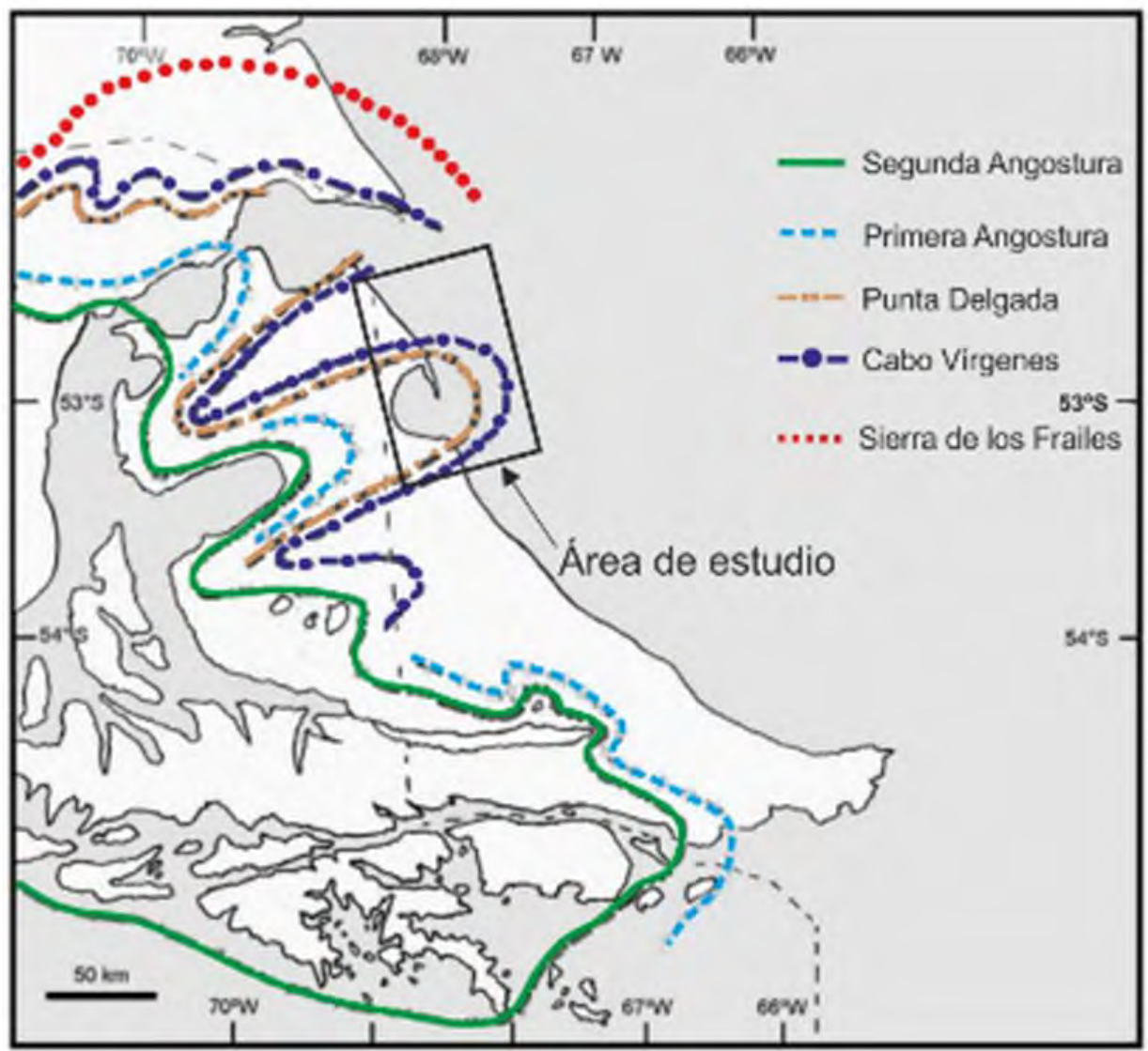

Fig.3.5. Mapa de Tierra del Fuego con los límites de las glaciaciones desde el Pleistoceno, tomado de Coronato et al. (2007), basado en Coronato et al. (2004b) y Rabassa y Coronato (2007)

La Gran Glaciación Patagónica (GGP, ca. $1 \mathrm{Ma}$ ) fue la responsable de la mayoría del paisaje actual (Rabassa et al. 2011). Coronato et al. (2007) infieren por la cercanía del manto de hielo de montaña presente en la Cordillera Darwin que la GGP debió desarrollarse por toda la Isla Grande de Tierra del Fuego, pero sus evidencias en algunas zonas debieron ser borradas por las glaciaciones siguientes.

Luego de la GGP se sucedieron otros eventos glaciales extendiéndose los paleoglaciares patagónicos por más de $300 \mathrm{~km}$ desde el frente de montaña (Coronato et al. 2007). En la Isla Grande de Tierra del Fuego, los principales glaciares cuaternarios discurrieron a través del Estrecho de Magallanes, bahía Inútil-bahía San Sebastián, lago Fagnano, valle de Carvajal y el Canal Beagle, además de pequeños valles tributarios y 
colgantes (Rabassa et al. 2011). En todos los casos, estos glaciares provinieron del manto de hielo de montaña de la Cordillera Darwin. Desde el Ultimo Máximo Glaciar (UMG, aproximadamente hace $24 \mathrm{ka}$; Rabassa, 2008) se produjo un mejoramiento climático que provocó un retroceso del hielo, a excepción de varias interrupciones durante el Tardiglaciar y avances glaciarios menores durante el Holoceno (Rabassa y Coronato 2007), adquiriendo las costas argentinas la configuración actual a los 9 ka (Ponce et al. 2011).

En el sector norte de Tierra del Fuego y Estrecho de Magallanes, Meglioli (1992) identificó desde el Pleistoceno distintos eventos glaciares a los que les dio nombres locales del valle principal, correlacionados posteriormente con la GPG y las siguientes glaciaciones (Coronato et al. 2004b, Rabassa et al. 2011) (Tabla 3.1).

Las evidencias de las glaciaciones más antiguas plio-pleistocenas son la presencia de bloques erráticos y till muy meteorizado en la zona próxima a la localidad de Río Grande, que Meglioli (1992) denominó Drift Río Grande, habiendo sido erosionado posteriormente por corrientes glacifluviales durante las etapas glaciales posteriores (Coronato et al. 2004b). Aunque la discusión de la glaciación total de la isla aún está abierta, estos remanentes glacigénicos son una fuerte evidencia en ese sentido (Rabassa 2008). La glaciación Pampa de Beta (glaciación Sierra de los frailes, GGP) se desarrolló durante el Pleistoceno inferior y muestra depósitos muy bien preservados en este sector, extendiéndose hacia el este de la actual línea de costa (Meglioli 1992, Isla y Schnack 1995). Las glaciaciones Río Cullen (glaciación Cabo Vírgenes, Post GGP-1) y San Sebastián (glaciación Punta Delgada, Post GGP-2) desarrolladas durante el Pleistoceno medio también cubrieron toda la depresión y parte de la actual plataforma continental (Isla y Schnack 1995). Los dos siguientes eventos glaciales, correspondientes con las glaciaciones Laguna Seca (glaciación Primera Angostura, Post GPG III) y Bahía Inútil (glaciación Segunda Angostura, UMG) del Pleistoceno medio y superior tuvieron una extensión cada vez más reducida restringiéndose al sector chileno (Meglioli 1992).

La extensión de las glaciaciones hacia la plataforma continental fue estudiada inicialmente por Caldenius (1932), estableciendo unos límites tentativos de las glaciaciones plio-pleistocenas. Isla y Schnack (1995) a partir de estudios sísmicos detectaron dos sistemas de morenas sumergidas: uno localizado a $60 \mathrm{~m}$ de profundidad denominada Cabo Vírgenes, correspondiente con las morenas Cabo Vírgenes y el Drift Río Grande, y otro ubicado a una profundidad de 40-50 m relacionado con el Drift de San Sebastián. Mouzo (2005c) discrepa con esta interpretación ya que no detectó rasgos que pudieran ser atribuidos a esas morenas y que la supuesta ubicación de ellas coincide con las laderas norte y sur del denominado valle glacial sumergido del Estrecho de Magallanes. Según 
este autor a partir de datos morfológicos, sedimentarios y estructurales (Mouzo 2005a y b) se puede sostener que los depósitos glacigénicos se extienden mar adentro desde la costa actual entre unos 15 y $60 \mathrm{~km}$ (máxima distancia al este de la Estancia Cullen) y los bloques erráticos entre 20 y $100 \mathrm{~km}$. Sitúa el nivel del mar en el Plioceno a una profundidad de $40-$ 60 metros respecto a la actual, coincidiendo con escarpes. Esta profundidad se superaría durante el UMG, localizándose el nivel del mar entre 120 y $140 \mathrm{~m}$ por debajo del nivel actual (Ponce et al. 2011), ubicando la línea de costa a más de $170 \mathrm{~km}$ mar adentro en este sector.

Más adelante, en la sección 3.3 Geología Local, se describen los depósitos glacigénicos localizados en el sector argentino entre el cabo Espíritu Santo y punta Sinaí, que engloban los Drift Pampa de Beta, Río Cullen y San Sebastián.

\begin{tabular}{|c|c|c|c|c|}
\hline & $\begin{array}{l}\text { Lóbulo del Estrecho de } \\
\text { Magallanes }\end{array}$ & $\begin{array}{l}\text { Lóbulo Bahía Inútil-San } \\
\text { Sebastián }\end{array}$ & Lóbulo del Canal Beagle & Período \\
\hline Neoglaciaciones & & & Martial & \\
\hline Transgresión & Fm. San Sebastián & Fm. San Sebastián & Fm. Beagle & Holoceno \\
\hline Tardiglacial & Estadios glaciales $\mathrm{D}$ y $\mathrm{E}$ & Estadios glaciales $\mathrm{D}$ y $\mathrm{E}$ & Complejo Punta Segunda & Pleistoceno \\
\hline $\begin{array}{l}\text { UMG } \\
\text { Interglacial }\end{array}$ & Segunda Angostura & Segunda Angostura & Moat & tardío \\
\hline $\begin{array}{l}\text { Post GGP III } \\
\text { Interglacial }\end{array}$ & Primera Angostura & Lagunas Secas & Sloggett & Pleistoceno \\
\hline $\begin{array}{l}\text { Post GGP II } \\
\text { Interglacial }\end{array}$ & Punta Delgada & San Sebastián & & medio \\
\hline Post GGP I & Cabo Vírgenes & Río Cullen & & \\
\hline $\begin{array}{l}\text { Interglacial } \\
\text { GGP } \\
\text { Interglacial }\end{array}$ & Sierra de los Frailes & Pampa de Beta & & $\begin{array}{l}\text { Pleistoceno } \\
\text { temprano }\end{array}$ \\
\hline Pre-GGP & Río Grande & Río Grande & & Plioceno tardío \\
\hline
\end{tabular}

Tabla 3.1. Depósitos del Plioceno tardío al Holoceno en el norte de Tierra del Fuego. Tomado de Rabassa y Coronato (2007) basado a su vez en Coronato et al. (2004a y b). UMG, Último Máximo Glacial; GGP, Gran Glaciación Patagónica.

\subsection{Geología local}

\subsubsection{Estratigrafía}

La zona costera de trabajo comprende de norte a sur el área desde cabo Espíritu Santo hasta punta Sinaí. En este sector se reconocen unidades estratigráficas desde el Mioceno hasta el Holoceno (Fig.3.7).

\subsubsection{Grupo Cabo Domingo (Oligoceno-Mioceno superior)}

El Grupo Cabo Domingo incluye en su mayor parte los bancos sedimentarios subhorizontales expuestos desde punta Gruesa a cabo Domingo y al norte de la falla frontal 
que marca el límite septentrional de la Faja Corrida y Plegada (Malumián 1999). En nuestro sector de trabajo incluye las formaciones Carmen Silva y Castillo.

La unidad más antigua con la cual comienza la columna estratigráfica corresponde a la Fm. Carmen Silva (Mioceno inferior-medio), perteneciente a la parte superior del Grupo Cabo Domingo (Oligoceno-Mioceno superior) (Olivero y Malumián 2008). Se corresponde con limoarcilitas, areniscas y conglomerados bien estratificados con disposición horizontal/subhorizontal, pudiéndose diferenciar dos niveles de base a techo (Codignotto y Malumián 1981): el nivel inferior está constituido por arcilitas, principalmente compuestas por montmorillonita y en menor medida caolinita y clorita, y limolitas con pirita framboidal microscópica. Hacia el techo, la Formación se vuelve conglomerádica con rodados de naturaleza principalmente andesítica junto con pelitas silicificadas y cuarzo policristalino de manera subordinada, aumentando también el contenido en fósiles (moluscos), correspondiendo en algunas zonas con coquinas. La mineralogía en esta parte está dominada por calcita, plagioclasa y agregados arcillosos, y frecuentemente hornblenda verde, piroxenos y escaso cuarzo.

En nuestro sector de trabajo aflora al sur de la bahía San Sebastián, observándose en las proximidades de la costa únicamente parte del nivel inferior constituido por limos, limolitas y areniscas (Fig.3.6).

Según Codignotto y Malumián (1981), la parte inferior se relaciona con ambientes marginales de tipo deltaico y la parte superior indica un régimen deltaico marino de condiciones de mayor energía.

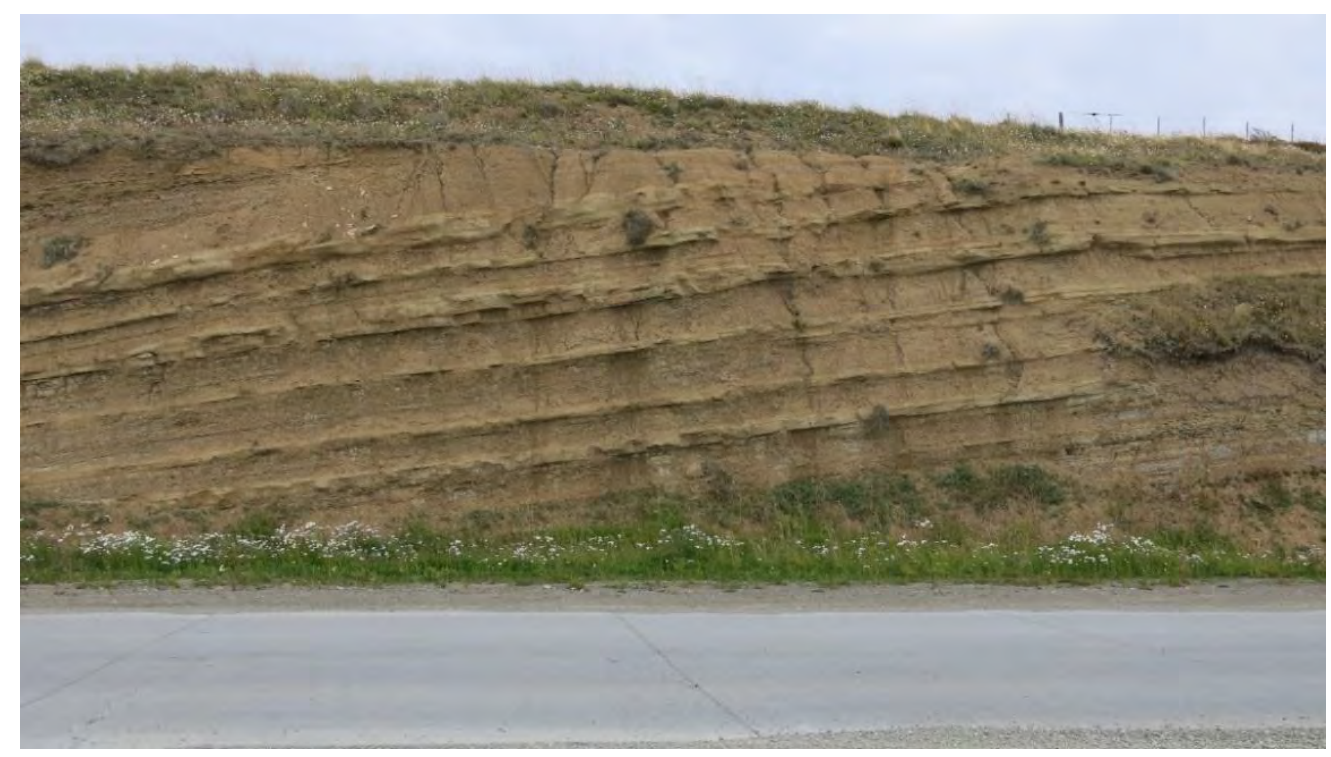

Fig.3.6 Formación Carmen Silva sobre la Ruta 3, adyacente a la localidad de San Sebastián. Alternancia de niveles de areniscas finas y limolitas. 
Dentro del mismo Grupo Cabo Domingo, se encuentra la Fm. Castillo del Mioceno superior (Olivero et al. 2006) compuesta por depósitos fluviales constituidos por areniscas conglomerádicas sin presencia de invertebrados marinos.

Según Olivero y Malumián (2008), la discordancia que separa la base de este Grupo de los estratos de edad Eoceno superior representa el estado final de la deformación compresional en la faja plegada, a lo que le siguió una profundización de la Cuenca Austral. La cuenca se rellenó durante el Oligoceno inferior-Mioceno inferior con limolitas y areniscas de ambiente marino profundo, completándose el relleno durante el Mioceno medio a superior con depósitos marinos poco profundos, deltaicos y sistemas fluviales.

\subsubsection{Fm. Punta Basílica (Mioceno superior-Plioceno inferior)}

Por encima y en relación de concordancia prosigue la Fm. Punta Basílica (Mioceno superior-Plioceno inferior) (Olivero et al. 2006). Aflora en la base del acantilado al sur de San Sebastián y se corresponde con areniscas limosas con un aumento hacia el techo de restos vegetales (tallos y hojas), asociadas con un ambiente marino marginal inestable, perteneciente a la última ingresión marina precuaternaria (Codignotto y Malumián 1981, Olivero et al. 1999). Estos investigadores reconocen piroxenos (hipersteno y augita), plagioclasas, cuarzo y hornblenda verde, además de vidrio volcánico. 


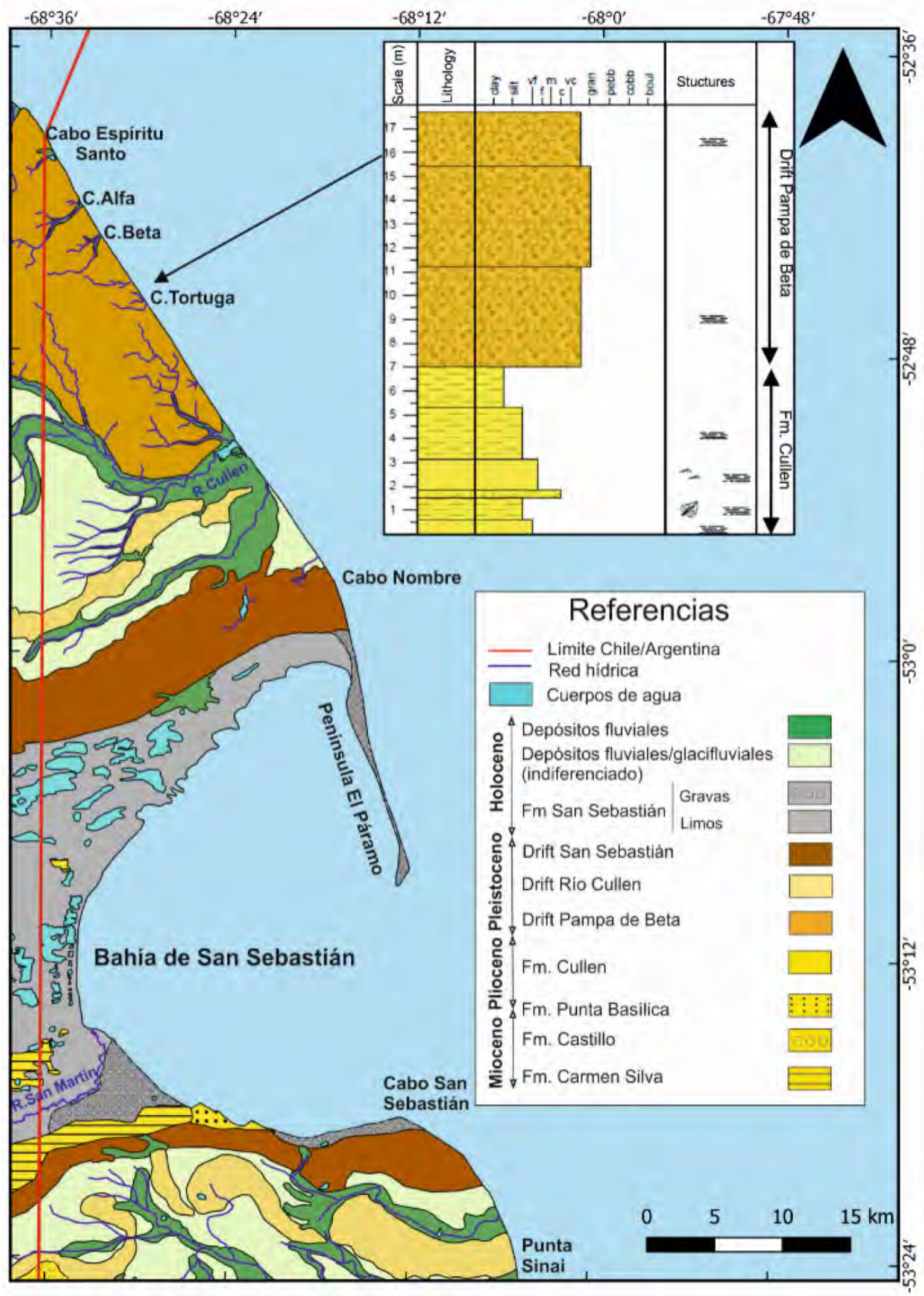

Fig.3.7. Mapa geológico de la zona de trabajo. Cartografía realizada a partir datos de campo, imágenes satelitales (Landsat 8) y bibliografía previa (Codignotto 1979; Codignotto y Malumián 1981; Agüero et al. 2003, Olivero et al. 2006 y Darvill et al. 2015b). 


\subsubsection{Formación Cullen (Mioceno superior-Plioceno).}

Depositada en forma casi simultánea con la Fm. Punta Basílica, aflora más al norte la Formación Cullen del Mioceno superior-Plioceno (Olivero et al. 2006), observada en la base de los acantilados, desde el sur del cañadón Tortuga hasta el cabo Espíritu Santo. Está compuesta por bancos de areniscas, tobas y limolitas con restos vegetales de tallos, hojas y troncos del género Nothofagus. En este nivel se encuentran en algunas zonas fragmentos carbonizados (lignito) (Fig.3.8). Codignotto y Malumián (1981) describen la composición de los bancos tobáceos, constituida principalmente por vidrio volcánico, plagioclasas, hornblenda verde y fragmentos de rocas volcánicas. También identificaron hipersteno y epidoto, pero con una baja abundancia. Se relaciona con un ambiente estuarino o deltaico con un importante aporte continental (Codignotto y Malumián 1981). Esta Formación, junto con las Areniscas de Punta Basílica se asocia con la cuarta transgresión marina precuaternaria (Bujalesky et al. 2001).

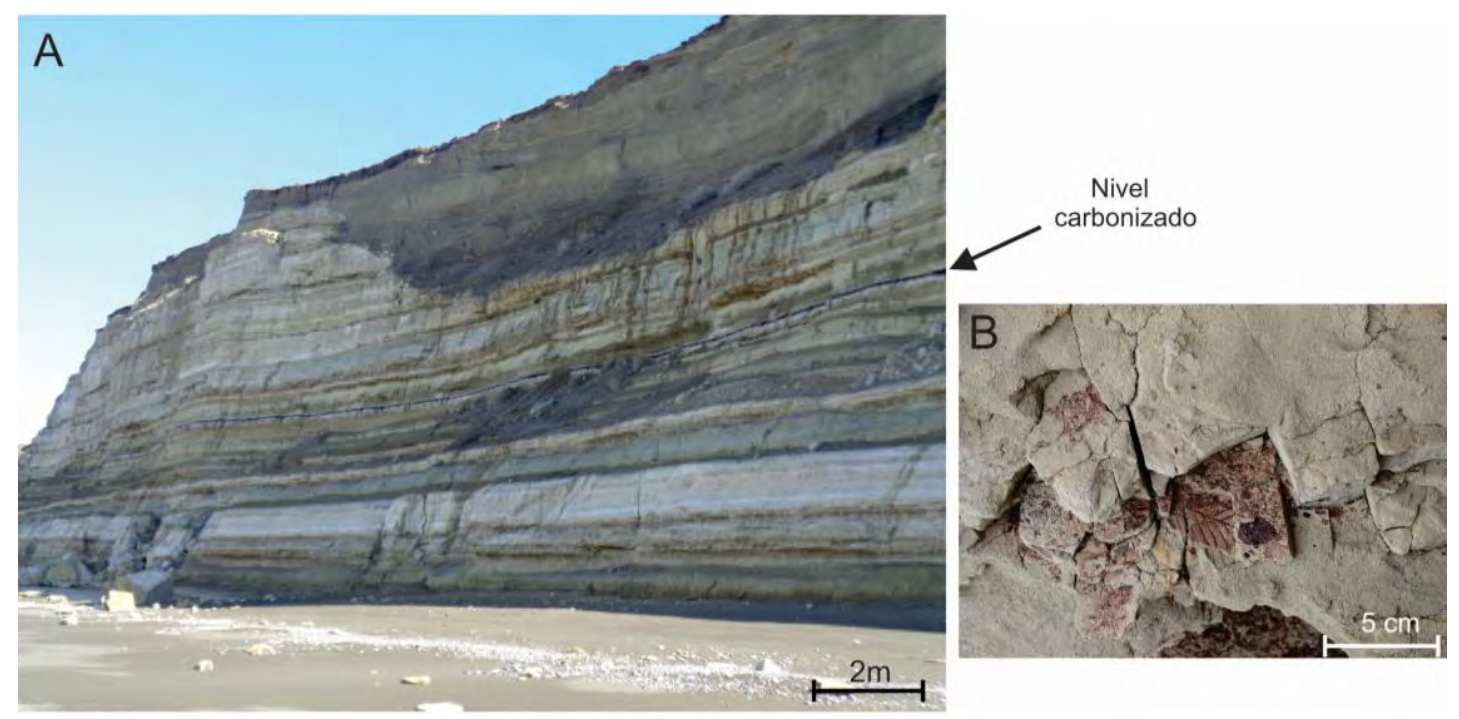

Fig.3.8. A) Formación Cullen al sur del cañadón Alfa donde se aprecia en la parte media un nivel carbonizado. B) Detalle hoja de Nothofagus presente en los acantilados del cañadón Tortuga.

\subsubsection{Depósitos Glaciales (Pleistoceno).}

Los depósitos terciarios descritos anteriormente están cubiertos por sedimentos glacigénicos de edad pleistocena, denominados por Codignotto (1979) como Drift Tapera Sur. Meglioli (1992) diferenció en nuestra zona el Drift Pampa de Beta con una topografía plana (Fig.3.9) y los Drift Río Cullen y San Sebastián, con un relieve ondulado y separados por depósitos glacifluviales. 
Al Drift Pampa de Beta, Díaz et al. (2018b) lo describen como "diamictos depositados por repetidos avances del glaciar intercalados con sedimentos glacifluviales de ambientes proglaciales". Estos depósitos se encuentran bien preservados en el sector argentino al norte del Río Cullen, localizándose en una suave llanura que abarca la zona de Pampa de Beta y Pampa del Rincón, alcanzando una cota máxima de 100m s.n.m. que aumenta hacia el SO en la Sierra del Boquerón (sector chileno). Al sur de la bahía San Sebastián se ubican en la zona de la Estancia Sara (Meglioli 1992).

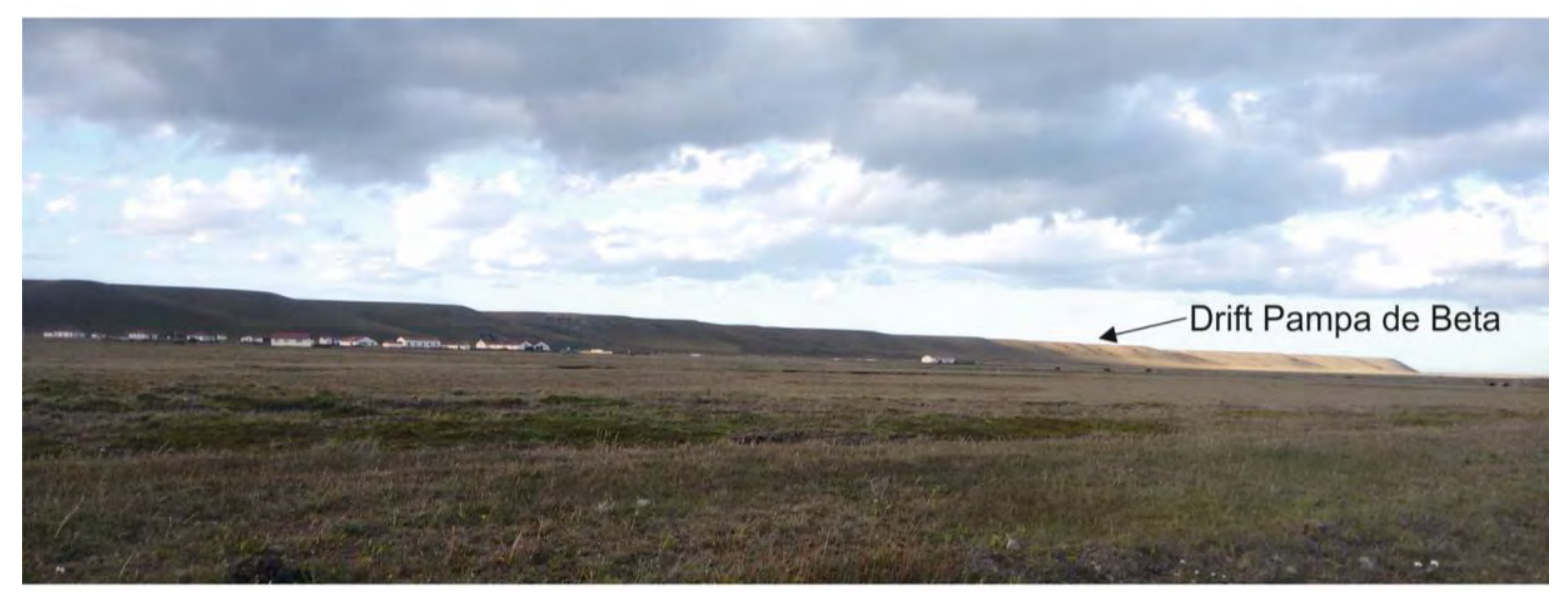

Fig.3.9. Topografía plana del Drift Pampa de Beta vista desde la depresión del río Cullen, a la altura de la Estancia Cullen. Fotografía tomada desde el SE hacia el NO.

Como indican Codignotto y Malumián (1981), en los acantilados de la costa atlántica el espesor de estos depósitos aumenta del SE al NO, a expensas del descenso del techo de la Formación Cullen que desaparece al sur del cañadón Tortuga donde el sedimento glacial alcanza un máximo de $70 \mathrm{~m}$ de cota.

Los depósitos correspondientes con el Drift Río Cullen se enmarcan dentro de uno de los avances principales del Lóbulo Bahía Inútil - Bahía San Sebastián. Los límites laterales de la glaciación se muestran como morenas latero-frontales (Rabassa y Coronato 2007, Díaz Balocchi et al. 2018a) con una topografía ondulada tipo kame y kettle (Fig. 3.10). Se localiza tanto al norte como al sur de bahía San Sebastián, con una extensión de los límites entre 1 y $2 \mathrm{~km}$ y una elevación máxima de $180 \mathrm{~m}$ s.n.m al sur del Cerro Cabeza de León. La morena del norte de la bahía San Sebastián, a diferencia de la del sur, no se observa que alcance la costa atlántica como consecuencia de la erosión por el agua de deshielo. Hacia el oeste, en el sector chileno, las morenas del Río Cullen se localizan al norte y sur de la bahía Inútil, alcanzando una altura máxima de 390 m s.n.m en las estribaciones de la sierra del Boquerón, pero son difícilmente distinguibles como consecuencias de la erosión (Meglioli 1992). Estos depósitos se caracterizan por la presencia de grandes bloques erráticos de composición granodiorítica originados por una 
o más avalanchas de bloques en la Cordillera Darwin, transportándose de manera supraglaciar durante aproximadamente $250 \mathrm{~km}$ hasta depositarse en la zona de punta Sinaí (Coronato et al. 1999, Coronato et al. 2004b, Darvill et al. 2015a).

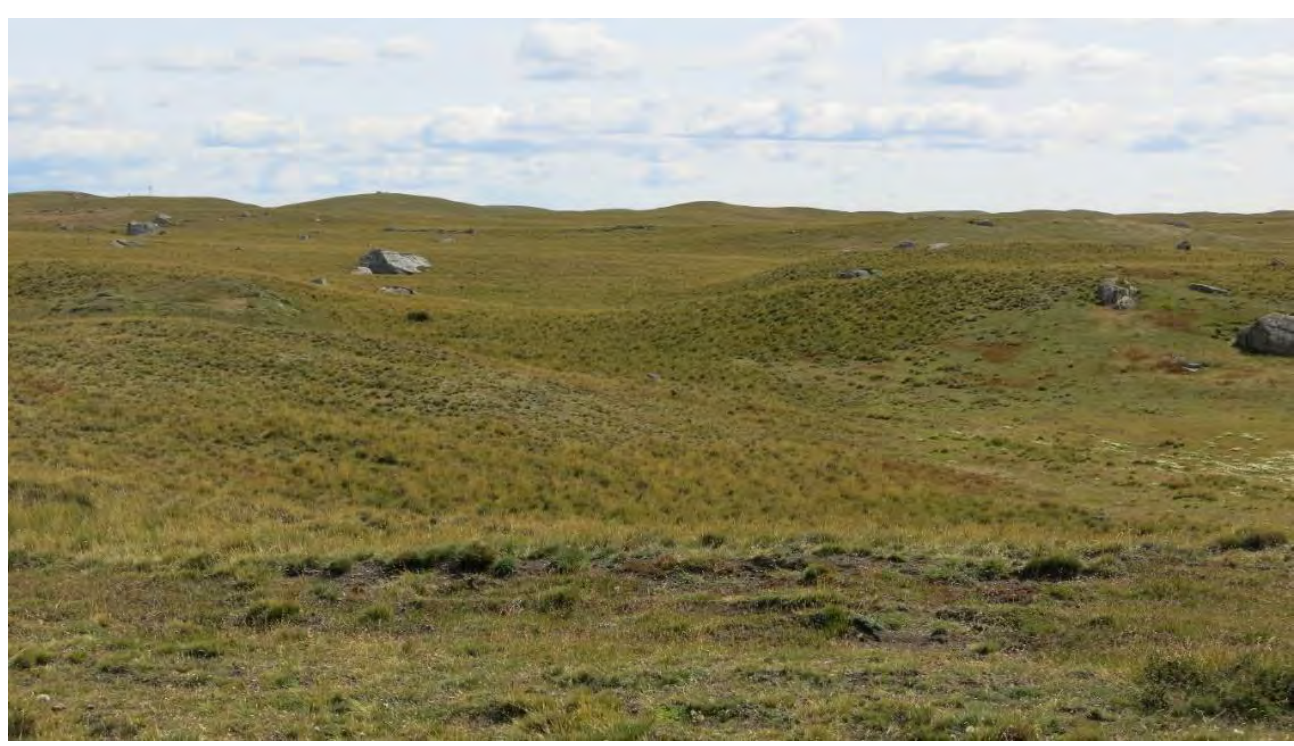

Fig.3.10. Topografía ondulada y bloques erráticos correspondientes con el Drift Río Cullen en el sector de punta Sinaí.

Finalmente, el Drift de San Sebastián en el sector argentino está representado por cinturones de morenas latero-frontales con una topografía kame y kettle tanto al norte como al sur de la depresión bahía Inútil-bahía San Sebastián (Fig.3.11). Presenta una orientación SO-NE paralela al Drift Río Cullen, con una extensión de los límites laterales entre 2 y 4 km, localizándose al norte de la bahía San Sebastián en la sierra homónima y al sur en la sierra Carmen Silva. Estos depósitos alcanzan espesores de hasta $20 \mathrm{~m}$ en los acantilados presentes en cabo Nombre (Meglioli 1992).

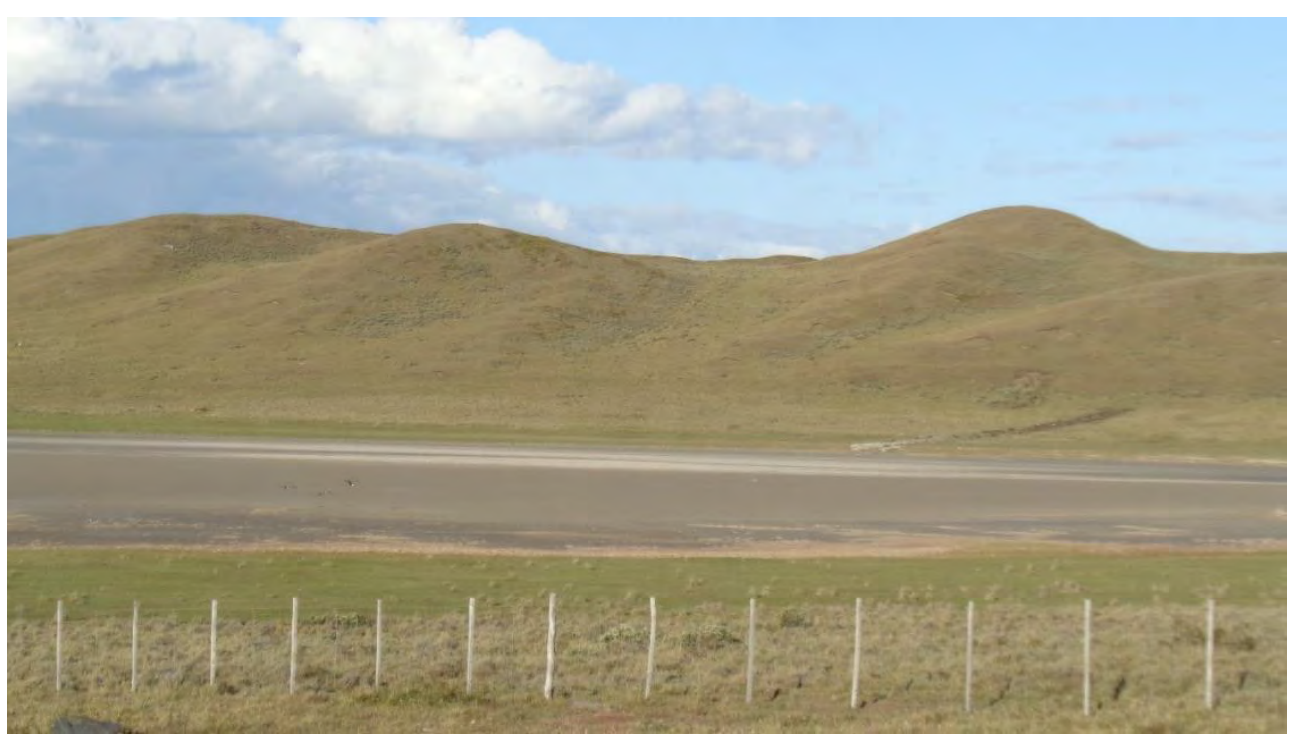

Fig.3.11. Drift San Sebastián en la Serranía de San Sebastián, sector de la laguna Salada 
Estos depósitos se correlacionan con los sedimentos de las glaciaciones del lóbulo Estrecho de Magallanes. El Drift Pampa de Beta se correlaciona con el Drift Sierra de los Frailes, el Drift Río Cullen con el Drift Cabo Vírgenes y el Drift de San Sebastián con el Drift Punta Delgada (Meglioli 1992, Bujalesky 2007, Coronato y Rabassa 2011).

\subsubsection{Formación San Sebastián (Holoceno).}

Finalmente, el Holoceno del sector investigado está representado por la Fm. San Sebastián asociada a la trasgresión post-glacial holocena que engloba los depósitos marinos que conforman las crestas de playas y terrazas marinas ascendidas (Codignotto y Malumián 1981), incluyendo la espiga Península el Páramo, los depósitos presentes en la depresión de la bahía Inútil-bahía San Sebastián y los cordones litorales de gravas. Según estos investigadores los depósitos finos están compuestos por sedimentos limo-arenosos y arcillosos con una composición de estos últimos de montmorillonita y en las arenas se puede reconocer hornblenda verde y castaña, cuarzo, plagioclasas, ceolitas y minerales opacos, junto con restos orgánicos, vidrio volcánico, biotita y granates.

\subsubsection{Sector Costero}

\subsubsection{Condiciones hidrodinámicas}

A fin de enmarcar un contexto de las condiciones hidrodinámicas que han controlado la formación de los depósitos detríticos de minerales pesados en el litoral atlántico de la Isla Grande de Tierra del Fuego, se presenta a continuación una breve reseña de los regímenes imperantes de mareas, olas y deriva litoral en la región estudiada.

La costa atlántica sur de la Patagonia Argentina tiene un rango macromareal de tipo semidiurno. En la zona de la bahía San Sebastián la onda de flujo y reflujo alcanza una velocidad de 1,5-1,4 nudos (2,8-2,6 km/h) en dirección NO y SE, respectivamente (Servicio de Hidrografía Naval 2019). A partir de los datos de alturas y amplitudes de marea tomados en esta bahía, se observa que la playa actual está sometida a una amplitud de 2,8 m en cuadratura y 10,4 m en sicigia (Servicio de Hidrografía Naval 1988, visto en Bujalesky 1990).

El oleaje en esta región es relativamente benigno como consecuencia de la resistencia que provoca el fuerte viento del oeste. A partir de las observaciones realizadas por IMCOS Marine Limited (1978), vistas en Bujalesky 2007, entre 1949-1968 para la zona comprendida entre el meridiano $65^{\circ} \mathrm{O}$ y los paralelos $50^{\circ} \mathrm{S}$ y $55^{\circ} \mathrm{S}$, indicaron entre otros 
datos una baja frecuencia de olas con alturas mayores a 3,5 m; el 20\% de las olas presentó un promedio anual de alturas inferiores a $1 \mathrm{~m}$, la frecuencia de las olas de largo períodos fue baja y aquellas con períodos iguales o mayores a 10 segundos provinieron del sector E al NE.

El sentido de la deriva litoral en la playa atlántica del NE de Tierra del Fuego es hacia el sur-sureste durante la mayor parte del año como consecuencia de la influencia oblicua del mar de leva, proveniente de áreas alejadas del NNE (Bujalesky 1990). El transporte de sedimentos hacia el sur condiciona el sentido de crecimiento de las espigas y cordones litorales. Este mismo transporte se reconoce al norte de la zona de trabajo, en la costa presente desde Río Gallegos hasta punta Dungeness, produciéndose un desplazamiento de los depósitos detríticos hacia el sur (Codignotto et al. 1992). Sin embargo, durante eventuales temporales del sureste, el transporte litoral se invierte hacia el N-NE (Bujalesky 1990).

Las olas incidentes en pleamar sobre la zona intermareal alta dan origen a rompientes de volteo ("plunging"), características de playas de alta pendiente donde la cresta se incurva dejando un hueco debajo y se desploma sobre la superficie del agua, mientras que durante la bajamar queda expuesta la zona intermareal baja subhorizontal originándose una rompiente en derrame (“spilling”) (Bujalesky 1997), caracterizada por una rotura gradual de la ola (Fig.3.12).

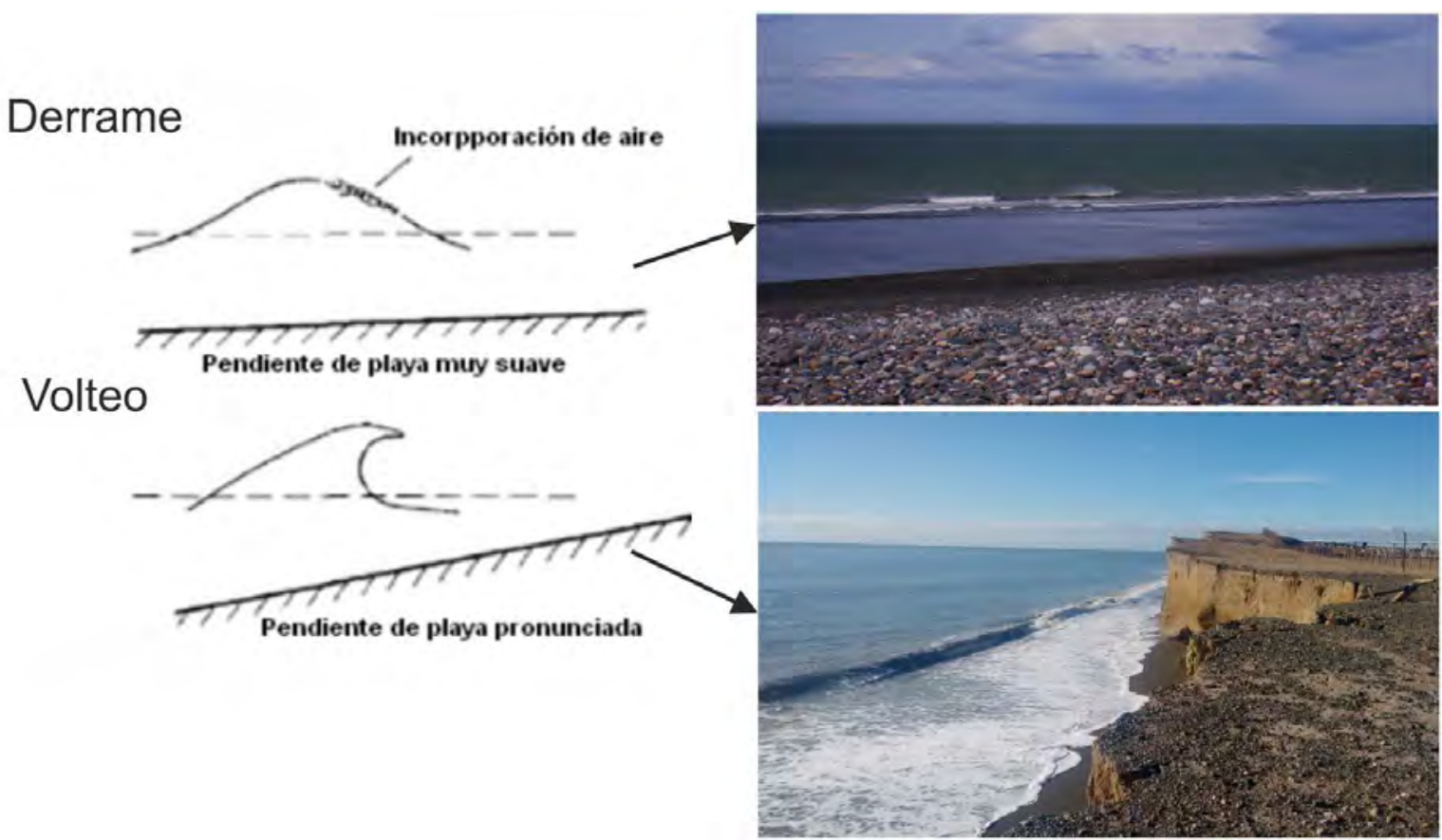

Fig.3.12. Tipos de rotura del oleaje presente en la zona de estudio. Fotografía superior tomada en la espiga de El Páramo y la inferior desde los acantilados al sur del río Cullen. 
En la zona de estudio, el oleaje retrabaja los depósitos glacígenos presentes en los acantilados y en la plataforma hasta el nivel base del oleaje. La erosión y transporte de los minerales pesados presentes en estos materiales permite su concentración y acumulación en ciertas partes de la playa, generando horizontes ricos o productivos. Las mareas y los fuertes vientos pueden acentuar en algunos sitios el proceso de concentración de los minerales pesados. Adicionalmente, la fuerte deriva litoral presente en la zona, distribuye los minerales a lo largo de la costa.

\subsubsection{Geomorfología litoral}

Desde el punto de vista de la geomorfología de costas el sector de trabajo costero localizado al NE de Tierra de Fuego comprende tres grandes rasgos litorales: la bahía San Sebastián, la península El Páramo y altos acantilados en retroceso.

Los acantilados, localizados al norte y sur de la bahía San Sebastián, están constituidos por sedimentos glaciales pleistocenos, correspondientes con los Drifts San Sebastián y Río Cullen, aflorando al norte también el Drift Pampa de Beta (Meglioli 1992) junto con sedimentitas miocenas de la Formación Cullen al norte y las formaciones Carmen Silva y Punta Basílica en el sector meridional (Codignotto y Malumián 1981).

Los acantilados se encuentran afectados por procesos de remoción en masas, como desprendimientos y avalanchas de derrubios según la clasificación vista en González de Vallejo et al. (2004), debido principalmente a la erosión generada en la base del acantilado por el oleaje. Durante fuertes tormentas se pueden provocar marcados retrocesos de hasta 3,7 $\mathrm{m}$ en unas pocas horas como por ejemplo en cabo Nombre (Bujalesky 1990). Vilas et al. (1987) calcularon a partir de cambios operados en construcciones humanas cercanas a los bordes del acantilado un retroceso de entre 2 y 3 $\mathrm{m}$ por año. Este proceso se ve incrementado por la percolación continua, procesos de congelamiento y fusión (Bujalesky 2007) y erosión eólica. El retroceso se pudo observar en el transcurso de la presente investigación en la zona costera de El Páramo. Como consecuencia de la erosión progresiva entre diciembre de 2016 y enero de 2020 , se produjo el desprendimiento y caída gravitacional de un gran bloque (Fig.3.13). En el sector costero donde se encuentra el campamento Río Cullen de la empresa TOTAL AUSTRAL también se observó como el acantilado está perdiendo terreno. 


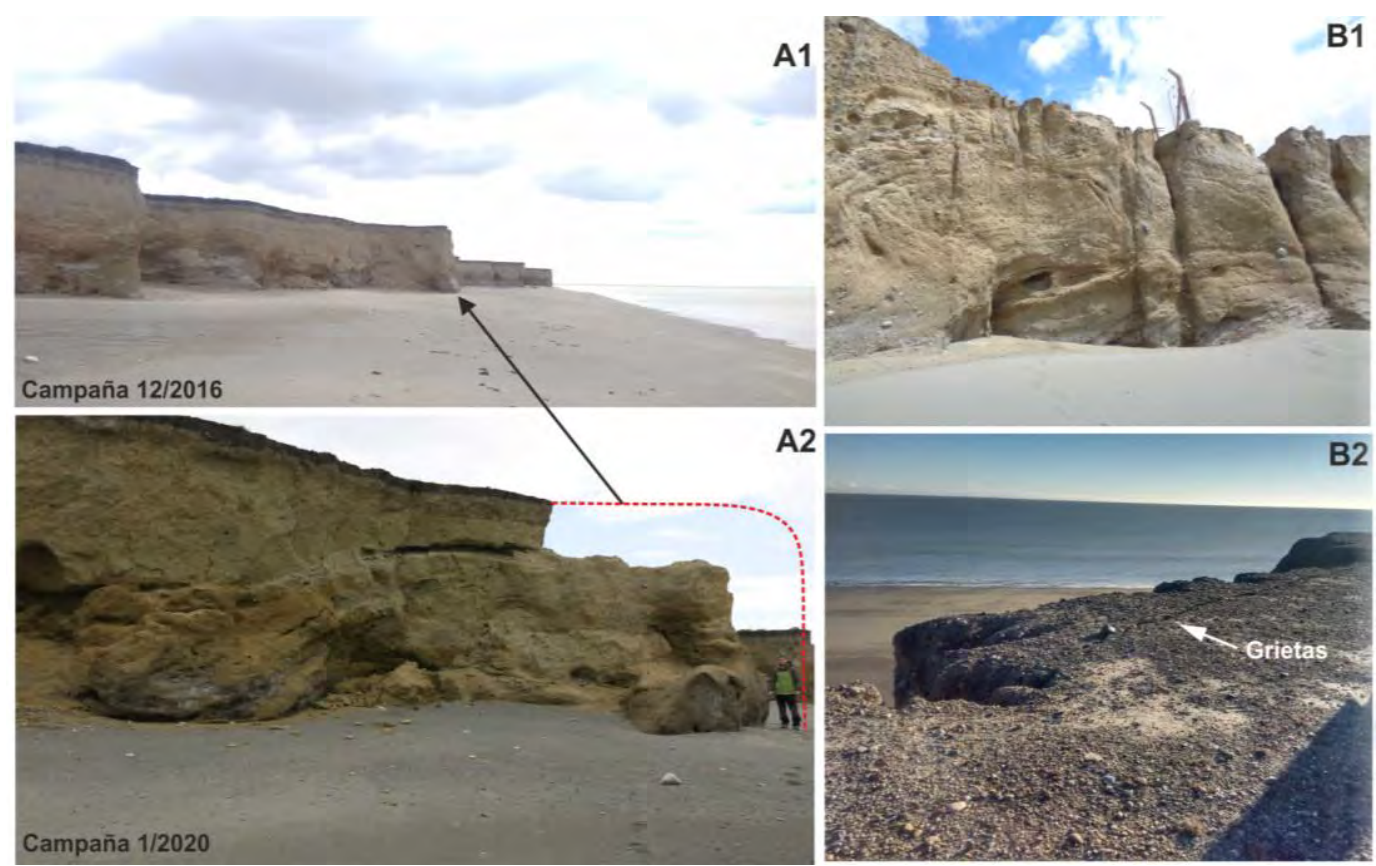

Fig.3.13. Retroceso del acantilado en las playas de El Páramo (A1 y A2). Valla colgando y grietas en superficie en el sector costero del campamento Río Cullen (B1 y B2).

La bahía San Sebastián se localiza en la depresión de origen glacial bahía Inútilbahía San Sebastián generada durante el Pleistoceno y posteriormente remodelada por la transgresión marina holocena (Fm. San Sebastián, Codignotto y Malumián 1981). Es una bahía semicircular $(35 \mathrm{~km} \times 25 \mathrm{~km})$ donde se pueden diferenciar distintos ambientes (Vilas et al. 1987, Isla et al. 1991, Bujalesky 1997, 2007) (Fig.3.14).

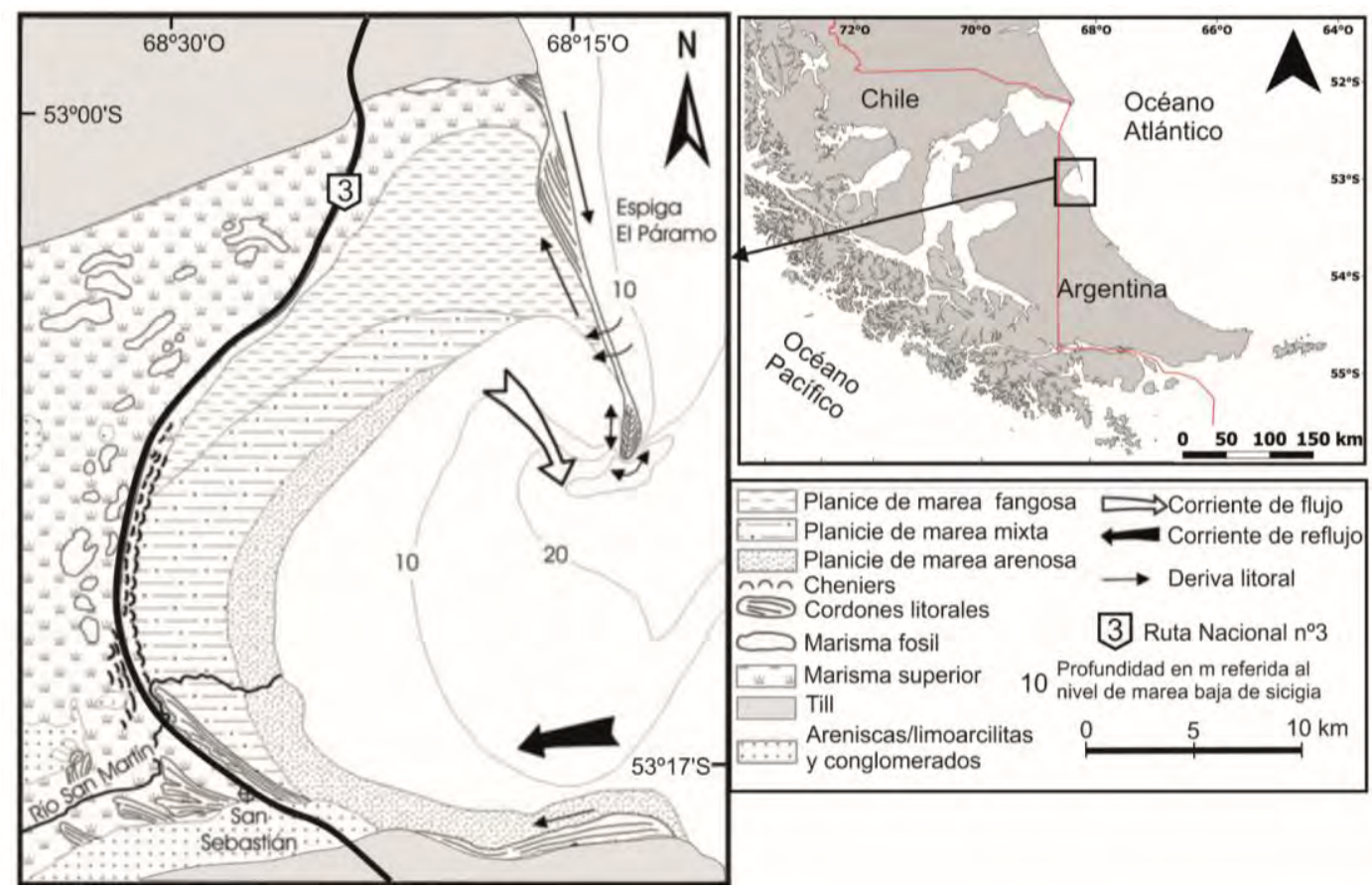

Fig.3.14. Morfología, sedimentología y procesos dominantes en la bahía San Sebastián. Modificado de Bujalesky (2007) e Isla et al. (1991). 
Marisma fósil: marisma inactiva localizada al oeste de la ruta nacional $\mathrm{N}^{\circ} 3$. Esta ruta actúa como barrera, ya que previa a su construcción la marisma se inundaba episódicamente por el mar. Ahora está sometida a una fuerte deflación, presentando lagunas someras temporarias que migran hacia el este como consecuencia de la deflación eólica.

Marisma superior: está controlada por procesos de deflación y está colonizada por Salicornia sobre la planicie fangosa, arbustos de Lepidophyllum y gramíneas.

Cordones litorales de gravas: como consecuencia del ingreso de las olas atlánticas en el sector meridional de la bahía se produce una deriva de la grava hacia el NE, generándose una planicie de cordones litorales de grava y arena gruesa al sur del río San Martín. Las crestas fósiles se construyeron durante fases regresivas de las fluctuaciones del nivel del mar (Fig.3.15A).

Cheniers: al norte del río San Martín, se localizan unos depósitos de valvas de moluscos y arena sobre la planicie fangosa como resultado de la deriva litoral. Los cordones de gravas y los cheniers son resultado del oleaje de tormenta que ingresa en la bahía.

Planicie de mareas: dentro de la bahía las corrientes de las mareas se desplazan en el sentido de las agujas del reloj, decreciendo el tamaño de grano en esa dirección. Se pueden diferenciar planicies arenosas, mixtas y fangosas (Fig.3.15B).

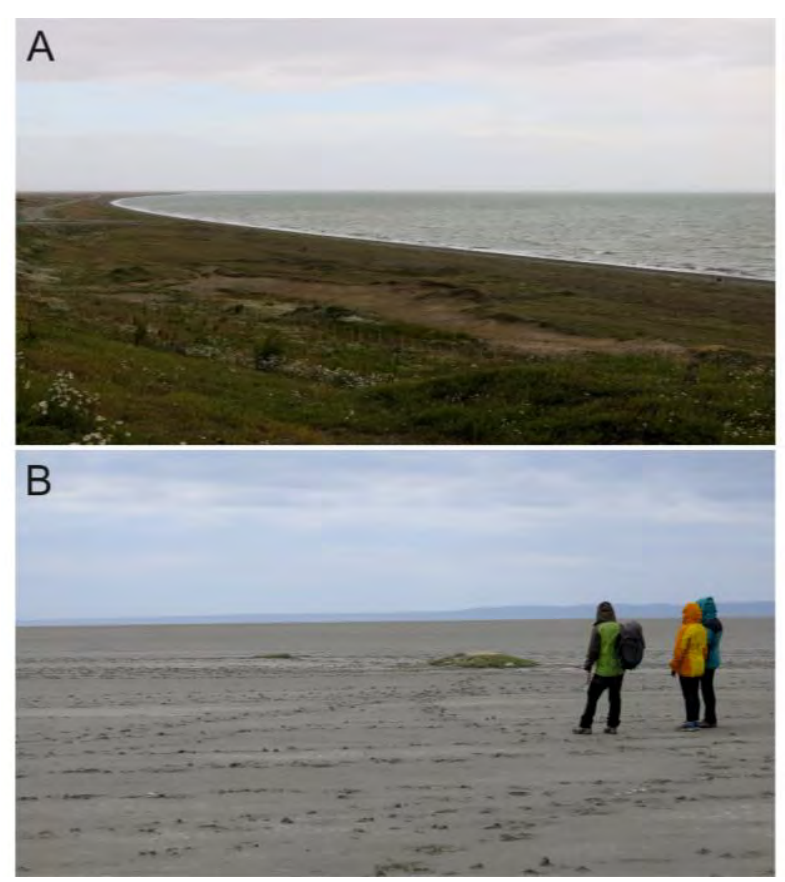

Fig.3.15. Bahía San Sebastián. A) Sector de cordones litorales a la altura del puesto fronterizo, sur de la bahía. B) Extensa llanura mareal fangosa al norte de la bahía, al fondo se ve la sierra Carmen Silva. 
La península El Páramo es una espiga de grava de $20 \mathrm{~km}$ de largo que cierra parcialmente la bahía San Sebastián (Fig.3.16). Esta espiga es de tipo transgresivo ya que prograda longitudinalmente hacia el sur y lateralmente hacia el oeste. Presenta canales de sobrelavado en su zona central, activos durante olas de tormenta u olas de mar de leva con mareas de sicigia (Bujalesky 2007). La principal fuente de aporte de la espiga correspondería a los depósitos glacigénicos localizados al norte (Vilas et al. 1987, Isla et al. 1991, Bujalesky 2007). La sedimentación en la bahía San Sebastián comenzó hace $5270 \pm 190$ ma. (datos de ${ }^{14} \mathrm{C}$, Vilas et al. 1999) por lo tanto se infiere que la espiga tendría esa edad.

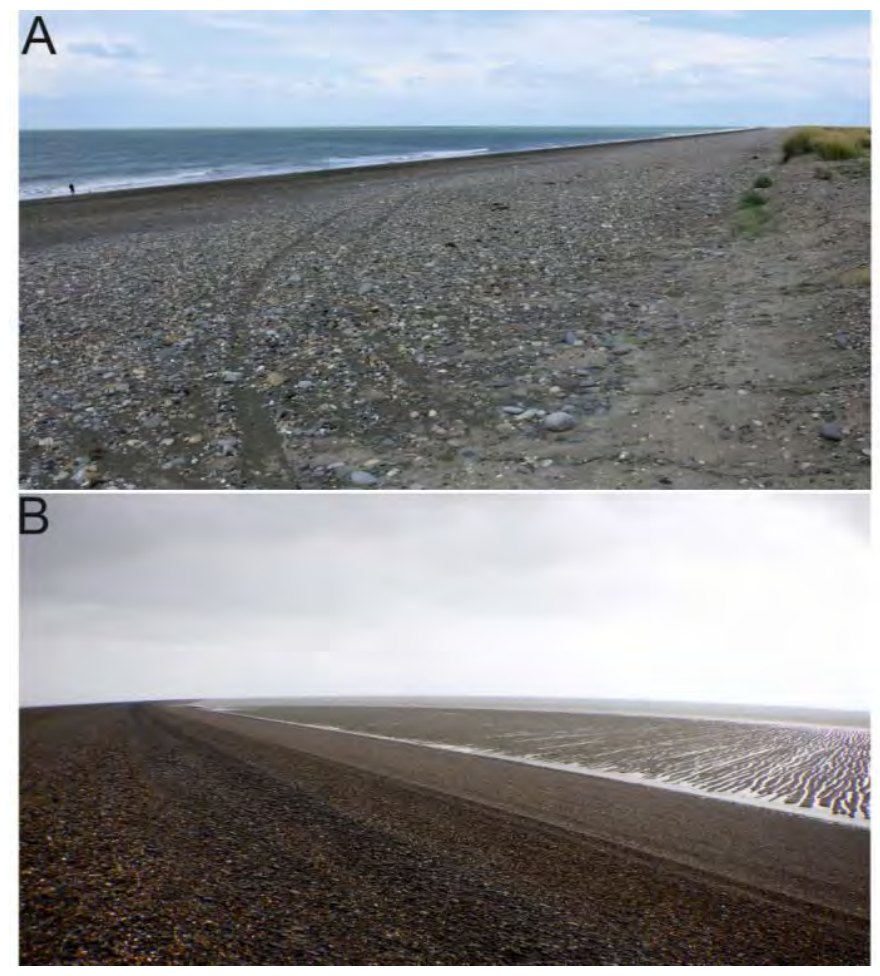

Fig.3.16. Espiga de El Páramo. A) Sector Atlántico. B) Sector interno.

\subsubsection{Estado morfodinámico de la playa actual.}

Bujalesky $(1990,1997)$ concluyó que la playa atlántica del norte de la Isla Grande presenta características reflectivas durante la marea alta, diferenciando cinco zonas distintas, con un desnivel de 9,5 m: cresta de berma de tormenta, terraza de lavado de tormenta, cresta de berma de marea, zona intermareal alta y zona intermareal baja (estos dos últimos correspondientes con el talud intermareal y la terraza de bajamar de Flor 2004).

La cresta de berma de tormenta está constituida por bloques y grava gruesa junto con arena media y muy gruesa; presenta una pendiente media de $3,5^{\circ}$ y una extensión de $15 \mathrm{~m}$. La terraza de lavado de tormenta presenta una extensión de $25 \mathrm{~m}$ y un pendiente de 
$2^{\circ}$. Estas dos zonas, englobadas en el presente trabajo con el término de berma de tormenta, se ubican por encima de las pleamares ordinarias, alcanzándoles el oleaje de tormenta u olas de alta energía, en pleamares equinocciales de sicigia de perigeo.

La cresta de berma de marea presenta grava fina y media, abarcando unos $10 \mathrm{~m}$ de ancho cuya posición varía en función de pleamares de cuadratura y sicigia. Para esta zona se adoptó el término de berma de marea. Junto con la berma de tormenta constituyen la zona supramareal.

La zona intermareal alta presenta una granulometría granocreciente desde la zona próxima a la berma de marea hacia el pie de la playa, desde un predominio de arena media a ser dominante las gravas. La pendiente media es $7^{\circ}$ y su extensión es de $60 \mathrm{~m}$. Esta zona se comporta como reflectiva con rompientes de tipo volteo.

La zona intermareal baja presenta una granulometría de arena fina, con una inclinación subhorizontal y una extensión de $70 \mathrm{~m}$, quedando expuesta durante las bajamares de sicigia. Esta zona, a diferencia de la intermareal alta, presenta un estado disipativo con rompientes de derrame (Fig.3.17).

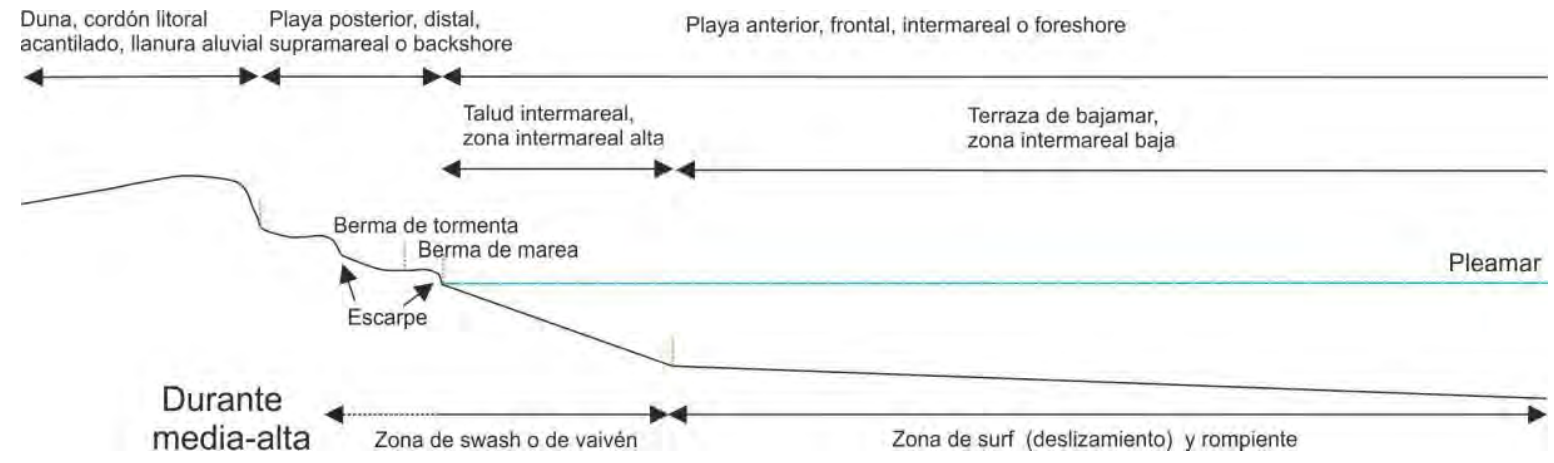

Fig.3.17. Perfil tipo transversal, sin escala, de la playa presente en la costa atlántica de Tierra del Fuego.

Isla et al. (2006) describieron las playas del norte de la isla Grande de Tierra del Fuego como bimodales con bermas gravosas y terrazas de baja mar constituidas por arena fina. Estos tipos de playa se denominan mixtas o heterogéneas (Flor 2004).

En función del estado de la marea o condiciones de tormenta, la playa frontal es afectada por el vaivén o batida del oleaje ("swash zone") y del deslizamiento, rompiente o agitación ("surf zone"). La zona de surf corresponde con la zona donde la masa de agua turbulenta que queda después de la rotura de la ola se mueve hacia tierra arrastrando consigo la carga de fondo y el sedimento en suspensión, afectándole las corrientes en dirección contraria denominadas de resaca ("rip currents"). Lo que queda de la ola alcanza la zona de batida extendiéndose pendiente arriba como una lámina fina hasta que agota su energía cinética y se detiene depositando el sedimento que arrastraba, volviendo hacia 
el mar según la pendiente y removiendo el sedimento más fino y liviano ya que no tiene suficiente energía para mover el resto (Dabrio 2010).

Como consecuencia del estado morfodinámico presente en la zona de estudio, en la playa actual de la zona de investigación, se pueden reconocer acumulaciones superficiales rojizas y oscuras de minerales pesados de tamaño arena media a fina en la zona de swash, siendo más abundantes en la zona supramareal. Durante marea baja, como consecuencia del drenaje de la playa frontal hacia el mar, se generan acumulaciones de minerales pesados principalmente opacos de tamaño arena fina a muy fina en los canales de marea y sobre las óndulas (Fig.3.18).

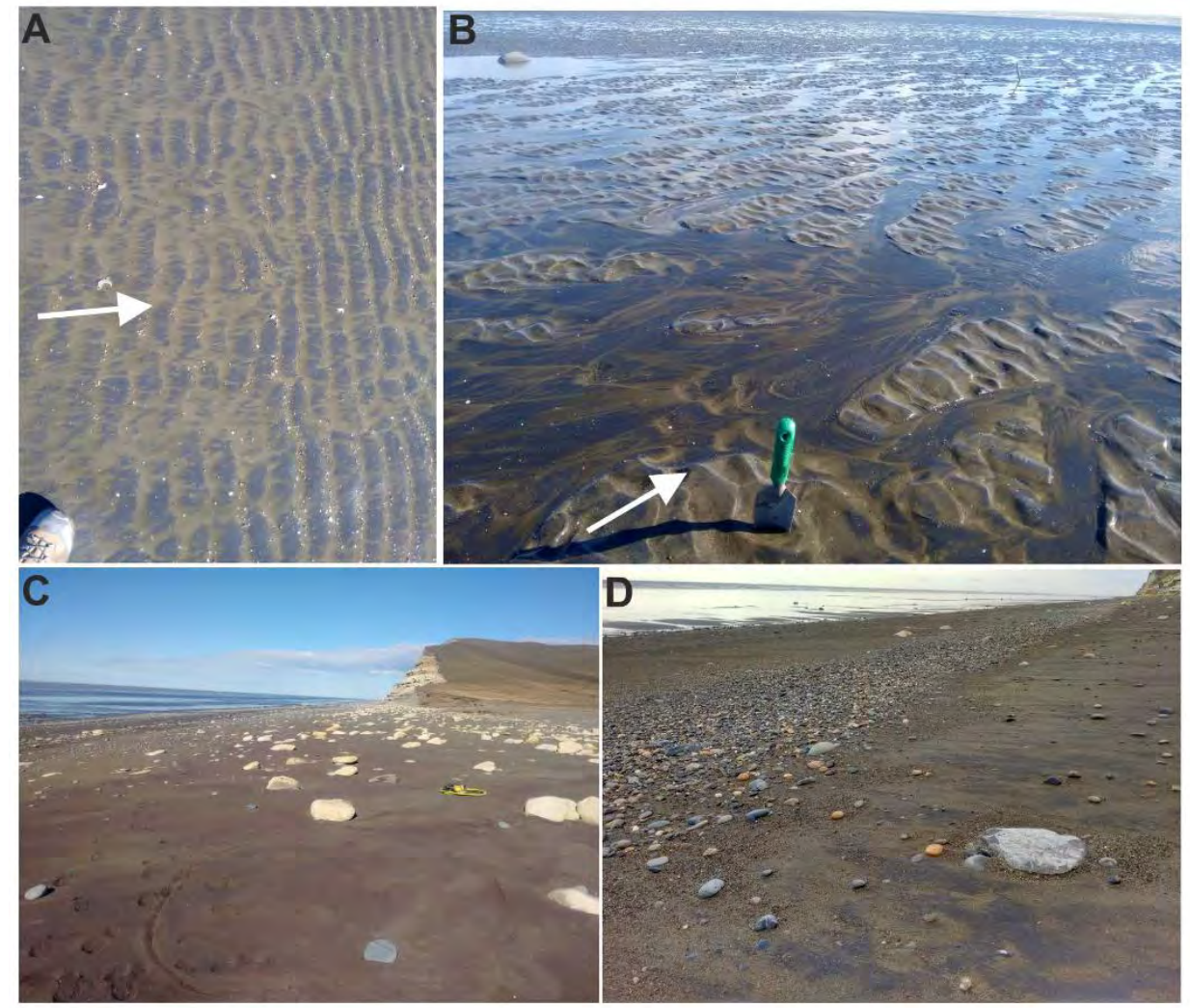

Fig.3.18. Acumulaciones de minerales pesados en la playa del cañadón Beta. A) y B) óndulas y canales mareales en la zona intermareal baja. La flecha indica la dirección de transporte durante bajamar. C y $D$ zona supramareal con niveles superficiales enriquecidos.

\subsubsection{Transporte sedimentario.}

A fines de tener una comprensión integrada de los procesos físico-químicos que se han sucedido durante el transporte y la concentración de los depósitos detríticos del NE de Tierra del Fuego, se dará a continuación una rápida reseña de aquellos factores que los han controlado y los sigue controlando actualmente.

Los factores que determinan la clasificación o selección de los sedimentos pueden ser muy variados (Tabla 3.2), siendo la densidad, tamaño y forma de los granos los más 
característicos (Steidtmann 1982). Se pueden diferenciar cuatro tipos distintos de procesos que provocan la clasificación del sedimento: selección por arrastre (entrainment sorting), selección por transporte (transport sorting), selección por cizalla (shear sorting) y selección por suspensión (suspension sorting) (Slingerland 1984, Slingerland y Smith 1986, Komar 2007). El primero opera durante la erosión, los dos siguientes durante el transporte y el último en la depositación (Fig.3.19)

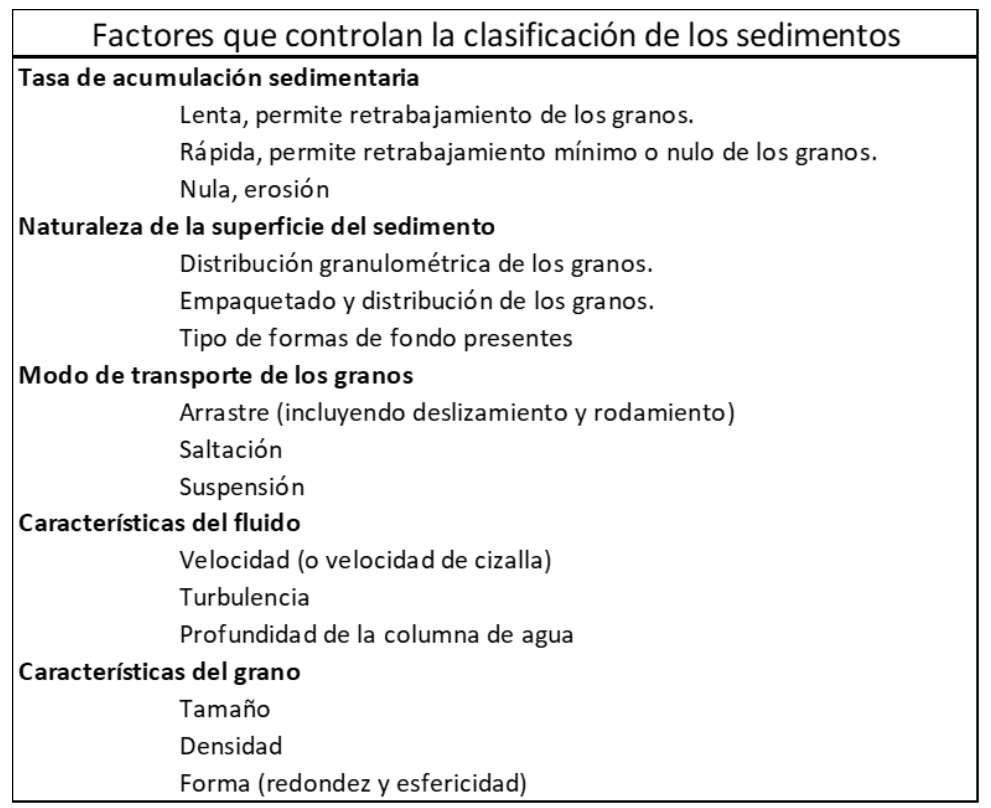

Tabla 3.2. Factores que controlan la clasificación del sedimento, extractado de Steidtmann (1982).

Selección por arrastre: la clasificación se realiza en función del esfuerzo crítico de cizallamiento o velocidad crítica para levantar el grano del lecho. Depende de las características de los granos y de la configuración del lecho. Se produce durante la erosión por lo que los granos que requieran un esfuerzo de cizalla menor al que genera el fluido son transportados, mientras que el resto permanece inmóvil. Las densidades más altas y los tamaños de grano más fino provocan una mayor resistencia a la entrada en movimiento por el flujo del agua.

Selección por transporte: clasifica los minerales pesados y livianos en función de sus velocidades relativas de transporte e incluye el transporte como carga de fondo o arrastre y suspensión. Depende de las características del grano, la configuración del lecho y la velocidad del fluido. Aquellos granos que se transportan más fácilmente recorrerán una distancia mayor.

Selección por cizalla o corte: provoca el ordenamiento vertical en láminas horizontales como repuesta al cizallamiento en la capa de fondo por el fluido en movimiento y la acción dispersiva resultante entre los granos al colisionar (Komar 2007). Según 
Bagnold (1954) depende del diámetro y densidad de los granos, concentración de éstos y la tasa de cizallamiento. Este investigador indica que los granos más gruesos tienden a migrar hacia arriba mientras que los más finos se mueven hacia abajo, generando una clasificación inversa y dado que los minerales pesados son normalmente más pequeños que los livianos, se concentrarán hacia la base. Existen otras hipótesis alternativas como la de Middleton (1970) que indica que la clasificación se produce porque las partículas más pequeñas tienden a caer en los espacios entre las partículas más grandes, desplazando a estas hacia la superficie. Cualquiera que sea el mecanismo que haya producido las laminaciones, la clasificación inicialmente da como resultado solo una separación menor de minerales pesados y livianos, sin embargo, es posible que debido al cizallamiento repetido por el oleaje en la zona de swash, los materiales pesados sean conducidos progresivamente hacia abajo concentrándose, mientras que los granos de cuarzo y feldespato más grandes se elevan a la superficie de la zona de cizalla para ser transportados.

Selección por transporte en suspensión: los granos se clasifican de acuerdo a la velocidad de decantación o sedimentación, dependiendo de las características del grano y naturaleza de la turbulencia del flujo. Aquellos granos que presenten mayor velocidad de sedimentación se depositarán primero. Para este fenómeno se desarrolló el concepto de tamaño hidráulico equivalente (Rubey 1933, Rittenhouse 1943) que indica que dos partículas de diferentes tamaños y densidades son hidráulicamente equivalentes si se depositan al mismo tiempo (misma velocidad de asentamiento) bajo determinadas condiciones hidráulicas.

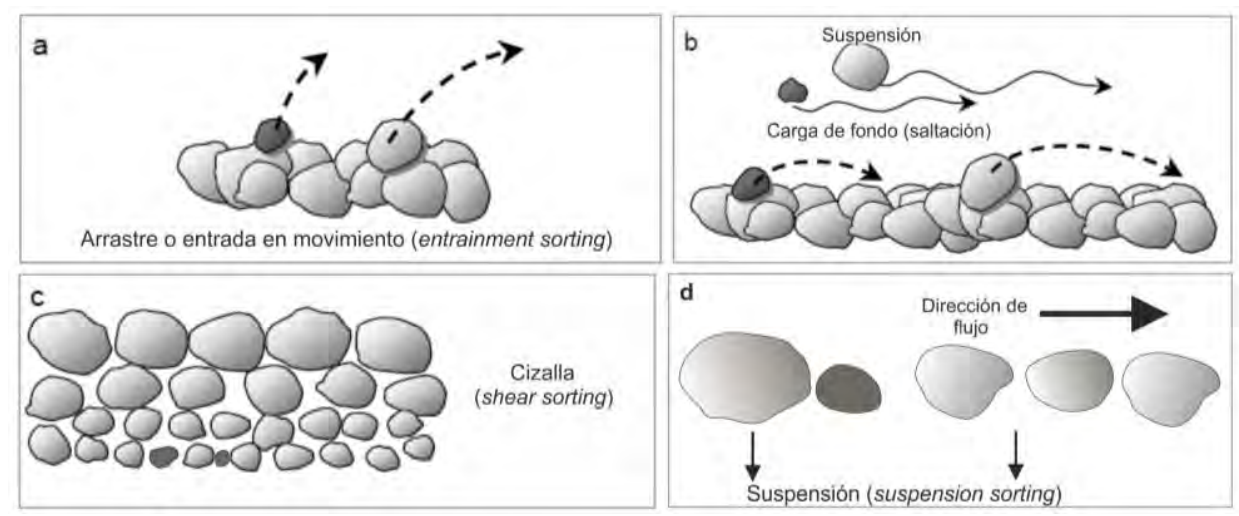

Fig.3.19. Diferentes mecanismos relacionados clasificación del sedimento: a) selección por arrastre, b) selección por transporte en suspensión y como carga de fondo (tipo saltación en este caso), c) selección por cizalla y d) selección por suspensión. Modificado de Manso Galván (2001). 


\subsubsection{Depósitos de tipo placer.}

A lo largo de la historia de la humanidad se han explotado yacimientos detríticos de tipo placer, principalmente para la obtención de oro. El término "placer" hace referencia a un tipo de yacimiento mineral caracterizado por la concentración natural de minerales pesados debido a la actividad de agentes de transporte exógeno como el agua, el viento o el hielo.

La alta densidad, estabilidad mecánica o física y química, así como el tamaño de grano, son requisitos previos para la formación de depósitos detríticos económicamente valiosos (Kudrass 2016).

La densidad constituye el parámetro más importante para la formación del depósito, pudiendo diferenciarse entre minerales livianos, como el cuarzo con una densidad de 2,65 $\mathrm{g} / \mathrm{cm}^{3}$ y minerales pesados con densidades que cubren un amplio rango desde $2,8 \mathrm{~g} / \mathrm{cm}^{3}$ para minerales del supergrupo del anfíbol a 19,3 g/ $\mathrm{cm}^{3}$ para el oro (Mange y Maurer, 1992).

La estabilidad química también es importante ya que los minerales son sometidos a distintos procesos de meteorización química como la corrosión durante su liberación y transporte desde la roca progenitora en los sectores montañosos hasta las zonas bajas (Andò et al. 2012), siendo el oro uno de los minerales más resistentes; por el contrario, la apatita es muy inestable en suelos ácidos produciéndose su disolución (Mange y Maurer 1992). La estabilidad mecánica, puede estimarse mediante la escala de dureza de Mohs, sin embargo, hay que tener en cuenta también la fragilidad ya que algunos minerales se rompen fácilmente como los piroxenos y anfíboles o la maleabilidad que evita su ruptura como el caso del oro (Kudrass 2016). Minerales que no se desgastan fácilmente por la abrasión pueden ser el rutilo, circón, magnetita o ilmenita (Kudrass 1987). Minerales resistentes a la meteorización tanto química como física son los denominados "resistatos" (Tabla 3.3).

El tamaño de grano de los minerales pesados depende de la cristalización durante su formación en la roca fuente magmática o metamórfica, presentando una gran variabilidad, normalmente dentro de la fracción arena (Mange y Maurer 1992). 


\begin{tabular}{|c|c|c|c|c|c|}
\hline Mineral & Composición & Densidad $\left(\mathrm{g} / \mathrm{cm}^{3}\right)$ & Estabilidad química & Dureza (Mohs) & Tenacidad \\
\hline Oro & $\mathrm{Au}$ & $15-19,3$ & Muy alta & 2,5 & Muy dúctil y maleable \\
\hline Rutilo & $\mathrm{TiO}_{2}$ & 4,2 & Muy alta & $6-6,5$ & Semi-frágil \\
\hline Corindón & $\mathrm{Al}_{2} \mathrm{O}_{3}$ & 4 & Muy alta & 9 & Fuerte \\
\hline Ilmenita & $\mathrm{FeTiO}_{3}$ & $4,5-5,0$ & Alta & $5-6$ & Semi-frágil \\
\hline Magnetita & $\mathrm{Fe}_{3} \mathrm{O}_{4}$ & $5,2-6,5$ & Alta & $5-6$ & Semi-frágil \\
\hline Zircón & $(\mathrm{Zr}, \mathrm{Hf}, \mathrm{U}) \mathrm{SiO}_{4}$ & $4,2-4,9$ & Muy alta & 7,5 & Frágil \\
\hline Gr.Granate & $(\mathrm{Mg}, \mathrm{Fe}, \mathrm{Mn}, \mathrm{Ca}) \mathrm{Al}_{2} \mathrm{Si}_{3} \mathrm{O}_{12}$ & $3,5-4,2$ & Alta & $7-7,5$ & Semi-frágil \\
\hline Monacita & $(\mathrm{Ce}, \mathrm{La}, \mathrm{Th}) \mathrm{PO}_{4}$ & $4,9-5,3$ & Alta & $5-5,5$ & Frágil \\
\hline Cromita & $\mathrm{FeCr}_{2} \mathrm{O}_{4}$ & $4,5-4,8$ & Alta & 5,5 & Frágil \\
\hline Espinela & $\mathrm{MgAl}_{2} \mathrm{O}_{4}$ & $3,6-4,1$ & Alta & $7,5-8$ & Frágil \\
\hline Titanita & $\mathrm{CaTiSiO}_{5}$ & $3,5-3,6$ & Alta & $5-5,5$ & Frágil \\
\hline Andalucita & $\mathrm{Al}_{2} \mathrm{SiO}_{5}$ & 3,2 & Baja & 7,5 & Frágil \\
\hline Sillimanita & $\mathrm{Al}_{2} \mathrm{SiO}_{5}$ & 3,2 & Baja & $6,5-7,5$ & Frágil \\
\hline Apatita & $\mathrm{Ca}_{5}(\mathrm{~F}, \mathrm{OH})(\mathrm{PO} 4)_{3}$ & 3,2 & Muy alta & 5 & Frágil \\
\hline Gr.Turmalina & $(\mathrm{Na}, \mathrm{Ca})(\mathrm{Li}, \mathrm{Mg}, \mathrm{Al})(\mathrm{Al}, \mathrm{Fe}, \mathrm{Mn})_{6}\left(\mathrm{BO}_{3}\right)_{3}\left(\mathrm{Si}_{6} \mathrm{O}_{18}\right)(\mathrm{OH})$ & 3,1 & Alta & $7-7,5$ & Semi-frágil \\
\hline Epidoto & $\mathrm{Ca}_{2}(\mathrm{Al}, \mathrm{Fe}) \mathrm{Al}_{2} \mathrm{O}\left(\mathrm{SiO}_{4}\right)\left(\mathrm{Si}_{2} \mathrm{O}_{7}\right)(\mathrm{OH})$ & 3,4 & Baja & $6-7$ & Semi-frágil \\
\hline Estaurolita & $\mathrm{Fe}_{2} \mathrm{Al}_{9} \mathrm{O}_{6}\left(\mathrm{SiO}_{4}\right)_{4}(\mathrm{O}, \mathrm{OH})_{2}$ & 3,7 & Alta & $7-7,5$ & Fuerte \\
\hline Gr.Piroxeno & $\mathrm{XYZ}_{2} \mathrm{O}_{6}$ (fórmula general) & $3,2-3,5$ & Baja & $5-6,5$ & Frágil \\
\hline Gr.Anfíbol & $\mathrm{W}_{0-1} \mathrm{X}_{2} \mathrm{Y}_{5} \mathrm{Z}_{8} \mathrm{O}_{22}(\mathrm{OH}, \mathrm{F})_{2}$ (fórmula general) & $2,8-3,6$ & Baja & $5-6$ & Muy frágil \\
\hline
\end{tabular}

Tabla 3.3. Minerales pesados comunes presentes en los depósitos de tipo placer. Información de las propiedades físicas obtenidas de Morton y Hallsworth (2007), Kudrass (2016) y Anthony et al. (1990).

Según Viladevall (2005) para la formación de un placer se tiene que dar la interacción de tres procesos: a) litosférico, con la presencia de un área fuente enriquecida que pueda proporcionar los minerales de interés económico; b) ambiental, de tipo climático que permita la liberación de los minerales y finalmente c) un factor geodinámicogeomorfológico que permita la acumulación y preservación de los minerales liberados. Ligado a los dos últimos, será necesaria la interacción de otros procesos de tipo hidráulico que serían la causa de la liberación de los minerales, transporte y sedimentación en las cuencas fluviales, lacustres y marinas.

Según la clasificación de Smirnov (1982), en el sector de investigación de la presente tesis se han generado y se generan yacimientos de tipo placer de playa-oceánica. Para la formación de los niveles enriquecidos, Kudrass (2016) describe la selección que se produce desde la zona de surf, donde el flujo turbulento de la ola transporta diversas partículas de diferentes tamaños y densidades hacia la zona superior de la playa o zona de swash $(\mathrm{A})$, depositándose los minerales en suspensión en función de la velocidad de asentamiento a medida que la energía de la ola disminuye ("suspensión sorting") (B). Durante el retorno de la ola hacia el mar ("backwash") el flujo laminar del agua arrastra más fácilmente los minerales livianos más grandes que los minerales pesados ("entrainment sorting") (C), generando una lámina rica en minerales pesados en la parte superior de la playa (D) (Fig.3.20). Este proceso de selección se mejora con la mayor capacidad de rodamiento de los minerales livianos o la clasificación por cizalla en la que se genera un ordenamiento vertical en láminas horizontales como repuesta al cizallamiento en la capa de fondo por el fluido en movimiento ("shear sorting"). Cuando las corrientes litorales 
suministran continuadamente sedimento nuevo se pueden llegar a generar capas gruesas de minerales pesados (Kudrass 2016).

Los procesos de concentración en la zona de swash son ideales para el desarrollo de concentrados de minerales pesados, ya que los procesos generados en esta zona son similares a los movimientos del agua inducidos por los buscadores de oro (Komar 2007).

Flujo ascendente (swash)

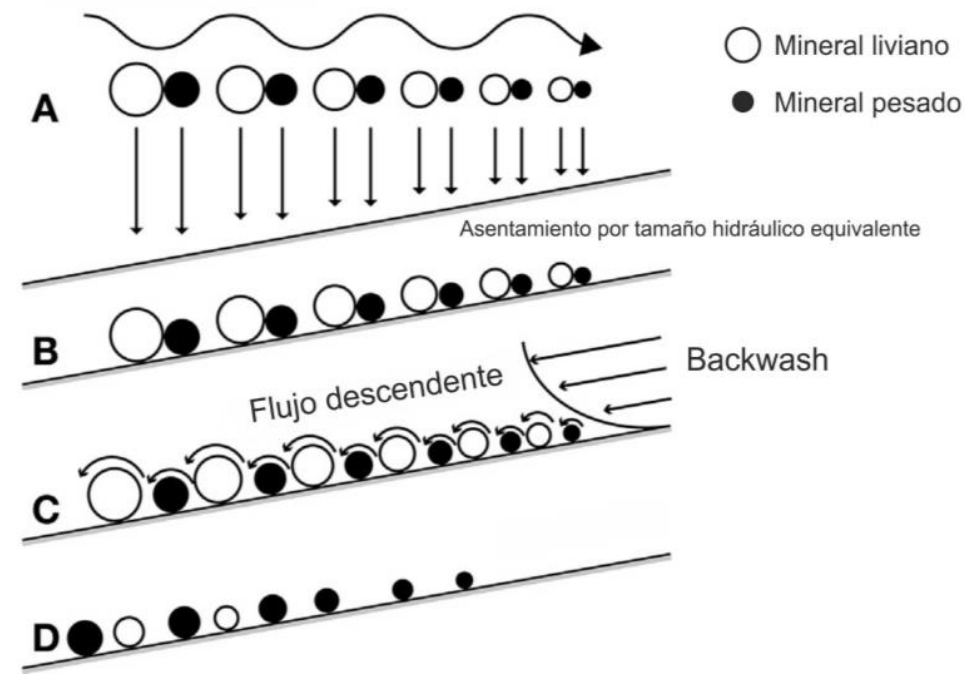

Fig.3.20. Transporte de minerales pesados y livianos desde la zona de surf hasta la zona de swash. Modificado de Kudrass (2016) a su vez modificado de Seibold y Berger (1982).

\subsection{Plataforma Continental Argentina}

La zona de muestreo cubrió un sector meridional de la Plataforma Continental Argentina (PCA). Esta zona se localiza dentro del Margen Continental Argentino (MCA), que abarca además de la plataforma, el talud y la emersión continental. El margen continental argentino, localizado en el Océano Atlántico Sur Occidental, es uno de los márgenes más grandes de mundo, siendo el mayor de Sudamérica con una superficie aproximada de $2 \times 10^{6} \mathrm{~km}^{2}$, con una orientación general NNE-SSO (Cavallotto et al., 2011). Su evolución geológico-geomorfológica se explica a partir de la combinación e interacción de factores geotectónicos, oceanográficos y climáticos (Violante et al. 2017b). Debido a su historia geológica, en el MCA se pueden diferenciar cuatro tipos de márgenes continentales: activo, pasivo, transcurrente y mixto (Ramos 1996, Paterlini et al. 2017, Violante et al. 2017a, 2017b) (Fig.3.21A). 

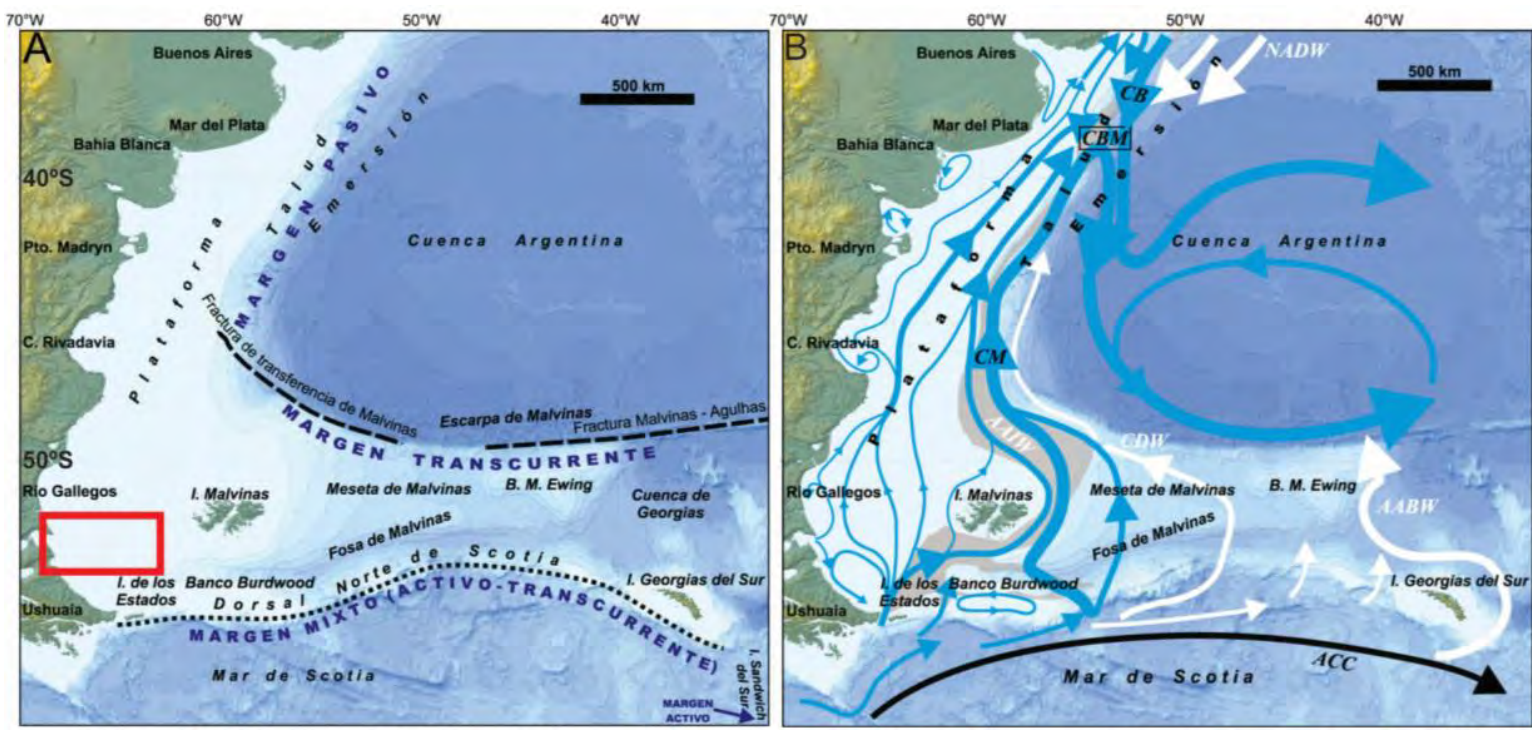

Fig.3.21. A) Localización y tipos de márgenes y B) Corrientes marinas presentes en el Margen Continental Argentino. CB: Corriente de Brasil; CM: Corriente de las Malvinas; AAIW: Agua Intermedia Antártica; CDW: Agua Circumpolar Profunda; AABW: Agua de Fondo Antártica; NADW: Agua Profunda del Atlántico Norte; ACC: Corriente Circumpolar Antártica. Mapas tomados de Violante et al. (2017a) y referencias allí citadas. El rectángulo rojo indica la zona de muestreo.

Respecto a la dinámica oceánica en este sector se pueden diferenciar distintas masas de aguas tanto superficiales como profundas (Violante et al. 2017a, Paterlini et al. 2017). La circulación superficial de las aguas es debida a la interacción entre la Corriente de las Malvinas (CM) con sentido al N-NE y la Corriente de Brasil (CB) que fluye hacia el S-SE, generándose una zona de confluencia aproximadamente en la latitud de la localidad de Mar del Plata. Se identifican también corrientes más profundas como son la Masa de Agua Antártica Intermedia (AAIW), la Masa de Agua Circumpolar Antártica Profunda (CDW) y la Masa de Agua Atlántica Profunda Norte (NADW) (Fig.3.21B).

Según Violante et al. (2017a) esta circulación de las aguas, con una orientación N$\mathrm{S}$, comenzó a configurarse a partir del Eoceno-Oligoceno con la expansión del Océano Atlántico, así como el cierre del Mar Mediterráneo y el Istmo de Panamá, y la apertura de los Pasajes de Drake y Tasmania. A partir del Mioceno medio a superior y el Plioceno superior se alcanzó la estructuración actual de la Plataforma Continental que permitió la configuración morfosedimentaria con la formación de terrazas y cuerpos contorníticos.

La Plataforma Continental Argentina (PCA), donde se localiza parte de nuestra zona de trabajo, es una de las plataformas submarinas más extensas del mundo (Paterlini et al. 2017). Presenta una superficie aproximada de $960.000 \mathrm{~km}^{2}$, con un relieve suave y una longitud entre el río de la Plata y el cabo de Hornos que alcanza los $2.400 \mathrm{~km}$ (Violante et al. 2014). En el margen continental pasivo la anchura se incrementa hacia el sur, desde $170 \mathrm{~km}$ en el norte a $850 \mathrm{~km}$ a la altura de las Islas Malvinas. En los márgenes mixto o 
activo meridionales, la plataforma es mucho más estrecha, presentando al sur de la Isla de los Estados escasos kilómetros (Violante et al. 2017b).

\subsubsection{Regiones y zonas de la Plataforma Continental Argentina}

En función de las características morfosedimentarias, se pueden distinguir distintas regiones dentro de la PCA. Parker (1996) diferenció siete provincias fisiográficas (Fig.3.22).

La Terraza Rioplatense se ubica en la desembocadura del río de la Plata hasta la isobata de $30 \mathrm{~m}$, con una superficie subhorizontal, correspondiente con el sector norte de la denominada Terraza I (Parker et al. 1997). Su configuración final se relaciona con la transgresión postglacial (Cavalotto et al. 2014, Paterlini et al. 2017 y sus referencias).

Los frentes deltaicos de los ríos Colorado y Negro están relacionados con los ambientes deltaicos producidos durante el Cuaternario y los aportes sedimentarios de ambos ríos (Paterlini et al. 2017).

Los golfos norpatagónicos son cuencas semicirculares y semicerradas que alcanzan en algunos casos profundidades más grandes que el borde exterior de la plataforma (Parker et al. 1996). Se les atribuye un origen hidro-eólico con posterior inundación durante las transgresiones (Ponce et al. 2011 y referencias allí citadas).

La Plataforma Interior Patagónica se corresponde con el sector de la plataforma adyacente a la costa Patagónica desde el golfo Nuevo hasta el sur del río Santa Cruz, extendiéndose a profundidades equivalentes a la base de la terraza I, entre 70 y $80 \mathrm{~m}$ (Violante et al. 2017a). Las características principales son el paralelismo de las isobatas con la costa y la influencia de los frentes deltaicos gravosos de los ríos patagónicos que genera morfologías en forma de lóbulos (Parker et al. 1996, Paterlini et al. 2017).

La Plataforma Exterior Patagónica es la más extensa de las subprovincias fisiográficas, localizándose desde el Río de la Plata hasta el extremo sur de la Provincia de Santa Cruz, limitando hacia el este con el talud continental. En ella se localizan las terrazas II, III y IV. Se considera que se desarrolló una extensa red fluvial cuando su superficie estaba emergida (Parker et al. 1996).

La plataforma de Tierra del Fuego se extiende al este de la Isla Grande de Tierra del Fuego. Se caracteriza por el carácter glacial que se les atribuye a los depósitos de fondo y morfologías en la franja de la plataforma más cercana a la costa (Isla y Schnack 1995, Parker et al. 1996, Mouzo 2005a). 


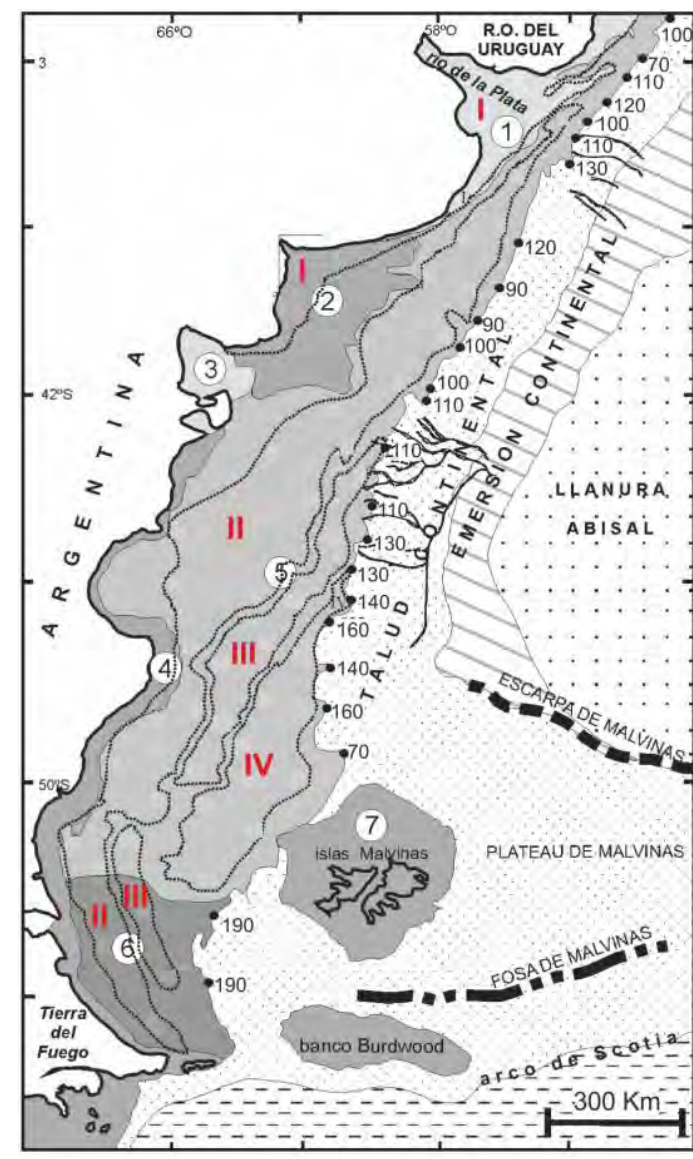

1 Terraza Rioplatense

2 Frente deltaico ríos Colorado y Negro

3 Golfos norpatagónicos

4 Plataforma Interior Patagónica

5 Plataforma Exterior Patagónica

6 Plataforma de Tierra del Fuego

7 Plataforma de Malvinas

Terrazas I,II,III,IV

Cañones

Fig.3.22. Mapa geomorfológico tomado de Violante et al. (2014), basado en los datos de Parker et al. (1996). Se indican las provincias fisiográficas, las diferentes terrazas presentes en la plataforma y la profundidad de quiebre de la plataforma.
Finalmente, la plataforma de las Malvinas se caracteriza por presentar una morfología uniforme con llanuras planas (Ponce et al. 2011). Representa una extensión de la Plataforma Exterior Patagónica (Violante et al. 2017b).

A partir de la dinámica sedimentaria se pueden reconocer tres regiones distintas en la PCA: interior, media y exterior (Mouzo 2005a, Violante et al. 2014, Violante et al. 2017b). La región interior se localiza desde la línea de costa hasta una profundidad de 30 m. Los sedimentos litorales están afectados por las condiciones hidrodinámicas actuales influenciadas por la sedimentación costera, las corrientes litorales, olas y mareas. Estos sedimentos resultantes de la combinación de más de un proceso reciben en geología el nombre de palimpsestos. La región media se desarrolla entre los 30 y 90 m de profundidad, con baja movilidad de los sedimentos (denominados relictos) y finalmente la plataforma exterior que se extiende desde los $90 \mathrm{~m}$ hasta el borde exterior de la plataforma o inicio del talud continental. En esta zona dominan las corrientes de borde y procesos gravitacionales influenciados por la presencia de cañones submarinos.

En función de la ubicación geográfica y los procesos sedimentarios dominantes, la PCA también puede ser dividida en tres regiones: norte, central y sur (Violante et al. 2014, 2017b). La región norte se corresponde con la zona adyacente al Río de la Plata. Debido a la presencia de este río, domina la actividad fluvial sobre los procesos marinos. La central se localiza entre las regiones de la Pampa y la zona central y norte de la Patagonia. Presenta un predominio del oleaje y las mareas sobre la acción fluvial, a excepción de las desembocaduras de los ríos principales (como el Colorado y Negro) y finalmente en la 
región sur hay predominio de las mareas frente al oleaje o actividad fluvial. Este sector está caracterizado por la presencia de hielos durante el Plioceno-Pleistoceno que alcanzaron la plataforma, por lo que es común encontrar gravas y sedimentos glacifluviales.

Uno de los rasgos morfológicos más destacados en la PCA es la presencia de cuatro terrazas escalonadas localizadas en el sector pasivo a una profundidad de $25 / 30 \mathrm{~m}$ (I), 85/95m (II), 110/120m (III) y 130/150m (IV) (Parker, et al., 1997). El origen de las terrazas se vincula con momentos de estabilización del nivel del mar durante su ascenso en la transgresión postglacial, correspondiendo los escalones de las terrazas con los antiguos acantilados costeros (Parker et al. 1997, Ponce et al. 2011). Violante et al. (2014) indican que las terrazas II, III y IV podrían estar influenciadas además por reajustes isostáticos al desarrollarse en la región meridional de la Patagonia donde estos efectos fueron importantes.

La posible edad de estos niveles varía según la interpretación de diferentes autores. Ponce et al. (2011) estimaron una edad de 11 ka (coincidente con el evento Younger Dryas), $15 \mathrm{ka}$ y $22 \mathrm{ka}$ para las terrazas I, II y III, respectivamente. La terraza IV la relacionan con alguna glaciación más profunda, posiblemente con la Gran Glaciación Patagónica (GGP), hace $1 \mathrm{Ma}$. Por su parte, Violante (2005) sitúa los límites en 11ka (TI), 12-13ka (TII relacionada con Reversión Fría Antártica), 14-15ka (TIII) y 16-18ka (IV).

En el sector sur de la Patagonia se pueden reconocer tres de estas terrazas: TII, TIII y TIV. TII es la más extensa ya que está presente desde el río de la Plata hasta Tierra del Fuego. Su superficie está cubierta por arenas finas arcillo-limosas y a partir de la profundidad de $90 \mathrm{~m}$, arenas medianas y gruesas con concentraciones de gravas (Violante, et al. 2017b). Según estos investigadores el cambio sedimentológico indicaría una mayor actividad fluvial durante épocas de nivel del mar bajo como consecuencia de un mayor gradiente. La terraza TIII se localiza entre las latitudes $43^{\circ}$ y $54^{\circ}$ sur y se caracteriza por presentar relictos de una antigua red fluvial con cobertura de arenas bioclásticas y gravas con posible origen glacifluvial (Violante et al. 2014). La terraza TIV se ubica desde la latitud $46^{\circ}$ hasta $52^{\circ} \mathrm{S}$. Los sedimentos presentes en su superficie se consideran de origen glacifluvial presentando antiguas redes fluviales relícticas (Violante et al. 2017b).

\subsubsection{Plataforma Continental en el sector NE de Tierra del Fuego}

Durante el Cuaternario, como consecuencia de los eventos glaciales la PCA fue modelada con sucesivas transgresiones y regresiones marinas. Los movimientos eustáticos durante los diferentes períodos glaciales e interglaciales provocaron grandes variaciones del nivel del mar, situándose durante los episodios glaciales entre 100 y $140 \mathrm{~m}$ 
por debajo del nivel actual (Rabassa 2008). La exposición subaérea durante el Último Máximo Glacial (hace aproximadamente 24.000 años) dejó gran parte de la plataforma emergida, evidenciándose actualmente en antiguas redes fluviales, depósitos y geoformas glacigénicas y paleosuelos continentales (Violante et al. 2014). Según Ponce et al. (2011) durante el Último Máximo Glacial, el nivel del mar se situó entre 120 y 140m por debajo del nivel actual, quedando una superficie expuesta de la PCA de aproximadamente 590.000 $\mathrm{km}^{2}$. Se extiende desde la desembocadura actual del Río de la Plata hasta el sur de la isla de los Estados, con un ancho variable entre $490 \mathrm{~km}$ y $100 \mathrm{~km}$. En la costa atlántica de Tierra del Fuego la superficie que emergió como consecuencia del descenso del nivel del mar fue aproximadamente de $45.000 \mathrm{~km}^{2}$. En la zona de trabajo, la línea de costa se situó a más de $170 \mathrm{~km}$ mar adentro, dando una superficie de la plataforma continental emergida de aproximadamente $16.000 \mathrm{~km}^{2}$ (Fig.3.23).

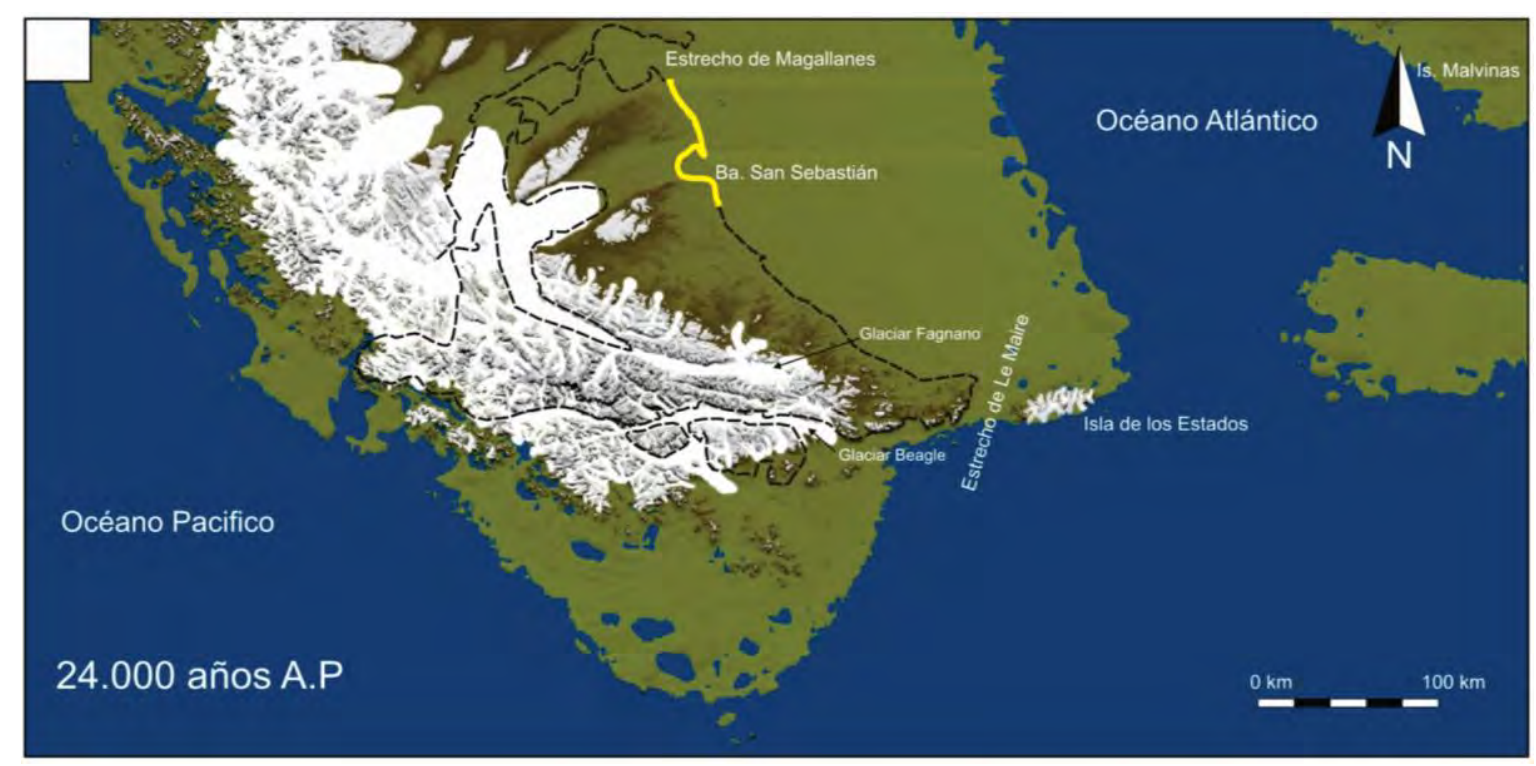

Fig.3.23. Extensión de Plataforma Continental emergida durante el Último Máximo Glaciar. Tomado de Ponce et al. (2011). En amarillo se marca el sector costero correspondiente con el área continental de trabajo.

En el sector meridional de la Plataforma, que abarca nuestra zona de trabajo, los hielos provenientes de la cordillera andina alcanzaron las zonas costeras dejando relictos de depósitos glacigénicos. Mouzo (2005a y b) estudió la batimetría, morfología y las características litológicas, sísmicas y estructurales de las capas sedimentarias más superficiales bajo el fondo oceánico en este sector. Describió asimismo la secuencia estratigráfica con las unidades terciarias como roca de base, sobre las que se asientan los depósitos glacigénicos del Pleistoceno y/o sedimentos marinos recientes. Respecto a la morfología, localizó un espolón, un valle glacial sumergido de unos 125 km de longitud, dos 
hoyas, tres altos batimétricos posiblemente relacionados con remanentes de morenas frontales y un escalón a una profundidad de 40-60m considerado como una antigua línea de costa (Fig.3.24).

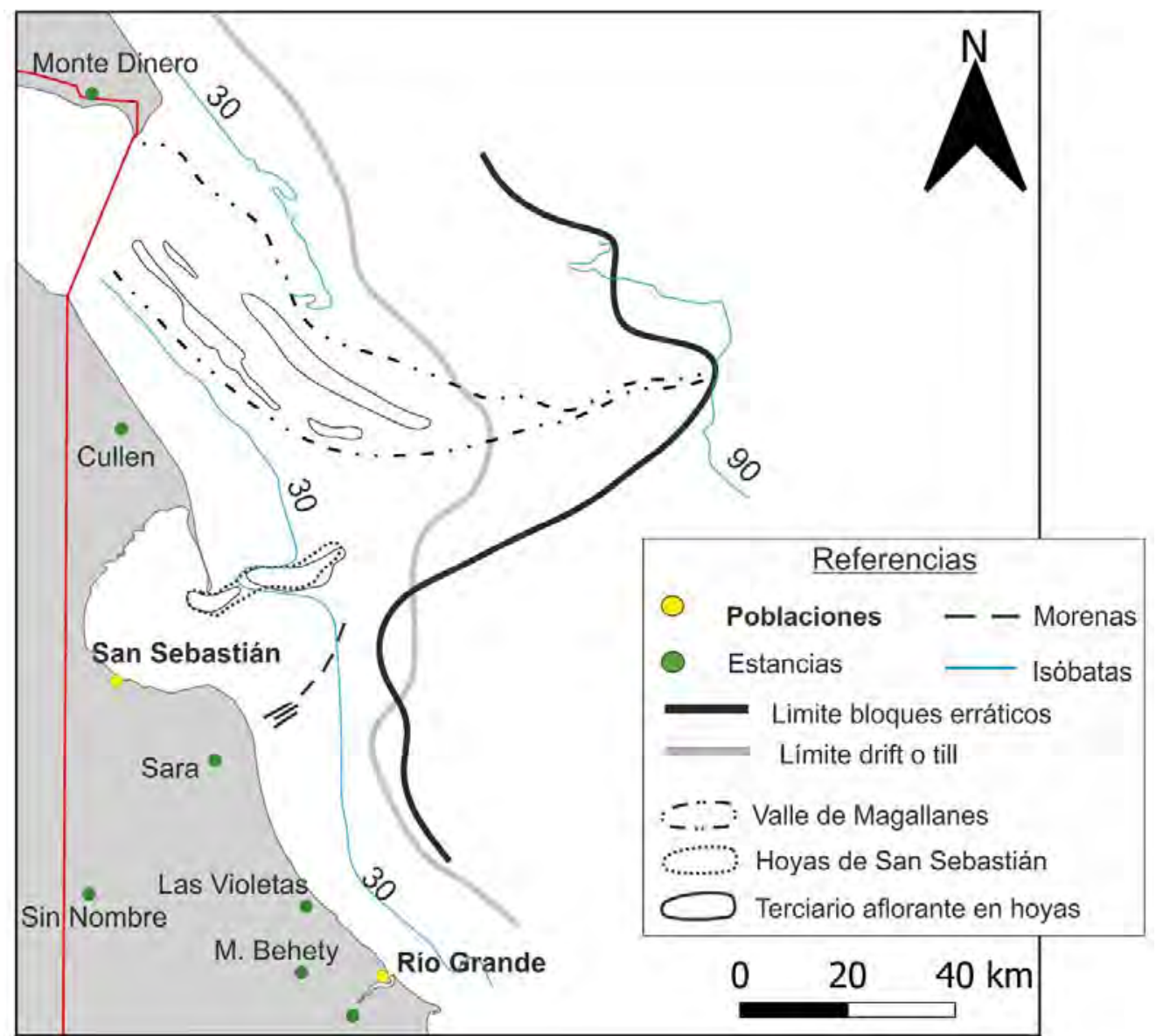

Fig.3.24. Morfología de la PCA en el sector NE de Tierra del Fuego, (Mouzo 2005 a,b,c). 


\section{Capítulo 4: SECTOR CONTINENTAL GLACIAL}

\subsection{Introducción}

La Isla Grande de Tierra del Fuego representa una de las regiones del sector austral de la Patagonia donde mejor se han preservado los registros de las glaciaciones ocurridas durante el Pleistoceno inferior a medio. El sector argentino constituye la porción oriental de esas glaciaciones, las cuales además se extendieron muchos kilómetros al este de la actual línea de costa atlántica.

La estratigrafía glacial está constituida por diferentes unidades litoestratigráficas con características geomorfológicas acordes a los procesos acumulativos y a los erosivos, tanto de origen glacial como glacifluvial.

\subsection{Muestreo y descripción de los afloramientos}

Se muestrearon los depósitos glacigénicos en un total de 17 estaciones (Est.) distribuidas en todos los sectores considerados representativos, principalmente al norte de la bahía San Sebastián (Fig.4.1), aprovechando antiguas canteras de áridos, incisiones realizadas en el terreno por los arroyos y los afloramientos en acantilados.

El acceso a las diferentes estaciones se realizó utilizando la Ruta Nacional $N^{\circ} 3$ y caminos secundarios que debido a la actividad petrolera y ganadera se mantienen en buenas condiciones. Desde las playas es posible muestrear los depósitos en los acantilados desde el sur del cañadón Tortuga hasta punta Sinaí a causa de la profundización tectónica de las sedimentitas transicionales de la Fm. Cullen. Sin embargo, como consecuencia del retroceso de los acantilados debido a la acción combinada del oleaje marino, el viento y la escorrentía superficial, junto con la inestabilidad de los frentes litorales de los sedimentos glacigénicos (susceptibles a la erosión), se producen procesos de remoción en masa como desprendimientos de grandes bloques de material y avalanchas de derrubios, siendo por ello peligroso trabajar en las proximidades del acantilado.

Los sedimentos glacigénicos se corresponden con tres glaciaciones distintas producidas durante el Pleistoceno inferior y medio. Los depósitos generados por estos glaciares se agrupan en el Drift Pampa de Beta (DPB), Drift Río Cullen (DRC) y Drift San Sebastián (DSS) (Meglioli 1992). 

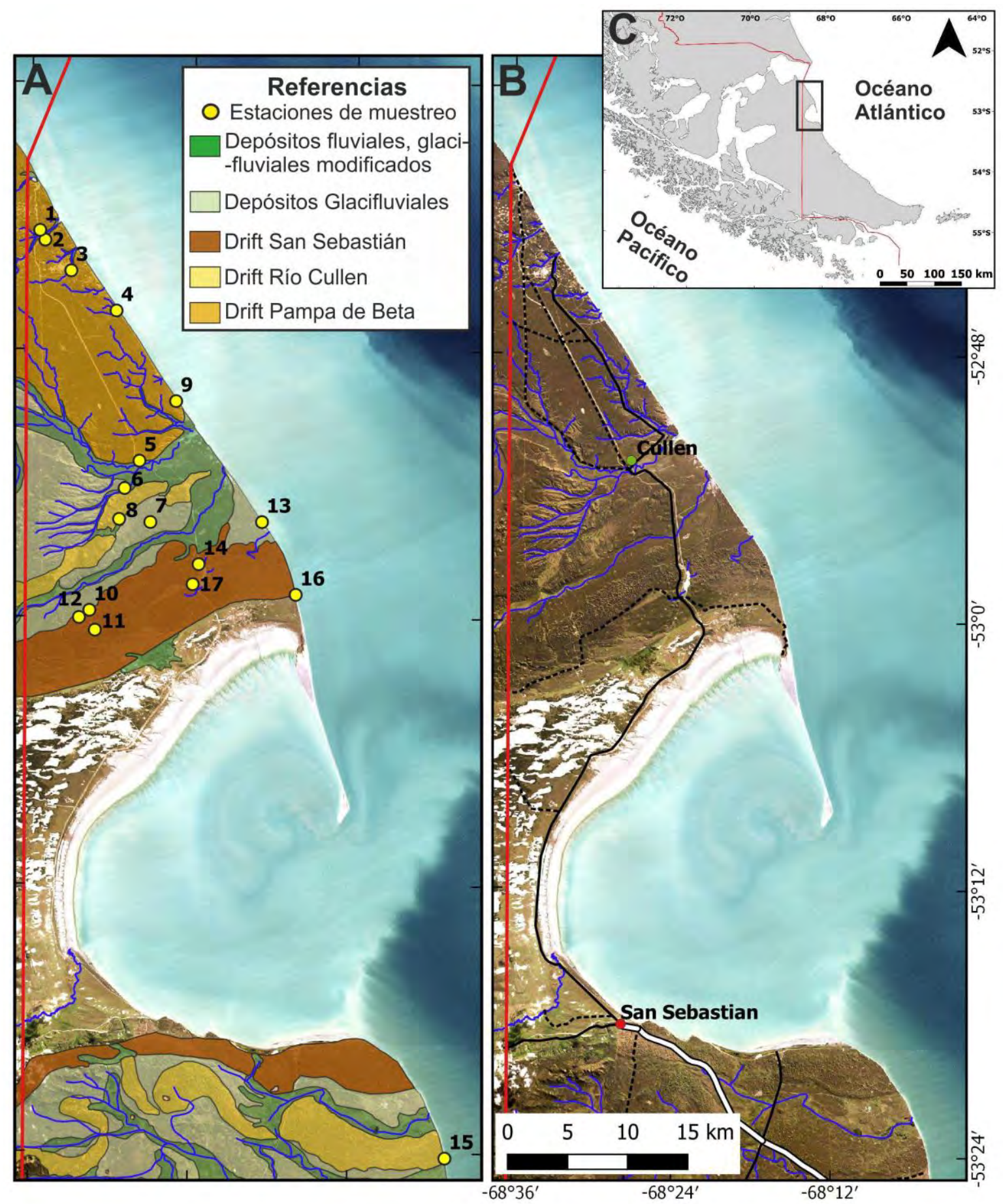

Fig.4.1. A) Mapa geológico-geomorfológico con la ubicación de las diferentes estaciones de muestreo. B) Mapa geográfico con los principales accidentes geográficos y puntos de interés: 1, punta Sinaí; 2, cabo San Sebastián; 3, sierra Carmen Silva; 4, península El Páramo; 5, sierra de San Sebastián; 6, cabo Nombre; 7, Cullen Sur; 8, Río Cullen; 9, Cullen Norte; 10, Pampa de Rincón; 11, cañadón Tortuga; 12, Pampa de Beta; 13, cañadón Beta; 14, cañadón Alfa; 15, cabo Espíritu Santo. C) Mapa de ubicación de la zona continental de trabajo. Cartografía realizada a partir de datos de campo, imagen satelital (Landsat 8) y bibliografía previa (Codignotto y Malumián 1981, Agüero et al. 2003, Olivero et al. 2006, Darvill et al. 2015b). 


\subsubsection{Drift Pampa de Beta (DPB)}

El DPB se muestreó en seis estaciones al norte del río Cullen aprovechando los cañadones Alfa, Beta y Tortuga (Est. 1 a 4) y los cortes realizados por la construcción de la ruta Nacional №3 o para la extracción de áridos (Est. 5 y 9). En los acantilados se puede observar toda la secuencia de base a techo alcanzando espesores de hasta $70 \mathrm{~m}$ (Fig.4.2A y B).
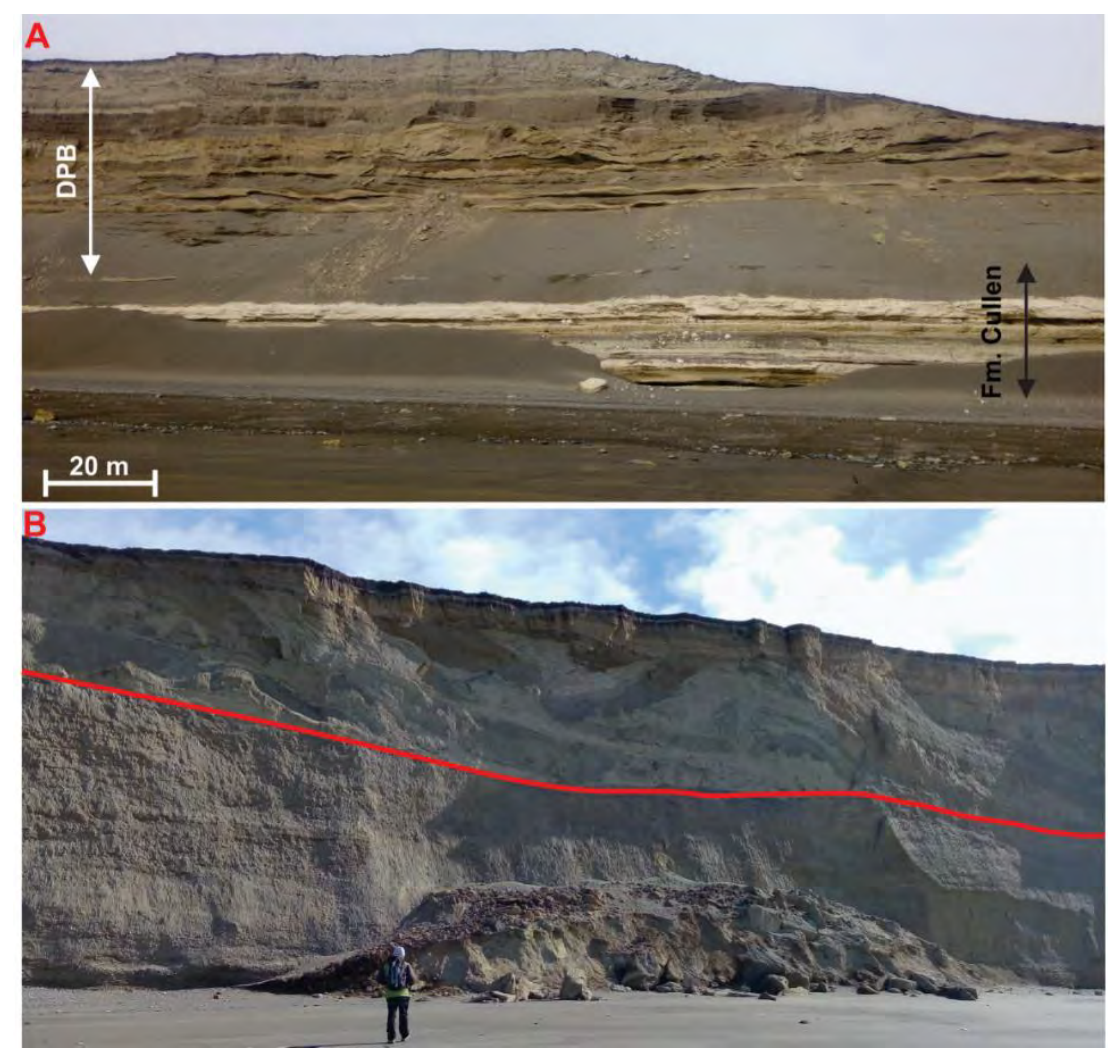

Fig.4.2. A, acantilados al sur del cañadón Beta; B, acantilados al norte de Cullen S. La línea roja separa un paquete inferior estratificado de otro superior matriz-sostenido con lentes gravosas, los dos pertenecientes al DPB.

Los afloramientos se caracterizan por presentar una alternancia de niveles sin y con estratificación marcada (Fig.4.3). Los primeros presentan una textura matriz-sostenida constituida mayoritariamente por limos y arcillas junto con arenas y gravas con clastos principalmente subredondeados (tamaño más común entre 5 y $10 \mathrm{~cm}$ ). Son comunes las lentes gravosas de hasta 1,5 m de espesor. Los niveles estratificados están conformados principalmente por gravas y en menor proporción arenas, limos y arcillas, con clastos redondeados a subredondeados (tamaño más común entre 3 y $5 \mathrm{~cm}$ ). No se observan bloques erráticos en la superficie ni grandes bloques en los perfiles. La forma superficial de estos depósitos corresponde a una suave planicie o llanura suavemente ondulada únicamente interrumpida por los cañadones presentes en el sector. 

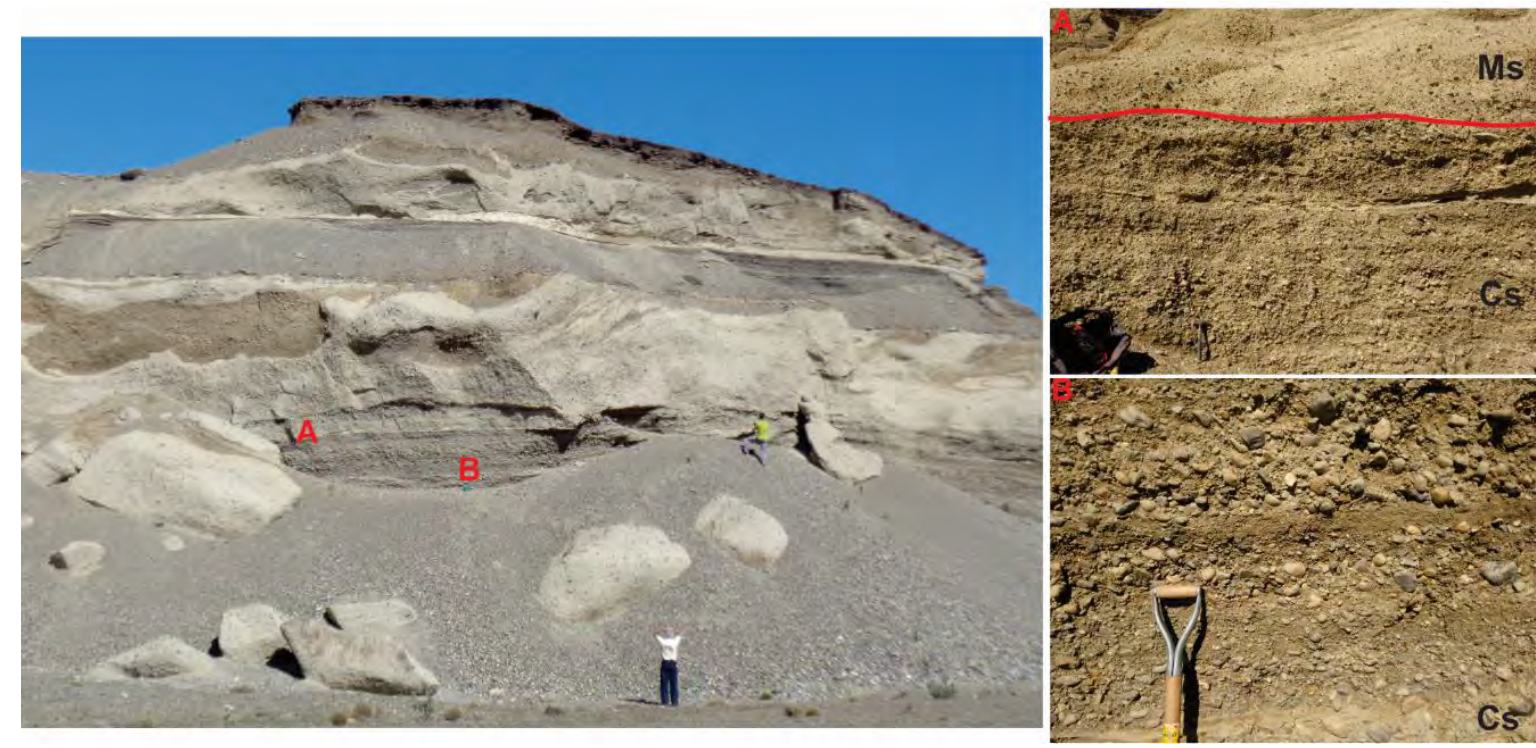

Fig.4.3. Afloramiento en el Drift Pampa de Beta (Est. 3). A) Ms: matriz-sostenido; B) Cs: clasto-sostenido.

\subsubsection{Drift Río Cullen (DRC)}

Los depósitos del DRC se muestrearon en tres estaciones localizadas en las morenas laterales, dos al norte de la bahía San Sebastián (Est. 6 y 8 ) y una al sur (Est.15), en la zona de punta Sinaí.

Al norte, estos depósitos presentan una abundante matriz limo/arcillosa y arenosa con gravas subordinadas desde subredondeadas a subangulosas, con un tamaño máximo de $20 \mathrm{~cm}$, mal seleccionados, con distribución caótica (Fig.4.4). Dentro de este conjunto matriz-sostenido se observan lentes constituidas por grava y arena gruesa. En el sector sur los depósitos tienen características similares a los del norte, pero a diferencia de estos se reconocen grandes bloques erráticos angulosos de hasta $7 \mathrm{~m}$ de largo (estimación $180 \mathrm{t}$ ) con una composición mayoritariamente tonalítica y granodiorítica con xenolitos dioríticos y filones pegmatíticos cuarzo-feldespáticos (Fig.4.4C-E). Como consecuencia del retroceso de los acantilados principalmente por la erosión marina, estos bloques se observan también sobre la playa y mar adentro cuando hay bajamar. Ambos sectores presentan una topografía en superficie ondulada tipo kame y kettle. 

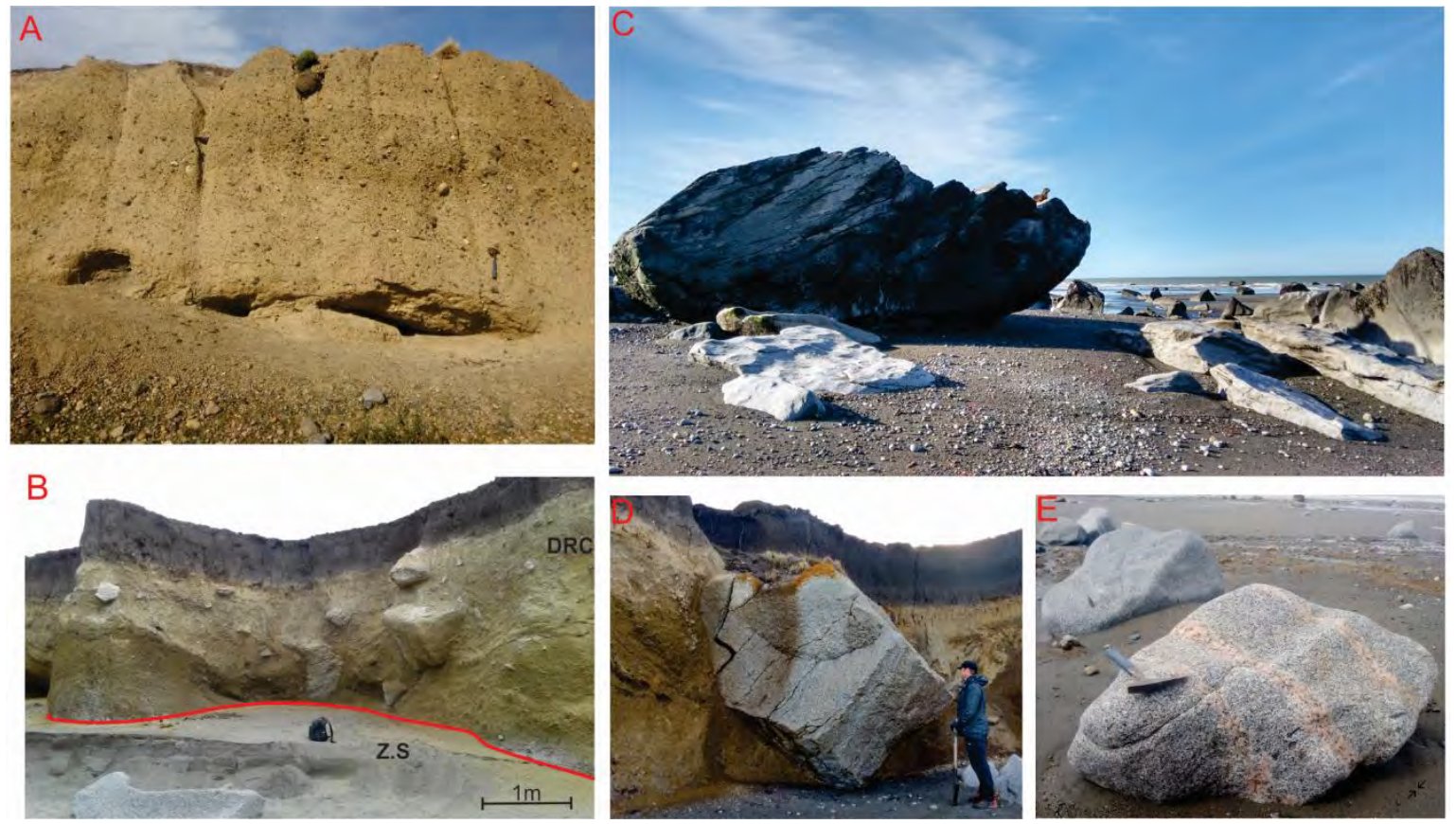

Fig.4.4. Depósitos Drift Río Cullen. A) Est. 8, norte de la bahía San Sebastián. B) Est.15, en punta Sinaí: Z.S, zona supramareal. Las fotos $C, D$ y E muestran bloques erráticos presentes en punta Sinaí.

\subsubsection{Drift San Sebastián (DSS)}

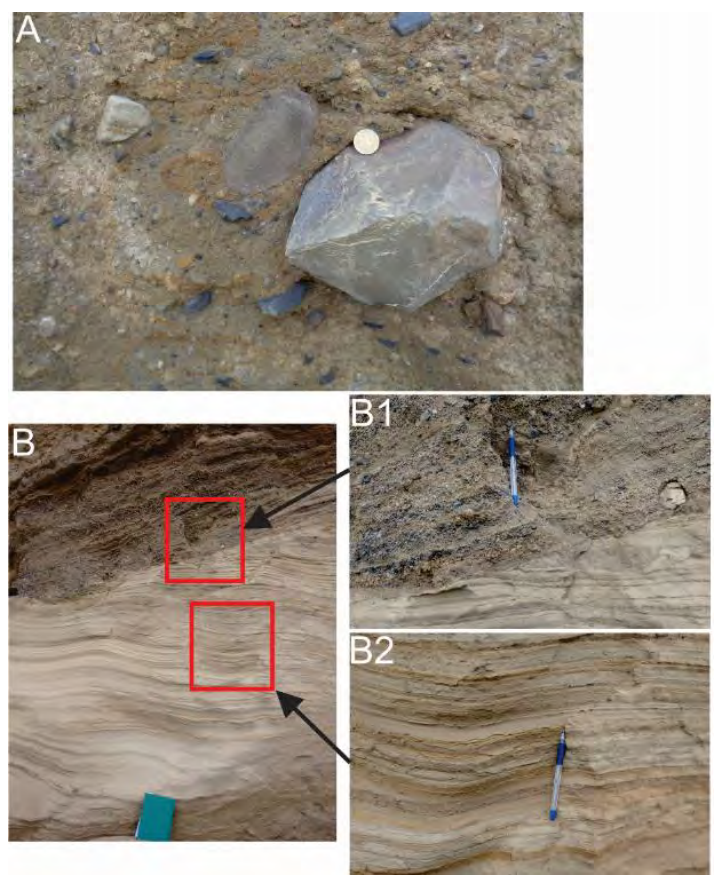

Fig.4.5. Depósitos del DSS en El Páramo (Est.16). A: till; B1, glacifluvial; B2: glacilacustre.
EI DSS se muestreó en siete estaciones correspondientes a la morena lateral distribuida a lo largo de la sierra de San Sebastián (Est. 10 a la 14, y 17), incluyendo los acantilados en el sector de El Páramo (Est.16).

EI DSS comprende depósitos muy heterogéneos, principalmente matriz sostenidos con bloques que en algunos casos alcanzan dimensiones de hasta un metro (tamaño más común de las gravas entre 10 y $15 \mathrm{~cm}$ ), presentando en algunos lugares lentes de canales glacifluviales estratificados compuestos principalmente por gravas y arenas gruesas, y depósitos glacilacustres finamente estratificados constituidos por una alternancia de láminas de arenas muy finaslimosas y arenas finas (Fig.4.5 A y B). 
Se observaron microplegamientos y microfallas tanto inversas (con un desplazamiento de $1,5 \mathrm{~cm}$ ) como normales (desplazamiento entre 1,5 y 2,5 cm) de alto ángulo. Estas microestructuras están posiblemente asociadas a la subsidencia o colapso como consecuencia del descongelamiento del suelo infrayacente (Gutiérrez 2008) o al empuje por las masas de hielo del material previamente depositado como consecuencia de los avances de los márgenes frontales ocurridos durante el Pleistoceno. Los bloques erráticos superficiales presentan la misma litología que los encontrados en punta Sinaí, granodioritas y tonalitas (Fig.4.6). Al igual que en el DRC, en superficie el DSS presenta una topografía ondulada tipo kame y kettle.
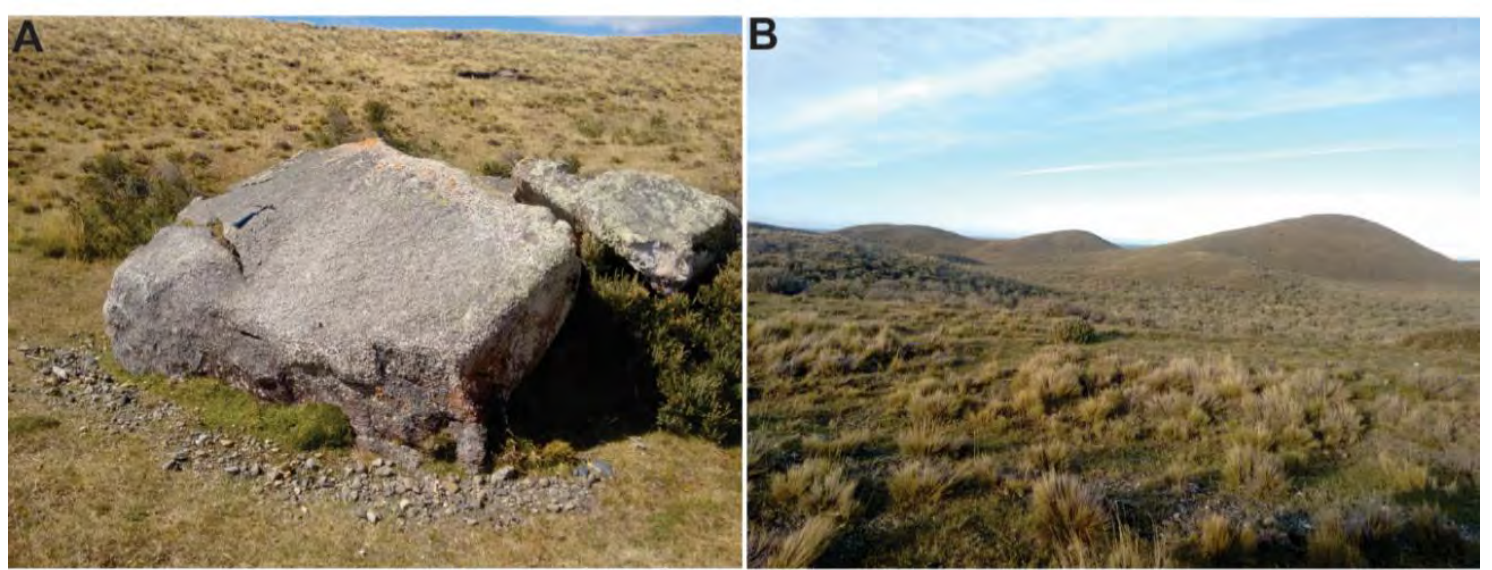

Fig. 4.6. A) Bloques erráticos granodioríticos presentes en el DSS y B) topografía típica kame y kettle.

Entre el DRC y el DSS se desarrollan planicies glacifluviales (out wash o sandur) (Est. 7 y 13) constituidas por gravas y arenas estratificadas junto con, en algunos sectores, depósitos fluviales actuales (Fig.4.7).

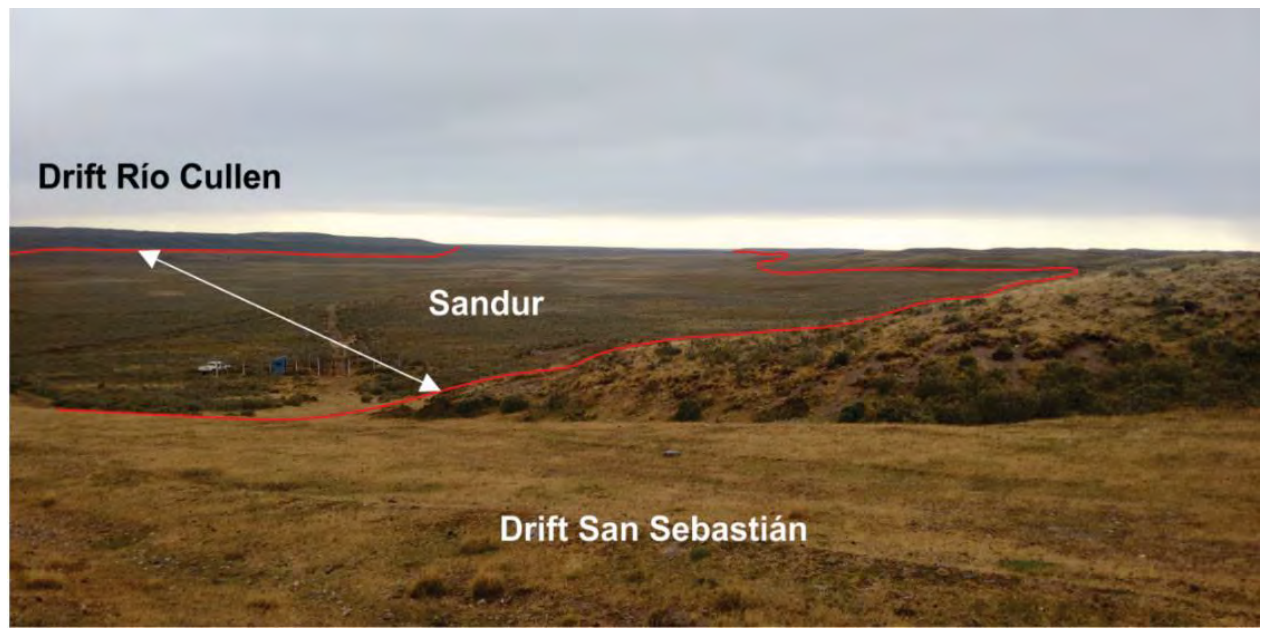

Fig. 4.7. Planicie glacifluvial presente entre el DRC y DSS. Sector al norte de la bahía San Sebastián 


\subsection{Composición litológica y mineralógica}

\subsubsection{Fracción psefítica}

La composición de la fracción psefítica determinada mediante lupa binocular dio los siguientes resultados:

En el DPB el $49 \%$ de las gravas analizadas correspondió a rocas metamórficas (cuarcitas, metapelitas, anfibolitas, milonitas y esquistos con cuarzo), 20\% a rocas plutónicas (granodioritas, dioritas, microdioritas y gabros), $11 \%$ a rocas volcánicas (pórfidos riodacíticos, riolíticos y andesíticos), $11 \%$ a rocas sedimentarías (grauvacas y chert) y $9 \%$ a cuarzo de veta y variedades de la sílice como jaspe, ópalo y calcedonia (Fig.4.8A-F).

En el DRC el resultado fue similar, con un $45 \%$ de rocas metamórficas (pizarras, filitas, metapelitas, anfibolitas y cuarcitas), $23 \%$ de rocas plutónicas (granodioritas, microdioritas, tonalitas, monzonitas y rocas ultramáficas), el 18\% correspondió a rocas volcánicas (pórfidos riolíticos) y un $14 \%$ a cuarzo de veta.

Las gravas del DSS mostraron valores composicionales promedios algo diferentes, con un $36 \%$ de rocas volcánicas (pórfidos riolíticos, basaltos alterados o espilitas), $32 \%$ de rocas plutónicas (dioritas, microdioritas, granodioritas, hornblenditas y microgabros), $27 \%$ de rocas sedimentarias (sílice criptocristalina como chert y ftanita), 18\% de rocas metamórficas (metapelitas) y un $18 \%$ cuarzo de veta.
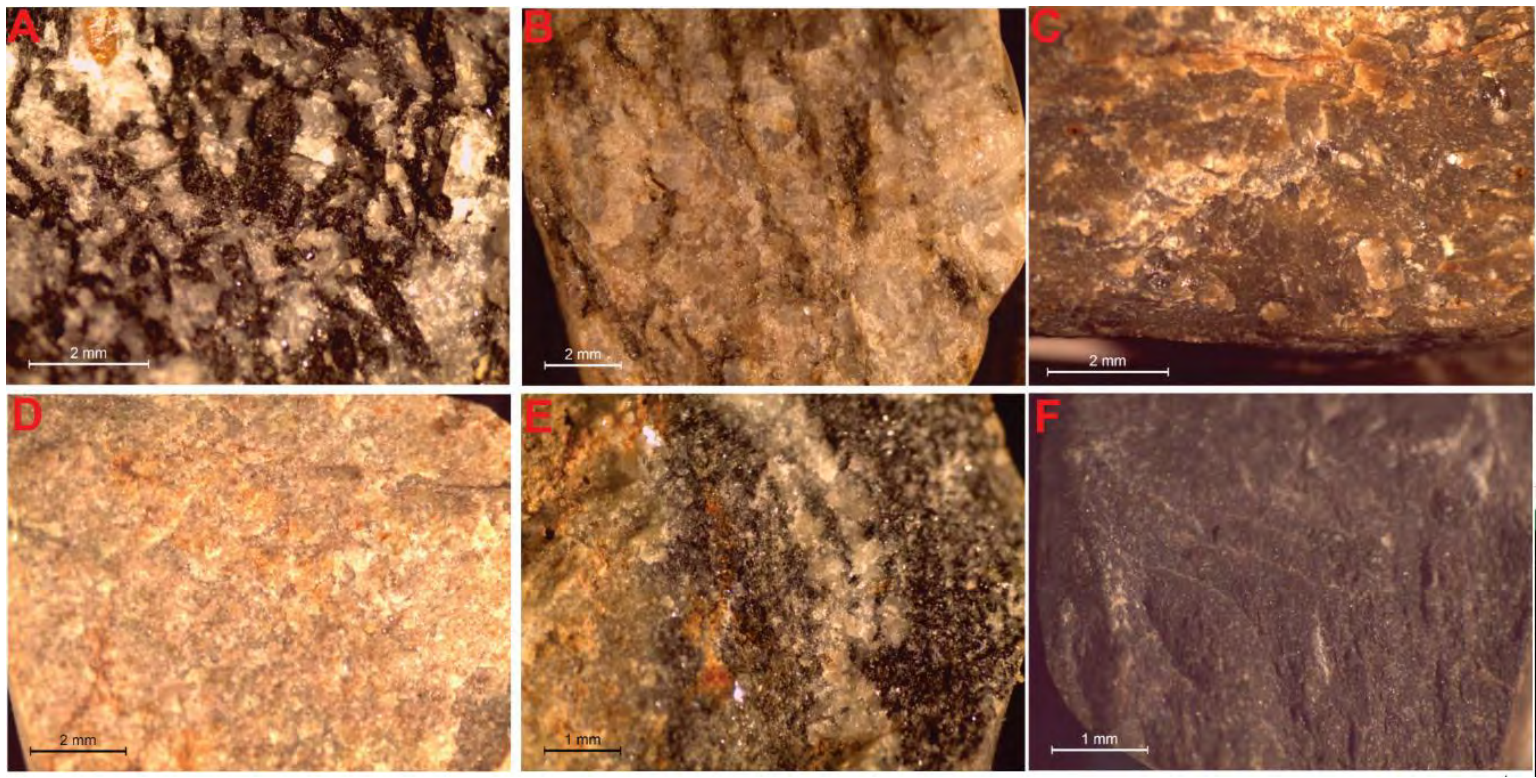

Fig. 4.8. Fotografías bajo lupa binocular de secciones de clastos de gravas (Est. 2, DPB): A, diorita; B, granodiorita; C, pórfido riolítico; $D$, riolita; $E$, anfibolita $F$, metapelita.

A partir del estudio mediante microscopio petrográfico se pudo describir más detalladamente algunas de estas rocas (Fig.4.9) 
Las hornblenditas presentaron una textura que se puede definir como granuda, con cristales idiomorfos y tamaño inequigranular de grano fino a medio. Se reconoció principalmente clinoanfíbol (anfíbol cálcico) y plagioclasa (andesina, determinada mediante el método de Michel Levy), identificando moscovita como posible mineral de alteración junto a clorita, epidoto y carbonatos.

Las dioritas mostraron una textura granuda con cristales idiomorfos-subidiomorfos y textura equigranular de grano fino. Se identificaron principalmente plagioclasa (andesina) y anfíbol cálcico, con biotita, titanita, circón y minerales opacos como minerales accesorios.

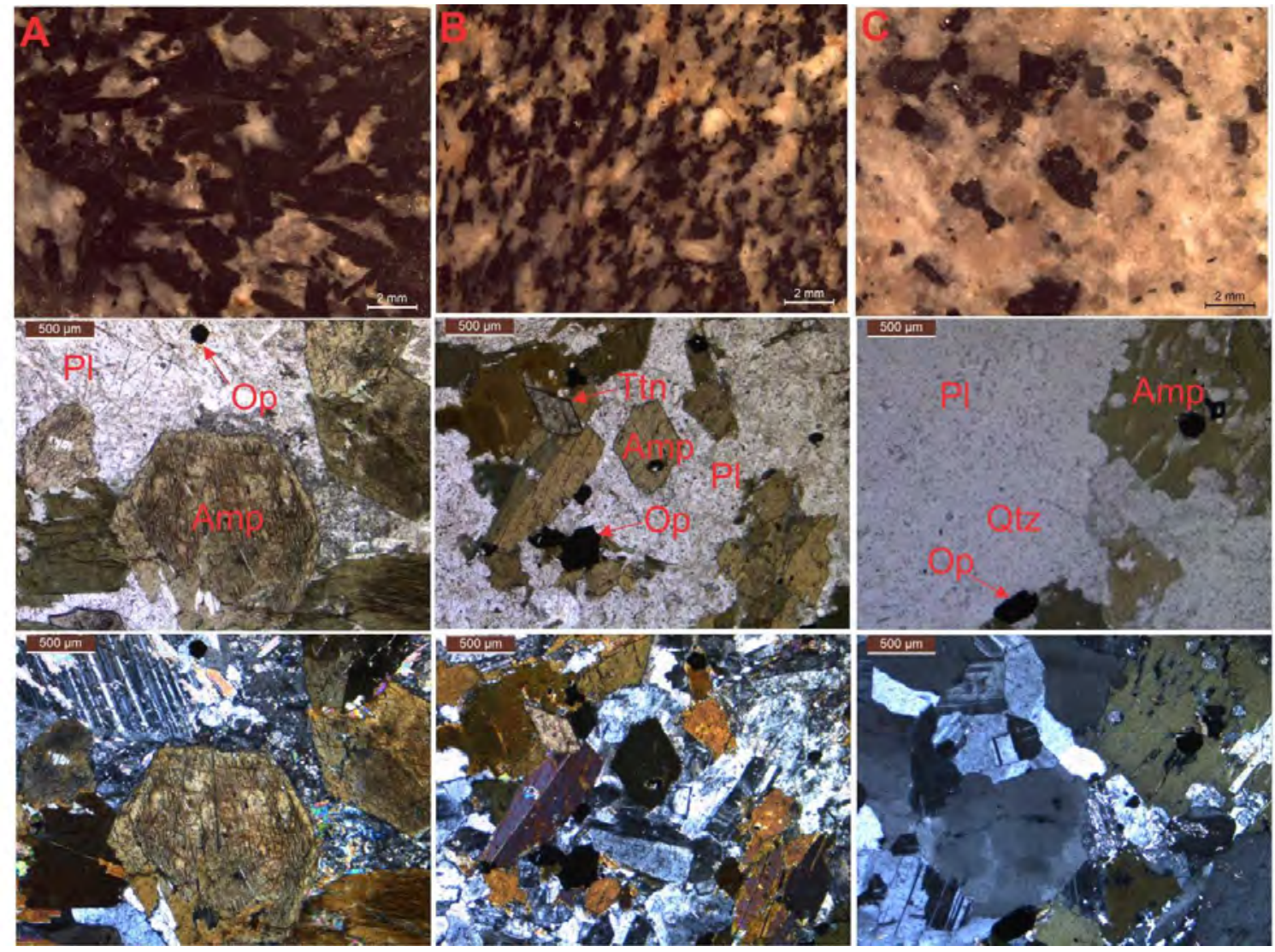

Fig. 4.9. Fotos en corte fresco de las muestras y en láminas delgadas con polarizadores en paralelo y cruzados (Est.16, DSS): A, hornblendita; B, diorita; C, Granodiorita. Abreviaturas: PI, plagioclasa; Amp, anfíbol cálcico; Ttn, titanita: Qtz, Cuarzo; Op, minerales opacos.

Las granodioritas presentaron una textura granuda, con cristales subidiomorfos, textura inequigranular de grano fino a medio, reconociéndose además textura mirmequítica. Los minerales principales correspondieron con plagioclasa (andesina), ortosa, cuarzo y anfíbol cálcico, observándose también cristales de titanita y minerales opacos.

Dentro de las rocas metamórficas se pudo identificar anfibolitas con textura granonematoblástica constituida por anfíbol cálcico con alteración a clorita y cuarzo. También se reconocieron minerales opacos, epidoto y micas. 


\subsubsection{Fracción psamítica}

Los resultados de los análisis efectuados mediante líquidos densos en el sedimento glacigénico indicaron porcentajes de materiales pesados en la fracción arena desde un $3,2 \%$ y hasta un $7,4 \%$ (Fig.4.10).

En el DSS se obtuvo un valor más alto en las lentes glacifluviales estratificadas (Est.17 E con un 7,4\%) que en las facies morénicas no estratificadas (Est.16 con un 5,2\%). En el DRC la proporción de componentes pesados en el till varió entre una 4,9\% y un 7,1\%. Finalmente, en el DPB se obtuvo un resultado ligeramente mayor de concentración de pesados en las zonas estratificadas glacifluviales (Est.3 E) con un 5,5\% frente a un 4,9\% en los niveles morénicos (Est.3) localizados en el mismo punto.

El valor promedio de componentes pesados mostró porcentajes de un $4,7 \%$ en el DPB, $6 \%$ en el DRC y $6,3 \%$ en el DSS. Normalmente se observó un ligero aumento de minerales pesados en los materiales estratificados.
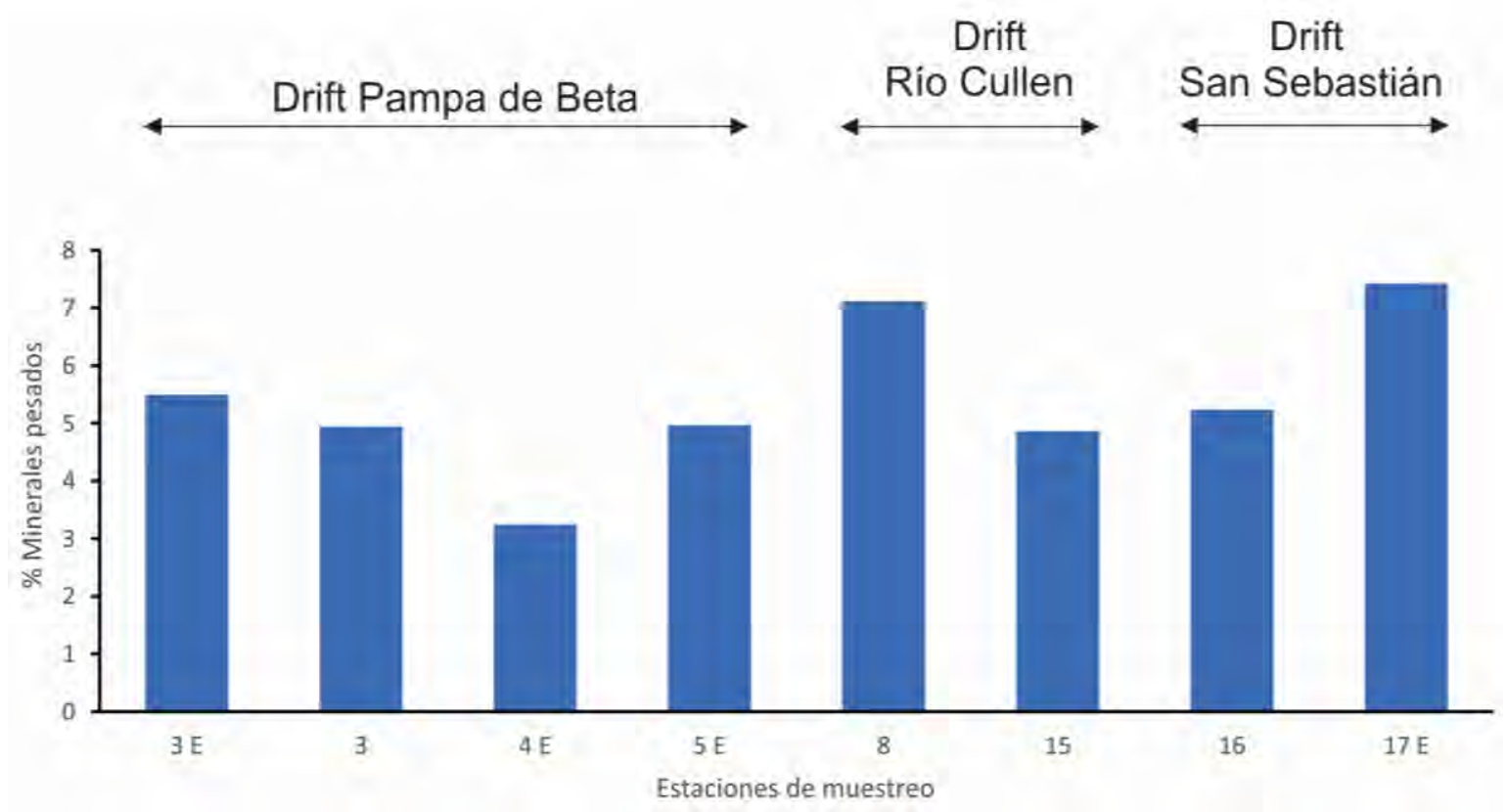

Fig.4.10. Histograma de distribución de minerales pesados presentes en la fracción arena media a fina en los diferentes afloramientos. E: corresponde con niveles glacifluviales estratificados.

A partir de la identificación y estudio cuantitativo de las distintas fases mediante microscopio petro-calcográfico, se determinó que la fracción liviana es constante en estos depósitos, siendo los fragmentos líticos los granos más abundantes (60\%), seguidos por el cuarzo (30\%) y la plagioclasa (10\%) (Fig.4.11). Feldespato potásico se identificó como accesorio. 

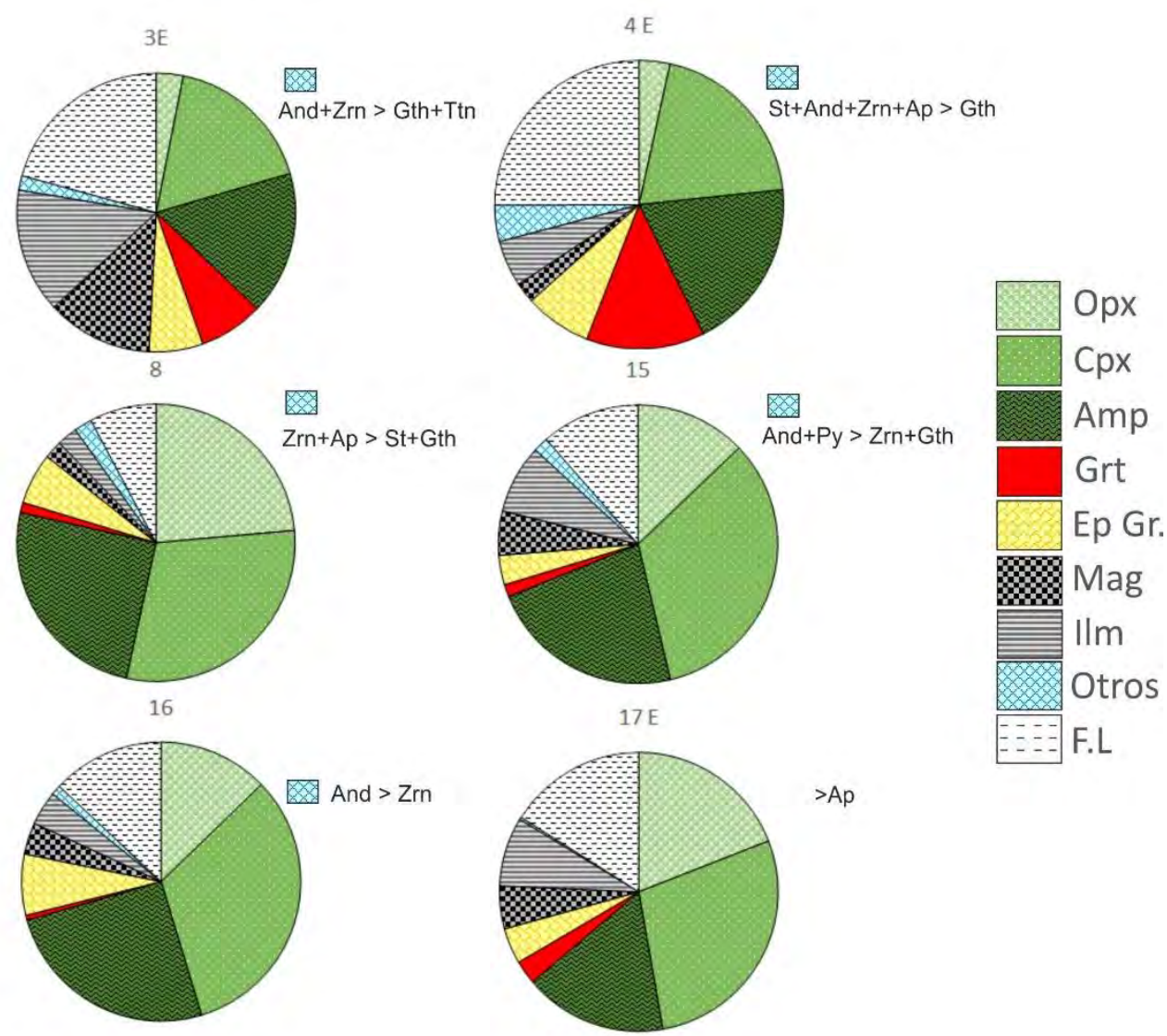

Fig. 4.11. Análisis cuantitativo de los sedimentos glacigénicos. 3E y 4 E muestras de los niveles glacifluviales de DPB. 8 y 15 de till del DRC. 16 y 17 E muestras de till y de los niveles glacifluviales del DSS. Abreviaturas: And andalucita, Ap grupo de la apatita, Zrn circón, Amp anfíbol cálcico, Cpx clinopiroxeno, St estaurolita, F.L fragmentos líticos, Ep. Gr grupo del epidoto, Gth goethita, Grt grupo del granate, IIm IImenita s.l., Mag magnetita s.l., Opx ortopiroxeno, Py pirita y Ttn titanita.

\begin{tabular}{|c|c|c|c|c|c|c|}
\hline & \multicolumn{6}{|c|}{ Puntos de muestreo } \\
\hline & \multicolumn{2}{|c|}{ Drift Pampa de Beta } & \multicolumn{2}{|c|}{ Drift Río Cullen } & \multicolumn{2}{|c|}{ Drift San Sebastián } \\
\hline & $3 \mathrm{E}$ & 4E & 8 & 15 & 16 & 17E \\
\hline Ortopiroxeno & 3 & 3 & 24 & 13 & 13 & 19 \\
\hline Clinopiroxeno & 17 & 20 & 30 & 33 & 33 & 28 \\
\hline Anfibol cálcico & 17 & 19 & 25 & 23 & 25 & 17 \\
\hline Gr. Granate & 7 & 13 & 1 & 1 & 1 & 3 \\
\hline Gr. Epidoto & 6 & 7 & 6 & 3 & 7 & 4 \\
\hline Circón & 1 & 1 & 1 & $*$ & $*$ & $*$ \\
\hline Estaurolita & & 1 & $*$ & & & \\
\hline Andalucita & 1 & 1 & & 1 & 1 & \\
\hline Gr. Apatita & & 1 & 1 & & & $*$ \\
\hline Titanita & * & & & & & \\
\hline Magnetita s.l. & 12 & 2 & 2 & 5 & 4 & 5 \\
\hline Ilmenita s.I. & 14 & 5 & 2 & 8 & 4 & 8 \\
\hline Pirita & & & & 1 & & \\
\hline Goethita & $*$ & $*$ & $*$ & $*$ & & \\
\hline Fragmentos líticos & 21 & 25 & 8 & 11 & 13 & 16 \\
\hline
\end{tabular}

Tabla 4.1 Porcentaje de minerales pesados presentes en los depósitos glacigénicos. * trazas. 
Respecto a los minerales pesados, los clinopiroxenos constituyeron el subgrupo mineral más frecuente (17\%-33\%), junto con los clinoanfíboles (17\%-25\%) y los ortopiroxenos (3\%-24\%). Los minerales del grupo del granate $(1 \%-13 \%)$ y los minerales del grupo del epidoto (3\%-7\%) también presentaron un contenido significativo en algunas de las muestras. Dentro de los minerales opacos, los más comunes fueron la ilmenita s.l. (sensu lato) (2\%-14\%) y la magnetita s.l. (2\%-12\%). En estos minerales se utiliza el término s.l. porque como se verá más adelante, en el capítulo 7 , debido a la gran variación composicional que presentan en relación al contenido en $\mathrm{Ti}$, se pueden diferenciar varias fases. Como minerales accesorios o trazas se identificaron andalucita, estaurolita, circón, minerales del grupo de la apatita, goethita, pirita y titanita (Fig.4.12). Los fragmentos líticos representan un porcentaje importante de la muestra (8\%-25\%) (Fig.4.11 y Tabla 4.1).

Se observó una mayor concentración de minerales opacos y minerales del grupo del granate en los niveles glacifluviales del sector septentrional de la zona de trabajo, correspondientes con el DPB.

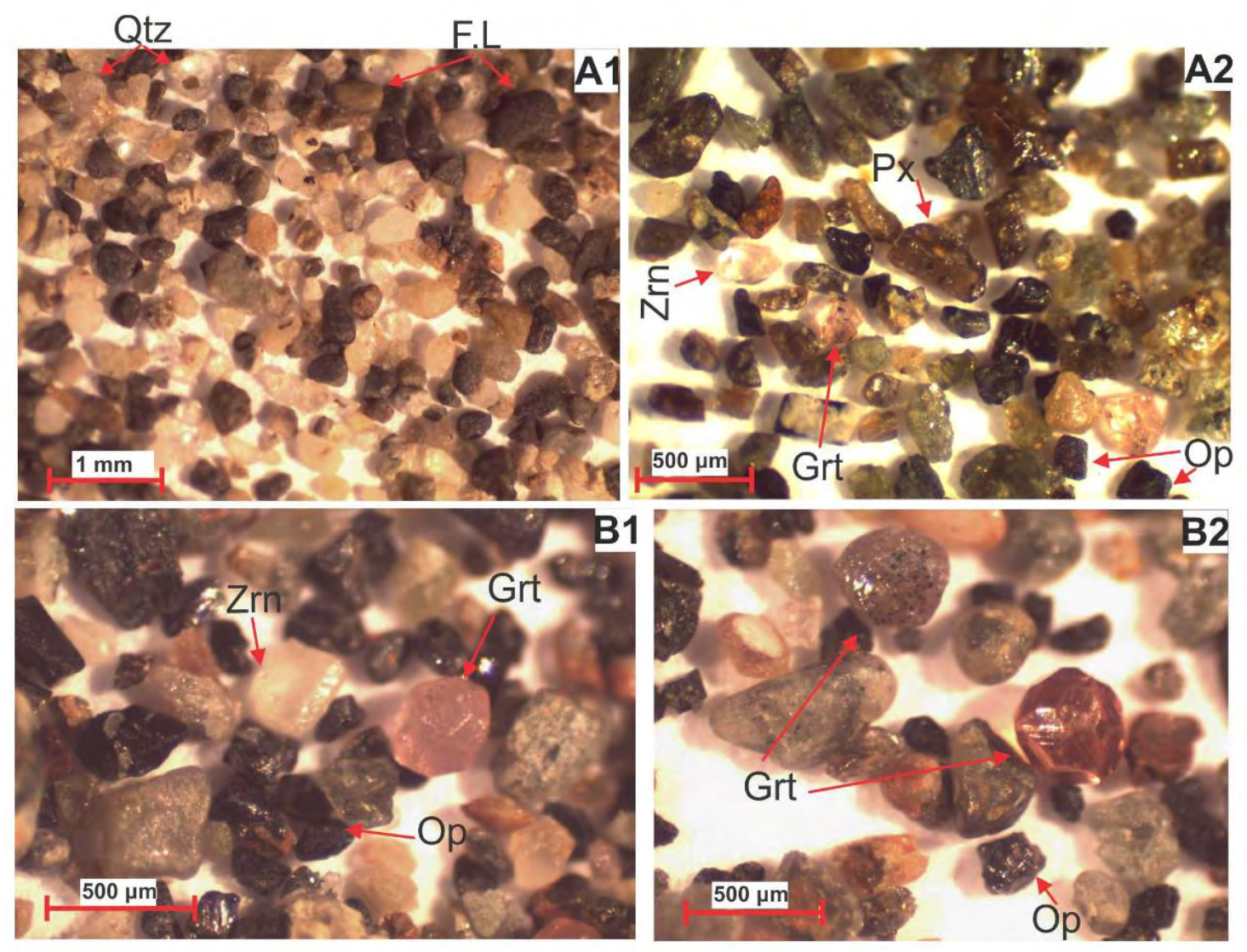

Fig.4.12. Fotografías realizadas mediante lupa binocular en granos sueltos. A1, Fracción liviana A2; fracción pesada (Est.17, DSS); B1 y B2 Cristales de granates idiomorfos (rombododecaedros y combinados con trapezoedros) con tonalidades desde rosados hasta anaranjados (Est.4, DPB). Abreviaturas: Px, piroxenos; Zrn, circón; Grt, grupo del granate; Qtz, Cuarzo, Op, minerales opacos y F.L., fragmentos líticos. 


\subsubsection{Descripción mineralógica de las arenas}

\subsection{Minerales y fragmentos líticos de la fracción pesada}

Dentro del grupo de los inosilicatos, los clinopiroxenos se identificaron con un pleocroísmo suave de incoloro a verde pálido o marrón, secciones subidiomorfas con hábito prismático, normalmente con clivaje bien marcado según (110) e inclusiones sólidas de minerales opacos y transparentes, algunos granos con alteración a clorita. Del subgrupo de los ortopiroxenos se identificó enstatita rica en Fe, con un pleocroísmo moderado de incoloro a rosa o marrón claro, normalmente en secciones idiomorfas con hábito prismático y clivaje no siempre marcado (001), con extinción recta e inclusiones sólidas de minerales opacos y transparentes (Fig.4.13).

En los clinoanfíboles se pudo identificar anfíbol cálcico con un fuerte pleocroísmo de verde a castaño y en una menor cantidad de granos de castaño a rojo oscuro. Normalmente presentó hábito prismático alargado, subidiomorfo, con clivaje en la sección prismática (110), aunque también se reconoció en secciones basales redondeadas con clivaje oblicuo en dos direcciones. Comúnmente se identificaron inclusiones sólidas de minerales transparentes y opacos.

Bajo la lupa, los minerales del grupo del granate mostraron tonalidades desde rosadas hasta anaranjadas (más raro), generalmente con formas idiomorfas, equidimensionales (rombododecaédricas y combinación de éstas con trapezoedros). También se identificaron granates en granos subidiomorfos redondeados o alotriomorfos. Con frecuencia presentaron inclusiones sólidas de minerales opacos y transparentes, en algunos casos con distribución concéntrica.

Del grupo del epidoto se identificaron los minerales epidoto s.s. (sensu stricto) y en forma subordinada clinozoisita, con desarrollos cristalinos desde idiomorfos, con hábito prismático, hasta alotriomorfos. También se reconocieron en agregados o como granos aislados. El epidoto s.s. se presentó normalmente como granos con pleocroísmo moderado desde incoloro a verde amarillento. La clinozoisita presentó clivaje en las secciones prismáticas, sin pleocroísmo y birrefringencia baja con colores de interferencia gris azulados. 

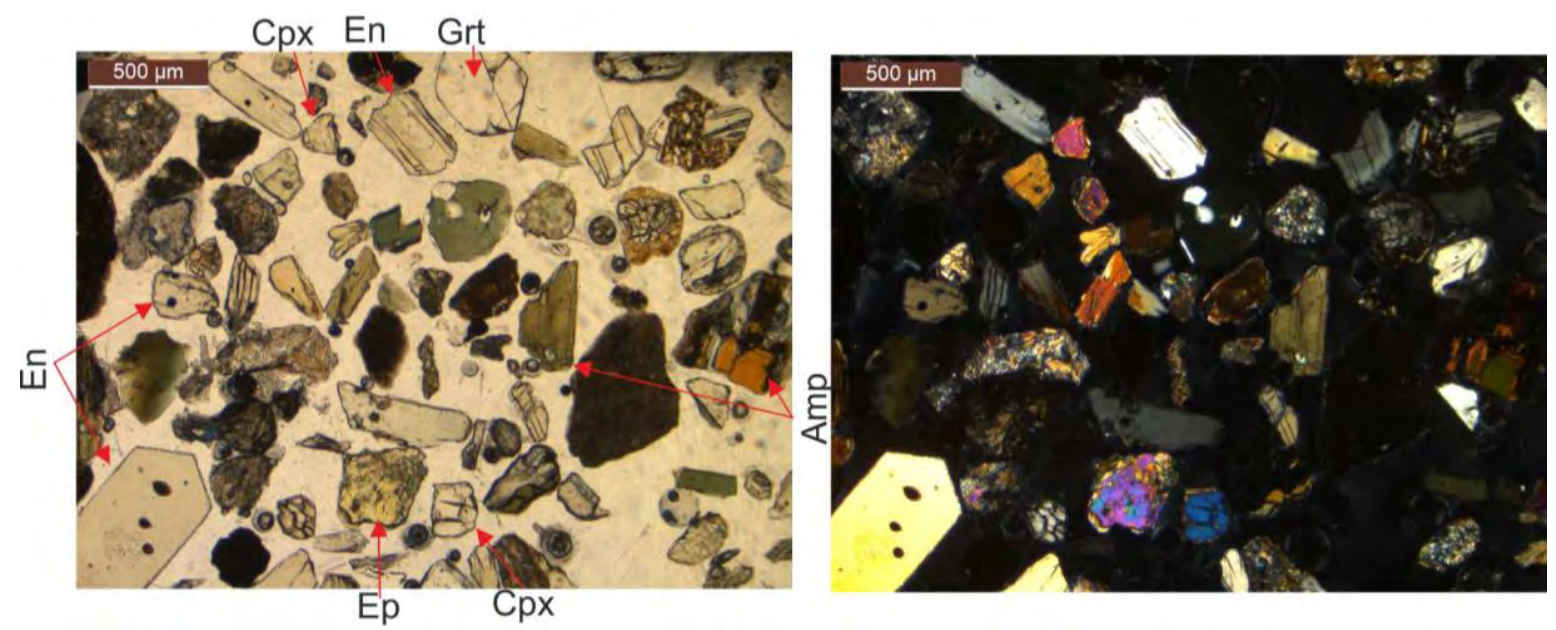

Fig.4.13. Fotomicrografías de minerales pesados (Est. 17, DSS). Izquierda con nicoles paralelos y derecha con nicoles cruzados. Amp, supergrupo del anfibol; Cpx, clinopiroxeno; En, enstatita rica en Fe; Ep, epidoto; Grt, granate.

Dentro de los minerales opacos se diferenciaron magnetitas s.I., ilmenitas s.l., pirita e hidróxidos de Fe como la goethita.

La magnetita s.I. generalmente se presentó como subidiomorfa o idiomorfa (octaédricos) con exsoluciones en enrejado (trellis texture) paralelas al plano (111) en general de hematita titanífera y magnetita titanífera. Se identificaron granos de magnetita martitizada.

La ilmenita s.I. se reconoció como granos idiomorfos-subidiomorfos alargados, muy frecuentemente con lamelas de exsolución de óxidos de Fe-Ti (ver Capítulo 7), de una o dos generaciones paralelas al plano basal (0001) y en algunos ejemplares agujas de rutilo perpendiculares a las exsoluciones.

La pirita se identificó con textura framboidal y tonalidades amarillas. La goethita se reconoció por presentar un color gris-blanco y abundantes reflexiones internas de color marrón rojizas.

Como minerales subordinados y accesorios se pudieron identificar andalucita, estaurolita, minerales del grupo de la apatita, circón y titanita (Fig.4.14).

La andalucita generalmente se presentó como incolora con hábito prismático o en secciones basales cuadradas idiomorfas a subidiomorfas, a veces redondeadas. En las secciones prismáticas se observó en algunos granos clivaje marcado según (110). Mostró baja birrefringencia con color de interferencia blanco y gris de primer orden, signo de elongación negativo y signo óptico biáxico negativo, con numerosas inclusiones sólidas de minerales opacos y transparentes.

La estaurolita presentó un fuerte pleocroísmo de amarillo a castaño claro, con formas idiomorfas de hábito prismático, birrefringencia débil con color de interferencia 
amarillo de primer orden y abundantes inclusiones sólidas de minerales opacos (óxidos de Fe y Ti) y transparentes.

Los cristales del grupo de la apatita identificados fueron muy escasos. Presentaron secciones prismáticas, extinción recta, baja birrefringencia, con colores de interferencia desde blancos a grises de primer orden e inclusiones de minerales opacos.

El circón se reconoció en secciones desde idiomorfas prismáticas a subidiomorfas redondeadas, con relieve muy alto al igual que la birrefringencia y signo óptico uniáxico positivo, normalmente con inclusiones sólidas trasparentes.

La titanita se identificó con formas prismáticas subidiomorfas con bordes irregulares, birrefringencia muy alta, signo óptico biáxico positivo e inclusiones sólidas de minerales opacos.
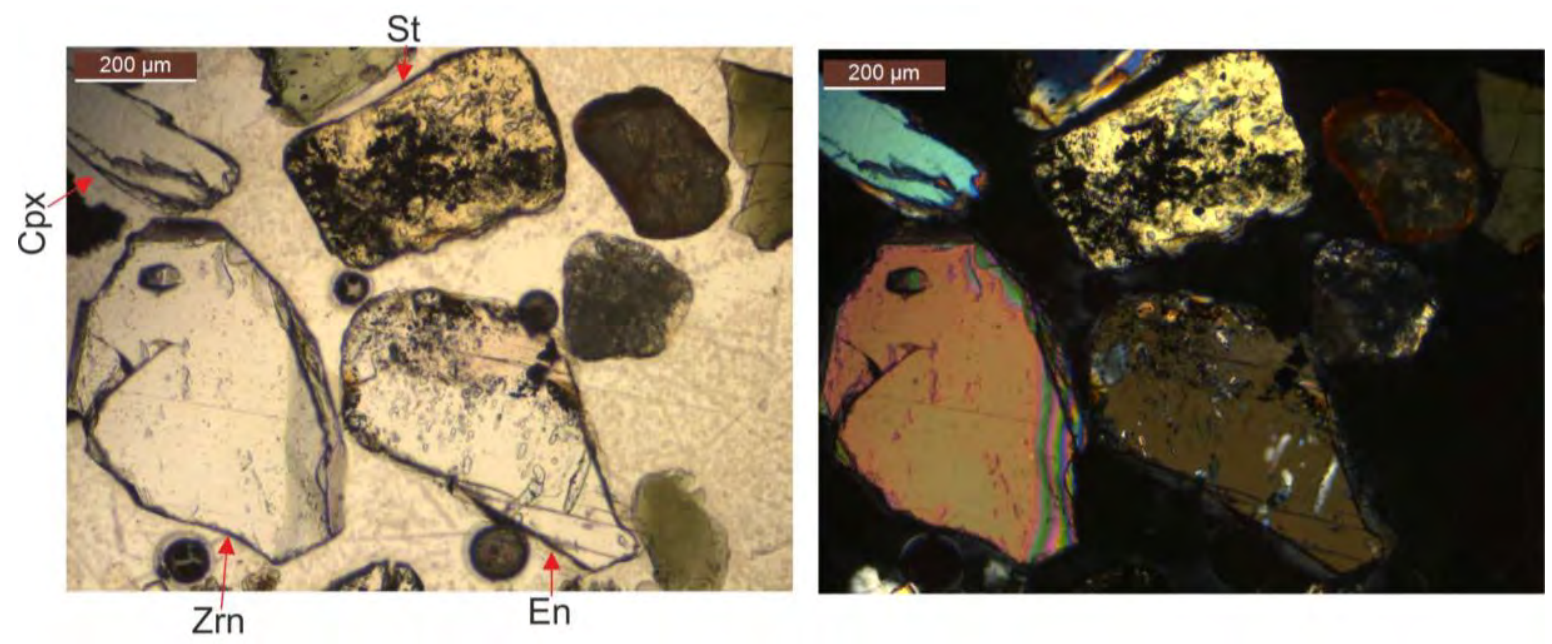

Fig.4.14. Fotomicrografías con polarizadores en paralelo y cruzados de minerales pesados accesorios presentes en los sedimentos glacigénicos (Est.4, DPB). Zrn circón, Cpx clinopiroxeno; En, enstatita rica en Fe y St estaurolita.

Un porcentaje importante de las muestras correspondió a fragmentos líticos principalmente asociados con rocas plutónicas. Se identificaron agregados de cuarzo+epidoto+piroxeno, clinoanfíbol+plagioclasa (hornblendita) y fragmentos líticos alterados constituidos por epidoto+clorita. También se reconocieron algunos granos correspondientes con rocas metamórficas como esquistos micáceos y fragmentos constituidos por sillimanita que indicarían un grado metamórfico hasta la facies de anfibolita. Es de destacar la presencia de algunos fragmentos líticos de la facies de alto grado de esquistos verdes o anfibolitas donde se observaron grandes cristales de granates, muy similares a los presentes como granos sueltos, junto con biotita, cuarzo, feldespatos, anfíboles y minerales opacos (Fig.4.15). Los fragmentos de rocas volcánicas fueron muy escasos, reconociéndose únicamente andesita constituida por fenocristales idiomorfos de plagioclasa y minerales del grupo del piroxeno, con matriz cloritizada. 


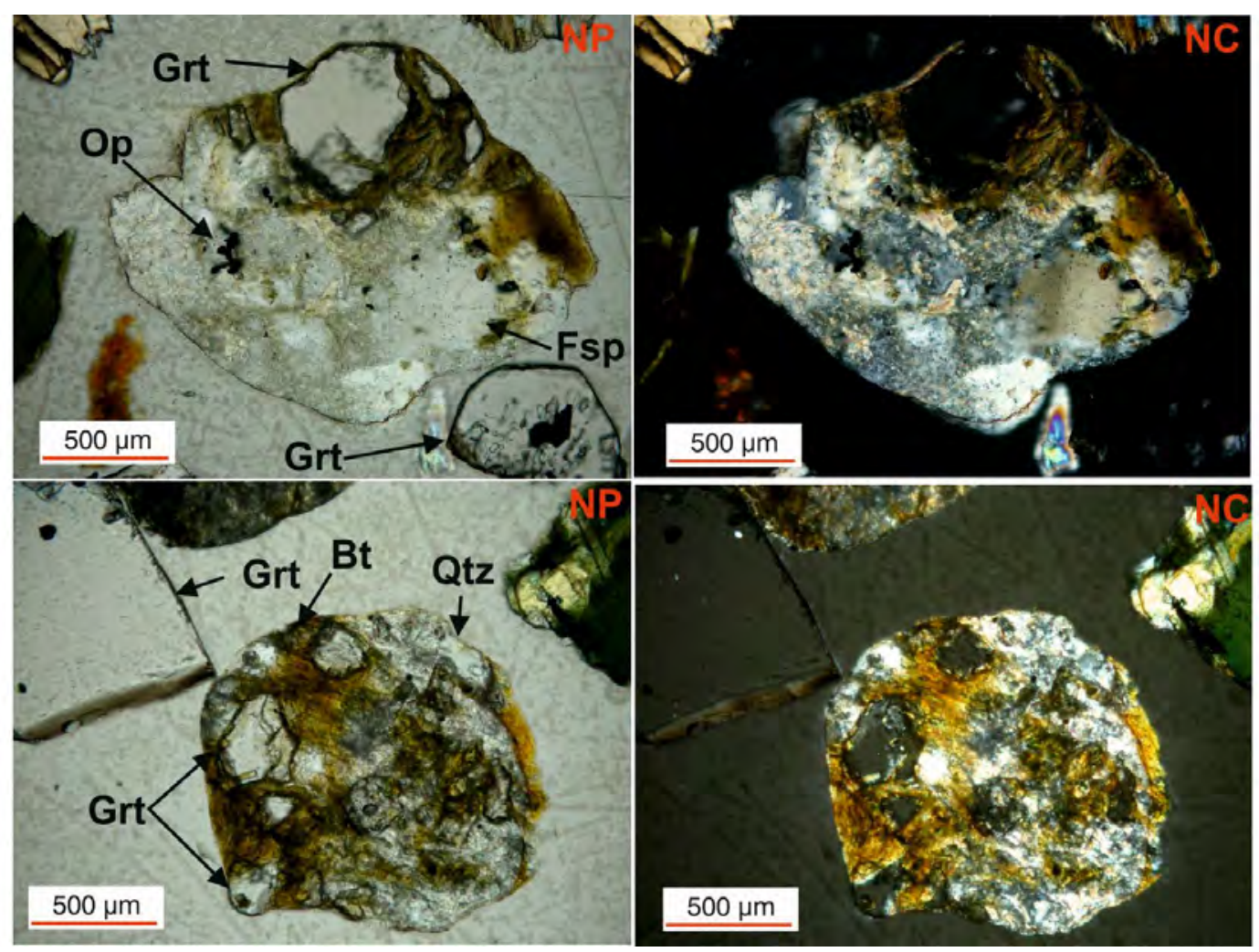

Fig.4.15. Fotomicrografías de fragmentos líticos (Est. 4, DPB). Abreviaturas: NP, nícoles en paralelo; NC, nícoles cruzados; Bt, biotita; Fsp, feldespato; Grt, granate; Op, opacos.

\subsection{Minerales y fragmentos líticos de la fracción liviana}

La fracción liviana representó la mayor parte de las muestras, entre un 93\% y 97\%, donde los granos más abundantes fueron fragmentos líticos muy redondeados (Fig.4.16). La mayoría de ellos se correspondieron con rocas volcánicas andesíticas con textura hipocristalina y microporfídica con cristales de feldespatos (plagioclasa), anfíboles y cuarzo. Aparecieron también agregados con textura granuda holocristalina de feldespatos con minerales opacos (rocas plutónicas), gneises con cristales orientados de cuarzo, micas y minerales opacos, y agregados policristalinos de cuarzo.

Los granos de cuarzo se encontraron como cristales alotriomorfos o subidiomorfos en secciones prismáticas y hexagonales, con extinción ondulante y baja birrefringencia con color de interferencia gris de primer orden.

Los cristales de plagioclasa se presentaron como granos alargados prismáticos subidiomorfos, con maclas polisintéticas y en combinación de estas con las de Carlsbad. A partir del método de Michel Levy se estimó una composición de la plagioclasa desde andesina hasta labradorita. 
Los granos de feldespato potásico fueron muy escasos, identificando únicamente la fase ortosa. Se reconoció en secciones idiomorfas con hábito prismático y macla de Carlsbad.

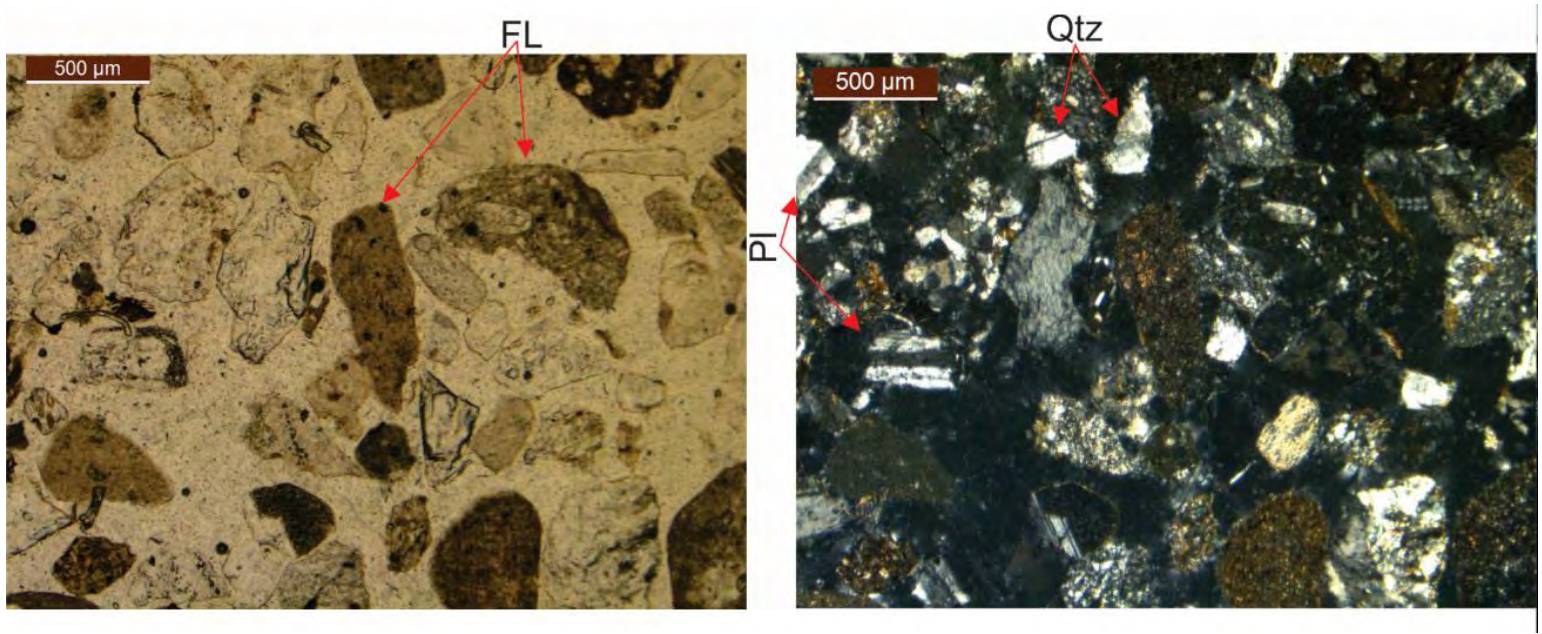

Fig.4.16. Fotomicrografías con nicoles paralelos y cruzados de la fracción liviana (Est.17, DSS). FL: Fragmentos líticos; Qtz: cuarzo; PI: Plagioclasa. 


\section{Capítulo 5: SECTOR COSTERO}

\subsection{Introducción}

El sector investigado se corresponde con una extensa faja costera, de rumbo aproximado NO-SE, únicamente interrumpida por la bahía San Sebastián. Exceptuando esta bahía y la espiga que la cierra parcialmente por el norte, las playas están limitadas por altos acantilados activos constituidos por sedimentitas terciarias y depósitos glacigénicos pleistocenos.

Las playas constituyen el ambiente morfosedimentario costero localizado en el límite entre el mar y el continente. Requieren un aporte continuado de sedimentos ya sea por el transporte que realizan los ríos o por la erosión de los acantilados, distribuyéndose además a lo largo de la playa como consecuencia de la deriva litoral, siempre y cuando no haya accidentes naturales o artificiales que la interrumpan.

Los depósitos de playa presentan una composición y tamaño de grano muy variado, desde sedimentos pelíticos hasta psefíticos, aunque predominan ampliamente las fracciones psamíticas.

El límite superior de las playas se corresponde con la zona emergida que es alcanzada únicamente por el oleaje de tormenta y el inferior se localiza donde el oleaje deja de tener efecto sobre el sedimento. Dentro de estos límites, en las playas mareales se pueden diferenciar distintas zonas en función de su morfología.

Bujalesky (1990) concluyó que la playa atlántica del norte de la Isla Grande de Tierra del Fuego presenta características reflectivas durante la marea alta, diferenciando cinco zonas distintas, con un desnivel de 9,5 m: berma de tormenta (15 m de ancho y $3,5^{\circ}$ de pendiente), terraza de lavado de tormenta ( $25 \mathrm{~m}$ de ancho y $2^{\circ}$ de pendiente), berma de marea (10 $\mathrm{m}$ de ancho), zona intermareal alta (50 $\mathrm{m}$ de ancho y $7^{\circ}$ de pendiente, playa reflectiva) y zona intermareal baja (70 $\mathrm{m}$ de ancho, subhorizontal, playa disipativa). La diferencia de altura entre la cresta de la playa y el pie estaría relacionada con la topografía de la plataforma de abrasión (Bujalesky 2007).

En el sector de los acantilados, la playa desarrollada tiene una extensión más reducida siendo incluso incompleta en algunos sectores en los que el nivel del mar durante la marea alta alcanza la base del acantilado, no presentando una zona supramareal. Sin embargo, en aquellos lugares donde los cursos fluviales cortan el acantilado generando un pequeño valle, la playa emergida muestra una mayor extensión. 
En todo el sector costero se desarrollan yacimientos detríticos de tipo placer, conformados por minerales pesados entre los que se incluye el oro, debido a los efectos del oleaje y corrientes marinas que concentran y acumulan los minerales pesados en ciertas partes del perfil de la playa. Las mareas y los fuertes vientos pueden acentuar en algunos sitios el proceso de concentración de los minerales pesados.

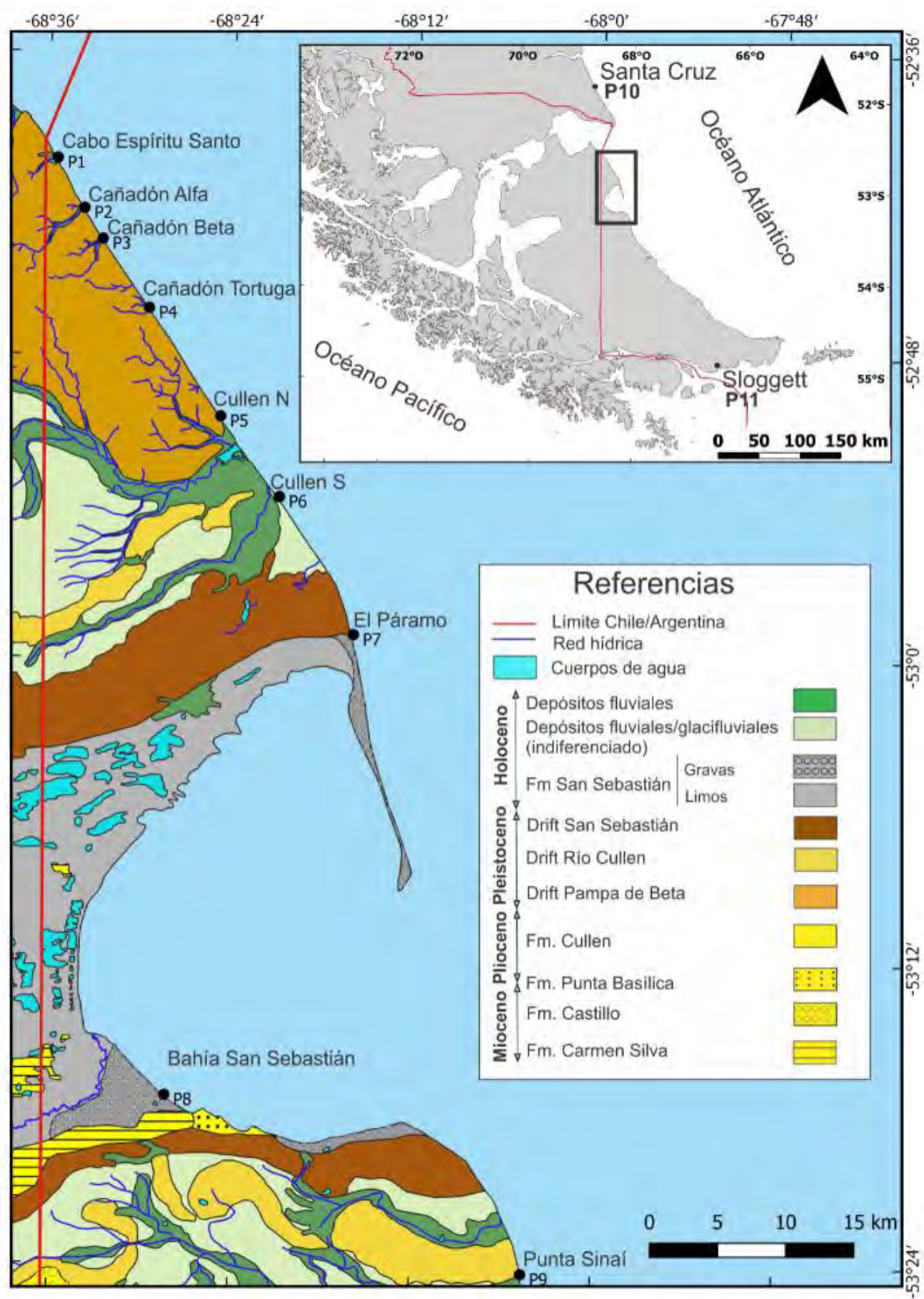

Fig.5.1. Mapa geológico con la localización de los lugares de muestreo en las playas. Cartografía realizada a partir datos de campo, imagen satelital (Landsat 8) y bibliografía previa (Codignotto 1979; Codignotto y Malumián 1981; Agüero et al. 2003, Olivero et al. 2006 y Darvill et al. 2015b). 


\subsection{Muestreo y descripción del sector costero}

Se seleccionaron nueve lugares de muestreo en las playas distribuidos en función de la geología, geografía y antecedentes de explotación mineral. Se añadieron dos sectores externos a la zona de trabajo con fines comparativos, en los cuales había registros de la presencia de oro y minerales pesados. Uno al norte del Estrecho de Magallanes (P10), donde la geología y dinámica litoral muestran continuidad con la zona de trabajo, y otro al sur de la Isla Grande de Tierra del Fuego, en las playas de bahía Sloggett (P11), lugar histórico por la extracción de oro en sus playas a principios del siglo XX (Fig.5.1).

\subsubsection{Cabo Espíritu Santo (P1)}

En esta zona se localiza la playa muestreada más septentrional de la zona de trabajo, fácilmente accesible a través de la Ruta Nacional №3 (Fig.5.1).

Este sector se caracteriza por el desarrollo de acantilados que pueden alcanzar los $90 \mathrm{~m}$ de altura, constituidos principalmente por areniscas y limolitas subhorizontales terciarias de la Formación Cullen (Fig.5.2. A y B). Por encima de éstas se localizan depósitos glacigénicos con un espesor aproximado entre $1 \mathrm{~m}$ y $2 \mathrm{~m}$ correspondientes con el Drift Pampa de Beta. En los acantilados se ubica un valle por el cual se puede acceder a la playa.

En los acantilados de este sector durante los temporales el oleaje puede alcanzar su base, lo que provoca junto con la erosión eólica, la escorrentía y la meteorización, el desprendimiento de grandes bloques correspondientes a sedimentitas de la Formación Cullen. Debido a la presencia del acantilado se llega a generar una duna remontante, como consecuencia de los fuertes vientos, que alcanza los $5 \mathrm{~m}$ de altura. Estas dunas se generan cuando el viento cargado de arena o una duna migratoria se encuentran con una barrera topográfica (en este caso el acantilado) y la traspasa total o parcialmente. En los sectores sin acantilado, se generan pequeñas dunas embrionarias con vegetación. 

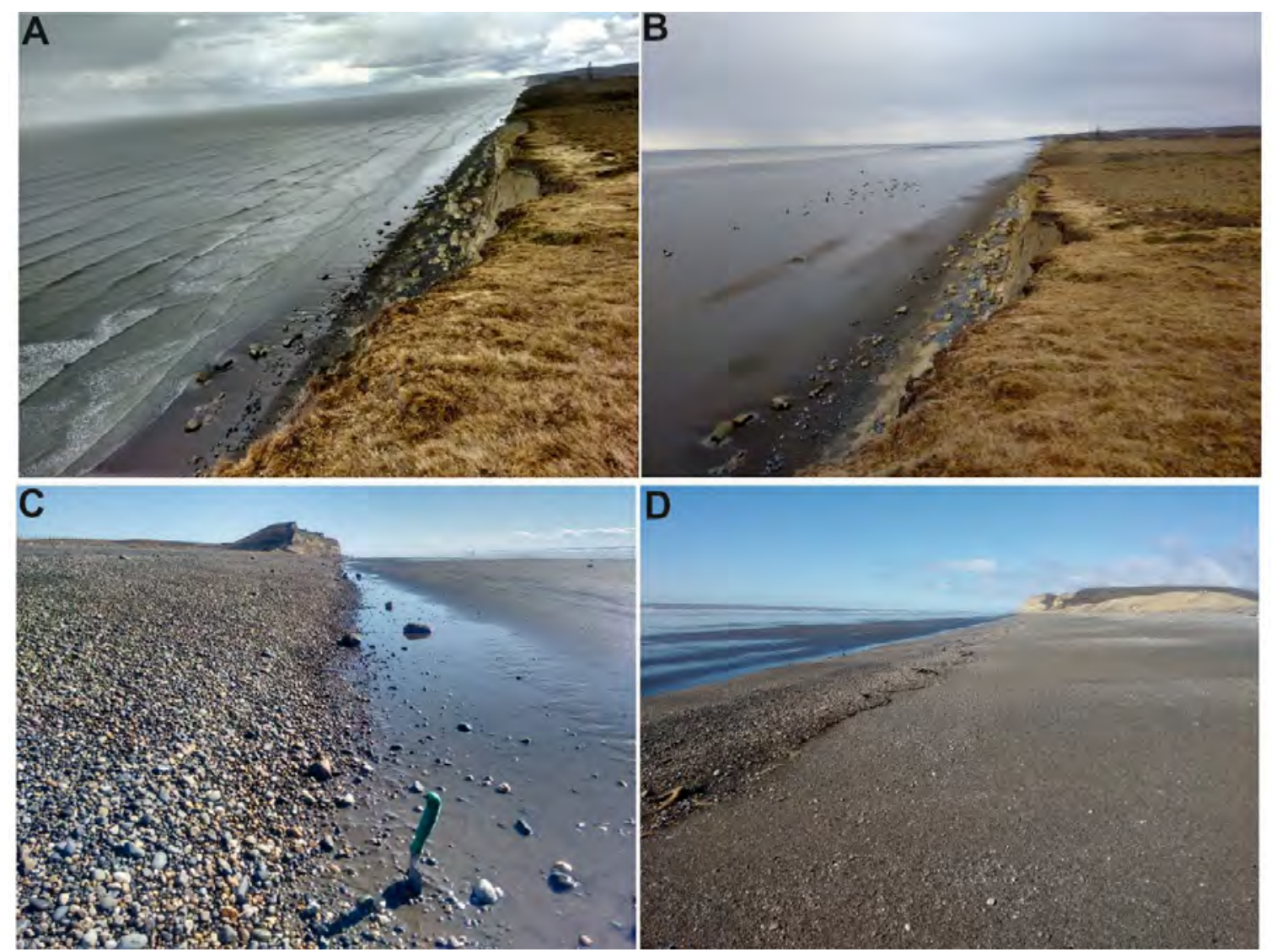

Fig.5.2. A y B) Corresponden a fotografías tomadas desde el acantilado del cabo Espíritu Santo, durante la marea alta (en ascenso) y baja respectivamente C) límite entre la zona intermareal alta y baja D) berma de marea.

Según la morfología de la playa, se pueden reconocer tres zonas bien marcadas (Fig.5.2 C y D y Fig.5.3): supramareal, intermareal alta e intermareal baja.

En la zona supramareal, dependiendo de la época del año, se pueden identificar dos bermas, de marea y de tormenta, y una pequeña duna embrionaria adyacente a la barra litoral como consecuencia de la deflación eólica. Presenta una pendiente subhorizontal en las bermas y su extensión varía entre $16 \mathrm{~m}$ y $30 \mathrm{~m}$. Está constituida principalmente por gravas y aproximadamente un $20 \%$ de arenas, polimodales y mal seleccionadas. Hacia la zona dunar (foredune), en donde la influencia eólica es mayor, el depósito es más arenoso.

La zona intermareal alta se reconoce por el aumento de pendiente, aproximadamente entre $4^{\circ}$ y $5^{\circ}$, llegando alcanzar un promedio de $13^{\circ}$ en el perfil de primavera coincidente con marea de sicigia, con una extensión muy variable en función de mareas, desde los $4 \mathrm{~m}$ hasta los $20 \mathrm{~m}$. Está constituida por gravas y arenas, aumentando considerablemente estas últimas con respecto a la zona supramareal. Son polimodales y muy mal seleccionadas. 
Por último, la zona intermareal baja corresponde a un sector prácticamente horizontal (pendiente $<1^{\circ}$ ), con una extensión que alcanza los $800 \mathrm{~m}$ durante la marea baja, desarrollándose canales de desagüe y óndulas (ripple marks). Está constituido por sedimentos unimodales, compuestos mayoritariamente por arenas finas, disminuyendo el tamaño hacia la playa sumergida y aumentando también su selección de moderada a bien seleccionada en ese mismo sentido.

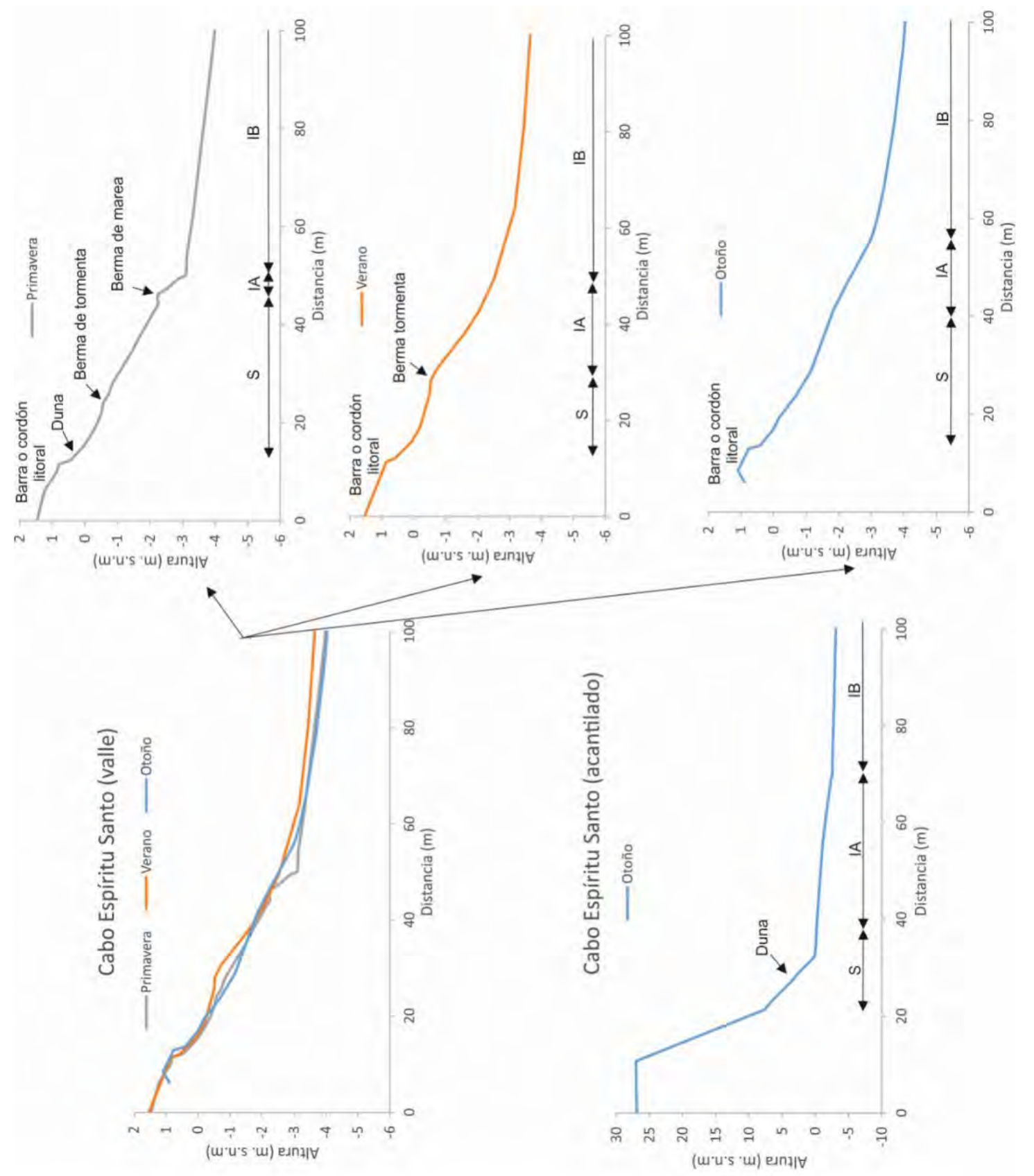

Fig.5.3. Perfiles en distintos momentos de la playa presentes en la zona del cabo Espíritu Santo. Abreviaturas: S, zona supramareal; IA, zona intermareal alta e IB, zona intermareal baja. 


\subsubsection{Cañadón Alfa (P2)}

Se localiza a unos $4 \mathrm{~km}$ al sur del cabo Espíritu Santo. Para acceder a este sector se debe tomar un desvío de la Ruta Nacional $N^{\circ} 3$ por un camino secundario de unos $2 \mathrm{~km}$, dificultándose el tránsito a medida que nos acercamos a la playa debido a su falta de mantenimiento (Fig.5.1).
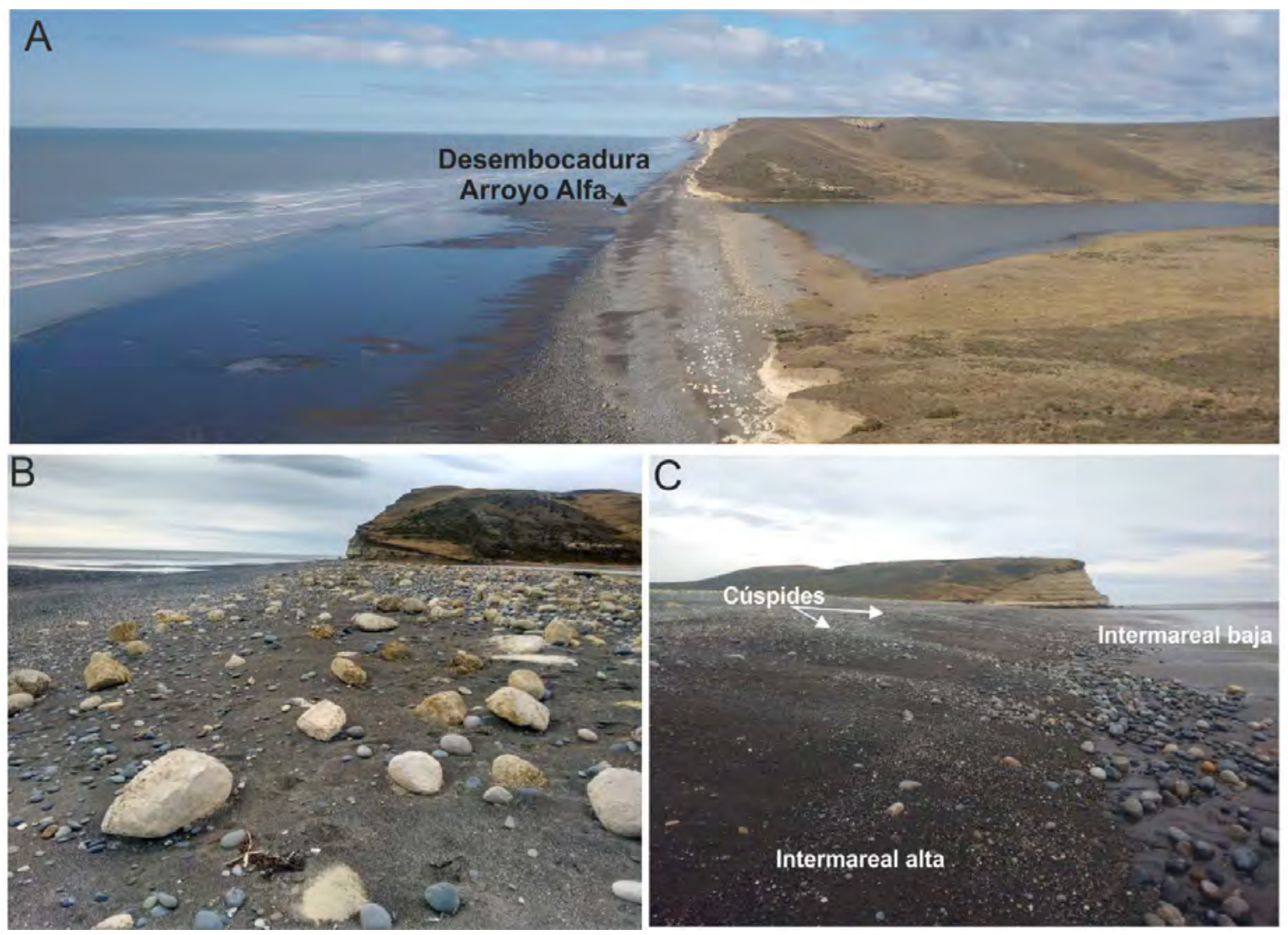

Fig.5.4. A) Vista panorámica de la playa del cañadón Alfa, mirando hacia el sur, B) zona supramareal vista hacia el sur y C) zona intermareal alta y baja, vista hacia el norte.

En este sector desemboca el arroyo Alfa, que ha excavado un valle principalmente a través de los depósitos terciarios de la Formación Cullen. Por encima de éstos, y rellenando el valle, se localizan los sedimentos glacigénicos del Drift Pampa de Beta. Los acantilados presentes en ambos lados del valle alcanzan alturas de más de $60 \mathrm{~m}$. La acción erosiva del oleaje y la deriva litoral permitió el desarrollo de una barrera (spit) constituida por arenas y gravas, truncando la desembocadura de este arroyo y generando una laguna (lagoon) con la desembocadura al sur de la playa (Fig.5.4 A-C). No se observaron canales de sobrelavado, pero es de esperar por lo que ocurre en la espiga de El Páramo que, durante fuertes temporales, el oleaje rompa la barrera y la sobrepase.

Respecto al perfil de la playa (Fig.5.5), la zona supramareal muestra una gran extensión, con más de 60 m en la zona de la desembocadura del arroyo, observándose en 
algunos momentos dos bermas muy bien marcadas, como es el caso del perfil realizado en primavera. Son depósitos polimodales constituidos por gravas y arenas muy mal seleccionadas en los cuales se observan tanto en la superficie después de la berma de tormenta como en profundidad niveles ricos en minerales pesados (óxidos de Fe y Ti junto con granates) especialmente desarrollados al sur de la desembocadura del arroyo, al pie de los acantilados, donde el oleaje durante las tormentas puede alcanzar esta zona. En el sector al norte del valle, no se llega a desarrollar una playa completa ya que el nivel del mar durante la marea alta alcanza la base del acantilado.

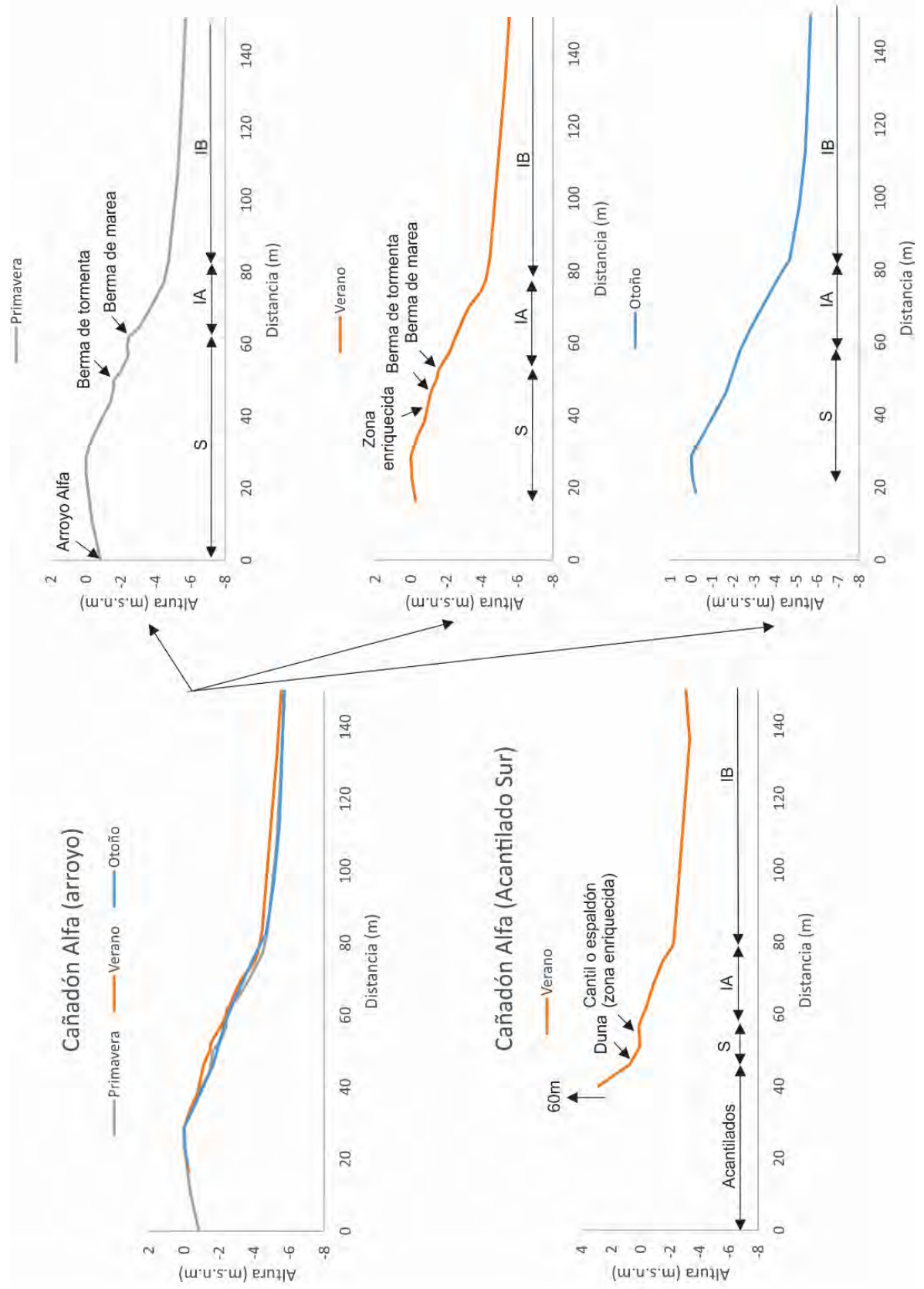

Fig.5.5. Perfiles realizados en la playa presente en la desembocadura del cañadón Alfa. 
El sector intermareal alto muestra una extensión aproximada de $25 \mathrm{~m}$ desde la berma de marea hasta el quiebre con la zona intermareal baja, con una pendiente entre 6 y $8^{\circ}$. Son depósitos polimodales, mal seleccionados, constituidos principalmente por gravas con arenas. En determinados momentos, se forman arcos de playa (beach cusps) correspondientes con formas rítmicas constituidas por cúspides, donde se acumula el material grueso, separadas por pequeñas bahías con material más fino (Fig.5.4C). Estas morfologías son frecuentes en los sectores reflejantes de la playa (Flor 2004).

La zona intermareal baja presenta una gran extensión durante la marea baja, con pendientes inferiores a $1^{\circ}$. Los sedimentos son unimodales, desde moderadamente seleccionados a moderadamente bien seleccionados, constituidos principalmente por arena fina y muy fina a medida que nos alejamos de la zona intermareal alta. Se reconocen óndulas suavemente asimétricas cortadas por canales mareales donde se depositan minerales pesados finos, principalmente opacos. En la desembocadura del arroyo aparecen sobre la zona intermareal baja rodados de unos $20-30 \mathrm{~cm}$, al igual que en el límite entre la zona intermareal alta y baja.

\subsubsection{Cañadón Beta (P3)}

Este sector de muestreo se localiza a $3 \mathrm{~km}$ al sur del cañadón Alfa. Para acceder por camino se debe tomar un desvío de la Ruta Nacional $\mathrm{N}^{\circ} 3$, a la altura de la planta de Total S.A. Cañadón Alfa, por el que se debe transitar unos $4,5 \mathrm{~km}$ hasta acceder a la playa (Fig.5.1). En este paraje se encuentra un puesto de la Estancia Cullen, instalaciones precarias de un lavadero de oro y un puesto de pescadores.

Al igual que en el cañadón Alfa, el arroyo Beta ha disectado el acantilado desarrollándose una amplia terraza fluvial. A ambos lados del valle los acantilados constituidos por sedimentitas marinas y sedimentos glacigénicos alcanzan los $65 \mathrm{~m}$ de altura (Fig.5.6A-C).

El perfil de la playa en la desembocadura del arroyo muestra una morfología similar en las estaciones de otoño, primavera y verano, marcándose un poco más las bermas de marea y tormenta en el perfil realizado en esta última (Fig.5.7). 


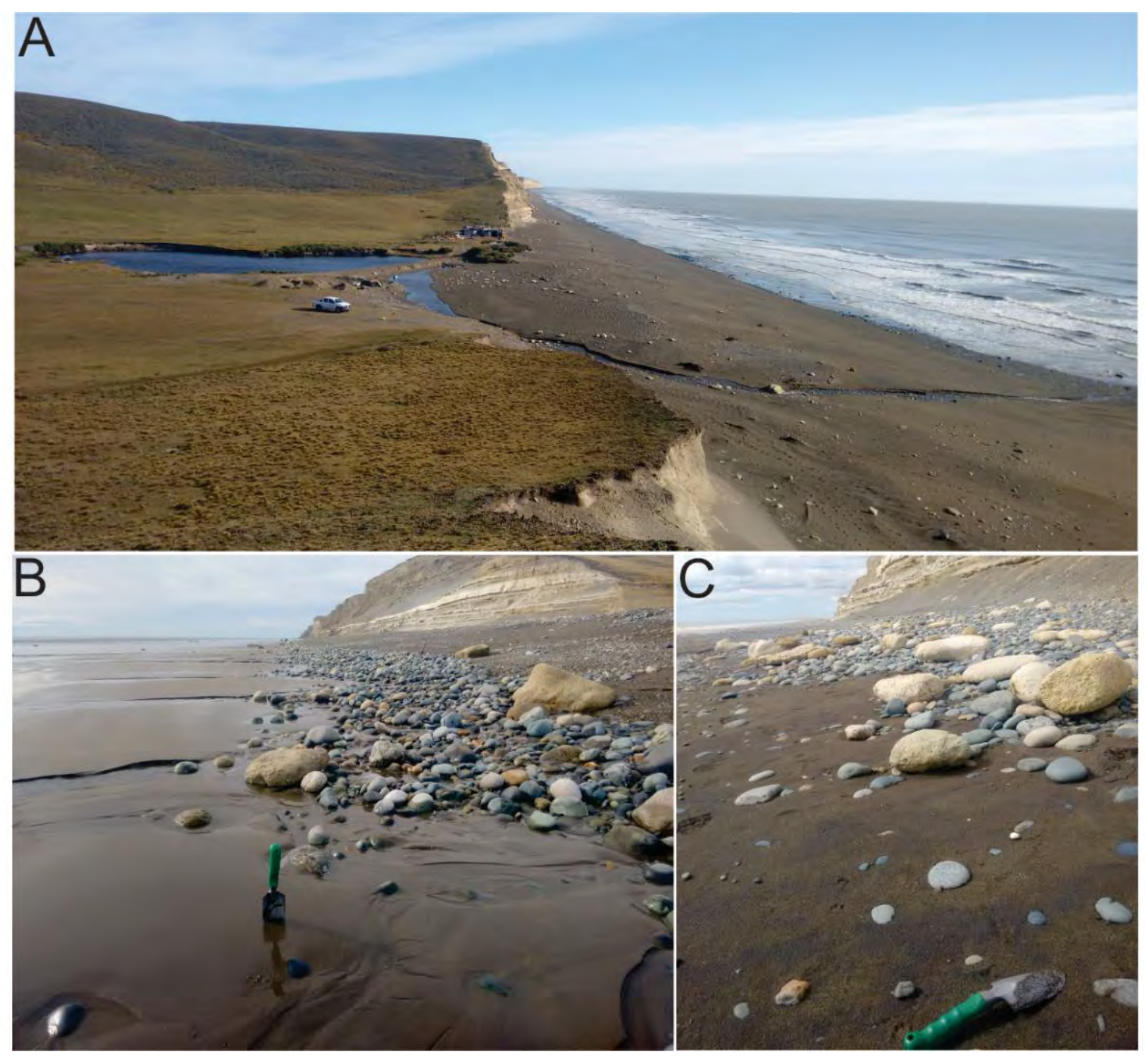

Fig.5.6. A) Panorámica hacia el norte desde el acantilado al sur del arroyo Beta, B) límite intermareal de las zonas altabaja y C) superficie de la zona supramareal al pie del acantilado enriquecida con minerales pesados.

La zona supramareal presenta una extensión aproximada entre $40 \mathrm{~m}$ y $50 \mathrm{~m}$, constituida principalmente por gravas y arenas medias, con una granulometría más arenosa pendiente abajo. Los cantos rodados o bloques mayores se corresponden con fragmentos de lutitas y areniscas de la Formación Cullen. Son depósitos que van desde muy mal a mal seleccionados mostrando polimodalidad en la zona de tormenta y unimodalidad en la terraza de marea. En todo este sector se observan depósitos de minerales pesados en la superficie y en profundidad, siendo mayores las acumulaciones al pie de los acantilados y después de una tormenta (perfil de verano). La coloración oscura y rojiza de los niveles enriquecidos refleja una composición principalmente de minerales opacos (óxidos de Fe y Ti) y granates. 


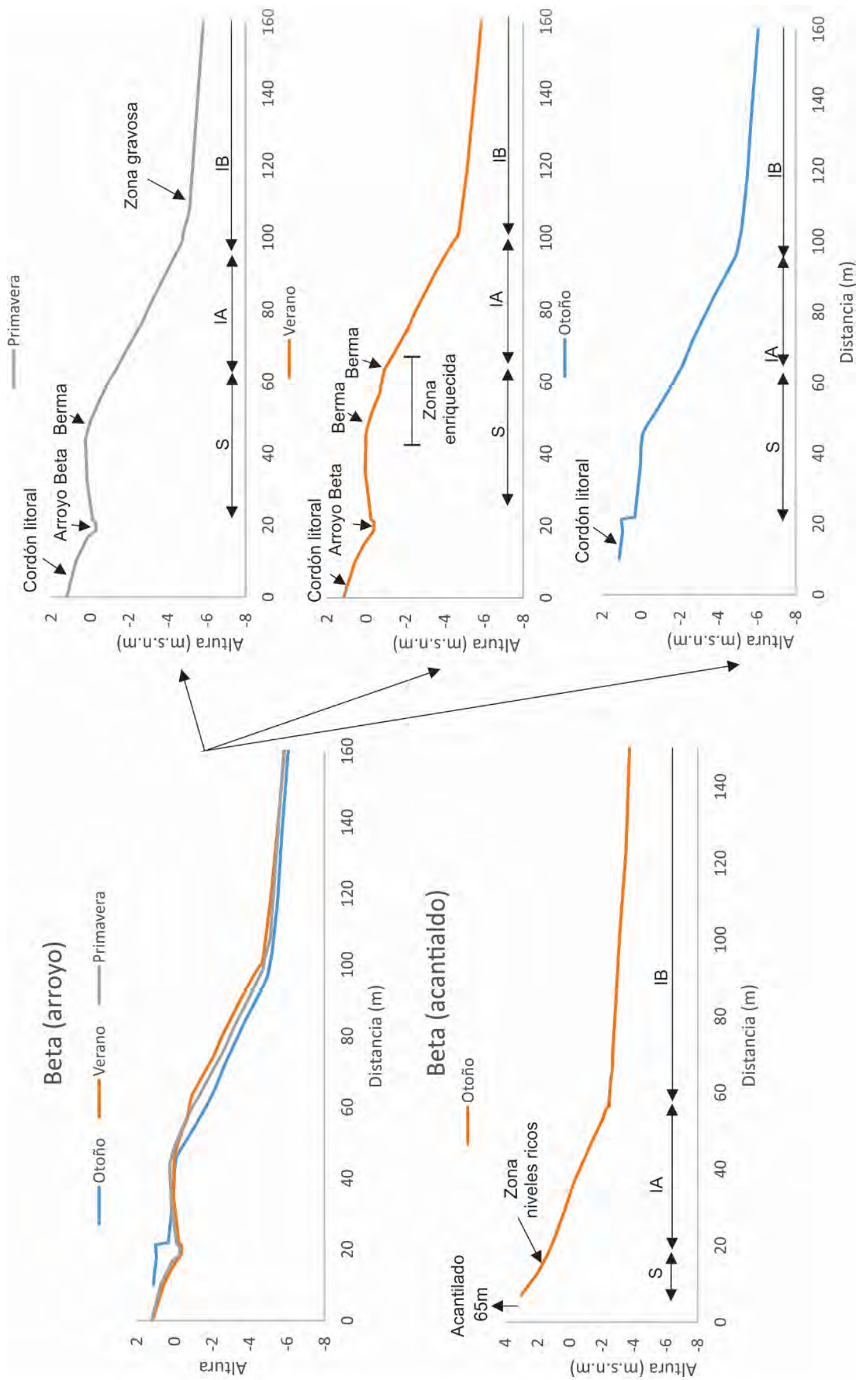

Fig.5.7. Perfiles en las playas del cañadón Beta. 
La zona intermareal alta con una extensión entre $30 \mathrm{~m}$ y $40 \mathrm{~m}$ y una pendiente entre $5^{\circ}$ y $6^{\circ}$, está constituida por gravas y arenas muy mal seleccionadas. A medida que nos acercamos a la zona de quiebre con el sector intermareal bajo, la granulometría aumenta hasta encontrar gravas de gran tamaño en la base, coincidiendo con el afloramiento del bed rock o plataforma de abrasión en algunos sectores, constituida por sedimentitas cenozoicas compactas (Fig.5.8).

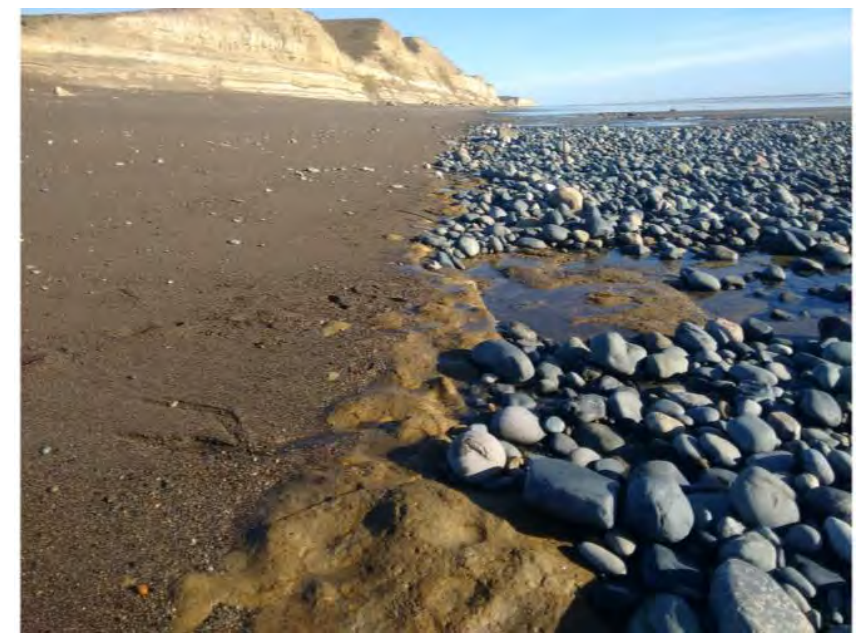

Fig.5.8. Plataforma de abrasión aflorante durante marea baja en la zona intermareal baja

La zona intermareal baja al igual que en los puntos de muestreo anteriormente mencionados tiende a la horizontalidad hacia el mar $\left(<1^{\circ}\right)$ y está constituida por arenas finas y muy finas. Son arenas unimodales moderadamente bien seleccionadas. Presentan óndulas suavemente asimétricas con minerales pesados en las crestas y en los canales mareales que las cortan. Se observan algunos bloques aislados de hasta $1 \mathrm{~m}$ de diámetro distribuidos de manera aleatoria por todo este sector.

\subsubsection{Cañadón Tortuga (P4)}

Para llegar a este sector utilizamos el mismo desvío de la Ruta Nacional $N^{\circ} 3$ con el que se accede al cañadón Beta. El acceso presenta cierta dificultad respecto de la anterior localidad ya que la traza de la huella más cercana sólo permite acercarse hasta la parte superior del acantilado, cuya altura alcanza los $50 \mathrm{~m}$. Aprovechando el corte del cañadón se pudo acceder hasta la playa. En este caso el cañadón formado por acción fluvial es activo únicamente en momentos esporádicos de grandes escorrentías.

Los acantilados muestran una mayor potencia de los depósitos glacigénicos en relación con los anteriores puntos descritos observándose claramente la alternancia de niveles estratificados y morénicos asentados sobre las sedimentitas marinas de la Formación Cullen (Fig.5.9A-C). 


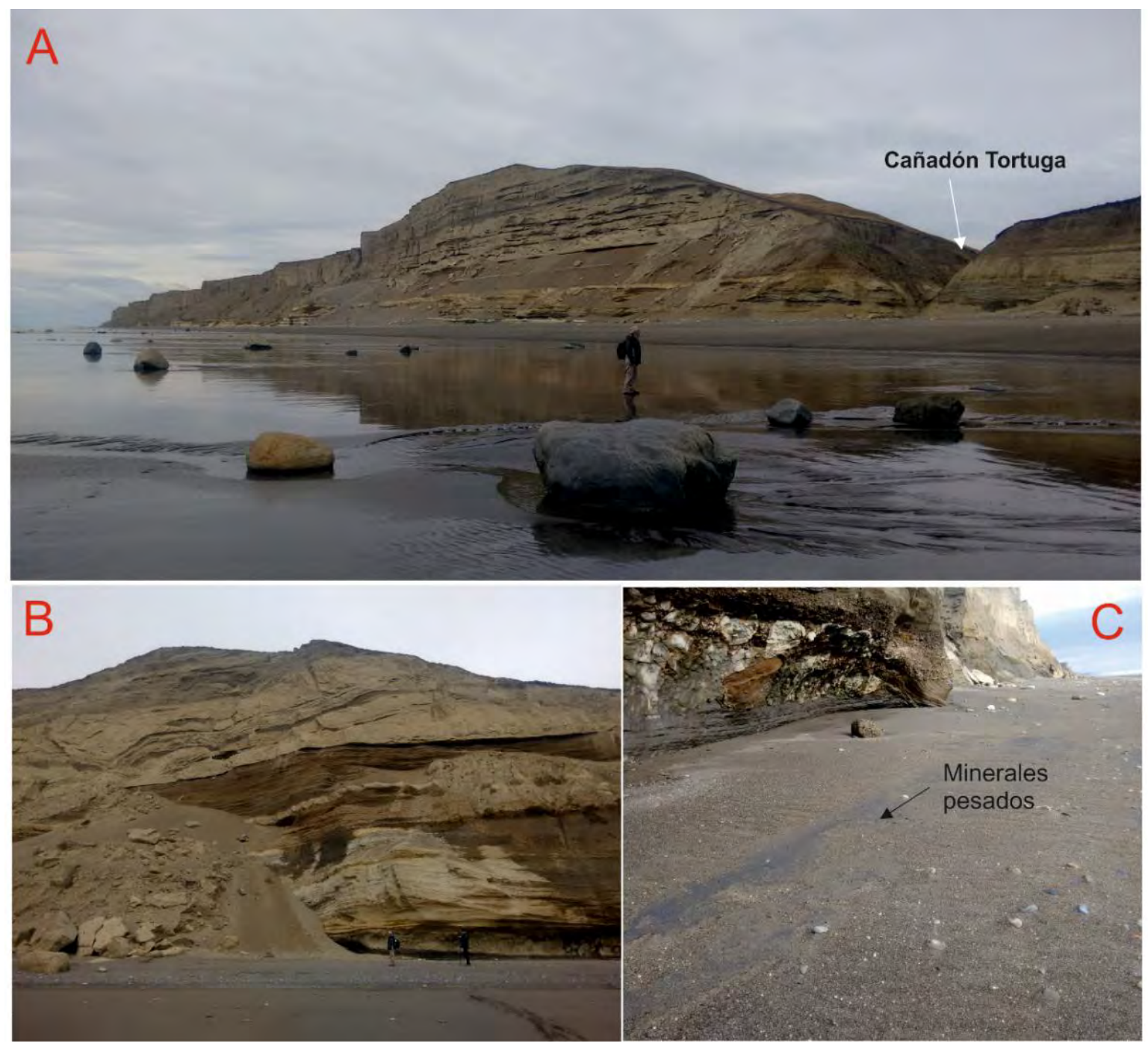

Fig.5.9. A) Cañadón Tortuga, vista hacia el sur desde la zona intermareal baja B) Acantilados activos con grandes deslizamientos de material poco cohesivo de origen glacigénico C) Zona supramareal con acumulación de minerales pesados en superficie.

En relación al perfil de la playa, (Fig.5.10) la zona supramareal es más reducida, llegando a alcanzar durante las tormentas la base del acantilado donde se observan acumulaciones de minerales pesados, principalmente óxidos de Fe y Ti (ilmenita s.l. y magnetita s.l.) y granates. La longitud varía entre $10 \mathrm{~m}$ y $30 \mathrm{~m}$. Debido a la erosión y la poca cohesión de material glacigénico, en algunos sectores la zona supramareal está completamente cubierta por los desprendimientos gravitacionales de los depósitos correspondientes con el Drift Pampa de Beta (gravas, arenas limos y arcillas). Esta zona está constituida por arenas y gravas mal seleccionadas.

La zona intermareal alta varía entre $30 \mathrm{~m}$ y $40 \mathrm{~m}$ de longitud, con una pendiente aproximada de $5^{\circ}$. En el perfil de verano se observa el desarrollo de un surco en el límite entre la zona intermareal alta y baja. Está compuesta por sedimentos polimodales muy 
mal seleccionados, con una granulometría más gruesa que en la zona supramareal como consecuencia de la removilización durante el oleaje de alta energía, dominando las gravas sobre las arenas.

La pendiente de la zona intermareal baja varía entre $1^{\circ}$ y $3^{\circ}$, aumentando en la zona más próxima a la playa emergida y disminuyendo hacia el mar donde se hace prácticamente horizontal. Está constituida, cerca del quiebre con la zona intermareal alta, principalmente por arena fina mal seleccionada, presentando en la superficie grandes bloques relictos que alcanzan los $2 \mathrm{~m}$ de largo.

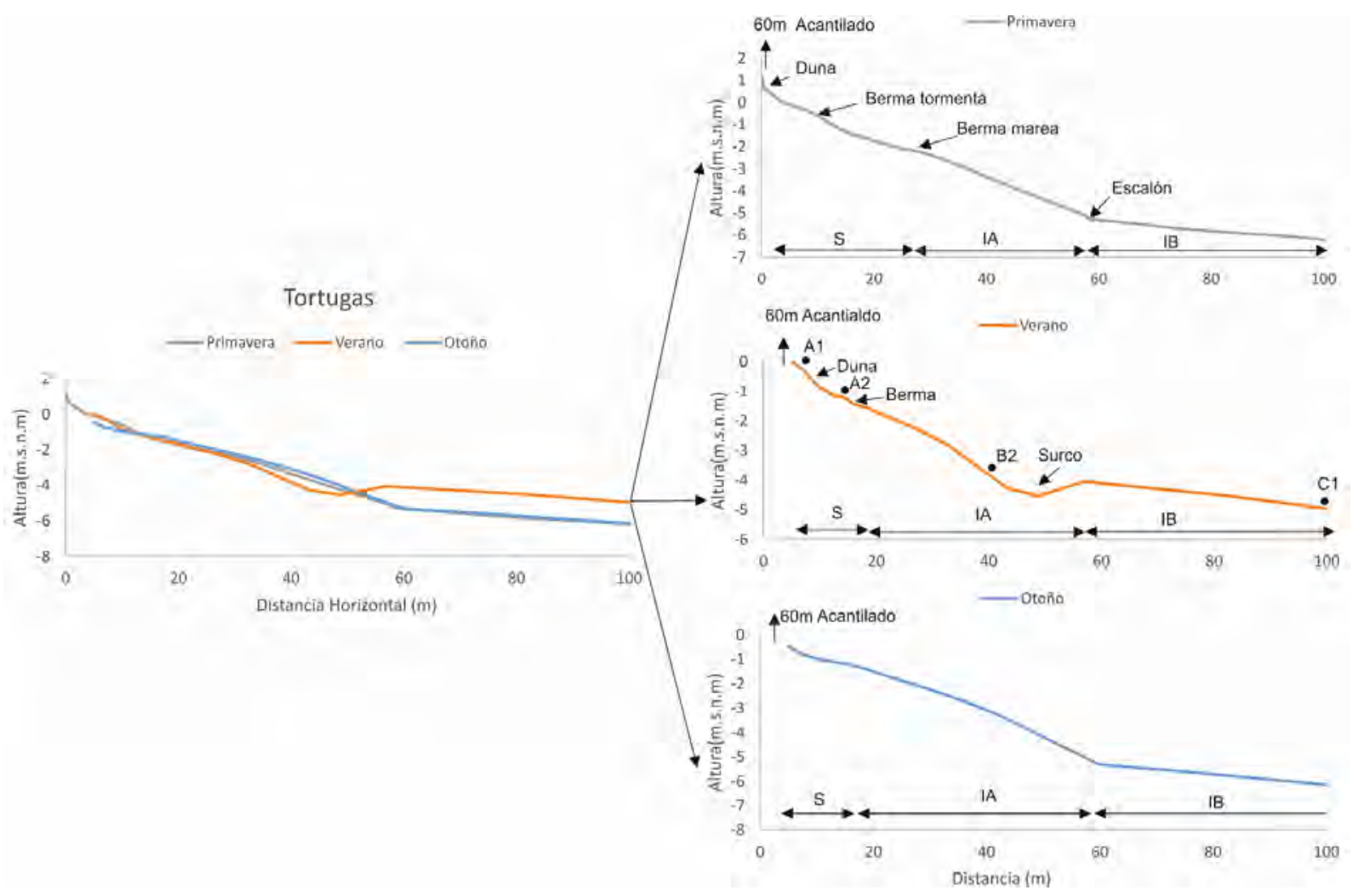

Fig.5.10. Perfiles en las playas del cañadón Tortuga.

\subsubsection{Cullen Norte (P5)}

Para acceder a este sector se tomó un camino saliendo desde la Estancia Cullen y bordeando el río Cullen por su margen norte. En algunos puntos, debido a las cárcavas producidas por el agua, fue necesario desviarse a campo traviesa (Fig.5.1).

La zona se sitúa en el límite de la meseta constituida por el Drift Pampa de Beta y el valle fluvial originado por el río Cullen. Debido a la profundización de la Fm. Cullen, en los acantilados únicamente afloran depósitos glacigénicos correspondientes con el Drift Pampa de Beta, cuya base en algunas zonas es alcanzada por las olas durante las tormentas o marea de sicigia (Fig.5.11 A-B). 

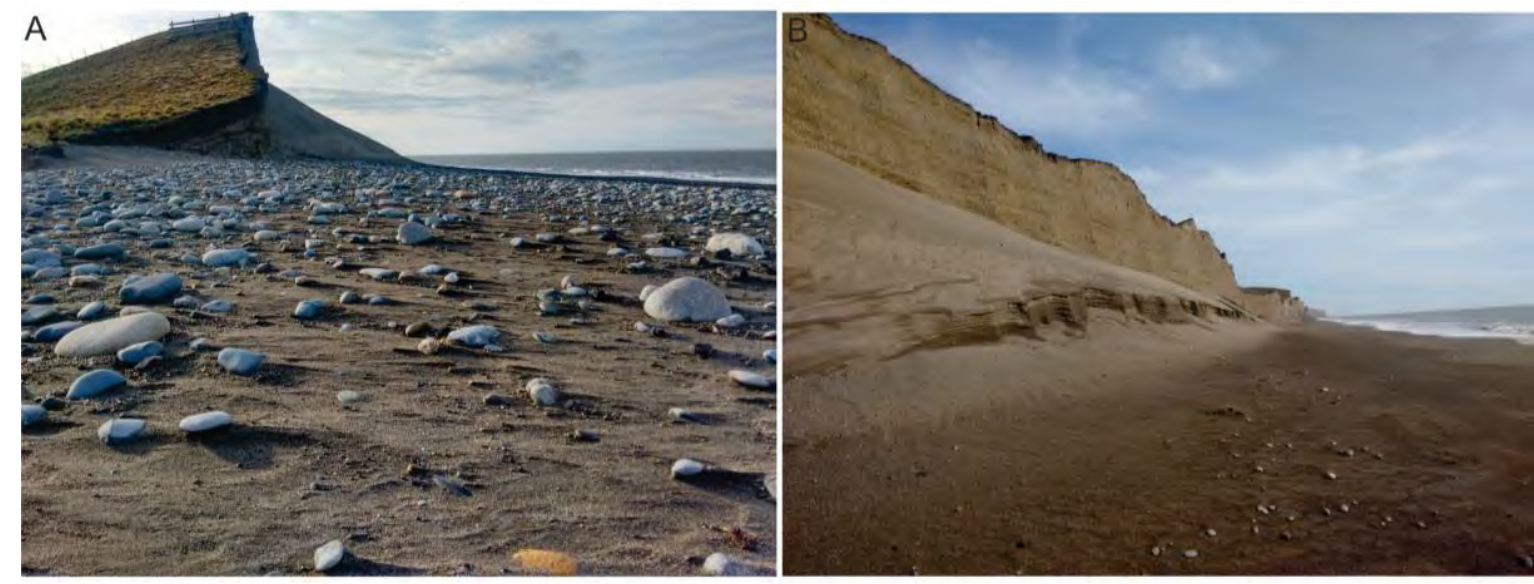

Fig.5.11. A) Sector de Cullen Norte donde finaliza el acantilado y B) duna remontante generada al pie del acantilado como consecuencia de los fuertes vientos.

Esta playa se caracteriza en que, a diferencia de las anteriormente descritas, no se desarrolla una zona intermareal baja. El perfil de la playa en la zona de la desembocadura del río Cullen muestra una morfología similar en las dos estaciones medidas (otoño y verano), marcándose un poco más las bermas en el perfil realizado en verano (Fig.5.12).

La zona supramareal presenta una extensión aproximada de entre 60 m y $70 \mathrm{~m}$, constituida mayoritariamente por gravas de gran tamaño y arenas, aumentando estas últimas, principalmente arena media, en la terraza de la berma de marea. La selección varía desde muy mal a mal seleccionada, con depósitos desde polimodales a unimodales en la terraza de marea. Durante la campaña de verano, sobre la superficie de la zona de swash, se identifican minerales pesados (principalmente ilmenitas s.l. y magnetitas s.l.), constituyendo depósitos muy finos e irregulares. Debajo del acantilado se desarrolla una duna remontante que alcanza los $4 \mathrm{~m}$ de altura y $300 \mathrm{~m}$ de longitud.

La zona intermareal alta tiene una pendiente aproximada de $6^{\circ}$ con un gran desarrollo longitudinal, alcanzado los $65 \mathrm{~m}$ durante la marea baja. Está constituida por gravas y arenas, polimodales y mal seleccionadas. 


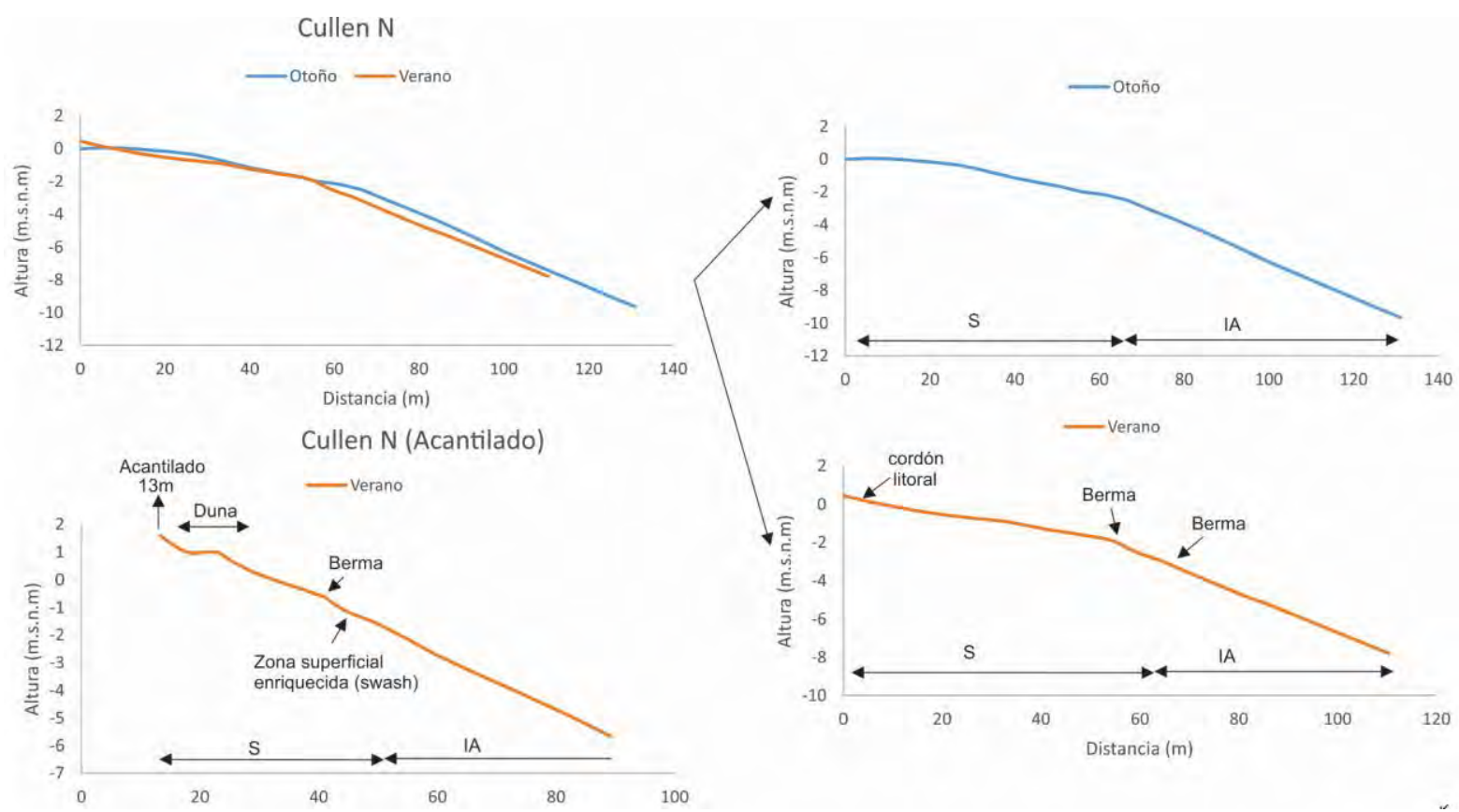

Fig.5.12. Perfiles en las playas de Cullen Norte.

\subsubsection{Cullen Sur (P6)}

Este punto se localiza al sur del río Cullen. Para acceder a la playa se toma un desvío de la ruta Nacional $N^{\circ} 3$ una vez pasada la sierra de San Sebastián al norte, por el cual hay que transitar durante $6 \mathrm{~km}$ hasta la playa (Fig.5.1).

En esta zona, la playa se encuentra limitada por un acantilado que alcanza $12 \mathrm{~m}$ de altura constituido por 4-5 m de till glacial cubierto por 2 metros de sedimento glacifluvial. Estos sedimentos se asocian con el Drift Río Cullen del Pleistoceno medio. El oleaje durante las tormentas alcanza la base del acantilado erosionándolo y provocando su retroceso (Fig.5.13A-C).

La playa presenta una morfología y granulometría muy similar a la de Cullen $\mathrm{N}$, sin desarrollo de una zona intermareal baja (Fig.5.14).

La zona supramareal varía entre $20 \mathrm{~m}$ y $35 \mathrm{~m}$, mostrando una menor extensión durante la campaña de verano. Son sedimentos bimodales mal seleccionados constituidos por arenas y gravas.

La zona intermareal presenta una pendiente entre 7 y $8^{\circ}$. La granulometría aumenta ligeramente con respecto a la zona supramareal, disminuyendo su selección a muy mal seleccionada. Al igual que en la anterior playa, se observan niveles de minerales pesados en la superficie de la zona de swash, pero de escaso desarrollo, constituidos esencialmente por óxidos de Fe y Ti (ilmenitas s.l. y magnetita s.l.). 


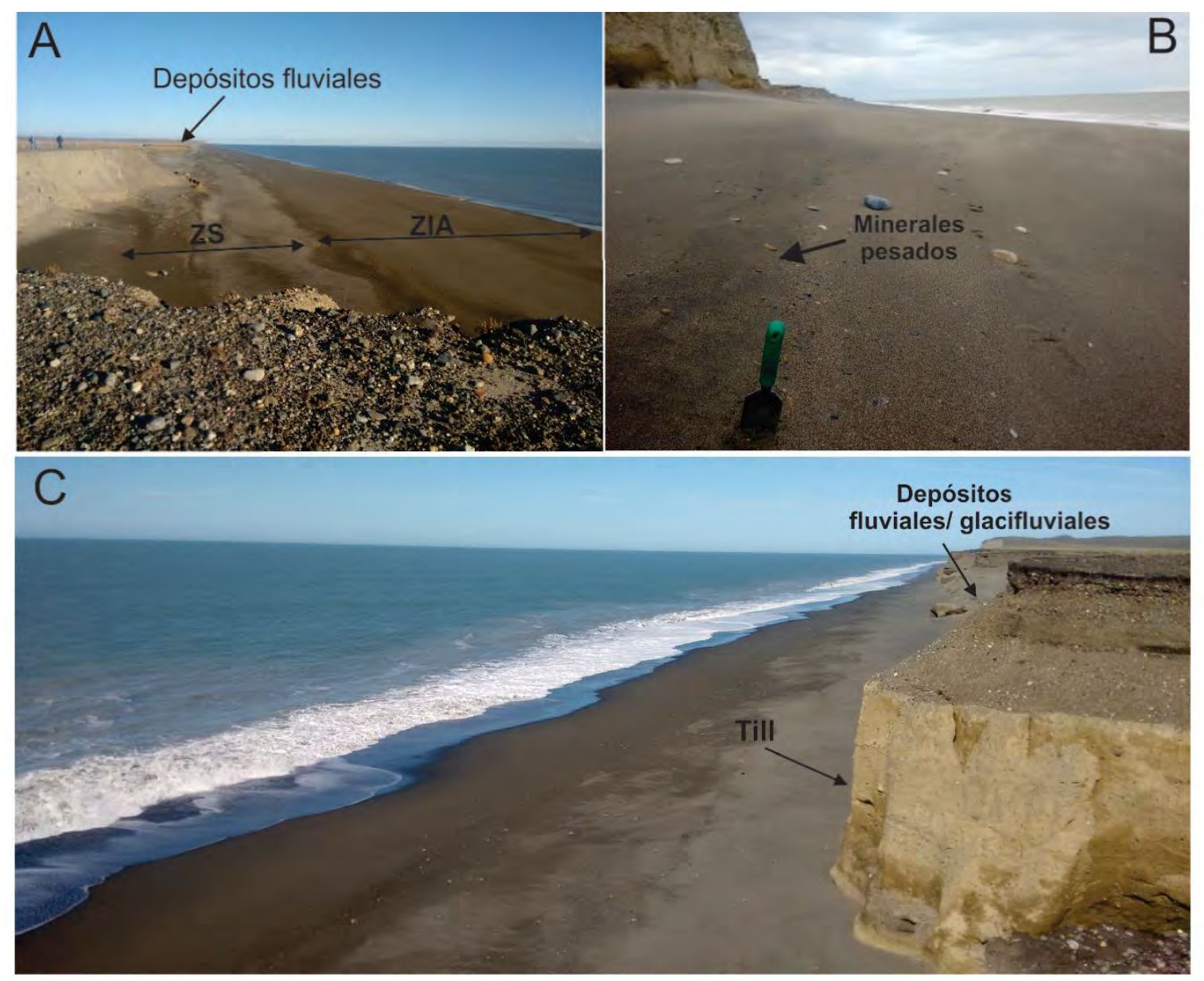

Fig.5.13. A) Vista de la playa al sur de la desembocadura del río Cullen. ZS: zona supramareal; ZIA; zona intermareal, B) minerales pesados en la zona de swash y C) acantilados.

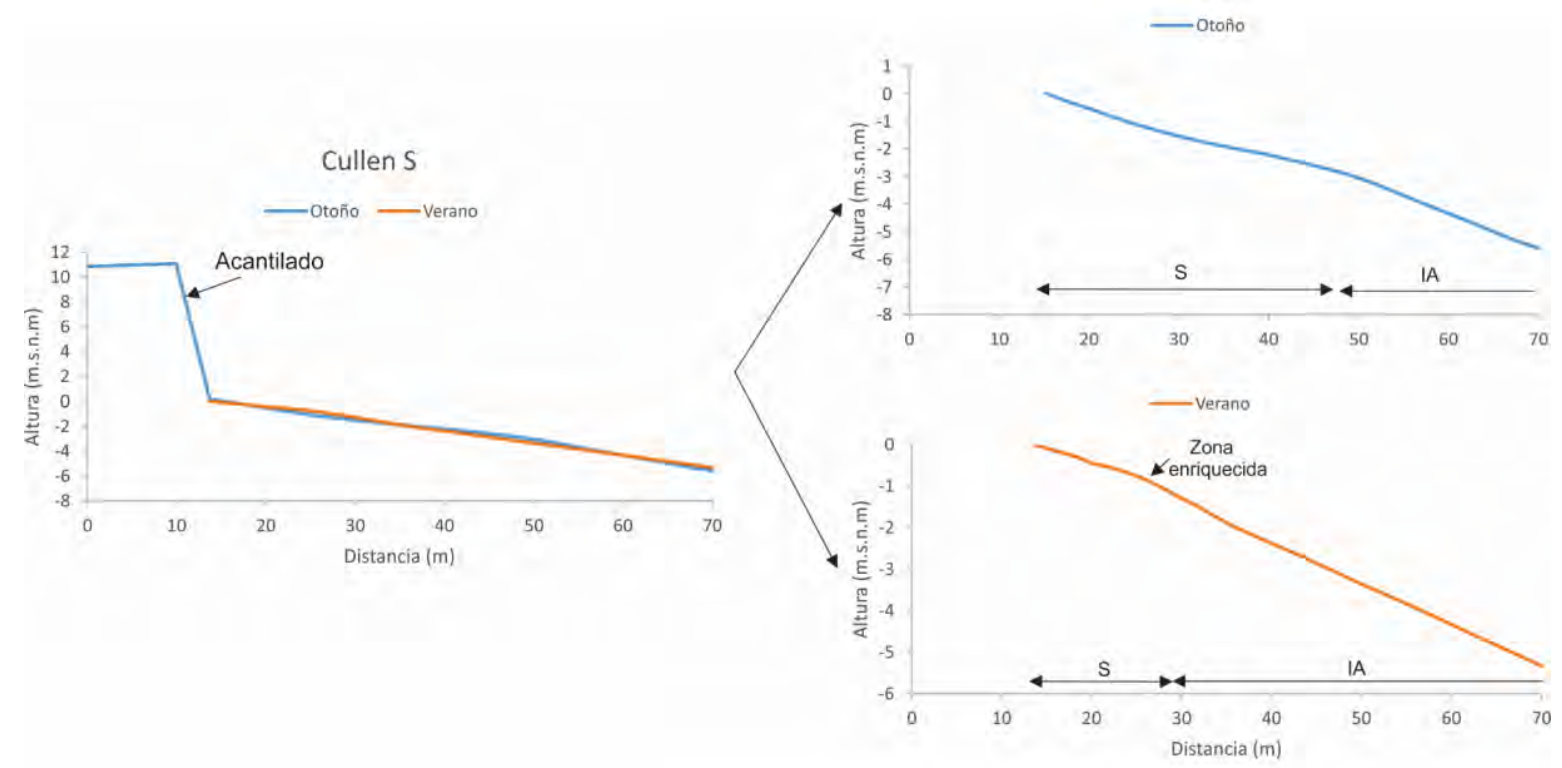

Fig. 5.14. Perfiles en la playa de Cullen Sur. 


\subsubsection{El Páramo (P7)}

La playa localizada en este sector fue uno de los lugares donde el Ingeniero Julius Popper extrajo la mayor parte del oro a finales del siglo XIX. Para acceder a esta playa se debe tomar un desvío localizado a la altura del puesto de Gendarmería Grupo Cullen a 42,5 km de San Sebastián, al sur de la sierra del homónima, por el que se debe transitar por espacio de unos $7 \mathrm{~km}$ hasta llegar la playa.

Esta zona se sitúa en el límite sur de la sierra de San Sebastián, constituida por sedimentos glacigénicos y la península de El Páramo, que corresponde con una espiga de gravas de 20 km de largo que cierra parcialmente la bahía San Sebastián (Fig. 5.1 y 5.15A). Esta espiga es de tipo transgresivo ya que prograda longitudinalmente hacia el sur y lateralmente hacia oeste, siendo los depósitos glacigénicos localizados al norte la principal fuente de aporte (Vilas et al. 1987, Bujalesky 2007).
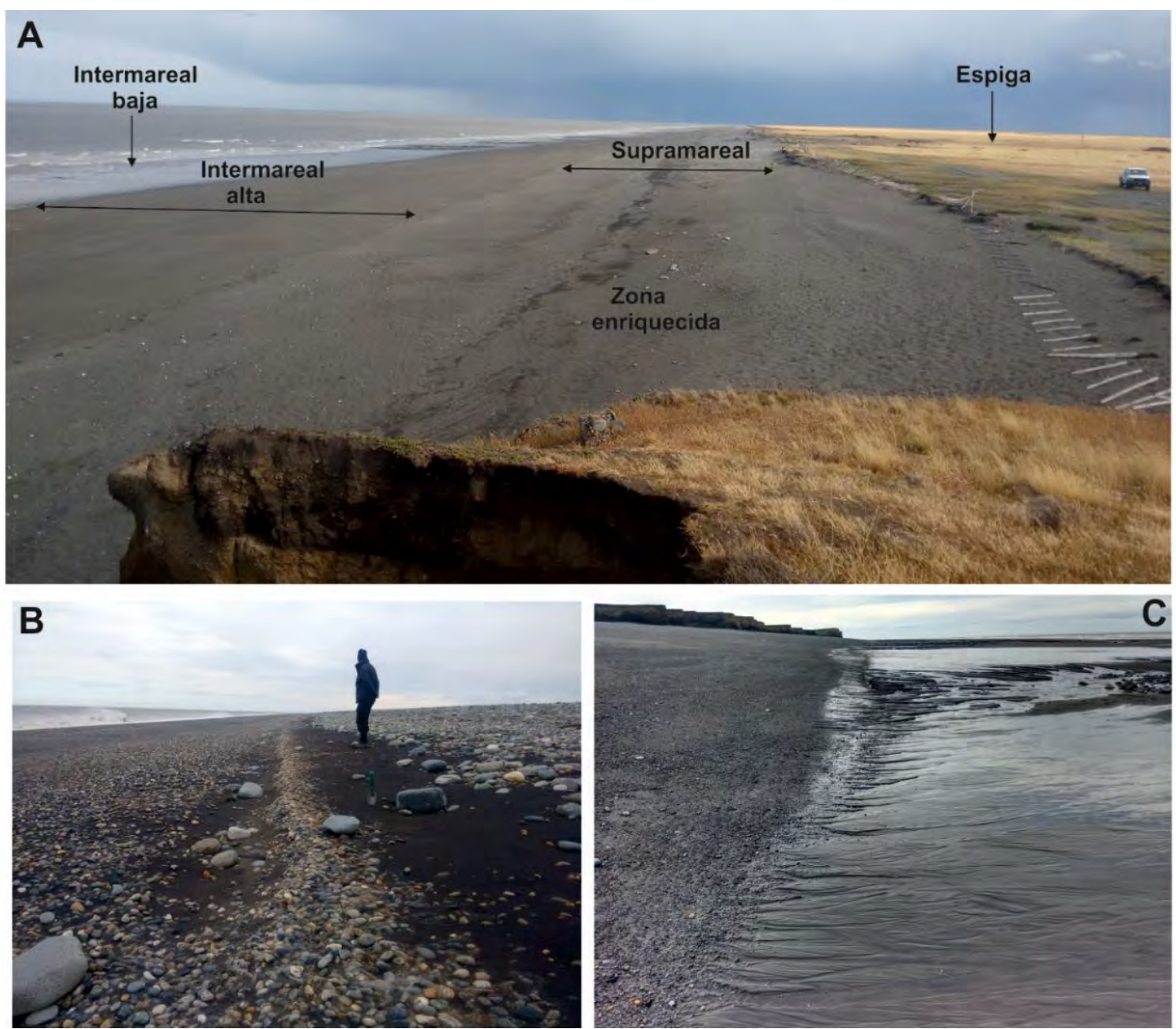

Fig.5.15. Playa El Páramo. A) Vista de la playa hacia el sur desde el acantilado, B) zona enriquecida en minerales pesados localizada en la zona supramareal (espiga) y C) límite entre la zona intermareal alta y baja 
En la zona próxima al cordón litoral se ha generado una angosta zona dunar como consecuencia de la acción eólica, presentando en algunos sectores una vegetación pionera (duna embrionaria).

En la playa se pueden diferenciar tres zonas: supramareal e intermareal alta y baja (Fig.5.16).

El sector supramareal presenta una extensión variable dependiendo de la época del año, desde $30 \mathrm{~m}$ en verano hasta $50 \mathrm{~m}$ en primavera, observando en el perfil de verano dos bermas bien marcadas, correspondientes con la de marea y la de tormenta. En todo este sector es común encontrar niveles minerales pesados tanto en superficie como en profundidad, presentando algunas zonas espesores de hasta $2 \mathrm{~cm}$ (Fig.5.15B). Los depósitos son polimodales y muy mal seleccionados constituidos por arenas y gravas, disminuyendo su tamaño hacia la terraza de la berma de marea y cerca del cordón litoral como consecuencia de la acumulación de arenas por el viento. Hacia el sur, en la espiga, los depósitos están constituidos principalmente por gravas

En la zona intermareal alta la pendiente varía entre 5 y $6^{\circ}$ presentando una gran extensión, entre $60 \mathrm{~m}$ y $80 \mathrm{~m}$. Está constituida por arenas que representan depósitos mal seleccionados y bimodales (Fig.5.15.C)

Por último, la zona intermareal baja presenta una pendiente entre 0,6 y $2^{\circ}$, con una extensión de $90 \mathrm{~m}$, donde se desarrollan canales mareales y óndulas. Son depósitos unimodales, moderadamente bien seleccionados, constituidos mayoritariamente por arenas finas. En algunos sectores se encuentran acumulaciones de gravas en niveles superficiales. La plataforma de abrasión, conformada por sedimentos glacigénicos, puede reconocerse en períodos de bajamar (Fig.5.17). 
El Páramo
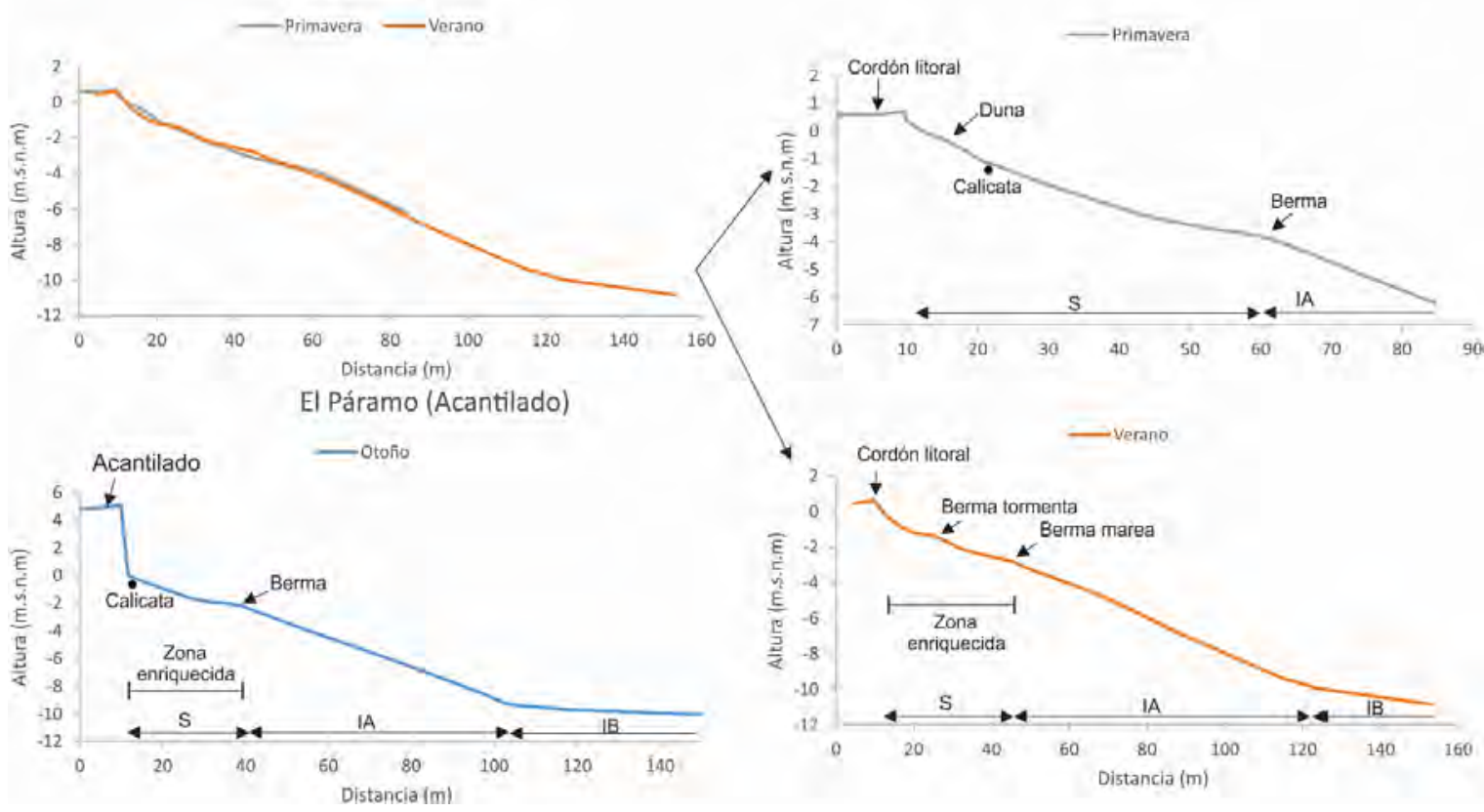

Fig.5.16. Perfiles realizados en las playas de El Páramo.

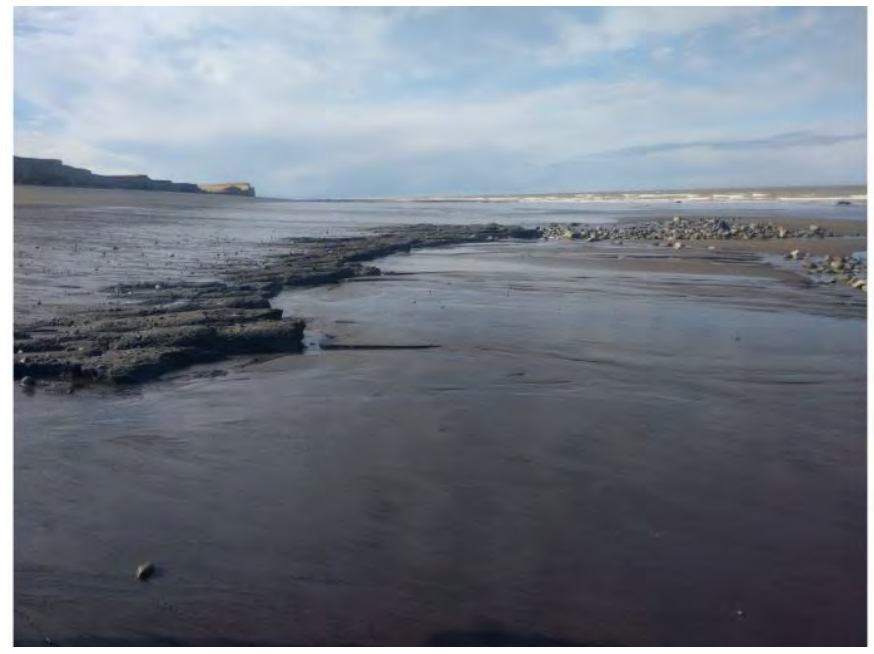

Fig.5.17. Plataforma de abrasión en El Páramo.

\subsubsection{Bahía San Sebastián (P8)}

La bahía se localiza en la depresión bahía Inútil-San Sebastián generada durante las glaciaciones del Pleistoceno y remodelada durante la transgresión holocena (Bujalesky 2007). Limita al norte con la sierra de San Sebastián y al sur con la sierra Carmen Silva. Está parcialmente cerrada como consecuencia del desarrollo de la espiga anteriormente citada, que constituye una geoforma costera que la protege del oleaje. En este sector se desarrollan distintos ambientes como marismas, cheniers, extensas planicies y canales de 
marea y cordones litorales de gravas al sur donde la influencia del oleaje se vuelve a intensificar (Bujalesky 2007).

El sector que se eligió para muestrear se localiza al sur de la bahía donde se presenta una playa de arena y grava detrás de una llanura mareal arenosa y fangosa (Vilas et al. 1987) (Fig.5.18). Antiguos cordones litorales se desarrollan con orientación SE-NO generados durante etapas regresivas del nivel del mar (Vilas et al. 1987, Bujalesky 2007). A esta playa se puede acceder a través de la Ruta Nacional $N^{\circ} 3$, a $1,5 \mathrm{~km}$ al norte del puesto fronterizo de San Sebastián.
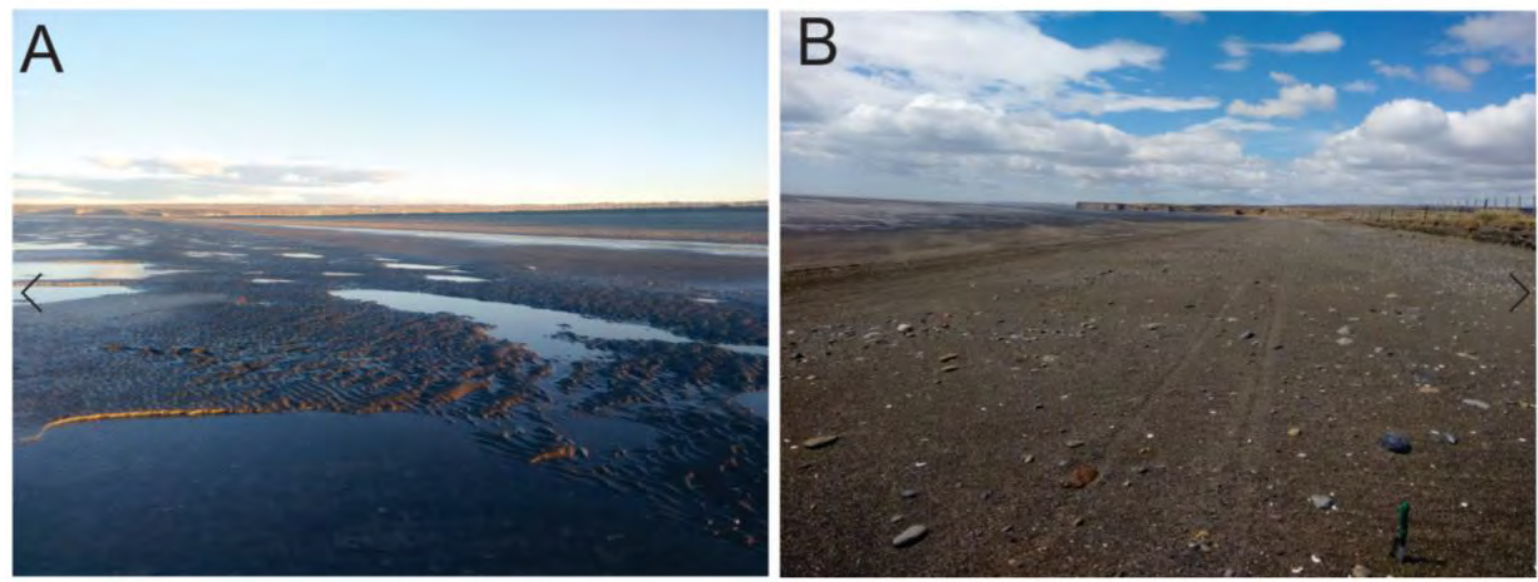

Fig.5.18. Playa de San Sebastián. A, zona intermareal; B, zona supramareal

Adyacente al cordón litoral, se generan pequeñas acumulaciones de arena como consecuencia del transporte eólico (duna embrionaria).

Los perfiles realizados en las campañas primavera y verano no muestran grandes diferencias (Fig.5.19). La zona supramareal presenta una extensión entre 16 y 20 m y está constituida principalmente por arenas con gravas subordinadas, bimodales y mal seleccionadas. En la zona de swash es posible ver una fina capa de minerales pesados, de coloraciones gris oscuras, fundamentalmente integrada por óxidos de $\mathrm{Fe} \mathrm{y} \mathrm{Ti}$, pero de reducidas dimensiones. En la zona intermareal alta tiene una extensión entre 25 y $30 \mathrm{~m}$ con una inclinación entre $3^{\circ}$ y $4^{\circ}$, con una granulometría constituida por arena (principalmente fina) y algo de grava, bimodal y mal seleccionada. En la zona intermareal baja la pendiente es $<2^{\circ}$, horizontalizándose hacia el mar, con un sedimento constituido por limos con arenas finas a muy finas mal seleccionadas, disminuyendo el contenido de arenas hacia la playa sumergida. Se observan óndulas en superficie y canales de desagüe que constituyen el sistema de drenaje de marea. Este sector se corresponde con la planicie o llanura de marea. 


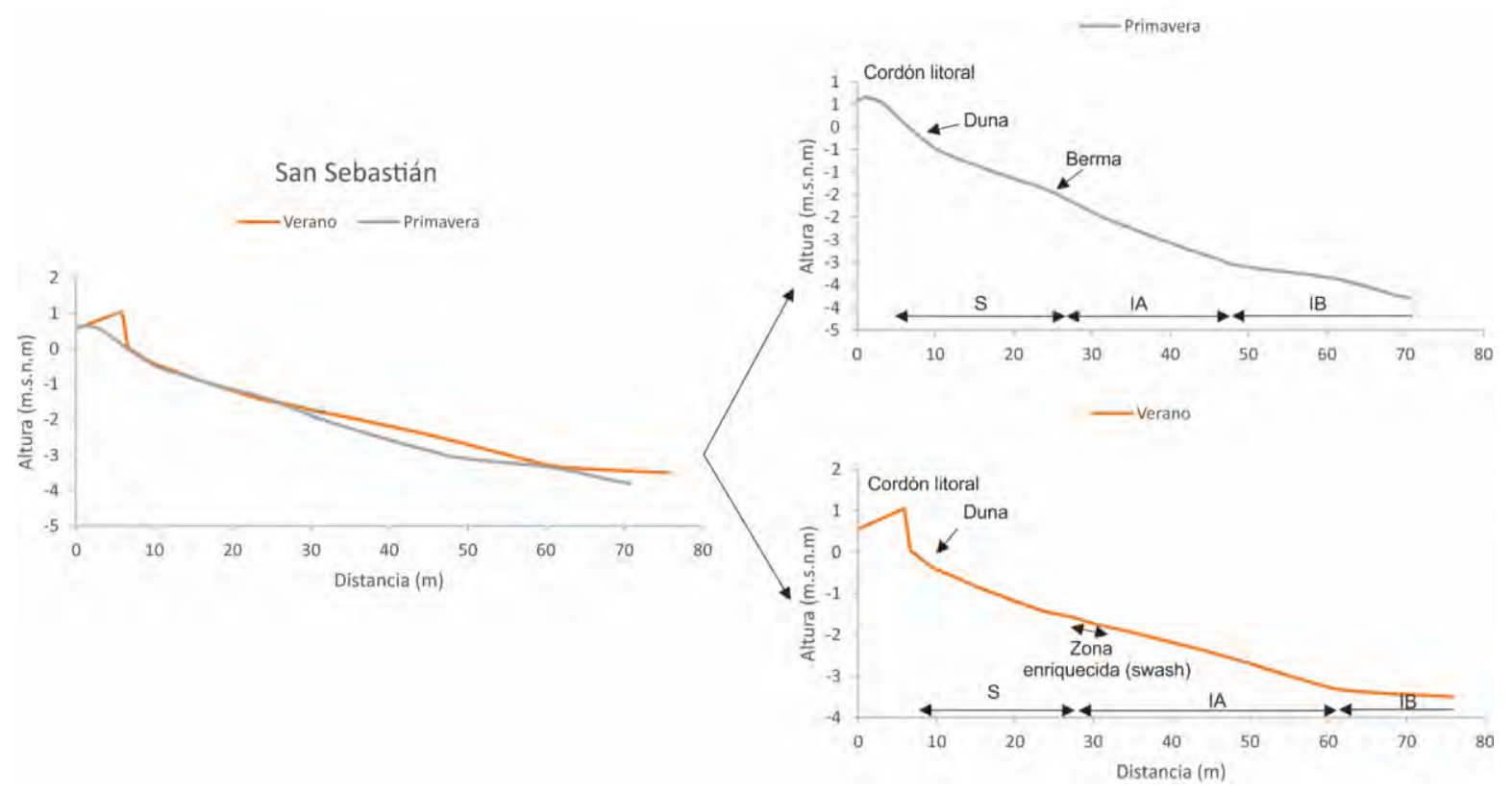

Fig.5.19. Perfiles playa bahía San Sebastián.

\subsubsection{Punta Sinaí (P9)}

Representa la playa más meridional de la zona de trabajo. Para acceder a ella se utilizó la Ruta Nacional $N^{\circ} 3$ hasta Estancia Sara donde hay que tomar hacia el este por un camino privado perteneciente a esta estancia por espacio de unos $7,5 \mathrm{~km}$ hasta arribar a la playa.

El sector de punta Sinaí se ubica al sur de la sierra Carmen Silva, en el límite de la morena lateral del Drift Río Cullen (Fig.5.1). Esta unidad pertenece a una de las glaciaciones que se desplazó por la depresión bahía Inútil-bahía San Sebastián. Su límite frontal se localiza a una distancia de $26 \mathrm{~km}$ mar adentro a una profundidad de $60 \mathrm{~m}$ (Isla y Schnack, 1995). A partir de aquí y hacia el sur se desarrollan extensos cordones litorales correspondientes con la Fm. Sara (Codignotto y Malumián, 1981). Los acantilados están constituidos por sedimentos glacigénicos donde se destaca la presencia de grandes bloques de litología muy variada tanto en superficie como incorporados dentro del sedimento. El oleaje de tormenta alcanza la base del acantilado provocando el retroceso de estos depósitos, quedando como relictos los grandes bloques sobre la superficie de la playa y mar adentro (Fig.5.20A-C). 

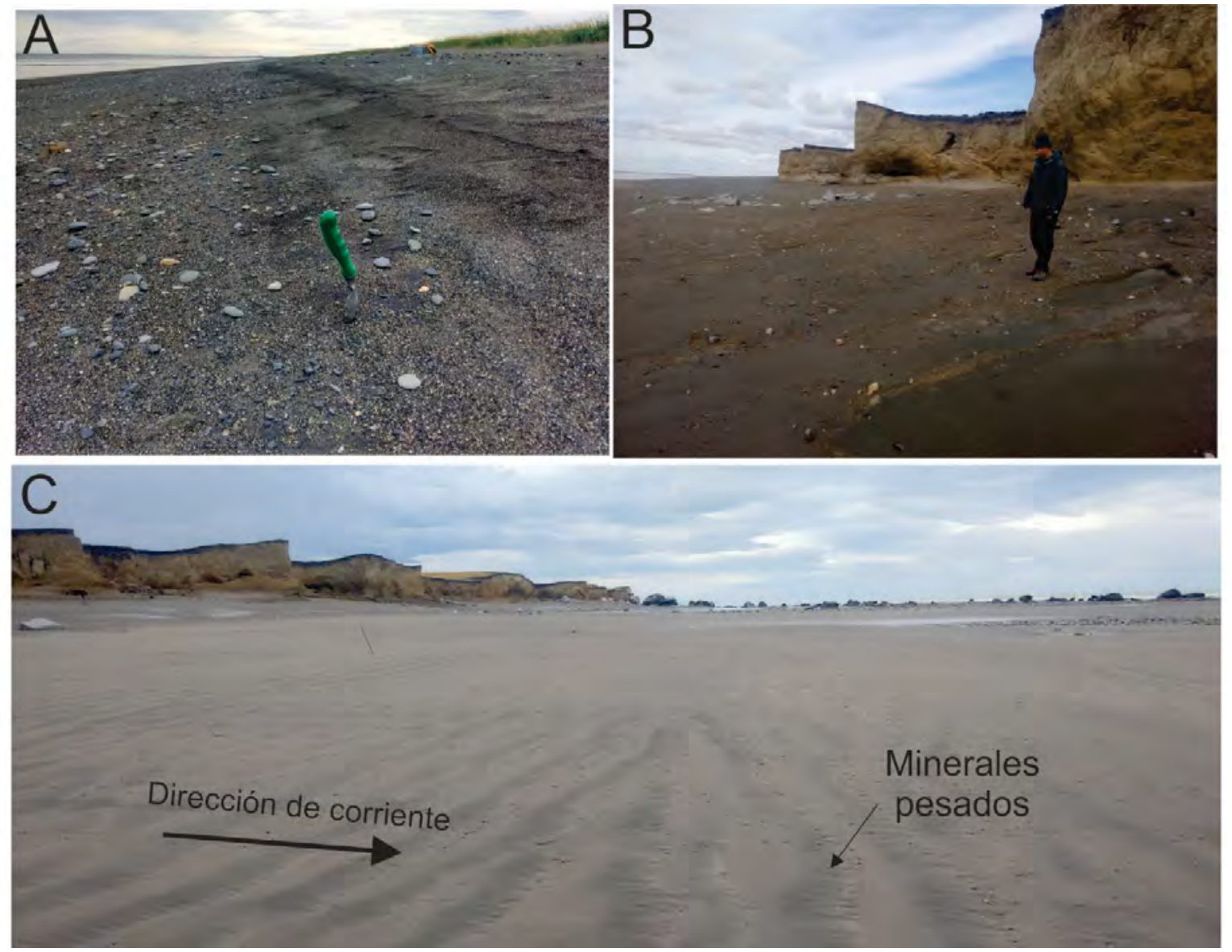

Fig.5.20. Playa en punta Sinaí. A, acumulación de minerales pesados en la berma de tormenta. B, plataforma de abrasión constituida por sedimentos glacigénicos. $C$, óndulas asimétricas con acumulación de minerales pesados finos en la zona intermareal baja. Al fondo, bloques relictos de los sedimentos glaciales.

Se realizaron perfiles durante la campaña de verano pudiéndose reconocer los tres sectores de playa durante la marea baja (Fig.5.21A-B). La zona supramareal tiene una extensión de $30 \mathrm{~m}$. Se pueden diferenciar dos bermas, de marea y de tormenta, observando, sobre la terraza de esta última, concentración de minerales pesados. Presenta una granulometría más fina que en el resto de las playas muestreadas, constituida por arenas (principalmente de tamaño medio). En la playa bordeada por acantilados la zona supramareal es más reducida (12,5 m). Se pueden reconocer también concentraciones de minerales pesados al pie de los acantilados de coloraciones gris oscuras constituidas fundamentalmente por óxidos de Fe y Ti. En algunos sectores aflora la superficie de abrasión constituida por depósitos glacigénicos más antiguos.

La zona intermareal alta tiene una extensión de unos $34 \mathrm{~m}$ con pendiente de $6^{\circ}$. Está compuesta por sedimentos polimodales muy mal seleccionados constituidos por arenas mayoritariamente de tamaño medio a muy grueso y gravas. 
Finalmente, la zona intermareal baja tiene una pendiente casi horizontal $\left(<1^{\circ}\right)$ disminuyendo suavemente hacia la playa sumergida. Está formada principalmente por arena fina, que presenta en las óndulas asimétricas acumulaciones de minerales pesados en la parte superior de la cara con menor pendiente, indicando dirección de transporte hacia la playa sumergida.
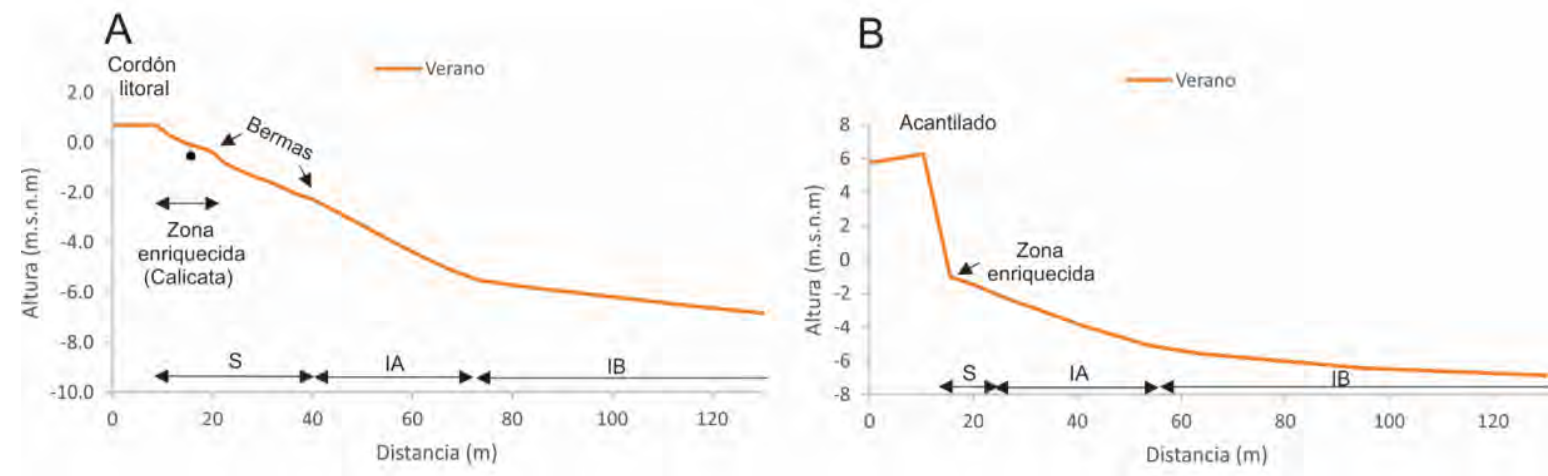

Fig.5.21. Perfiles de playa en punta Sinaí.

\subsection{Morfología de las playas: Análisis granulométrico y perfiles}

Las playas son ambientes sedimentarios afectados por una dinámica continua y de energía variable. En función del momento del año en el cual se realice el perfil, se pueden llegar a observar diferencias en cuanto a la extensión de la zona intermareal alta y supramareal y a la presencia o ausencia de bermas bien marcadas en esta última, pero no se evidencian cambios importantes en cuanto a la pendiente o pérdidas y ganancias de material. Los perfiles de las playas gravosas suelen permanecer estables en el tiempo como consecuencia de la alta energía que se debe aplicar para poner en movimiento materiales más gruesos, por lo tanto, no se pueden diferenciar perfiles de tormenta o calma.

Acumulaciones superficiales importantes de minerales pesados en la zona supramareal pueden indicar condiciones de tormenta recientes ya que se producen como consecuencia de un oleaje de mayor energía.

En los perfiles realizados durante la campaña de primavera, coincidiendo con marea de sicigia, se observó un mayor desarrollo de la zona supramareal que los realizados en las otras campañas, identificando en la mayoría de las playas dos bermas, de marea y tormenta. Los perfiles realizados en la campaña de otoño son similares a los de verano en cuanto a la extensión de las zonas, pero con las bermas más suavizadas.

Los perfiles elaborados durante el verano, a diferencia de los de las otras estaciones, presentan un diseño ligeramente más tendido, con la zona supramareal más 
reducida mostrando una berma de tormenta mejor marcada sobre la cual se observan depósitos superficiales ricos en minerales pesados, especialmente abundantes en las playas de los cañadones Alfa y Beta, El Páramo y punta Sinaí. Por otro lado, comparando los perfiles realizados a lo largo de la zona de trabajo, se observa un mayor desarrollo de la zona intermareal alta progresivamente hacia el sur, desde el cabo Espíritu Santo hasta El Páramo, donde se genera una zona de acumulación evidenciada por la formación de la espiga más al sur (Fig.5.22). En la bahía San Sebastián, donde la energía del oleaje es atenuada por la presencia de la espiga que cierra parcialmente la bahía, la extensión e inclinación de la zona intermareal alta y supramareal son menores

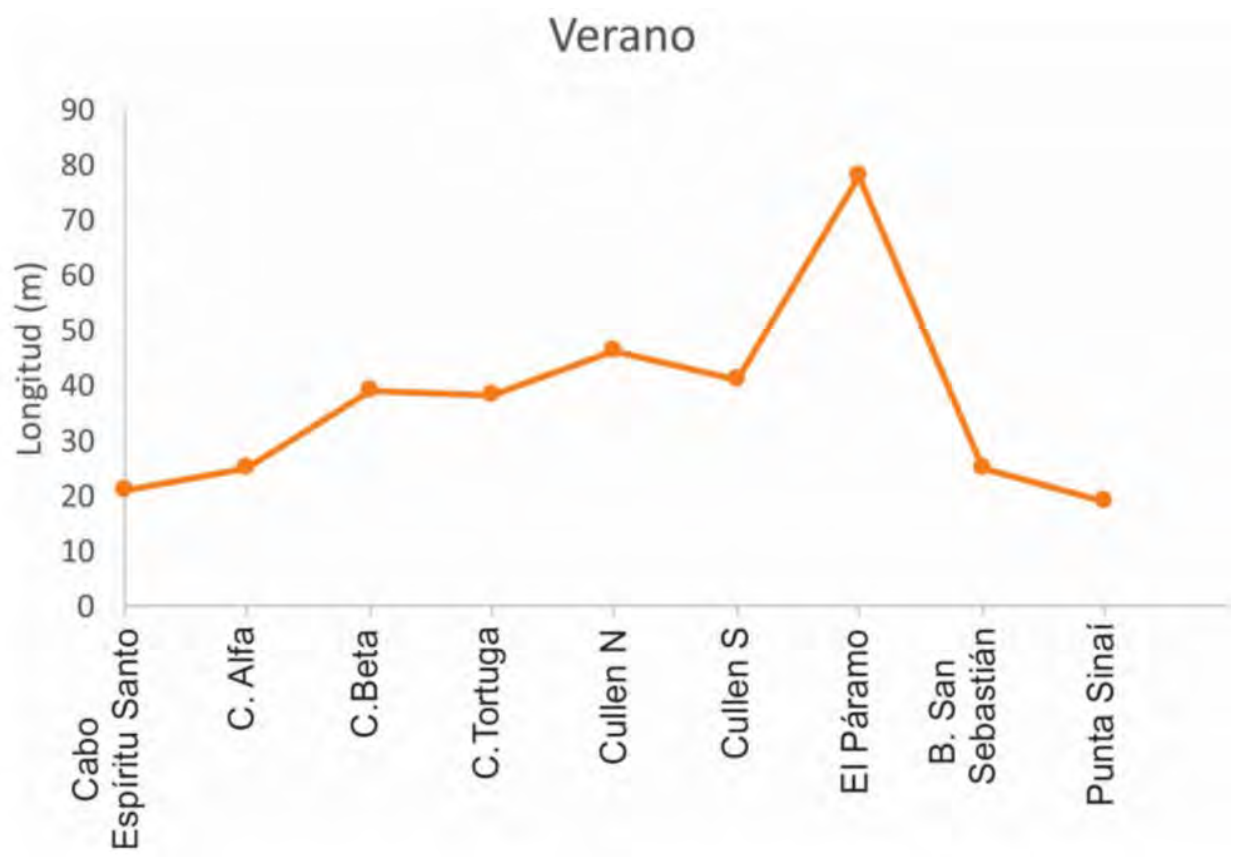

Fig.5.22. Extensión de la zona intermareal alta en las distintas playas. 


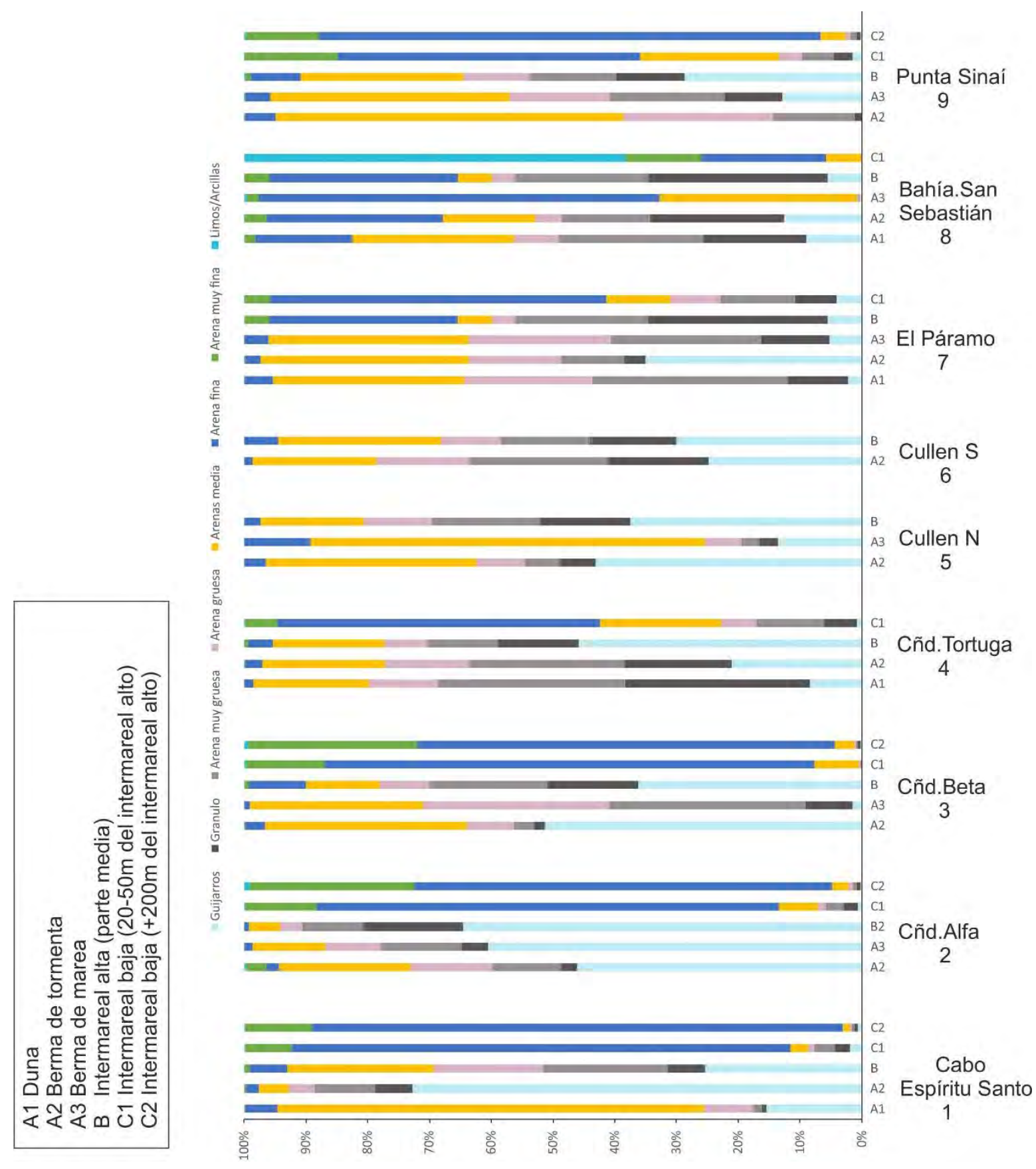

Fig.5.23. Gráfico de columnas apiladas con los porcentajes granulométricos de las muestras extraídas en los sectores de las playas (campaña de verano). 


\begin{tabular}{|c|c|c|c|c|c|c|c|c|c|}
\hline 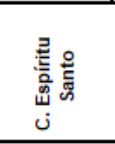 & $\begin{array}{l}\mathrm{A} 1 \\
\mathrm{~A} 2 \\
\mathrm{~B} \\
\mathrm{C} 1 \\
\mathrm{C} 2 \\
\end{array}$ & $\begin{array}{c}0,64 \\
-2,79 \\
-0,56 \\
2,48 \\
2,55 \\
\end{array}$ & $\begin{array}{l}1,79 \\
1,95 \\
2,22 \\
0,84 \\
0,43 \\
\end{array}$ & $\begin{array}{c}-0,73 \\
0,51 \\
-0,29 \\
-0,29 \\
0,16 \\
\end{array}$ & $\begin{array}{l}3,46 \\
1,00 \\
0,83 \\
2,75 \\
1,07 \\
\end{array}$ & $\begin{array}{l}\text { Arena gruesa } \\
\text { Grava fina } \\
\text { Arena muly gruesa } \\
\text { Arena fina } \\
\text { Arena fina } \\
\end{array}$ & $\begin{array}{l}\text { Pobremente seleccionda } \\
\text { Pobremente seleccionda } \\
\text { Muy pobremente seleccionda } \\
\text { Mod. seleccionda } \\
\text { Bien seleccionada }\end{array}$ & $\begin{array}{l}\text { Muy asimétrica gruesos } \\
\text { Muy asimétrica finos } \\
\text { Asimétrico gruesos } \\
\text { Asimétrico gruesos } \\
\text { Asimétrico finos } \\
\end{array}$ & $\begin{array}{l}\text { Extrem. leptocúrtico } \\
\text { Mesocúrtico } \\
\text { Platicúrtico } \\
\text { Muy leptocúrtico } \\
\text { Mesocúrtico }\end{array}$ \\
\hline 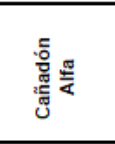 & $\begin{array}{l}\mathrm{A} 2 \\
\mathrm{~A} 3 \\
\mathrm{~B} 2 \\
\mathrm{C} 1 \\
\mathrm{C} 2\end{array}$ & $\begin{array}{l}-1,54 \\
-2,34 \\
-2,81 \\
2,49 \\
2,75 \\
\end{array}$ & $\begin{array}{l}2,87 \\
2,28 \\
1,88 \\
0,81 \\
0,59 \\
\end{array}$ & $\begin{array}{c}-0,23 \\
0,51 \\
0,38 \\
-0,22 \\
0,24 \\
\end{array}$ & $\begin{array}{l}0,51 \\
0,67 \\
0,83 \\
2,37 \\
0,94 \\
\end{array}$ & $\begin{array}{l}\text { Grava muy fina } \\
\text { Grava fina } \\
\text { Grava fina } \\
\text { Arena fina } \\
\text { Arena fina } \\
\end{array}$ & $\begin{array}{l}\text { Muy pobremente seleccionda } \\
\text { Muy pobremente seleccionda } \\
\text { Pobremente seleccionda } \\
\text { Mod. seleccionda } \\
\text { Mod. bien seleccionada }\end{array}$ & $\begin{array}{l}\text { Asimétrico gruesos } \\
\text { Muy asimétrica finos } \\
\text { Muy asimétrica finos } \\
\text { Asimétrico gruesos } \\
\text { Asimétrico finos } \\
\end{array}$ & $\begin{array}{l}\text { Muy platicúrtico } \\
\text { Muy platicúrtico } \\
\text { Platicúrtico } \\
\text { Muy leptocúrtico } \\
\text { Mesocúrtico } \\
\end{array}$ \\
\hline 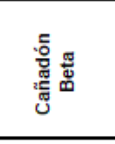 & $\begin{array}{l}\mathrm{A} 2 \\
\mathrm{~A} 3 \\
\mathrm{~B} \\
\mathrm{C} 1 \\
\mathrm{C} 2 \\
\end{array}$ & $\begin{array}{r}-2,90 \\
0,33 \\
-1,24 \\
2,53 \\
2,76 \\
\end{array}$ & $\begin{array}{l}2,86 \\
1,08 \\
2,51 \\
0,52 \\
0,59 \\
\end{array}$ & $\begin{array}{c}0,89 \\
-0,03 \\
-0,05 \\
0,05 \\
0,24 \\
\end{array}$ & $\begin{array}{l}0,46 \\
0,85 \\
0,77 \\
1,30 \\
0,93 \\
\end{array}$ & $\begin{array}{l}\text { Grava fina } \\
\text { Arena gruesa } \\
\text { Grava muy fina } \\
\text { Arena fina } \\
\text { Arena fina } \\
\end{array}$ & $\begin{array}{l}\text { Muy pobremente seleccionda } \\
\text { Pobremente seleccionda } \\
\text { Muy pobremente seleccionda } \\
\text { Mod. bien seleccionada } \\
\text { Mod. bien seleccionada }\end{array}$ & $\begin{array}{l}\text { Muy asimétrica finos } \\
\text { Simétrico } \\
\text { Simétrico } \\
\text { Simétrico } \\
\text { Asimétrico finos } \\
\end{array}$ & $\begin{array}{l}\text { Muy platicúrtico } \\
\text { Platicúrtico } \\
\text { Platicúrtico } \\
\text { Leptocúrtico } \\
\text { Mesocúrtico } \\
\end{array}$ \\
\hline Cullen S & $\begin{array}{l}\mathrm{A} 2 \\
\mathrm{~B}\end{array}$ & $\begin{array}{l}-0,64 \\
-0,76 \\
\end{array}$ & $\begin{array}{l}1,78 \\
2,21 \\
\end{array}$ & $\begin{array}{l}-0,07 \\
-0,14 \\
\end{array}$ & $\begin{array}{l}0,81 \\
0,72 \\
\end{array}$ & $\begin{array}{l}\text { Arena muy gruesa } \\
\text { Arena muy gruesa }\end{array}$ & $\begin{array}{l}\text { Pobremente seleccionda } \\
\text { Muy pobremente seleccionda }\end{array}$ & $\begin{array}{l}\text { Simétrico } \\
\text { Asimétrico gruesos }\end{array}$ & $\begin{array}{l}\text { Platicúrtico } \\
\text { Platicúrtico } \\
\end{array}$ \\
\hline 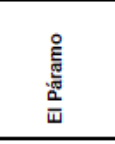 & $\begin{array}{l}\mathrm{A} 1 \\
\mathrm{~A} 2 \\
\mathrm{~A} 3 \\
\mathrm{~B} \\
\mathrm{C} 1\end{array}$ & $\begin{array}{l}0,35 \\
-1,18 \\
0,33 \\
0,23 \\
1,46 \\
\end{array}$ & $\begin{array}{l}1,19 \\
2,82 \\
1,27 \\
1,83 \\
1,57 \\
\end{array}$ & $\begin{array}{r}-0,02 \\
-0,53 \\
-0,15 \\
0,32 \\
-0,64 \\
\end{array}$ & $\begin{array}{l}0,79 \\
0,47 \\
0,82 \\
0,57 \\
0,84 \\
\end{array}$ & $\begin{array}{l}\text { Arena gruesa } \\
\text { Grava muy fina } \\
\text { Arena gruesa } \\
\text { Arena gruesa } \\
\text { Arena media } \\
\end{array}$ & $\begin{array}{l}\text { Pobremente seleccionda } \\
\text { Muy pobremente seleccionda } \\
\text { Pobremente seleccionda } \\
\text { Pobremente seleccionda } \\
\text { Pobremente seleccionda }\end{array}$ & $\begin{array}{l}\text { Simétrico } \\
\text { Muy asimétrica gruesos } \\
\text { Asimétrico gruesos } \\
\text { Muy asimétrica finos } \\
\text { Muy asimétrica gruesos } \\
\end{array}$ & $\begin{array}{l}\text { Platicúrtico } \\
\text { Muy platicúrtico } \\
\text { Platicúrtico } \\
\text { Muy platicúrtico } \\
\text { Platicúrtico } \\
\end{array}$ \\
\hline 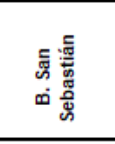 & $\begin{array}{l}\mathrm{A} 1 \\
\mathrm{~A} 2 \\
\mathrm{~A} 3 \\
\mathrm{~B} \\
\mathrm{C} 1\end{array}$ & $\begin{array}{l}0,21 \\
0,35 \\
2,18 \\
0,23 \\
3,92 \\
\end{array}$ & $\begin{array}{l}1,81 \\
1,99 \\
0,61 \\
1,83 \\
2,30 \\
\end{array}$ & $\begin{array}{c}-0,01 \\
-0,05 \\
-0,22 \\
0,32 \\
0,08 \\
\end{array}$ & $\begin{array}{l}0,88 \\
0,65 \\
0,84 \\
0,57 \\
0,82 \\
\end{array}$ & $\begin{array}{l}\text { Arena gruesa } \\
\text { Arena gruesa } \\
\text { Arena fina } \\
\text { Arena gruesa } \\
\text { Arena muy fina } \\
\end{array}$ & $\begin{array}{l}\text { Pobremente seleccionda } \\
\text { Pobremente seleccionda } \\
\text { Mod. bien seleccionada } \\
\text { Pobremente seleccionda } \\
\text { Muy pobremente seleccionda }\end{array}$ & $\begin{array}{l}\text { Simétrico } \\
\text { Simétrico } \\
\text { Asimétrico gruesos } \\
\text { Muy asimétrica finos } \\
\text { Simétrico } \\
\end{array}$ & $\begin{array}{l}\text { Platicúrtico } \\
\text { Muy platicúrtico } \\
\text { Platicúrtico } \\
\text { Muy platicúrtico } \\
\text { Platicúrtico } \\
\end{array}$ \\
\hline
\end{tabular}

Tabla 5.1. Parámetros estadísticos en grados Ф según Folk y Ward (1957) de las diferentes granulometrías de las muestras obtenidas en los distintos sectores investigados. Abreviaturas: Mod, Moderadamente, Extrem, Extremadamente. Grava muy fina=gravilla y grava fina=guijarros.

A partir de los cálculos del coeficiente de escala de rompiente $(\varepsilon)$ realizados por Bujalesky (1990; 1997), donde obtuvo un dominio disipativo en la zona intermareal baja $(\varepsilon$ promedio $=183)$ y reflectivo en la intermareal alta $(\varepsilon$ promedio $=3,49)$, junto a las características morfológicas, granulométricas (Fig.5.23 y Tabla 5.1) e hidrodinámicas que presentan las playas macromareales del sector NE de la Isla Grande de Tierra del Fuego, se pueden clasificar dentro del grupo de playas reflejantes como reflejantes o como playas con terrazas de bajamar y corrientes de resaca puntuales (Masselink y Short 1993, Flor 2004). Las primeras se localizan en el sector comprendido desde el sur del cañadón Tortuga (aproximadamente desde la zona de Tapera Sur) hasta cabo Nombre, donde la zona intermareal baja no está presente. El oleaje rompe en volteo sobre la zona intermareal alta o talud intermareal, presentando pendiente elevada y desarrollo en ocasiones de formas rítmicas en la parte superior (arcos de playa). El resto de sectores se clasifica como playas con terrazas de bajamar. Presentan una zona intermareal alta con fuerte pendiente y granulometría gruesa, seguido por una zona intermareal baja o terraza de bajamar con pendiente muy suave constituida por materiales finos. En pleamar los procesos son 
similares al de las playas reflejantes, con desarrollo en determinados momentos de arcos de playa. En bajamar, se torna disipativo con roturas del oleaje por derrame.

En algunas zonas se llegan a desarrollar acumulaciones eólicas formando dunas remontantes en los sectores con acantilados y dunas embrionarias. Sin embargo, la extensión y distribución de estas geoformas es muy reducida.

En el perfil costero se pueden diferenciar tres zonas: supramareal, intermareal alta talud intermareal) e intermareal baja (terraza de baja marea) faltando esta última en las playas únicamente reflectivas.

La zona supramareal (A2 y A3) es muy cambiante entre las diferentes playas debido a la presencia de acantilados, cordones o barras litorales y depósitos eólicos. Presenta una extensión entre $70 \mathrm{~m}$ y $10 \mathrm{~m}$ con una pendiente subhorizontal en las terrazas aumentando hacia las dunas y las bermas. Se pueden llegar a observar una o dos bermas dependiendo del momento en el cual se realice el perfil, correspondientes con la de marea (cuadratura o sicigia) y tormenta. Cuando se desarrolla una tormenta aumenta el nivel del mar y se produce el desmantelamiento de la berma de marea, generándose una única berma de tormenta. Toda esta zona está afectada por procesos de deflación eólica y se corresponde con el lugar donde las acumulaciones de minerales pesados son más abundantes.

Respecto a la granulometría (Fig.5.24) en la zona supramareal la media muestra valores entre $1 \Phi$ y $-3 \Phi$, dominando la fracción gravosa en las playas localizadas al norte y disminuyendo su tamaño hacia el sur donde domina la fracción arena (bahía San Sebastián y punta Sinaí). Todas ellas se caracterizan por ser polimodales (bimodales y algunas trimodales). El grado de selección (desviación estándar) varía desde mal seleccionadas hasta muy mal seleccionadas, aumentando a moderadamente seleccionadas en punta Sinaí. En relación a la asimetría, salvo en cabo Espíritu Santo y en el cañadón Beta que la asimetría es positiva (cola hacia sedimentos finos), en el resto muestra valores simétricos y negativos (cola hacia granulometrías gruesas). Finalmente, los valores correspondientes a curtosis geométrica varían desde mesocúrticas hasta muy platicúrticas (curvas achatadas con mayor selección en los extremos). 
$\mathrm{A} 2 \rightarrow \mathrm{B} \rightarrow \mathrm{C} 1 \rightarrow \mathrm{C} 2$
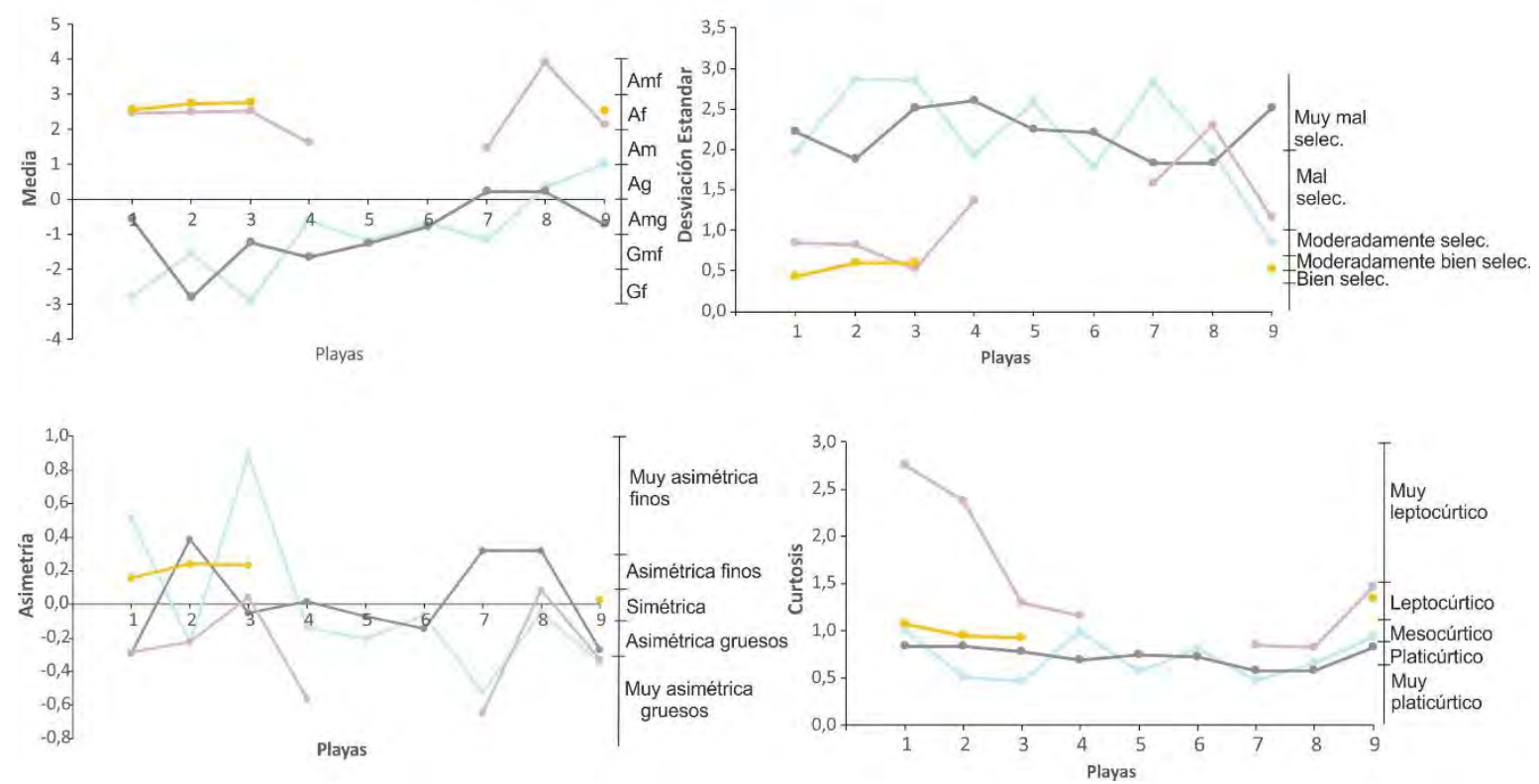

Fig.5.24. Parámetros estadisticos en grados $\Phi$ de los diferentes sectores muestreados. Mismas referencias que en Fig.5.23. Abreviaturas granulométricas: Amf arena muy fina, Af, arena fina, Am arena media, Ag arena gruesa, Amg arena muy gruesa, Gmf grava muy fina y Gf grava fina.

La zona intermareal alta (B) o talud intermareal muestra una pendiente entre $6^{\circ} \mathrm{y}$ $8^{\circ}$ y una extensión promedio de $34 \mathrm{~m}$, presentando los valores más altos las playas localizadas en la zona septentrional, coincidiendo con un tamaño de grano mayor. En la bahía San Sebastián el perfil de la playa es más llano, mostrando la zona intermareal una inclinación entre $3^{\circ}$ y $4^{\circ}$. La mayor extensión de esta zona se observa en las playas de Cullen $\mathrm{N}$ y $\mathrm{S}$ y EI Páramo.

En relación a la granulometría, esta zona presenta valores desde arena gruesa hasta grava muy fina (entre $-2,8 \Phi$ y $0,2 \Phi$ ), mostrando la misma polimodalidad que la zona supramareal, pero hacia valores más finos, mostrando un aumento del grosor en la base de la zona intermareal alta, coincidente con el límite entre la zona de surf y batida. Al igual que la zona supramareal, presenta un decrecimiento del tamaño de grano de norte a sur, variando la desviación estándar desde mal seleccionada hasta muy mal seleccionada. Los valores de asimetría muestran depósitos de playa cercanos a la simetría o con valores negativos a excepción de las playas de la bahía San Sebastián y El Páramo donde los valores son positivos. De acuerdo con los datos de la curtosis gráfica se observa la misma tendencia que en la zona supramareal, pero con valores en general ligeramente más altos, predominando las curvas mesocúrticas a muy platicúrticas.

La zona intermareal baja (C1 y C2) no presenta grandes diferencias entre las distintas playas. Muestra una pendiente muy suavizada, normalmente inferior al $1^{\circ}$, con 
una extensión máxima en la zona del cabo Espíritu Santo que alcanza los $800 \mathrm{~m}$. Se desarrollan canales de marea y óndulas tanto asimétricas como casi simétricas con minerales pesados en la cara con menor pendiente o en la cresta y en el fondo de los canales mareales. En la bahía San Sebastián el desarrollo de esta llanura alcanza una gran extensión llegándose a desarrollar llanuras fangosas, mixtas y arenosas. En el sector comprendido entre las playas de Cullen $\mathrm{N}$ y S, no llega a aflorar esta zona.

Respecto a la granulometría, las muestras correspondientes con la zona intermareal baja son principalmente unimodales con un predominio de la fracción arena fina, entre $2 \Phi$ y $3 Ф$ (a excepción de la muestra de la bahía San Sebastián donde la granulometría es limosa). La selección en la zona intermareal baja aumenta hacia el mar con valores desde moderados hasta bien seleccionados, por lo tanto, tienen un tamaño de grano más uniforme. La asimetría cambia también hacia el mar con valores desde negativos a simétricos en las muestras más cercanas a la zona intermareal alta y valores positivos en las más alejadas. La medida de curtosis es muy variable desde platicúrticas hasta muy leptocúrticas, con valores más altos que en el resto de las zonas (mejor selección en el centro de la curva que en los extremos).

Al graficar la desviación estándar frente al tamaño medio, se observa como a menor tamaño de grano la selección aumenta, pudiéndose diferenciar claramente la zona C (intermareal baja) con un tamaño de grano más pequeño y mejor seleccionada que la zona A (supramareal de tormenta) y B (intermareal alta) (Fig.5.25).

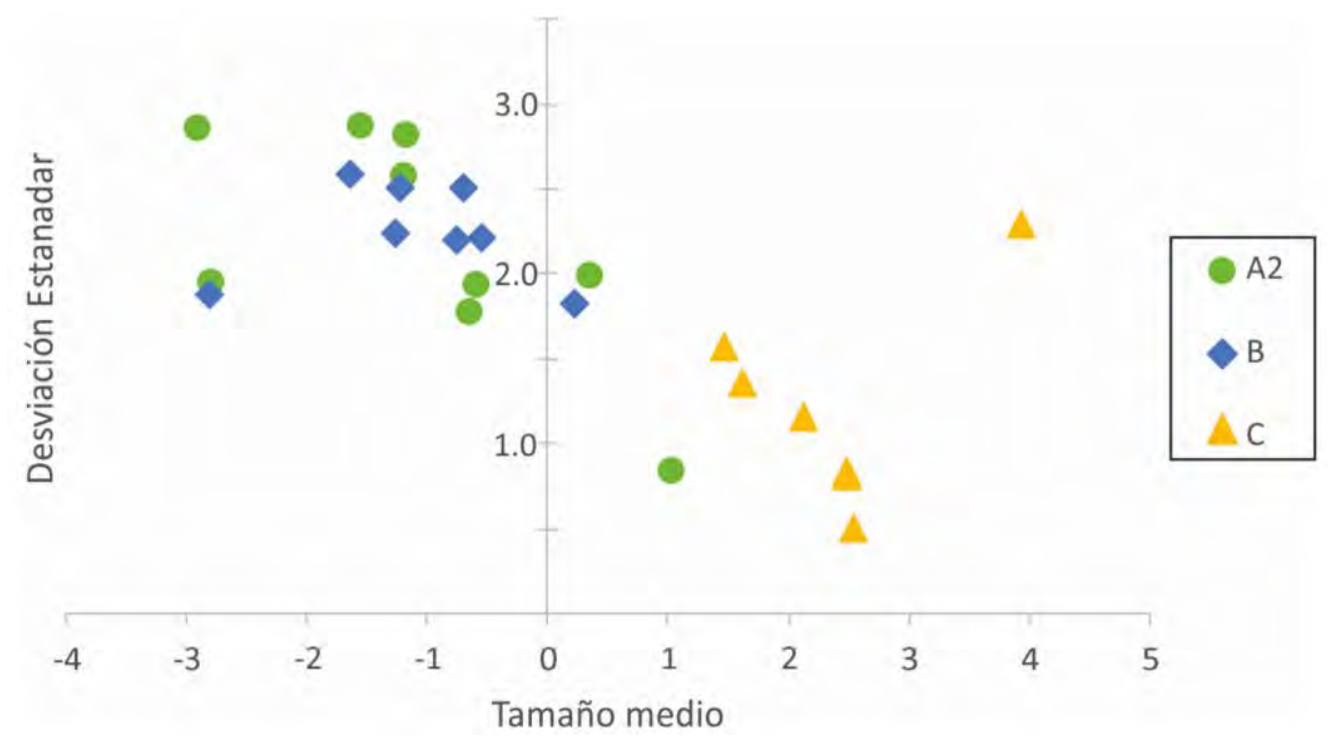

Fig.5.25. Grafico bivariante entre desviación estándar y media (unidades Ф). Mismas referencias que en Fig.5.23. 


\subsection{Composición litológica y mineralógica de los depósitos detríticos de playa.}

\subsubsection{Fracción psefítica}

Al igual que en el sedimento glacigénico, la fracción psefítica está constituida por una gran variabilidad composicional de rocas (Fig.5.26).

Las playas al norte del río Cullen presentaron un predominio de rodados de cuarzo de veta $(32 \%)$ seguido por rocas sedimentarias $(22 \%)$, volcánicas $(18 \%)$, metamórficas $(14 \%)$ y plutónicas (14\%). Las rocas sedimentarias correspondieron a fragmentos de la Fm. Cullen (pelitas), aflorante en los acantilados, y ftanitas. Como rocas volcánicas se identificaron basaltos alterados (espilitas), riolitas, andesitas y pórfidos riolíticos y andesíticos. Dentro de las rocas metamórficas se diferenciaron metacuarcitas, migmatitas y metapelitas. Las rocas plutónicas correspondieron a dioritas, tonalitas, monzonitas, granodioritas, aplitas, microgabros y rocas ultramáficas (hornblenditas y peridotitas).

Al sur del río Cullen se observó un predominio de rocas volcánicas (34\%) y metamórficas $(30 \%)$, seguido por cuarzo de veta (13\%), rocas sedimentarias $(13 \%)$ y plutónicas $(10 \%)$. Como rocas volcánicas se diferenciaron pórfidos cuarcíferos y feldespáticos, basaltos con fenocristales de piroxenos y anfíboles, basaltos alterados (espilitas) y vulcanitas indiferenciadas. Las rocas metamórficas correspondieron a metapelitas mientras que las sedimentarias a ftanitas, alguna de ellas piríticas. Dentro de las rocas plutónicas se identificaron dioritas, granodioritas y rocas ultramáficas con fenocristales de piroxeno, anfíbol y plagioclasa (hornblenditas y piroxenitas). 

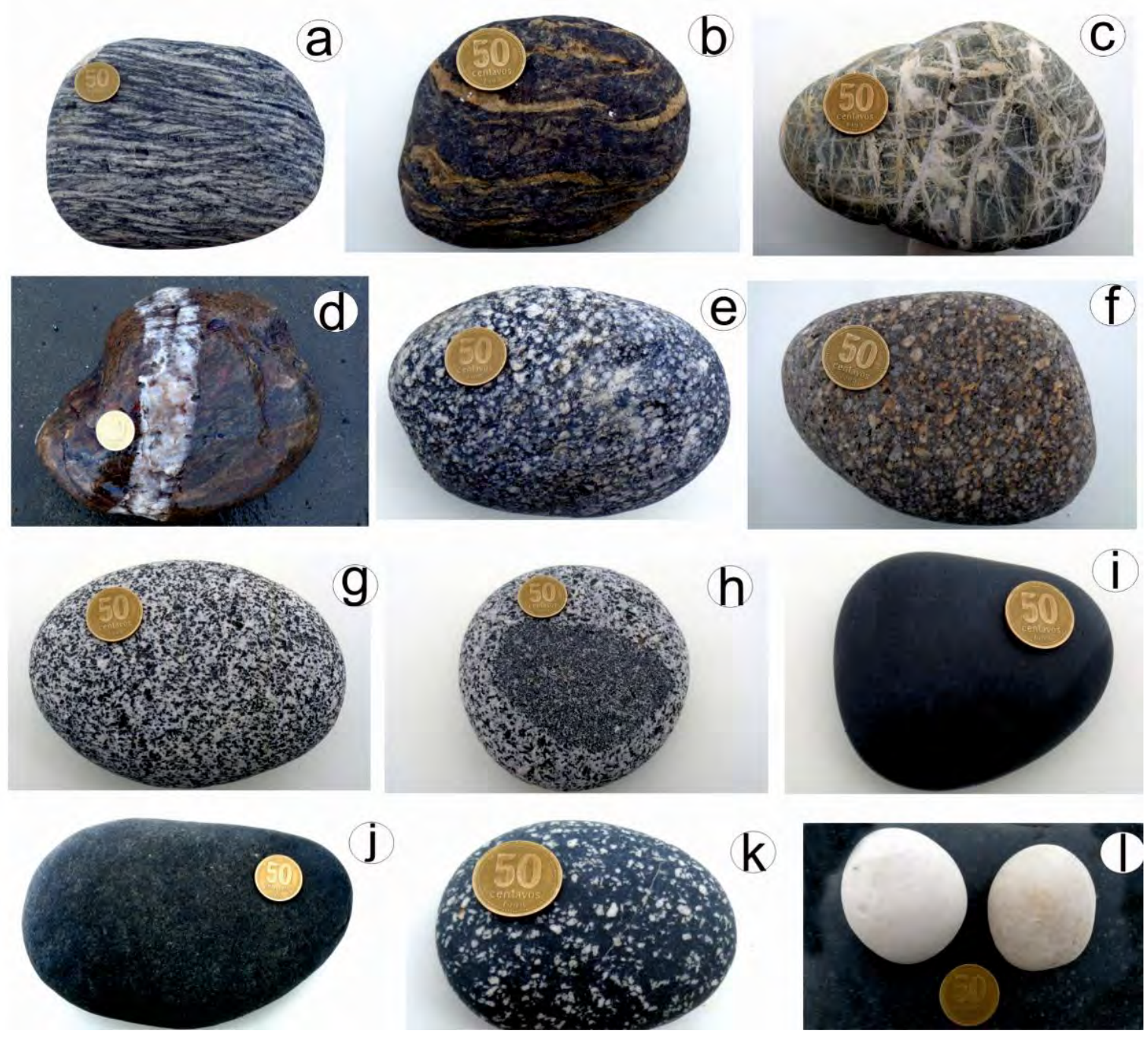

Fig.5.26. Principales composiciones litológicas identificadas de los individuos psefíticos presentes en las playas: $a$ y b, migmatitas; $c$, migmatita con múltiples venulaciones cuarzosas; $d$, migmatita con un denso enrejado de vetilla cuarzosa (stockwork?); $e$, diorita, $f$, granodiorita; $g$, tonalita; $h$, tonalita con enclave máfico microgranular diorítico; $i$, basalto; $j$, basandesita; $k$, andesita y l, rodados de cuarzo de veta. Diámetro de moneda: $24 \mathrm{~mm}$.

El estudio de láminas delgadas de algunas de estas rocas permitió profundizar en el reconocimiento de los distintos minerales presentes (Fig.5.27).

Las dioritas mostraron textura granuda hipidiomorofa e inequigranular. Como minerales principales se identificó plagioclasa (andesina) y anfíbol (anfíbol cálcico), además de biotita, titanita, zircón y minerales opacos como minerales accesorios.

En los pórfidos andesíticos se pudieron diferenciar fenocristales de andesina (algunas de ellas alteradas a sericita) y anfíbol, con una pasta muy alterada con epidoto, sericita y clorita. En las rocas porfídicas cuarzosas se identificaron fenocristales de cuarzo junto con algún cristal de feldespato, además de minerales máficos alterados a clorita.

En los basaltos se reconocieron minerales pseudomorfos totalmente alterados a epidoto, prehnita-pumpellyíta y clorita, con una pasta muy cloritizada. 


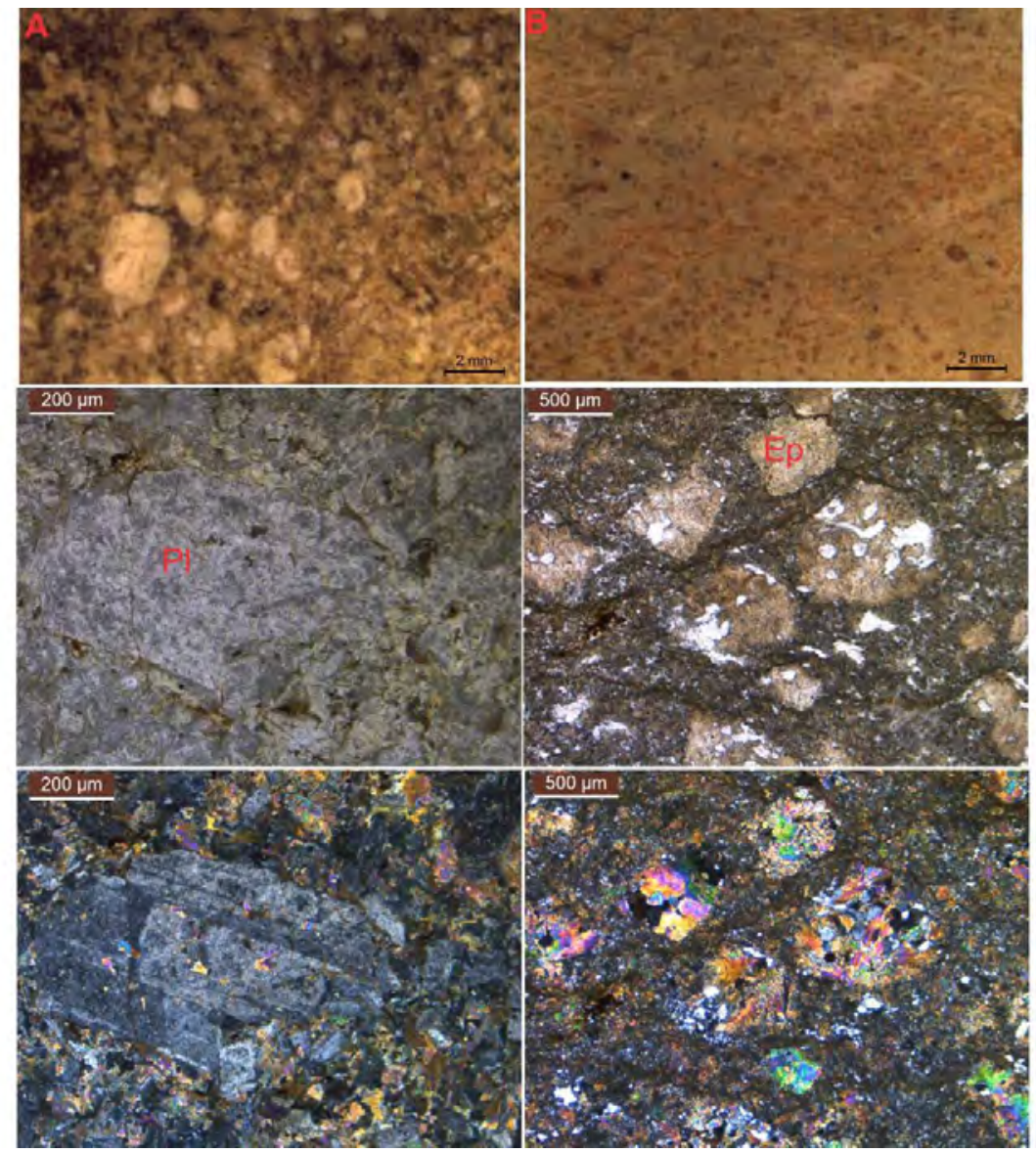

Fig.5.27. Fotos en corte fresco de las muestras y debajo fotografía de la lámina delgada mediante nicoles paralelos y nicoles cruzados. A: pórfido andesítico; B: roca máfica. Pl, plagioclasa; Ep, epidoto.

\subsubsection{Fracción psamítica}

En las fracciones arenosas el porcentaje de materiales pesados varió desde un $4,4 \%$ hasta un $33,3 \%$, observándose la proporción más alta en las playas de los cañadones Alfa, Tortuga y Beta, El Páramo y en punta Sinaí. Los valores más bajos se encontraron en las playas del cabo Espíritu Santo, Cullen Sur y bahía San Sebastián. Desde el cañadón Alfa, donde se localizaron las concentraciones más elevadas, se observó una disminución de la concentración hacia el sur (Fig.5.28). 


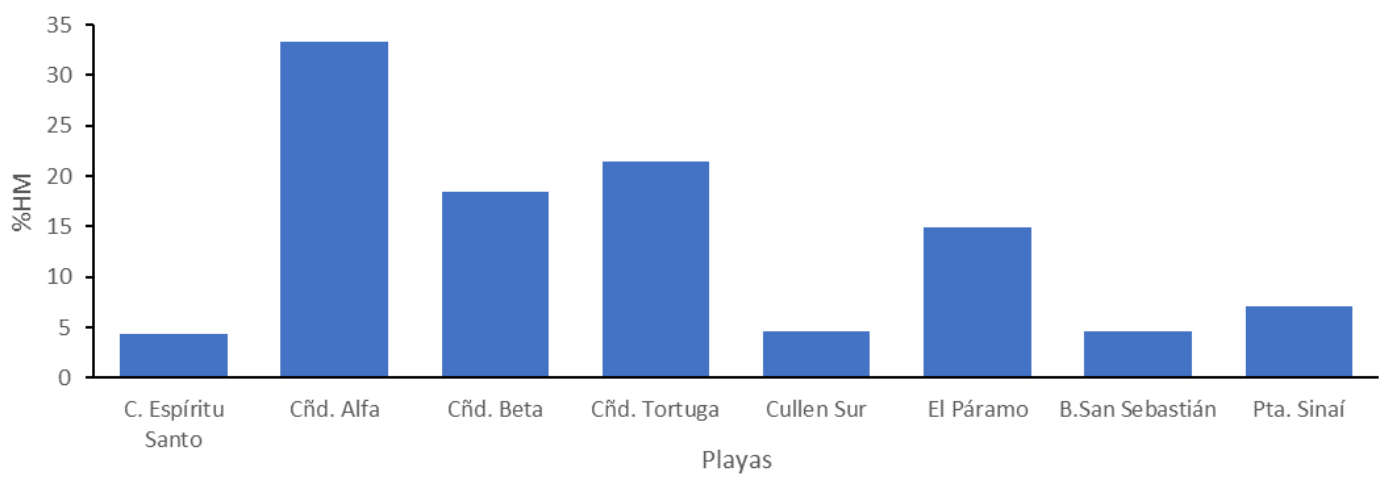

Fig.5.28. Histograma de distribución de minerales pesados presentes en la fracción arena media a fina en las diferentes playas.
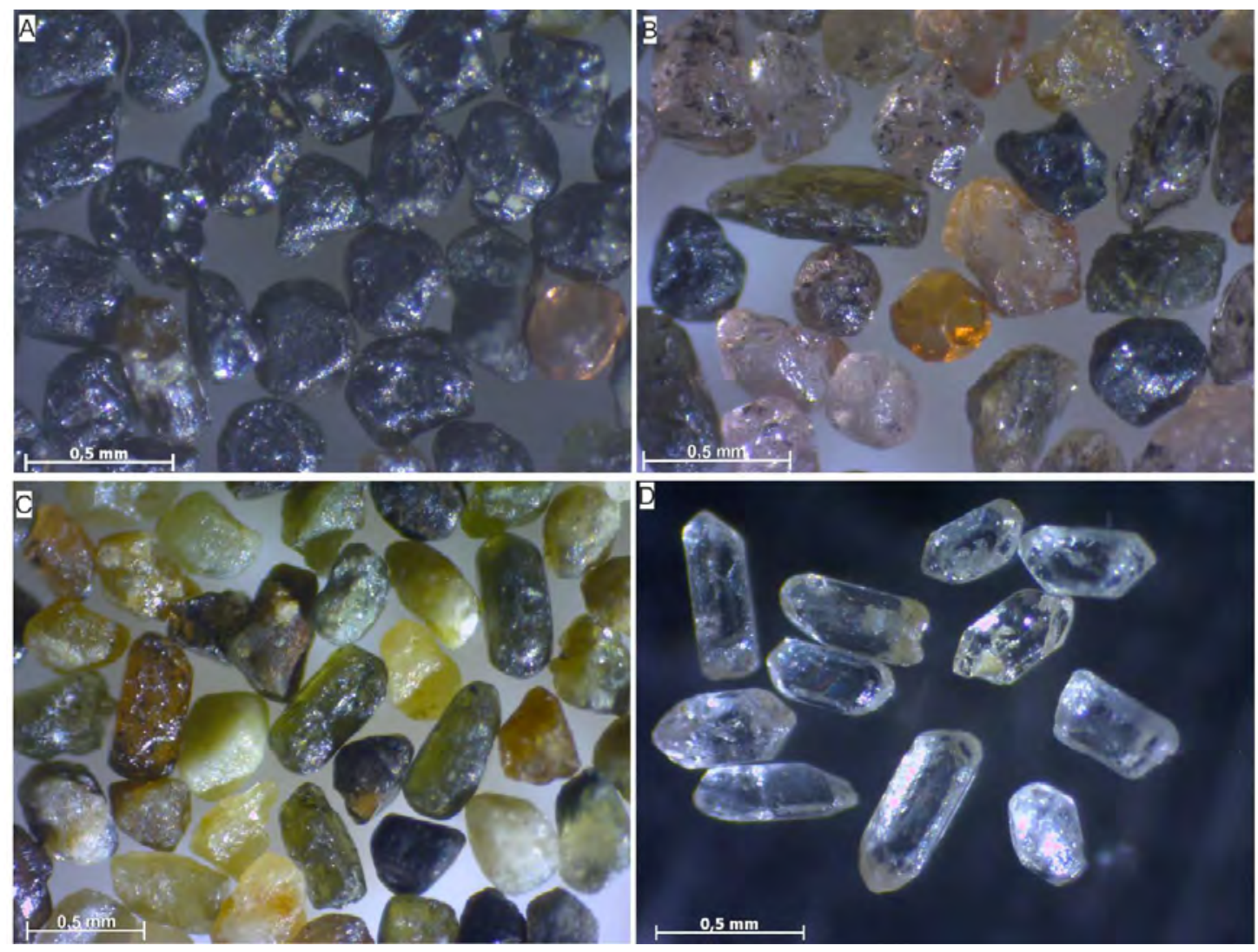

Fig.5.29. Detalle de diferentes minerales pesados vistos mediante lupa binocular (muestra nivel rico presente en la playa del cañadón Alfa). A) Ilmenitas s.l. y magnetitas s.I. B) granates con ilmenitas s.l., piroxenos y anfíboles C) piroxenos, anfíboles, minerales del grupo del epidoto y fragmentos líticos D) circones.

El contenido en ortopiroxenos y clinopiroxenos fluctuó entre un $4-20 \%$ y $7-50 \%$ respectivamente, obteniéndose los valores más bajos en las muestras de las playas de los cañadones Alfa, Beta y Tortuga. Los clinoanfíboles variaron entre un 2-21\%, coincidiendo los valores más bajos con las muestras de playa de los cañadones anteriormente citados. Sin embargo, estos tres puntos de muestreo presentaron los valores más altos para los 
minerales del grupo del epidoto (4-24\%), del granate (1-16\%) y minerales opacos (ilmenita s.I. y magnetita s.I.; 0-45\%). El porcentaje de fragmentos líticos fue elevado, entre un 9$32 \%$. Como minerales minoritarios se identificaron también estaurolita, circón, andalucita, goethita, pirita framboidal, hematita y calcopirita (Fig.5.29 y 5.30 y Tabla 5.2).

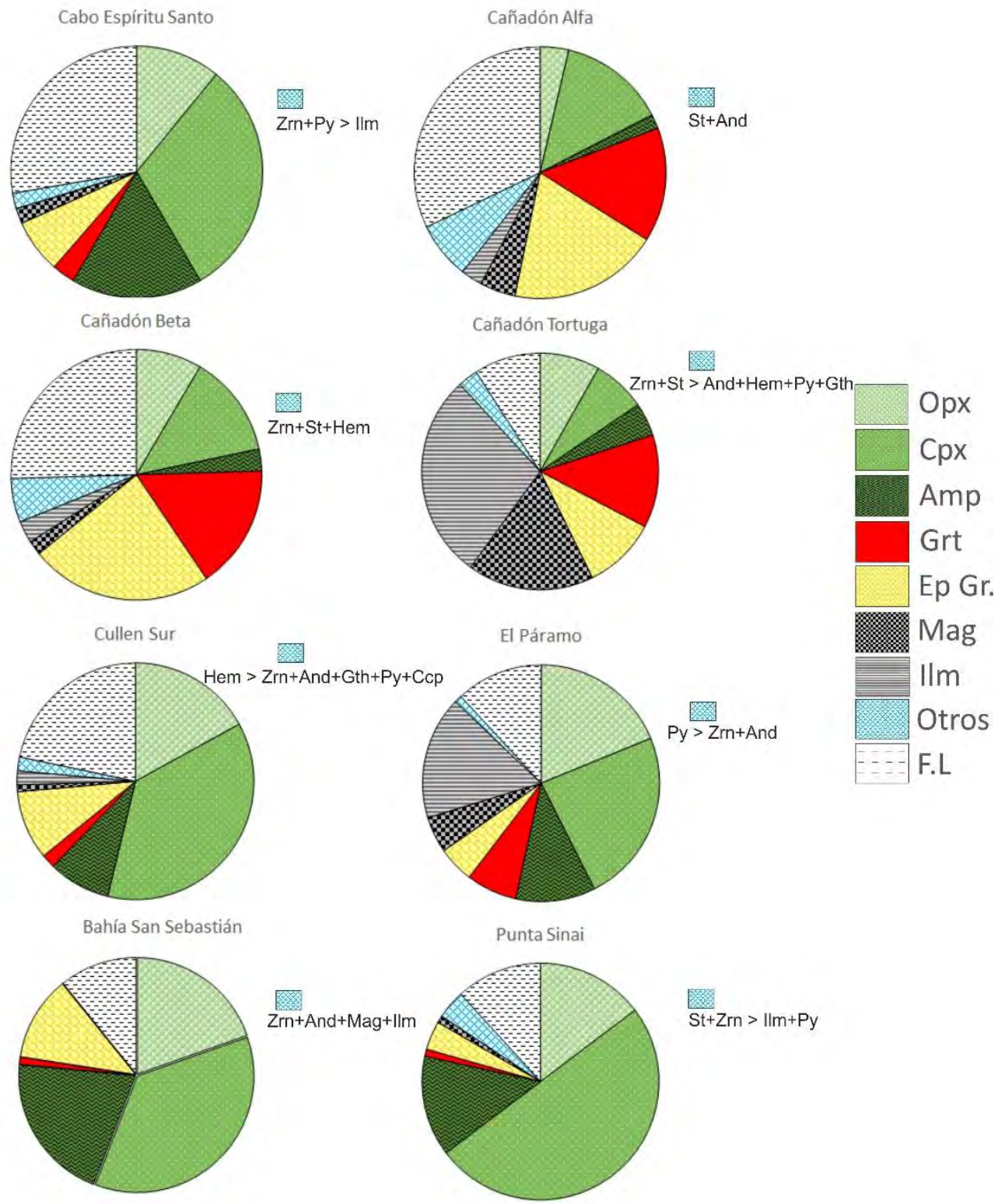

Fig.5.30. Análisis cuantitativo de los diferentes minerales y fragmentos líticos presentes en la fracción pesada en las distintas playas muestreadas. Abreviaturas: And andalucita, Ccp calcopirita, Zrn circón, Amp anfíbol cálcico, Cpx clinopiroxeno, St estaurolita, F.L fragmentos líticos, Ep. Gr grupo del epidoto, Gth goethita, Grt grupo del granate, Hem hematita, IIm IImenita s.l., Mag magnetita s.l., Opx ortopiroxeno y Py pirita. 


\begin{tabular}{|c|c|c|c|c|c|c|c|c|}
\hline & \multicolumn{8}{|c|}{ Puntos de muestreo } \\
\hline & C. Espíritu Santo & Cñd. Alfa & Cñd. Beta & Cñd. Tortuga & Cullen Sur & El Páramo & $\begin{array}{c}\text { Ba. San } \\
\text { Sebastián }\end{array}$ & Punta Sinaí \\
\hline Ortopiroxeno & 11 & 4 & 8 & 8 & 17 & 19 & 20 & 15 \\
\hline Clinopiroxeno & 31 & 14 & 13 & 7 & 37 & 24 & 36 & 50 \\
\hline Anfíbol cálcico & 17 & 2 & 3 & 5 & 8 & 11 & 21 & 14 \\
\hline Gr. Granate & 3 & 15 & 16 & 13 & 2 & 7 & 1 & 1 \\
\hline Gr. Epidoto & 7 & 19 & 24 & 10 & 9 & 5 & 12 & 4 \\
\hline Circón & 1 & * & 3 & 2 & * & * & * & 1 \\
\hline Estaurolita & & 6 & 2 & 1 & & & & 3 \\
\hline Andalucita & & 1 & & * & * & * & * & \\
\hline Magnetita s.I & 2 & 5 & 2 & 17 & 1 & 5 & * & 1 \\
\hline IImenita s.I & $*$ & 3 & 3 & 28 & 2 & 17 & * & * \\
\hline Hematita & & & 1 & * & 2 & & & \\
\hline Pirita & 1 & & * & * & $*$ & 1 & & \\
\hline Calcopirita & & & & & * & & & \\
\hline Goethita & & & & * & * & & & \\
\hline Fragmentos líticos & 28 & 32 & 25 & 9 & 22 & 12 & 11 & 12 \\
\hline
\end{tabular}

Tabla 5.2. Porcentajes de minerales pesados presentes en la zona supramareal de las playas. * trazas

La fracción liviana estuvo constituida principalmente por fragmentos líticos (60\%) y cuarzo (40\%); aparecieron muy subordinadamente plagioclasa, feldespato potásico y carbonatos (conchillas) (Fig.5.31).

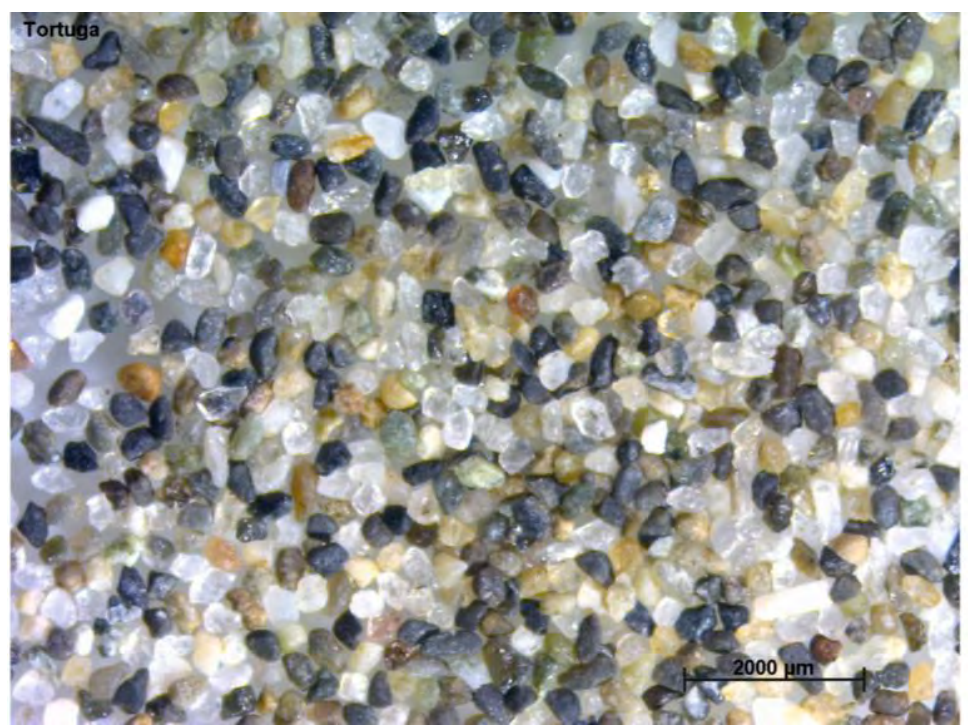

Fig.5.31. Muestra de playa de la zona supramareal del cañadón Tortuga sin separación de fases livianas y pesadas. Se observa un predominio da la fracción liviana con fragmentos líticos oscuros y granos de cuarzo transparentes.

\subsubsection{Descripción mineralógica de las arenas}

\subsection{Minerales y fragmentos líticos de la fracción pesada}

Los minerales pesados identificados en las fracciones arenosas de los depósitos detríticos de playa se dividen en dos grandes grupos: transparentes y opacos. Los minerales transparentes mostraron claramente tres poblaciones, una fase muy abundante integrada por especies ferromagnesianas-cálcicas que comprendió minerales del 
supergrupo del anfíbol y de los grupos del piroxeno y del epidoto. Una población minoritaria integrada por minerales del grupo del granate y estaurolita y finalmente un conjunto de minerales accesorios como la andalucita y el circón.

Por su parte, en los minerales opacos también se pudieron diferenciar dos poblaciones con proporciones muy distintas. Como minerales mayoritarios se destacaron la ilmenita s.l. y magnetita s.l. A su vez, entre los minerales opacos accesorios se reconocieron: pirita, hematita, goethita y algún grano de calcopirita.

En los niveles ricos en minerales pesados, se identificaron además algunas fases minerales como titanita, rutilo, espinela s.s., minerales del grupo de la apatita y el mineral de mayor interés económico de los depósitos detríticos, el oro (Fig.5.32).

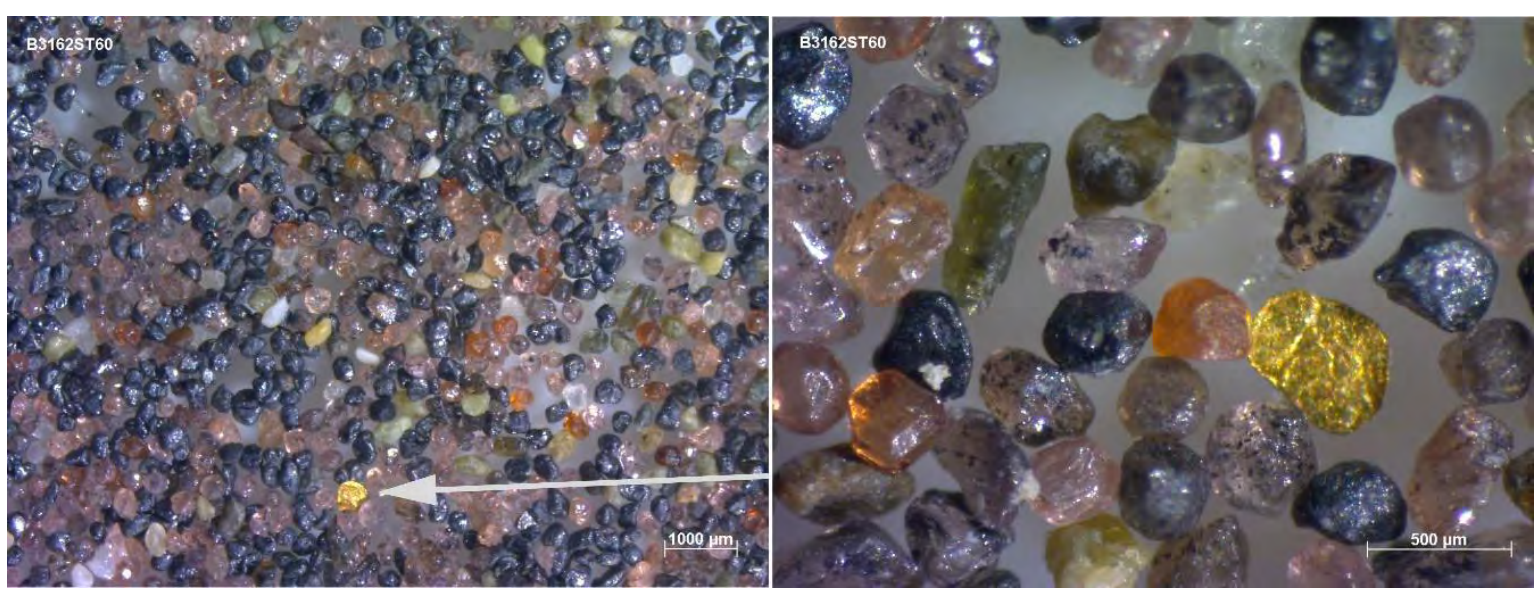

Fig.5.32. Fotografía con lupa binocular de concentrado de minerales pesados procedente de la playa del cañadón Beta. Hacia la parte inferior (flecha) nótese grano de color amarillo de oro en hábito laminar. En la amplificación de la fotografía de la derecha se diferencia además granates de color rosado-anaranjado, ilmenitas s.l. y magnetitas s.l. como minerales opacos y algún piroxeno de color verde.

\section{a) Minerales transparentes}

Los minerales del grupo del granate fueron especialmente abundantes en los niveles ricos localizados en las playas de los cañadones Alfa y Beta. Presentan una gran gama de colores desde incoloros o rosados claros hasta anaranjados y rojos, generalmente como granos equidimensionales idiomorfos/subidiomorfos redondeados con secciones hexagonales y octogonales y también como cristales alotriomorfos (Fig.5.33). Están muy fracturados y presentan inclusiones tanto de minerales opacos como transparentes, en algunos casos con distribución concéntrica, que se comentará más adelante. La zonación normalmente no es visible con el microscopio petrográfico.

Los inosilicatos son minerales muy abundantes en todo el litoral de la zona de trabajo. Los clinopiroxenos se identificaron como granos desde incoloros a tonalidades claras de castaño y verde con un pleocroísmo leve. El hábito es generalmente prismático 
corto, con desarrollo cristalino idiomorfo a subidiomorfo, con una dirección de clivaje muy marcada en la sección (110). Algunos cristales presentan inclusiones sólidas principalmente de minerales opacos, aunque también se reconocen inclusiones fluidas con polifases (líquido, gas y sólido). Por su parte, los ortopiroxenos muestran preferencialmente desarrollos idiomorfo-subidiomorfos con hábito prismático y pleocroísmo moderado de incoloro a castaño. En estos cristales el clivaje es siempre visible, paralelo al eje c según el plano (001) y con frecuencia presentan inclusiones sólidas de minerales opacos y transparentes. Se reconoció la fase enstatita rica en Fe.

Dentro de los clinoanfíboles, se identificaron distintas especies del anfíbol cálcico en función del pleocroísmo y ángulo de extinción: verde oscuro a claro y castaño (ángulo de extinción entre $12^{\circ}$ y $16^{\circ}$ ) y castaño anaranjado a rojo oscuro (ángulo de extinción menor a $6^{\circ}$ ). Su relieve es moderado a alto. Presentan formas subidiomorfas con cristales normalmente con hábito prismático y clivaje visible. Las secciones basales con dos juegos de exfoliación son escasas y presentan extinción simétrica. Algunos cristales muestran inclusiones sólidas de minerales opacos.

Dentro de los minerales correspondientes con el grupo del epidoto se identificaron las fases epidoto s.s. y clinozoisita. El epidoto s.s muestra secciones desde alotriomorfas a subidiomorfas prismáticas o rómbicas. El color varía de incoloro hasta amarillo o amarillo verdoso, presentando en alguno caso un pleocroísmo moderado e inclusiones sólidas de minerales opacos. Sus colores de interferencia son fuertes, de segundo y tercer orden. La clinozoisita es más escasa identificándose normalmente en un mismo grano junto con epidoto s.s (zonación núcleo-borde) o en granos individuales. Su birrefringencia es más débil, con colores de interferencia gris azulados anómalos, no presenta pleocroísmo y su signo óptico es positivo.

La estaurolita es mucho menos abundante. Se encuentra en cristales subidiomorfos de hábito prismático corto y muy esporádicamente en secciones basales de seis lados. Presenta fuerte pleocroísmo dese incoloro hasta amarillo, relieve alto y birrefringencia débil. Su extinción es paralela con signo de elongación positivo. El clivaje no es apreciable o es malo y presenta muchas inclusiones tanto de minerales transparentes como opacos.

La andalucita es escasa y se distingue por presentar formas idiomorfas con secciones basales cuadradas y también prismáticas, y su clivaje no visible.

El circón presenta desarrollos cristalinos idiomorfos por la combinación de prismas con terminaciones bipiramidales. Normalmente están muy redondeados y fracturados como consecuencia del intenso transporte que han sufrido. Son incoloros con tonalidades 
pálidas, relieve alto y birrefringencia muy alta. La extinción es paralela y su elongación positiva. Se observan inclusiones sólidas transparentes asignables a silicatos.

La titanita se presenta en cristales de desarrollo idiomorfo a subidiomorfo en secciones rómbicas agudas o en granos irregulares. Por lo general los individuos son incoloros o débilmente coloreados con pleocroísmo (amarillo-marrón). Su relieve es muy alto, la birrefringencia extrema y signo óptico biáxico negativo.

La apatita es incolora con hábito prismático, relieve moderado, extinción recta y la birrefringencia baja con color de interferencia blanco y gris de primer orden con elongación negativa.

En las muestras el rutilo como grano suelto fue muy escaso. Se reconoce por su coloración pardo rojiza en ocasiones muy oscura. De manera más abundante se encontró como inclusiones o exsoluciones dentro de magnetitas e ilmenitas.

Espinela s.s. se reconoce como granos con coloración verdosa, relieve alto, formas redondeadas y subidiomorfas octaédricas o cúbicas. Es totalmente isótropo. Aparece también como inclusiones en magnetitas.

\section{b) Minerales opacos}

Dentro de los minerales opacos se pudieron diferenciar principalmente ilmenitas s.l. y magnetita s.l. De manera accesoria también se reconoció pirita, hidróxidos de hierro (goethita) y oro. A continuación, se describen sus propiedades ópticas vistas con el microscopio calcográfico.

La ilmenita s.l. presenta color gris-blanco y fuerte anisotropía, sin embargo en aquellos individuos con menor contenido en Ti es más baja (ver Capítulo 7). Muestra desarrollos cristalinos idiomorfos a subidiomorfos tabulares, homogéneos o con exsoluciones de óxidos de Fe y Ti (ver Capítulo 7), de dos generaciones paralelas a la sección (0001). La primera generación de exsoluciones presenta un espesor individual variable de 10 a $22 \mu \mathrm{m}$ y la segunda entre 1-2 $\mu \mathrm{m}$, observándose también en algún grano bandas de exsolución con un espesor similar. Perpendiculares a estas lamelas se pudo identificar también rutilo. Algunas ilmenitas s.l. presentan bordes de alteración a materiales ricos en titanio (leucoxeno?) y son comunes las inclusiones sólidas tanto de minerales opacos (óxidos y/o sulfuros) como trasparentes (silicatos).

La magnetita s.l. se identifica al microscopio por presentar una coloración gris ratón y ser isótropo. En general muestra formas alotriomorfas y subidiomorfas, redondeadas, homogéneas o con inclusiones sólidas de minerales opacos (ilmenita) y trasparentes. Algunos cristales idiomorfos presentan formas cristalinas octaédricas $\{111\}$ o cúbicas redondeadas $\{100\}$ en menor medida. Se identificó textura en enrejado ("trellis texture") y 
hematita producto de la martitización parcial o total. La hematita se reconoce por la marcada anisotropía y las reflexiones internas rojas.

La pirita se encuentra como granos subidiomorfos redondeados, a veces con textura framboidal, con bordes de alteración a goethita. Muestra un calor blanco amarillento e isotropía.

La goethita corresponde con un mineral secundario producto de la oxidación de la pirita. Se reconoce por las abundantes reflexiones internas marrón rojizas que presenta.

La calcopirita únicamente se detectó en una muestra en la zona de playa de Cullen Sur. Se identifica por su color amarillo y moderada anisotropía.

Finalmente, el oro se reconoce por su inconfundible color desde amarillo muy brillante a individuos ligeramente más claros (electrum), baja dureza e isotropía. Se encuentra como granos aislados con formas subredondeadas a redondeadas. Se presentan tanto homogéneos como zonados en los bordes y las inclusiones son muy escasas. La morfología de los granos se describe con mayor detalle más adelante.
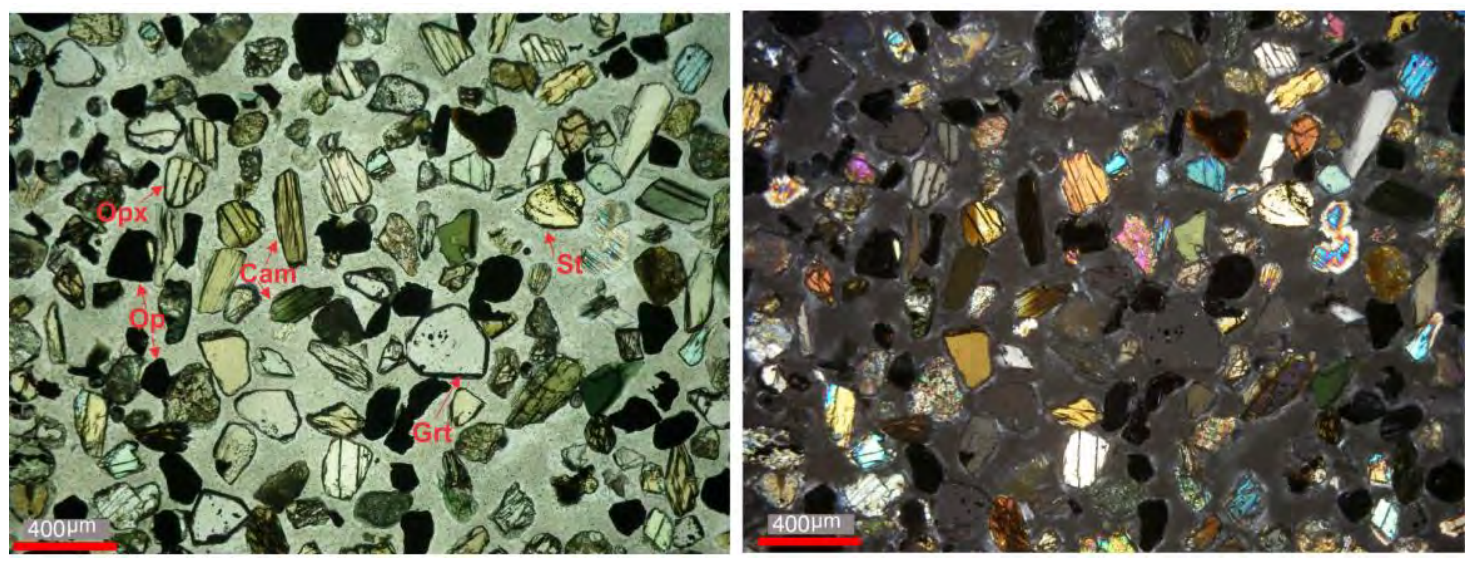

Fig.5.33. Fotomicrografías de minerales pesados. Izquierda con nicoles paralelos y derecha con nicoles cruzados. Muestra proveniente de las playas de El Páramo. Abreviaturas: Cam, clinoanfíboles; St, estaurolita; Grt, granate; Op, minerales opacos; Opx, ortopiroxeno.

\section{c) Fragmentos líticos}

Respecto a los fragmentos líticos que aparecen con la fracción pesada de minerales pesados (Fig.5.34), estos están constituidos principalmente por granos con textura holocristalina constituida por epidoto+anfíbol+plagioclasa (en la hornblendita), piroxeno+plagioclasa y agregados de cuarzo con silicatos (epidoto). Las rocas metamórficas también están presentes con fragmentos de esquistos con sillimanita-cuarzo $>$ filosilicatos orientados con textura lepidoblástica y granolepidoblástica. Las rocas volcánicas son escasas, reconociéndose únicamente fragmentos de pórfidos andesíticos. 


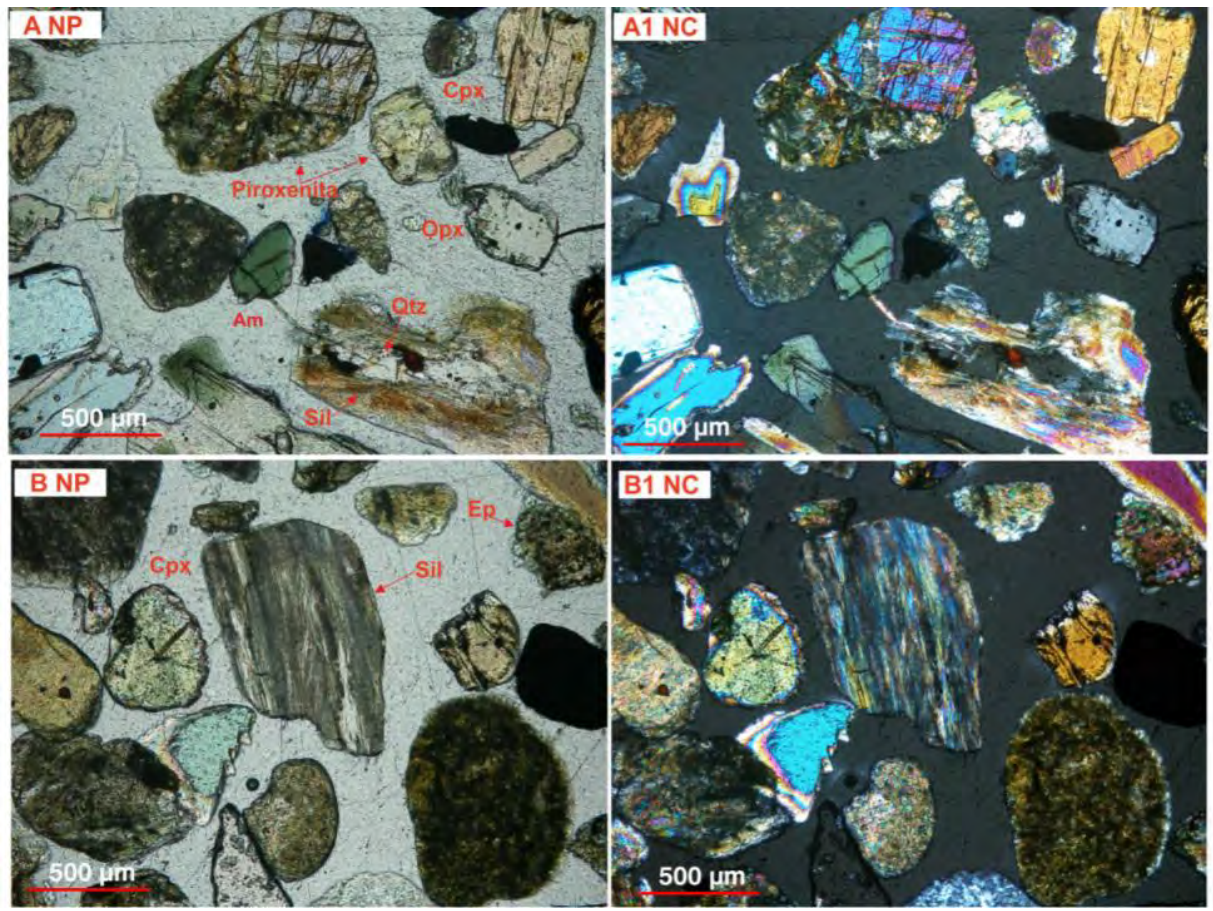

Fig.5.34. Fotomicrografías de fragmentos líticos en la fracción pesada. A y A1 muestra de la playa de punta Sinaí, B y B1 muestra de la playa del cañadón Alfa. Abreviaturas: Am, anfibol; Cpx, clinopiroxeno; Ep, epidoto; Qtz, cuarzo; Sil, sillimanita.

\subsection{Minerales y fragmentos líticos de la fracción liviana}

Los individuos de menor densidad o livianos correspondieron a la fracción mayoritaria de las muestras, con porcentajes de concentraciones comprendidos entre $67 \%$ y $96 \%$. Se diferencian en dos grandes grupos: a) fragmentos líticos y b) minerales transparentes (Fig.5.35).

\section{a) Fragmentos líticos.}

Los fragmentos líticos están compuestos principalmente por andesitas con textura hipocristalina tanto porfídica como microporfídica con cristales de feldespato (plagioclasa en cristales idiomorfos prismáticos y subidiomorfos), cuarzo y en ocasiones minerales opacos, piroxenos y/o anfíboles, distribuidos en una pasta vítrea. Atravesando algunos granos se observan venas de cuarzo. Las rocas metamórficas están representadas por fragmentos de esquistos micáceos con textura granolepidoblástica y cuarcitas con textura granoblástica equigranular e inequigranular. También se identificaron en menor medida granos con textura holocristalina e inequigranular constituida por cristales de piroxeno+plagioclasa+cuarzo>titanita.

\section{b) Minerales transparentes.}

Los cristales de cuarzo son los más frecuentes. La gran mayoría son incoloros observándose también blanquecinos lechosos hasta de coloraciones rosadas. Presentan 
formas redondeadas algunas de ellas subidiomorfas con hábito prismático y equigranular de desarrollo alotriomorfo, con aristas muy redondeadas y con biterminaciones romboédricas, normalmente con extinción ondulante por deformación.

Los cristales de plagioclasa presentan secciones prismáticas principalmente subidiomorfas con maclas polisintéticas (010) y en combinación con Carlsbad. La composición varía desde oligoclasa a labradorita (determinación efectuada mediante método de Michel Levy).

Con menor concentración se identificó feldespato potásico, presentando cristales subidiomorfos redondeados con macla de Carlsbad correspondientes con la fase ortosa y subordinadamente individuos con macla en enrejado difuso asignables a microclino.

Los carbonatos presentes se corresponden con restos de conchillas de calcita.

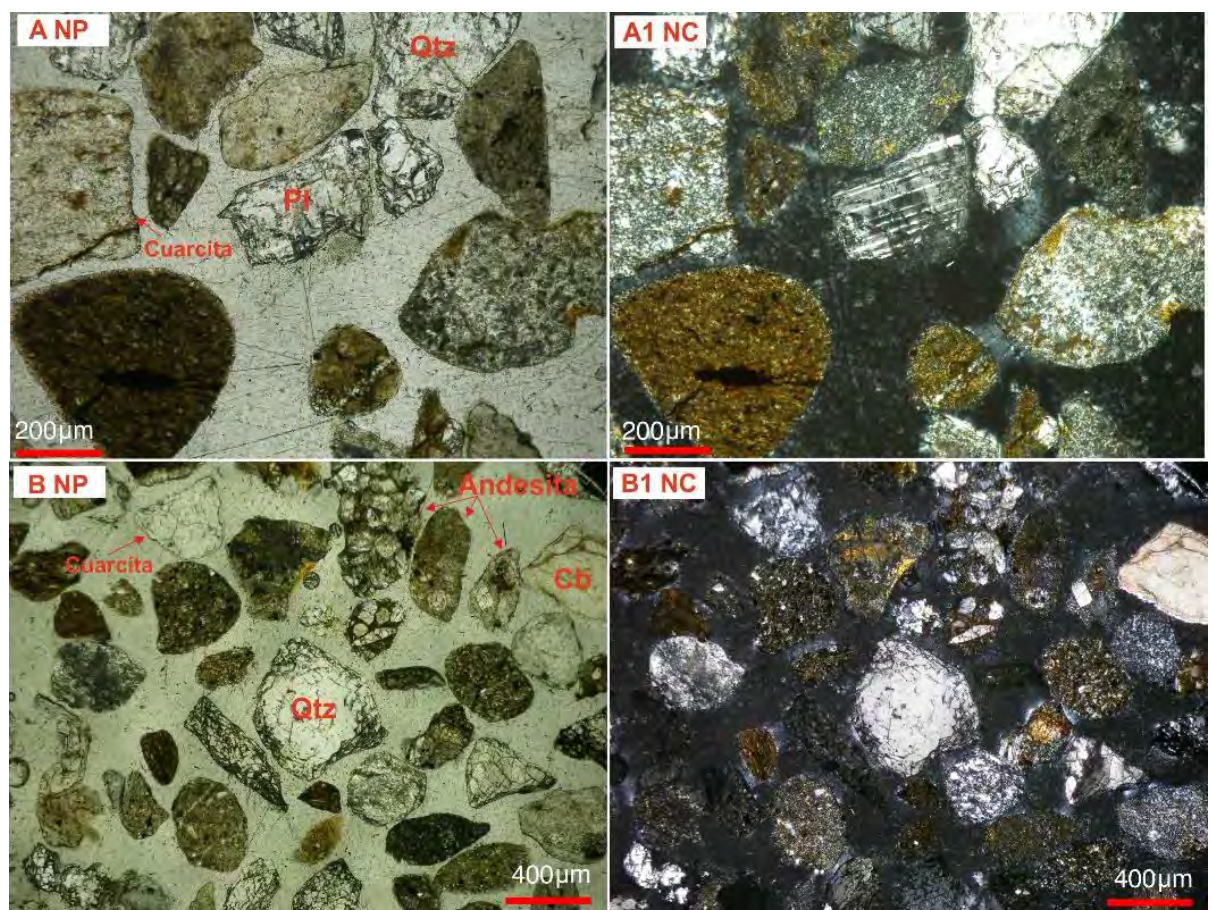

Fig.5.35. Fotomicrografías de fracción liviana de las arenas (muestra zona supramareal de la playa del cañadón Alfa). NP nicoles paralelos y NC nicoles cruzados. Se reconocen principalmente fragmentos líticos junto con cuarzo (Qtz), plagioclasa (PI) y carbonato $(\mathrm{Cb})$.

\subsection{Acumulaciones de minerales pesados}

En toda la zona de trabajo, se reconocieron finas capas discontinuas de arenas enriquecidas en minerales pesados en la zona superior de la playa (swash). Sin embargo, hay sectores donde estos niveles son más potentes y se repiten en profundidad. A partir de calicatas realizadas con pala mecánica o manual en la zona supramareal se pudo reconocer la existencia de la repetición de capas centimétricas de minerales pesados que se sitúan en los primeros 2 metros de profundidad. Así, se distinguieron los cañadones Alfa 
y Beta, El Páramo y punta Sinaí como las zonas más enriquecidas en minerales pesados, siendo especialmente potentes los niveles en las dos primeras (Fig.5.36A-D). En las playas del cañadón Tortuga se identificaron también importantes acumulaciones de minerales pesados en superficie, pero no se observaron niveles netos en profundidad.

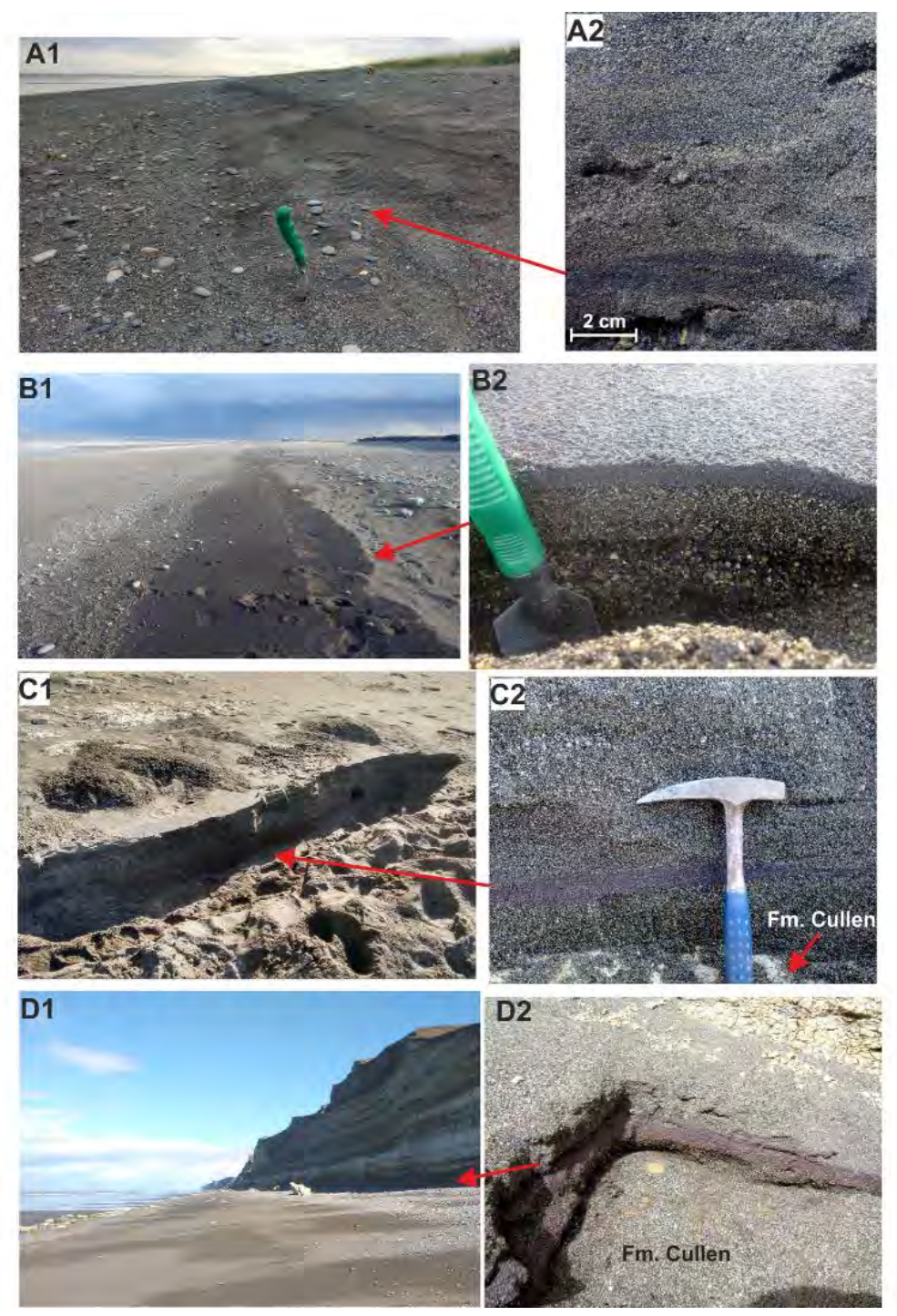

Fig.5.36. Zonas enriquecidas en minerales pesados en el sector supramareal de las playas: A, playa de punta Sinaí; B, playa del El Páramo; C, playa del cañadón Beta; D, playa del cañadón Alfa. En las fotografías C2 y D2 se alcanza a ver el bed rock correspondiente a la Fm. Cullen.

En los cañadones Alfa y Beta, estos niveles lenticulares alcanzan los $7 \mathrm{~cm}$ de espesor, repitiéndose en las capas más profundas (Fig.5.37A-B). Presentan una coloración rojiza como consecuencia del alto contenido en granates y una granulometría predominantemente de arena media (Tabla 5.3). Normalmente las zonas más enriquecidas se localizan cercanas al bed rock. La mineralogía está dominada por minerales del grupo del granate junto con ilmenita s.I. y magnetita s.I. (Fig.5.38 y Fig.5.39). 

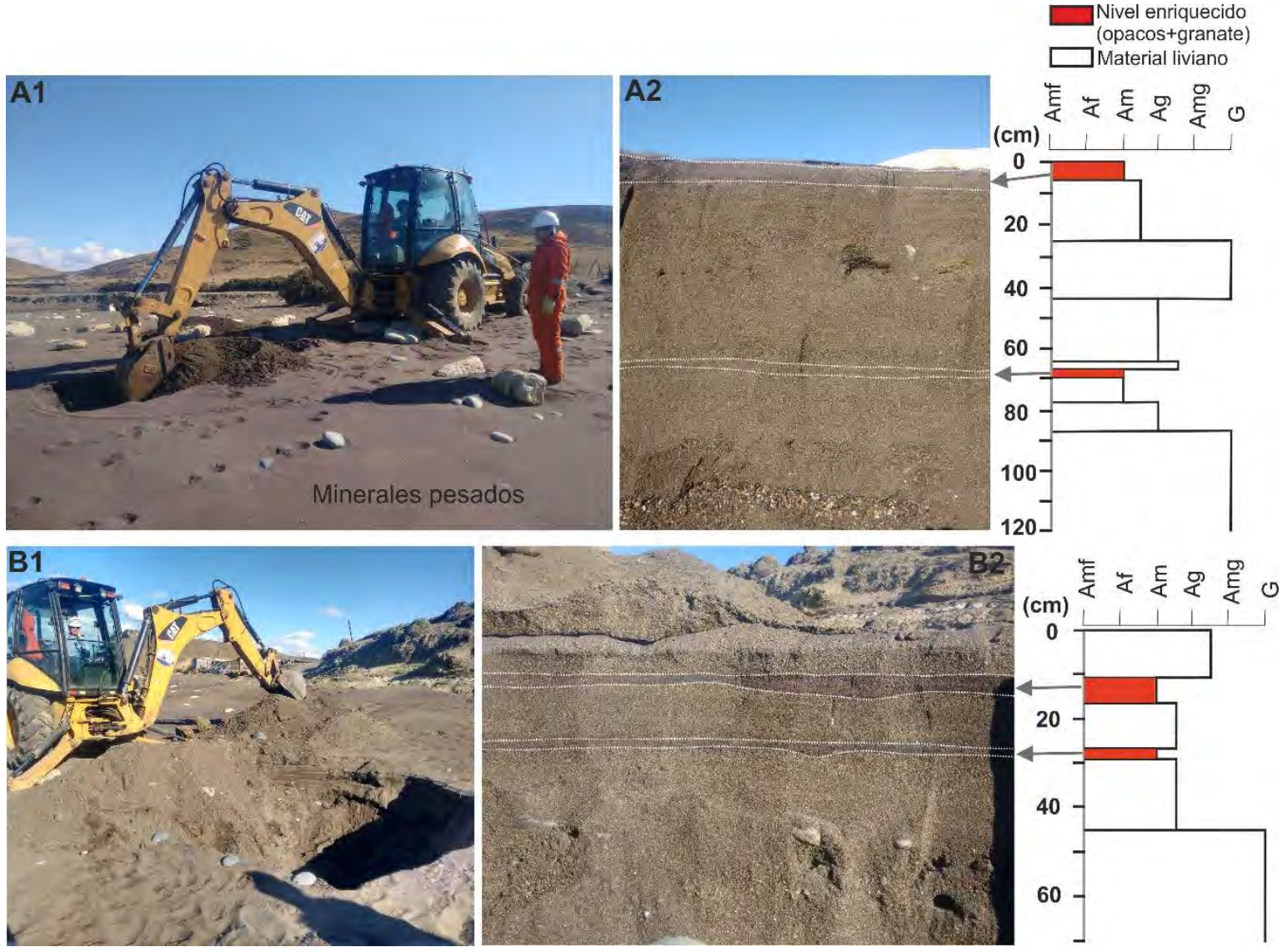

Fig. 5.37. Calicatas realizadas mediante máquina retroexcavadora en la zona supramareal de la playa del cañadón Beta, al norte de la desembocadura del arroyo (A1 y A1) y adyacente al acantilado septentrional (B1 y B2). A la derecha perfiles levantados (con la profundidad indicada en centímetros) donde se muestra la granulometría obtenida por estimación visual en el campo y la presencia de niveles enriquecidos en minerales pesados, delimitados con un punteado blanco. Las coloraciones rosado-rojizas denotan abundancia de minerales del grupo del granate y los tonos más oscuros un predominio de minerales opacos. Exceptuando estos niveles, la composición dominante se corresponden con minerales y fragmentos líticos livianos. Abreviaturas: Amf, arena muy fina; Af, arena fina; Am, arena media; Ag, arena gruesa; Amg, arena muy gruesa, $G$, gravas

\begin{tabular}{cccccc}
$\begin{array}{c}\text { Puntos de } \\
\text { muestreo }\end{array}$ & $\begin{array}{c}\text { Arena muy gruesa } \\
\mathbf{2 - 1} \mathbf{m m}\end{array}$ & $\begin{array}{c}\text { Arena gruesa } \\
\mathbf{1 - 0 , 5} \mathbf{m m}\end{array}$ & $\begin{array}{c}\text { Arena media } \\
\mathbf{0 , 5 - 0 , 2 5} \mathbf{m m}\end{array}$ & $\begin{array}{c}\text { Arena fina } \\
\mathbf{0 . 2 5 - 0 , 1 2 5} \mathbf{m m}\end{array}$ & $\begin{array}{c}\text { Arena muy fina } \\
<\mathbf{0 , 1 2 5} \mathbf{m m}\end{array}$ \\
\hline Cañadón Alfa & 0,44 & 3,65 & 86,16 & 9,69 & 0,07 \\
Cañadón Beta & 0,43 & 1,52 & 62,76 & 34,41 & 0,88 \\
El Páramo & 0,38 & 0,81 & 79,36 & 19,39 & 0,06 \\
Punta Sinaí & 4,32 & 5,43 & 67,53 & 22,32 & 0,39 \\
\hline
\end{tabular}

Tabla 5.3. Granulometría de los niveles ricos en minerales pesados (\% en peso). 

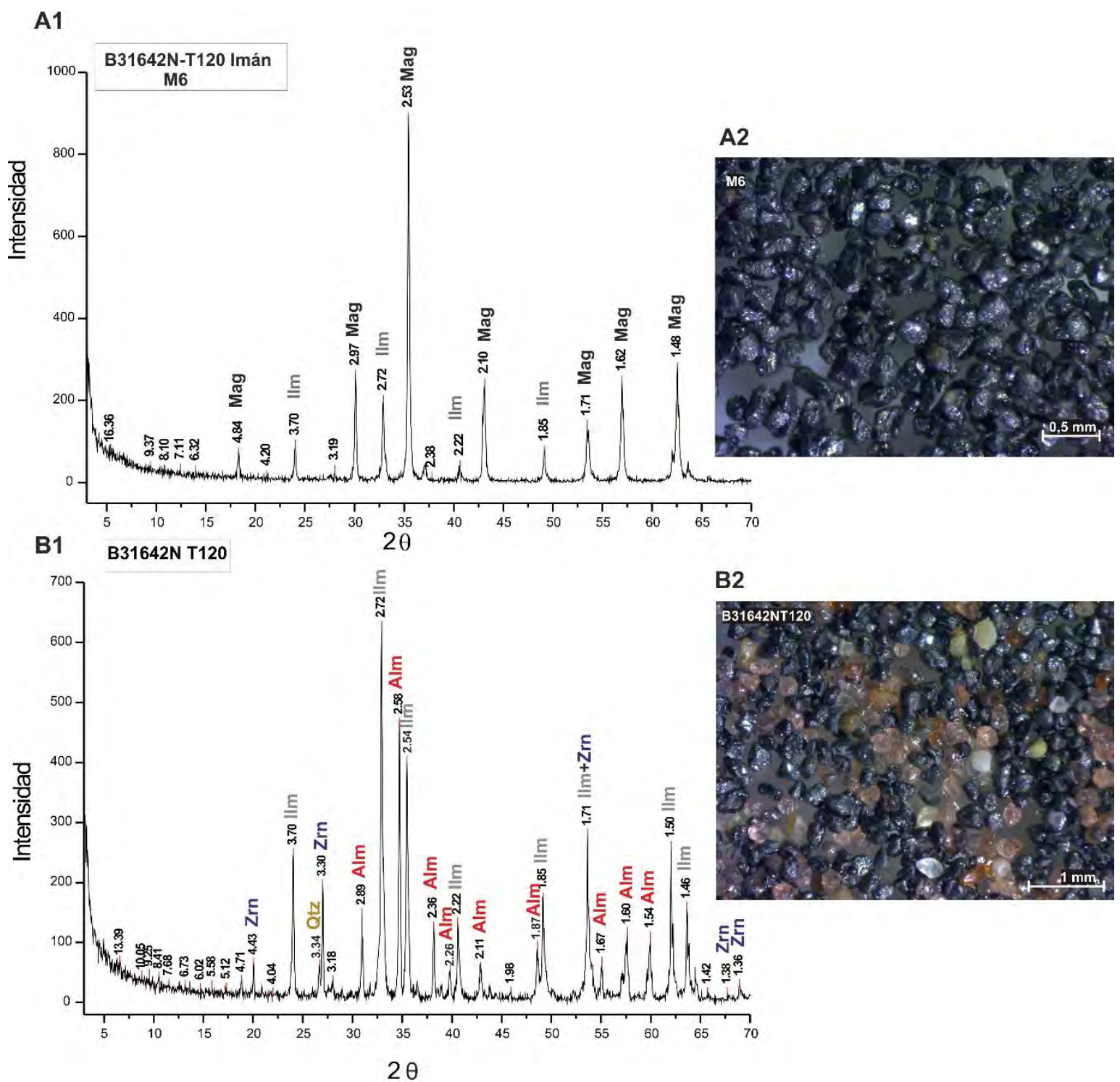

Fig.5.38. Difractogramas y fotografías realizadas mediante lupa binocular de una muestra procedente de un nivel enriquecido de la playa del cañadón Beta. La muestra fue tamizada, correspondiendo la granulometría a la fracción arena fina. Para evitar la superposición de picos y tener una mayor claridad en el difractograma, se separó el material más magnético mediante un imán normal. A1 y A2 corresponden a la porción más magnética y B1 y B2 con el material resultante. Abreviaturas: Alm, almandino; Zrn, circón; Qtz, cuarzo; IIm, ilmenita y Mag, magnetita.

En las playas de El Páramo y punta Sinaí, estos niveles son más oscuros y generalmente menos potentes, entre 1 y $2 \mathrm{~cm}$ predominando los minerales opacos (óxidos de Fe y Ti). En algunos sectores de la espiga de El Páramo, la berma de tormenta está constituida por un escalón endurecido desarrollándose en la parte superior una superficie muy rica en minerales pesados con un tamaño predominante de arena media intercalada con las gravas que constituyen la espiga (Fig.5.15B). La mineralogía está dominada por minerales opacos (ilmenita s.l. y magnetita s.l.) junto con minerales del grupo del piroxeno en el caso de las playas de punta Sinaí. 
En menor proporción y accesorios, en estos niveles también se pudieron identificar minerales del grupo del epidoto, clinoanfíboles (anfíbol cálcico), estaurolita, circón, titanita, pirita, goethita, rutilo, espinela s.s. y oro.

La longitud lateral de estos niveles enriquecidos en minerales pesados no supera normalmente los tres metros. La morfología de los niveles enriquecidos comprende desde tabular hasta lenticular (Fig.5.37).

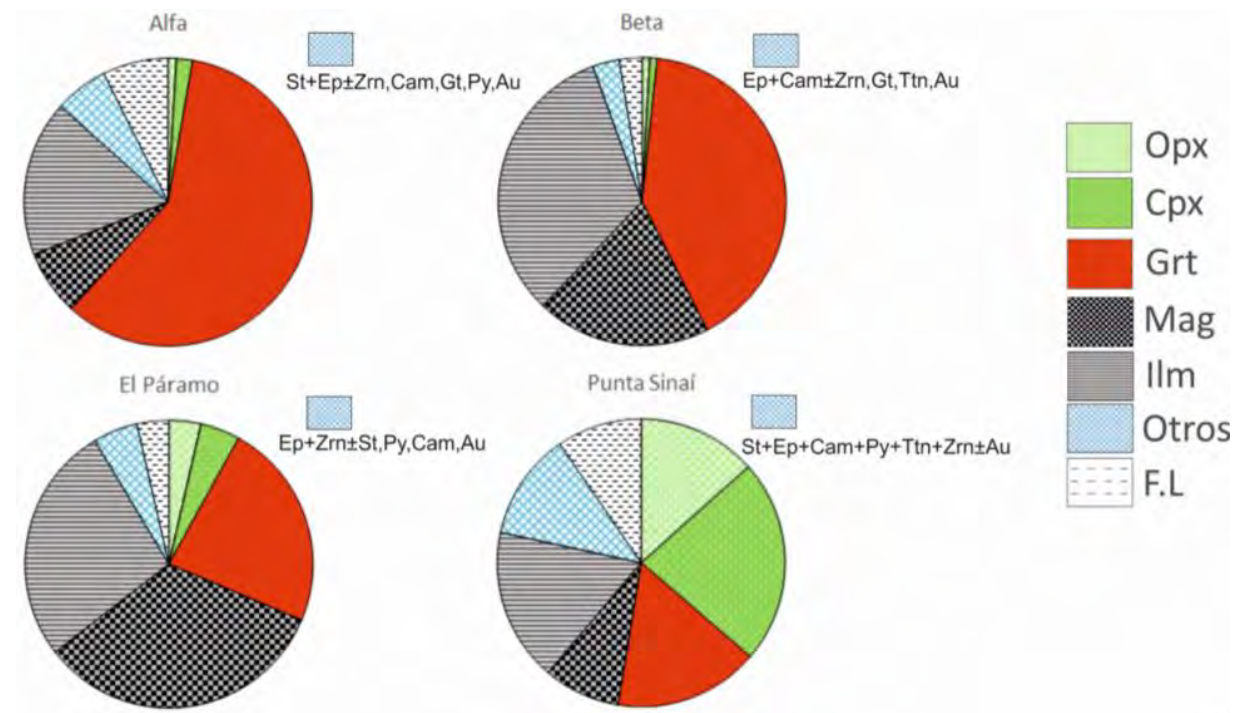

Fig.5.39. Gráficos circulares con los datos del análisis cuantitativo por contaje de puntos realizado en muestras provenientes de niveles enriquecidos de las playas.

\begin{tabular}{|c|c|c|c|c|c|}
\hline & & \multicolumn{4}{|c|}{ Puntos de muestreo } \\
\hline & & El Páramo & Punta Sinaí & Cñd.Alfa & Cñd.Beta \\
\hline \multirow{17}{*}{ 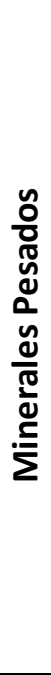 } & Ortopiroxenos & 4 & 13 & 1 & 1 \\
\hline & Clinopiroxenos & 4 & 23 & 2 & 1 \\
\hline & Anfíbol cálcico & $*$ & 2 & $*$ & 1 \\
\hline & Gr. Granate & 23 & 16 & 59 & 41 \\
\hline & Titanita & & 1 & & $*$ \\
\hline & Gr. Epidoto & 4 & 4 & 1 & 3 \\
\hline & Circón & 1 & 1 & $*$ & $*$ \\
\hline & Gr. Apatita & $*$ & & & \\
\hline & Estaurolita & $*$ & 4 & 6 & \\
\hline & Magnetita s.I & 33 & 9 & 7 & 19 \\
\hline & Ilmenita s.I & 27 & 17 & 17 & 32 \\
\hline & Pirita & $*$ & 1 & $*$ & \\
\hline & Goethita & & & $*$ & $*$ \\
\hline & Rutilo & & $*$ & & $*$ \\
\hline & Espinela s.s & $*$ & & & $*$ \\
\hline & Gr. Oro & $*$ & $*$ & $*$ & $*$ \\
\hline & Fragmentos líticos & 4 & 10 & 7 & 3 \\
\hline
\end{tabular}

Tabla 5.4. Abundancia de minerales y fragmentos líticos presentes en los niveles enriquecidos. Valores expresados en porcentajes. * Trazas.

A partir de la separación magnética de los minerales pesados de estos niveles mediante un separador Frantz e imán de mano para los minerales más ferromagnéticos, 
se pudieron agrupar los minerales pesados según la susceptibilidad magnética que presentaban. Se eligieron tres rangos de amperaje identificándose distintos minerales en cada uno de ellos: 0-0,2 amperios, minerales muy ferromagnéticos como magnetita e ilmenita; 0,2-0,6 amperios, minerales menos magnéticos (paramagnéticos), principalmente granate e ilmenita junto con minerales del grupo del piroxeno y supergrupo del anfíbol con inclusiones magnéticas; 0,5-1 amperios, se encuentra la mayor parte de los minerales del supergrupo del anfíbol y de los grupos del piroxeno y del epidoto, además de estaurolita, espinela s.s., minerales del grupo del granate, ilmenita y rutilo; $>1$ amperios, se agrupan principalmente minerales sin magnetismo (diamagnéticos) o muy poco como el circón, rutilo, minerales de grupo de la apatita y oro, junto con algún mineral liviano como cuarzo o feldespato ya que en estas muestras no se hizo la separación con líquido densos (Fig. 5.40 y 5.41).
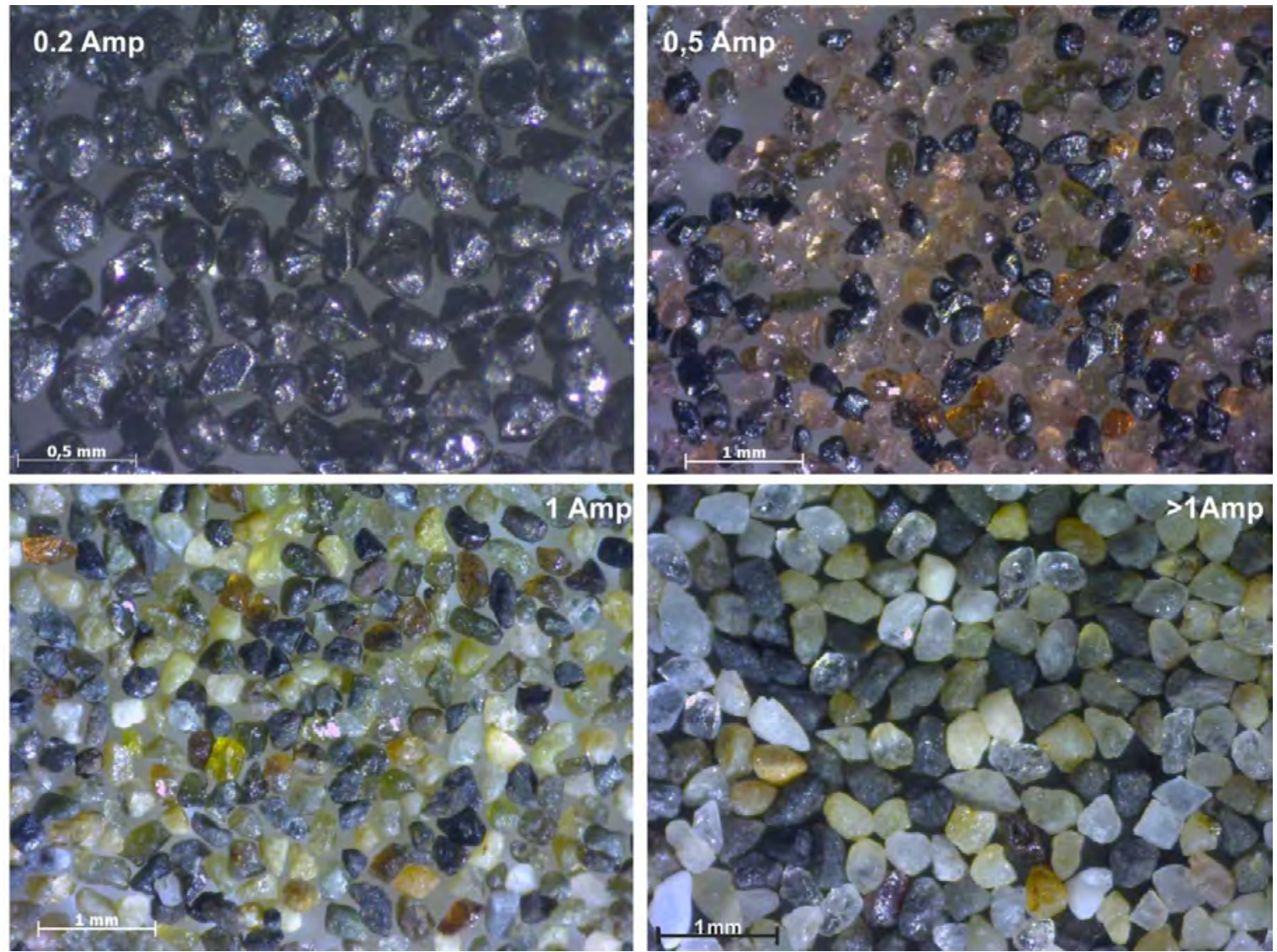

Fig.5.40. Separación magnética de minerales de una muestra correspondiente a un nivel enriquecido presente en la playa del cañadón Alfa. Tamaño de grano arena fina.

Se observó que el contenido de minerales ferromagnéticos es mayoritario en la fracción de arena fina en todas las muestras salvo en las de punta Sinaí, donde dominan los minerales del grupo del piroxeno y del supergrupo del anfíbol. Sin embargo, si esta 
separación se realiza con un tamaño de grano más grande $(0,3-0,25 \mathrm{~mm})$, la cantidad de granates aumenta, llegando a dominar en la muestra correspondiente al cañadón Alfa.

La diferencia de tamaño y densidad de estos minerales se puede explicar a partir del concepto de tamaño hidráulico equivalente, con el cual minerales más grandes y livianos son depositados junto con otros más pequeños y densos bajo determinadas condiciones hidrodinámicas.

Arena fina, $0.25-0,125 \mathrm{~mm}$

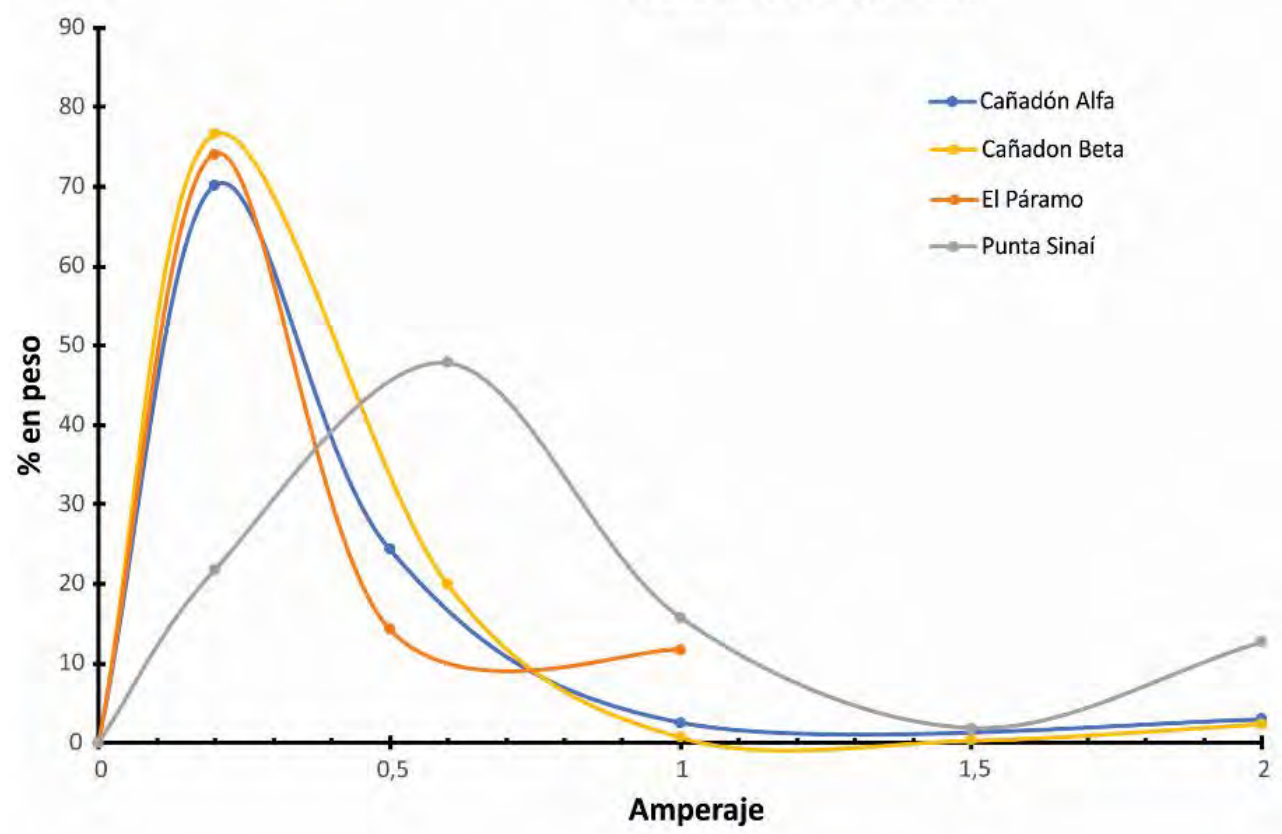

Arena media $0,3-0,25 \mathrm{~mm}$

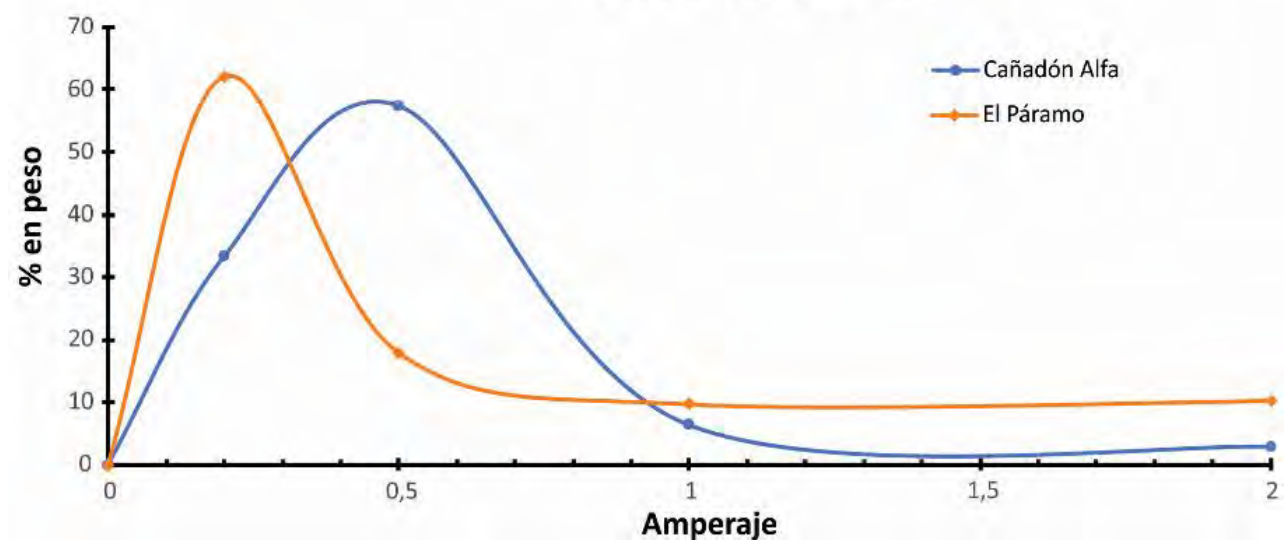

Fig.5.41. Separación mineral mediante métodos magnéticos de las fracciones arena fina y arena media. 


\subsection{Oro. Muestreo y morfometría}

\subsubsection{Muestreo}

El muestreo para la obtención de oro fue realizado teniendo en cuenta los distintos subambientes geológicos, tanto en el sedimento glacigénico (till y glacifluvial) como en las playas actuales. Debido a la muy baja ley aurífera de los depósitos glaciales no se pudo identificar oro, pero sí el resto de los minerales pesados que aparecen en las zonas enriquecidas de las playas, comprobándose una llamativa analogía entre los conjuntos minerales de ambos subambientes. En el litoral atlántico, se obtuvieron granos de oro de los niveles ricos presentes en las playas de los cañadones Alfa y Beta y El Páramo. En las playas de punta Sinaí también se identificó oro, pero debido a su finísimo tamaño no se pudo concentrar.

En el campo y laboratorio se concentró el oro mediante el uso de una canaleta tipo sluice box construida para tal fin y una batea plástica (Fig.5.42A-B).

La canaleta consiste en una estructura de hierro de 1,5 m de longitud, con pintura impermeable, a través de la cual se hizo pasar una corriente de agua, en este caso propulsada por una bomba. La canaleta consta en su fondo de un conjunto de rifles o escalones que ralentizan el movimiento del agua. Estos rifles representan obstáculos para que el oro pueda quedar atrapado en una malla de aluminio junto con un paño de tela de corderoy que tapiza el fondo. Mediante unos pernos situados en la cabecera de la canaleta, se puede regular su pendiente para controlar la velocidad del flujo de agua. Con un tamiz colocado en la tolva de alimentación, se elimina la entrada de las gravas más gruesas. Con esta técnica, no se obtuvieron resultados satisfactorios. El tamaño muy pequeño de los granos de oro fue un inconveniente difícil de resolver como para obtener en forma efectiva concentrados significativos de este metal precioso.

La batea es un plato de goma con fondo plano y finos rifles en la pared de los bordes (Fig.5.42 C y D). A partir de un movimiento circular se pueden separar los granos de oro del resto de minerales pesados y livianos si los hubiera. Mediante esta técnica, se obtuvieron mejores resultados, concentrando numerosos granos de una manera más rápida y eficiente. 

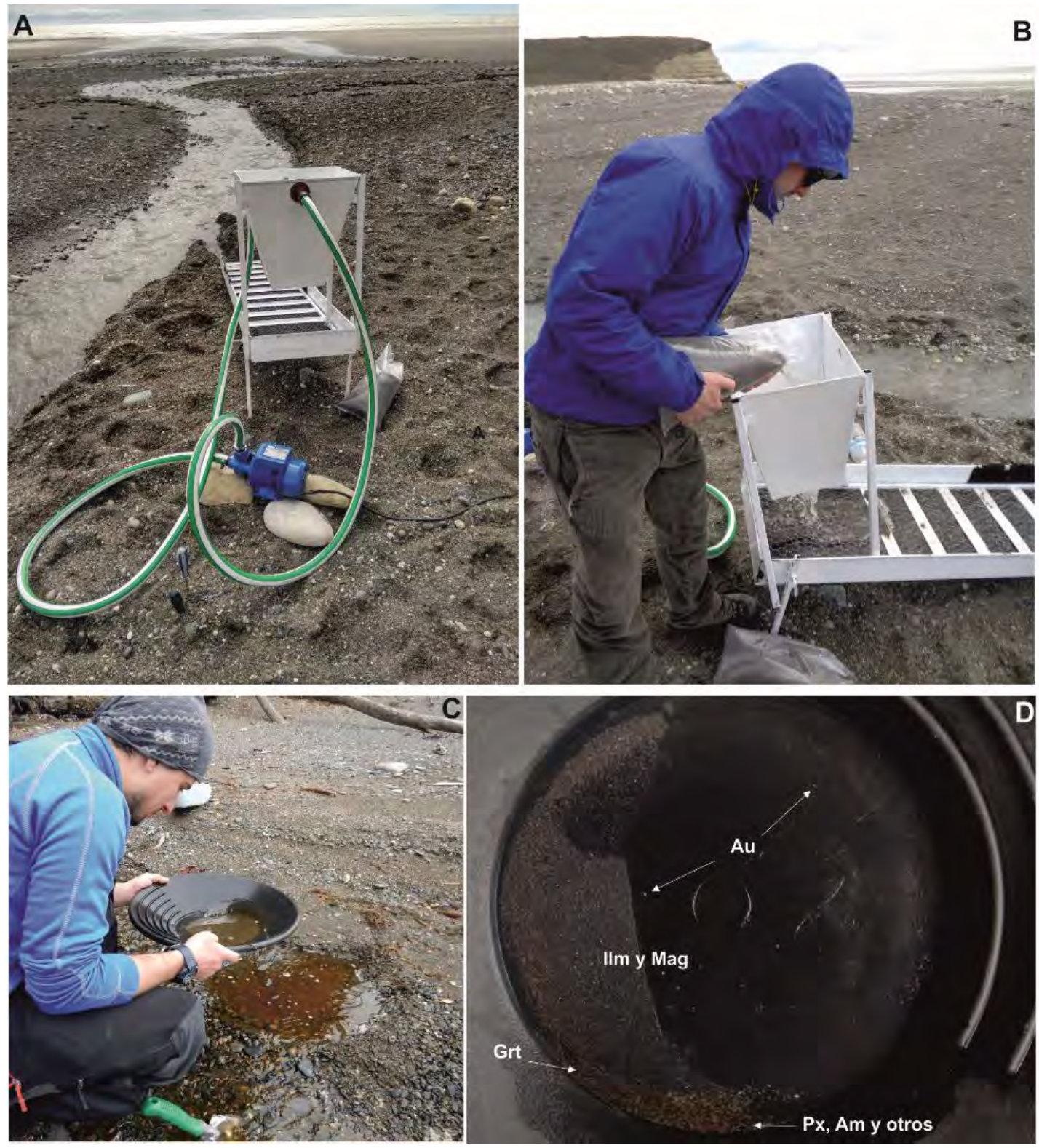

Fig.5.42. Métodos de concentración de oro: A y B mediante el uso de una canaleta, C y D con una batea.

\subsubsection{Estudio morfométrico}

El estudio morfométrico del oro (morfología y tamaño de grano) se realizó mediante lupa binocular en un total de 96 granos recolectados en diferentes sectores de las playas: 38 del cañadón Alfa, 27 del cañadón Beta y 31 de El Páramo (Fig.5.43 y 5.44). Los granos se montaron en probetas mediante resina Epoxy, se desbastaron y pulieron y se caracterizaron con microscopio de luz reflejada para su posterior análisis químico por microsonda electrónica. 
En los granos de oro de las playas del cañadón Alfa la longitud varía de 0,25 a 0,8 $\mathrm{mm}$ y el ancho de 0,17 a 0,61 mm, con un espesor entre 0,02 y 0,03 mm. El promedio de los granos da unos valores de 0,45 $\mathrm{mm}$ de largo, 0,32 $\mathrm{mm}$ de ancho y 0,03 $\mathrm{mm}$ de espesor. El 66\% de los granos tiene una morfología discoidal y el resto laminar alargado. Todos los granos presentan morfologías planas. Es común observar su superficie con impactos ("martillado") y en dos casos se observaron cavidades. Algunos granos presentaron óxidos en su superficie. Los bordes son regulares y están pulidos, observándose en algunos granos zonas plegadas debido a la maleabilidad del oro. Según la plantilla de comparación visual de Powers (1953), los granos discoidales presentan alta esfericidad desde subredondeados a redondeados, los granos laminares muestran baja esfericidad variando desde subredondeados a redondeados.

En la playa del cañadón Beta se analizaron 27 granos de oro. La longitud varía de 0,25 hasta $0,95 \mathrm{~mm}$, el ancho de 0,19 a $0,44 \mathrm{~mm}$ y el espesor muy fino, con valores de entre 0,02 y $0,03 \mathrm{~mm}$. El promedio de los granos dio valores parecidos a los de las playas de Alfa, 0,43 mm de longitud, 0,29 $\mathrm{mm}$ ancho y 0,03 $\mathrm{mm}$ de espesor. El $56 \%$ de los granos presenta morfología discoidal plana y el $44 \%$ laminar alargado, con los bordes regulares pulidos y la superficie con impactos. Un grano presentó concavidad y en cuatro se observaron bordes irregulares. Los granos discoidales presentan alta esfericidad desde subangulosos a bien redondeados y los granos laminares, de baja esfericidad, varían desde subangulosos a bien redondeados.

En la playa de El Páramo los 31 granos de oro extraídos tienen un rango de 0,2 a $0,8 \mathrm{~mm}$ de longitud, 0,13 a $0,55 \mathrm{~mm}$ de ancho y un espesor que varía desde 0,02 a 0,14mm. Únicamente dos granos presentaron un espesor considerable, entre 0,11 y 0,14 mm, el resto quedó comprendido entre 0,02 y $0,03 \mathrm{~mm}$. El promedio de los granos dio valores de $0,36 \mathrm{~mm}$ de longitud, $0,25 \mathrm{~mm}$ de ancho y $0,04 \mathrm{~mm}$ de espesor. El $61 \%$ de los granos muestra morfología discoidal plana, el resto laminar alargado. Uno de los granos con mayor relieve presentó un hábito arriñonado. Todos los granos muestran impactos en la superficie y bordes regulares pulidos. En dos de ellos se observaron pliegues en los bordes. En esta playa, se identificaron más granos con un índice de redondez mayor y tamaño más pequeño. Los granos discoidales muestran alta esfericidad desde subredondeados a bien redondeados y los granos laminares presentan baja esfericidad variando desde subredondeados a bien redondeados. 

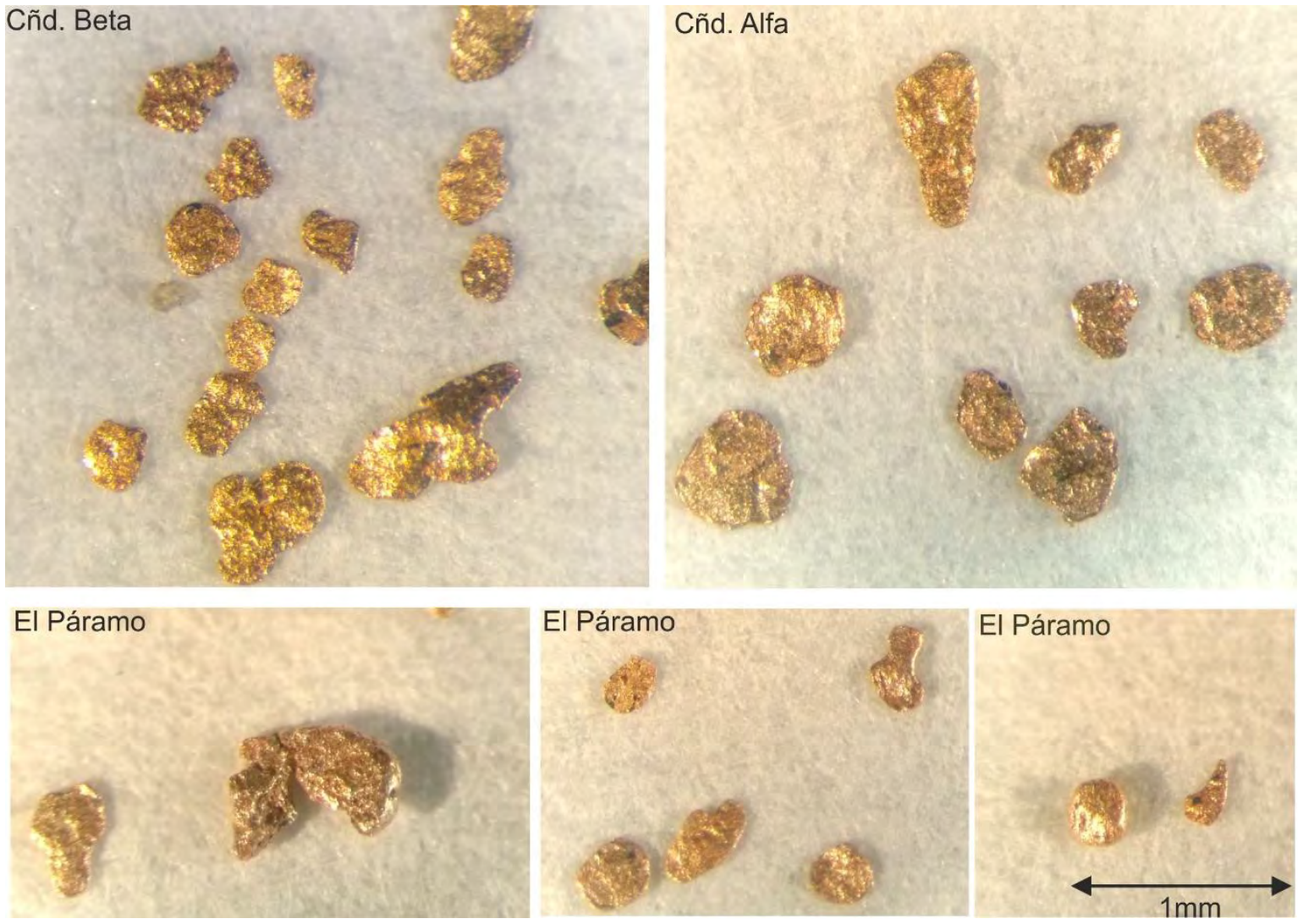

Fig.5.43. Granos de oro estudiados con lupa binocular de las distintas playas. Misma escala gráfica para todas las fotos. La diferente coloración que muestran las fotografías es debido a las condiciones de iluminación.

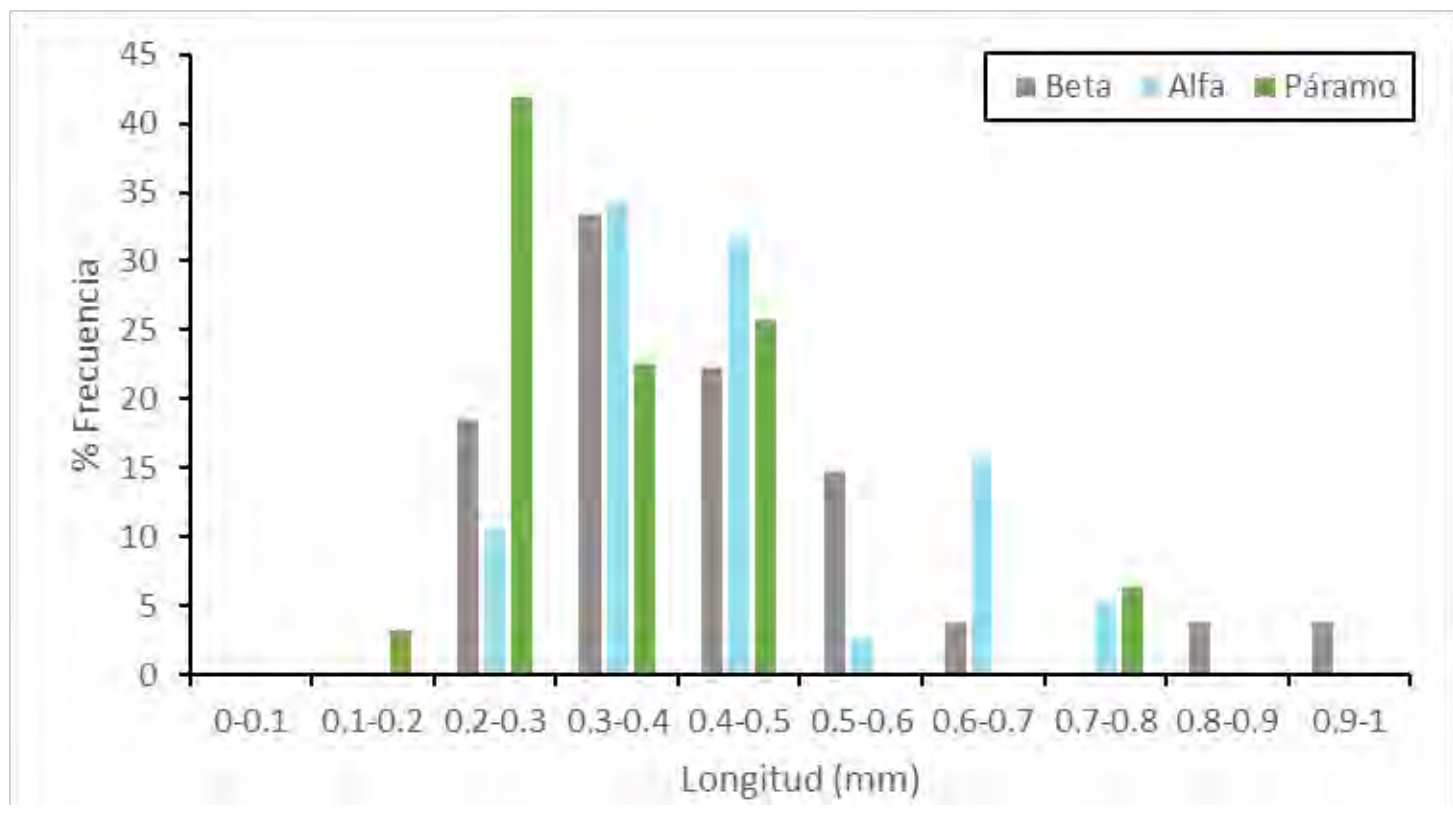

Fig.5.44. Histograma de frecuencia (\%) vs Longitud $(\mathrm{mm})$ de los granos de oro de los sectores de playa de Alfa, Beta y EI Páramo. Se observa una mayor longitud de los granos en Alfa y Beta con respecto a El Páramo. Los granos de la playa del Cñd. Tortuga no se tuvieron en cuenta debido a su escasez. 


\subsection{Sectores de punta Loyola, provincia de Santa Cruz y bahía Sloggett, sur de Tierra del Fuego}

Con fines comparativos, se añadieron a la presente tesis doctoral dos sectores que presentan continuidad geológica y/o geomorfológica con el ambiente geológico imperante en el norte de la isla Grande de Tierra del Fuego. Estos dos sectores se sitúan en el tramo más austral de la provincia de Santa Cruz, sector de punta Loyola y en la bahía Sloggett, sur de Tierra del Fuego. Ambas regiones además corresponden a lugares históricos donde se explotó el oro localizado en sus playas a principios del siglo $\mathrm{XX}$.

El área al sur de la localidad de Río Gallegos (Provincia de Santa Cruz), presenta buena parte de su superficie cubierta por depósitos glacigénicos pleistocenos correspondientes a la lengua glacial del Estrecho de Magallanes

Al noreste del Canal Beagle, en la bahía Sloggett, el glaciar Beagle proveniente de la Cordillera Darwin alcanzó este sector, trasportando material desde la cordillera hasta la boca oriental del canal, quedando relictos en el sector de la bahía.

\subsubsection{Minerales pesados en las playas del área de punta Loyola, Provincia de Santa Cruz}

Las playas localizadas al sur de la localidad de Río Gallegos, en la provincia de Santa Cruz, fueron explotadas para la extracción de oro a finales del siglo XIX. En toda esta zona la geología y geomorfología son similares a las presentes en la porción septentrional de Tierra del Fuego, diferenciando al norte, desde punta Loyola y hasta el sur del chorrillo de los Frailes, un sector con depósitos marinos holocenos constituidos por cordones litorales, en el centro, entre Zanja Pique y cabo Vírgenes, acantilados activos constituidos por depósitos del Drift Sierra de los Frailes del Pleistoceno y finalmente al sur, entre el cabo Vírgenes y punta Dungeness, gravas caladas (sedimento inconsolidado donde el material más fino que ocupaba los intersticios ha sido transportado) al pie de un acantilado inactivo (Codignotto et al. 1992) (Fig.5.45). 


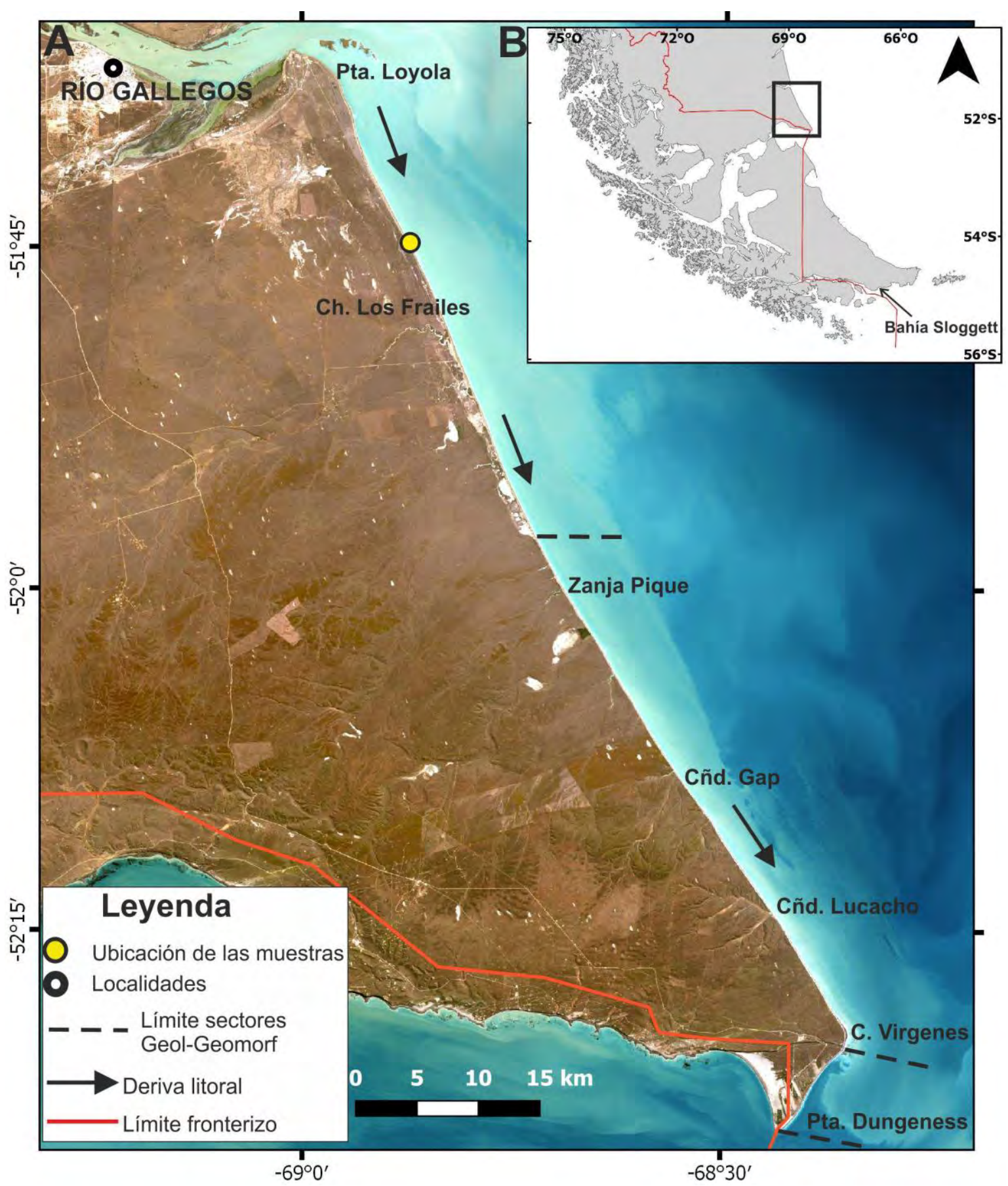

Fig.5.45. A) Mapa geográfico de ubicación del muestreo y límites de los diferentes sectores geológicos-geomorfológicos que se pueden diferenciar en la costa. Imagen Landsat 8, LO82280962016268COAO0, combinación de bandas 4,3,2. Descargada de la CONAE. B) Mapa de ubicación regional del sector de estudio de la provincia de Santa Cruz. En la región SE del mapa se incluye la ubicación de la bahía Sloggett.

Durante el desarrollo de la presente investigación se tuvo acceso a un muestreo procedente de un perfil trasversal en la playa localizada a $15 \mathrm{~km}$ al sur de punta Loyola donde se pudieron analizar 10 muestras distribuidas desde la zona intermareal hasta la zona supramareal. Las muestras se tamizaron en los laboratorios del INREMI para obtener la fracción arenosa donde se concentran la mayoría de las fases minerales pesadas. Una 
vez obtenida la fracción arena media a muy fina $(0,5-0,063 \mathrm{~mm})$, se procedió a la separación según la densidad entre minerales pesados y livianos utilizando la técnica de bateo con recipiente acanalado de vidrio. Finalmente, para facilitar el estudio mediante lupa binocular, se separaron los minerales de la fase pesada en función de la susceptibilidad magnética que presentaban.

Los minerales pesados se concentran desde un tamaño de arena media hasta arena fina (la arena muy fina es muy escasa), obteniéndose las mayores concentraciones en la zona de la berma de marea y tormenta.

Se identificaron minerales ferromagnéticos (magnetita, ilmenita y hematita), minerales de los grupos del piroxeno y granate, del supergrupo del anfíbol y algún circón, comprobándose las mismas características que la asociación mineral encontrada en el sector de trabajo de Tierra del Fuego en cuanto al hábito, color o presencia de inclusiones. El oro no se identificó en estas muestras, sin embargo, trabajos realizados por Beros y Prez (1987) y Codignotto et al. (1992) indican su presencia en la zona supramareal de las playas.

\subsubsection{Minerales pesados en la playa de bahía Sloggett}

La playa de bahía Sloggett, localizada en la boca oriental del Canal Beagle (Fig.5.1), ha sido otro lugar del sector argentino de Tierra del Fuego donde históricamente fue explotado el oro a principios del siglo XX, quedando los vestigios oxidados de una gran draga perteneciente a la compañía The Argentina Tierra del Fuego Exploration Co. Ltd (Fig.5.46A).

No existen caminos de acceso a la bahía Sloggett. Se puede arribar a la zona a pie por la costa recorriendo unos $40 \mathrm{~km}$ aproximadamente desde el destacamento de Moat (P.N.A). En esta bahía desemboca el río López (Fig.5.46C) que fluye de norte a sur con un diseño de red de tipo dendrítico y meandriforme, con profundidades variables y un caudal importante (Carrillo et al. 1989).

Según la información sobre las mareas en bahía Aguirre, correspondiente con el punto de medida más cercano del Servicio de Hidrografía Naval, las mareas en este sector son micromareales ( $<2 \mathrm{~m}$ amplitud) con un régimen mixto preponderantemente semidiurno.

La zona sur de Tierra del Fuego presenta una configuración costera recortada (entrantes y salientes) por lo que el efecto de la deriva litoral es mínimo (Isla et al. 2000). La dinámica marina regional presenta una dirección oeste-este (Corriente de Cabo de Hornos y Corriente Circumpolar Antártica) asociada a los fuertes vientos dominantes del suroeste. 


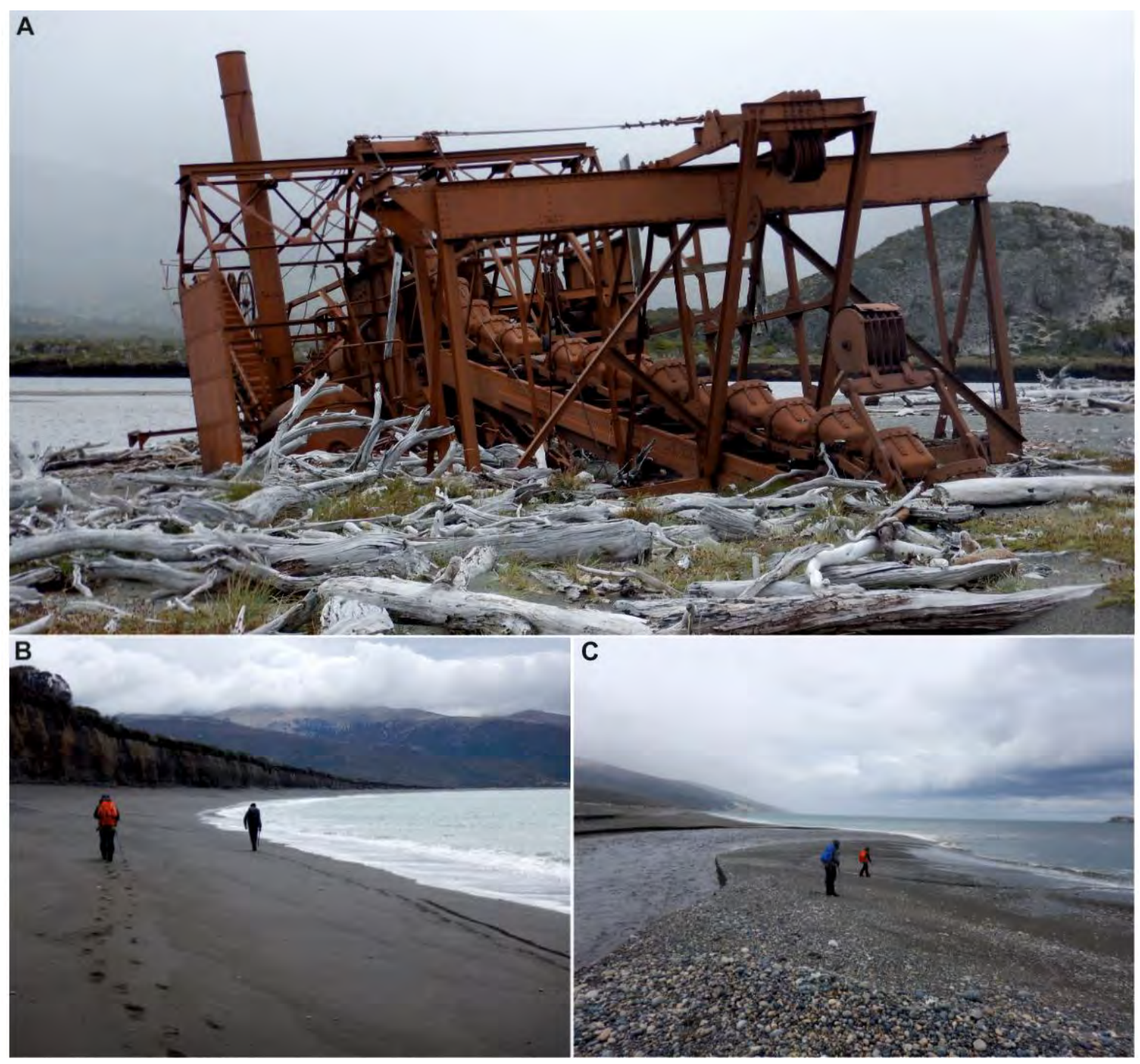

Fig.5.46. A) Draga abandonada en la playa de bahía Sloggett B) acantilados al sur del río López, constituidos por depósitos glacifluviales en la base y turba en el techo, distinguiéndose al fondo el monte Lucio López C) desembocadura del río López.

Respecto a la geología, al este de la desembocadura del río López aflora el complejo metavolcánico sedimentario submarino de rift de la Formación Lemaire, junto con un pequeño sector constituido por sedimentitas fluviales compuestas por conglomerados, areniscas y fangolitas, con troncos carbonizados correspondientes a la Formación Sloggett (Caminos, et al., 1981). Al sur afloran las metasedimentitas marinas profundas de cuenca marginal correspondientes a la Formación Yahgán. Todas estas unidades litológicas están cubiertas en discordancia por sedimentos glaciales y glacifluviales (Rabassa et al. 2003).

En este sector hay evidencias de englazamiento durante el Pleistoceno asociado con el glaciar que discurrió por el Canal Beagle o con el glaciar que descendía por el valle del río López (Rabassa et al. 2003). El Canal Beagle fue ocupado en varias ocasiones por glaciares de descarga provenientes del manto de hielo de montaña presente en la 
Cordillera Darwin. A pesar de que el extremo sur de Sudamérica ha sido afectado repetidamente por glaciaciones durante el Cuaternario, sólo se han encontrado evidencias morfológicas de las dos últimas glaciaciones. La más antigua se denomina glaciación Lennox (Caldenius 1932) donde se incluye localmente la llamada glaciación Sloggett (Rabassa 2008). Este evento habría alcanzado las islas Lennox y Nueva al sureste y la punta occidental de la bahía Sloggett en la costa norte generando colinas morénicas (till) y gravas glacifluviales. Durante el UMG (Glaciación Moat) el alcance del Glaciar Beagle se redujo hasta punta Moat, localizándose restos de un campo de drumlins entre las morenas laterales y terminales de esta glaciación (Rabassa 2008).

Los acantilados localizados al oeste de la bahía están constituidos por gravas glacifluviales cubiertas por turba de edad holocena (Rabassa et al. 2003). Según estos investigadores las gravas glacifluviales estarían asociadas con dos eventos de fusión. El inferior a una planicie glacifluvial del frente del glaciar Beagle (Glaciación Lennox) hacia el interior del frente montañoso y el superior a torrentes de descarga de la cuenca NE del río López de edad equivalente a la Glaciación Moat.

Es de destacar la presencia de un bosque sumergido asociado a un comportamiento tectónico diferencial en el Canal Beagle por la presencia de fracturas activas durante el Holoceno tardío. Estas fracturas habrían elevado las costas en el sector occidental y, por el contrario, en el sector oriental se habría producido un hundimiento, hecho que ha quedado registrado con la presencia de depósitos litorales y restos de este bosque por debajo del nivel de mar actual (Rabassa et al. 2003).

El muestreo se realizó en la parte superior de la playa, en la zona supramareal, localizándose las zonas más enriquecidas en profundidad cerca del bed rock o sustrato rocoso. Se realizó un concentrado utilizando el bateo y se identificó mediante microscopio petrocalcográfico diferentes minerales pesados como magnetita, pirita, ilmenita con exsoluciones, minerales del grupo del granate, ortopiroxenos, clinopiroxenos y oro.

Los granos de oro muestran una forma discoidal, con bordes irregulares y la superficie con impactos ("martilleado"), alcanzando a observarse oquedades o huecos en algunos de ellos (Fig.5.47). Presentan una alta esfericidad con un grado de redondez desde subanguloso a subredondeado, con tamaños más grandes que los granos de oro encontrados en el litoral Atlántico de Tierra del Fuego, alcanzando algunos de ellos un peso de 2,3 gramos (granos obtenidos actualmente por pirquineros). Estas características reflejarían un menor transporte y desgaste que los granos presentes en las playas del norte de la isla. 
El estudio realizado bajo microscopio petro-calcográfico indicó que la mayoría de los granos no presentan zonaciones y en tres de ellos se identificaron inclusiones metálicas gris-azuladas posiblemente correspondientes con algún telururo o seleniuro.
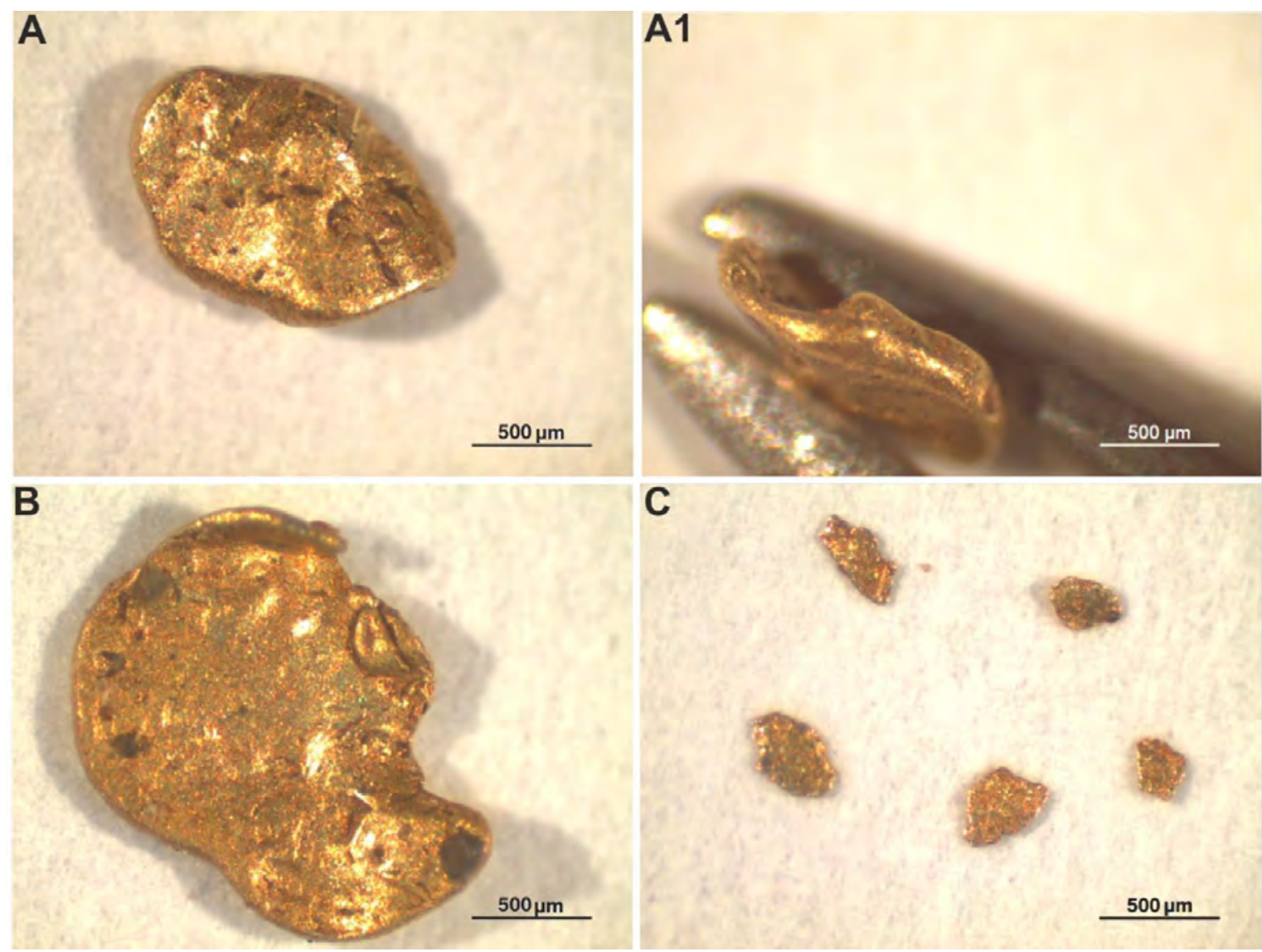

Fig.5.47. Granos de oro encontrados en la playa de la bahía Sloggett. 


\section{Capítulo 6: PLATAFORMA CONTINENTAL}

\subsection{Introducción}

La Plataforma Continental de la Isla Grande de Tierra del Fuego se extiende extensamente hacia al este del litoral Atlántico y se caracteriza por presentar geoformas y depósitos de origen glacial resultantes de las distintas glaciaciones que se desarrollaron durante el Plioceno-Pleistoceno en la región meridional de la Patagonia (Caldenius 1932, Isla y Schnack 1995, Mouzo 2005c). Como consecuencia de estas glaciaciones y de los períodos interglaciales el nivel del mar varió enormemente modelando la plataforma durante sucesivas regresiones y transgresiones marinas.

\subsection{Muestreo y análisis granulométrico}

Se analizaron un total de 28 muestras del fondo marino presentes en la Plataforma Continental Argentina localizada al este de la costa sur de la provincia de Santa Cruz y noreste de la Isla Grande de Tierra del Fuego y Estrecho de Magallanes. Fueron proporcionadas por el Servicio de Hidrografía Naval de la República Argentina y corresponden a cuatro campañas oceanográficas realizadas entre los años 1970 y 1984. La mayoría de estas muestras son provenientes de la plataforma interna y media a una profundidad de entre $1,2 \mathrm{~m}$ y $88 \mathrm{~m}$. Cuatro muestras se ubicaron en la plataforma exterior, entre $128 \mathrm{~m}$ y $205 \mathrm{~m}$ de profundidad (Fig.6.1).

Al este de cabo Vírgenes se analizaron seis muestras de profundidades desde los $82 \mathrm{~m}$ hasta $205 \mathrm{~m}$, correspondientes con la plataforma externa y límite con la media. El análisis sedimentológico dio una composición granulométrica principalmente de arena media a fina con limos subordinados y algo de grava bien redondeada en la muestra más alejada de la costa. Debido a la reducida cantidad de muestra en tres de ellas, el análisis granulométrico se hizo mediante estimación visual.

Una muestra tomada al norte de cabo Vírgenes a una profundidad de entre $50 \mathrm{~m}$ y $60 \mathrm{~m}$ (plataforma media) presentó una granulometría más gruesa constituida por arena (principalmente muy gruesa) con gravas y limos subordinados (Tabla 6.1). 


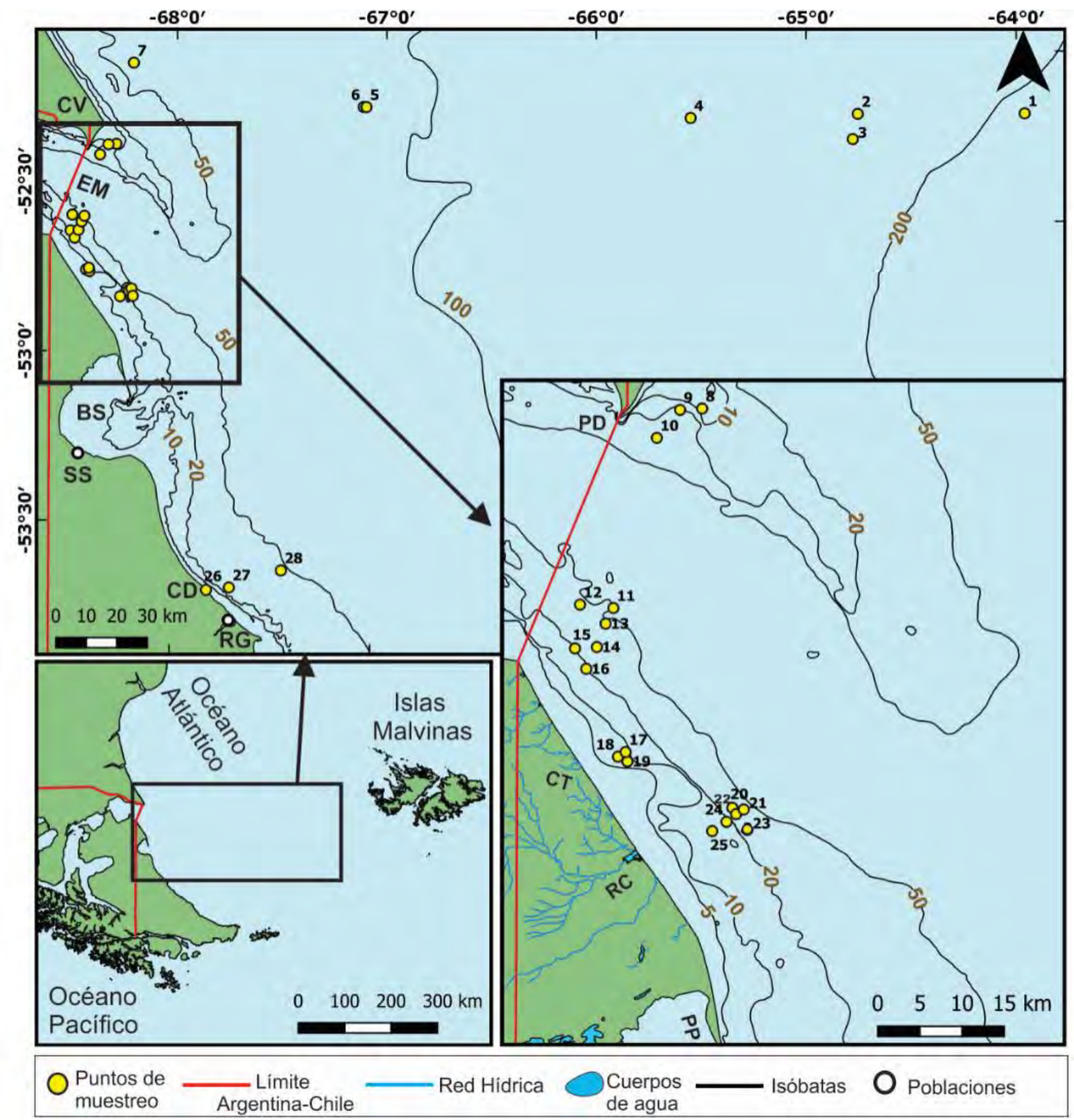

Fig.6.1. A) Localización de las muestras de la PCA. SS: San Sebastián; RG: Rio Grande; CV: cabo Vírgenes; EM: Estrecho de Magallanes; BS: bahía de San Sebastián; CD: cabo Domingo; PD: punta Dungeness; PP: península El Páramo; CT: cañadón Tortuga; RC: río Cullen.

En la zona oriental del Estrecho de Magallanes se analizó un total de nueve muestras a profundidades que varían desde los $18 \mathrm{~m}$ hasta $59 \mathrm{~m}$. Los análisis granulométricos indicaron sedimentos más gruesos en la zona norte de la plataforma interior, constituidos por arenas finas a medias con limos y gravas, que en el sector meridional compuesto por limos con arcillas principalmente. Esta zona se correspondería con los límites norte y sur del Valle Glaciar Sumergido de Magallanes identificado por Mouzo (2005a).

En la plataforma adyacente a Tierra del Fuego se estudiaron cuatro muestras provenientes del sector situado frente al cañadón Tortuga a profundidades entre $8 \mathrm{~m}$ y 26 
m (plataforma interna), presentando estos sedimentos una granulometría muy fina compuesta principalmente de limos con arenas muy finas y arcillas. Frente a la desembocadura del río Cullen se analizaron seis muestras tomadas a profundidades que varían desde los $14 \mathrm{~m}$ hasta los $33 \mathrm{~m}$ cuyos resultados granulométricos dieron principalmente arenas y limos junto con un porcentaje importante de gravas en la muestra más profunda. Finalmente se analizaron tres muestras situadas al sur del cabo Domingo a profundidades desde 1,2 $\mathrm{m}$ hasta $48 \mathrm{~m}$. En este sector la granulometría aumenta de arenas finas a muy finas con limos subordinados hasta arenas medias a gruesas a medida que se acrecienta la profundidad desde la plataforma interior a la media.

\begin{tabular}{|c|c|c|c|c|c|c|c|c|c|c|c|}
\hline & & & Arcillas & Limos & MF & $\mathbf{F}$ & $M$ & $\mathbf{G}$ & MG & Arena(T) & Grava \\
\hline & Muestra & $P(m)$ & $>3,9 \mu$ & $3,9-63 \mu$ & $63-125$ & $125-250$ & $250-500$ & $500-1000$ & $1000-2000$ & $63-2000 \mu$ & $<2000 \mu$ \\
\hline \multirow{6}{*}{ 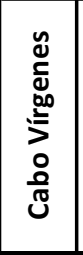 } & 1 & 205 & 1 & 9 & 1 & 21 & 45 & 8 & 3 & 78 & 12 \\
\hline & $3^{*}$ & 170 & 0 & 0 & & & & & & 100 & 0 \\
\hline & 2 & 155 & 1 & 10 & 1 & 24 & 50 & 9 & 4 & 88 & 0 \\
\hline & 4 & 128 & 6 & 15 & 21 & 54 & 4 & 0 & 0 & 79 & 0 \\
\hline & $5^{*}$ & 88 & 0 & 0 & & & & & & 100 & 0 \\
\hline & $6^{*}$ & 82 & 0 & 0 & & & & & & 97 & 3 \\
\hline \multirow{10}{*}{ 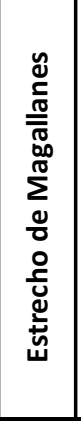 } & 7 & $50-60$ & 8 & 28 & 5 & 7 & 4 & 2 & 26 & 43 & 21 \\
\hline & 8 & 21 & 0 & 0 & 0 & 0 & 0 & 0 & 11 & 11 & 89 \\
\hline & 9 & 26 & 0 & 0 & 6 & 41 & 38 & 5 & 8 & 100 & 0 \\
\hline & 10 & 29 & 8 & 25 & 17 & 29 & 20 & 1 & 0 & 67 & 0 \\
\hline & 11 & 59 & 0 & 0 & 0 & 1 & 34 & 48 & 8 & 91 & 9 \\
\hline & 12 & 49 & 10 & 34 & 1 & 7 & 31 & 16 & 0 & 56 & 0 \\
\hline & 13 & 59 & 5 & 15 & 4 & 13 & 39 & 14 & 8 & 79 & 1 \\
\hline & 14 & 40 & 12 & 43 & 8 & 11 & 20 & 6 & 0 & 45 & 0 \\
\hline & 15 & 21 & 15 & 62 & 7 & 7 & 7 & 2 & 0 & 23 & 0 \\
\hline & 16 & 18 & 24 & 72 & 4 & 1 & 0 & 0 & 0 & 4 & 0 \\
\hline \multirow{3}{*}{ 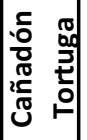 } & 17 & $9-10$ & 14 & 72 & 11 & 3 & 0 & 0 & 0 & 14 & 0 \\
\hline & 18 & $8-9$ & 15 & 75 & 9 & 1 & 0 & 0 & 0 & 10 & 0 \\
\hline & 19 & $8-9$ & 12 & 58 & 22 & 8 & 0 & 0 & 0 & 29 & 0 \\
\hline \multirow{6}{*}{ 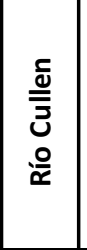 } & 20 & $21-26$ & 11 & 38 & 13 & 29 & 9 & 0 & 0 & 51 & 0 \\
\hline & 21 & $29-33$ & 9 & 28 & 3 & 4 & 3 & 1 & 31 & 42 & 22 \\
\hline & 22 & $24-25$ & 12 & 45 & 12 & 24 & 7 & 0 & 0 & 43 & 0 \\
\hline & 23 & $21-28$ & 3 & 11 & 5 & 8 & 28 & 36 & 7 & 84 & 2 \\
\hline & 24 & $18-20$ & 15 & 48 & 14 & 20 & 3 & 0 & 0 & 37 & 0 \\
\hline & 25 & $14-16$ & 10 & 49 & 21 & 19 & 1 & 0 & 0 & 41 & 0 \\
\hline \multirow{3}{*}{ 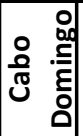 } & 26 & 1,2 & 0 & 0 & 16 & 64 & 19 & 0 & 0 & 100 & 0 \\
\hline & 27 & 7,3 & 6 & 27 & 22 & 35 & 9 & 0 & 0 & 67 & 0 \\
\hline & 28 & 48 & 0 & 0 & 0 & 9 & 60 & 31 & 0 & 100 & 0 \\
\hline
\end{tabular}

Tabla 6.1. Granulometría de las muestras de la plataforma continental. P, profundidad; MF, muy fina; F, fina; M, media; $G$, gruesa y MG, muy gruesa. * Granulometría realizada por estimación visual. 


\subsection{Composición litológica y mineralógica de los depósitos detríticos}

\subsubsection{Fracción psefítica}

La fracción psefítica debido a la escasa proporción en las muestras únicamente se pudo analizar con detenimiento en la $\mathrm{n}^{\circ} 8$ localizada al norte del Estrecho de Magallanes. El estudio, realizado a partir de lupa binocular, indicó un predominio de rocas volcánicas (45\%), seguido por plutónicas (22\%) y en menor medida metamórficas $(11 \%)$, cuarzo de veta y variedades del cuarzo (14\%), restos de conchillas $(5 \%)$ y rocas sedimentarias $(3 \%)$.

Como rocas volcánicas se identificaron basaltos, basaltos alterados (espilitas), riolitas y pórfidos riolíticos y andesíticos. Las rocas plutónicas que se reconocieron fueron dioritas, granodioritas y microgabros. Dentro de las rocas metamórficas se diferenciaron metapelitas y anfibolitas. Las rocas sedimentarias fueron muy escasas, habiéndose reconocido grauvacas (Fig.6.2).

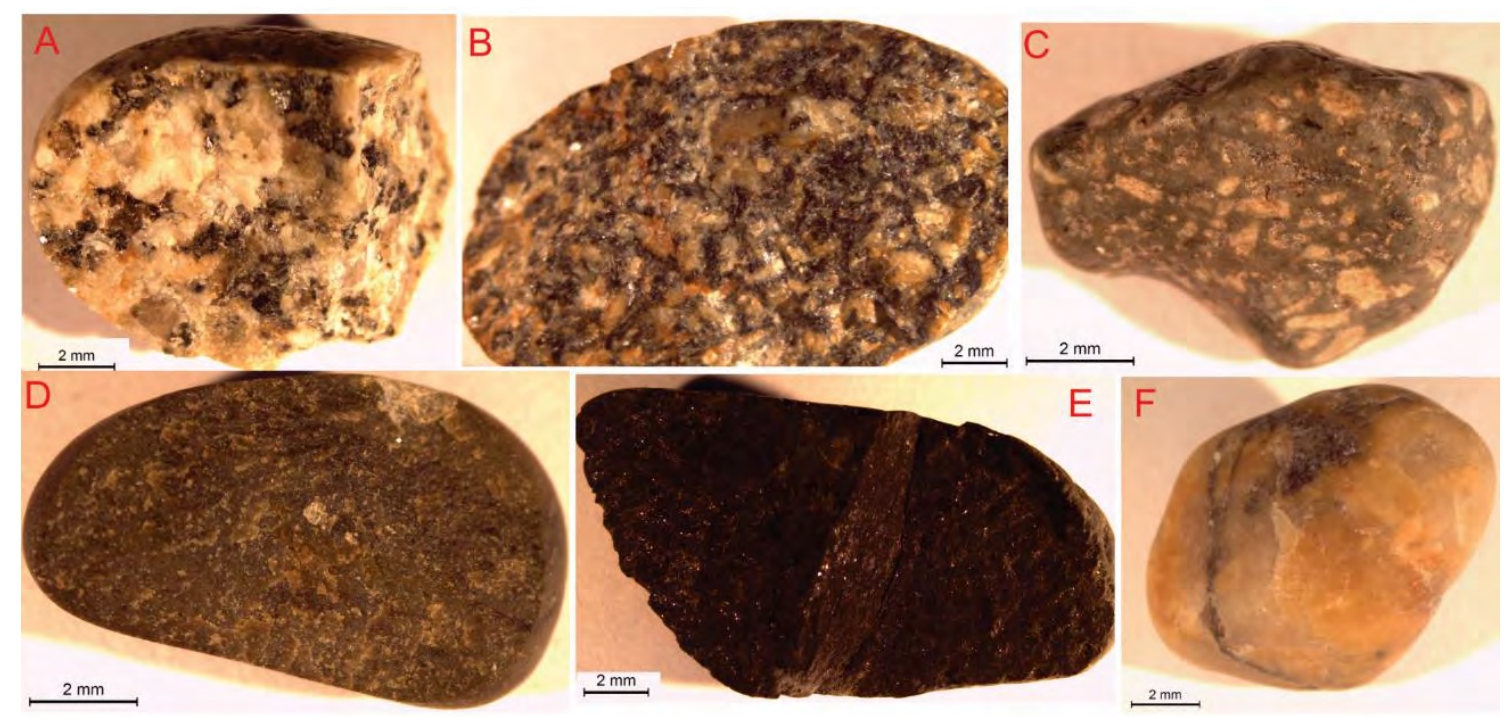

Fig.6.2. Clastos psefíticos presentes en la plataforma continental. A, granodiorita; B, diorita; C, andesita; D, basalto; E, metapelita; F, cuarzo de veta.

Estudios microscópicos más detallados realizados a partir de láminas delgadas permitieron profundizar en las características petrográficas de algunas de estas rocas.

En los basaltos se identificaron principalmente plagioclasa, clinopiroxeno y minerales alterados a clorita. Se reconocieron también pequeños cristales idiomorfos de titanita y minerales opacos, con carbonato y clorita rellenando las vesículas. Se observaron zonas más ricas en vidrio y otras donde el desarrollo cristalino fue mayor (Fig. 6.3A). 
Los pórfidos riolíticos mostraron textura microporfídica donde se identificaron fenocristales subidiomorfos prismáticos de plagioclasa, cuarzo y algunos cristales de feldespato potásico, con matriz holocristalina alterada (clorita y epidoto) (Fig.6.3B).

Algunos granos que a ojo desnudo parecían basaltos alterados, resultaron corresponder con metapelitas de bajo grado (facies de biotita) con retrogradación reflejada en la generación de hidróxidos de Fe provenientes de los filosilicatos. Sin embargo no se descarta que también pudiera deberse a alteración meteórica (supergénica). Se reconocieron cuarzo, biotita, feldespatos (plagioclasa y feldespato potásico) y minerales opacos (pirita), observándose una ligera orientación de los filosilicatos.
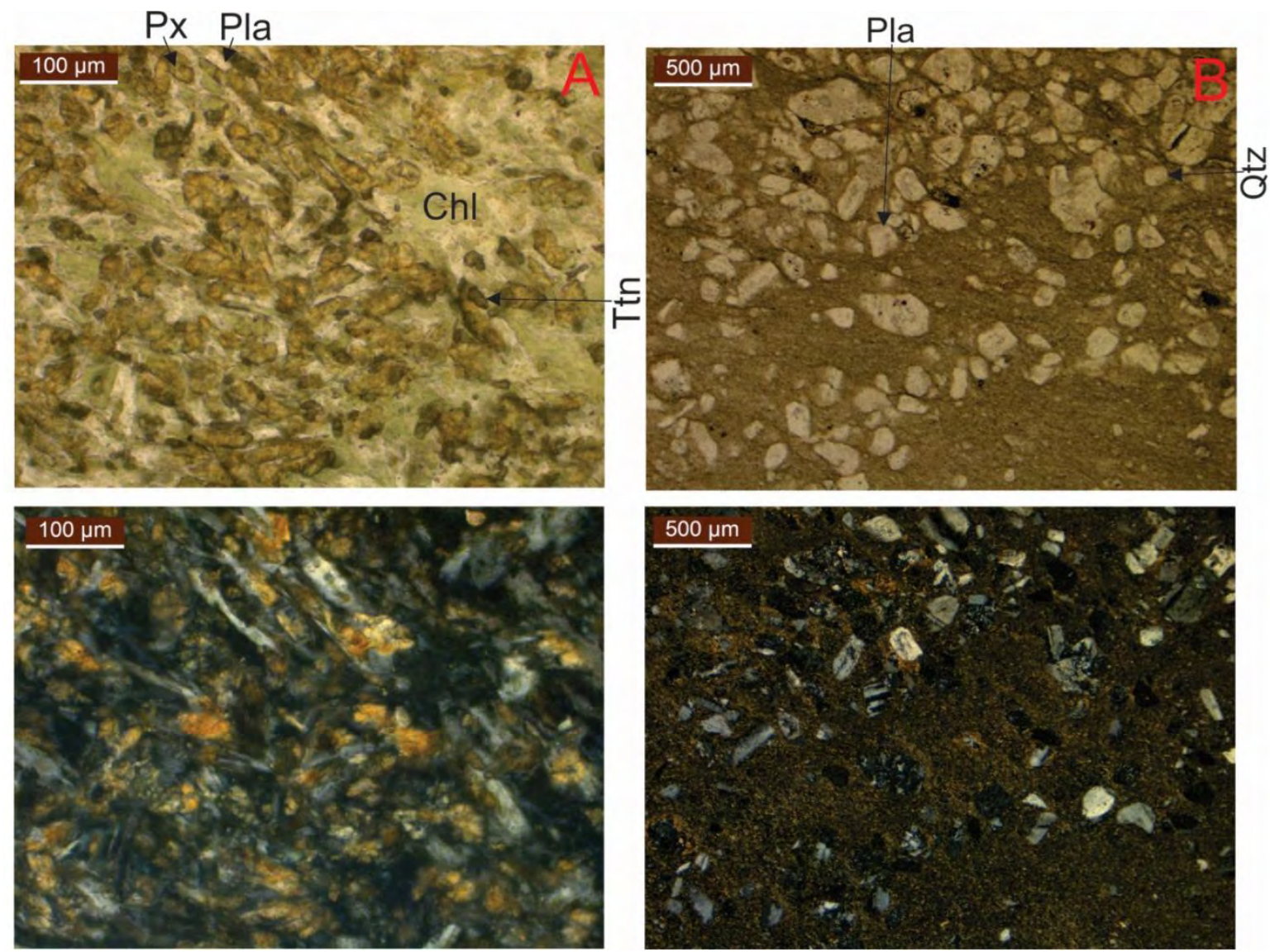

Fig.6.3. Fotografía tomados bajo microscopio petrográfico, con los polarizadores en paralelo (imágenes superiores) y cruzados (imágenes inferiores). A) basalto B) pórfido riolítico.

\subsubsection{Fracción psamítica}

En seis muestras seleccionadas, en función de la granulometría más gruesa y la ubicación en diferentes sectores de la plataforma continental, se separaron los minerales pesados de los livianos mediante la metodología de líquidos densos.

Las proporciones de los minerales y fragmentos líticos pesados obtenidos dieron valores entre $0,25 \%$ y $8,7 \%$, alcanzándose los porcentajes más altos en las muestras 
localizadas en la plataforma media de la zona oriental del Estrecho de Magallanes (12) y en la plataforma externa frente a cabo Vírgenes (2) (Fig.6.4). Los resultados indicaron sedimentos muy variables respecto al contenido en minerales pesados tanto en la plataforma externa como en la media y más constantes en la plataforma interna.

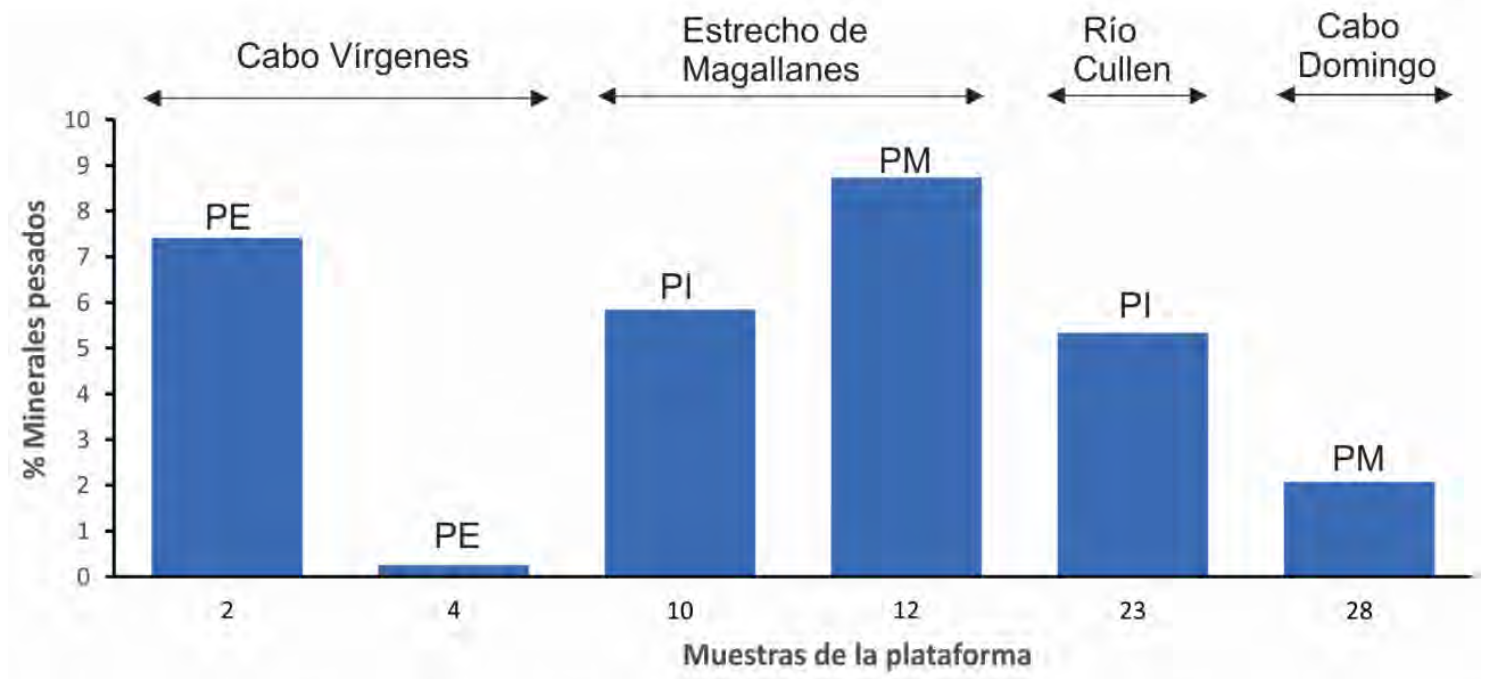

Fig.6.4. Histograma con la proporción de minerales pesados presente en distintos puntos de la Plataforma Continental. $P E$, plataforma externa; PM, plataforma media y PI, plataforma interna.

Respecto a la composición mineral, la fracción liviana se compuso principalmente de fragmentos líticos (50-60\%) seguidos por granos de cuarzo (35-40\%) y plagioclasa (5$10 \%$ ), identificándose también feldespato potásico como mineral accesorio. La cantidad de plagioclasa aumentó ligeramente en las muestras de la plataforma interna y media, disminuyendo en la plataforma continental externa donde hay más cantidad de cuarzo.

En la fracción pesada se reconocieron principalmente minerales del grupo del piroxeno (44\%-49\%), siendo más comunes los clinopiroxenos en las muestras más cercanas a la costa (plataforma interna y media) y los ortopiroxenos en las más alejadas (plataforma externa). Le siguieron en abundancia los clinoanfíboles (14\%-16\%), minerales del grupo del epidoto (4\%-9\%), principalmente epidoto s.s. y algún cristal de clinozoisita y del grupo del granate $(>2 \%)$. Este último aumentó ligeramente en las muestras de la plataforma media y externa. Dentro de los minerales opacos se identificaron ilmenita s.l. (2-7\%) y magnetita s.l. (1-5\%), siendo estos minerales más escasos en la zona de la plataforma interna. También se reconocieron andalucita, circón y titanita. Los fragmentos líticos presentaron porcentajes considerables en todas las zonas (15\%-23\%) (Fig.6.5 y Tabla 6.2). 

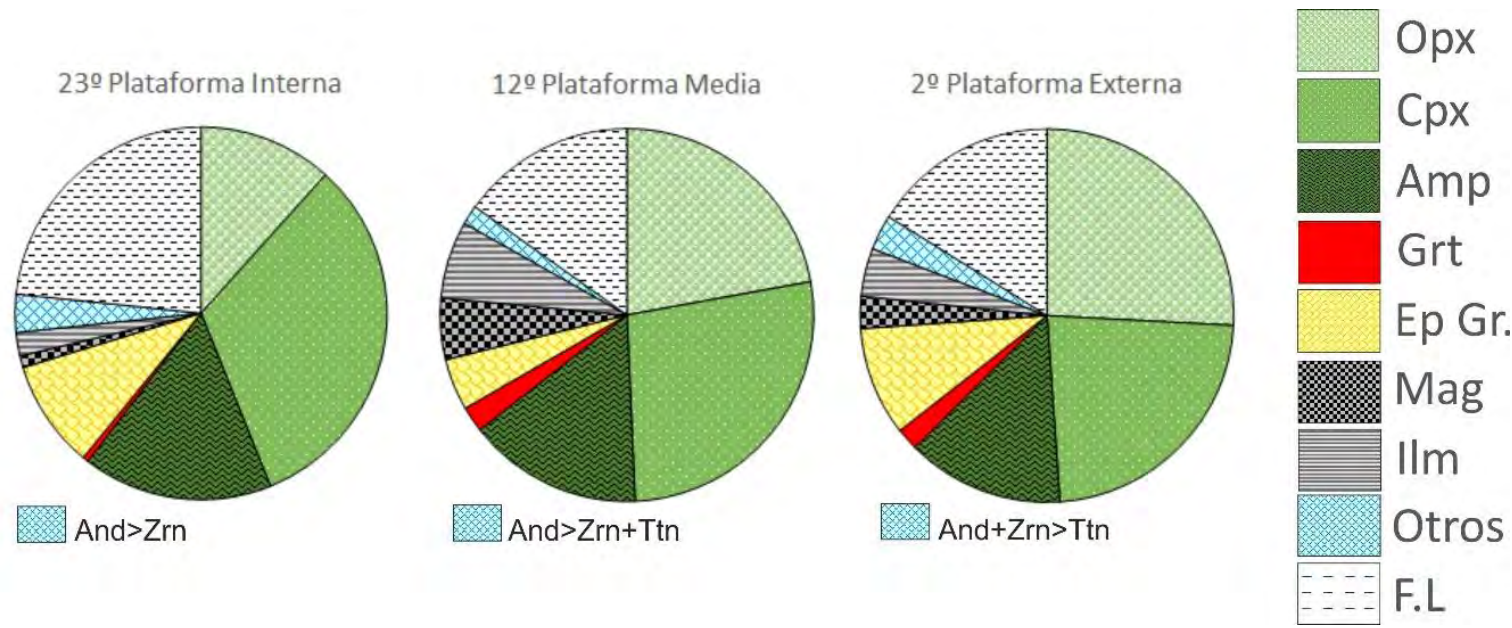

Fig.6.5. Diagramas de "torta" con el análisis cuantitativo por contaje de puntos de las distintas fracciones de minerales pesados. Valores expresados en porcentajes. Abreviaturas: And, andalucita; Zrn, circón; Amp, anfíbol cálcico; Cpx, clinopiroxeno; F.L, fragmentos líticos; Ep. Gr, grupo del epidoto; Grt, grupo del granate; Hem, hematita; Ilm, IImenita s.I.; Mag, magnetita s.I.; Opx, ortopiroxeno y Ttn, titanita.

\begin{tabular}{|c|c|c|c|}
\hline & \multicolumn{3}{|c|}{ Puntos de muestreo } \\
\hline & Plataforma Interna & Plataforma Media & Plataforma Externa \\
\hline & n-23 & no12 & $n \div 2$ \\
\hline Ortopiroxeno & 12 & 22 & 26 \\
\hline Clinopiroxeno & 32 & 27 & 23 \\
\hline Anfíbol cálcico & 16 & 15 & 14 \\
\hline Gr. Granate & 1 & 2 & 2 \\
\hline Gr. Epidoto & 9 & 4 & 9 \\
\hline Circón & $*$ & * & 1 \\
\hline Titanita & $*$ & $*$ & $*$ \\
\hline Andalucita & 3 & 1 & 2 \\
\hline Magnetita s.I & 1 & 5 & 3 \\
\hline IImenita s.I & 2 & 7 & 4 \\
\hline Hematita & $*$ & $*$ & $*$ \\
\hline Fragmentos líticos & 23 & 15 & 16 \\
\hline
\end{tabular}

Tabla 6.2. Porcentaje de minerales pesados presentes en distintos sectores de la plataforma continental. * trazas

\subsubsection{Descripción mineralógica de las arenas}

\subsection{Minerales y fragmentos líticos de la fracción pesada}

Los clinopiroxenos se reconocieron como cristales idiomorfos-subidiomorfos redondeados con hábito prismático, pleocroísmo débil de incoloro a verde claro y clivaje marcado. Presentan inclusiones sólidas tanto de minerales opacos como transparentes. 
Del grupo de los ortopiroxenos se identificó la fase enstatita rica en Fe como granos idiomorfos prismáticos con pleocroísmo de incoloro a castaño claro, clivaje normalmente visible e inclusiones sólidas tanto de minerales opacos como transparentes.

De los minerales del supergrupo del anfíbol únicamente se identificaron clinoanfíboles, correspondientes al anfíbol cálcico, diferenciando una fase mayoritaria con fuerte pleocroísmo de verde a castaño y otra más escasa de anaranjado a castaño ambas con hábito idiomorfo-subidiomorfo prismático con clivaje en una dirección. Se reconocieron también secciones basales (escasas) en las hornblendas con dos direcciones de clivaje.

Del grupo del epidoto se identificaron principalmente epidoto s.s. y en menor cantidad clinozoisita. En el epidoto s.s el color varía desde incoloro hasta amarillo verdoso, mostrando en algunos casos un pleocroísmo moderado, normalmente en secciones redondeadas o con hábito prismático subidiomorfo. Muestra inclusiones sólidas de minerales opacos. Los cristales de clinozoisita presentan desde tonalidades castañas a incoloras. En ocasiones los granos muestran color de interferencia anómalo azul. Se encuentran formando agregados policristalinos junto con el epidoto o en granos individuales con hábito subidiomorfo prismático redondeado.

Los minerales del grupo del granate normalmente presentan formas subidiomorfas redondeadas con abundantes inclusiones sólidas de minerales opacos y transparentes (Fig.6.6).

Dentro de los minerales opacos, se identificó principalmente ilmenita s.l. como granos alargados subidiomorfos con cristales con exsoluciones a fases con más titanio e ilmenita con alteración a hematita en el borde. La magnetita s.l. (más escasa) se reconoció con formas alotriomorfas y en ocasiones martitizada.

Como minerales subordinados y accesorios se identificaron andalucita, circón y titanita. La andalucita presenta secciones prismáticas, algunas de ellas muy redondeadas, con inclusiones sólidas de minerales opacos y transparentes. El circón es muy escaso y normalmente esta redondeado o fragmentado. La titanita se muestra fracturada tanto con hábito prismático subidiomorfo como redondeada con tendencia a la esfericidad, tiene inclusiones sólidas y se observa zonación hacia el borde.

La mayoría de los fragmentos líticos correspondieron a granos de hornblenditas, piroxenitas o granitos, constituidos por agregados de $\mathrm{Pl}+\mathrm{Cam}$ (cloritizada), Qtz+Cam, $\mathrm{Px}+\mathrm{Pl}+\mathrm{Qtz}, \mathrm{Px}+\mathrm{PI}$ o Px+Ep (Fig.6.7). También se identificaron fragmentos de esquistos micáceos, migmatitas (con bandas claras constituidas por cuarzo y oscuras por minerales máficos no reconocibles por el pequeño tamaño de sus cristales) y rocas microporfídicas riolíticas. 


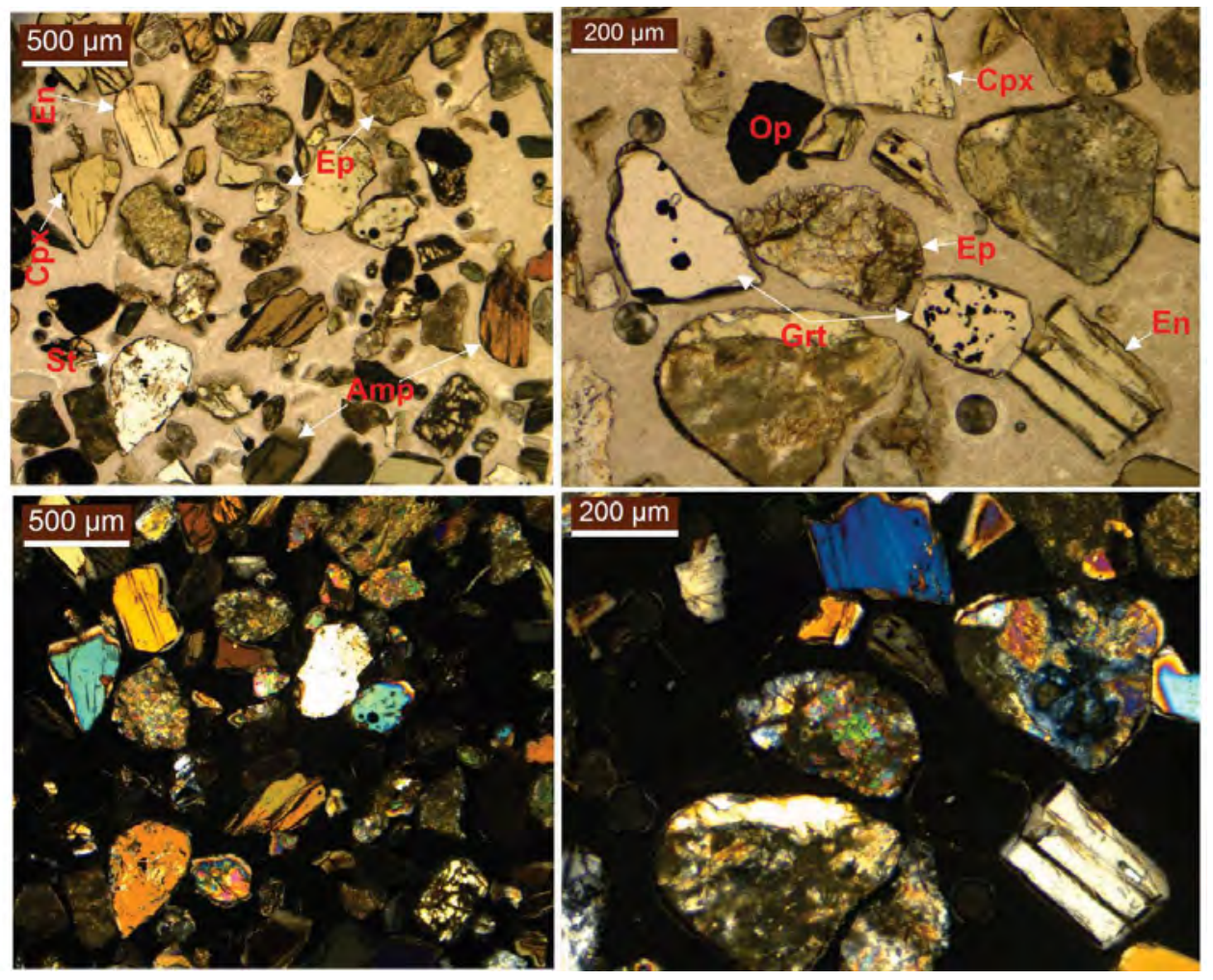

Fig.6.6. Minerales pesados vistos al microscopio petrográfico, con los polarizadores en paralelo en las imágenes superiores y cruzados en las inferiores (muestra no 23). Amp, anfíbol cálcico; Cpx, clinopiroxeno; En, enstatita; Ep, epidoto s.s; St, estaurolita; Grt, mineral del grupo de granate; St, estaurolita; Op, minerales opacos.

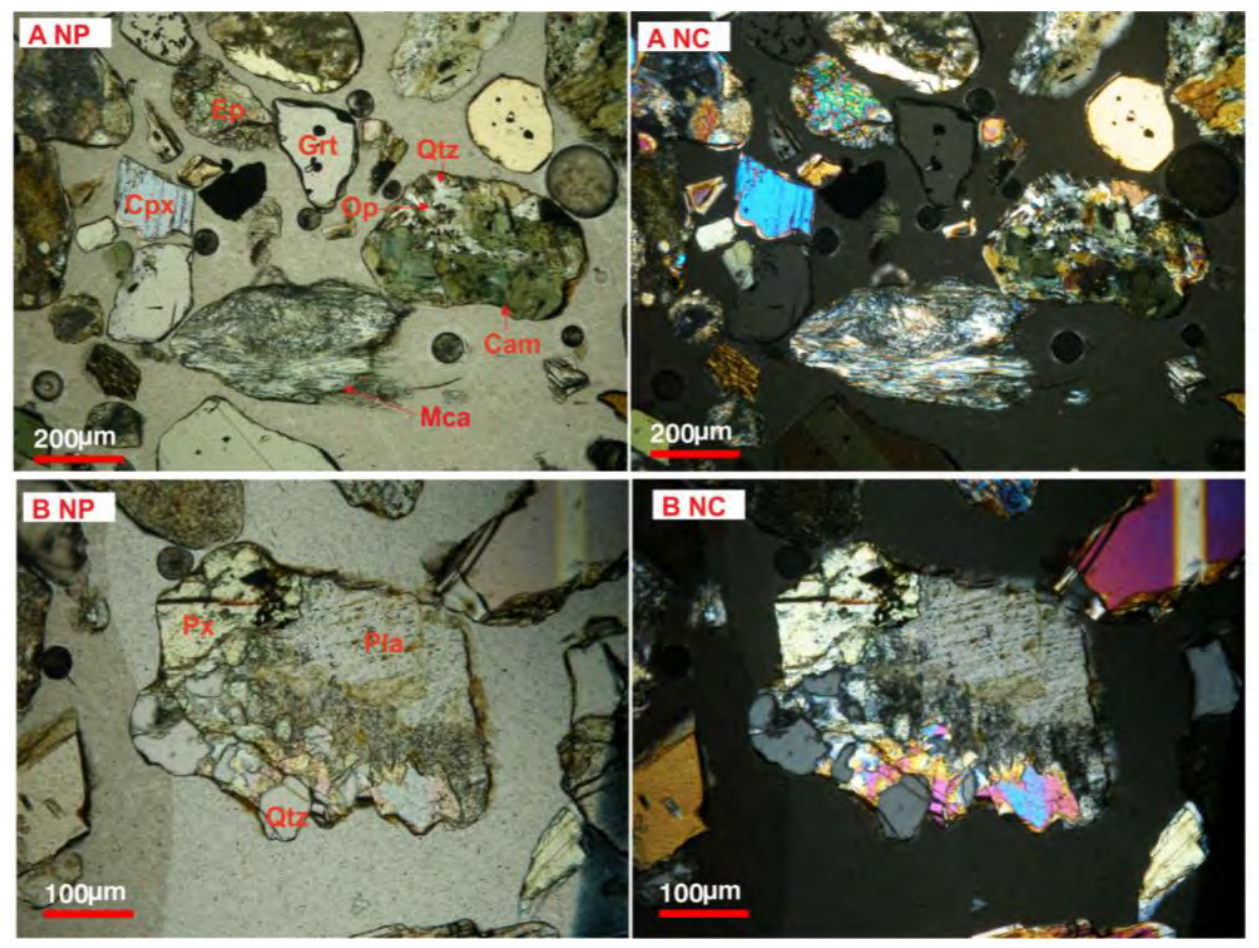

Fig.6.7. Microfotografías de fragmentos líticos y minerales pesados. NP, nicoles paralelos y NC, nicoles cruzados. (Muestra no23). Cam, clinoanfíbol; Qtz, cuarzo; Mca, mica; Pla, plagioclasa; Px, piroxeno. 


\subsection{Minerales y fragmentos líticos de la fracción liviana}

La fracción liviana correspondió a la mayor parte de las muestras, entre un $91 \%$ y 99\%. Está representada fundamentalmente por fragmentos líticos y granos monominerales. Los primeros están constituidos mayoritariamente por agregados de cuarzo con textura granoblástica tanto equigranular como inequigranular con cristales alotriomorfos (cuarcitas) y granos de dacitas con textura hipocristalina porfírica y microporfírica con cristales de cuarzo, feldespato (principalmente plagioclasa) y en algunos casos minerales opacos, rodeados de una pasta vítrea. También fueron observados algunos granos líticos alterados con textura holocristalina constituidos por agregados de epidoto s.s. y clinozoisita.

Entre los granos monominerales los cristales de cuarzo presentan formas subidiomorfas redondeadas, observándose en algunos casos extinción ondulante. Los cristales de plagioclasa presentan hábitos subidiomorfos prismáticos y tabulares, con macla polisintética según las secciones (010) y (001), y en algunos casos en combinación con la macla de Carlsbad (010). Su composición, determinada por el método de Michel Levy, varía desde albita a oligoclasa. Los granos de feldespato potásico tienen hábito prismático subidiomorfo, con macla de Carlsbad (ortosa) y macla en enrejado difuso (microclino) (Fig.6.8).
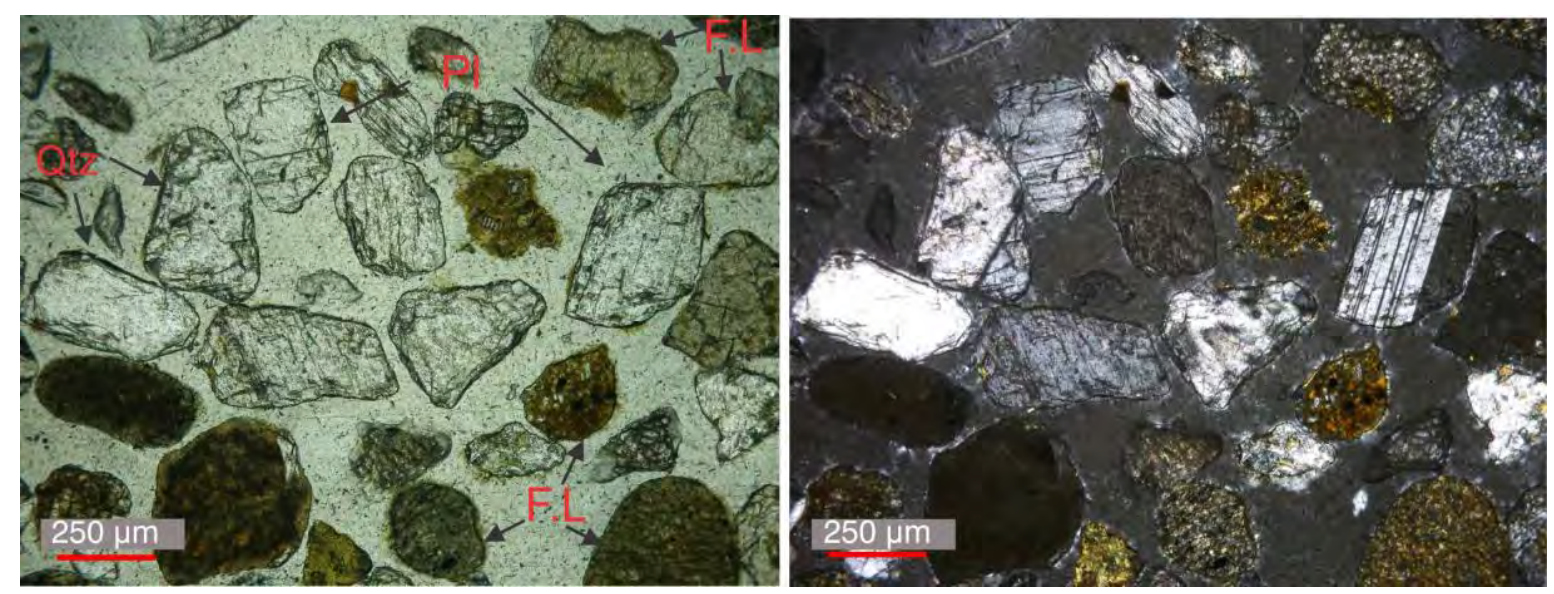

Fig.6.8. Fotomicrografías de granos monominerales y fragmentos líticos (FL) de la fracción de minerales livianos reconocidos en los sedimentos de fondo de la plataforma continental (con polarizadores en paralelo, izquierda y cruzados, derecha, muestra no2). 


\section{Capítulo 7: ANÁLISIS GEOQUÍMICOS DE LOS MINERALES DE LOS DEPÓSITOS DETRÍTICOS}

\subsection{Introducción}

A partir de análisis microquímicos puntuales se puede conocer la composición química de un mineral y por lo tanto clasificarlo. El estudio mineraloquímico de las distintas fases minerales presentes en los diferentes depósitos detríticos del área investigada se realizó mediante microsonda electrónica (EPMA, Electron Probe Micro-Analyzer). En los granos de los depósitos de playas se estudiaron además las inclusiones sólidas mediante microscopio electrónico de barrido (FE-SEM, Field Emision Scanning Electron Microscope) con detector EDS (Energy Dispersive X-ray Spectroscopy).

Como especies principales de la fracción separada de minerales pesados se analizaron minerales del supergrupo del anfíbol, de los grupos del piroxeno, granate, epidoto y espinela, además de óxidos de Fe y Ti. Como minerales accesorios se estudiaron circón, estaurolita, andalucita, titanita, minerales del grupo de la apatita, pirita, oxihidróxidos y minerales del grupo del oro. Respecto a la fracción liviana se analizó plagioclasa y cuarzo con inclusiones de minerales pesados y en grano suelto.

Estos análisis permitieron por un lado profundizar en el conocimiento de la asociación de minerales pesados previamente establecida con análisis petro-calcográficos y por otro lado aportar datos para postular las áreas de procedencia de las diferentes fases presentes.

\subsection{Composición química de las diferentes fases minerales}

\subsubsection{Supergrupo del anfíbol}

La fórmula general de los anfíboles se puede representar como $A B_{2}{ }^{V l} C_{5}{ }^{I V} T_{8} \mathrm{O}_{22}(\mathrm{OH})_{2}$, ocupándose el sitio $\mathrm{T}$ (posición tetraédrica) por Si y AlV; $\mathbf{C}$ (posición octaédrica) por $\mathrm{Al}, \mathrm{Ti}, \mathrm{Fe}^{3+}$, Cr y si todavía hay espacio por $\mathrm{Mg}, \mathrm{Fe}^{2+}$ y $\mathrm{Mn}$ hasta completar la posición; B (posición octaédrica) se ocupa por $\mathrm{Mg}, \mathrm{Fe}^{2+}, \mathrm{Mn}$ y $\mathrm{Ca}$ y A (posición octaédrica) por $\mathrm{Na}$ y K. La fórmula estructural se calculó en base a $23 \mathrm{O}$ y el contenido de $\mathrm{Fe}^{3+}$ según la máxima estimación de $\mathrm{Fe}^{+3}$ de acuerdo al procedimiento de Schumacher (1997). La clasificación de los anfíboles se realizó según Leake et al. (1997). Si bien existe una clasicación más moderna, Hawthorne et al. (2012), en esta tesis se decidió utilizar la 
clasifación de Leake et al. (1997) para que los término obtenidos fuesen comparables con los análisis de otros trabajos realizados en el sector de Cordillera Darwin y zonas aledañas.

Se analizaron 7 anfíboles del sedimento glacigénico (correspondiendo uno de ellos a una zona de alteración dentro un grano de ilmenita) de muestras tomadas en el sector de punta Sinaí (till) y una cantera próxima al cañadón Beta (glacifluvial) (A.1); 4 granos de las arenas procedentes de la Plataforma Continental media y externa (A.2) y finalmente 9 anfíboles presentes en las playas de El Páramo, bahía San Sebastián y punta Sinaí (A.3). Se realizaron análisis en el núcleo y en los bordes de los cristales para identificar posibles zonaciones.

La mayoría de los anfíboles de los tres subambientes muestreados correspondió a magnesiohastingsita seguida por magnesiohornblenda. Se identificaron otras fases como pargasita, tschermakita y ferropargasita en las playas y tschermakita también en los depósitos glaciales (Fig.7.1 y Tabla 7.1).

En algunos anfíboles se midieron también $\mathrm{V}_{2} \mathrm{O}_{3}, \mathrm{ZrO}_{2}, \mathrm{P}_{2} \mathrm{O}_{5}, \mathrm{NiO}, \mathrm{Cl}$ y $\mathrm{F}$ obteniéndose valores muy bajos o por debajo del límite de detección por lo que no se tuvieron en cuenta para la clasificación.
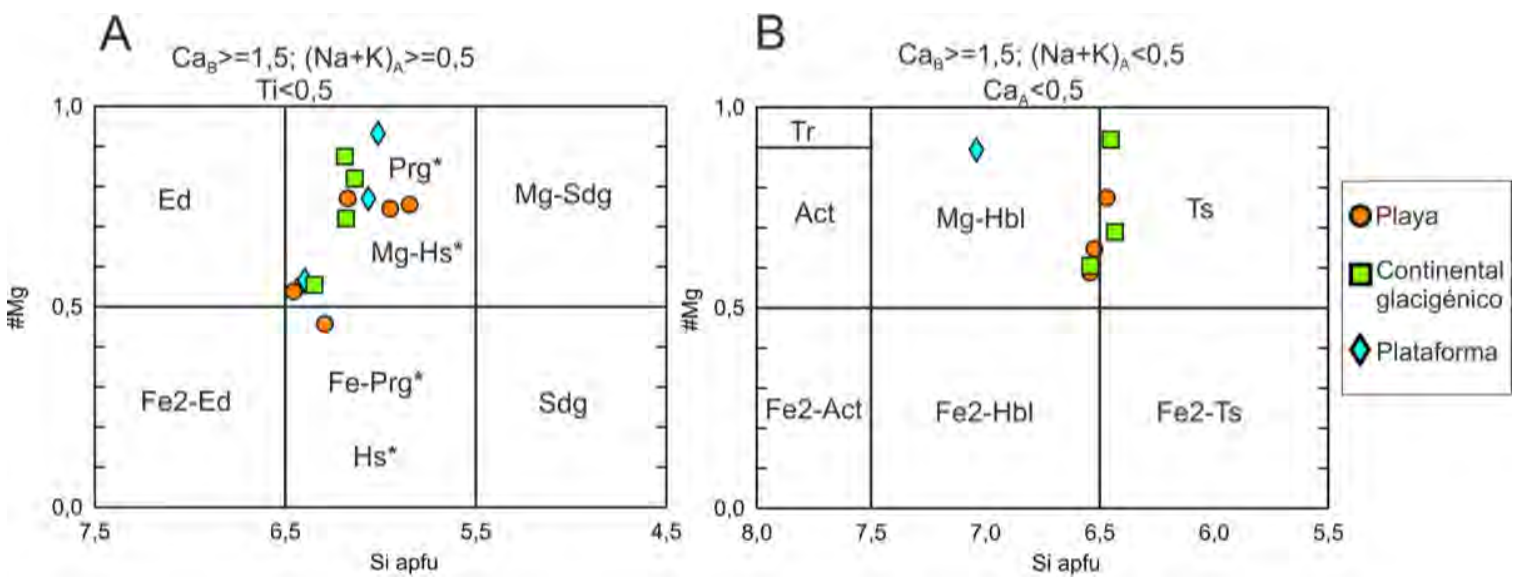

Fig.7.1. A y B clasificación de los anfíboles cálcicos según Leake et al (1997). \#Mg=Mg/(Mg+Fe $\left.{ }^{2+}\right), \mathrm{Prg}^{*}={ }^{V \prime} A l>=F e^{3+}, \mathrm{Mg}-$ $\mathrm{Hs}^{*}={ }^{\mathrm{V}} \mathrm{Al}<\mathrm{Fe}^{3+}, \mathrm{Fe}-\mathrm{Prg}^{*}={ }^{{ }^{\prime}} \mathrm{Al}>=\mathrm{Fe}^{3+}, \mathrm{Hs}^{*}={ }^{\mathrm{V}}{ }^{\prime} \mathrm{Al}<\mathrm{Fe}^{3+}$. Cada símbolo hace referencia al núcleo de un grano.

\subsubsection{Zonaciones}

Se identificaron zonaciones en algunos granos de núcleo a borde, pasando de magnesiohornblenda a edenita (mayor contenido de $\mathrm{Na}$ y $\mathrm{K}$ en posición $\mathrm{A}$ ), de magnesiohastingsita a tschermakita (menor contenido en $\mathrm{Na}$ en la posición $\mathrm{A}$ ) o de pargasita a magnesio-hastingsita (mayor contenido en $\mathrm{Fe}^{3+}$ ). 


\begin{tabular}{|c|c|c|c|c|c|c|c|c|c|c|c|}
\hline \multirow{4}{*}{$\begin{array}{l}\text { Submbiente } \\
\text { Lugar } \\
\text { Mineral } \\
\text { Posición }\end{array}$} & \multicolumn{3}{|c|}{ Continental glacigénico } & \multicolumn{3}{|c|}{ Plataforma } & \multicolumn{5}{|c|}{ Playa } \\
\hline & \multicolumn{2}{|c|}{ A.P.Sinaí } & \multirow{4}{*}{$\begin{array}{c}\text { A.C.Beta } \\
\text { Ts } \\
\text { N } \\
\text { A150 }\end{array}$} & \multirow{4}{*}{$\begin{array}{c}\text { Externa } \\
\text { Mg-Hs } \\
\text { N } \\
\text { A350 }\end{array}$} & \multicolumn{2}{|c|}{ Media } & \multicolumn{2}{|c|}{ *P.Sinaí } & \multirow{4}{*}{$\begin{array}{c}\text { *EI Páramo } \\
\text { Mg-Hbl } \\
\text { N } \\
\text { A460 }\end{array}$} & \multicolumn{2}{|c|}{ B.San Sebastián } \\
\hline & Mg-Hs & Mg-Hbl & & & Mg-Hbl & Mg-Hs & Mg-Hs & Fe-Prg & & Prg & Ts \\
\hline & $\mathrm{N}$ & $\mathbf{N}$ & & & $\mathbf{N}$ & $\mathbf{N}$ & $\mathrm{N}$ & $\mathbf{N}$ & & $\mathbf{N}$ & $\mathbf{N}$ \\
\hline & A22 & A25 & & & A423 & A427 & A449 & BR.162 & & OSR1.24 & OSR1.26 \\
\hline \multicolumn{12}{|l|}{$\%$ en peso } \\
\hline $\mathrm{SiO}_{2}$ & 41,972 & 43,533 & 45,448 & 42,175 & 49,897 & 41,542 & 42,510 & 40,360 & 44,175 & 42,278 & 44,045 \\
\hline $\mathrm{TiO}_{2}$ & 1,746 & 1,629 & 1,596 & 1,620 & 1,248 & 3,955 & 1,206 & 1,262 & 2,485 & 1,635 & 2,091 \\
\hline $\mathrm{Al}_{2} \mathrm{O}_{3}$ & 12,461 & 9,253 & 11,101 & 14,096 & 5,881 & 11,952 & 10,363 & 12,030 & 9,756 & 11,213 & 11,098 \\
\hline $\mathrm{Cr}_{2} \mathrm{O}_{3}$ & 0,105 & 0,000 & 0,129 & 0,070 & 0,000 & 0,000 & 0,000 & 0,000 & 0,034 & 0,000 & 0,000 \\
\hline $\mathrm{Fe}_{2} \mathrm{O}_{3}$ & 5,638 & 5,064 & 6,323 & 7,808 & 8,770 & 4,782 & 4,230 & 3,714 & 4,072 & 3,472 & 6,706 \\
\hline $\mathrm{eO}$ & 8,624 & 12,454 & 2,613 & 2,042 & 3,459 & 7,371 & 14,485 & 15,958 & 11,340 & 13,852 & 6,598 \\
\hline $\mathrm{MnO}$ & 0,304 & 0,779 & 0,084 & 0,085 & 0,448 & 0,210 & 0,699 & 0,587 & 0,669 & 0,540 & 0,379 \\
\hline $\mathrm{MgO}$ & 12,418 & 10,710 & 16,594 & 15,736 & 16,442 & 13,775 & 9,453 & 7,550 & 11,646 & 9,608 & 12,696 \\
\hline $\mathrm{CaO}$ & 12,044 & 11,647 & 11,319 & 11,954 & 11,276 & 11,611 & 11,750 & 11,080 & 11,455 & 11,585 & 10,642 \\
\hline $\mathrm{Na}_{2} \mathrm{O}$ & 1,855 & 1,240 & 2,504 & 2,435 & 1,145 & 2,119 & 1,368 & 1,720 & 1,708 & 1,225 & 1,942 \\
\hline 20 & 0,645 & 1,178 & 0,429 & 0,468 & 0,141 & 1,045 & 1,292 & 1,260 & 0,716 & 1,412 & 0,185 \\
\hline Total & 97,812 & 97,486 & 98,140 & 98,489 & 98,706 & 98,361 & 97,355 & 95,521 & 98,056 & 96,820 & 96,382 \\
\hline \multicolumn{12}{|c|}{ Fórmula estructural en base a 230} \\
\hline $\mathrm{Si}$ & 6,181 & 6,541 & 6,451 & 6,013 & 7,039 & 6,063 & 455 & 6,292 & 6,523 & ,413 & 6,469 \\
\hline AllV & 1,819 & 1,459 & 1,549 & 1,987 & 0,961 & 1,93 & 345 & 1,708 & 1,477 & & 1,531 \\
\hline $\operatorname{sum} T$ & 8,000 & 8,000 & 8,000 & 8,000 & 8,000 & 8,000 & 8,000 & 8,000 & 8,000 & 8,000 & 8,000 \\
\hline AIVI & 0,344 & 0,180 & 0,308 & 0,382 & 0,017 & 0,119 & 0,310 & 0,503 & 0,220 & 0,418 & 0,390 \\
\hline $\mathrm{Ti}$ & 0,193 & 0,184 & 0,170 & 0,174 & 0,132 & 0,434 & 0,138 & 0,148 & 0,276 & 0,186 & 0,231 \\
\hline $\mathrm{Fe}^{3+}$ & 0,625 & 0,573 & 0,675 & 0,838 & 0,931 & 0,525 & 0,483 & 0,436 & 0,452 & 0,396 & 0,741 \\
\hline $\mathrm{Cr}$ & 0,012 & 0,000 & 0,015 & 0,008 & 0,000 & & 000 & & 0,004 & & 0,000 \\
\hline $\mathrm{Mg}$ & 2,726 & 2,399 & 3,511 & 3,344 & 3,458 & 2,997 & 40 & 1,755 & 2,563 & 2,172 & 2,780 \\
\hline $\mathrm{Fe}^{2+}$ & 1,062 & 1,565 & 0,310 & 0,243 & 0,408 & 0,900 & 1,840 & 2,081 & 1,400 & 1,757 & 0,811 \\
\hline $\mathrm{Mn}$ & 0,038 & 0,099 & 0,010 & 0,010 & 0,054 & 0,02 & 0,090 & 0,078 & 0,084 & 0,069 & 0,047 \\
\hline $\mathrm{Ca}$ & 0,000 & 0,000 & 0,0 & 0,000 & 0,000 & 0,0 & 0 & 0,000 & 0,000 & 0 & 0,000 \\
\hline sum & 5,000 & 5,000 & 5,000 & 5,000 & 5,000 & 5,00 & 000 & 5,000 & 5,000 & 5,000 & 5,000 \\
\hline Mg & 0,000 & 0,000 & 0,000 & 0,000 & 0,000 & 0,000 & 0,000 & 0,000 & 0,000 & 0,000 & 0,000 \\
\hline $\mathrm{Fe}^{2+}$ & 0,000 & 0,000 & 0,000 & 0,000 & 0,000 & 0,000 & 0,000 & 0,000 & 0,000 & 0,000 & 0,000 \\
\hline $\mathrm{Mn}$ & 0,000 & 0,000 & 0,000 & 0,000 & 0,000 & 0,000 & 0,000 & 0,000 & 0,000 & 0,000 & 0,000 \\
\hline $\mathrm{Ca}$ & 1,900 & 1,875 & 1,721 & 1,826 & 1,705 & 1,816 & 1,912 & 1,851 & 1,812 & 1,883 & 1,675 \\
\hline $\mathrm{Na}$ & 0,100 & 0,125 & 0,279 & 0,174 & 0,295 & 0,18 & 0,088 & 0,149 & 0,188 & 0,117 & 0,325 \\
\hline sum & 2,000 & 2,000 & 2,000 & 2,000 & 2,000 & 2,000 & 2,000 & 2,000 & 2,000 & 2,000 & 2,000 \\
\hline $\mathrm{Ca}$ & 0,000 & 0,000 & 0,000 & 0,000 & 0,000 & 0,000 & 0,000 & 0,000 & 0,000 & 0,000 & 0,000 \\
\hline $\mathrm{Na}$ & 0,430 & 0,237 & 0,4 & 0,499 & 0,018 & 0,415 & 0,315 & 0,371 & 0,301 & 0,243 & 0,228 \\
\hline $\mathrm{K}$ & 0,121 & 0,226 & 0,078 & 0,085 & 0,025 & 0,195 & 0,250 & 0,251 & 0,135 & 0,273 & 0,035 \\
\hline $\operatorname{sum} A$ & 0,551 & 0,462 & 0,488 & 0,585 & 0,043 & 0,610 & 0,565 & 0,622 & 0,436 & 0,517 & 0,263 \\
\hline Total & 15,551 & 15,462 & 15,488 & 15,585 & 15,043 & 15,610 & 15,565 & 15,622 & 15,436 & 15,517 & 15,263 \\
\hline \#Mg & 0,72 & 0,61 & 0,92 & 0,93 & 0,89 & 0,77 & 0,54 & 0,46 & 0,65 & 0,55 & 0,77 \\
\hline
\end{tabular}

Tabla 7.1. Análisis representativos de los diferentes anfíboles identificados en las arenas de las playas, de los sedimentos glacigénicos continentales y del lecho de la Plataforma Continental. $\# \mathrm{Mg}=\mathrm{Mg} /\left(\mathrm{Mg}+\mathrm{Fe}^{2+}\right)$. ${ }^{*}$ Nivel enriquecido.

\subsubsection{Grupo del piroxeno}

Los piroxenos están representados por la fórmula $\mathrm{M}_{2} \mathrm{M}_{1} \mathrm{~T}_{2} \mathrm{O}_{6}$, donde $\mathbf{T}$ (posición tetraédrica) representa $\mathrm{Si}^{+4}, \mathrm{Al}^{3+}$ y $\mathrm{Fe}^{3+} ; \mathbf{M}_{1}$ (posición octaédrica) $\mathrm{Al}^{3+}, \mathrm{Fe}^{3+}$, $\mathrm{Ti}^{4+}, \mathrm{Cr}^{3+}, \mathrm{V}^{3+}, \mathrm{Ti}^{3+}, \mathrm{Zr}^{4+}, \mathrm{Sc}^{3+}, \mathrm{Zn}^{2+}, \mathrm{Mg}^{2+}, \mathrm{Fe}^{2+}$ y $\mathrm{Mn}^{2+} ;$ y $\mathbf{M}_{2}$ (coordinación octaédrica distorsionada) $\mathrm{Mg}^{2+}, \mathrm{Fe}^{2+}, \mathrm{Mn}^{2+}, \mathrm{Li}^{+}, \mathrm{Ca}^{2+}$ y $\mathrm{Na}^{+}$. Los piroxenos más comunes pueden representarse en diagramas ternarios $\mathrm{Ca}-\mathrm{Mg}-\mathrm{Fe}^{*}$ donde el $\mathrm{Ca}$ corresponde a la wollastonita $\left(\mathrm{CaSiO}_{3}\right), \mathrm{Mg}$ con la enstatita $\left(\mathrm{MgSiO}_{3}\right)$ y $\mathrm{Fe}^{*}\left(\mathrm{Fe}^{2+}+\mathrm{Fe}^{3+}+\mathrm{Mn}\right)$ con la ferrosilita (Morimoto et al. 1988). 
Se analizaron un total de 21 piroxenos de los depóstios glaciales presentes en punta Sinaí y acantilado próximo a los cañadones Beta y Tortuga (A.4 y A.5) ; 13 piroxenos de la plataforma interna, media y externa (A.6) y finalmente 78 piroxenos de las playas de punta Sinaí, bahía San Sebastián, El Páramo (incluyendo la espiga) y de los cañadones Alfa, Beta y Tortuga (A.7-A.11).

A partir del cálculo de los miembros extremos según Morimoto et al. (1988) se pudieron determinar las mismas fases minerales en los tres subambientes (Fig. 7.2). Dentro de los clinopiroxenos se diferenciaron augita $\left(\mathrm{Ca}, \mathrm{Mg}, \mathrm{Fe}^{2+}, \mathrm{Al}, \mathrm{Ti}\right)_{2}(\mathrm{Si}, \mathrm{Al})_{2} \mathrm{O}_{6}$ y en menor medida diópsido $\left(\mathrm{CaMgSi}_{2} \mathrm{O}_{6}\right)$. Los ortopiroxenos correspondieron únicamente a la fase enstatita rica en hierro $\left(\mathrm{Mg}, \mathrm{Fe}^{2+}\right) \mathrm{Si}_{2} \mathrm{O}_{6}$.

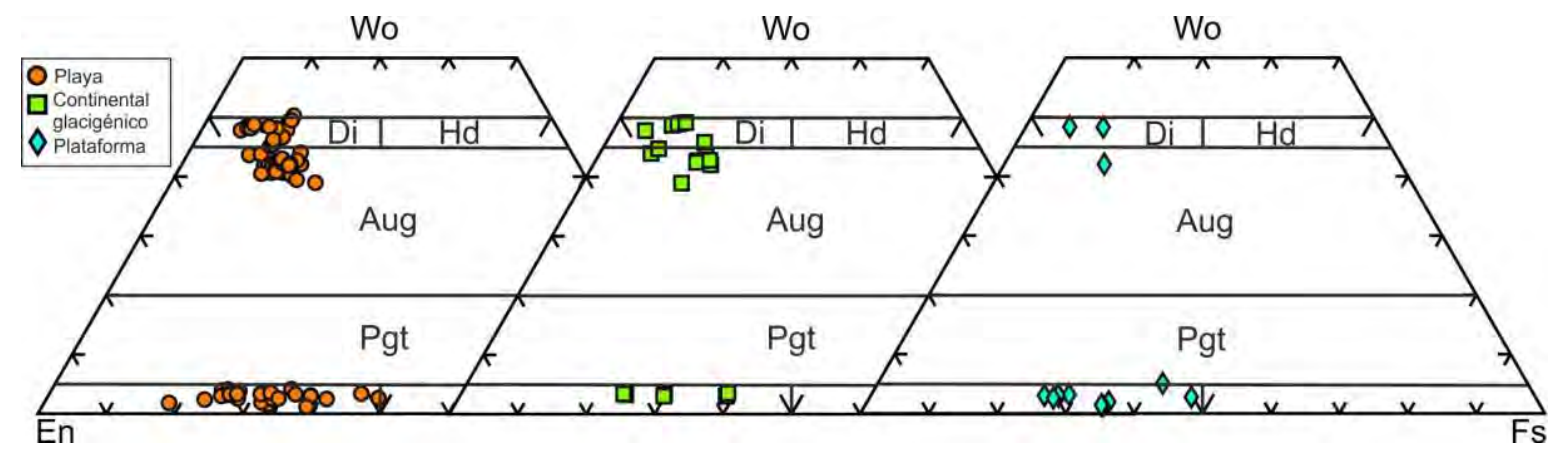

Fig.7.2. Diagramas composicionales ternarios Wo-En-Fs con la graficación de los principales piroxenos analizados en los distintos subambientes. Cada punto representa el núcleo de un grano.

Los piroxenos de las playas presentaron una composición media $W_{41,7} E_{43,6} F_{s_{14,7}}$ (augita), $W_{48} E n_{42} F s_{10}$ (diópsido), $W_{3} E n_{65} F s_{32}$ (enstatita rica en Fe). Por su parte en el sedimento glacial las composiciones correspondieron a $W_{{ }_{43}} E n_{43} F_{s_{14}}$ (augita), $W_{{ }_{48,2}} E n_{42,5} F s_{9,3}$ (diópsido), $W_{o_{3}} E n_{66} F s_{31}$ (enstatita rica en Fe). Finalmente, en los depósitos sedimentarios de la plataforma continental las composiciones obtenidas fueron $W_{42} E n_{43} F s_{15}$ (augita) $W_{0_{48}} E n_{43} F s_{9}$ (diópsido) $W_{0} E n_{66} F s_{32}$ (enstatita rica en Fe). Un grano de estas arenas correspondió a la fase pigeonita $W_{0} E n_{53} F s_{42}$ debido a un mayor contenido en $\mathrm{Ca}(2,2 \%)$ con respecto a la enstatita rica en Fe.

Los diópsidos mostraron un alto contenido en $\mathrm{CaO}$ y $\mathrm{MgO}$ con valores promedio de $23,25 \%$ y $14,77 \%$ respectivamente. El \#Mg (\#Mg=MgO/(MgO+FeO $\left.{ }^{2+}\right)$ varió entre 0,77 y 0,98 .

Las augitas se diferenciaron de los diópsidos principalmente por su menor contenido en $\mathrm{CaO}$, valor promedio de $20,31 \%$ y ligeramente mayor contenido de $\mathrm{FeO}$ y $\mathrm{Fe}_{2} \mathrm{O}_{3}$, con valores promedio de 6,6\% y 2,42\%. El \#Mg fue un poco menor en relación a la fase diópsido, con valores entre 0,66 y 0,91. 
Los ortopiroxenos presentaron la misma variación composicional en los tres subambientes, correspondiente a la fase enstatita rica en $\mathrm{Fe}$, con un contenido promedio de $\mathrm{FeO}$ de 18,88\%. A diferencia de los clinopiroxenos anteriormente citados, el contenido en $\mathrm{CaO}$ fue muy reducido, con valores promedio de 1,38\%. Un grano se localizó en el límite con la fase pigeonita debido al mayor contenido en $\mathrm{CaO}$. El \#Mg presentó un rango entre 0,52 y 0,82 .

Los valores de $\mathrm{Cr}, \mathrm{V}, \mathrm{Ni}, \mathrm{Zr}, \mathrm{K}, \mathrm{Zn}, \mathrm{P}$ y Ta normalmente fueron muy bajos o por debajo del límite de detección. En la Tabla 7.2 se indican los cálculos estadísticos realizados englobando los piroxenos de los tres subambientes.

No se detectaron zonaciones significativas de núcleo a borde en los diferentes piroxenos analizados.

\begin{tabular}{|c|c|c|c|c|}
\hline \multirow[b]{2}{*}{ wt $\%$} & \multicolumn{4}{|c|}{ Augita ( $\mathrm{N}=41$ ) } \\
\hline & Min & Max & Prom & D.S \\
\hline $\mathrm{SiO}_{2}$ & 48,060 & 53,214 & 50,994 & 1,288 \\
\hline $\mathrm{TiO}_{2}$ & 0,245 & 1,187 & 0,617 & 0,185 \\
\hline $\mathrm{Al}_{2} \mathrm{O}_{3}$ & 1,324 & 4,636 & 2,646 & 0,733 \\
\hline $\mathrm{Cr}_{2} \mathrm{O}_{3}$ & L.D & 0,438 & - & - \\
\hline $\mathrm{Fe}_{2} \mathrm{O}_{3}$ & 0,000 & 5,817 & 2,418 & 1,429 \\
\hline $\mathrm{FeO}$ & 2,821 & 12,328 & 6,596 & 1,907 \\
\hline $\mathrm{MnO}$ & 0,072 & 0,562 & 0,284 & 0,090 \\
\hline $\mathrm{MgO}$ & 13,400 & 16,966 & 15,171 & 0,942 \\
\hline $\mathrm{CaO}$ & 18,595 & 21,920 & 20,309 & 0,724 \\
\hline $\mathrm{Na}_{2} \mathrm{O}$ & 0,211 & 0,541 & 0,323 & 0,068 \\
\hline $\mathrm{K}_{2} \mathrm{O}$ & L.D & 0,011 & 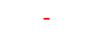 & 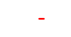 \\
\hline $\mathrm{NiO}$ & L.D & 0,043 & - & - \\
\hline $\mathrm{ZnO}$ & L.D & L.D & - & - \\
\hline $\mathrm{V}_{2} \mathrm{O}_{3}$ & L.D & 0,096 & - & - \\
\hline $\mathrm{Zr}_{2} \mathrm{O}$ & L.D & 0,097 & - & - \\
\hline \multicolumn{5}{|l|}{ a.p.f.u } \\
\hline $\mathrm{Si}$ & 1,827 & 1,982 & 1,902 & 0,033 \\
\hline $\mathrm{Ti}$ & 0,007 & 0,034 & 0,017 & 0,005 \\
\hline $\mathrm{Al}^{\mathrm{IV}}$ & 0,059 & 0,202 & 0,116 & 0,032 \\
\hline $\mathrm{Cr}$ & 0,000 & 0,013 & 0,002 & 0,003 \\
\hline $\mathrm{Fe}^{3+}$ & 0,000 & 0,160 & 0,068 & 0,040 \\
\hline $\mathrm{Fe}^{2+}$ & 0,090 & 0,390 & 0,206 & 0,060 \\
\hline $\mathrm{Mn}$ & 0,002 & 0,018 & 0,009 & 0,003 \\
\hline Mg & 0,756 & 0,926 & 0,843 & 0,046 \\
\hline $\mathrm{Ca}$ & 0,751 & 0,860 & 0,812 & 0,024 \\
\hline $\mathrm{Na}$ & 0,015 & 0,039 & 0,023 & 0,005 \\
\hline K & 0,000 & 0,001 & 0,000 & 0,000 \\
\hline $\mathrm{Ni}$ & 0,000 & 0,001 & 0,000 & 0,000 \\
\hline $\mathrm{Zn}$ & 0,000 & 0,000 & 0,000 & 0,000 \\
\hline v & 0,000 & 0,003 & 0,001 & 0,001 \\
\hline $\mathrm{Zr}$ & 0,000 & 0,002 & 0,000 & 0,000 \\
\hline En & $\mid 39,578$ & 48,538 & 43,546 & 2,195 \\
\hline Wo & 38,933 & 44,732 & 41,918 & 1,355 \\
\hline Fs & 7,526 & 21,096 & 14,536 & 2,592 \\
\hline$\# M g$ & 0,665 & 0,909 & 0,805 & 0,052 \\
\hline
\end{tabular}

\begin{tabular}{cccc}
\multicolumn{5}{c}{ Diópsido(N=25) } \\
\hline Min & Max & Prom & D.S \\
\hline 48,738 & 53,391 & 51,135 & 1,596 \\
0,095 & 0,838 & 0,458 & 0,215 \\
1,018 & 6,849 & 3,322 & 1,607 \\
L.D & 0,605 & - & - \\
0,000 & 4,112 & 1,802 & 1,183 \\
0,500 & 7,291 & 4,113 & 1,525 \\
0,000 & 0,790 & 0,163 & 0,145 \\
12,348 & 16,798 & 14,766 & 1,199 \\
21,139 & 24,258 & 23,246 & 0,848 \\
0,153 & 0,460 & 0,249 & 0,071 \\
L.D & 0,032 & - & - \\
L.D & 0,092 & - & - \\
L.D & L.D & - & - \\
L.D & 0,334 & - & - \\
L.D & L.D & - & - \\
& & & \\
1,797 & 1,960 & 1,895 & 0,047 \\
0,003 & 0,023 & 0,013 & 0,006 \\
0,045 & 0,298 & 0,145 & 0,071 \\
0,000 & 0,017 & 0,006 & 0,005 \\
0,000 & 0,116 & 0,050 & 0,033 \\
0,015 & 0,225 & 0,128 & 0,048 \\
0,000 & 0,025 & 0,005 & 0,005 \\
0,698 & 0,919 & 0,816 & 0,060 \\
0,850 & 0,957 & 0,923 & 0,030 \\
0,011 & 0,033 & 0,018 & 0,005 \\
0,000 & 0,002 & 0,000 & 0,000 \\
0,000 & 0,003 & 0,000 & 0,001 \\
0,000 & 0,000 & 0,000 & 0,000 \\
0,000 & 0,010 & 0,000 & 0,002 \\
0,000 & 0,000 & 0,000 & 0,000 \\
& & & \\
37,463 & 47,447 & 42,425 & 2,615 \\
45,082 & 50,259 & 48,053 & 1,281 \\
4,746 & 14,394 & 9,522 & 2,646 \\
0,772 & 0,984 & 0,864 & 0,051 \\
& & &
\end{tabular}

\begin{tabular}{|c|c|c|c|c|}
\hline \multicolumn{4}{|c|}{ Enstatita- $(\mathrm{Fe})(\mathrm{N}=45)$} & \multirow{2}{*}{$\frac{\text { Pigeonita ( } N=1}{5 \mathrm{AC} 3121}$} \\
\hline Min & Max & Prom & D.S & \\
\hline 50,275 & 55,602 & 53,048 & 1,106 & 52,497 \\
\hline 0,062 & 0,447 & 0,222 & 0,089 & 0,425 \\
\hline 0,326 & 3,140 & 1,014 & 0,548 & 3,033 \\
\hline L.D & 0,175 & - & - & 0,000 \\
\hline 0,000 & 4,517 & 0,778 & 1,287 & L.D \\
\hline 11,246 & 28,153 & 18,876 & 3,846 & 21,968 \\
\hline 0,223 & 1,637 & 0,757 & 0,373 & 0,713 \\
\hline 16,907 & 28,932 & 23,484 & 2,686 & 16,530 \\
\hline 0,546 & 2,084 & 1,375 & 0,398 & 2,182 \\
\hline L.D & 0,107 & - & - & 0,540 \\
\hline L.D & 0,016 & - & - & L.D \\
\hline L.D & 0,046 & - & - & L.D \\
\hline L.D & L.D & - & - & L.D \\
\hline L.D & 0,114 & - & - & L.D \\
\hline L.D & 0,050 & - & - & L.D \\
\hline 1,888 & 2,004 & 1,966 & 0,027 & 2,031 \\
\hline 0,002 & 0,013 & 0,006 & 0,002 & 0,012 \\
\hline 0,014 & 0,134 & 0,044 & 0,023 & 0,138 \\
\hline 0,000 & 0,005 & 0,000 & 0,001 & 0,000 \\
\hline 0,000 & 0,128 & 0,022 & 0,036 & 0,000 \\
\hline 0,340 & 0,904 & 0,587 & 0,130 & 0,711 \\
\hline 0,007 & 0,053 & 0,024 & 0,012 & 0,023 \\
\hline 0,968 & 1,538 & 1,295 & 0,126 & 0,953 \\
\hline 0,022 & 0,083 & 0,055 & 0,016 & 0,090 \\
\hline 0,000 & 0,008 & 0,001 & 0,002 & 0,040 \\
\hline 0,000 & 0,001 & 0,000 & 0,000 & 0,000 \\
\hline 0,000 & 0,001 & 0,000 & 0,000 & 0,000 \\
\hline 0,000 & 0,000 & 0,000 & 0,000 & 0,000 \\
\hline 0,000 & 0,003 & 0,000 & 0,001 & 0,000 \\
\hline 0,000 & 0,001 & 0,000 & 0,000 & 0,000 \\
\hline 48,912 & 79,887 & 65,366 & 6,493 & 53,296 \\
\hline 1,097 & 4,134 & 2,756 & 0,797 & 5,055 \\
\hline 18,303 & 48,445 & 31,879 & 6,618 & 41,649 \\
\hline 0,517 & 0,817 & 0,688 & 0,068 & 0,573 \\
\hline
\end{tabular}

Tabla 7.2. Análisis estadísticos de los valores analíticos porcentuales y parámetros de fórmula química de elementos mayoritarios y minoritarios obtenidos mediante microsonda electrónica en los piroxenos de los tres subambientes. L.D: valores por debajo de límite de detección, no utilizados para los cálculos. - cálculo estadístico no realizado. \#Mg= $\mathrm{MgO} /\left(\mathrm{MgO}+\mathrm{FeO}^{2+}\right)$. La estimación del $\mathrm{Fe}^{+2}$ y $\mathrm{Fe}^{+3}$ se realizó siguiendo el método de Droop (1987) y los miembros finales se calcularon según Morimoto et al. (1988). 
Las inclusiones sólidas de los clinopiroxenos analizados mediante FE-SEM correspondieron a pirrotina (cristales alargados), plagioclasa (andesina-anortita), ilmenita, magnetita titanífera, flúorapatita y galena (Fig.7.3A-C). Análisis realizados con microsonda electrónica en inclusiones solidas presentes en las fases augita y enstatita rica en Fe indicaron inclusiones de magnetita titanífera.

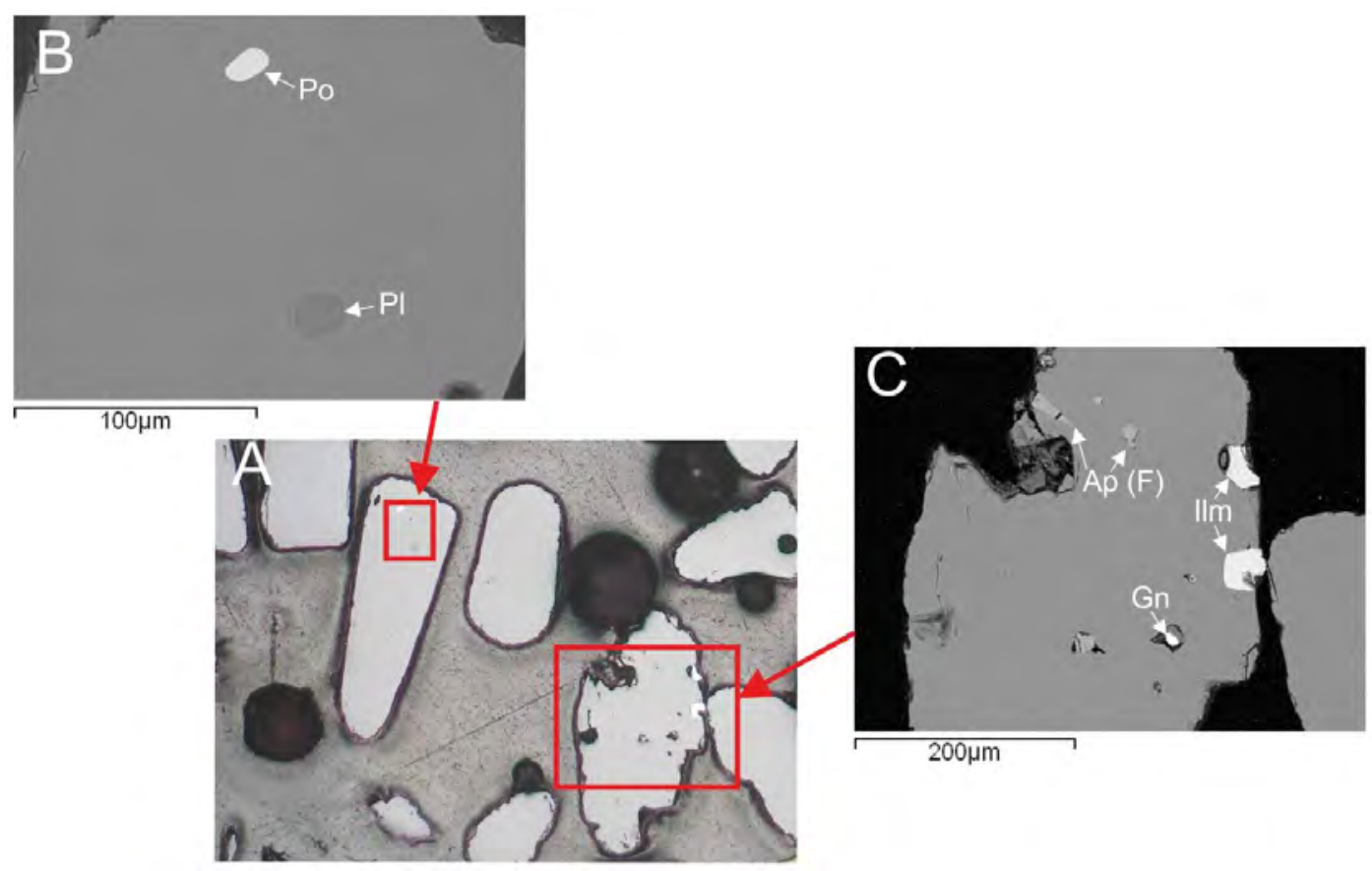

Fig. 7.3. A) Microfotografía realizada mediante microscopio de luz reflejada. B) y C) imágenes obtenidas con microscopio electrónico de barrido (FESEM). Po: Pirrotina, Pl: Plagioclasa, Ap (F): Flúorapatita, Ilm: Ilmenita, Gn: Galena.

\subsubsection{Grupo del granate}

La fórmula general de los granates anhidros se puede resumir como $\mathrm{X}_{3} \mathrm{Y}_{2} \mathrm{Z}_{3} \mathrm{O}_{12}$. Siguiendo la metodología utilizada por Locock (2008) el tetraedro $\mathbf{Z}$ está ocupado por Si que puede ser sustituido por $\mathrm{Al}$ y $\mathrm{Fe}^{3+}$ hasta llenar todo el sitio (3 a.p.f.u), el sitio octaédrico Y está compuesto por el exceso de $\mathrm{Si}$, el resto de $\mathrm{Al}$ y $\mathrm{Fe}^{3+}$ y todo el $\mathrm{Ti}, \mathrm{Zr}, \mathrm{Cr}, \mathrm{y} \mathrm{V}$. Si es necesario se utiliza el $\mathrm{Fe}^{2+}$ para completarlo (2 a.p.f.u). El sitio $\mathbf{X}$ es ocupado por todo el $\mathrm{Na}, \mathrm{Ca}, \mathrm{Mn}^{2+}$ y el resto de $\mathrm{Mg}$ y Fe ${ }^{2+}$ (3 a.p.f.u). Pueden contener bajas concentraciones de otros elementos como $\mathrm{P}, \mathrm{K}, \mathrm{Ni}, \mathrm{Zn}, \mathrm{Nb}, \mathrm{Ta}$, pero no se consideran ya que no contribuyen porcentualmente en forma significativa a la composición de los granates.

Se analizó un total de 113 granates de las playas de los cañadones Alfa, Beta y Tortuga, El Páramo (incluyendo la espiga), bahía San Sebastián y punta Sinaí (A.12-A.20); 12 del sedimento glacigénico de los acantilados de los cañadones Beta y Tortuga (depósitos glacifluviales) y punta Sinaí (depósitos de till) (A.21 y A.22) y 10 de la Plataforma 
Continental interna, media y externa (A.23). Se efectuaron análisis tanto del núcleo como del borde de los granos, realizándose en algunos de ellos perfiles transversales.

Los análisis realizados mostraron una gran variabilidad composicional de los granates, dominando en las playas principalmente la fase almandino con $\mathrm{Alm}_{64,6}>\mathrm{Sps}_{20,4} \mathrm{y}$ en menor medida $\operatorname{Alm}_{74,3}>\operatorname{Prp}_{11,7}$ y $\operatorname{Alm}_{67,3}>\mathrm{Grs}_{13,6}$. En dos granos analizados dominó la fase espessartina $\mathrm{Sps}_{46,6}>\mathrm{Alm}_{38,4}$.

En el sedimento glacigénico solo se encontraron granates de tipo almandino dominando la fase $A_{1 m_{71}}>\operatorname{Sps}_{15,4}$, seguida por Alm66,2 $>\operatorname{Grs}_{17,5}$ y $\operatorname{Alm}_{69,1}>\operatorname{Prp}_{20,6}$.

Por su parte en la plataforma continental se identificaron granates de la especie almandino, con Alm $64>\mathrm{Sps}_{17,8}, \mathrm{Alm}_{78,7}>\mathrm{Pir}_{10,3}$, y escasos granos con $\mathrm{Alm}_{63}>\mathrm{Grs}_{16}$.

En los tres subambientes los elementos V, Cr, Zr y Na se detectaron en muy bajas concentraciones o no fueron detectados.

En función de los valores obtenidos en los granates se puede concluir que en los tres subambientes existe un predominio de la fase almandino, rica en $\mathrm{Mn}$ y en menor medida $\mathrm{Ca}$ y $\mathrm{Mg}$. Únicamente en los granates de las playas se identificó la variedad espessartina. La coexistencia de estos minerales en las tres zonas con una composición similar, Alm>Sps, Alm>Prp y Alm>Grs, indica que estos minerales provienen de las mismas fuentes. La fase espessartina, detectada únicamente en los niveles ricos muestreados en las playas de los cañadones Alfa y Beta, posiblemente sea debido a que la concentración de granates como consecuencia del transporte marino es mucho mayor. En la Tabla 7.3 se muestran los valores porcentuales analíticos y los cálculos estadísticos realizados. 


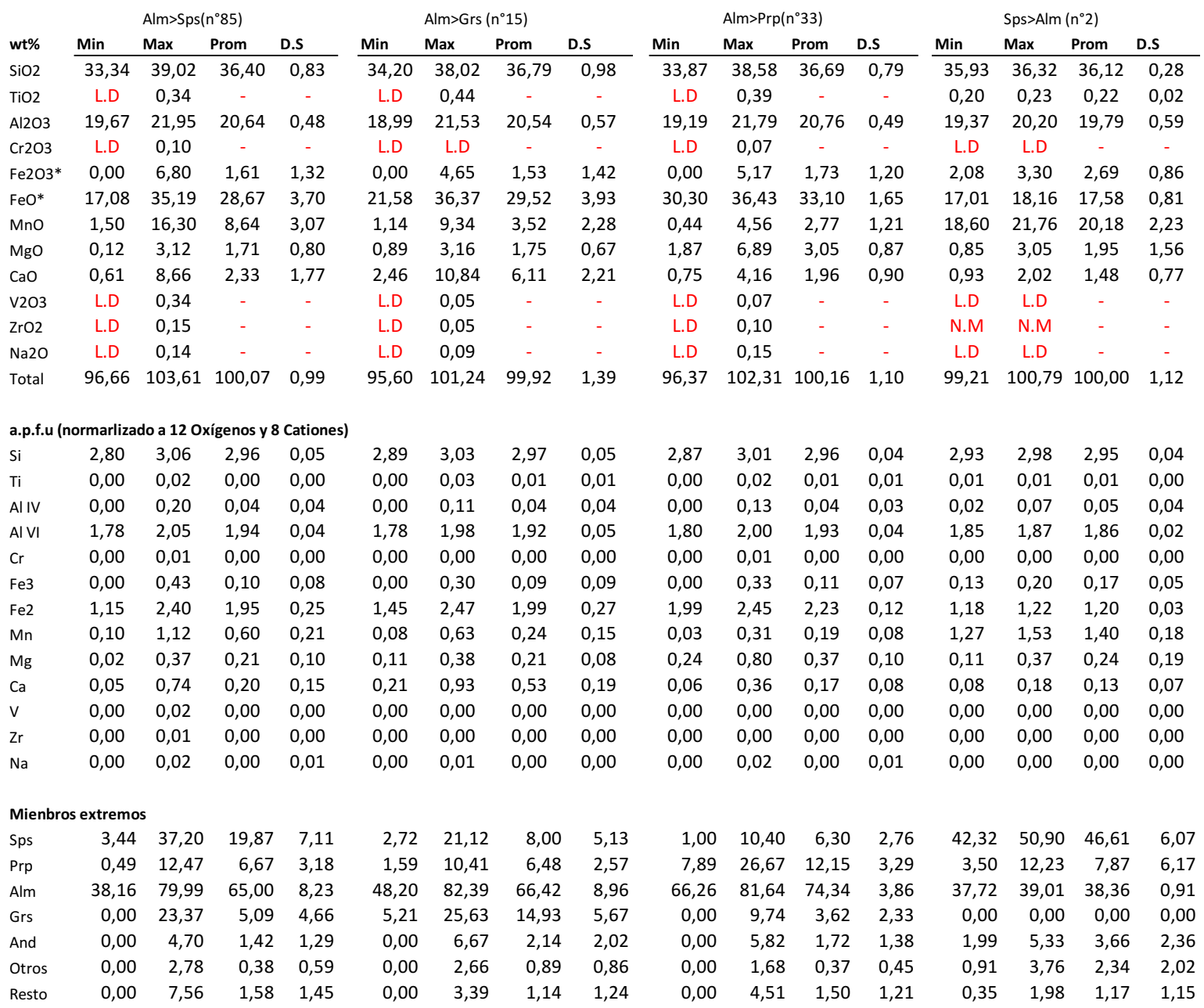

Tabla 7.3. Promedios de los granates analizados en los tres subambientes. $\mathrm{Fe}_{2} \mathrm{O}_{3} *$ y $\mathrm{FeO}^{*}$ calculados según el método de Droop (1987). L.D: por debajo del límite de detección; N.M: elemento no medido; -parámetro estadístico no calculado. Miembros extremos calculados mediante la planilla de Locock (2008). Algunos resultados analíticos si bien tienen cierres composicionales por debajo del $98 \%$ y por encima del 102\%, han sido incluidos para brindar una información cualitativasemicuantitativa.

A partir de los análisis realizados con FE-SEM y microsonda electrónica se determinó que las inclusiones solidas de los granates corresponden a cuarzo (con inclusiones de rutilo), ilmenita, sulfuro de Fe (probablemente pirita o pirrotina), circón, calcopirita, flúorapatita, monacita-(Ce) y allanita-(Ce) (Fig.7.4). 

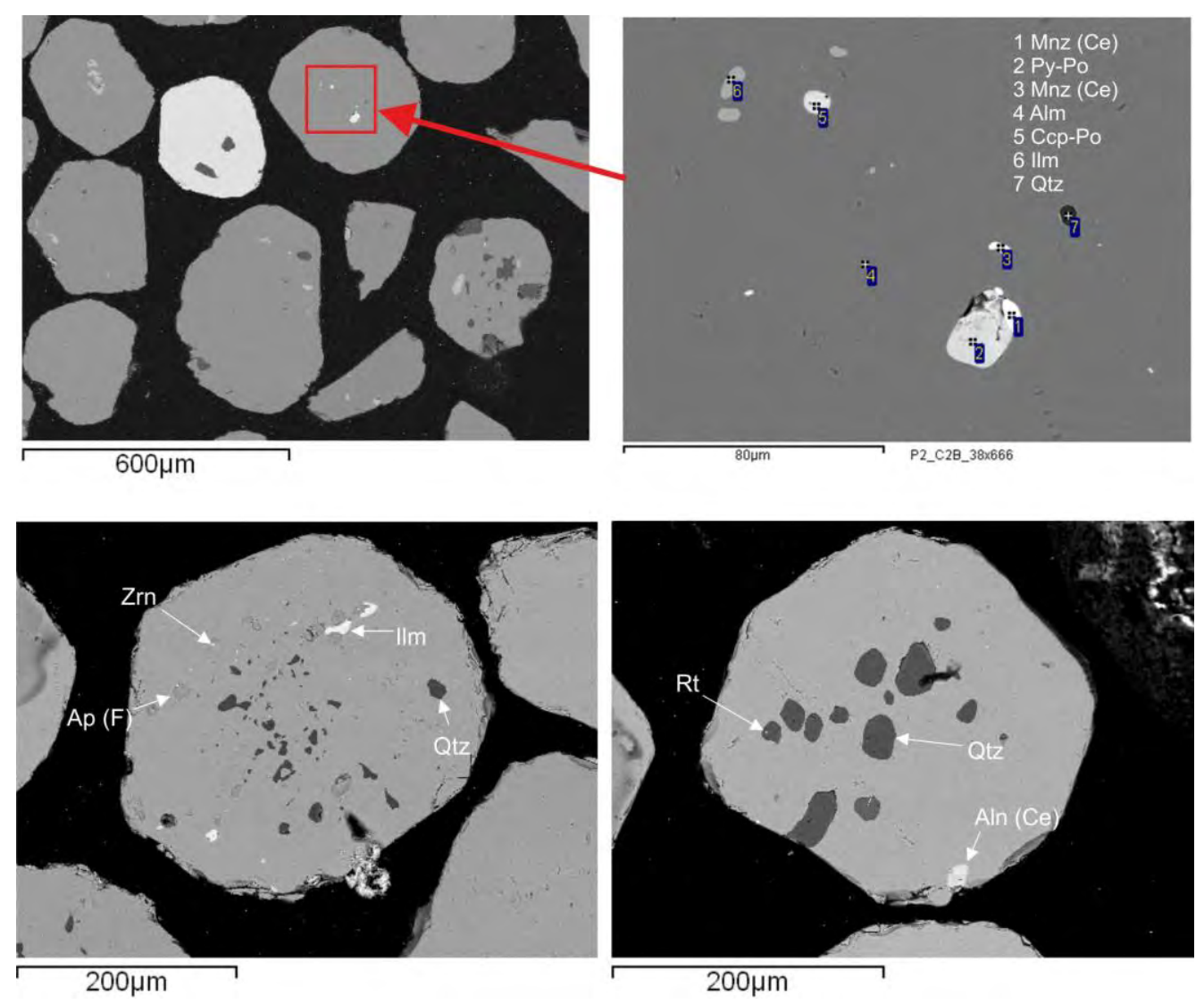

Fig. 7.4. Imágenes realizadas mediante SEM a granos de granate. Abreviaturas: $\mathrm{Mnz}$ (Ce), monacita-(Ce); Py, pirita; Alm, almandino; Ccp, calcopirita; Po, pirrotina; Ilm, ilmenita; Qtz, cuarzo; Zrn, circón; Ap (F), flúorapatita; Aln (Ce), allanita-(Ce) y $R$ t, rutilo.

\subsubsection{Zonaciones}

En la mayoría de los granates no se observa zonación. Solamente en una minoría se determinó un aumento de Fe y Mg hacia los bordes, disminuyendo el de Ca y Mn (Fig. 7.5).
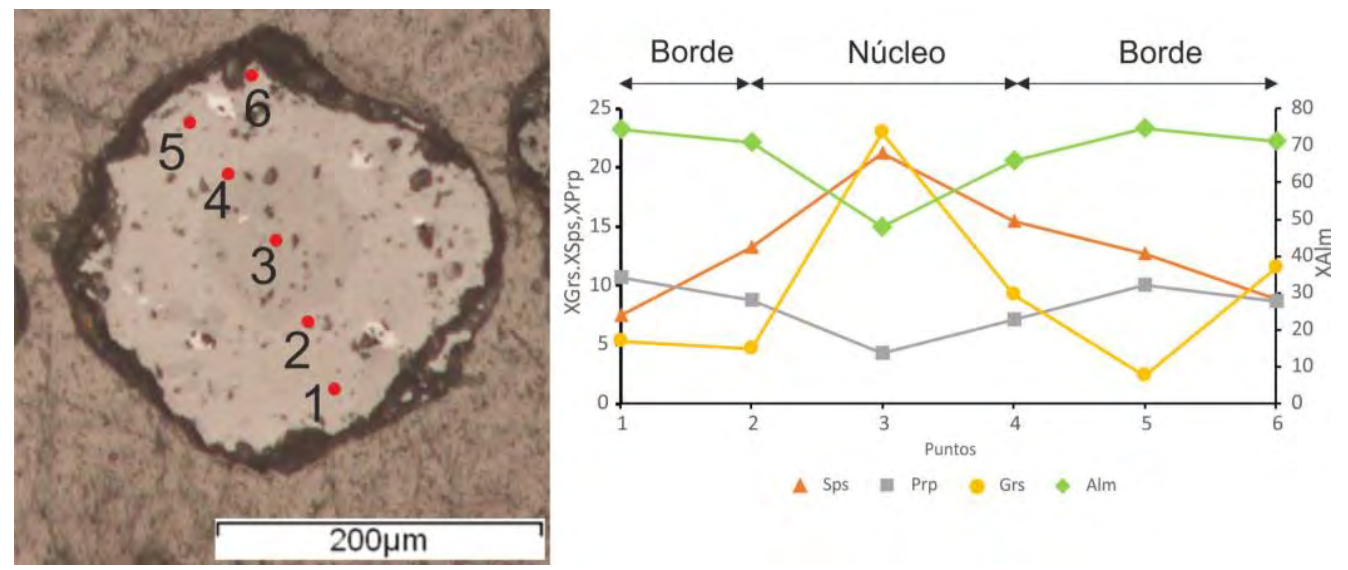

Fig. 7.5. Imagen realizada mediante microscopio petrocalcográfico en granate analizado por microsonda electrónica donde se observa cierta variación composicional entre el núcleo y los bordes del grano. Muestra de la playa del sector de El Páramo. 


\subsection{4 Óxidos de Fe y $\mathrm{Ti}$}

Mediante el diagrama $\mathrm{FeO}-\mathrm{Fe}_{2} \mathrm{O}_{3}-\mathrm{TiO}_{2}$ se pueden dividir los principales óxidos en cuatro grupos (Buddington y Lindsley 1964, Meinhold 2010): (1) solución sólida ulvoespinela-magnetita, (2) ilmenita-hematita, (3) pseudobrookita-ferroseudobrookita y (4) rutilo (Fig.7.6).

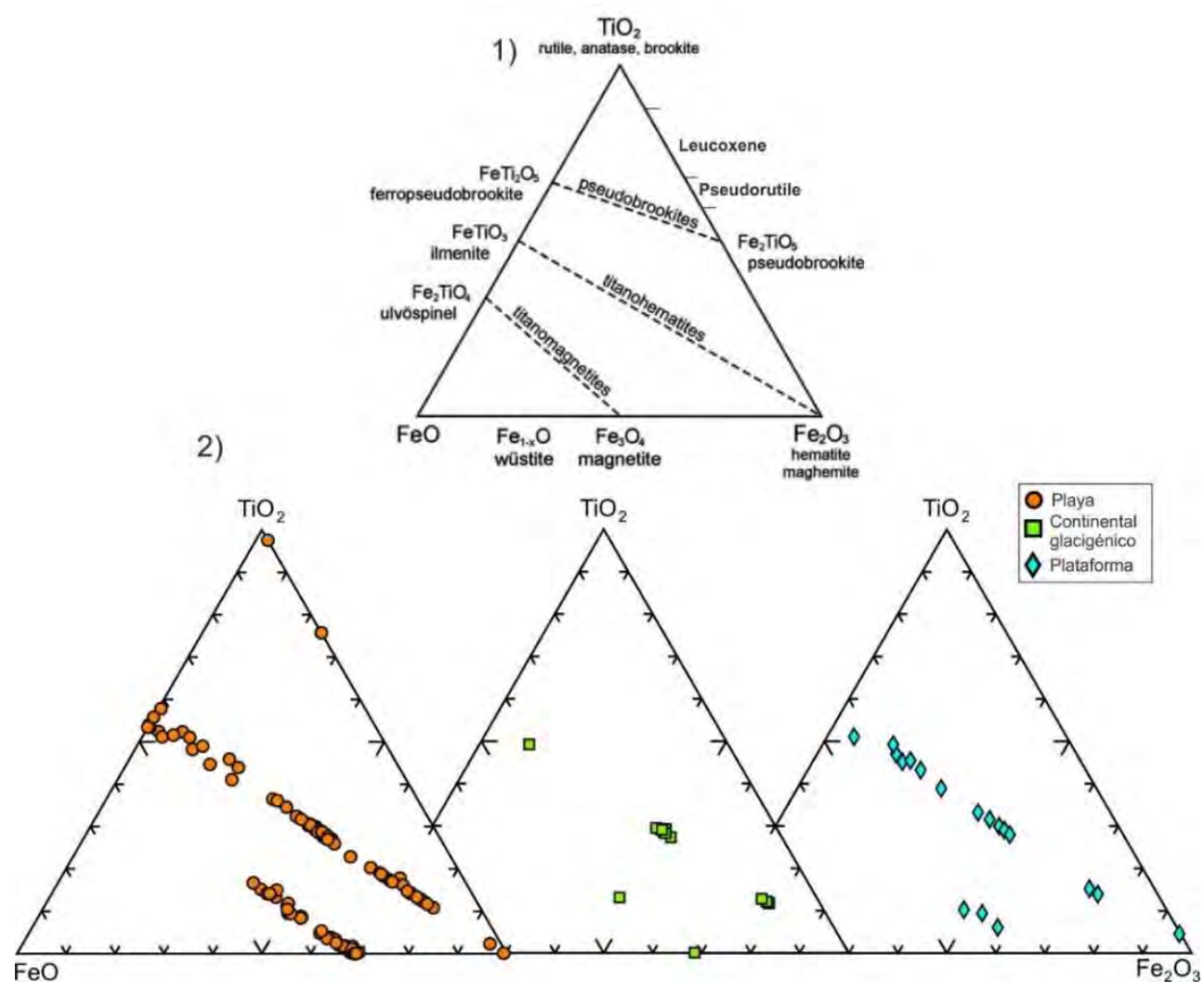

Fig. 7.6. Diagramas ternarios $\mathrm{TiO}_{2}-\mathrm{FeO}-\mathrm{Fe}_{2} \mathrm{O}_{3}$. 1) Clasificación de los óxidos de Fe-Ti. Las líneas a trazos indican solución sólida completa entre miembros extremos a altas temperaturas (Buddington y Lindsley 1964, Reyneke y Wallmach 2007, Meinhold 2010). 2) Diagramas ternarios con los análisis realizados en los diferentes subambientes.

Dentro de la solución sólida ilmenita-hematita, en relación al contenido en Ti, los óxidos de Fe y Ti se pueden agrupar en ilmenitas, óxidos intermedios de Fe-Ti y hematita titanífera (incluyendo la hematita; Dill et al. 2018). Estas fases corresponden a grupos diferentes de minerales (grupo de la llmenita y grupo de la hematita), pero muchas veces es difícil establecer un límite en los términos intermedios con respecto al contenido de Ti.

La fórmula de las ilmenitas puede ser expresada como $\left(\mathrm{Fe}^{+2}, \mathrm{Mg}, \mathrm{Mn}\right) \mathrm{TiO}_{3}$, pudiéndose encontrar también cantidades significativas de $\mathrm{Fe}^{3+}, \mathrm{Al}, \mathrm{Cr}$ y V. A medida que disminuye el contenido en $\mathrm{Ti}$ y aumenta $\mathrm{el} \mathrm{Fe}^{3+}$ la solución sólida se traslada hacia el extremo de la hematita $\mathrm{Fe}_{2} \mathrm{O}_{3}$. 
Se analizaron un total de 92 granos en las playas de los cañadones Alfa, Beta y Tortuga, El Páramo (incluyendo la espiga), bahía San Sebastián y punta Sinaí (A.24-A.31); 13 del sedimento glacial (till) de los acantilados del cañadón Beta y punta Sinaí (A.32) y 15 de la Plataforma Continental interna, media y externa (A.33). Se realizaron análisis tanto en el núcleo de los granos como en las lamelas de exsolución.

Las ilmenitas analizadas en las playas tuvieron un contenido en $\mathrm{TiO}_{2}$ entre un $39,8 \%$ y un $56,8 \%$ encontrándose en menor medida ilmenitas ricas en $\mathrm{MnO}$, con un contenido entre $5,1 \%$ y $8,3 \%$, o ricas en $\mathrm{MgO}$ cuyo porcentaje en peso varió entre $3 \%$ y 3,6\%. Presentaron como elementos minoritarios $\mathrm{V}, \mathrm{Si}, \mathrm{Ca}, \mathrm{Al}$. Los óxidos intermedios de Fe y $\mathrm{Ti}$, fase mayoritaria en las muestras, el contenido en $\mathrm{TiO}_{2}$ varió entre $22,3 \%$ y $35,7 \%$. Como componentes minoritarios se detectaron $\mathrm{Mn}, \mathrm{Mg}, \mathrm{Al}, \mathrm{V}$ y $\mathrm{Cr}$. Las hematitas titaníferas analizadas mostraron un contenido en $\mathrm{TiO}_{2}$ variable entre $0,1 \%$ y $19,1 \%$, con $\mathrm{Al}, \mathrm{Ti}, \mathrm{V}, \mathrm{Cr}$, Ca y Si como elementos minoritarios (Tabla 7.4). Las hematitas s.s. con muy bajo contenido en Ti son muy escasas. 


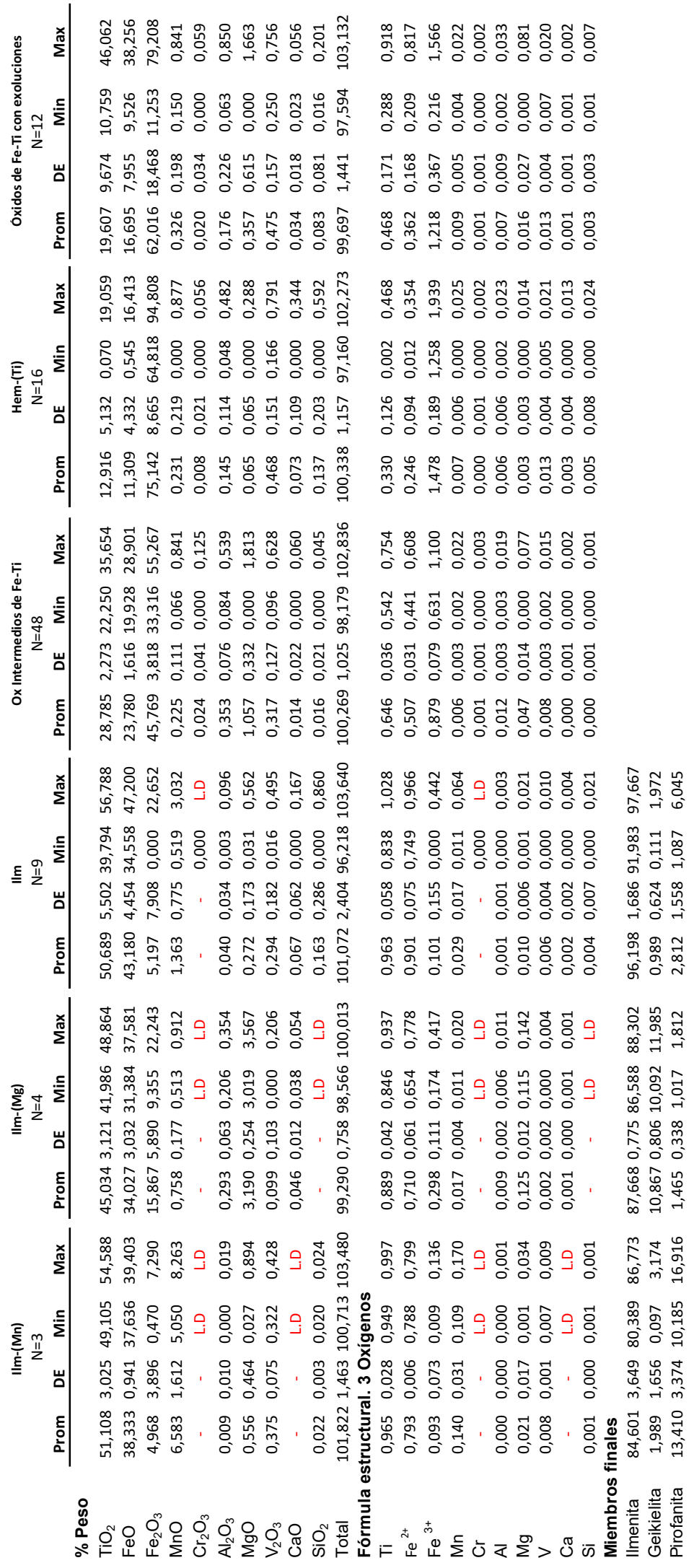

Tabla 7.4. Contenidos analíticos porcentuales y parámetros estadísticos de los óxidos de Fe y Ti analizados en las playas. L.D por debajo del límite de detección; - parámetro estadístico no calculado. IIm-( $\mathrm{Mn})$, ilmenita enriquecida en pirofanita molar; Ilm-(Mg), ilmenita enriquecida en geikielita molar; Hem-(Ti), hematita titanífera. 
Los óxidos intermedios de Fe y Ti presentaron inclusiones de circón con formas idiomórficas de hábito prismático, flúorapatita y cloroapatita en secciones basales o como cristales prismáticos alargados con terminaciones en bipirámides, calcopirita, pirrotina y plagioclasa (andesina).

Es común encontrar granos subidiomorfos alargados con texturas de exsolución. Principalmente correspondieron a hematitas titaníferas y óxidos intermedios de $\mathrm{Fe} \mathrm{y} \mathrm{Ti}$ (contenido en $\mathrm{TiO}_{2}$ entre 14\% y $26 \%$ ), con dos generaciones o lamelas de exsolución de ilmenitas paralelas a la sección (0001) (Fig.7.7A y B y Fig.7.7B). La primera generación de exsoluciones presentó un espesor variable entre 10 y $22 \mu \mathrm{m}$ y la segunda entre 1 y $2 \mu \mathrm{m}$. Las exsoluciones mostraron una mayor variabilidad composicional en relación al contenido en $\mathrm{TiO}_{2}$, desde un $26 \%$ hasta $48 \%$ en peso. Como elementos minoritarios en estos granos se detectaron V, Mg, Mn, Al, Si y un grano además $\operatorname{Cr}(0,06 \%)$.

Con menor frecuencia se identificaron granos de ilmenitas con una generación de exsolución de hematitas titaníferas paralela al plano (0001) (Fig.7.7C) o con exsoluciones a magnetita titanífera en una proporción similar, generando bandas deformadas (Fig.7.8A).

En los granos de hematitas titaníferas con exsoluciones se detectaron inclusiones de plagioclasa (andesina), flúorapatita y titanita. Algunos granos presentaron un borde de reacción con rutilo que separa el grano de hematita titanífera de una zona sin exsoluciones compuesta por hematita. El rutilo aparece como agregados irregulares perpendiculares a las lamelas de exsolución de ilmenita y sustituyendo a éstas (Fig.7.7B y Fig.7.8B). En algunos casos también se observó cómo agujas.

\section{B}
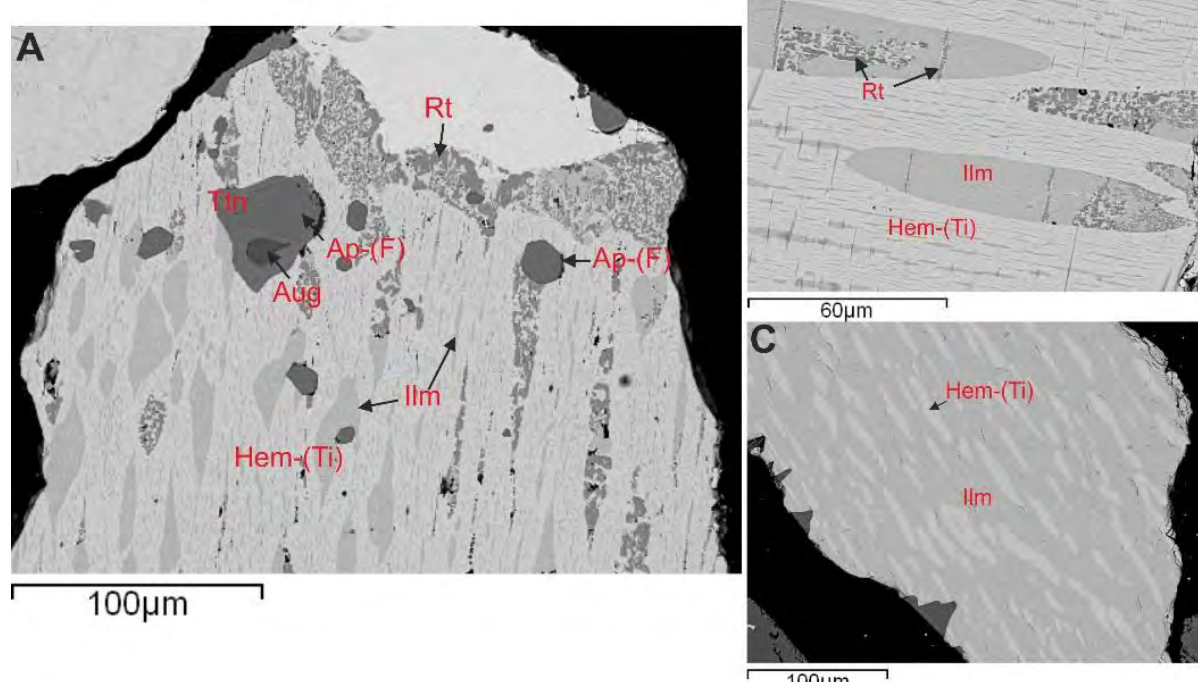

Fig. 7.7. Imágenes de electrones retrodispersados. A) Grano de hematita titanífera (Hem-(Ti)) con exsolución a ilmenita $(\mathrm{Ilm})$, rutilo (Rt) producto de alteración y reemplazo y finalmente inclusiones de augita (Aug), titanita (Ttn), Ap-(F) (flúorapatita). B) grano Hem-(Ti) con dos generaciones de exsoluciones a ilmenita y rutilo como alteración de las lamelas de exsolución y C) ilmenita con exsoluciones a hematita titanífera. 
A

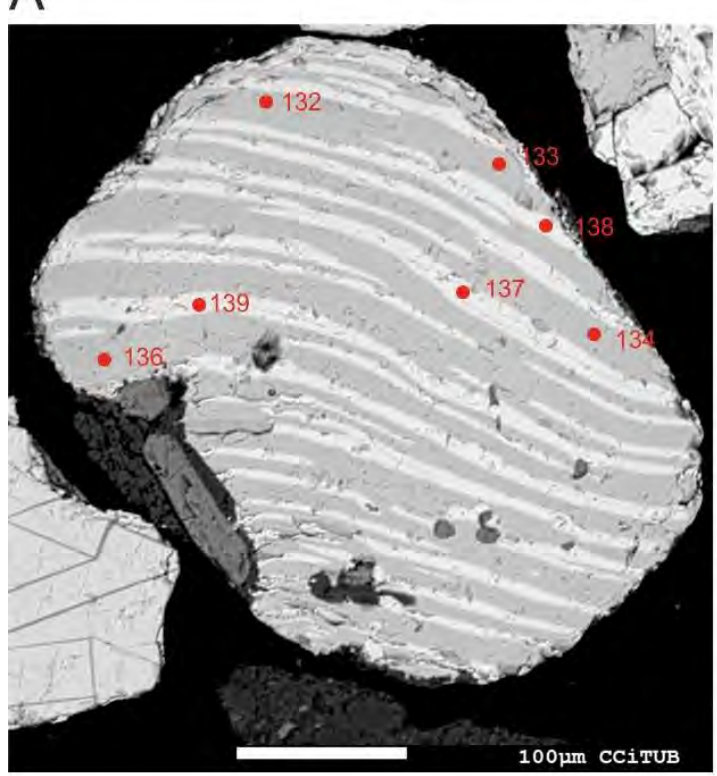

Mineral $\quad I m \quad I m \quad I I m \quad H e m-(T i) H e m-(T i) ~ H e m-(T i) ~ H e m-(T i)$

\begin{tabular}{lccccccc} 
Punto & BR.74 & BR.75 & BR.76 & BR.77 & BR.78 & BR.79 & BR.80 \\
\hline $\mathrm{TiO}_{2}$ & 47,09 & 46,74 & 46,61 & 15,76 & 12,38 & 15,37 & 13,16 \\
$\mathrm{FeO}^{*}$ & 39,81 & 39,59 & 39,59 & 13,69 & 10,77 & 13,30 & 11,49 \\
$\mathrm{Fe}_{2} \mathrm{O}_{3}{ }^{*}$ & 10,89 & 12,06 & 11,70 & 70,23 & 77,11 & 69,94 & 75,08 \\
$\mathrm{MnO}^{*}$ & 1,76 & 1,74 & 1,68 & 0,30 & 0,19 & 0,35 & 0,18 \\
$\mathrm{Al}_{2} \mathrm{O}_{3}$ & 0,00 & 0,04 & 0,00 & 0,07 & 0,11 & 0,09 & 0,10 \\
$\mathrm{MgO} \mathbf{O}$ & 0,44 & 0,39 & 0,36 & 0,11 & 0,10 & 0,11 & 0,09 \\
$\mathbf{V}_{2} \mathrm{O}_{3}$ & 0,44 & 0,40 & 0,40 & 0,58 & 0,52 & 0,51 & 0,55
\end{tabular}

B

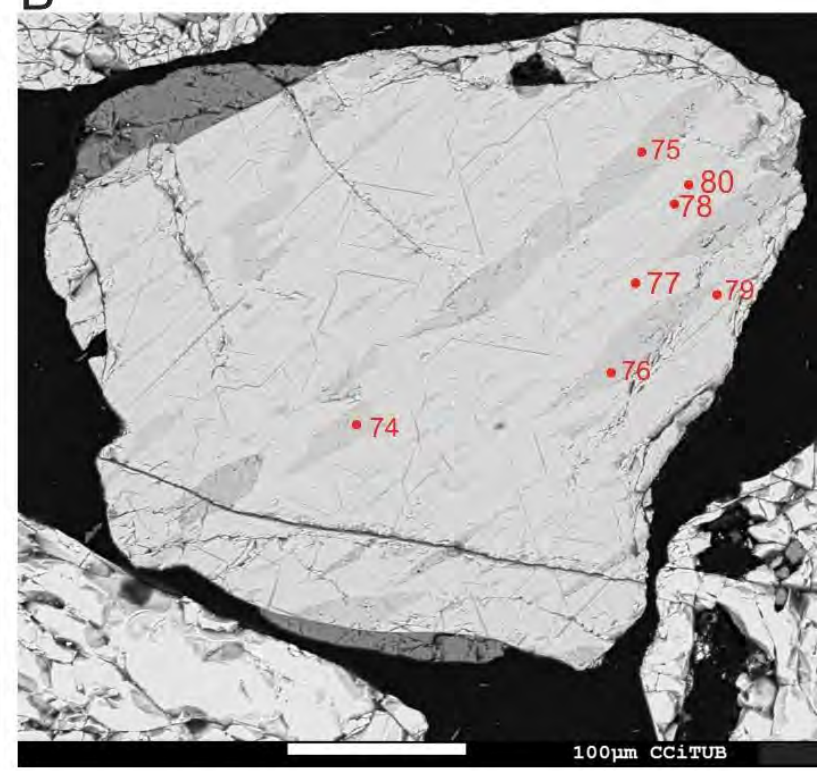

Mineral $\|m \quad\| m \quad\|m \quad\| m \quad \| m \quad M a g-(T i) \quad M a g-(T i) ~ M a g-(T i)$ \begin{tabular}{lllllll} 
Punto & BR.132 & BR.133 BR.134 BR.135 & BR.136 & BR.137 & BR.138 & BR.139 \\
\hline
\end{tabular} $\begin{array}{lllllllll}\mathrm{TiO}_{2} & 45,94 & 45,19 & 44,93 & 47,14 & 47,11 & 7,13 & 3,79 & 5,63\end{array}$ $\begin{array}{lllllllll}\text { FeO* }^{*} \quad 38,80 & 36,63 & 36,40 & 39,70 & 39,70 & 36,23 & 33,87 & 34,92\end{array}$

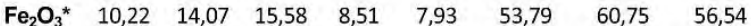

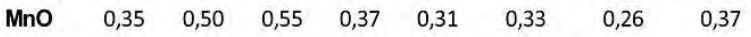

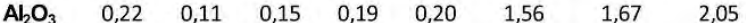
$\begin{array}{lllllllll}\text { MgO } & 1,17 & 1,97 & 1,93 & 1,29 & 1,28 & 0,99 & 0,81 & 1,10\end{array}$

$\begin{array}{lllllllll}\mathrm{V}_{2} \mathrm{O}_{3} & 0,47 & 0,44 & 0,40 & 0,51 & 0,40 & 0,38 & 0,41 & 0,45\end{array}$

Fig. 7.8. Imágenes con electrones dispersados de: A) IImenita con exsolución a magnetita titanífera y B) Hematita titanífera con exsoluciones a Ilmenita y agujas de rutilo. Estas tablas muestran los principales elementos medidos, estando los resultados completos en el Anexo.

En el sedimento glacial, dentro de los óxidos de Fe y Ti se diferenciaron ilmenitas con un alto contenido en $\mathrm{Mn}(3,4 \% \mathrm{MnO})$, óxidos intermedios de Fe-Ti con un contenido en $\mathrm{TiO}_{2}$ que varió entre 26,8 y $28,8 \%$ y hematitas titaníferas con mayor contenido en Fe (Tabla 7.5). Los granos con exsoluciones corresponden principalmente a hematitas titaníferas con exsoluciones a óxidos intermedios de Fe-Ti e ilmenitas. 


\begin{tabular}{|c|c|c|c|c|c|c|c|c|c|c|}
\hline & \multicolumn{4}{|c|}{$\begin{array}{l}\text { Oxidos Intermedios de Fe-Ti } \\
\qquad N=9\end{array}$} & \multicolumn{4}{|c|}{$\begin{array}{l}\text { Hem-(Ti) con exsoluciones } \\
\qquad N=2\end{array}$} & \multirow{2}{*}{$\begin{array}{c}\text { Hem-(Ti) } \\
\mathrm{N}=1 \\
\text { A143 }\end{array}$} & \multirow{2}{*}{$\begin{array}{c}\text { IIm-(Mn) } \\
N=1 \\
\text { A136 }\end{array}$} \\
\hline & Prom & $\mathrm{DE}$ & Min & Max & Prom & DE & Min & Max & & \\
\hline \multicolumn{11}{|l|}{$\%$ en peso } \\
\hline $\mathrm{TiO}_{2}$ & 27,965 & 0,593 & 26,804 & 28,840 & 12,238 & 0,812 & 11,664 & 12,812 & 12,062 & 47,561 \\
\hline $\mathrm{FeO}$ & 22,790 & 0,586 & 21,892 & 23,962 & 10,870 & 0,755 & 10,336 & 11,404 & 10,599 & 39,208 \\
\hline $\mathrm{Fe}_{2} \mathrm{O}_{3}$ & 46,769 & 1,188 & 44,871 & 49,150 & 76,773 & 0,928 & 76,117 & 77,429 & 76,770 & 9,830 \\
\hline $\mathrm{MnO}$ & 0,279 & 0,090 & 0,198 & 0,498 & 0,064 & 0,021 & 0,049 & 0,079 & 0,175 & 3,395 \\
\hline $\mathrm{Cr}_{2} \mathrm{O}_{3}$ & - & - & L.D & L.D & - & - & L.D & L.D & L.D & L.D \\
\hline $\mathrm{Al}_{2} \mathrm{O}_{3}$ & 0,422 & 0,099 & 0,350 & 0,666 & 0,138 & 0,037 & 0,112 & 0,164 & 0,080 & 0,000 \\
\hline $\mathrm{MgO}$ & 1,169 & 0,267 & 0,932 & 1,838 & 0,041 & 0,002 & 0,040 & 0,043 & 0,042 & 0,077 \\
\hline $\mathrm{V}_{2} \mathrm{O}_{3}$ & 0,269 & 0,138 & 0,047 & 0,430 & 0,403 & 0,041 & 0,374 & 0,432 & 0,457 & 0,122 \\
\hline $\mathrm{CaO}$ & - & - & N.M & N.M & - & - & N.M & N.M & N.M & N.M \\
\hline $\mathrm{SiO}_{2}$ & - & - & N.M & N.M & - & - & N.M & N.M & N.M & N.M \\
\hline Total & 99,664 & 0,247 & 99,326 & 100,077 & 100,527 & 0,619 & 100,090 & 100,965 & 100,185 & 100,194 \\
\hline \multicolumn{11}{|c|}{ Fórmula estructural. 3 Oxígenos } \\
\hline $\mathrm{Ti}$ & 0,635 & 0,011 & 0,614 & 0,653 & 0,321 & 0,017 & 0,308 & 0,333 & 0,318 & 0,934 \\
\hline $\mathrm{Fe}^{2+}$ & 0,489 & 0,013 & 0,467 & 0,516 & 0,237 & 0,015 & 0,227 & 0,248 & 0,232 & 0,830 \\
\hline $\mathrm{Fe}^{3+}$ & 0,903 & 0,023 & 0,869 & 0,948 & 1,507 & 0,028 & 1,487 & 1,527 & 1,513 & 0,187 \\
\hline $\mathrm{Mn}$ & 0,007 & 0,002 & 0,005 & 0,013 & 0,002 & 0,001 & 0,001 & 0,002 & 0,005 & 0,075 \\
\hline $\mathrm{Cr}$ & - & - & L.D & L.D & - & - & L.D & L.D & L.D & L.D \\
\hline $\mathrm{Al}$ & 0,015 & 0,003 & 0,012 & 0,023 & 0,006 & 0,002 & 0,005 & 0,007 & 0,003 & 0,000 \\
\hline Mg & 0,053 & 0,012 & 0,042 & 0,082 & 0,002 & 0,000 & 0,002 & 0,002 & 0,002 & 0,003 \\
\hline $\mathrm{V}$ & 0,007 & 0,003 & 0,001 & 0,010 & 0,011 & 0,001 & 0,011 & 0,012 & 0,013 & 0,003 \\
\hline $\mathrm{Ca}$ & - & - & N.M & N.M & - & - & N.M & N.M & N.M & N.M \\
\hline $\mathrm{Si}$ & - & - & N.M & N.M & - & - & N.M & N.M & N.M & N.M \\
\hline \multicolumn{11}{|c|}{ Miembros finales } \\
\hline IImenita & & & & & & & & & & 92,867 \\
\hline Geikielita & & & & & & & & & & 0,274 \\
\hline Pirofanita & & & & & & & & & & 6,859 \\
\hline
\end{tabular}

Tabla 7.5. Contenidos analíticos porcentuales y parámetros estadísticos de los óxidos de Fe y Ti analizados en los depósitos de till continentales. L.D límite de detección; N.M elemento no medido con la microsonda electrónica; - parámetro estadístico no calculado.

En las muestras provenientes de la Plataforma Continental se diferenciaron, en función del contenido en $\mathrm{TiO}_{2}$, ilmenitas $\left(38,1\right.$ y $\left.50 \% \mathrm{TiO}_{2}\right)$ incluyendo ilmenitas ricas en $\mathrm{MgO}(2,6$ y $4 \%)$, óxidos intermedios de $\mathrm{Fe}-\mathrm{Ti}\left(27,5\right.$ y $\left.32,6 \% \mathrm{TiO}_{2}\right)$ y hematitas titaníferas $\left(0,2\right.$ y $\left.13 \% \mathrm{TiO}_{2}\right)$. Presentaron como elementos minoritarios $\mathrm{V}$ y Al (Tabla 7.6). Los granos con exsoluciones correspondieron a hematitas titaníferas con lamelas de una o dos generaciones de Ilmenita u óxidos intermedios de Fe y Ti paralelas al plano (0001). 


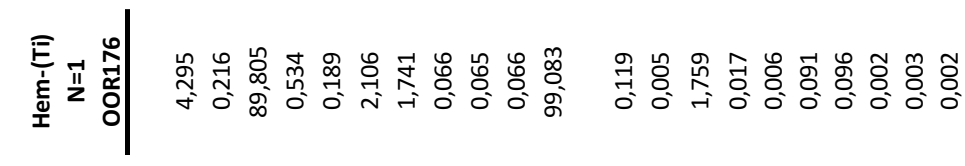

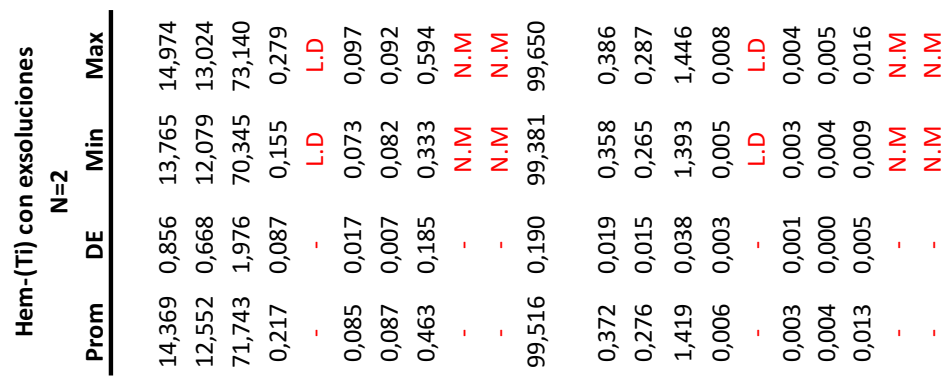

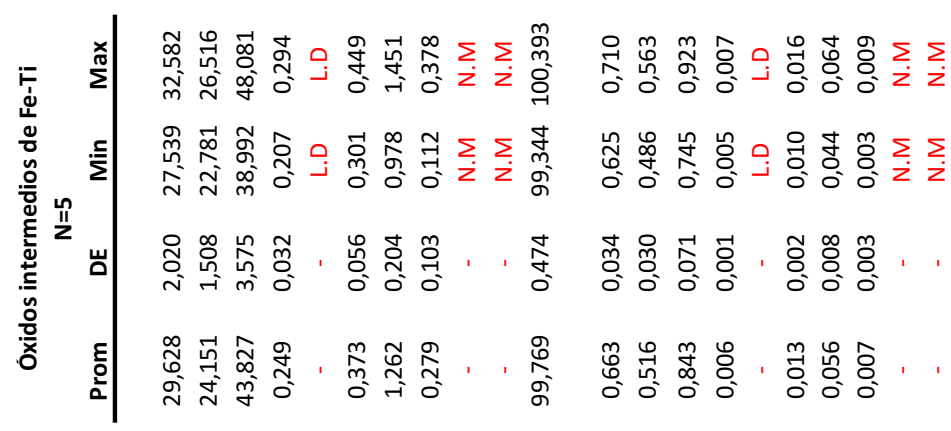

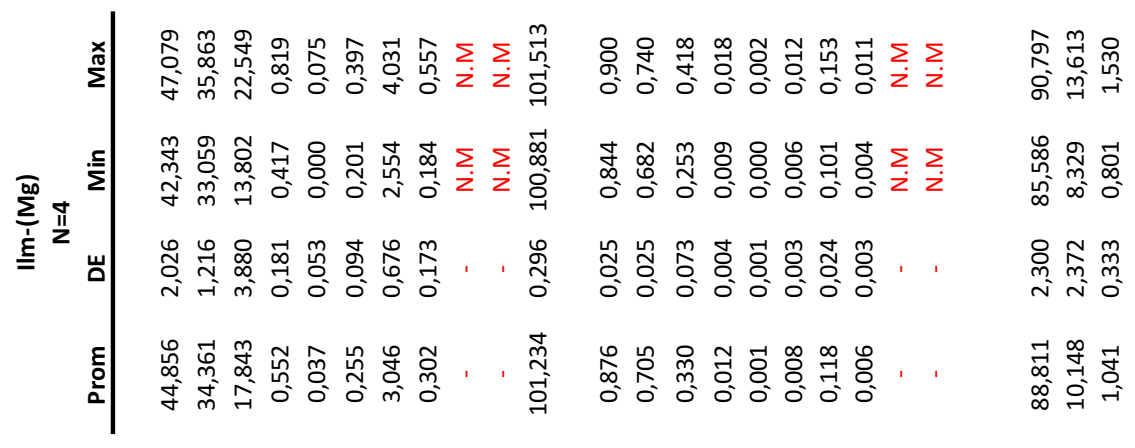

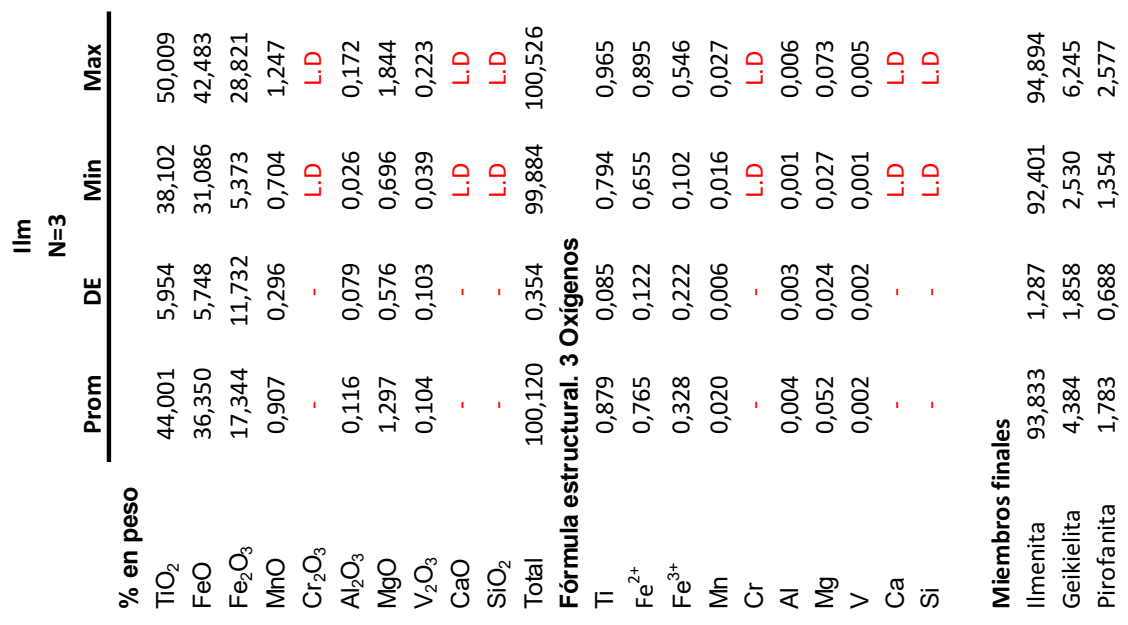

Tabla 7.6. Contenidos porcentuales y parámetros estadísticos de elementos mayoritarios y minoritarios obtenidos mediante microsonda electrónica de óxidos de Fe y Ti analizados en el sedimento proveniente de la Plataforma Continental. L.D límite de detección, N.M elemento no medido, - parámetro estadístico no calculado por falta de medición y/o límite de detección por debajo. 
A partir de la comparación de diagramas binarios se pudo determinar que en los tres subambientes los óxidos de Fe y Ti presentaron una composición similar, faltando alguna de las fases en el sedimento proveniente de la Plataforma Continental (IIm enriquecida en pirofanita molar) y en los depósitos glaciales continentales (IIm e $\mathrm{Im}$ enriquecida en geikielita molar) debido posiblemente al menor número de granos analizados (Fig. 7.9). Las exsoluciones mostraron generalmente un aumento del contenido en $\mathrm{TiO}_{2}$ y $\mathrm{MnO}$ con respecto al grano mineral (Fig.7.10).
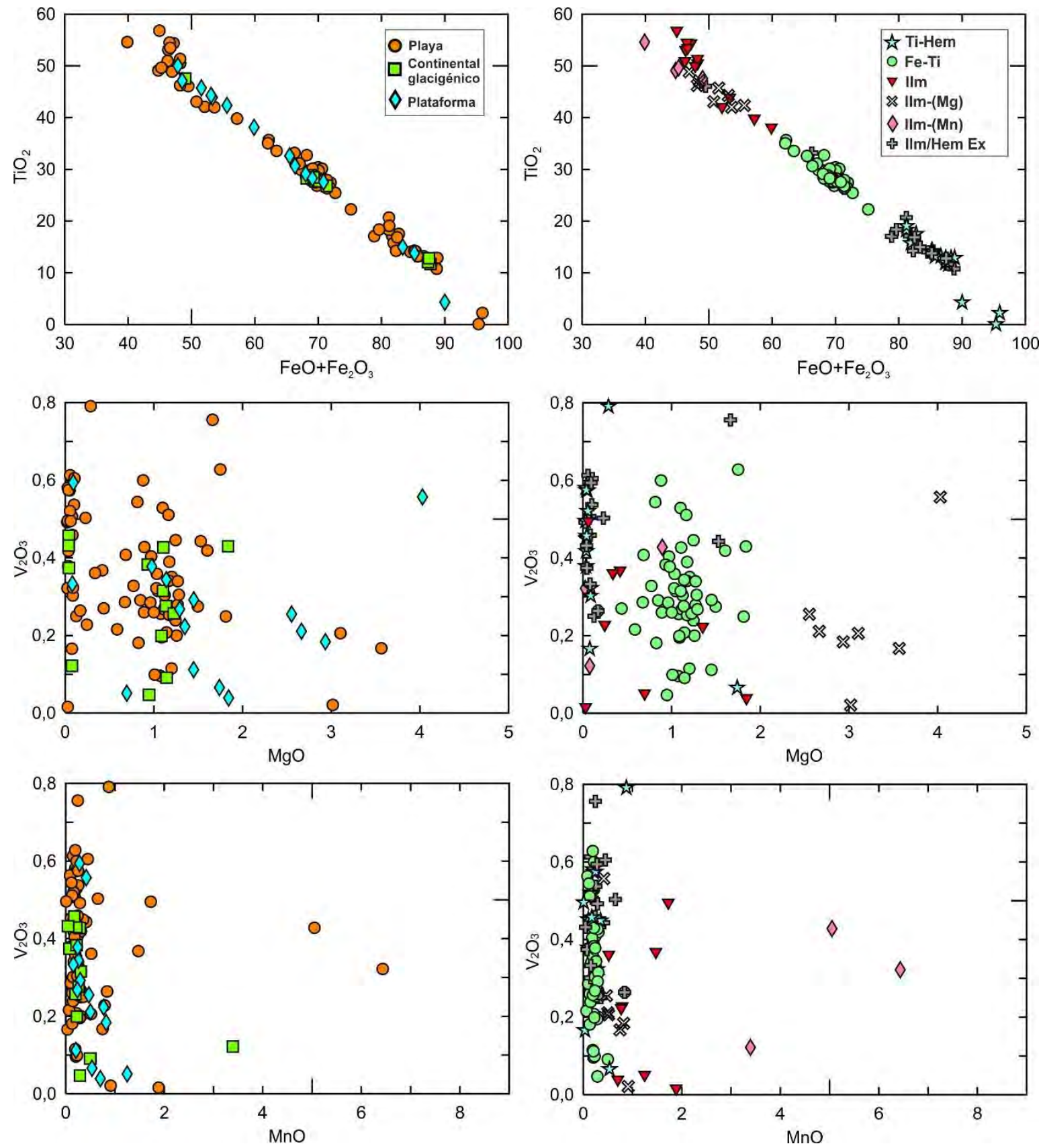

Fig.7.9. Diagramas binarios para los óxidos de $\mathrm{Fe}$ y $\mathrm{Ti}$. $\mathrm{TiO}_{2}-\mathrm{FeO}+\mathrm{Fe}_{2} \mathrm{O}_{3}, \mathrm{~V}_{2} \mathrm{O}_{3}-\mathrm{MgO}$ y $\mathrm{V}_{2} \mathrm{O}_{3}-\mathrm{MnO}$.A la izquierda separado por el subambiente y la derecha por fases. IIm (ilmenitas), IIm Mn (IImenitas ricas en Mn), IIm Mg (IImenitas ricas en Mg), $\mathrm{Fe}$-Ti (óxidos intermedios de Fe-Ti), Hem-(Ti) (hematitas titaníferas) e Ilm/Hem Ex (granos con exsoluciones). 

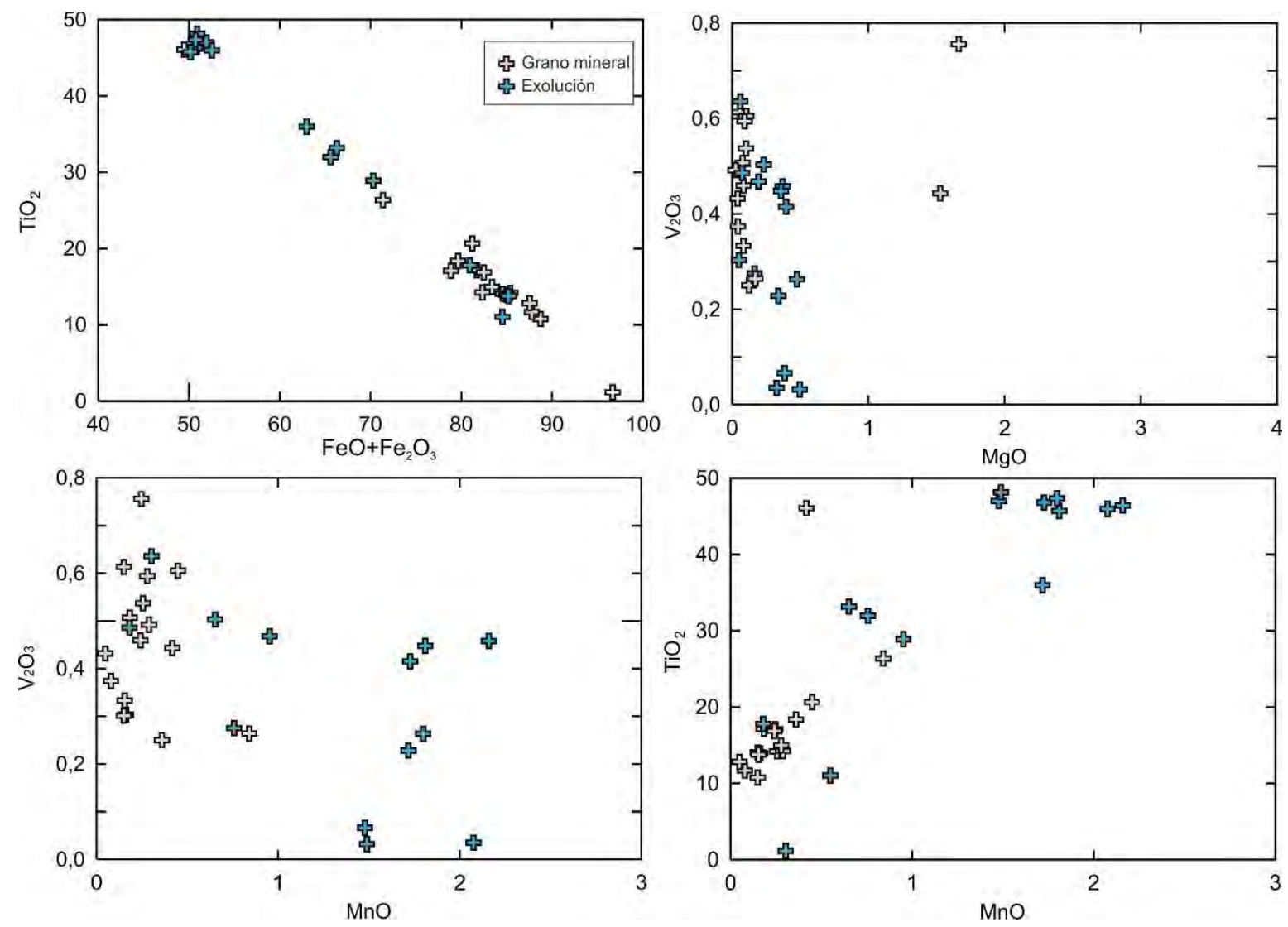

Fig.7.10. Diagramas binarios para los óxidos de Fe y Ti con exsoluciones, diferenciando los análisis realizados en las exsoluciones presentes.

\subsubsection{Rutilo y productos de alteración}

La serie pseudobrookita presenta dos miembros extremos, uno enriquecido en $\mathrm{Fe}^{3+}$ (pseudobrookita) y otro en $\mathrm{Fe}^{2+}$ (ferroseudobrookita). Por la eliminación del $\mathrm{Fe}^{+2}$ durante la oxidación de las ilmenitas se genera pseudorutilo y la eliminación del $\mathrm{Fe}^{3+}$ por lixiviación e hidrólisis leucoxeno (Mücke y Bhadra Chaudhuri 1991). Frost et al. (1983) clasificaron los productos de alteración de la ilmenita en función de la relación $\mathrm{Ti} /(\mathrm{Ti}+\mathrm{Fe})$ como: ilmenita inalterada $<0,5$, ilmenita hidratada 0,5-0,6, pseudorutilo 0,6-0,7 y leucoxeno $>0,7$.

En la zona de trabajo fueron reconocidos pocos individuos de rutilo. Únicamente se identificaron y analizaron dos granos provenientes de las arenas de las playas correspondientes a rutilo y pseudorutilo-leucoxeno como producto de alteración de la ilmenita. El pseudorutilo-leucoxeno presentó un mayor contenido de $\mathrm{Fe}_{2} \mathrm{O}_{3}, \mathrm{MnO}, \mathrm{Al}_{2} \mathrm{O}_{3}$, $\mathrm{SiO}_{2}$ y $\mathrm{CaO}$ que el rutilo (Tabla 7.7). El rutilo se encontró con mayor frecuencia como inclusión o en zonas de exsolución en las hematitas titaníferas. 


\begin{tabular}{|c|c|c|}
\hline Mineral & Rt & Pseudorutilo-Leucoxen \\
\hline Nombre & BR.215 & OOR3.50 \\
\hline Ubicación & $\mathrm{N}$ & $\mathrm{N}$ \\
\hline $\mathrm{n}^{\circ}$ análisis & 1 & 1 \\
\hline Subambiente & Playa & Playa \\
\hline Localización & *P.Sinaí & ${ }^{*}$ C. Tortuga \\
\hline \multicolumn{3}{|l|}{$\%$ Peso } \\
\hline $\mathrm{TiO}_{2}$ & 97,960 & 64,772 \\
\hline $\mathrm{Fe}_{2} \mathrm{O}_{3}$ & 2,456 & 20,803 \\
\hline $\mathrm{MnO}$ & L.D & 9,541 \\
\hline $\mathrm{Cr}_{2} \mathrm{O}_{3}$ & 0,000 & 0,000 \\
\hline $\mathrm{Al}_{2} \mathrm{O}_{3}$ & 0,022 & 1,900 \\
\hline $\mathrm{MgO}$ & 0,000 & 0,234 \\
\hline $\mathrm{V}_{2} \mathrm{O}_{3}$ & 0,654 & 0,000 \\
\hline $\mathrm{Nb}_{2} \mathrm{O}_{5}$ & N.M & 0,130 \\
\hline $\mathrm{CaO}$ & 0,019 & 0,415 \\
\hline $\mathrm{SiO}_{2}$ & 0,025 & 1,715 \\
\hline Total & 101,135 & 99,509 \\
\hline \multicolumn{3}{|c|}{ Formula Estructural: Rutilo (2 oxígenos) y pseudorutilo-leucoxeno (9 oxígenos) } \\
\hline $\mathrm{Ti}$ & 0,976 & 3,207 \\
\hline $\mathrm{Fe}^{3+}$ & 0,024 & 1,030 \\
\hline $\mathrm{Mn}$ & L.D & 0,532 \\
\hline $\mathrm{Cr}$ & 0,000 & 0,000 \\
\hline Al & 0,000 & 0,147 \\
\hline $\mathrm{Mg}$ & 0,000 & 0,023 \\
\hline $\mathrm{V}$ & 0,007 & 0,000 \\
\hline $\mathrm{Nb}$ & N.M & 0,004 \\
\hline $\mathrm{Ca}$ & 0,000 & 0,029 \\
\hline $\mathrm{Si}$ & 0,000 & 0,113 \\
\hline $\mathrm{XFe}^{2+}$ & 0,00 & 0,00 \\
\hline $\mathrm{XFe}^{3+}$ & 2,45 & 24,31 \\
\hline $\mathrm{XTi}$ & 97,55 & 75,69 \\
\hline $\mathrm{Ti} /(\mathrm{Ti}+\mathrm{Fe})$ & 0,98 & 0,76 \\
\hline
\end{tabular}

Tabla 7.7. Granos de rutilo y leucoxeno analizadas en el sedimento proveniente de las arenas de las playas. A partir del método de Droop (1987) se asumió que todo el hierro es $\mathrm{Fe}^{3+} .{ }^{*}$ nivel enriquecido en minerales pesados.

\subsubsection{Grupo de la espinela}

Los miembros del grupo de la espinela son un conjunto de óxidos que forman soluciones sólidas entre sí (Fig.7.6 y 7.11.). La fórmula general se puede representar como $A^{2+} B_{2}^{3+} \mathrm{O}_{4}$, donde $\mathrm{A}$ corresponde a $\mathrm{Mg}, \mathrm{Fe}^{2+}, \mathrm{Zn}, \mathrm{Mn}, \mathrm{Ni}, \mathrm{Co}, \mathrm{Cu}$ y $\mathrm{Ge}$. B puede corresponder a los elementos $\mathrm{Al}, \mathrm{Fe}^{3+}, \mathrm{Cr}, \mathrm{V}$ y Ti (Bowles et al. 2011). 


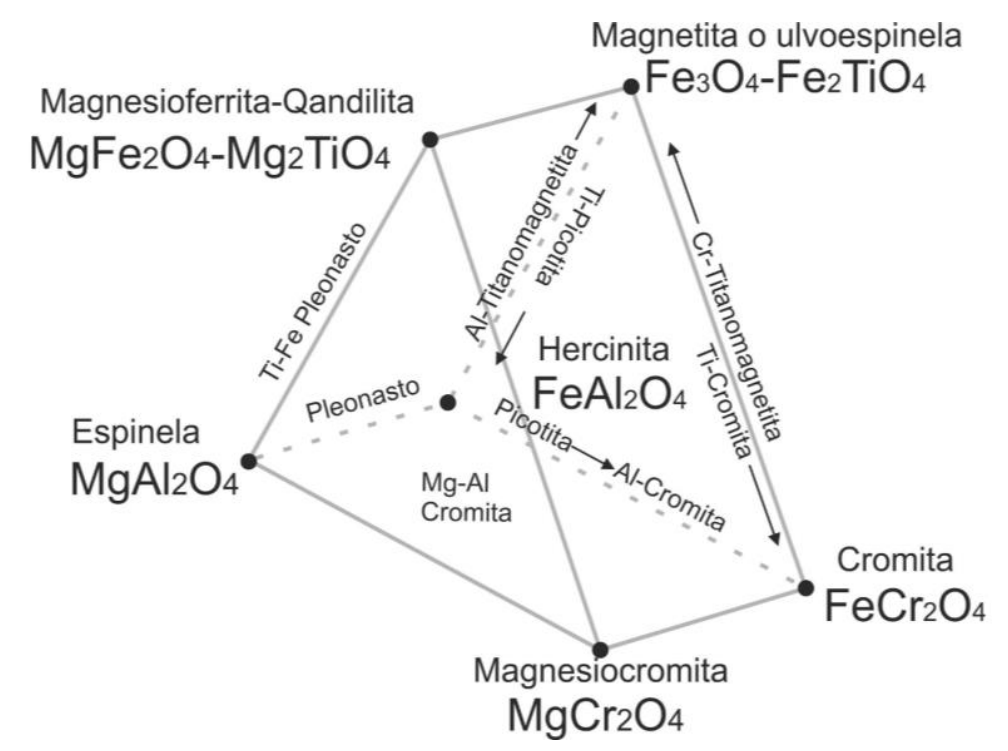

Fig.7.11. Representación mediante un prisma multicomponente de algunos de los miembros extremos del grupo de la Espinela y fases intermedias (Deer et al. 2013).

La gran mayoría de los granos de espinelas analizados pertenecieron a la solución sólida magnetita $\left(\mathrm{Fe}^{2+} \mathrm{Fe}_{2}^{3+} \mathrm{O}_{4}\right)$-ulvoespinela $\left(\mathrm{Fe}_{2}^{2+} \mathrm{TiO}_{4}\right)$. Se analizaron un total de 87 granos provenientes de las arenas de las playas de los cañadones Alfa, Beta y Tortuga, Él Páramo (incluyendo el sector de la espiga) y punta Sinaí (A.34-38); 2 granos del sedimento glacial (till) proveniente de los acantilados próximos al cañadón Beta y Punta Sinaí y finalmente 3 granos de la Plataforma Continental interna y media (A.39).

En las magnetitas se pudieron diferenciar magnetita s.s. con un contenido bajo en $\mathrm{TiO}_{2}$, entre 0 y $0,7 \%$ y magnetita titanífera entre un $1,1 \%$ y $15.2 \%$. En las segundas se observó un aumento del contenido en $\mathrm{Al}_{2} \mathrm{O}_{3}, \mathrm{MgO}, \mathrm{V}_{2} \mathrm{O}_{3}$ y $\mathrm{MnO}$. Con frecuencia se encontraron granos de magnetitas parcial o totalmente martitizados. En algún cristal de magnetita s.s. se identificaron exsoluciones en enrejado "trellis texture" de magnetita titanífera o hematita titanífera, reconociéndose inclusiones de otros óxidos como espinela rica en Fe, titanita o rutilo (Fig.7.12 y Tabla 7.8). 

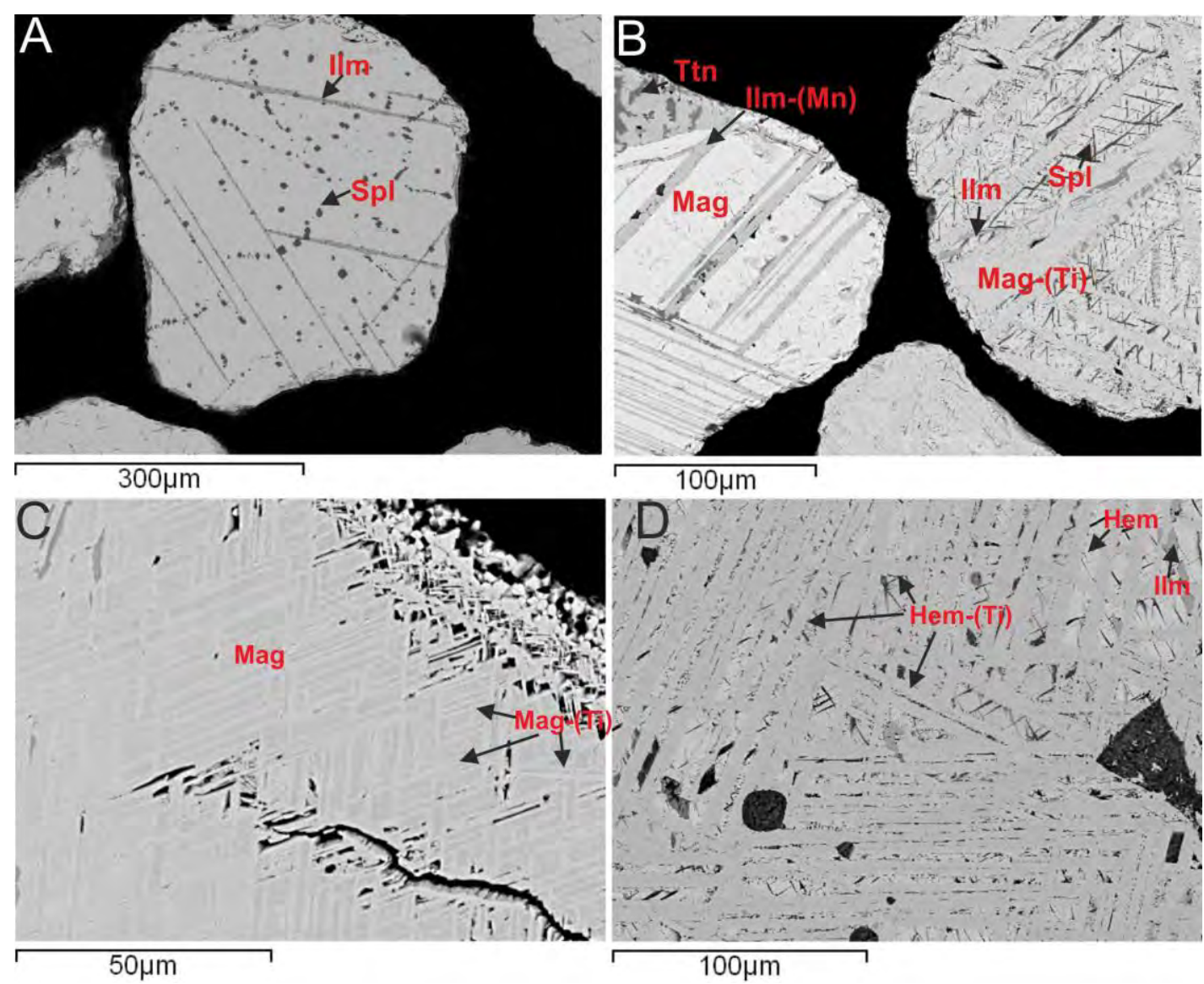

Fig. 7.12. Imágenes realizadas mediante electrones retrodispersados. A) Magnetita con inclusiones de espinela rica en Fe y exsoluciones de ilmenita. B) Magnetita con exsoluciones de ilmenita rica en manganeso e intercrecida con un grano de titanita. A la derecha grano de magnetita con exsoluciones de magnetita titanífera y espinela. C) Magnetita con textura en enrejado octaédrico. D) Magnetita martitizada.

En las magnetitas sin exsoluciones las inclusiones son frecuentes. Se reconocieron flúorapatita y cloroapatita (secciones basales y prismáticas), pirrotina, calcopirita, rutilo, cristales idiomorfos cúbicos de espinela rica en Fe, anfíbol y circón (Fig.7.13).
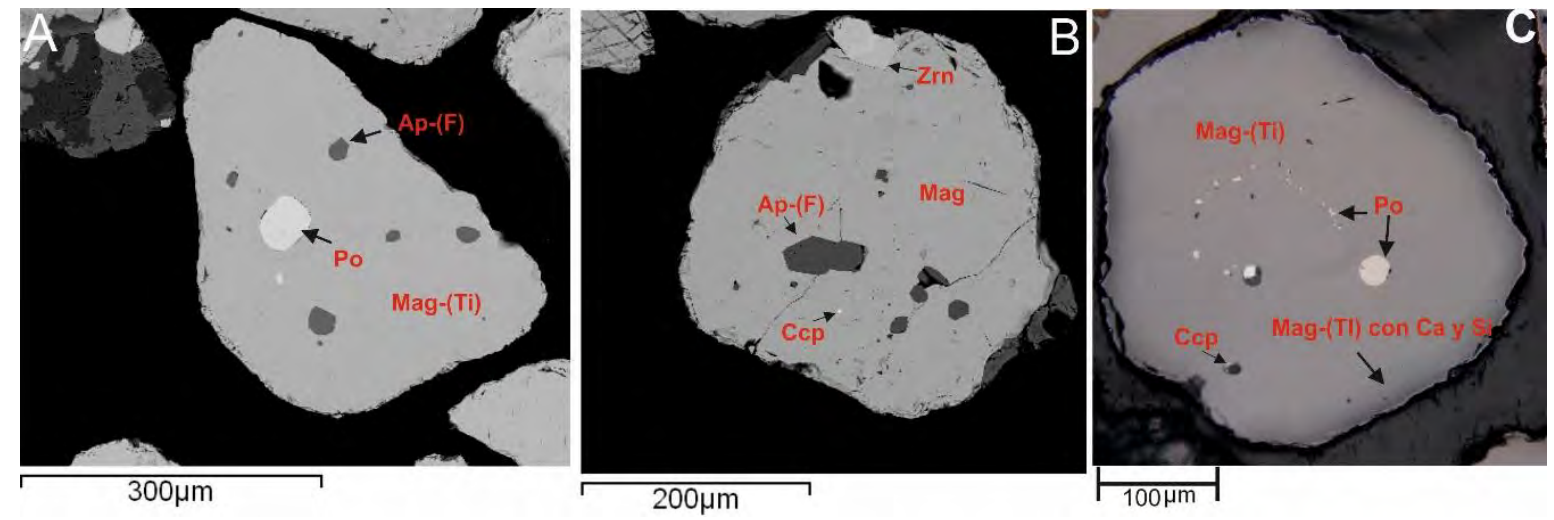

Fig.7.13. Imágenes realizadas mediante electrones retrodispersados (A y B) y microscopio petrográfico (C). A) Magnetita titanífera con inclusiones de flúorapatita (F-Ap) y pirrotina (Po), B) magnetita s.s. con inclusiones de F-Ap, circón (Zrn) y calcopirita $(C c p)$ y C) magnetita titanífera con inclusiones de Po. Se diferenció una zonación en el borde más rica en Ca y Si. 


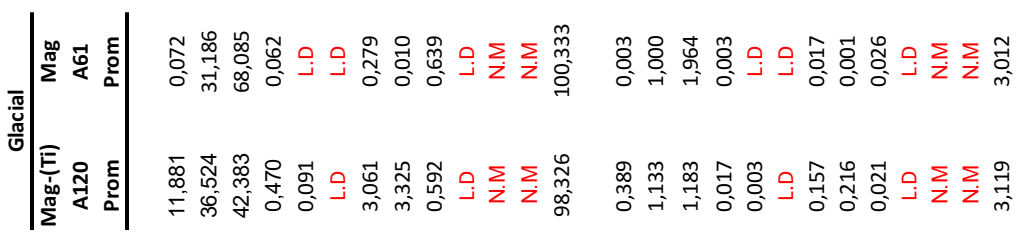

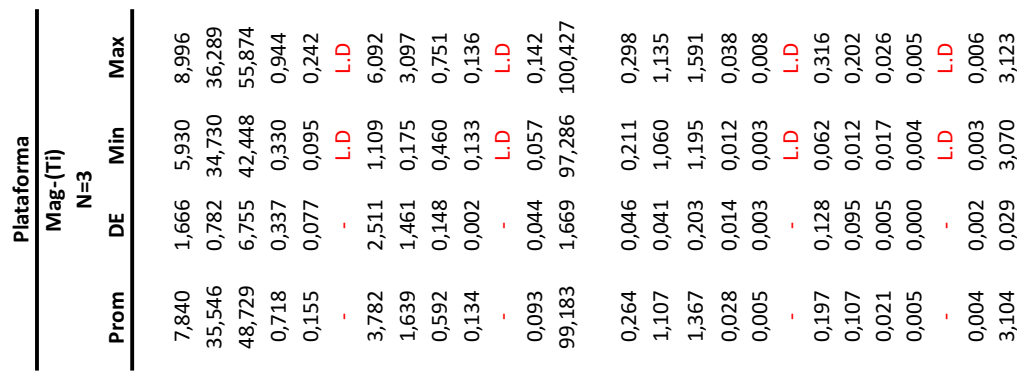

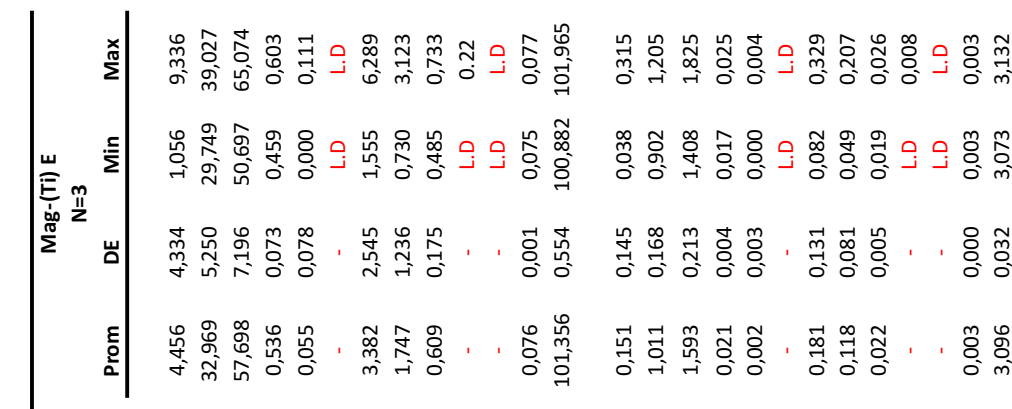

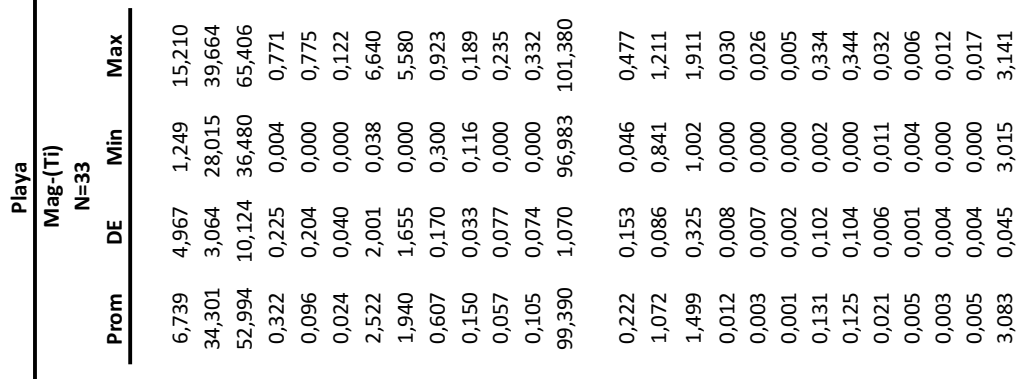

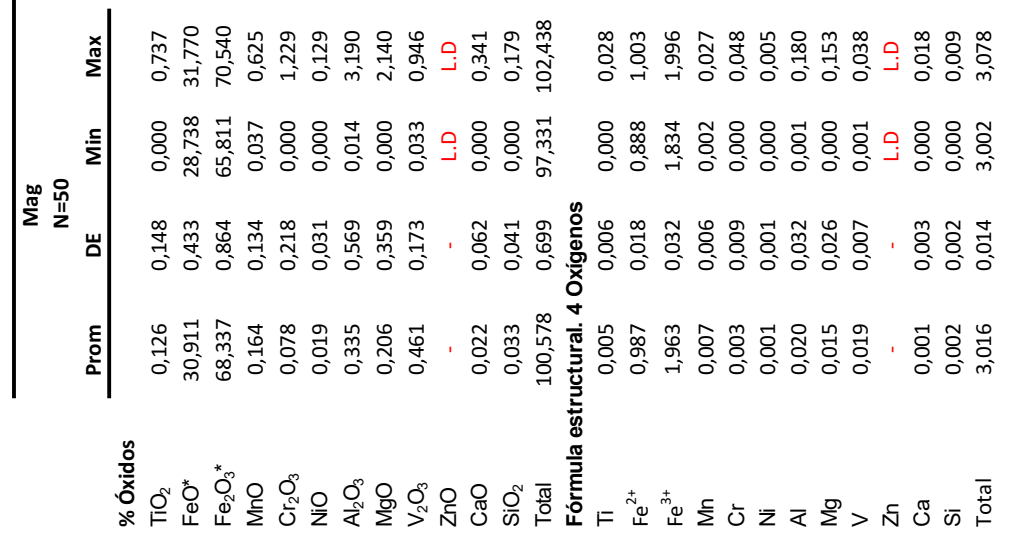

Tabla 7.8. Contenidos porcentuales analíticos y parámetros estadísticos de magnetitas provenientes de los diferentes subambientes estudiados. L.D por debajo del límite de detección, N.M elemento no medido y-parámetro estadístico no calculado por falta de datos. A120 y A61 corresponden con los nombres del grano ya que únicamente se identificaron estos dos. 
Se identificaron otras espinelas, con una abundancia mucho menor, en los niveles ricos presentes en las playas de El Páramo (incluyendo la espiga) y los cañadones Beta y Tortuga. Las fases correspondieron con espinela s.s. rica en $\mathrm{Fe}^{2+}$ o pleonasto, magnetita rica en Al y espinela s.s. rica en Cr o magnesiocromita. En la espinela cromífera se observó zonación de núcleo a bordes, aumentando en ese sentido el contenido en FeO y disminuyendo el porcentaje en peso del $\mathrm{MgO}$ y ligeramente del $\mathrm{Cr}_{2} \mathrm{O}_{3}$, correspondiente con la composición de una hercinita rica en $\mathrm{Cr}$ (Tabla 7.9, Fig.7.14 y Fig.7.15).

\begin{tabular}{|c|c|c|c|c|c|c|c|c|c|c|c|c|}
\hline Mineral & Epl-(Fe) & Epl-(Fe) & Epl-(Fe) & Epl-(Fe) & Epl-(Fe) & Epl-(Fe) & Mag-(Al) & Mag-(Al) & Epl-Mg Chr & Epl-Mg Chr & $\mathrm{Hc}-\mathrm{Chr}$ & $\mathrm{Hc}-\mathrm{Chr}$ \\
\hline no análisis & 1 & 1 & 1 & 1 & 1 & 1 & 1 & 1 & 1 & 1 & 1 & 1 \\
\hline Ambiente & Playa & Playa & Playa & Playa & Playa & Playa & Playa & Playa & \multicolumn{4}{|c|}{$\begin{array}{c}\text { Playa } \\
\text { La Espiga }\end{array}$} \\
\hline \multicolumn{13}{|l|}{$\%$ Peso } \\
\hline $\mathrm{TiO} 2$ & 0,163 & 5,655 & 0,008 & 0,083 & 0,028 & 1,379 & 0,572 & 0,778 & 0,059 & 0,197 & 0,089 & 0,140 \\
\hline $\mathrm{MnO}$ & 0,315 & 0,515 & 0,138 & 0,267 & 0,185 & 0,247 & 0,137 & 0,205 & 0,089 & 0,066 & 0,730 & 0,758 \\
\hline $\mathrm{Cr} 2 \mathrm{O} 3$ & L.D & L.D & 1,766 & 0,294 & L.D & L.D & 0,000 & L.D & 28,750 & 29,060 & 26,300 & 25,890 \\
\hline $\mathrm{NiO}$ & 0,000 & 0,000 & L.D & L.D & L.D & 0,000 & 0,000 & 0,017 & 0,284 & 0,247 & 0,243 & 0,142 \\
\hline $\mathrm{Al} 2 \mathrm{O} 3$ & 52,260 & 61,461 & 64,471 & 66,493 & 65,986 & 65,826 & 20,206 & 12,350 & 35,210 & 35,370 & 33,190 & 31,890 \\
\hline $\mathrm{MgO}$ & 16,160 & 15,354 & 20,807 & 18,892 & 19,189 & 20,850 & 6,896 & 5,860 & 17,080 & 17,230 & 5,250 & 3,090 \\
\hline V2O3 & 0,132 & N.M & N.M & N.M & N.M & N.M & N.M & 0,515 & 0,156 & 0,144 & 0,131 & 0,139 \\
\hline \multicolumn{13}{|c|}{ Fórmula estructural. 4 Oxígenos } \\
\hline $\mathrm{Ti}$ & 0,003 & 0,110 & 0,000 & 0,002 & 0,001 & 0,026 & 0,016 & 0,023 & 0,001 & 0,004 & 0,002 & 0,003 \\
\hline $\mathrm{Fe} 2+$ & 0,324 & 0,358 & 0,219 & 0,275 & 0,273 & 0,243 & 0,685 & 0,724 & 0,259 & 0,257 & 0,718 & 0,803 \\
\hline $\mathrm{Fe} 3+$ & 0,326 & 0,000 & 0,051 & 0,000 & 0,026 & 0,003 & 1,212 & 1,475 & 0,142 & 0,138 & 0,137 & 0,116 \\
\hline $\mathrm{Mn}$ & 0,008 & 0,011 & 0,003 & 0,006 & 0,004 & 0,005 & 0,004 & 0,007 & 0,002 & 0,002 & 0,020 & 0,021 \\
\hline $\mathrm{Cr}$ & L.D & L.D & 0,035 & 0,006 & L.D & L.D & 0,000 & L.D & 0,667 & 0,669 & 0,658 & 0,674 \\
\hline $\mathrm{Ni}$ & 0,000 & 0,000 & L.D & L.D & L.D & 0,000 & 0,000 & 0,001 & 0,007 & 0,006 & 0,006 & 0,004 \\
\hline $\mathrm{Al}$ & 1,734 & 1,881 & 1,923 & 1,993 & 1,977 & 1,944 & 0,892 & 0,582 & 1,218 & 1,214 & 1,237 & 1,238 \\
\hline $\mathrm{Mg}$ & 0,678 & 0,594 & 0,785 & 0,716 & 0,727 & 0,779 & 0,385 & 0,349 & 0,747 & 0,748 & 0,248 & 0,152 \\
\hline V & 0,003 & N.M & N.M & N.M & N.M & N.M & N.M & 0,017 & 0,004 & 0,003 & 0,003 & 0,004 \\
\hline $\mathrm{Zn}$ & N.M & N.M & N.M & N.M & N.M & N.M & N.M & N.M & N.M & N.M & N.M & N.M \\
\hline $\mathrm{Ca}$ & 0,002 & L.D & L.D & 0,000 & 0,000 & 0,000 & 0,000 & L.D & 0,000 & 0,001 & L.D & 0,000 \\
\hline $\mathrm{Na}$ & 0,014 & L.D & L.D & L.D & L.D & 0,000 & L.D & 0,003 & 0,000 & 0,002 & 0,008 & 0,014 \\
\hline
\end{tabular}

Tabla 79 Contenidos porcentuales de espinelas presentes en los niveles ricos en minerales pesados de las playas. D.L Límite de detección y N.M no medido. Inc. inclusión*Análisis de R.D. Acevedo, com. pers. Chr, cromita; Epl-(Al), espinela s.s. rica en Al; Epl-(Fe), espinela s.s. rica en Fe; $\mathrm{Mg} \mathrm{Chr}$, magnesiocromita; $\mathrm{Hc}$, hercinita. Si bien los resultados analíticos de las Mag-(Al), no son de gran calidad por presentar un cierre demasiado elevado, se han sido incluidos para brindar información cualitativa-semicuantitativa 


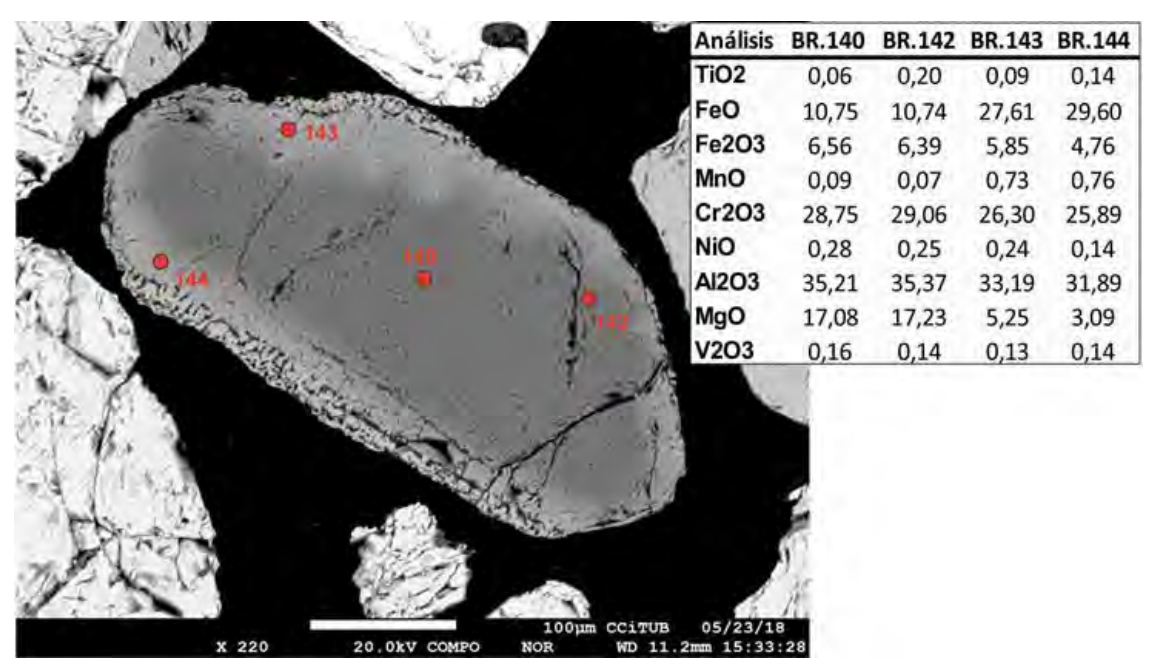

Fig.7.14. Imagen realizada mediante electrones retrodispersados de una espinela s.s. rica en Cr. Los análisis fueron realizados mediante microsonda electrónica.

A) $\mathrm{MgFe}_{2} \mathrm{O}_{4}$

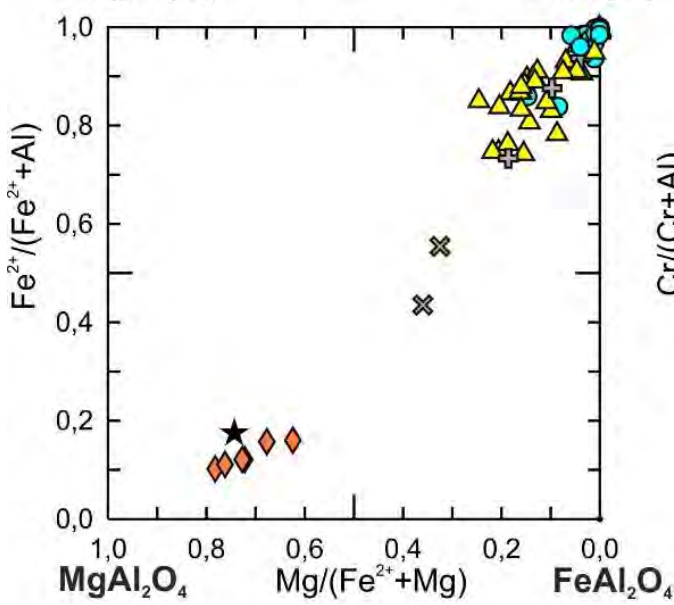

C) $\mathrm{MgCr}_{2} \mathrm{O}_{4}$

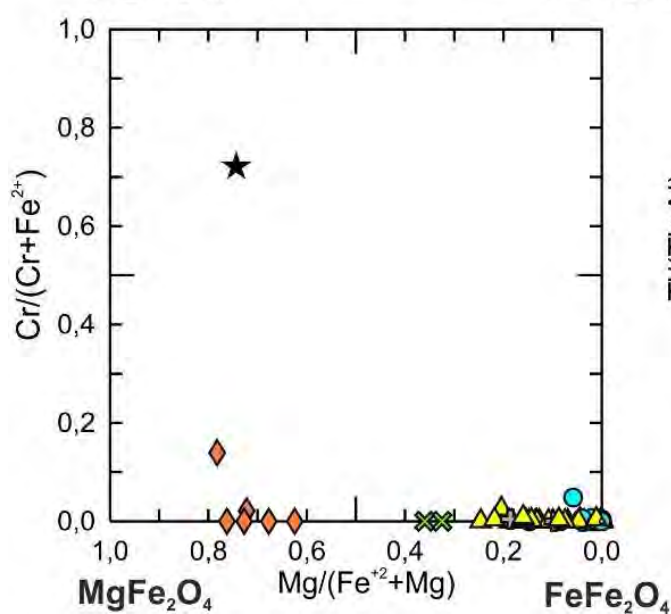

B)

$\mathrm{FeFe}_{2} \mathrm{O}_{4} \quad \mathrm{MgCr}_{2} \mathrm{O}_{4}$

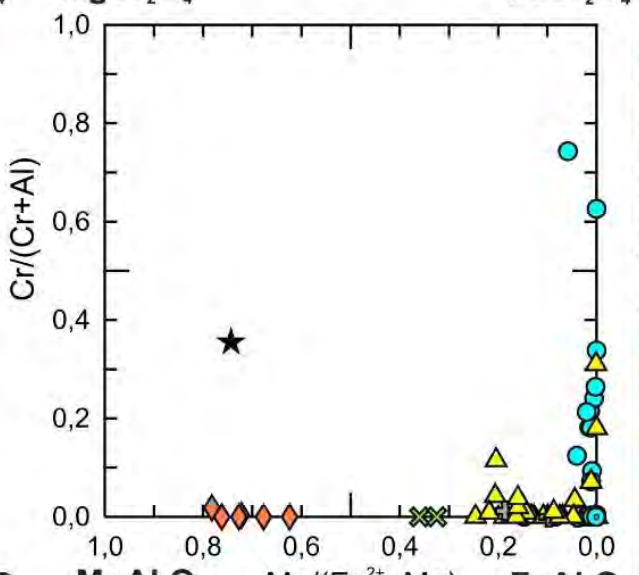

D)

$\mathrm{Fe}_{2} \mathrm{TiO}_{4}$

O Mag

$\triangle$ Mag-(Ti)

\Mag-(Al)

$\diamond \mathrm{Epl}-(\mathrm{Fe})$

$\star \mathrm{Epl}-(\mathrm{Cr})$

Magnesioferrita $\mathrm{MgFe}_{2} \mathrm{O}_{4}$

Magnetita

$\mathrm{FeFe}_{2} \mathrm{O}_{4}$

Magnesiocromita $\mathrm{MgCr}_{2} \mathrm{O}_{4}$

$\mathrm{FeCr}_{2} \mathrm{O}_{4}$

Espinela s.s

$\mathrm{MgAl}_{2} \mathrm{O}_{4}$

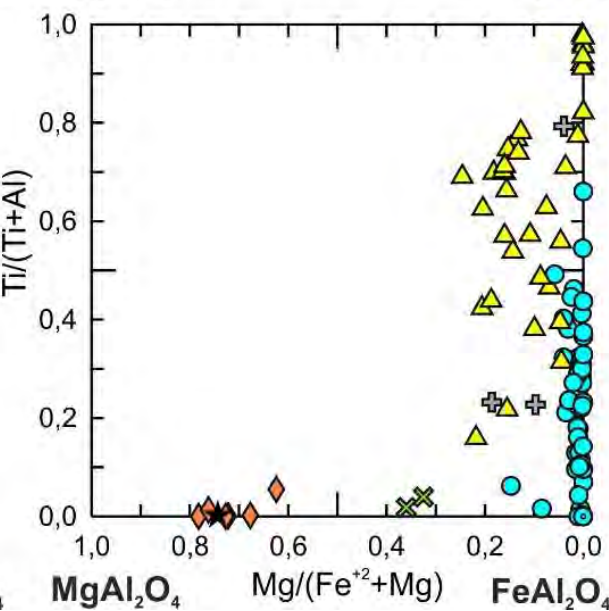

Hercinita

Oandilita

$\mathrm{Mg}_{2} \mathrm{TiO}_{2}$

Ulvoespinela

$\mathrm{Fe}_{2} \mathrm{TiO}_{4}$

Fig.7.15. Representación mediante diagramas de las diferentes composiciones de las espinelas. A) $\left.\mathrm{Fe}^{+2} /\left(\mathrm{Fe}^{+2}+\mathrm{Al}\right) \mathrm{B}\right)$

$\mathrm{Cr} /(\mathrm{Cr}+\mathrm{Al}), \mathrm{C}) \mathrm{Cr} /\left(\mathrm{Cr}+\mathrm{Fe}^{+2}\right)$ y D $) \mathrm{Ti} /(\mathrm{Ti}+\mathrm{Al})$ vs $\mathrm{Mg} /\left(\mathrm{Fe}^{+2}+\mathrm{Mg}\right)$. 


\subsubsection{Sulfuros y oxihidróxidos}

Ocasionalmente se identificaron pirita, calcopirita y oxihidróxidos. Se realizaron análisis en algunas piritas presentes en los materiales de till glacial presentes en los acantilados de punta Sinaí (A.40) (Tabla 7.10). Oxihidróxidos se analizaron por un lado en los sedimentos de till de los acantilados de punta Sinaí y del cañadón Beta y por otro en los niveles enriquecidos de las arenas de playa del cañadón Alfa. Los oxihidróxidos aparecen como granos sueltos o como alteración de la pirita (bordes de alteración) bajo condiciones oxidantes (Weibel y Friis 2007).

En las piritas se detectó únicamente $\mathrm{Fe}$ y $\mathrm{S}$. Se intentaron medir elementos minoritarios ( $\mathrm{Zn}, \mathrm{Au}, \mathrm{Ni}, \mathrm{Ag}, \mathrm{Sb}, \mathrm{Co}, \mathrm{Cu}, \mathrm{As}, \mathrm{Te}, \mathrm{Hg}$, Se, $\mathrm{Pb}, \mathrm{Bi}$ ) pero los registros estuvieron por debajo del límite de detección del método y por lo tanto no confiables como para ser tenidos en cuenta. Los oxihidróxidos a partir de las observaciones realizadas previamente con microscopio petrográfico y los resultados de los análisis químicos probablemente correspondan con la fase goethita resultante de la oxidación de sulfuros con hierro.

\begin{tabular}{|c|c|c|c|c|c|c|c|c|}
\hline \multirow{3}{*}{$\begin{array}{l}\text { Mineral } \\
\text { Subambiente } \\
\text { Lugar } \\
\text { Posición } \\
\text { Nombre }\end{array}$} & \multicolumn{4}{|c|}{$\begin{array}{c}\text { Till } \\
\text { Acantilado punta Sinaí }\end{array}$} & $\begin{array}{l}\text { Mineral } \\
\text { Subambiente } \\
\text { Lugar }\end{array}$ & & Oxihidróxido & Acantilado Beta \\
\hline & Bor & rde & Nú & cleo & Posición & $\mathbf{N}$ & B & B \\
\hline & 9A.C5.1.1 & 9A.C5.1.2 & 9A.C51.3 & 9A.C51.4 & Nombre & 9B.C3.5.1 & 9B.C3.5.2 & 9B.C3.5.3 \\
\hline \% Peso & & & & & \% Peso & & & \\
\hline $\mathbf{S}$ & - & - & 54,431 & 53,297 & $\mathrm{Fe} 2 \mathrm{O} 3$ & 76,863 & 77,910 & 77,196 \\
\hline $\mathrm{Fe}$ & - & - & 46,036 & 45,810 & $\mathrm{MnO}$ & 1,285 & 1,141 & 0,773 \\
\hline $\mathrm{Fe} 2 \mathrm{O} 3$ & 75,239 & 88,158 & & & Al203 & 0,633 & 0,627 & 0,794 \\
\hline MgO & 0,098 & 0,129 & - & - & MgO & 0,361 & 0,272 & 0,289 \\
\hline Total & 75,336 & 88,287 & 100,466 & 99,107 & Total & 79,142 & 79,950 & 79,052 \\
\hline
\end{tabular}

Tabla 7.10. Análisis realizados mediante microsonda electrónica en piritas y oxihidróxidos (sin calcular el contenido de $\mathrm{H}_{2} \mathrm{O}$ ).

\subsubsection{Grupo del epidoto}

La fórmula estructural ideal de los minerales del grupo del epidoto se puede expresar como $\mathrm{X}_{2} \mathrm{Y}_{3} \mathrm{Z}_{3}(\mathrm{O}){ }_{12}(\mathrm{OH}, \mathrm{F})$ donde $\mathrm{X}=\mathrm{Ca}, \mathrm{REE}, \mathrm{Y}, \mathrm{Th}, \mathrm{Fe}^{2+}, \mathrm{Mn}^{2+}, \mathrm{Mn}^{3+} ; \mathrm{Y}=\mathrm{Al}$, $\mathrm{Fe}^{3+}, \mathrm{Mn}^{2+}, \mathrm{Fe}^{2+}, \mathrm{Ti}$ y $\mathrm{Z}=\mathrm{Si}$, Be (Deer et al. 1992). En estos minerales se puede detectar también $\mathrm{V}^{+3}, \mathrm{P}^{5+} \circ \mathrm{Cr}^{3+}$ entre otros elementos (Armbruster et al. 2006). Dentro del amplio grupo del epidoto se distinguen diferentes subgrupos (Armbruster et al. 2006, Mills et al. 2009), siendo los minerales más comunes clinozoisita, epidoto s.s., allanita y piemontita. A una temperatura de $730^{\circ} \mathrm{C}$ existe una solución sólida continua entre el 
epidoto s.s. y la clinozoisita (Deer et al. 2013). Estas dos fases se identificaron en granos sueltos y la allanita-(Ce) únicamente como inclusión en la estaurolita.

Se analizaron mediante microsonda electrónica 13 minerales del grupo del epidoto provenientes de las playas de los cañadones Beta y Tortuga, El Páramo, bahía San Sebastián y punta Sinaí (A.41). De los depósitos glacigénicos solamente se analizó un epidoto s.s. presente en los depósitos de till de punta Sinaí. En la Tabla 7.11 se muestran análisis representativos de las diferentes fases identificadas.

\begin{tabular}{|c|c|c|c|c|c|}
\hline Mineral & Ep & Ep & Czo & \multicolumn{2}{|c|}{ Ep } \\
\hline Ambiente & Playa & Playa & Playa & \multicolumn{2}{|c|}{ Till } \\
\hline Localización & *El Páramo & ${ }^{*}$ C. Beta & ${ }^{*}$ C. Beta & \multicolumn{2}{|c|}{ A.P.Sinaí } \\
\hline Posición análisis & Núcleo & Núcleo & Núcleo & Núcleo & Borde \\
\hline Nombre & BR.64 & OSR3.18 & OSD.30b.2.1 & A77 & A79 \\
\hline \multicolumn{6}{|l|}{$\% w t$} \\
\hline $\mathrm{SiO}_{2}$ & 38,100 & 37,015 & 37,626 & 38,195 & 38,062 \\
\hline $\mathrm{TiO}_{2}$ & 0,093 & 0,022 & 0,035 & 0,027 & 0,047 \\
\hline $\mathbf{V}_{2} \mathrm{O}_{3}$ & 0,040 & L.D & N.M & L.D & L.D \\
\hline $\mathrm{Al}_{2} \mathrm{O}_{3}$ & 24,250 & 24,359 & 25,318 & 24,280 & 23,117 \\
\hline $\mathrm{Cr}_{2} \mathrm{O}_{3}$ & L.D & L.D & L.D & L.D & L.D \\
\hline $\mathrm{Fe}_{2} \mathrm{O}_{3}$ & 12,124 & 10,530 & 5,470 & 12,529 & 13,560 \\
\hline MnO & 0,133 & 0,087 & 0,176 & 0,101 & 0,128 \\
\hline MgO & 0,018 & 0,274 & 2,505 & 0,032 & 0,025 \\
\hline $\mathrm{CaO}$ & 23,220 & 23,424 & 23,163 & 23,536 & 23,330 \\
\hline $\mathrm{P}_{2} \mathrm{O}_{5}$ & N.M & 0,265 & 0,360 & N.M & N.M \\
\hline Total & 97,978 & 95,977 & 94,653 & 98,700 & 98,270 \\
\hline \multicolumn{6}{|c|}{ Átamos por fórmula unidad $(12,50)$} \\
\hline Si & 3,015 & 2,982 & 3,021 & 3,006 & 3,021 \\
\hline $\mathrm{Ti}$ & 0,006 & 0,001 & 0,002 & 0,002 & 0,003 \\
\hline v & 0,003 & 0,000 & 0,000 & 0,000 & 0,000 \\
\hline Al & 2,262 & 2,313 & 2,396 & 2,252 & 2,162 \\
\hline $\mathrm{Cr}$ & 0,000 & 0,000 & 0,000 & 0,000 & 0,000 \\
\hline $\mathrm{Fe}^{3+}$ & 0,722 & 0,638 & 0,330 & 0,742 & 0,810 \\
\hline $\mathrm{Mn}$ & 0,009 & 0,006 & 0,012 & 0,007 & 0,009 \\
\hline Mg & 0,002 & 0,033 & 0,300 & 0,004 & 0,003 \\
\hline $\mathrm{Ca}$ & 1,969 & 2,022 & 1,992 & 1,984 & 1,984 \\
\hline $\mathbf{P}$ & 0,000 & 0,018 & 0,024 & 0,000 & 0,000 \\
\hline Suma & 7,986 & 8,014 & 8,077 & 7,996 & 7,991 \\
\hline XEp & 24 & 22 & 12 & 25 & 27 \\
\hline
\end{tabular}

Tabla 7.11.. Composición porcentual de elementos mayoritarios y minoritarios de minerales representativos. Datos obtenida por microsonda electrónica en los minerales del grupo del epidoto analizados en las playas y en el sedimento glacial presente en los acantilados. El contenido en agua no se calculó. Se consideró todo el Fe como Fe ${ }^{3+}$ ya que no se aconseja utilizar el método de Droop (1987) por el escaso contenido en $\mathrm{Fe}^{2+}$. XEp $=\mathrm{Fe}^{3+} /\left(\mathrm{Fe}^{3+}+\mathrm{Al}\right) * 100$. Alguno de los granos quedó con un cierre composicional demasiado bajo, sin embargo se decidió dejarlo para dar información cuantitativasemicuantitativa.

Los resultados de los análisis químicos determinaron composiciones correspondientes a la solución sólida epidoto-clinozoisita, perteneciendo la mayoría de los granos a la fase epidoto (XEp>14, valor tomado de Deer et al. 1997a). Únicamente dos granos mostraron un bajo contenido en $\mathrm{Fe}_{2} \mathrm{O}_{3}$ correspondiendo su composición con la fase 
clinozoisita. El contenido de $\mathrm{CaO}$ varió entre un 21 y 23\%; solamente un grano correspondiente con la fase clinozoisita presentó un contenido mayor de $34 \%$. Presentan bajos contenidos en $\mathrm{Mn}_{2} \mathrm{O}(<1 \%)$ y $\mathrm{MgO}(<0,3 \%$ para los epidotos y $<2,5 \%$ para las clinozoisitas). En algunos granos se alcanzó a medir el contenido en $\mathrm{P}_{2} \mathrm{O}_{5}$ dando valores entre 0,23 y $0,44 \% . \mathrm{V}_{2} \mathrm{O}_{3}$ fue detectado solamente en dos granos, con valores ente 0,04 y $0,17 \%$. Se analizaron otros elementos como el $\mathrm{Ta}^{+5}, \mathrm{Zn}, \mathrm{Ni}, \mathrm{Na}$ y $\mathrm{Cr}^{+3}$, pero no se logró detectarlos.

La composición del grano de epidoto s.s. analizado en una muestra proveniente de los depósitos de till continentales coincidió con la composición de los granos de esta fase presentes en las playas.

\subsubsection{Estaurolita}

La fórmula general de la estaurolita se puede representar como $\left(\mathrm{Fe}^{2+}, \mathrm{Mg}\right)_{2} \mathrm{Al} 9(\mathrm{Si}$, $\mathrm{Al})_{4} \mathrm{O}_{20}(\mathrm{O}, \mathrm{OH})_{4}$, pudiendo incorporar $\mathrm{Zn}$, Co, $\mathrm{Li}, \mathrm{Fe}^{+3}$, Ti o Cr. Los cálculos del a.p.f.u. se realizaron en base a $23 \mathrm{O}$. Los elementos volátiles como el $\mathrm{H}_{2} \mathrm{O}$ y Li no fueron calculados.

Se analizó un total de 9 granos de estaurolitas procedentes de muestras de la zona supramareal de las playas de la bahía San Sebastián y de los niveles enriquecidos presentes en los cañadones Alfa, Beta y Tortuga (A.42).

Los análisis mostraron una composición muy similar en todos los granos, detectando variaciones mínimas de núcleo a bordes. El contenido de $\mathrm{SiO}_{2}$ presentó un promedio de $26,96 \%, \mathrm{Al}_{2} \mathrm{O}_{3}$ de $54,91 \%$, $\mathrm{FeO}$ de $14,1 \%$, $\mathrm{MgO}$ de 1,47 y $\mathrm{MnO}$ de $0,48 \%$. El contenido de $\mathrm{TiO}_{2}$ varió entre 0,23-0,7\%, ZnO se detectó en algunos granos donde alcanzó el valor máximo de $0,48 \%$ y $\mathrm{Cr}_{2} \mathrm{O}_{3}$ únicamente se halló en un grano con un valor de $0,085 \%$. El valor de $\mathrm{X}_{\mathrm{Mg}}$ varió entre 0,12 y 0,19 y $\mathrm{X}_{\mathrm{Fe}}$ entre 0,81 y 0,88. En la tabla 7.12 se muestra la composición química de dos estaurolitas consideradas representativas (para mayor información de todas las estaurolitas analizadas se remite al lector al anexo analítico).

Las estaurolitas muestran abundantes inclusiones o intercrecimientos, cuya composición analizada mediante FE-SEM permitió reconocer cuarzo, circón, plagioclasa (oligoclasa), allanita-(Ce), ilmenita, pirita y fosfatos como monacita-(Ce) con abundante Th y flúorapatita (Fig.7.16). 


\begin{tabular}{|c|c|c|c|c|}
\hline Análisis & 2 & 2 & 1 & 2 \\
\hline Subambiente & \multicolumn{2}{|c|}{ Playa } & \multicolumn{2}{|c|}{ Playa } \\
\hline Localización & \multicolumn{2}{|c|}{${ }^{*}$ C.Alfa } & \multicolumn{2}{|c|}{${ }^{*}$ C. Beta } \\
\hline Posición & $\mathbf{N}$ & B & $\mathbf{N}$ & B \\
\hline Nombre & P205 & P206 & P326 & P328 \\
\hline \multicolumn{5}{|l|}{$\%$ en peso } \\
\hline $\mathrm{K} 2 \mathrm{O}$ & L.D & L.D & L.D & L.D \\
\hline $\mathrm{CaO}$ & L.D & L.D & L.D & L.D \\
\hline $\mathrm{TiO} 2$ & 0,366 & 0,404 & 0,570 & 0,582 \\
\hline $\mathrm{FeO}$ & 13,784 & 14,112 & 13,365 & 13,595 \\
\hline $\mathrm{MnO}$ & 0,557 & 0,627 & 0,427 & 0,450 \\
\hline $\mathrm{Na} 2 \mathrm{O}$ & L.D & L.D & L.D & L.D \\
\hline $\mathrm{Cr} 2 \mathrm{O} 3$ & L.D & L.D & L.D & L.D \\
\hline $\mathrm{NiO}$ & L.D & L.D & L.D & L.D \\
\hline $\mathrm{SiO} 2$ & 26,860 & 27,556 & 26,586 & 27,105 \\
\hline $\mathrm{Al} 2 \mathrm{O} 3$ & 54,787 & 54,826 & 54,882 & 54,463 \\
\hline $\mathrm{MgO}$ & 1,208 & 1,178 & 1,765 & 1,811 \\
\hline V2O3 & L.D & L.D & L.D & L.D \\
\hline $\mathrm{ZnO}$ & 0,106 & 0,199 & 0,467 & 0,380 \\
\hline Total & 97,667 & 98,903 & 98,062 & 98,386 \\
\hline \multicolumn{5}{|l|}{ APFU (230) } \\
\hline $\mathrm{Ti}$ & 0,038 & 0,042 & 0,060 & 0,061 \\
\hline $\mathrm{Fe} 2+$ & 1,608 & 1,627 & 1,553 & 1,574 \\
\hline $\mathrm{Mn}$ & 0,066 & 0,073 & 0,050 & 0,053 \\
\hline $\mathrm{Cr}$ & 0,000 & 0,000 & 0,000 & 0,000 \\
\hline $\mathrm{Si}$ & 3,746 & 3,798 & 3,693 & 3,753 \\
\hline $\mathrm{Al}$ & 9,005 & 8,906 & 8,985 & 8,888 \\
\hline $\mathrm{Mg}$ & 0,251 & 0,242 & 0,365 & 0,374 \\
\hline $\mathrm{Zn}$ & 0,000 & 0,020 & 0,048 & 0,039 \\
\hline Total & 14,713 & 14,707 & 14,755 & 14,742 \\
\hline XMg & 0,14 & 0,13 & 0,19 & 0,19 \\
\hline XFe & 0,86 & 0,87 & 0,81 & 0,81 \\
\hline
\end{tabular}

Tabla 7.12. Análisis químicos representativos realizados mediante microsonda electrónica de dos estaurolitas. L.D límite de detección. N núcleo B borde. * Grano procedente de nivel enriquecido en minerales pesados.
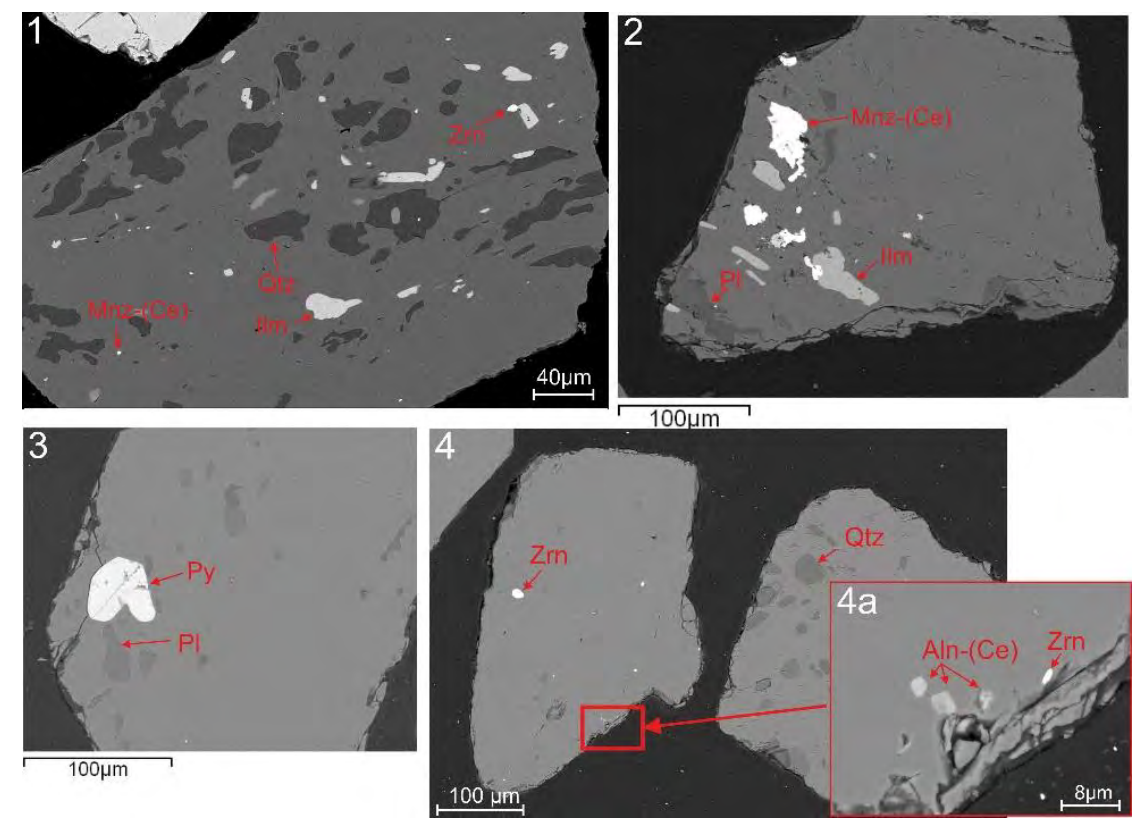

Fig.7.16. Imágenes realizadas mediante electrones retrodispersados de estaurolitas. Abreviaturas: Aln-(Ce), allanita(Ce); Zrn, circón; Qtz, cuarzo; IIm, ilmenita; Mnz-(Ce), monacita-(Ce); Pl, plagioclasa; Py, pirita. 


\subsubsection{Titanita}

La fórmula de la titanita se expresa como $\mathrm{CaTi}\left(\mathrm{SiO}_{4}\right)(\mathrm{O}, \mathrm{OH}, \mathrm{F})$. Puede presentar pequeñas cantidades de tierras raras (livianas generalmente), $\mathrm{Fe}, \mathrm{Al}, \mathrm{Mn}, \mathrm{Mg}$ y $\mathrm{Zr}$.

Se analizaron 2 titanitas provenientes de la Plataforma Continental media y externa, 2 titanitas de los niveles ricos localizados en las playas de los cañadones Beta y Tortuga, y finalmente del sedimento glacial presente en los acantilados del cañadón Beta se estudió una ilmenita alterada en los bordes a titanita (Tabla 7.13). Los granos analizados mostraron enriquecimiento en $\mathrm{Al}$ y $\mathrm{Fe}^{+3}$. Se alcanzó a medir en algunos cristales concentraciones menores de $\mathrm{Mn}, \mathrm{Nb}, \mathrm{P}, \mathrm{V}$ y $\mathrm{F}$ apenas por encima del límite de detección.

\begin{tabular}{|c|c|c|c|c|c|c|c|}
\hline $\begin{array}{l}\text { Mineral } \\
\text { Nombre }\end{array}$ & $\begin{array}{c}\text { Ttn } \\
\text { OOR3.73 }\end{array}$ & $\begin{array}{c}\text { Ttn } \\
\text { OSD.70 }\end{array}$ & $\begin{array}{c}\text { Ttn } \\
\text { OSR1.1 }\end{array}$ & $\begin{array}{c}\text { Ttn } \\
\text { OSR1.2 }\end{array}$ & $\begin{array}{c}\text { Ttn } \\
\text { OSR1.3 }\end{array}$ & $\begin{array}{c}\text { Ttn } \\
\text { OSR1.4 }\end{array}$ & $\begin{array}{c}\text { Ttn } \\
\text { A145 }\end{array}$ \\
\hline Ubicación & $\mathbf{N}$ & Ti-Mag con Ttn & N & B & $\mathbf{N}$ & B & Ti-Hem con Ttn y Am \\
\hline $\mathrm{n}^{\circ}$ análisis & 1 & 1 & 1 & 1 & 1 & 1 & 1 \\
\hline Subambiente & Playa & Playa & \multirow{2}{*}{\multicolumn{2}{|c|}{$\begin{array}{c}\text { Plataforma } \\
\text { Externa }\end{array}$}} & \multirow{2}{*}{\multicolumn{2}{|c|}{$\begin{array}{c}\text { Plataforma } \\
\text { Media }\end{array}$}} & Till \\
\hline Localización & ${ }^{*}$ C.Beta & ${ }^{*} \mathrm{C}$. Tortuga & & & & & A.C.Beta \\
\hline \multicolumn{8}{|l|}{$\%$ en peso } \\
\hline $\mathrm{SiO}_{2}$ & 26,724 & 30,536 & 30,311 & 29,798 & 30,846 & 30,788 & 30,339 \\
\hline $\mathrm{TiO}_{2}$ & 41,989 & 38,047 & 37,512 & 38,296 & 38,359 & 36,553 & 38,475 \\
\hline $\mathrm{Nb}_{2} \mathrm{O}_{3}$ & L.D & N.M & 0,137 & 0,217 & 0,154 & 0,200 & N.M \\
\hline $\mathrm{Ta}_{2} \mathrm{O}_{5}$ & 0,234 & N.M & 0,278 & 0,166 & L.D & 0,293 & N.M \\
\hline $\mathrm{V}_{2} \mathrm{O}_{3}$ & 0,262 & N.M & L.D & L.D & 0,332 & L.D & 0,308 \\
\hline $\mathrm{Al}_{2} \mathrm{O}_{3}$ & 3,601 & 2,165 & 1,254 & 1,162 & 1,295 & 1,561 & 0,922 \\
\hline $\mathrm{Cr}_{2} \mathrm{O}_{3}$ & L.D & L.D & 0,000 & 0,000 & 0,000 & L.D & L.D \\
\hline $\mathrm{Fe}_{2} \mathrm{O}_{3}$ & 0,498 & 2,265 & 1,849 & 1,690 & 1,006 & 1,491 & 1,837 \\
\hline $\mathrm{ZnO}$ & L.D & N.M & L.D & L.D & L.D & L.D & L.D \\
\hline $\mathrm{MnO}$ & L.D & L.D & 0,168 & 0,201 & 0,089 & 0,174 & 0,084 \\
\hline $\mathrm{MgO}$ & 0,056 & 0,000 & 0,049 & 0,104 & L.D & 0,099 & L.D \\
\hline $\mathrm{CaO}$ & 24,928 & 27,740 & 27,334 & 27,009 & 27,960 & 27,757 & 28,287 \\
\hline $\mathrm{Na}_{2} \mathrm{O}$ & N.M & L.D & L.D & L.D & 0,000 & 0,000 & L.D \\
\hline $\mathrm{P}_{2} \mathrm{O}_{5}$ & N.M & 0,387 & 0,408 & 0,392 & 0,358 & 0,418 & N.M \\
\hline $\mathrm{F}$ & N.M & N.M & L.D & 0,158 & 0,329 & 0,273 & N.M \\
\hline $\mathrm{Cl}$ & N.M & N.M & 0,000 & 0,000 & L.D & L.D & N.M \\
\hline $\mathrm{O}=\mathrm{F}$ & - & - & - & 0,066 & 0,139 & 0,115 & - \\
\hline $\mathrm{O}=\mathrm{Cl}$ & - & - & - & 0,000 & - & - & - \\
\hline Total & 99,423 & 102,304 & 100,440 & 100,188 & 101,593 & 100,505 & 101,399 \\
\hline \multicolumn{8}{|c|}{ Fórmula estructural. 5 aniones } \\
\hline $\mathrm{Si}$ & 0,886 & 0,983 & 0,997 & 0,981 & 0,997 & 1,008 & 0,991 \\
\hline $\mathrm{Ti}$ & 1,047 & 0,922 & 0,928 & 0,949 & 0,933 & 0,900 & 0,946 \\
\hline $\mathrm{Nb}$ & L.D & N.M & 0,002 & 0,004 & 0,003 & 0,003 & N.M \\
\hline $\mathrm{Ta}$ & 0,002 & N.M & 0,002 & 0,001 & L.D & 0,003 & N.M \\
\hline $\mathrm{V}$ & 0,007 & N.M & L.D & L.D & 0,009 & L.D & 0,008 \\
\hline Al & 0,141 & 0,082 & 0,049 & 0,045 & 0,049 & 0,060 & 0,036 \\
\hline $\mathrm{Cr}$ & L.D & L.D & 0,000 & 0,000 & 0,000 & L.D & L.D \\
\hline $\mathrm{Fe}$ & 0,012 & 0,055 & 0,046 & 0,042 & 0,024 & 0,037 & 0,045 \\
\hline $\mathrm{Zn}$ & L.D & N.M & L.D & L.D & L.D & L.D & L.D \\
\hline $\mathrm{Mn}$ & L.D & L.D & 0,005 & 0,006 & 0,002 & 0,005 & 0,002 \\
\hline $\mathrm{Mg}$ & 0,003 & 0,000 & 0,002 & 0,005 & L.D & 0,005 & L.D \\
\hline $\mathrm{Ca}$ & 0,885 & 0,957 & 0,963 & 0,953 & 0,968 & 0,974 & 0,990 \\
\hline $\mathrm{Na}$ & N.M & L.D & L.D & L.D & 0,000 & 0,000 & L.D \\
\hline $\mathrm{P}$ & N.M & 0,011 & 0,011 & 0,011 & 0,010 & 0,012 & N.M \\
\hline $\mathrm{F}$ & N.M & N.M & L.D & 0,016 & 0,034 & 0,028 & N.M \\
\hline $\mathrm{Cl}$ & N.M & N.M & 0,000 & 0,000 & L.D & L.D & N.M \\
\hline Suma & 2,984 & 3,010 & 3,006 & 3,014 & 3,029 & 3,034 & 3,019 \\
\hline
\end{tabular}

Tabla 7.13 Análisis de microsonda electrónica realizados en titanitas. Todo el Fe fue considerado como Fe ${ }^{3+}$. N núcleo y B borde. * Nivel enriquecido. OSD.70 análisis realizado por de R.D. Acevedo (com. pers.). 


\subsubsection{Grupo de la apatita}

El grupo de la apatita se representa con la fórmula $\mathrm{Ca}_{5}\left(\mathrm{PO}_{4}\right)_{3}(\mathrm{OH}, \mathrm{F}, \mathrm{Cl})$. Las variedades más comunes y que constituyen los miembros extremos son la flúorapatita (con F), cloroapatita (con $\mathrm{Cl}$ ) e hidroxiapatita (con $\mathrm{OH}$ ). El F, $\mathrm{Cl}$ y OH pueden sustituirse entre sí dando origen a una seria completa. Las apatitas pueden presentar otros elementos como $\mathrm{Si}^{4+}, \mathrm{Na}^{+}, \mathrm{Mn}, \mathrm{Mg}, \mathrm{Fe}^{2+}, \mathrm{Sr}$ o tierras raras (Klein y Hurlbut 1997, Piccoli y Candela 2002).

Se analizaron 4 apatitas: dos provenientes del sedimento glacial de los acantilados del cañadón Beta y punta Sinaí y otras dos de los niveles ricos presentes en las playas de los cañadones Beta y Tortuga correspondientes a una inclusión dentro de un óxido intermedio de $\mathrm{Fe}-\mathrm{Ti}$ y a un grano constituido por rutilo y apatita.

A partir del análisis químico se determinaron las fases flúorapatita e hidroxiapatita, con un contenido en $\mathrm{F}$ corregido (sobrestimación con la microsonda) que varió entre 1,1$1,3 \%$ y $0,5-0,6 \%$ respectivamente (Tabla 7.14 ).

\begin{tabular}{|c|c|c|c|c|c|c|c|c|}
\hline Mineral & \multicolumn{3}{|c|}{ Ap } & \multicolumn{3}{|c|}{ Ap } & \multirow{2}{*}{$\begin{array}{c}\text { Ap inclusión en Ox Fe-Ti } \\
\text { ODP.29 }\end{array}$} & \multirow{2}{*}{$\begin{array}{l}\text { Ap+Rut } \\
\text { ODP.89 }\end{array}$} \\
\hline Nombre & A104 & A106 & A107 & A200 & A201 & A202 & & \\
\hline Ubicación & $\mathbf{N}$ & B & B & $\mathbf{N}$ & B & B & $\mathbf{N}$ & $\mathbf{N}$ \\
\hline$n^{\circ}$ análisis & 1 & 1 & 1 & 1 & 1 & 1 & 1 & 1 \\
\hline Subambiente & \multicolumn{3}{|c|}{ Till } & \multicolumn{3}{|c|}{ Till } & Playa & Playa \\
\hline Localización & \multicolumn{3}{|c|}{ A.P.Sinaí } & \multicolumn{3}{|c|}{ A.C.Beta } & ${ }^{*}$ C. Beta & ${ }^{*} \mathrm{C}$. Tortuga \\
\hline$\%$ en peso & & & & & & & & \\
\hline $\mathrm{SiO}_{2}$ & 0,172 & 0,215 & 0,130 & 0,075 & 0,085 & 0,047 & 0,120 & 0,060 \\
\hline $\mathrm{Al}_{2} \mathrm{O}_{3}$ & L.D & L.D & 0,000 & L.D & 0,058 & L.D & L.D & L.D \\
\hline $\mathrm{FeO}$ & L.D & L.D & L.D & 0,331 & 0,294 & 0,347 & 1,330 & 0,374 \\
\hline $\mathrm{MnO}$ & 0,136 & 0,186 & 0,179 & 0,206 & 0,210 & 0,216 & 0,190 & 0,346 \\
\hline $\mathrm{MgO}$ & 0,030 & 0,000 & 0,000 & 0,156 & 0,154 & 0,175 & 0,166 & 0,003 \\
\hline $\mathrm{CaO}$ & 54,891 & 54,679 & 55,264 & 54,736 & 54,461 & 54,535 & 54,122 & 54,224 \\
\hline $\mathrm{Na}_{2} \mathrm{O}$ & 0,000 & 0,000 & 0,000 & 0,000 & 0,000 & 0,000 & L.D & L.D \\
\hline $\mathrm{K}_{2} \mathrm{O}$ & 0,000 & 0,005 & 0,002 & 0,003 & 0,000 & 0,000 & 0,000 & 0,013 \\
\hline $\mathrm{P}_{2} \mathrm{O}_{5}$ & 42,434 & 42,692 & 42,565 & 42,733 & 42,651 & 43,115 & 43,718 & 43,975 \\
\hline$F$ & 3,035 & 2,626 & 2,729 & 1,359 & 1,238 & 1,138 & - & - \\
\hline $\mathrm{Cl}$ & 0,046 & 0,063 & 0,055 & 0,636 & 0,759 & 0,766 & - & - \\
\hline $\mathrm{H}_{2} \mathrm{O}^{* *}$ & 0,344 & 0,532 & 0,488 & 0,992 & 1,014 & 1,071 & 1,826 & 1,822 \\
\hline$F=O$ & 1,278 & 1,106 & 1,149 & 0,572 & 0,521 & 0,479 & 0,000 & 0,000 \\
\hline $\mathrm{Cl}=\mathrm{O}$ & 0,010 & 0,014 & 0,012 & 0,143 & 0,171 & 0,173 & 0,000 & 0,000 \\
\hline Total & 99,798 & 99,879 & 100,250 & 100,512 & 100,230 & 100,757 & 101,472 & 100,817 \\
\hline \multicolumn{9}{|c|}{ Fórmula Estructural. 25 oxígenos } \\
\hline $\mathrm{Si}$ & 0,029 & 0,036 & 0,022 & 0,013 & 0,014 & 0,008 & 0,020 & 0,010 \\
\hline $\mathrm{Al}$ & 0,000 & 0,000 & 0,000 & 0,000 & 0,011 & 0,000 & 0,000 & 0,000 \\
\hline $\mathrm{Fe}^{2+}$ & 0,000 & 0,000 & 0,000 & 0,046 & 0,041 & 0,048 & 0,183 & 0,051 \\
\hline $\mathrm{Mn}$ & 0,019 & 0,026 & 0,025 & 0,029 & 0,030 & 0,030 & 0,026 & 0,048 \\
\hline Mg & 0,007 & 0,000 & 0,000 & 0,039 & 0,038 & 0,043 & 0,041 & 0,001 \\
\hline $\mathrm{Ca}$ & 9,860 & 9,795 & 9,888 & 9,779 & 9,755 & 9,706 & 9,520 & 9,561 \\
\hline $\mathrm{Na}$ & 0,000 & 0,000 & 0,000 & 0,000 & 0,000 & 0,000 & 0,000 & 0,000 \\
\hline K & 0,000 & 0,001 & 0,000 & 0,001 & 0,000 & 0,000 & 0,000 & 0,003 \\
\hline$P^{5+}$ & 6,022 & 6,043 & 6,017 & 6,032 & 6,036 & 6,063 & 6,076 & 6,127 \\
\hline$F$ & 1,609 & 1,389 & 1,441 & 0,717 & 0,654 & 0,598 & 0,000 & 0,000 \\
\hline $\mathrm{Cl}$ & 0,007 & 0,018 & 0,016 & 0,180 & 0,215 & 0,216 & 0,000 & 0,000 \\
\hline $\mathrm{OH}$ & 0,384 & 0,593 & 0,543 & 1,104 & 1,131 & 1,187 & & \\
\hline $\mathrm{XOH}$ & 0,192 & 0,297 & 0,272 & 0,552 & 0,565 & 0,593 & N.C & N.C \\
\hline XF & 0,805 & 0,694 & 0,720 & 0,358 & 0,327 & 0,299 & N.C & N.C \\
\hline $\mathrm{XCl}$ & 0,003 & 0,009 & 0,008 & 0,090 & 0,108 & 0,108 & N.C & N.C \\
\hline
\end{tabular}

Tabla 7.14. Análisis químicos por microsonda electrónica de las diferentes apatitas identificadas. * Análisis realizado por de R.D. Acevedo (com. pers.). $\mathrm{H}_{2} \mathrm{O}^{* *}$ estimado a partir del $\mathrm{OH}(\mathrm{OH}=2-\mathrm{F}-\mathrm{Cl})$. 


\subsubsection{Circón}

El circón $\mathrm{ZrSiO}_{4}$ siempre contiene algo de $\mathrm{Hf}$ y en numerosas ocasiones pequeñas cantidades de tierras raras, Th y $U$ (Deer et al. 1992).

Se analizó un total de 26 granos de circón: 22 provenientes de las playas de los cañadones Beta y Tortuga, El Páramo (incluyendo la espiga), bahía San Sebastián y punta Sinaí (A.43 y 44); 3 de los depósitos glacigénicos continentales presentes en los acantilados de los cañadones Beta y Tortuga y finalmente 1 de la Plataforma Continental media (A.45). Uno de los circones analizados procedente de la playa de la espiga de El Páramo corresponde a una inclusión dentro de una ilmenita rica en Mn.

En todos los granos se detectó $\mathrm{Zr}$, Hf y $\mathrm{P}$. También se intentó medir diferentes elementos de las tierras raras, Th y $\mathrm{U}$, pero la gran mayoría de ellos no pudo ser detectado. Todos los granos mostraron un contenido en $\mathrm{Zr}$, Hf, $\mathrm{P}$ e $\mathrm{Y}$ similar, variando entre un 64 y $67 \%$ el $\mathrm{ZrO}_{2}, 1,1$ y $2 \%$ el $\mathrm{HfO}_{2}, 0,1$ y $0,3 \%$ el $\mathrm{P}_{2} \mathrm{O}_{5}$ y 0,03 y $0,2 \%$ el $\mathrm{Y}_{2} \mathrm{O}_{3}$ (Tabla 7.15 y Fig.7.17). Hacia el borde de los granos se midió en forma recurrente un aumento en el contenido de $\mathrm{Hf}$ e $\mathrm{Y}$, y leve disminución del $\mathrm{P}$.

\begin{tabular}{|c|c|c|c|c|c|c|c|c|c|c|c|}
\hline Mineral & \multicolumn{3}{|c|}{ Zrn } & \multicolumn{5}{|c|}{ Zrn } & \multicolumn{3}{|c|}{ Zrn } \\
\hline Nombre & A466 & A467 & A468 & A182 & A183 & A184 & A185 & A186 & ORZ.77 & ORZ.78 & ORZ.79 \\
\hline Ubicación & $\mathbf{N}$ & B & Int & $\mathbf{N}$ & Int & Int & Int & B & Int & $\mathbf{N}$ & B \\
\hline Subambiente & \multirow{2}{*}{\multicolumn{3}{|c|}{$\begin{array}{c}\text { Playa } \\
\text { *La Espiga } \\
\end{array}$}} & \multirow{2}{*}{\multicolumn{5}{|c|}{$\begin{array}{c}\text { Till } \\
\text { A.C.Beta }\end{array}$}} & \multirow{2}{*}{\multicolumn{3}{|c|}{$\begin{array}{c}\text { Plataforma } \\
\text { Media }\end{array}$}} \\
\hline Localización & & & & & & & & & & & \\
\hline peso & & & & & & & & & & & \\
\hline $\mathrm{SiO}_{2}$ & 33,012 & 33,066 & 32,780 & 33,326 & 33,464 & 33,006 & 32,791 & 33,220 & 32,493 & 32,815 & 32,681 \\
\hline $\mathrm{ZrO}_{2}$ & 65,118 & 64,625 & 66,019 & 65,147 & 65,274 & 65,600 & 65,772 & 64,680 & 65,125 & 65,089 & 64,728 \\
\hline $\mathrm{HfO}_{2}$ & 1,103 & 1,645 & 1,537 & 1,332 & 1,385 & 1,472 & 1,332 & 2,006 & 1,322 & 1,252 & 1,519 \\
\hline $\mathrm{P}_{2} \mathrm{O}_{5}$ & 0,223 & 0,204 & 0,189 & 0,213 & 0,197 & 0,214 & 0,184 & 0,117 & 0,146 & 0,201 & 0,190 \\
\hline $\mathrm{ThO}_{2}$ & L.D & L.D & L.D & 0,000 & 0,000 & 0,000 & 0,000 & L.D & L.D & 0,053 & 0,045 \\
\hline $\mathrm{Nd}_{2} \mathrm{O}_{3}$ & 0,047 & L.D & L.D & 0,034 & L.D & 0,047 & L.D & 0,032 & 0,033 & L.D & 0,035 \\
\hline $\mathrm{Dy}_{2} \mathrm{O}_{3}$ & L.D & 0,000 & 0,000 & L.D & L.D & 0,000 & 0,000 & L.D & 0,061 & 0,000 & 0,087 \\
\hline $\mathrm{Yb}_{2} \mathrm{O}_{3}$ & 0,000 & L.D & L.D & L.D & L.D & 0,000 & 0,000 & L.D & L.D & L.D & 0,000 \\
\hline $\mathrm{Er}_{2} \mathrm{O}_{3}$ & L.D & 0,048 & 0,035 & L.D & 0,035 & 0,038 & 0,037 & 0,051 & 0,032 & 0,058 & 0,038 \\
\hline $\mathrm{Y}_{2} \mathrm{O}_{3}$ & 0,079 & 0,143 & 0,040 & 0,094 & 0,100 & 0,027 & 0,045 & 0,124 & 0,127 & 0,085 & 0,109 \\
\hline Total & 99,581 & 99,729 & 100,600 & 100,146 & 100,454 & 100,404 & 100,160 & 100,229 & 99,339 & 99,552 & 99,432 \\
\hline
\end{tabular}

Tabla 7.15. Análisis químicos de microsonda electrónica representativos de circones provenientes de las arenas de las playas, del sedimento glacial y la Plataforma Continental. $N$, núcleo $B$, borde Int, zona intermedia. 

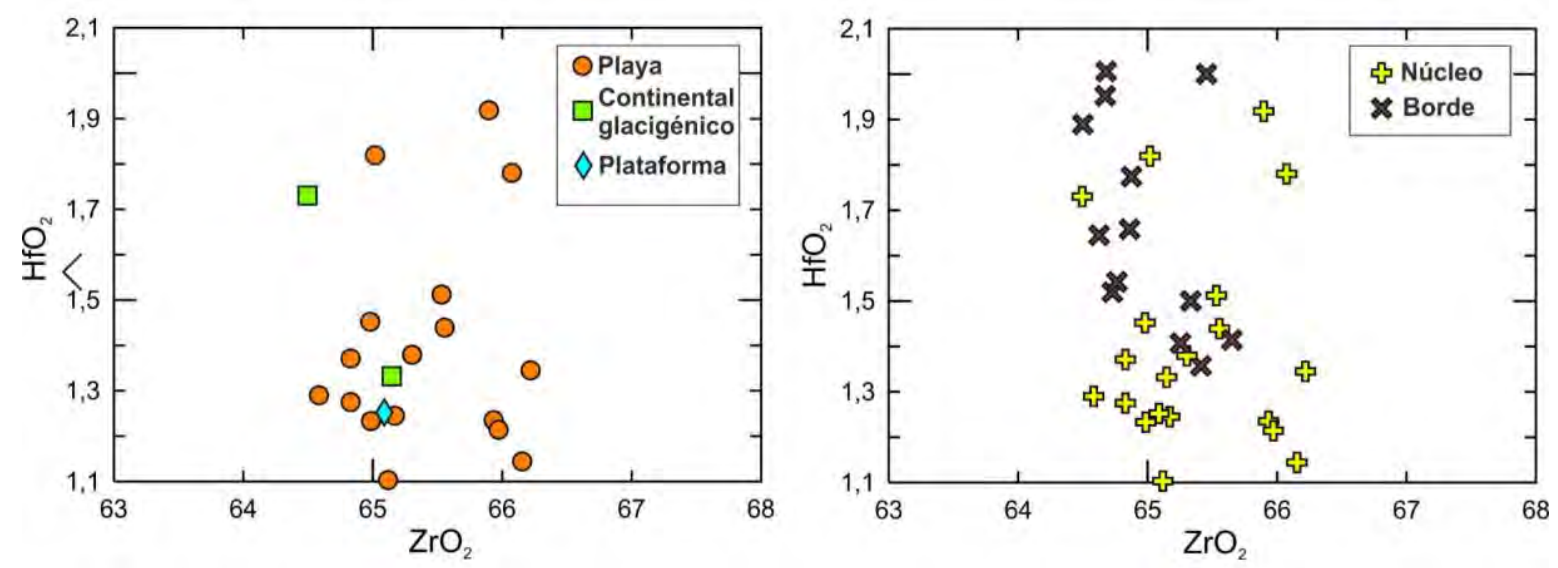

Fig.7.17. Diagrama binario $\mathrm{HfO}_{2}$ vs $\mathrm{ZrO}_{2}$ de los diferentes circones analizados.

A partir del análisis de las inclusiones en los granos de las playas mediante el detector de energía dispersiva (EDS) adosado a microscopio electrónico de barrido se determinó que la mayoría corresponden a cristales de flúorapatita, Ap- $(F)$, feldespato potásico, cuarzo y en menor medida plagioclasa (Fig.7.18).

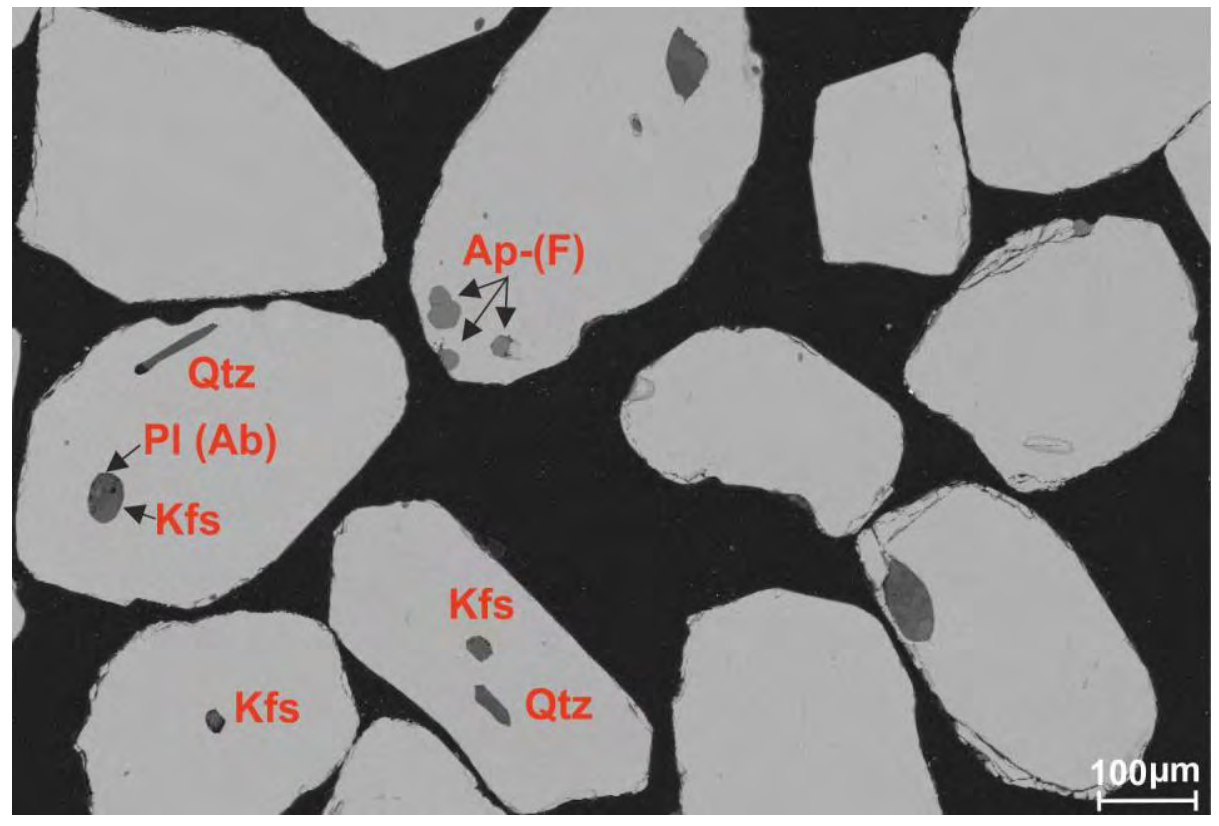

Fig.7.18. Imagen realizada mediante electrones retrodispersados de un concentrado de granos de circón proveniente de las arenas de las playas. Qtz, cuarzo, F-Ap flúorapatita, Pl (Ab), plagioclasa rica en Na, probablemente albita, Kfs, feldespato potásico.

\subsubsection{Andalucita}

La fórmula general de la andalucita se representa como $\mathrm{Al}_{2} \mathrm{SiO}_{5}$, pudiendo contener pequeñas cantidades de $\mathrm{Fe}^{3+}$ y $\mathrm{Mn}^{3+}$ sustituyendo el Al. El cálculo de la fórmula estructural se realizó en base a 20 O (Deer et al. 1992). 
Se analizaron cuatro andalucitas, dos de las arenas del sedimento glacigénico presente en los acantilados de los cañadones Beta (till) y Tortuga (glacifluvial), una procedente de la playa de la bahía San Sebastián y otra de los sedimentos de la cubierta superficial de la Plataforma Continental interna. Todas ellas presentaron una química similar, con un contenido promedio de $\mathrm{SiO}_{2} 36,4 \%, \mathrm{Al}_{2} \mathrm{O}_{3} 62,2 \%$ y $\mathrm{Fe}_{2} \mathrm{O}_{3}$ 0,3\%, aumentando ligeramente el porcentual en peso de este último óxido de núcleo a borde (Tabla 7.16).

\begin{tabular}{|c|c|c|c|c|c|c|c|c|}
\hline Análisis & 1 & 2 & 1 & 1 & 1 & 2 & 1 & 1 \\
\hline Posición & $\mathrm{N}$ & B & B & $\mathrm{N}$ & $\mathrm{N}$ & B & $\mathrm{N}$ & B \\
\hline Subambiente & \multicolumn{2}{|c|}{ Till } & \multicolumn{2}{|c|}{ Glacifluvial } & \multicolumn{2}{|c|}{ Playa } & \multicolumn{2}{|c|}{ Plataforma } \\
\hline Localización & \multicolumn{2}{|c|}{ A.C.Beta } & \multicolumn{2}{|c|}{ A.C.Tortuga } & \multicolumn{2}{|c|}{ B.S.Sebastián } & \multicolumn{2}{|c|}{ Interna } \\
\hline Nombre & A159 & A161 & OSR2.29 & OSR2.30 & OSR1.22 & OSR1.23 & OSR1.56 & OSR1.57 \\
\hline \multicolumn{9}{|l|}{$\%$ en peso } \\
\hline $\mathrm{K}_{2} \mathrm{O}$ & L.D & L.D & L.D & L.D & L.D & L.D & L.D & L.D \\
\hline $\mathrm{CaO}$ & L.D & L.D & L.D & L.D & L.D & L.D & L.D & L.D \\
\hline $\mathrm{TiO}_{2}$ & L.D & L.D & L.D & L.D & L.D & L.D & L.D & L.D \\
\hline $\mathrm{Fe}_{2} \mathrm{O}_{3}$ & 0,230 & 0,306 & 0,326 & 0,308 & 0,278 & 0,277 & 0,251 & 0,270 \\
\hline $\mathrm{MnO}$ & L.D & L.D & L.D & L.D & L.D & L.D & L.D & L.D \\
\hline $\mathrm{Na}_{2} \mathrm{O}$ & L.D & L.D & L.D & L.D & L.D & L.D & L.D & L.D \\
\hline $\mathrm{Cr}_{2} \mathrm{O}_{3}$ & L.D & L.D & L.D & L.D & L.D & L.D & L.D & L.D \\
\hline $\mathrm{NiO}$ & L.D & L.D & L.D & L.D & L.D & L.D & L.D & L.D \\
\hline $\mathrm{SiO}_{2}$ & 36,381 & 37,099 & 36,975 & 36,801 & 36,330 & 36,405 & 35,888 & 35,598 \\
\hline $\mathrm{Al}_{2} \mathrm{O}_{3}$ & 63,285 & 62,764 & 62,434 & 63,070 & 63,072 & 62,757 & 60,313 & 59,992 \\
\hline $\mathrm{MgO}$ & L.D & L.D & L.D & L.D & L.D & L.D & L.D & L.D \\
\hline $\mathrm{V}_{2} \mathrm{O}_{3}$ & L.D & L.D & L.D & L.D & L.D & L.D & L.D & L.D \\
\hline $\mathrm{ZnO}$ & L.D & L.D & L.D & L.D & L.D & L.D & L.D & L.D \\
\hline Total & 99,896 & 100,169 & 99,735 & 100,179 & 99,680 & 99,439 & 96,452 & 95,859 \\
\hline \multicolumn{9}{|l|}{$A P F U(200)$} \\
\hline $\mathrm{Fe}^{3+}$ & 0,014 & 0,019 & 0,017 & 0,017 & 0,016 & 0,017 & 0,020 & 0,019 \\
\hline $\mathrm{Si}$ & 2,354 & 2,404 & 2,357 & 2,370 & 2,416 & 2,411 & 2,407 & 2,380 \\
\hline $\mathrm{Al}$ & 10,181 & 10,110 & 10,174 & 10,157 & 10,096 & 10,102 & 10,104 & 10,141 \\
\hline Total & 12,549 & 12,532 & 12,548 & 12,543 & 12,528 & 12,530 & 12,531 & 12,540 \\
\hline
\end{tabular}

Tabla 7.16. Composiciones químicas porcentuales obtenidas mediante microsonda electrónica en andalucitas. Si bien hay algunos análisis que no son de gran calidad por estar el cierre composicional por debajo del 98\%, se han incluido ya que dan información cualitativa-semicuantitativa sobre la composición de la andalucita presente en los sedimentos de la Plataforma Continental.

\subsubsection{Grupo del Oro}

El oro nunca es puro ya que en la naturaleza se presenta constituyendo aleaciones principalmente con $\mathrm{Ag}$, Cu y $\mathrm{Hg}$. El Au y la Ag presentan el mismo radio atómico por lo que existe una serie completa de soluciones sólidas. Cuando el contenido en Ag supera el 20 $\%$, la aleación se denomina electrum (Hough et al. 2009). Según Macdonald (2007) este mineral presenta un porcentaje entre un $15 \%$ y $55 \%$ en $\mathrm{Ag}$. Las propiedades fisicoquímicas 


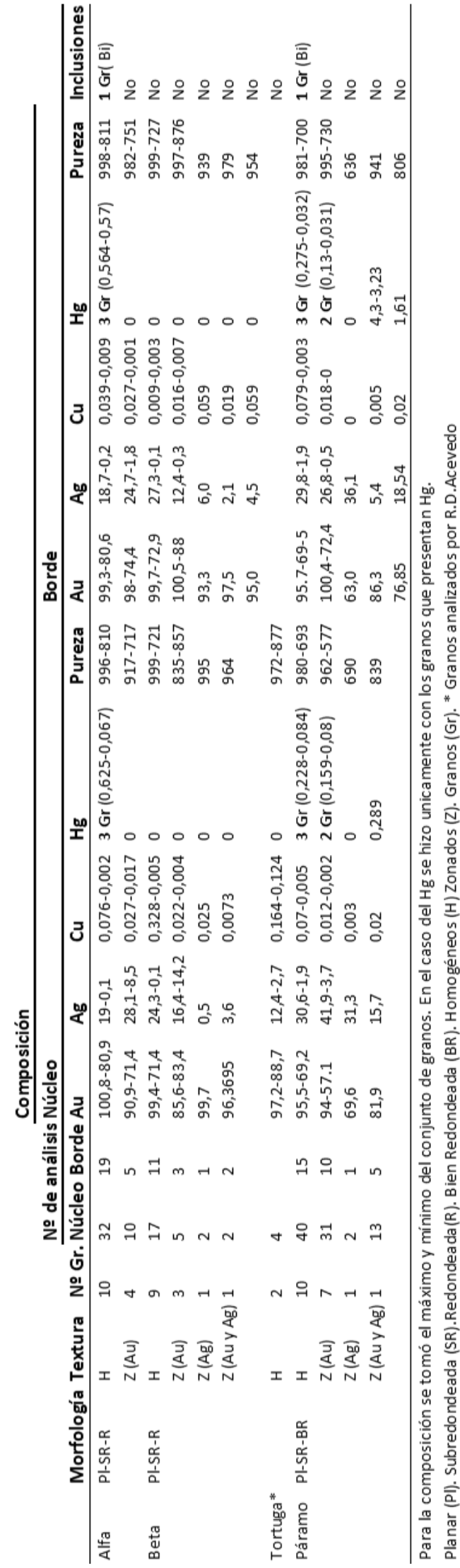

Tabla 7.17. Composición de los granos de oro analizados varían en función del contenido en Ag. El color se hace más claro a medida que aumenta la $\mathrm{Ag}$, disminuyendo la densidad y estabilidad, siendo más propenso a la alteración meteórica (Macdonald 2007).

La rutina analítica a la que fueron sometidos los granos de oro comprendió el análisis de $\mathrm{Au}, \mathrm{Ag}$, $\mathrm{Cu}, \mathrm{Hg}, \mathrm{Bi}$ y $\mathrm{Fe}$. Por otra parte, en 5 granos analizados por R.D. Acevedo (2 de las playas del cañadón Tortuga y 3 del cañadón Beta) se contaron además con valores analíticos de Pt y Pd. Debido a la pérdida de material durante el proceso de desbaste se pudo analizar un total de 49 granos de oro provenientes de los niveles ricos de las playas: 14 del cañadón Alfa, 14 del cañadón Beta, 19 de El Páramo y 2 del cañadón Tortuga (A.46 y 47).

En relación a la textura de los granos, pudimos diferenciar entre homogéneos y zonados. Los granos homogéneos no presentan diferencias significativas entre el núcleo y el borde, con valores por debajo del $<1 \%$ Ag. Los granos zonados muestran bordes enriquecidos en Au o Ag (Tabla 7.17).

Se observó un aumento progresivo hacia el SE de granos de oro con zonaciones, principalmente con bordes enriquecidos en Au. En el Cñd. Alfa $29 \%$ de los granos mostraron zonaciones, en el Cñd. Beta correspondieron a el $36 \%$ granos y en El Páramo representaron el $47 \%$ de los granos.

El contenido en $\mathrm{Au}, \mathrm{Ag}, \mathrm{Cu}$ y $\mathrm{Hg}$ en los núcleos de los granos varió en el Cñd. Alfa de $71,4 \%-100 \% \mathrm{Au}, 0,1 \%-28,1 \% \mathrm{Ag}, 0,002 \%-0,076 \%$ Cu y en 3 granos en los que se detectó Hg fluctuó entre 0,625-0,067\%. En el Cñd. Beta el oro mostró 
valores entre un $71,4 \%-99,7 \mathrm{Au}, 0,1-24,3 \% \mathrm{Ag}$ y $0,004-0,33 \% \mathrm{Cu}, \mathrm{Hg}$ no se detectó. En el Cñd. Tortuga varió entre 88,7-97,2\% Au, 2,7-12,4\% Ag y 0,12-0,16\% Cu, Hg no se detectó. Finalmente, en El Páramo, el rango composicional se movió entre un 57,1-95,5\% Au, 1,9$41,9 \% \mathrm{Ag}, 0,002 \%-0,07 \%$ Cu y en 5 granos se identificó $\mathrm{Hg}$ con valores de 0,08\%0,23\% $\mathrm{Hg}$.

El bismuto se detectó de manera puntual en un grano del Cñd. Alfa $(0,36 \%)$ y en dos granos de El Páramo (0,5 y 1,23\%). Pt se también se alcanzó a medir en dos granos, pero con valores bajísimos, uno proveniente del Cñd. Beta con un contenido de 48 ppm y otro del Cñd. Tortuga con un contenido de 62 ppm. El hierro se alcanzó a medir en algún grano, pero con valores muy bajos.

En dos granos homogéneos, uno del Cñd. Alfa y otro de El Páramo se observaron inclusiones de minerales ricos en $\mathrm{Bi}(51,98 \%)$.

Si comparamos los granos de oro de los cañadones Alfa, Beta y El Páramo en términos de su contenido en $\mathrm{Ag}$ frente a la frecuencia acumulada de los percentiles observamos curvas muy parecidas (Fig.7.19). Estos gráficos permiten comparar poblaciones con diferente número de granos (Chapman et al. 2000, Chapman et al. 2002). Cada núcleo de los granos de oro se representa como un percentil y se grafica frente al contenido en Ag.

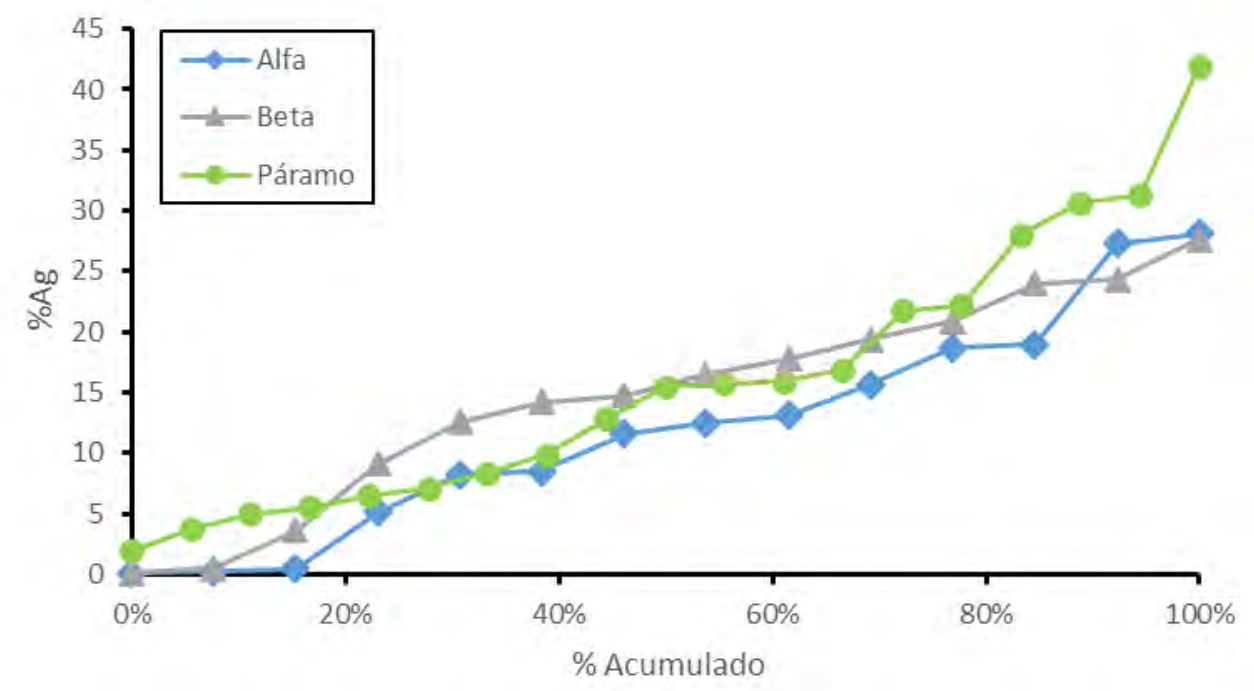

Fig.7.19 Diagrama binario de Ag \% frente al porcentaje acumulado del percentil. Cada punto representa el núcleo de un grano de oro

\subsubsection{Zonaciones}

En este punto se detallan las zonaciones de $\mathrm{Au}$ y $\mathrm{Ag}$ que se detectaron en los granos de oro. Enriquecimiento en Hg se identificó únicamente en el borde de un grano de 
El Páramo posiblemente por la incorporación de $\mathrm{Hg}$ en el medio para amalgamar las partículas de Au en los lavaderos de oro artesanales.

En un grano de El Páramo con alto contenido en $\mathrm{Ag}$ se hizo un mapeo de $\mathrm{Au}, \mathrm{Ag}$, $\mathrm{Cu}$ y $\mathrm{Hg}$ para detectar posibles variaciones composicionales, sin embargo, los resultados revelaron una notable homogeneidad (Fig.7.20).
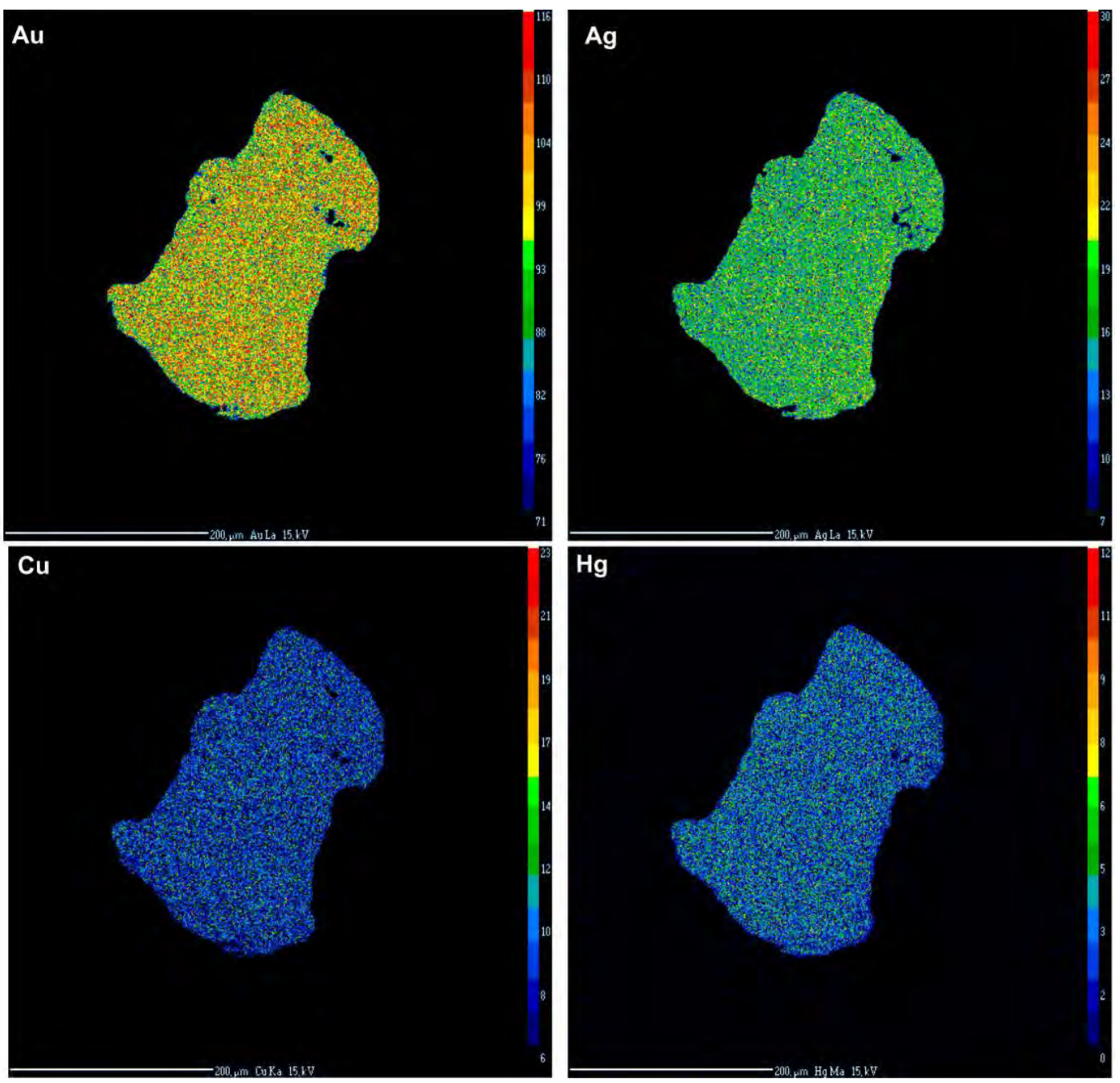

Fig.7.20. Mapeo cuantitativo mediante microsonda electrónica de Au, Ag, Cu y Hg de un grano de oro procedente de las playas de El Páramo. Obsérvese la notable homogeneidad en la distribución tanto de los valores altos de Au (colores amarillento-anaranjado-rojizos), los valores moderados de Ag (colores verdoso-amarillentos) como en los valores muy bajos de $\mathrm{Cu}$ y $\mathrm{Hg}$ (colores celeste-azulados).

\subsection{Bordes ricos en Au}

El $29 \%$ de los granos de oro obtenidos en las playas de los cañadones Alfa y Beta, y el $42 \%$ de los granos de la playa de El Páramo mostraron bordes enriquecidos en Au. Debido a ello, la pureza en estos granos de oro disminuyó de borde a núcleo: en Cñd. Alfa de 751-982 en los bordes a 717-917 en los núcleos, en el Cñd. Beta de 876-997 en los 
bordes a 835-857 en los núcleos y en la playa de El Páramo de 730-995 en los bordes a 577-962 en los núcleos (Fig.7.21).

Estas zonaciones se identificaron tanto en granos de alta como baja pureza, con contenidos en $\mathrm{Ag}$ desde 3,6\% hasta 41,9\% Ag (valores tomados en los núcleos de los granos).

El proceso de enriquecimiento en Au y disminución de Ag se puede explicar a partir de la disolución preferencial de la Ag (Desborugh et al. 1970, Freyssinet et al. 1989, Knight et al. 1999, Chapman et al. 2002, Macdonald 2007, Hough et al. 2009, Vishiti et al. 2015). Se considera que los granos de oro al ser transportados mecánicamente conservan en el núcleo la riqueza del área fuente, mientras que los bordes, grietas o cavidades se vuelven más ricos en Au, como consecuencia de la lixiviación de la plata de la superficie del grano. Esta concentración de oro se explica porque, en un ambiente acuoso, existe una mayor solubilidad de Ag frente al Au (Desborugh et al. 1970). La presencia de zonas enriquecidas en el interior del grano indica que los fluidos acuosos penetraron en el grano de oro a lo largo de las fracturas internas y planos cristalográficos, lixiviando Ag (Suh y Lehmann 2003). Asimismo, Knight et al. (1999) sugieren que en los bordes de los granos de oro se produce una eliminación de $\mathrm{Ag}, \mathrm{Hg}$ y $\mathrm{Cu}$, pero no precipitación de $\mathrm{Au}$, generando bordes masivos de alta pureza con un límite abrupto entre el núcleo y el borde como consecuencia del transporte. Este proceso se inicia en el momento en que el grano se expone a condiciones superficiales.

De acuerdo con los autores citados en el anterior párrafo, se considera que el enriquecimiento en Au observado en los bordes de los granos de oro presentes en las playas es producto de la lixiviación preferencial de Ag durante el transporte y depositación del grano en un ambiente acuoso.

\subsection{Bordes ricos en Ag}

Esta zonificación únicamente se ha encontrado en áreas restringidas de dos granos provenientes de las playas presentes en el Cñd. Beta y El Páramo. En el primero el núcleo presenta un $0,5 \%$ frente a un $6 \%$ de $\mathrm{Ag}$ en el borde. En el grano del El Páramo el núcleo presenta un $31,3 \%$ de $\mathrm{Ag}$ frente a una zona del borde con un 36,1\%. En otros dos granos de las mismas playas, estas zonas con mayor contenido en $\mathrm{Ag}$ aparecen junto con otros sectores con empobrecimiento en $\mathrm{Ag}$, enriquecimiento en $\mathrm{Au}$ y en un caso también de $\mathrm{Hg}$ (Fig. 7.21).

Según Svetlitskaya et al. (2018) la presencia de zonas enriquecidas en Ag es una característica de la fuente primaria del oro y estaría relacionada con el enriquecimiento 
gradual de Ag en las soluciones formadoras de minerales. Carrillo Rasúa et al. (2002) indican que la zonificación con enriquecimiento de Ag es común en cristales de oro de vetas epitermales.
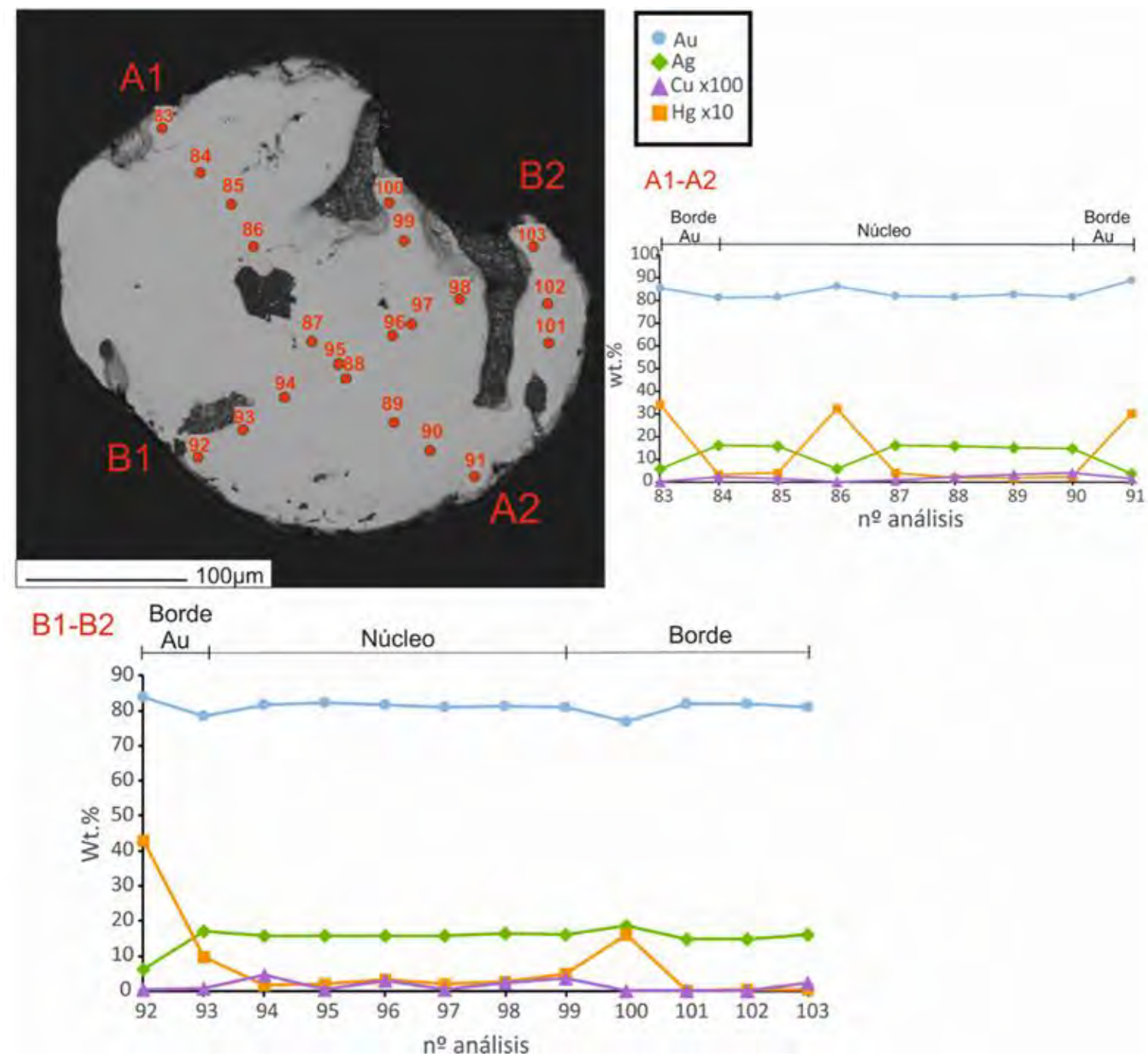

Fig.7.21. Imagen de electrones retrodispersados de un grano de Au del sector de El Páramo con leve a moderado aumento del Au y Hg y disminución de la Ag hacia los bordes. (BAu.103).

\subsubsection{Clasificación}

Teniendo en cuenta que los bordes no reflejan la composición original, sino que son producto de la acción de procesos supergénicos, se consideró solamente la composición del núcleo de los granos de oro para la clasificación y análisis del área fuente.

Los granos de oro analizados se caracterizaron por presentar una gran variabilidad composicional en el contenido de $\mathrm{Ag}(0,08-41,9 \% \mathrm{Ag})$, bajos contenidos en $\mathrm{Cu}(<0,33 \%$ 
$\mathrm{Cu})$ y $\mathrm{Hg}(<0,6 \% \mathrm{Hg})$ y tenores despreciables o ausencia de Pt, Bi, Fe y Pd. Normalmente sin inclusiones.

En función de la composición química estos minerales preciosos se pudieron diferenciar en dos grupos: uno pobre en $\mathrm{Ag}$ (Tipo 1, oro nativo) y otro rico en Ag (Tipo 2 o electrum) (Tabla 7.18 y Fig.7.22).

El primer grupo (Tipo 1) presenta un contenido en Ag de 0,08-19,38\% y en Au del 81,38-100\%. Como elementos minoritarios, el Cu alcanza un valor máximo de 0,328\% y el $\mathrm{Hg}$ de 0,516\%. La pureza de este grupo varía desde 808 hasta 999.

Este grupo representa $86 \%-71 \%-100 \%-68 \%$ de los granos provenientes de las playas de los cañadones Alfa, Beta y Tortuga, y El Páramo respectivamente. El 17\% y 50\% de los granos de los cañadones Alfa y Beta respectivamente, y el 38\% de El Páramo muestran zonaciones principalmente con bordes enriquecidos en Au.

El segundo grupo (Tipo 2) se caracteriza por presentar un contenido mayor de Ag, 20,9\%-41,9\% y menor de Au, 57,1\%-79,1\% con respecto al Tipo1. Muestra valores muy bajos de Cu y ausencia de $\mathrm{Hg}$. La pureza de los granos varía desde 577 hasta 791.

Representan el 14\%-29\%-32\% de los granos analizados provenientes de las playas de los cañadones Alfa y Beta, y El Páramo. De este grupo el $100 \%$ de los granos del Cñd. Alfa y $67 \%$ de los granos de El Páramo presentan bordes principalmente enriquecidos en Au. Los granos procedentes de la playa del Cñd. Beta no muestran zonaciones.

\begin{tabular}{|c|c|c|c|c|c|c|c|}
\hline Tipo Au & $\mathrm{n}-$ granos & wt\% & $\mathrm{Cu}$ & $\mathrm{Ag}$ & $\mathrm{Au}$ & $\mathrm{Hg}$ & Pureza \\
\hline \multirow[t]{4}{*}{ Tipo 1} & & 37 Promedio & 0,041 & 9,76 & 89,59 & 0,043 & 902 \\
\hline & & Max & 0,328 & 19,38 & 100,83 & 0,516 & 999 \\
\hline & & Min & 0,002 & 0,080 & 81,38 & 0,000 & 808 \\
\hline & & D.E & 0,062 & 6,171 & 6,235 & 0,103 & 62 \\
\hline \multirow[t]{4}{*}{ Tipo 2} & & 12 Mean & 0,010 & 27,33 & 72,39 & - & 726 \\
\hline & & Max & 0,037 & 41,9 & 79,07 & 0,000 & 791 \\
\hline & & Min & 0,002 & 20,91 & 57,14 & 0,000 & 577 \\
\hline & & D.E & 0,010 & 5,71 & 5,82 & - & 58 \\
\hline
\end{tabular}

Tabla 7.18. Clasificación de los granos de oro y parámetros estadísticos calculados en función de los análisis químicos realizados en el núcleo. 

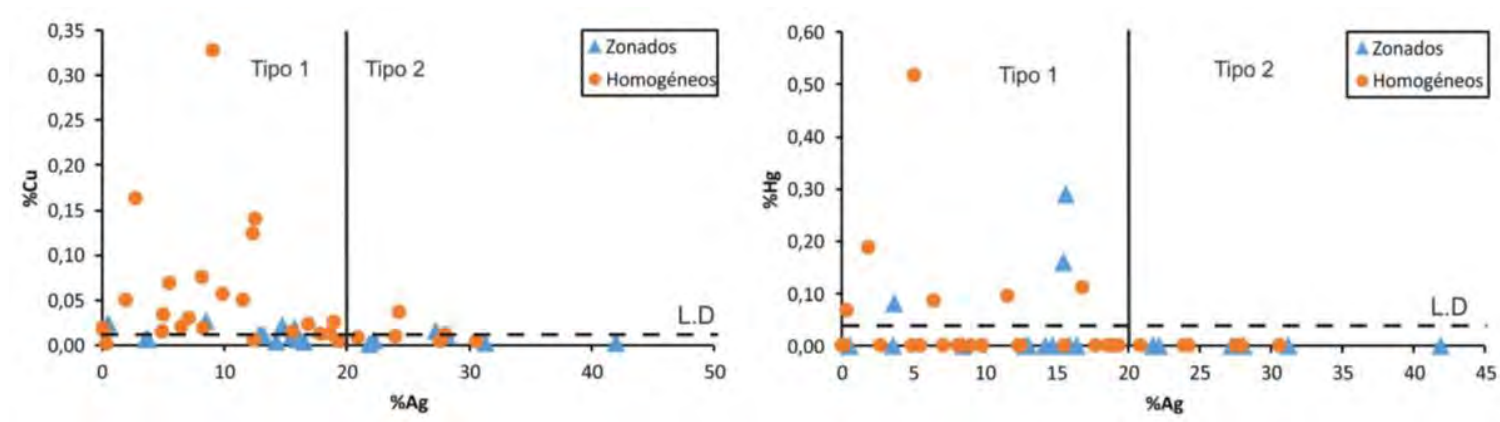

Fig. 7.22. \%Cu vs \%Ag y \% $\mathrm{Hg}$ vs \% Ag. Cada punto representa el promedio de los análisis efectuados en el núcleo de cada grano. D.L. Límite de detección.

\subsubsection{Minerales livianos}

Con respecto a los minerales livianos, se realizaron algunos análisis en los granos de plagioclasa presentes en las arenas de las playas, dando una composición entre oligoclasa y andesina, y en el caso de una inclusión dentro de un grano epidoto la composición se ajusta a la fase albita. También se analizó cuarzo presente como granos sueltos y en inclusiones (Tabla 7.19).

\begin{tabular}{|c|c|c|c|c|c|c|c|c|c|c|}
\hline $\begin{array}{l}\text { Mineral } \\
\text { Subambiente } \\
\text { Localización } \\
\text { Posición }\end{array}$ & $\begin{array}{l}\text { Oligoclasa } \\
\text { Playa } \\
\text { *El Páramo } \\
\text { Núcleo }\end{array}$ & \multicolumn{2}{|c|}{$\begin{array}{l}\text { Andesina } \\
\text { Playa } \\
\text { *Punta Sinaí } \\
\text { Núcleo }\end{array}$} & \multirow[t]{2}{*}{$\begin{array}{c}\text { Albita } \\
\text { Playa } \\
\text { *Punta Sinaí } \\
\text { Inclusión en epidoto } \\
\text { BR.195 }\end{array}$} & \multirow[t]{2}{*}{$\begin{array}{c}\text { Qtz } \\
\text { Playa } \\
\text { *Punta Sinaí } \\
\text { Núcleo } \\
\text { BR.218 } \\
\end{array}$} & Inclus & $\begin{array}{l}\text { Qtz } \\
\text { Playa } \\
\text { La Espig } \\
\text { siónes e }\end{array}$ & n Alm & $\begin{array}{r}\text { P } \\
{ }^{*} \text { EI } \mathrm{P} \\
\text { Inclusio }\end{array}$ & $\begin{array}{l}\text { tz } \\
\text { aya } \\
\text { áramo } \\
\text { és en IIm }\end{array}$ \\
\hline Nombre & BR.67 & BR.176 & BR.177 & & & BR.99 & BR.100 & BR.101 & BR.35 & BR.36 \\
\hline$\%$ PESO & & & & & & & & & & \\
\hline $\mathrm{SiO}_{2}$ & 68,370 & 54,810 & 55,950 & 67,950 & 100,590 & 98,470 & 98,290 & 98,210 & 97,900 & 98,510 \\
\hline $\mathrm{Al}_{2} \mathrm{O}_{3}$ & 17,960 & 27,040 & 26,240 & 20,490 & 0,464 & L.D & 0,000 & L.D & 0,575 & 0,524 \\
\hline $\mathrm{CaO}$ & 2,580 & 9,840 & 9,120 & 0,910 & 0,036 & 0,027 & 0,050 & 0,016 & 0,035 & 0,042 \\
\hline $\mathrm{TiO}_{2}$ & 0,014 & 0,019 & 0,030 & 0,000 & 0,022 & L.D & L.D & L.D & 0,261 & 0,226 \\
\hline MgO & 0,037 & 0,061 & 0,001 & 0,000 & 0,018 & 0,000 & 0,000 & 0,000 & 0,082 & 0,000 \\
\hline $\mathrm{Na}_{2} \mathrm{O}$ & 8,370 & 5,670 & 5,910 & 10,820 & 0,018 & 0,000 & 0,026 & 0,012 & 0,050 & 0,066 \\
\hline $\mathrm{FeO}$ & 0,127 & 0,457 & 0,484 & 0,101 & 0,010 & 0,547 & 0,513 & 0,494 & 0,494 & 0,413 \\
\hline $\mathrm{MnO}$ & 0,000 & 0,000 & 0,032 & 0,004 & 0,021 & 0,017 & 0,057 & 0,047 & 0,038 & 0,046 \\
\hline $\mathrm{K}_{2} \mathrm{O}$ & 0,062 & 0,189 & 0,211 & 0,102 & 0,040 & 0,000 & 0,000 & 0,000 & 0,140 & 0,055 \\
\hline Total & 97,520 & 98,086 & 97,977 & 100,377 & 101,218 & 99,061 & 98,937 & 98,779 & 99,575 & 99,881 \\
\hline APFU (8 O) & & & & & $A P F U(20)$ & & & & & \\
\hline $\mathrm{Si}$ & 3,046 & 2,519 & 2,566 & 2,959 & 0,995 & 0,997 & 0,997 & 0,997 & 0,989 & 0,991 \\
\hline Al & 0,943 & 1,465 & 1,419 & 1,051 & 0,005 & 0,000 & 0,000 & 0,000 & 0,007 & 0,006 \\
\hline $\mathrm{Ca}$ & 0,123 & 0,485 & 0,448 & 0,042 & 0,000 & 0,000 & 0,001 & 0,000 & 0,000 & 0,000 \\
\hline $\mathrm{Ti}$ & 0,000 & 0,001 & 0,001 & 0,000 & 0,000 & 0,000 & 0,000 & 0,000 & 0,002 & 0,002 \\
\hline $\mathrm{Mg}$ & 0,002 & 0,004 & 0,000 & 0,000 & 0,000 & 0,000 & 0,000 & 0,000 & 0,001 & 0,000 \\
\hline $\mathrm{Na}$ & 0,723 & 0,505 & 0,526 & 0,913 & 0,000 & 0,000 & 0,001 & 0,000 & 0,001 & 0,001 \\
\hline $\mathrm{Fe}^{2+}$ & 0,005 & 0,018 & 0,019 & 0,004 & 0,000 & 0,005 & 0,004 & 0,004 & 0,004 & 0,003 \\
\hline $\mathrm{Mn}$ & 0,000 & 0,000 & 0,001 & 0,000 & 0,000 & 0,000 & 0,000 & 0,000 & 0,000 & 0,000 \\
\hline K & 0,004 & 0,011 & 0,012 & 0,006 & 0,001 & 0,000 & 0,000 & 0,000 & 0,002 & 0,001 \\
\hline Suma & 4,846 & 5,006 & 4,992 & 4,975 & 1,002 & 1,003 & 1,003 & 1,003 & 1,007 & 1,005 \\
\hline An & 14,5 & 48,4 & 45,5 & 4,4 & & & & & & \\
\hline$A b$ & 85,1 & 50,5 & 53,3 & 95,0 & & & & & & \\
\hline Or & 0,4 & 1,1 & 1,3 & 0,6 & & & & & & \\
\hline
\end{tabular}

Tabla 7.19. Análisis químicos realizados en plagioclasas y cuarzo. Si bien algunos análisis de las plagioclasas son de baja calidad por presentar el cierre composicional demasiado bajo, se incluyen los resultados para dar información cualitativasemicuantitativa. 


\section{3 Área de procedencia}

\subsubsection{Supergrupo del anfíbol}

Según los diagramas binarios de Leake (1965) y Molina et al. (2009) todos los anfíboles tendrían un origen ígneo, asociado a magmas correspondientes con los campos subalcalino-alcalino y subalcalino (Fig.7.23A-B).

En la Cordillera Darwin el origen según el diagrama de Leake (1965) no podría encontrarse en los anfíboles del basamento metamórfico paleozoico, además, estos presentan valores más bajos en la relación \#Mg (Kohn et al. 1993, Maloney et al. 2011). Las rocas intrusivas presentes en Cordillera Darwin se agrupan en rocas plutónicas deformadas de la suite Darwin, constituidas principalmente por granitos y granodioritas (ahora metagranitos/metagranodioritas) intersectados por diques máficos (ahora anfibolitas) y rocas plutónicas no deformadas de la suite Beagle compuestas por tonalitas y granodioritas (Nelson et al. 1980). Todas ellas presentan anfíboles y es de esperar que los que aparecen en el sector de trabajo provengan de estas rocas, sin embargo, no se tienen datos de microsonda de estos minerales.

En rocas circundantes a la Cordillera Darwin, Dzogolyk (2007) analizó anfíboles pertenecientes a la zona sur del Batolito Sur Patagónico (al NE de la Cordillera Darwin) identificando mediante análisis de microsonda magnesiohornblenda, tschermakita y ferrohornblenda. 

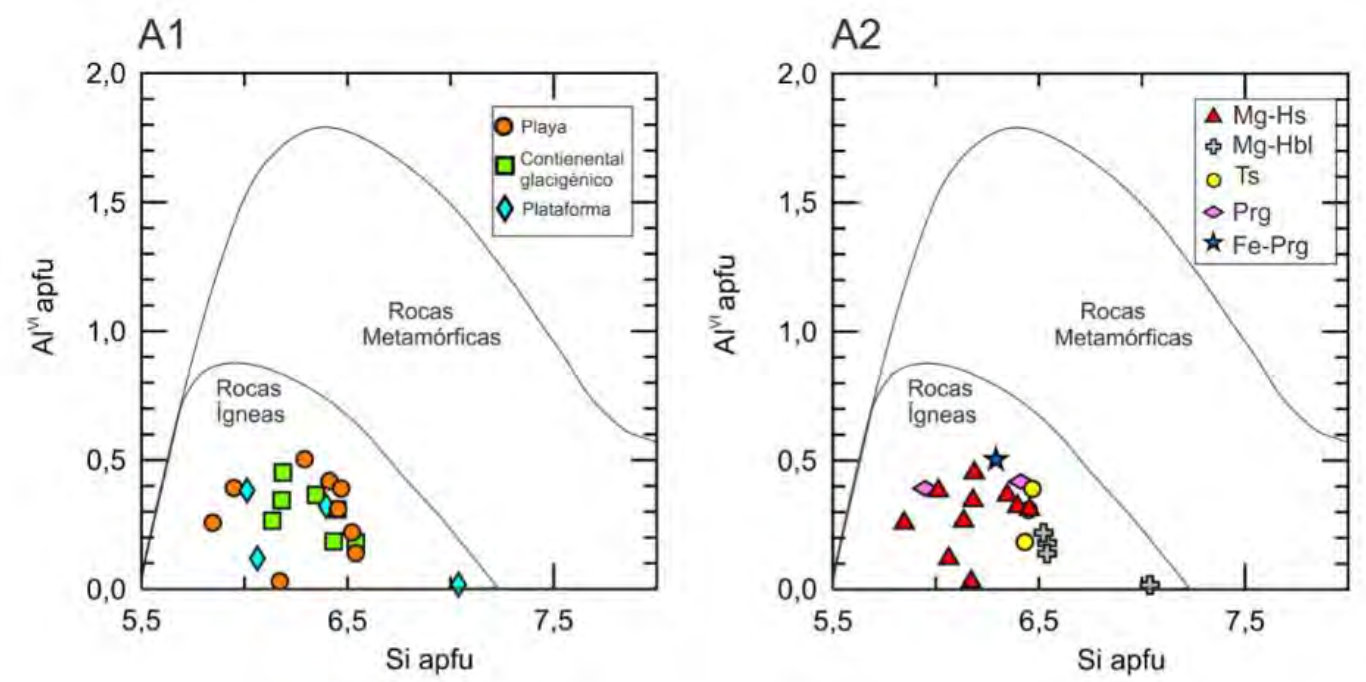

B1

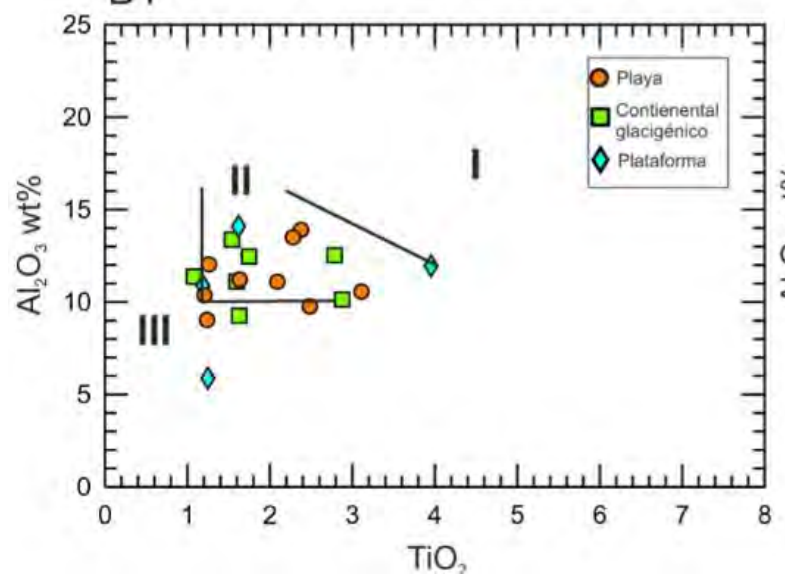

B2

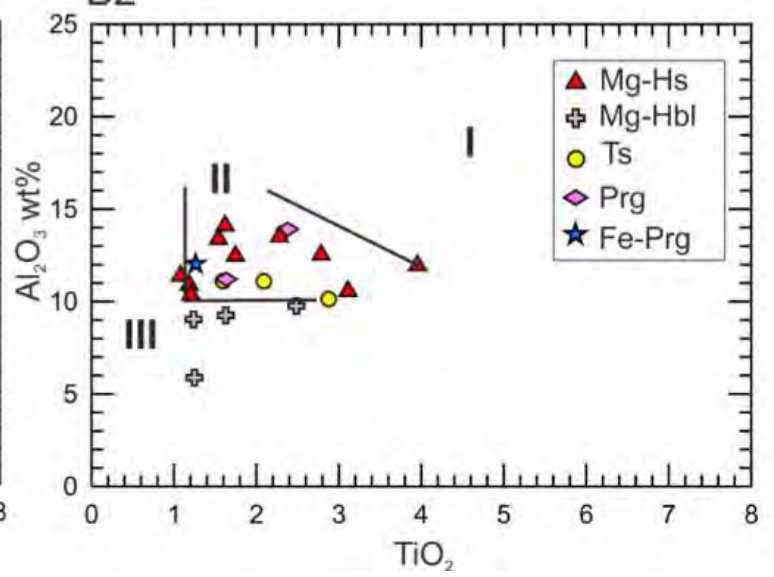

Fig. 7.23. A1 y A2 diagrama de discriminación de rocas ígneas y metamórficas (Leake, 1965). B1 y B2 diagrama de discriminación composicional magmática (Molina et al. 2009). Abreviaturas: I, alcalino; II, subalcalino-alcalino; III, subalcalino.

\subsubsection{Grupo del piroxeno}

Los piroxenos se encuentran en fases estables en casi todas las rocas ígneas y en rocas formadas bajo condiciones de metamorfismo regional y de contacto (Deer et al., 1992).

Los ortopiroxenos se encuentran típicamente en rocas plutónicas básicas y ultrabásicas, en volcánicas básicas o intermedias y en rocas metamórficas de alto grado (facies granulita) (Deer et al. 1997b) y están comúnmente asociados con clinopiroxenos cálcicos como el diópsido (Klein y Hurlbut 1997). Kerr (1972) indica que las enstatitas ricas en Fe son comunes en noritas, gabros hipersténicos, algunas andesitas y en las charnockitas. Debido al bajo contenido detectado en $\mathrm{Al}_{2} \mathrm{O}_{3}$ en los análisis efectuados se descartaría un origen metamórfico (<3,1\%) (Deer et al. 1997b). 
La augita se puede encontrar en gran variedad de rocas ígneas básicas como gabros, doleritas y basaltos, así como en rocas ultrabásicas e intermedias. También está presente en rocas metamórficas de alto grado, sin embargo el bajo contenido en $\mathrm{Al}$ descartaría esta opción (Deer, et al., 1992). El diópsido es el clinopiroxeno más común en rocas ultrabásicas, pero también se puede encontrar en rocas básicas y rocas alcalinas, así como en rocas metamórficas y metasomáticas como en skarns (serie diópsidohedenbergita) (Deer et al. 1997b).

Para saber si los clinopiroxenos derivan de rocas ácidas o de rocas intermedias a básicas hay que tener en cuenta el valor del $\mathrm{Al}^{\mathrm{IV}}$, a partir del cual $\mathrm{Al}^{\mathrm{IV}}>0,05$ a.p.f.u (átomos por fórmula unidad) indicaría minerales derivados de rocas básicas o intermedias e inferior parar rocas ácidas (Rodríguez et al. 2012). Los resultados de los análisis dieron el $97 \%$ de los granos con $\mathrm{Al}^{\mathrm{IV}}>0,05$ (Fig. 7.24).
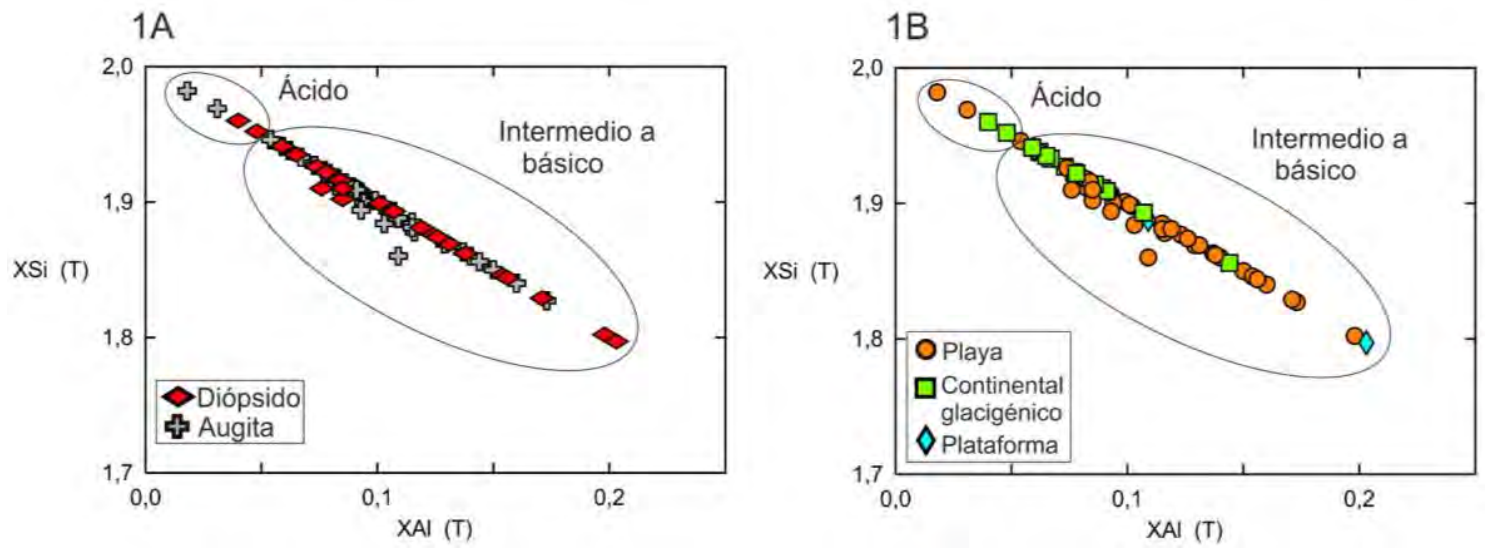

Fig.7.24. Si frente Allv en los clinopiroxenos

Para determinar en los clinopiroxenos el tipo de magma y las características tectónicas del área fuente de las rocas volcánicas se usaron los diagramas de Nisbet y Pearce (1977) y Leterrier et al. (1982).

A partir de los diagramas de discriminación de Leterrier et al. (1982) utilizando los contenidos de $\mathrm{Ti}, \mathrm{Cr}, \mathrm{Ca}, \mathrm{Al}$ y $\mathrm{Na}$ se puede conocer la afinidad magmática de la roca fuente en los clinopiroxenos de rocas volcánicas intermedias a básicas. Los resultados de estos diagramas indican que en los tres subambientes los clinopiroxenos abarcan una distribución similar en los diferentes campos (en el caso de la Plataforma Continental faltan datos ya que solo se tienen análisis de tres granos). Si se tienen en cuenta las distintas fases, augita y diópsido, se observa que esta última tiene más afinidad por las rocas basálticas alcalinas (ricas en $\mathrm{Ti}$ y $\mathrm{Na}$ ) salvo algún grano que presenta afinidad por basaltos orogénicos toleíticos de arco isla (ricos en Al y baja cantidad de Ti). Por otro lado, la fase augita se encuentra en todos los campos, habiendo una mayor proporción de granos en el 
campo de los basaltos orogénicos calcoalcalinos (con contenidos altos de Al y bajos de Ti) seguido por el campo de los basaltos orogénicos toleíticos de arco isla (Fig.7.25).
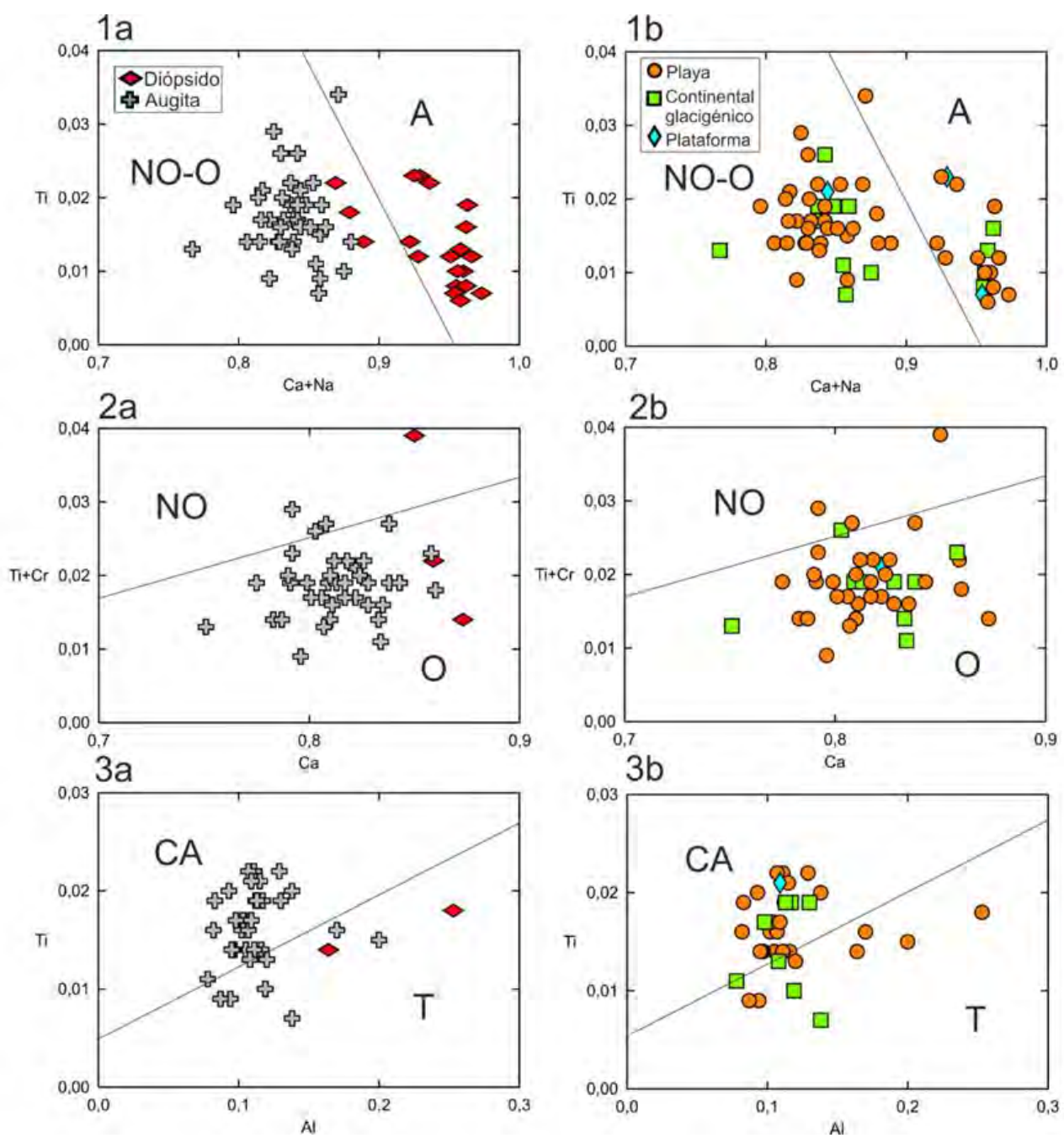

Fig.7.25. Diagramas de discriminación de afinidad magmática de Leterrier et al. (1982). Cada núcleo representa un grano de clinopiroxeno. Los diagramas de la izquierda (A) están clasificados según la fase mineral y los de la derecha (B) por el subambiente de depósito. Abreviaturas: $A$, basaltos alcalinos; $T$, basaltos toleíticos; $C A$, basaltos calcoalcalinos: $O$, basaltos orogénicos; NO, basaltos no orogénicos.

El diagrama de discriminación de ambiente tectónicos de Nisbet y Pearce (1977) ubica a la mayoría de los diópsidos dentro del campo de los basaltos de arco volcánico y a las augitas tanto en los basaltos de fondo oceánico (MORB) como en los basaltos de arco volcánico (Fig.7.26). 
$1 \mathrm{~A}$

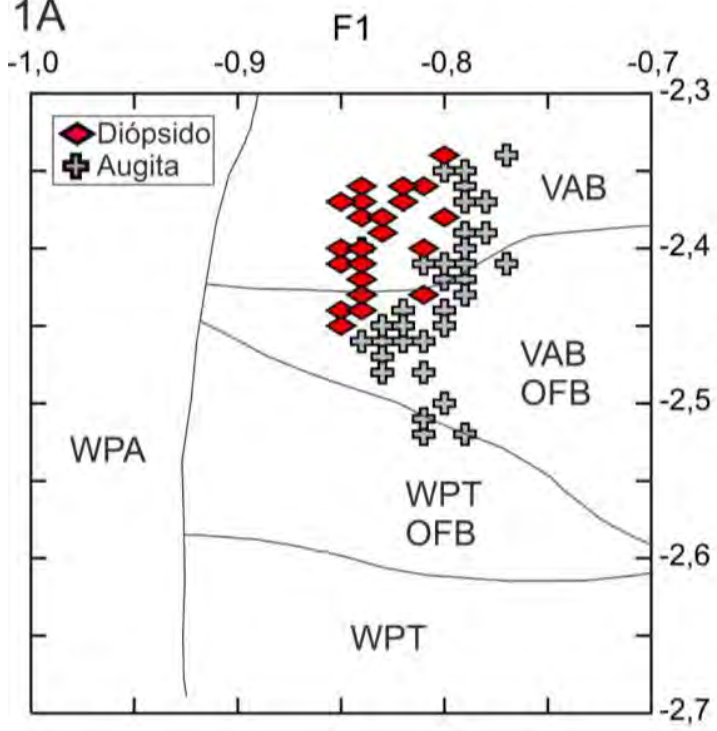

1B

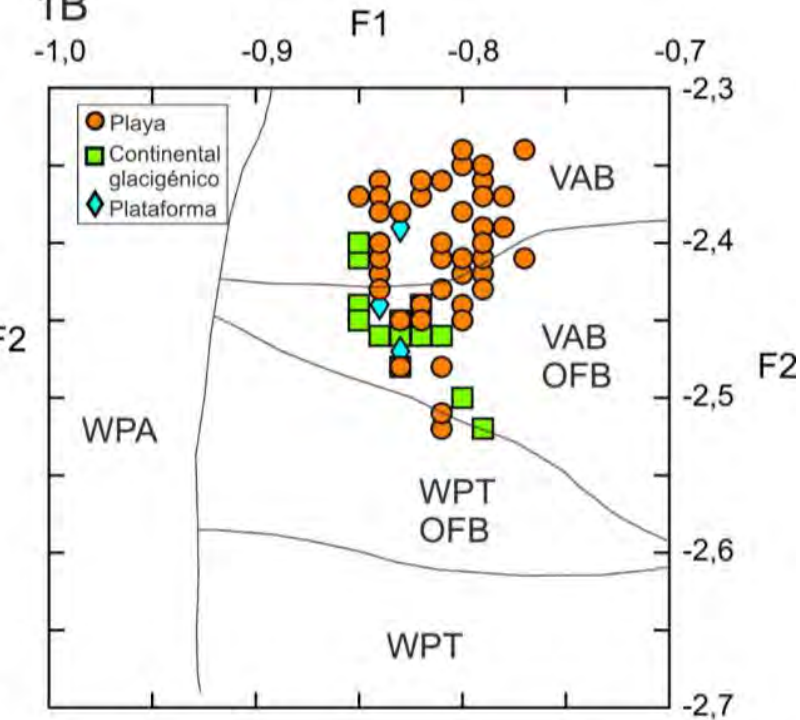

Fig.7.26. Diagrama de discriminación tectónica para clinopiroxenos (Nisbet y Pearce, 1977). VAB: basaltos de arco volcánico; OFB: basaltos de fondo oceánico; WPT: basaltos toleíticos de intraplaca; WPA; basaltos alcalinos de intraplaca. $\mathrm{F} 1=\left(-0,012 \times \mathrm{SiO}_{2}-0,0807 \times \mathrm{TiO}_{2}+0,0026 \times \mathrm{Al}_{2} \mathrm{O}_{3}-0,0012 \times \mathrm{FeO}-0,0026 \times \mathrm{MnO}+0,0087 \times \mathrm{MgO}-0,0128 \times \mathrm{CaO}-0,0419 \times\right.$ $\left.\mathrm{Na}_{2} \mathrm{O}\right) ; \mathrm{F} 2=\left(-0,0469 \times \mathrm{SiO}_{2}-0,0818 \times \mathrm{TiO}_{2}-0,0212 \times \mathrm{Al}_{2} \mathrm{O}_{3}-0,0041 \times \mathrm{FeO}-0,1435 \times \mathrm{MnO}-0,0029 \times \mathrm{MgO}+0,0085 \times \mathrm{CaO}\right.$ $\left.+0,0160 \times \mathrm{Na}_{2} \mathrm{O}\right)$.

A partir de estos diagramas se pudo concluir que los diópsidos tendrían una mayor afinidad por los basaltos alcalinos de arco volcánico y las augitas por los basaltos calcoalcalinos de arco volcánico y toleíticos de fondo oceánico.

Según Rodríguez et al. (2012), estudiando depósitos sedimentarios de Chile central, la coexistencia de distintas fases minerales con composición similar en diferentes ambientes permite inferir que provienen de las mismas fuentes, razonamiento que se puede aplicar en nuestro caso para los tres subambientes estudiados.

En la Cordillera Darwin, Avendaño (2008) identificó tanto ortopiroxenos como clinopiroxenos en la sucesión máfica ofiolítica del Complejo Tortuga, de afinidad toleítica y asociada a basaltos de fondo oceánico. Mediante análisis con microsonda electrónica diferenció en los gabros tanto diópsido y augita (con inclusiones de plagioclasa y olivina subordinada) como hipersteno (enstatita rica en $\mathrm{Fe}$ ), obteniendo unos resultados químicos de microsonda muy parecidos a los presentes en este manuscrito, con una composición $W_{0_{46,7}} E n_{44,3} F S_{9,0}$ para el diópsido, $W_{039,5} E n_{47,7} F s_{12,8}$ para la augita y $W_{2,2} E n_{77,7} F s_{20,1}$ para la enstatita rica en Fe. En el Complejo de Gabros (CG) correspondiente al Batolito Fueguino, de carácter calcoalcalino, también se reconocieron ortopiroxenos y clinopiroxenos (Hervé et al. 1984, González Guillot 2016), pero hasta la fecha no se tienen análisis químicos de estos minerales.

Isla et al. (2000) indicaron que estos minerales podrían provenir del campo volcánico de Pali Aike localizado al norte del Estrecho de Magallanes, sin embargo, se 
descartaría esta opción ya que las características composicionales que presentan son muy diferentes a las de los piroxenos localizados en la zona de investigación (En $n_{92-87}$ y Crdiópsidos $\mathrm{Cr}_{2} \mathrm{O}_{3}>1,2 \%$, Corbella, 2002).

En conclusión, a partir de los diagramas de discriminación tectónica, los datos provenientes de la geología regional y teniendo en cuenta también la dirección de avance de los glaciares que alcanzaron en el sector NE de la isla Grande de Tierra del Fuego, el área de procedencia más probable de los piroxenos analizados se localizaría en el Complejo Ofiolítico Tortuga de la Cordillera Darwin, donde se han identificado las mismas fases minerales.

\subsubsection{Grupo del granate}

Los granates derivan principalmente de rocas pelíticas. Se presentan en rocas metamórficas de contacto y metasomáticas, así como en algunas rocas magmáticas alcalinas, pegmatitas graníticas, granitos calcoalcalinos y raramente en rocas volcánicas (Dill 2010, Deer et al. 2013).

Utilizando los diagramas de discriminación de Mange y Morton (2007), Méres (2008) y Aubrecht et al. (2009) se pueden conocer las posibles áreas fuente de los granates.

A partir del diagrama ternario de Mange y Morton (2007) se determinó que los granates de los distintos subambientes (playa, plataforma y sedimento glacigénico) se distribuyen principalmente en los campos $\mathrm{Bi}$ y Bii correspondientes a rocas ígneas félsicasintermedias (posiblemente granitoides) y rocas metasedimentarias o metapelitas de la facies de anfibolita (Fig.7.27). 


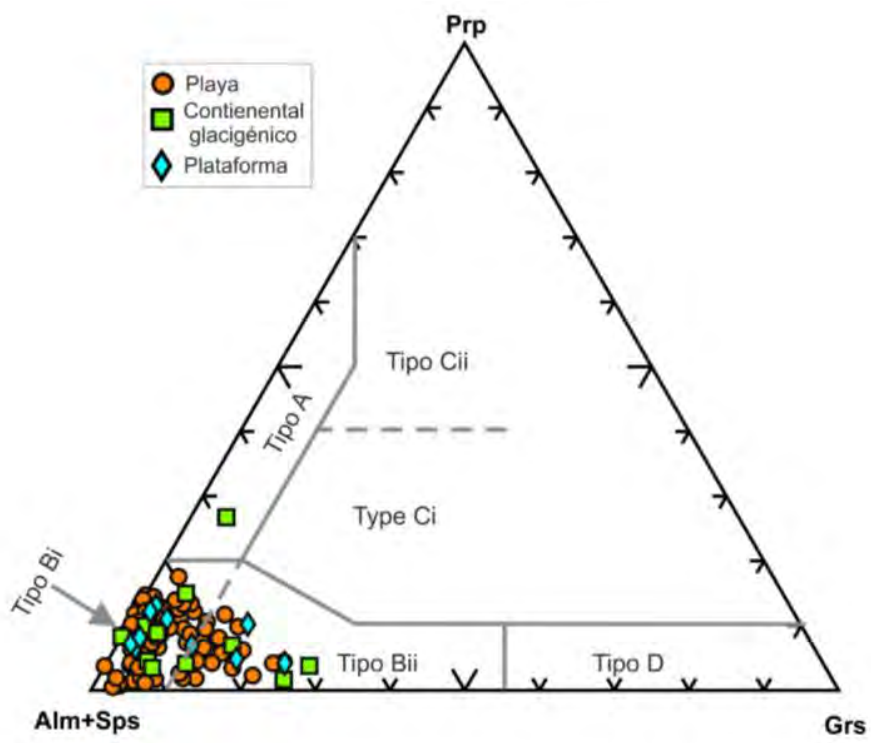

Fig. 7.27. Diagrama de discriminación Pir-Alm+Sps-Grs (Mange y Morton, 2007): Tipo A rocas metasedimentarias o charnockitas de alto grado de las facies de granulita y rocas ígneas félsicas intermedias de la parte más profunda de la corteza; Tipo Bi rocas ígneas félsicas-intermedias; Tipo Bii rocas metasedimentarias de la facies de anfibolita; Tipo Ci rocas básicas metamorfizadas de alto grado; Tipo Cii rocas ultramáficas con Mg (piroxenitas y peridotitas); Tipo $D$ rocas metasomáticas como skarns, rocas metabásicas de muy bajo grado y granulitas calcolisicatadas de temperatura muy alta.

Los diagramas de discriminación de Méres (2008) y Aubrecht et al. (2009) determinaron que los granates derivarían de gneisses o anfibolitas metamorfizados bajo condiciones de la facies de anfibolita (Fig.7.28).

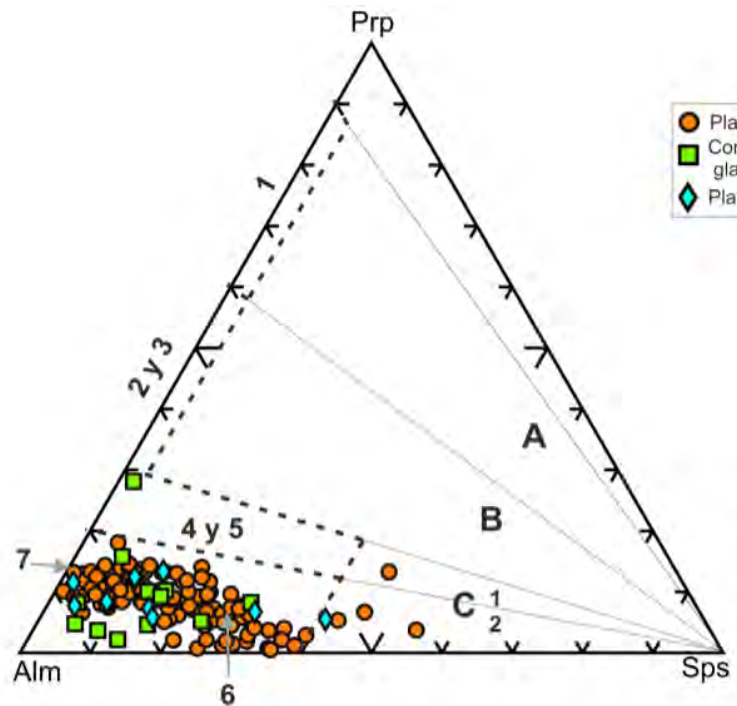

6

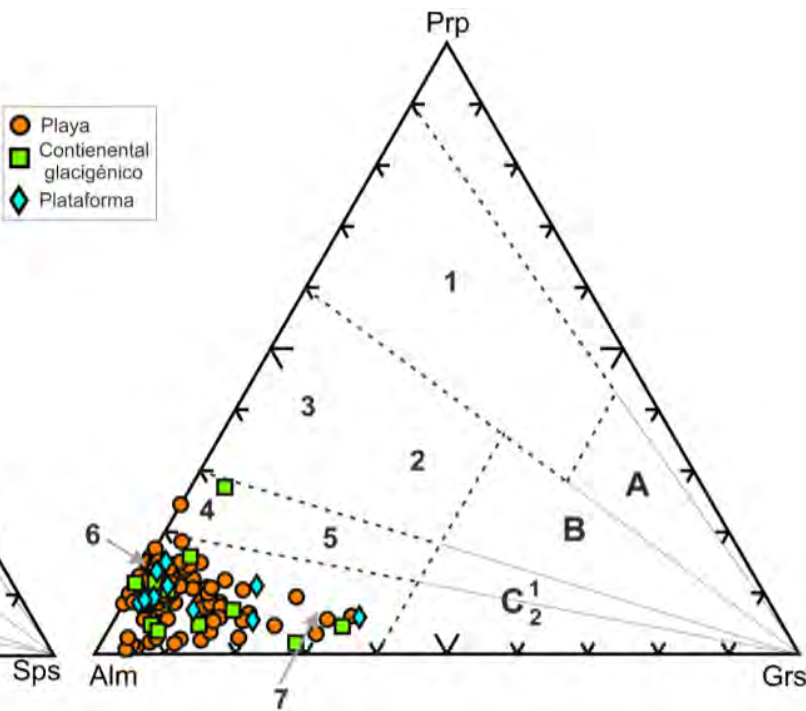

Fig. 7.28. Diagrama de discriminación Prp-Alm-Sps y Prp-Alm-Grs de Méres (2008) y Aubrecht et al. (2009): A, condiciones de alta y muy alta presión; $\boldsymbol{B}$, facies de granulitas y eclogita; $\boldsymbol{C}$, facies de anfibolita, diferenciando $\mathbf{C} 1$ correspondiente al campo transicional de las facies de anfibolita a granulita y $\mathbf{C}$ condiciones de la facies de anfibolita; 1, eclogitas o granates peridotíticos; 2, eclogitas y granulitas máficas; 3, granulitas félsicas o intermedias; 4, gneisses metamorfizados bajo condiciones de presión y temperatura transicional a las facies de granulitas y anfibolitas; $\mathbf{5}$ anfibolitas metamorfizadas bajo condiciones de presión y temperatura transicional a la facies de granulita y anfibolita; 6, gneisses metamorfizados bajo condiciones de la facies de anfibolita y 7 anfibolitas metamorfizadas bajo las condiciones de la facies de anfibolita 
En Tierra del Fuego, el grado más alto de metamorfismo se alcanza en la Cordillera Darwin, donde se encuentra el Complejo Metamórfico Cordillera Darwin. En esta zona se localizan esquistos pelíticos y anfibolitas con metamorfismo de la facies de anfibolita con granates (Cunningham, 1995), cuya composición corresponde a almandinos ricos en Ca y almandinos ricos en Mg y Mn (Kohn et al. 1993, Maloney et al. 2011) (Fig.7.29). Estos autores identificaron en los granates inclusiones de cuarzo, ilmenita, biotita, moscovita, epidoto, plagioclasa, titanita, circón y apatita, además de intercrecimientos de monacita y otros minerales.

En los depósitos glacígenos continentales se reconocieron fragmentos líticos de esquistos verdes o anfibolitas con granates de tamaños similares (ver Capítulo 4). El grado metamórfico de los esquistos de la facies de anfibolita presentes en la Cordillera Darwin coincide con el obtenido en los diagramas de discriminación para los granates del sector de trabajo, además su composición y conjunto de inclusiones son similares por lo que consideramos esta zona como la posible área de procedencia. 


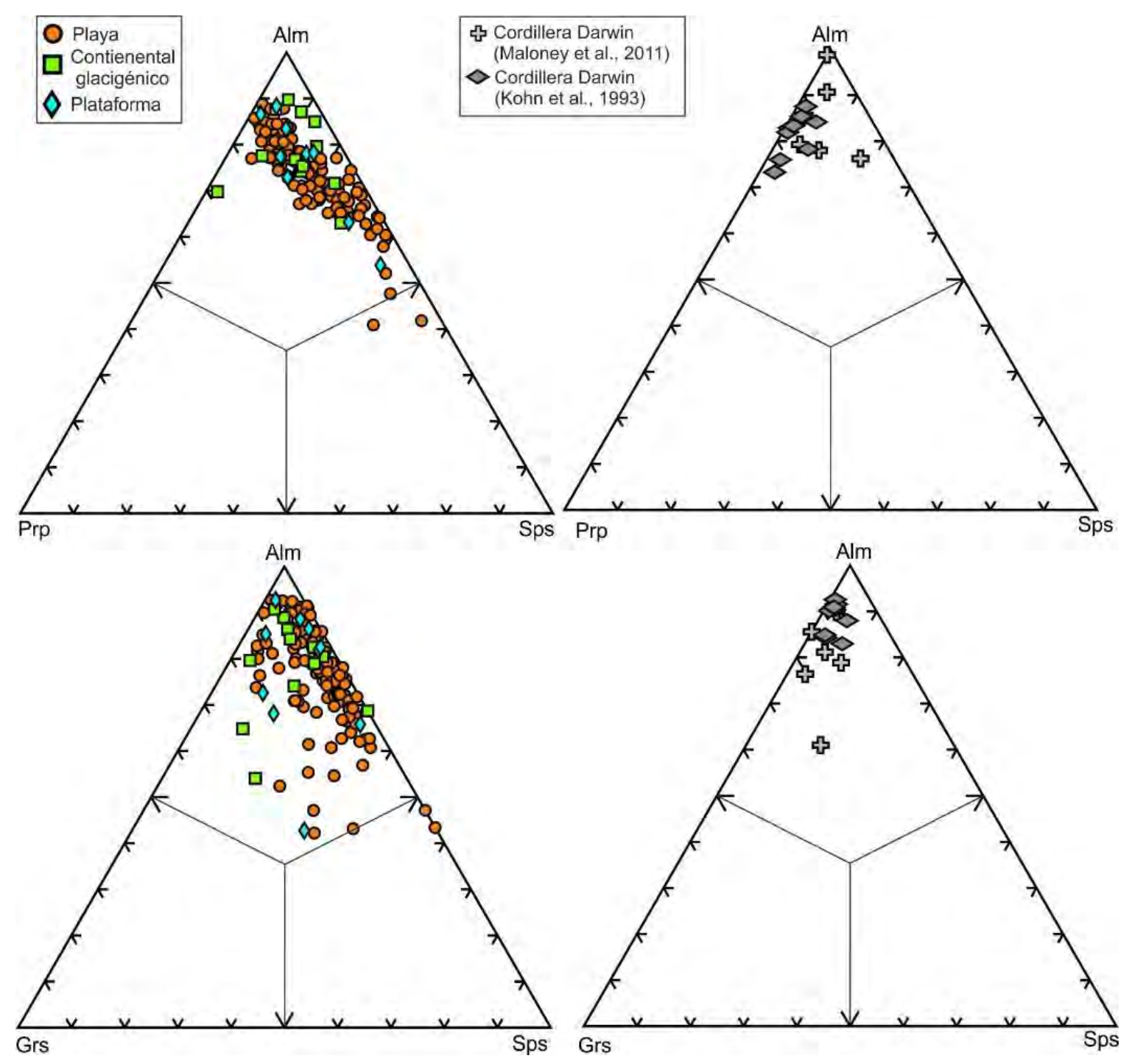

Fig.7.29. Diagramas Alm-Prp-Sps y Alm-Grs-Sps. a: muestras zona de trabajo; b: análisis realizados en granates en diferentes puntos de la cordillera.

\subsection{4 Óxidos, sulfuros y oxihidróxidos}

La magnetita e ilmenita son minerales muy comunes tanto en rocas ígneas como metamórficas. En rocas ígneas ultrabásicas, las magnetitas están asociadas con ilmenita y normalmente son ricas en $\mathrm{Ti}, \mathrm{V}$ y $\mathrm{Cr}$ (Bowles et al. 2011). En los análisis realizados en las magnetitas estos tres elementos están muy presentes en la mayoría de los casos, con contenidos máximos que alcanzan el $15 \%$ en $\mathrm{TiO}_{2}, 0,9 \%$ en $\mathrm{V}_{2} \mathrm{O}_{3}$ y $1,2 \%$ en $\mathrm{Cr}_{2} \mathrm{O}_{3}$. Estos valores permiten inferir una procedencia de rocas ultrabásicas (ultramáficas). La presencia de martitización refleja condiciones oxidantes.

En los óxidos de $\mathrm{Fe}$ y Ti, la mayor abundancia de granos con un contenido en $\mathrm{TiO}_{2}$ por debajo de $50 \%$ y la presencia de granos con contenidos en $\mathrm{MgO}$ mayores a $0,5 \%$ sugiere una fuente ígnea en lugar de metamórfica (Basu y Molinaroli 1989). Según estos 
autores, la presencia de lamelas de exsolución gruesas $(>10 \mu \mathrm{m})$ son comunes en granos derivados de orógenos reciclados.

En el Complejo Ofiolítico Tortuga se han reconocido en las rocas ígneas que lo conforman (gabros, diabasas, basaltos y diques lamprofíricos) diferentes óxidos de Fe-Ti (magnetita, titanomagnetita y hematita) y sulfuros (pirrotina, calcopirita y pirita; Coloma 2010). En los diques basálticos con alto contenido en $\mathrm{MgO}$ que cortan los gabros y diabasas se reconocieron espinelas cromíferas (picotita) (Elthon, 1979; Stern y Wit, 2003). Debido a la ubicación del complejo y la mineralogía que presenta, estas rocas podrían corresponder al área fuente más probable de los óxidos intermedios de Fe y Ti, hematita titanífera, minerales del grupo de la espinela y sulfuros presentes en la zona de trabajo. IImenita y rutilo se han identificado en el Complejo Metamórfico Cordillera Darwin, pero no se tienen hasta la fecha análisis químicos de estas fases (Kohn et al. 1993, Maloney et al. 2011).

\subsubsection{Grupo del epidoto y estaurolita}

Los miembros de la solución sólida epidoto-clinozoisita ocurren en una amplia variedad de rocas metamórficas siendo particularmente característicos de las facies de metamorfismo regional del grado de esquistos verdes y anfibolita-epidoto. También se pueden encontrar en rocas afectadas por un metamorfismo de contacto (Deer et al. 1992) o por un metamorfismo retrógrado en skarn obteniéndose como producto de reacción de la plagioclasa, piroxeno o anfíbol (Klein y Hurlbut 1997).

La estaurolita es un mineral característico de un grado medio de metamorfismo en esquistos pelíticos, apareciendo asociado con otros minerales como granates ricos en el miembro almandino y cianita (serie de facies barroviano, metamorfismo regional con presión media) o con cordierita, andalucita/sillimanita (serie de facies de Buchan, metamorfismo regional con presión baja; Deer et al. 1992).

En el Complejo Metamórfico Cordillera Darwin, Kohn et al. (1993) analizó epidoto y estaurolita presentes en las metapelitas afectadas por un metamorfismo de la facies de anfibolita, obteniendo una composición para el epidoto entre $E p_{11}$ y $E p_{17}$ y para la estaurolita un rango de $\mathrm{X}_{\mathrm{Fe}}$ entre 0,83 y 0,87. Maloney et al. (2011) también realizó análisis químicos mediante microsonda electrónica en la estaurolita obteniendo un rango de $\mathrm{X}_{\mathrm{Mg}}$ entre 0,10 y 0,27 . Las estaurolitas en este sector alcanzan tamaños centimétricos y presentan abundantes inclusiones sólidas (Cunningham 1995) entre las que se destacan cuarzo, ilmenita y rutilo (Maloney et al. 2011). 
Las similitudes mineraloquímicas que presentan estos minerales con los analizados en la zona de investigación permiten concluir que el área de procedencia del epidoto y la estaurolita se localizan en Complejo Metamórfico Cordillera Darwin.

\subsubsection{Titanita y grupo de la apatita}

La titanita es un mineral accesorio común en rocas ígneas como granitos, granodioritas, sienitas o sienitas nefelínicas, así como en algunas rocas metamórficas como gneisses y esquistos ricos en minerales ferromagnesianos y en rocas metamórficas calcolisicatadas (skarns; Deer et al. 1992).

Recientemente, Kowallis et al., (2018), comparando miles de individuos de titanitas de diversas procedencias, comprobaron que las de origen ígneo presentaban relaciones atómicas Fe/Al cercanas a 1:1 y casi siempre mayor de 1:2. En cambio en las titanitas metamórficas la relación Fe/Al era <1:2. Al graficar las titanitas (Fig. 7.30) de los depósitos detríticos de diferentes sectores del área investigada (depósitos glacifluviales, de playa y de plataforma submarina) en la presente tesis, se observó que la mayoría de los granos analizados, si bien escasos, quedó comprendida en el campo de las titanitas con relaciones entre $1: 1$ y 1:2, infiriéndose entonces que son de origen ígneo. El reducido número de granos analizados lleva a que esta conclusión debe ser considerada de carácter preliminar. Sin embargo, reforzando esta aseveración, es de destacar que en rodados psefíticos de composición granítica fueron reconocidas titanitas como minerales accesorios. El conjunto de estos datos permite deducir que el área de procedencia de las titanitas de los depósitos detríticos de Tierra del Fuego correspondería al sector del Batolito Fueguino, a la suite Beagle constituida por tonalitas y granodioritas, aflorante en el sector chileno (Cordillera Darwin). Igualmente no se debe descartar a las facies volcánicas de la Formación Tobífera también presentes en longitudes occidentales de la Cordillera Darwin, como un sector alternativo de aporte de las titanitas. 


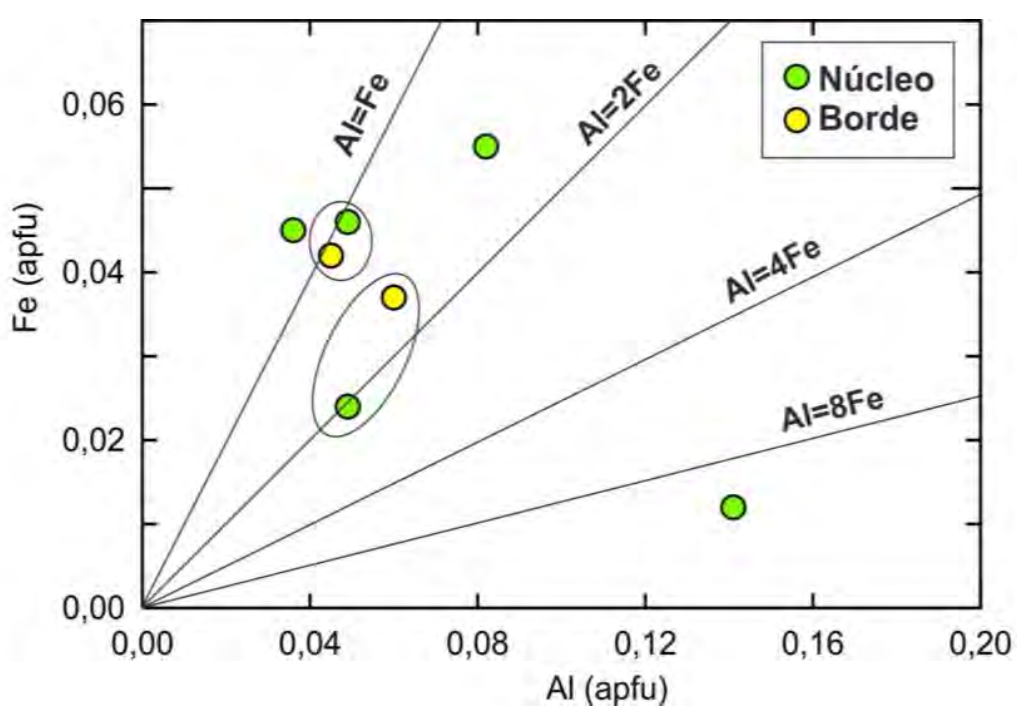

Fig.7.30. Gráfico Fe vs Al, tomado de Kowallis et al. (2018).

Por otro lado, la apatita también es un mineral accesorio común en las rocas ígneas. A partir del diagrama ternario composicional $\left(\mathrm{Fe}^{+2}-\mathrm{Mn}-\mathrm{Ca} / 100\right)$ propuesto por Piccoli y Candela (2002) se pueden discriminar distintos campos de rocas ígneas de las cuales pueden provenir las apatitas, tales como rocas félsicas-intermedias (granitoides, dacitas o riolitas), pegmatitas félsicas ácidas, rocas máficas (gabros o basaltos entre otras) o carbonatitas, que se superponen parcialmente. Descartando las carbonatitas, que no se han identificado en la región, las apatitas quedaron comprendidas en el campo de las rocas ígneas félsicas-intermedias (Fig.7.31).

En la Cordillera Darwin se identificaron apatitas en la suite Beagle del Batolito Fueguino constituidas por tonalitas y granodioritas (Suárez et al. 1985), por lo que se consideran estas rocas como el área fuente más probable. 


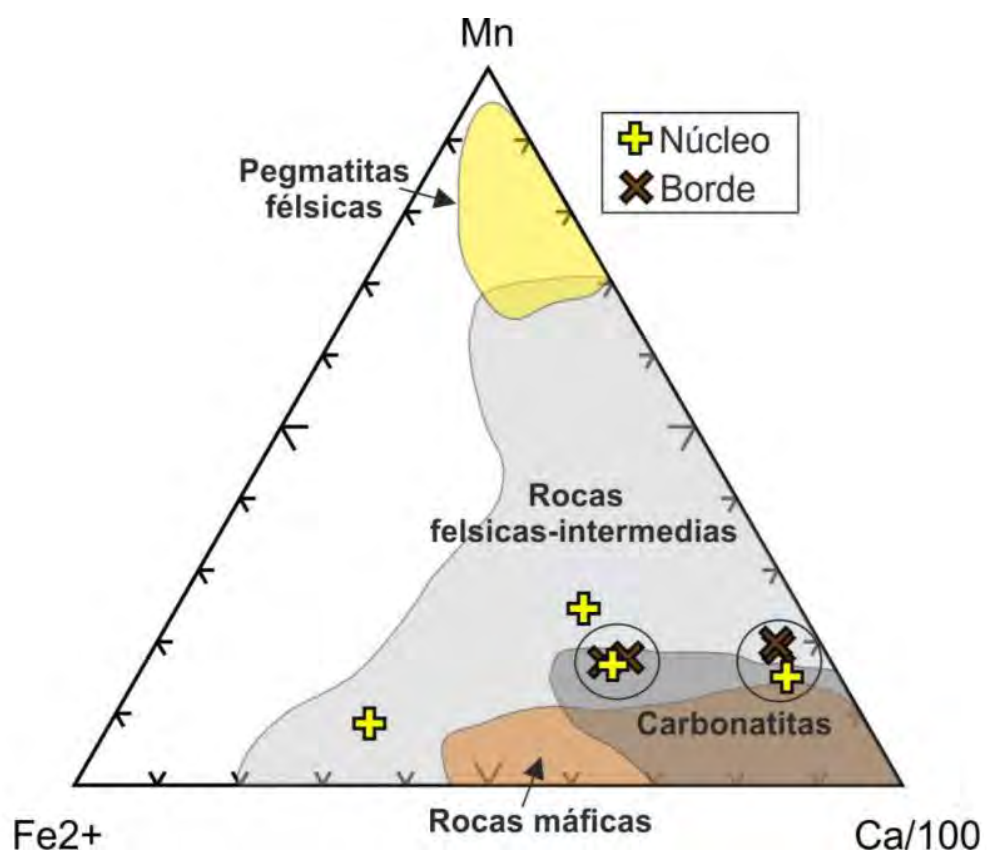

Fig.7.31. Apatitas analizadas graficadas en el diagrama Fe-Mn-Ca/100 (Piccoli y Candela 2002).

\subsubsection{Circón y andalucita}

El circón es un mineral accesorio corriente en las rocas ígneas, particularmente en las rocas plutónicas como granitos, granodioritas, sienitas y monzonitas (Klein y Hurlbut 1997). En rocas metamórficas puede encontrarse en ortogneisses originados por metamorfismo regional (Deer et al. 1997a).

Se han identificado circones en las rocas correspondientes al Batolito Fueguino (Nelson 1982, Suárez et al. 1985, Hervé et al. 2007, Montes 2013), tanto en los granitoides tipo $S$ en transición a I de la Cordillera Darwin como en los plutones de granitos I calcoalcalinos. También se han reconocido circones en las rocas del basamento paleozoico (Complejo Metamórfico Cordillera Darwin) (Kohn et al. 1993, Barbeau et al. 2009, Hervé et al. 2010, Maloney et al. 2011) y en la Formación Lemaire (Olivero et al. 1997). La imposibilidad de obtener posibles contenidos analíticos de elementos trazas como Th, U o tierras raras mediante las microsondas electrónicas utilizadas (quizás por debajo del límite de detección) ha impedido poder establecer con alguna certeza conclusiones sobre la procedencia ígnea o metamórfica de los circones analizados.

Por otro parte, la andalucita es un mineral típico de las aureolas de contacto asociadas a intrusiones ígneas en rocas pelíticas, pudiéndose también encontrar en terrenos afectados por un metamorfismo regional junto con sillimanita y cianita (Klein y Hurlbut 1997) y excepcionalmente en pegmatitas graníticas. 
En la isla Grande de Tierra del Fuego, se han identificado andalucitas asociadas con las intrusiones plutónicas en el sector cordillerano (Acevedo 2019). Sin embargo la falta de datos analíticos en la literatura geológica sobre este mineral, limite el estudio de su procedencia. Únicamente se puede indicar que las andalucitas reconocidas en los depósitos de playa podrían estar asociadas a las aureolas de metamorfismo de contacto desarrolladas por las intrusiones ígneas citadas.

\subsubsection{Grupo del oro}

La principal fuente de oro son los llamados filones de cuarzo donde el oro junto con otros sulfuros como la pirita fue depositado a partir de soluciones hidrotermales ascendentes que lo contenían (Klein y Hurlbut, 1997). Según Townley et al. (2003) el área de procedencia de los granos minerales se puede diferenciar en función de diagramas ternarios $\mathrm{Au}-\mathrm{Ag}-\mathrm{Cu}$ separando tres áreas de procedencia: 1) epitermal, con bajos contenidos de $\mathrm{Cu}$ y rico en $\mathrm{Ag} 2$ ) pórfidos de $\mathrm{Cu}$ ricos en $\mathrm{Au}$ con contenidos en $\mathrm{Cu}$ altos y variables respecto a la $\mathrm{Ag}$ y 3 ) pórfidos ricos en $\mathrm{Au}$, con bajos contenidos en $\mathrm{Cu}$ y contenidos en Ag más elevados que los granos provenientes de depósitos epitermales. De acuerdo con este diagrama, los diferentes tipos de grano se localizan en dos campos: depósitos epitermales y porfídicos ricos en Au para los granos Tipo 1 y depósitos porfídicos ricos en oro para los granos Tipo 2 (Fig.7.32).

Por otro lado, según Morrison et al. (1990) a partir de la pureza (Au*1000/(Au+Ag)) se puede llegar a conocer el tipo de roca fuente. Los granos asociados a rocas plutónicas (yacimientos mesotermales) presentan un valor promedio de 825, sin embargo, otros depósitos presentan una riqueza promedio más variable como los volcanogénicos de 650850 , los porfídicos de 700 a 1000 y los epitermales de 440-1000. Por el gran rango de amplitud y alta riqueza que presentan los granos de oro de las playas, probablemente correspondan a depósitos epitermales o porfídicos coincidiendo con los resultados del diagrama de discriminación. 


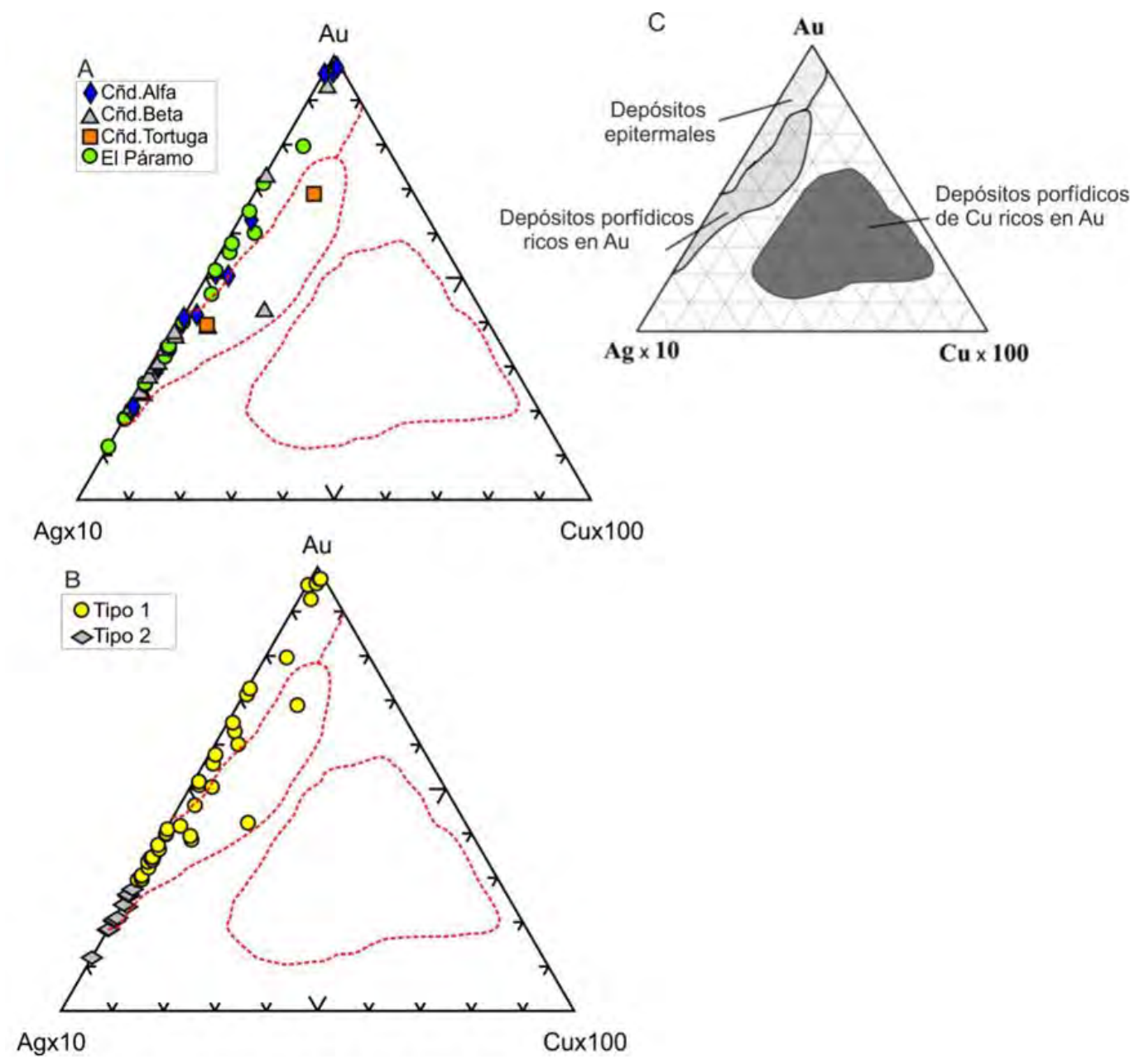

Fig.7.32. Diagramas triangulares Au-Agx10-Cux100. Cada punto representa el promedio del núcleo de un grano. A) Granos de oro según las zonas de procedencia. B) Granos de oro según la clasificación. C) Campos de discriminación propuestos por Townley et al. (2003).

En el Macizo del Deseado (Provincia de Santa Cruz) se produjeron depósitos epitermales de baja sulfuración de Au y Ag asociados con un vulcanismo Jurásico con oro, electrum, plata nativa y argentita (Schalamuk et al. 1997 y Schalamuk et al. 2002). El oro nativo presenta alta pureza (976-984) y el contenido de Ag en el electrum varía desde un 20 a un $68 \%$ de $\mathrm{Ag}$ confirmando de esta manera el amplio rango composicional que presenta el oro en vetas epitermales.

Siguiendo la trayectoria de las lenguas glaciales que discurrieron por el norte de la isla, el área fuente del oro presente en la playa se localizaría en el sector cordillerano. Algunos autores (Caldenius 1932, Methol y Sister 1949) han asociado a los granos de oro con "pegmatitas auríferas" presentes en los bloques de granodioritas derivadas del Batolito Fueguino. Si bien estas intrusiones han podido generar depósitos epitermales enriquecidos en $\mathrm{Au}$ en algunos sectores de la Cordillera Darwin, hasta el momento no se tiene conocimiento de su existencia. 
Por otro lado, durante el magmatismo de arco continental en Tierra del Fuego se produjeron algunos depósitos de sulfuros masivos VMS (Biel et al. 2010). Estos investigadores no detectaron Au en las piritas presentes en los sulfuros hospedados en las rocas volcánicas riolíticas de la Fm. Lemaire. En las facies mineralizadas del depósito Biel (2011) obtuvo valores bajos, entre 429 y $<2$ ppb de Au. Estos contenidos tan bajos descartarían los VMS como roca fuente.

En otras rocas del sector argentino de Tierra del Fuego se realizaron análisis químicos por fusión de roca total dando en todas ellas valores muy bajos en $\mathrm{Au}$, como en las hornblenditas piroxeníticas (14 ppb) asociadas con el Magmatismo Potásico Fueguino (González Guillot y Schalamuk 2009) o los pórfidos riolíticos (4-5 ppb) de la Formación Lemaire (R.D. Acevedo com. pers.).

A partir de la dirección de los glaciares, los diagramas de discriminación e información previa bibliográfica, se sugiere el ámbito del Batolito el Fueguino con el área de procedencia más probable para el oro.

\subsubsection{Minerales livianos}

Con respecto a los minerales identificados, como el cuarzo, plagioclasa o feldespato potásico, precisar la procedencia es muy difícil, ya que son fases muy comunes y abundantes en una gran variedad de rocas y, además, el número de análisis químicos que se realizó fue limitado.

A partir de los datos mineraloquímicos se pudo confirmar la composición más sódica de los granos de plagioclasa presentes en los depósitos detríticos de la zona de trabajo, estimada previamente mediante el método de Michel Levy en el microscopio petrográfico. Los términos más sódicos de las plagioclasas se suelen dar en rocas ígneas más ácidas como los granitoides (Klein y Hurlbut 1997).

La fase andesina se determinó también en fragmentos de dioritas, andesitas, hornblenditas y granodioritas mediante el método de Michel Levy. Cualquiera de estas rocas, asociadas con el Batolito Fueguino, podría ser la fuente de los cristales de plagioclasa.

\subsection{Discusión}

Todos los minerales pesados analizados e identificados tienen similitud composicional con los minerales presentes en las rocas ígneas y metamórficas de la Cordillera Darwin, localizada en el sector insular chileno. Sin embargo, en el sector 
argentino, en las rocas asociadas a las intrusiones de trasarco también se han identificado la gran mayoría de estos minerales como piroxenos, anfíboles, epidotos, circones, magnetitas, ilmenitas y sulfuros (pirita, calcopirita y pirrotina; Acevedo 1996, Acevedo et al. 2002, González Guillot 2009, González-Guillot y Schalamuk, 2009, González Guillot et al. 2018). También se encuentran minerales del grupo del granate correspondientes a las fases almandino y espessartina en las rocas metapelíticas de las formaciones Beauvoir y Yahgán sometidas a un metamorfismo de contacto relacionado con estas intrusiones (Acevedo et al. 1989, González Guillot 2009, González-Guillot y Acevedo 2009), cuya composición según unos análisis inéditos de R.D. Acevedo (com. pers.) correspondió a las fases espessartina y almandino.

La ausencia de intrusiones de trasarco en la dirección de los glaciares que ocuparon el Estrecho de Magallanes o la Bahía Inútil-Bahía San Sebastián descartaría esta fuente. Sin embargo, González Guillot (2016) indicó la posibilidad de que su ausencia en la Cordillera Darwin pueda ser debido a su erosión, ya que se emplazaron en niveles más superficiales que las intrusiones de arco correspondientes a la Suite Beagle. A falta de más información sobre la distribución de la actividad ígnea de trasarco, en la presente investigación se descarta la procedencia de los minerales pesados de estas rocas.

\subsection{Consideraciones finales}

A partir de los análisis químicos realizados mediante microsonda electrónica se pudo profundizar en el conocimiento mineralógico y de sus áreas de procedencia de los minerales pesados investigados.

Los análisis químicos efectuados han revelado una composición homogénea de cada una de las fases minerales analizadas en los tres grandes subambientes investigados del NE de la isla Grande de Tierra del Fuego: a) depósitos glacigénicos orientales, b) sector costero de playas del litoral atlántico y c) sedimentos de fondo de la Plataforma Continental. Esta gran similitud composicional permite inferir un mismo origen.

Se identificó una gran diversidad mineralógica dentro de cada uno de los grupos de minerales pesados analizados:

A) silicatos: magnesiohastingsita, magnesiohornblenda, tschermakita, pargasita y ferropargasita (supergrupo del anfíbol); augita, diópsido e enstatita rica en Fe (grupo de los piroxenos); epidoto y clinozoisita (grupo del epidoto); almandino y espessartina (grupo de los granates); estaurolita, andalucita (grupo de los polimorfos de Al), titanita (grupo de la Humita) y circón. 
B) Óxidos: óxidos intermedios de Fe-Ti, ilmenita y hematita titanífera (óxidos de $\mathrm{Fe}$ y $\mathrm{Ti}$ ); magnetita s.s., magnetita titanífera, magnetita rica en $\mathrm{Al}$, espinela ferrosa y espinela cromífera (grupo de la Espinela); rutilo (grupo del Rutilo).

C) Oxihidróxidos: goethita

D) Fosfatos: flúor e hidroxiapatita (grupo de la apatita).

E) Sulfuros: pirita y calcopirita.

F) Elementos nativos: oro y electrum (grupo del oro).

Aplicando gráficos de discriminación litológica o tectónica a partir de la composición química y/o comparando con la mineralogía presente en las diferentes rocas del sector cordillerano chileno, se pudo inferir la posible procedencia de las principales fases mineralógicas. El área fuente para todos estos minerales se localiza en la Cordillera Darwin (Chile), ya que es desde esta región de donde partieron los glaciares que cubrieron buena parte de la isla de Tierra del Fuego durante el Plioceno-Pleistoceno. Las diferentes fases mineralógicas podrían proceder de rocas plutónicas (Batolito Fueguino correspondientes a las suites Darwin y/o Beagle), volcánicas (Complejo Ofiolítico Tortuga y Fm. Lemaire) y metamórficas (Complejo Metamórfico Cordillera Darwin) (Tabla 7.20).

\begin{tabular}{|c|c|c|c|c|c|c|}
\hline \multirow[b]{3}{*}{ Minerales Pesados } & \multicolumn{5}{|c|}{ Abundancia } & \multirow[b]{3}{*}{ Procedencia } \\
\hline & \multicolumn{2}{|c|}{ Playa } & \multicolumn{2}{|c|}{ Glacigénico } & \multirow[b]{2}{*}{ Plataforma } & \\
\hline & Playa & N.R & Till & Glacifluvial & & \\
\hline Clinopiroxeno & $* * *$ & * & $* * *$ & ** & $* * *$ & 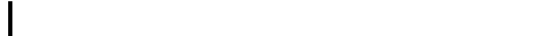 \\
\hline Ortopiroxeno & $* *$ & + & $* *$ & * & $* *$ & \\
\hline Hem-(Ti) y Ox Ti-Fe & $*$ & $* *$ & + & $*$ & + & Compleio Ofiolítico Tortuga \\
\hline Magnetita & + & $* *$ & + & $*$ & + & Compejo Utiontico Iortuga \\
\hline Espinela s.s & & $(+)$ & & & & \\
\hline Sulfuro (Py y Ccp) & $(+)$ & $(+)$ & $(+)$ & & & \\
\hline Gr. Granate & * & $* * *$ & + & * & + & \\
\hline Epidoto & $* *$ & + & + & * & $*$ & \\
\hline Clinozoisita & + & $(+)$ & $(+)$ & $(+)$ & $(+)$ & J CNICD \\
\hline Estaurolita & $(+)$ & + & $(+)$ & $(+)$ & & \\
\hline Ilmenita & $(+)$ & + & $(+)$ & $(+)$ & $(+)$ & LamCDis \\
\hline Rutilo & & $(+)$ & & & & \\
\hline Anfíbol cálcico & ** & $(+)$ & $* *$ & $* *$ & $* *$ & \\
\hline Titanita & & $(+)$ & & $(+)$ & $(+)$ & Batolito Fueguino/ Fm. Tobíferac?? \\
\hline Gr. Apatita & & $(+)$ & $(+)$ & $(+)$ & & \\
\hline Gr. Oro & & $(+)$ & & & & Pórfidos y/o filones epitermales. Batolito Fueguino¿? \\
\hline Circón & $(+)$ & $(+)$ & $(+)$ & $(+)$ & $(+)$ & Batolito Fueguino, CMCD o Fm. Tobífera¿?? \\
\hline Andalucita & $(+)$ & & $(+)$ & $(+)$ & + & Metamorfismo de contacto¿i? \\
\hline
\end{tabular}

Tabla 7.20. Tabla de los minerales pesados analizados, con su abundancia según los subambientes y procedencias. *** Abundante (25-50\%)**Común (10-25\%)* Presente (5-10\%) + Raro (1-5\%) (+) traza o accesorio (<1\%). N.R. niveles enriquecidos en minerales pesados presentes en las playas. CMCD Complejo Metamórfico Cordillera Darwin. 


\section{Capítulo 8: MODELO GENÉTICO}

\subsection{Introducción}

El modelo genético de los depósitos detríticos auríferos del litoral atlántico de la Isla Grande de Tierra del Fuego involucra un conjunto de subambientes geológicos que se han ido desarrollando a través del tiempo, desde el Mesozoico hasta la actualidad. La formación de esos depósitos implica el desarrollo previo de ciclos ígneo-metamórficos y sedimentarios que han condicionado el esquema evolutivo secuencial dando como producto final un enorme volumen anómalo de minerales pesados de muy variada naturaleza y procedencia.

Este modelo genético, desarrollado en una región de dimensiones extraordinarias, desde el sector costero austral de la provincia de Santa Cruz por el norte hasta la península Mitre por el sur, y desde las longitudes cordilleranas por el oeste hasta las islas Malvinas por el este, comprende una historia evolutiva que comienza con la conformación de la Cordillera de Darwin en el sector occidental, donde en un ambiente de arco magmático se han generado diferentes tipos de rocas ígneas como por ejemplo granitoides y gabros del Batolito Fueguino (Jurásico superior-Paleógeno), basaltos, gabros y diabasas del Complejo Ofiolítico Tortuga (Jurásico superior-Cretácico inferior), basaltos y pórfidos riolíticos de la Fm. Lemaire (Jurásico Superior) y basaltos y gabros en la Fm. Yahgán (Jurásico superiorCretácico inferior).

Durante el levantamiento de la cordillera, como consecuencia de un régimen compresivo, se alcanzó un metamorfismo de grado bajo a medio, generándose rocas metamórficas como pizarras, esquistos, anfibolitas y gneises. Luego del inicio de la exhumación del arco magmático y estructuración de la cordillera en tiempos postcretácicos, con el desarrollo de corrimientos con vergencia hacia el NE-NNE, se sucedieron procesos erosivos que dieron paso a ciclos de transporte y sedimentación hacia las cuencas de antepaís de Magallanes y Malvinas.

Hacia fines del Terciario y durante gran parte del Cuaternario, las glaciaciones acaecidas en Tierra del Fuego fueron los procesos geológicos dominantes. Jugaron un papel preponderante en la erosión y transporte de los materiales rocosos de la cordillera andina, llegando a trasladar estos materiales a más de 250 kilómetros desde su origen.

En esta historia geológica secuencial el siguiente paso correspondió a los procesos erosivos y de transporte glacifluvial y fluvial que desmembraron parcialmente los depósitos 
glacigénicos, los cuales poseían asociaciones minerales con muy variable grado de madurez textural y composicional.

Por lo tanto, durante el Cuaternario, los agentes de transporte fueron cambiando, a través del hielo durante los periodos glaciales o el agua durante los interglaciales, generando depósitos que cubrieron la actual Plataforma Continental. Así, en un medio dominantemente ácueo, comenzaron los procesos de selección mineral.

La siguiente etapa evolutiva dio lugar al retrabajo de los diferentes depósitos detríticos por la acción marina como consecuencia del ascenso del nivel del mar, concentrando en la zona litoral depósitos de minerales pesados entre los cuales el oro representa la principal fase de interés desde el punto de vista económico. Finalmente, la dinámica desarrollada en este sector fue llevando parcialmente los sedimentos detríticos hacia el fondo de la Plataforma Continental más somera, donde esporádicos eventos de fuertes tormentas pueden provocar el retrabajo de estos sedimentos y los depósitos relictos de la actividad glacial pasada, transportando minerales pesados hacia los sectores litorales.

En función de la historia evolutiva consignada en los párrafos anteriores se ha dividido el ambiente de formación de los depósitos detríticos en cinco grandes subambientes que aproximadamente de oeste a este son: a) Subambiente Cordillerano Andino, b) Subambiente glacial, c) Subambiente glacifluvial y fluvial, d) Subambiente marino costero y e) Subambiente marino de Plataforma Continental, en los cuales se resumirá a continuación sus principales características geológicas y asociaciones minerales presentes.

\subsection{Subambiente Cordillerano Andino}

En el esquema regional del modelo genético de los depósitos detríticos del litoral atlántico fueguino el ambiente Cordillerano Andino comprende esencialmente la Cordillera Darwin en Chile, área donde se considera que se generaron las principales masas de hielo y que constituyen el punto inicial de trayectoria de las lenguas glaciales durante el Pleistoceno. Está constituido por tres grandes unidades morfoestructurales: a) el Complejo Metamórfico Cordillera Darwin, b) el Batolito Fueguino y c) la Cuenca Marginal de Rocas Verdes.

El Complejo Metamórfico Cordillera Darwin comprende rocas metamórficas de edad paleozoica tardía hasta triásica asociadas con un prisma de acreción desarrollado en 
el margen pacífico de Gondwana, previo a la fragmentación del supercontinente (Mukasa y Daziel 1996). Está constituido por rocas metasedimentarias y metavolcánicas (Hervé et al. 2010).

Por su parte el Batolito Fueguino corresponde a un conjunto de rocas intrusivas de carácter principalmente calcoalcalino, desarrolladas durante el Jurásico superior y el Terciario en un ambiente de arco volcánico. Se pueden diferenciar las facies de granitoides de la Suite Darwin, los diques basálticos que intersectan a las rocas de la Suite Darwin y las tonalitas y granodioritas de la Suite Beagle.

Asimismo, los procesos extensivos asociados a la fragmentación de Gondwana durante el Jurásico y Cretácico inferior generaron la Cuenca Marginal de Rocas Verdes, cuyos depósitos están representados por las riolitas de la Formación Tobífera o Lemaire, las ofiolitas del Complejo Tortuga y el relleno vulcano-sedimentario de la Formación Yahgán.

\subsubsection{Paragénesis mineral}

En esta sección se consignan las asociaciones minerales características de las diferentes rocas que representan las posibles áreas fuente de los minerales que conforman los depósitos detríticos del litoral fueguino atlántico.

Las principales paragénesis minerales se resumen a continuación (Tabla 8.1): 


\begin{tabular}{|c|c|c|c|c|}
\hline $\begin{array}{c}\text { UNIDAD } \\
\text { MORFOESTRUCTURAL }\end{array}$ & \begin{tabular}{|c|} 
CARÁCTERÍSTICAS \\
GEOTECTÓNICAS
\end{tabular} & $\begin{array}{l}\text { PRINCIPALES TIPOS } \\
\text { LITOLÓGICOS }\end{array}$ & PARAGÉNESIS MINERALES & REFERENCIAS \\
\hline \multirow{2}{*}{$\begin{array}{c}\text { COMPLEJO } \\
\text { METAMÓRFICO } \\
\text { CORDILLERA } \\
\text { DARWIN }\end{array}$} & \multirow{2}{*}{$\begin{array}{l}\text { PRISMA DE } \\
\text { ACRECIÓN }\end{array}$} & Esquistos pelíticos & $\begin{array}{c}\mathrm{Qtz}+\mathrm{PI}+\mathrm{Ms}+\mathrm{Bt}+\mathrm{Chl}+\mathrm{Grt}+ \\
\quad+\mathrm{St}+|| \mathrm{m}+\mathrm{Ky}+\mathrm{Sil}>\mathrm{Rt}\end{array}$ & \multirow{2}{*}{$\begin{array}{c}\text { Kohn et al. (1993), } \\
\text { Hervé et al. (2008) } \\
\text { y Maloney et al. } \\
\text { (2011) }\end{array}$} \\
\hline & & Metabasitas & $\begin{array}{c}\text { Grt+Pl+Hbl+Bt+Chl+ } \\
+\mathrm{Qtz}+\mathrm{Ep}+\mathrm{Ttn}+\| \mathrm{Im}+\mathrm{Rt}\end{array}$ & \\
\hline \multirow{3}{*}{$\begin{array}{l}\text { BATOLITO } \\
\text { FUEGUINO }\end{array}$} & \multirow{3}{*}{$\begin{array}{c}\text { ARCO } \\
\text { MAGMÁTICO }\end{array}$} & $\begin{array}{l}\text { Suite Darwin } \\
\text { (ortogneisses } \\
\text { graníticos) }\end{array}$ & $\mathrm{Qtz}+\mathrm{Fsp}+\mathrm{Bt}>\mathrm{Grt}+\mathrm{Ms}+\mathrm{Amp}+\mathrm{Aln}+\mathrm{Zrn}$ & \multirow{3}{*}{$\begin{array}{l}\text { Nelson et al. } \\
\text { (1980) y Suárez } \\
\text { et al. (1985) }\end{array}$} \\
\hline & & $\begin{array}{l}\text { Diques basálticos } \\
\text { (anfibolitas) }\end{array}$ & $\mathrm{Amp}+\mathrm{PI}+\mathrm{Bt}+\mathrm{Op}+\mathrm{Ttn}+\mathrm{Grt}$ & \\
\hline & & $\begin{array}{l}\text { Suite Beagle } \\
\text { (tonalitas y } \\
\text { granodioritas) }\end{array}$ & $\begin{array}{c}\mathrm{Pl}+\mathrm{Kfs}+\mathrm{Qtz}+\mathrm{Hbl}+\mathrm{Bt}> \\
>\mathrm{Ap}+\mathrm{Ttn}+\mathrm{Op}+\mathrm{Zrn}+\mathrm{Aln} .\end{array}$ & \\
\hline \multirow{5}{*}{$\begin{array}{c}\text { CUENCA } \\
\text { MARGINAL DE } \\
\text { ROCAS VERDES }\end{array}$} & RIFT & $\begin{array}{c}\text { Fm. Tobífera } \\
\text { (esquistos y } \\
\text { pizarras, riolitas y } \\
\text { basaltos) }\end{array}$ & 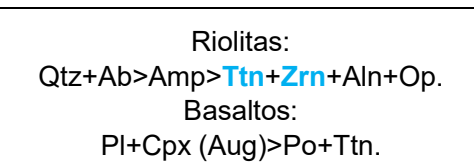 & $\begin{array}{c}\text { Olivero et al. (1997) } \\
\text { y González Guillot } \\
\text { (2016) }\end{array}$ \\
\hline & \multirow{4}{*}{$\begin{array}{l}\text { DORSAL } \\
\text { OCEÁNICA }\end{array}$} & \multirow{4}{*}{$\begin{array}{c}\text { Complejo Ofiolítico } \\
\text { Tortuga } \\
\text { (troctolitas, } \\
\text { gabros, diabasas y } \\
\text { basaltos) }\end{array}$} & Troctolitas: $\mathrm{Ol}+\mathrm{PI}>\mathrm{Cpx}+\mathrm{Opx}$ & \multirow{4}{*}{$\begin{array}{c}\text { Suárez et al. } \\
(1985), \\
\text { Avendaño (2008) } \\
\text { y Coloma (2010) }\end{array}$} \\
\hline & & & $\begin{array}{c}\text { Gabros: } \\
\mathrm{PI}+\mathrm{Cpx}(\mathrm{Di}-\mathrm{Aug})+\mathrm{OI} \\
(\mathrm{Fo})>\mathrm{Opx}(\mathrm{Hyp})+\mathrm{Op} \\
(\mathrm{Po}+\mathrm{Ccp}>\mathrm{Py}+\mathrm{Hem}+\mathrm{Mag}+\mathrm{Lm}+\mathrm{Bn})\end{array}$ & \\
\hline & & & $\begin{array}{c}\text { Diabasas: } \mathrm{Pl}+\mathrm{Cpx}+\mathrm{Opx}+\mathrm{Op} \\
(\mathrm{Ti}-\mathrm{Mag}+\mathrm{Hem}>\mathrm{Po}+\mathrm{Ccp}+\mathrm{Py}+\mathrm{Lm})\end{array}$ & \\
\hline & & & $\begin{array}{c}\text { Basaltos: } \\
\mathrm{Pl}+\mathrm{Cpx}+\mathrm{Opx}+\mathrm{Ol}>\mathrm{Op} \\
(\mathrm{Po}+\mathrm{Ccp}>\mathrm{Py}+\mathrm{Mag}+\mathrm{Lm})\end{array}$ & \\
\hline
\end{tabular}

Tabla 8.1. Tabla resumen con las principales áreas de procedencia de los minerales pesados y la paragénesis mineral característica. Los minerales en azul corresponden a las fases que forman parte de la fracción de minerales pesados presentes en los diferentes ambientes de la zona de trabajo. Abreviaturas: Amp, anfibol; Ap, apatita; Aug, augita; Aln, allanita, Bt, biotita; Bn, bornita; Ccp, calcopirita; Ky, cianita; Cpx, clinopiroxenos; Di, diópsido; St, estaurolita; Qtz, cuarzo; Zrn, circón; Ep, epidoto; Fsp, feldespato; Kfs, feldespato potásico; Grt, granate; Hem, hematita; Hyp, hipersteno (enstatita rica en Fe); IIm, ilmenita; Lm, limonita; Mag, magnetita; Ms, moscovita; Ol, olivina; Op, minerales opacos; Pl, plagioclasa; Py, pirita; Po, pirrotina; Rt, rutilo; Sil, sillimanita; Ttn, titanita.

\subsection{Subambiente glacial}

Durante el Cuaternario la isla grande de Tierra del Fuego estuvo afectada por diferentes glaciaciones. Los principales glaciares partieron desde la Cordillera Darwin arrastrando enormes cantidades de material, incluyendo grandes bloques erráticos como los presentes en punta Sinaí.

En el sector argentino del NE de la isla, los glaciares de piedemonte del Estrecho de Magallanes y Bahía Inútil-Bahía San Sebastián alcanzaron la actual Plataforma Continental, quedando como registro diversas geoformas y depósitos glaciales tanto en la plataforma como en las planicies y sierras al oeste de los acantilados actuales. Estos 
materiales corresponden al menos a tres glaciaciones desarrolladas durante el Pleistoceno inferior y medio: Pampa de Beta o Río Grande, Río Cullen o Cabo Vírgenes y San Sebastián o Punta Delgada (Meglioli 1992). Al oeste del cauce del río Cullen, Díaz Balocchi et al. (2020), a partir de la apariencia, el grado de consolidación, relaciones corte y elevación, indican que también podría haber depósitos asociados a la glaciación Río Grande propuesta por Meglioli (1992) de edad pliocena, sin embargo, todavía no se han realizado dataciones.

Los depósitos de tipo till se caracterizan por presentar una textura matriz-sostenida con gravas y en ocasiones bloques erráticos de grandes dimensiones, de hasta $7 \mathrm{~m}$ de diámetro, de composición mayoritariamente granodiorítica y tonalítica. Estos bloques se asocian con los depósitos correspondientes con las glaciaciones Río Cullen y San Sebastián.

El glaciar al transportar una gran cantidad de material sin seleccionar es muy difícil que llegue a generar un yacimiento de tipo placer de minerales pesados; únicamente las aguas de deshielo pueden seleccionar y por lo tanto concentrar minerales en algunas zonas (Smirnov, 1982). Por este motivo, a pesar que de que el oro se encuentra en estos materiales, su ley, como indicó Sister (1948) es muy baja.

Al sur de la isla, el glaciar de descarga del Canal Beagle alcanzó su boca oriental, depositando gran cantidad de material proveniente de la región andina en el sector de bahía Sloggett. En esta zona, la glaciación más antigua de la cual se tiene registro corresponde a la glaciación Lennox o Sloggett del Pleistoceno medio (Caldenius, 1932; Rabassa, 2008).

\subsubsection{Asociación mineral}

El contenido de los materiales pesados en las fracciones finas transportados por el glaciar varió entre $4,9 \%$ y $7,1 \%$ con respecto a las fases livianas.

La asociación de minerales pesados de las fracciones finas de los materiales transportados por el glaciar está constituida principalmente por clinopiroxenos (augita y diópsido), clinoanfíboles (magnesiohastingsita, tschermakita y magnesiohornblenda) y ortopiroxenos (enstatita rica en Fe). En menor medida se reportaron minerales del grupo del epidoto (epidoto > clinozoisita), óxidos de $\mathrm{Fe}$ y $\mathrm{Ti}$ (óxidos intermedios de $\mathrm{Fe}-\mathrm{Ti}>$ hematita titanífera), espinelas (magnetita s.s. y magnetita titanífera) y granates 
(almandino). Como minerales accesorios se identificaron andalucita, circón, minerales del grupo de la apatita (flúorapatita e hidroxiapatita), pirita, estaurolita y goethita.

En relación a los minerales livianos, correspondientes a las fases mayoritarias del sedimento, se reconoció principalmente cuarzo y en menor medida plagioclasa sódica y feldespato potásico (ortosa).

\subsection{Subambiente glacifluvial-fluvial}

Entre las diferentes glaciaciones que afectaron la isla se sucedieron etapas interglaciales con retroceso de los hielos. Durante estos momentos se generaron en la parte frontal de los glaciares ríos de deshielo que arrastraron consigo importantes volúmenes de sedimentos pudiendo generar, en sectores propicios, como consecuencia de este transporte una selección y/o concentración de minerales en función de la densidad y de las condiciones fisiográficas (Fig.8.2.b).

Los depósitos glacifluviales se depositaron generando planicies de tipo sandur u outwash compuestas por sedimentos estratificados de arenas y gravas. La mayor extensión de estos depósitos se reconoce al norte del río Cullen, asociada a ambientes proglaciales de la Gran Glaciación Patagónica, localmente denominada Pampa de Beta (Meglioli, 1992).

Como consecuencia del transporte por el agua se produjo una mayor concentración y selección de minerales pesados con respecto a los depósitos de till, correspondiendo, por lo tanto, a los materiales del sector continental que presentan mayor potencialidad económica en relación al oro (Sister, 1948; Greiner, 1991). Sin embargo, debido a la enorme de cantidad de material que conforman estos depósitos y la posible acumulación de minerales pesados únicamente en sectores propicios donde los ríos se encontraron con algún obstáculo o elemento fisiográfico que permitiera su acumulación, la ley de oro sigue siendo muy baja en el sector NE de la isla $\left(<0,052 \mathrm{~g} / \mathrm{m}^{3}\right.$, Sister, 1948).

Después de las etapas glaciales e interglaciales, los depósitos de till y glacifluviales resultantes fueron retrabajados en algunos sectores continentales por la actividad fluvial posterior y/o incluso eólica (por ejemplo, en los acantilados, donde también se producen procesos de remoción en masa), pudiendo la primera llegar a generar concentrados 
similares a los glacifluviales, como indica igualmente Greiner (1991) en el sector chileno de la isla.

\subsubsection{Asociación mineral}

El contenido de materiales pesados en la fracción arenosa de los depósitos glacifluviales fluctuó entre 3,2 y $7,4 \%$ con respecto a los minerales livianos. Las fases que se identificaron son similares a las de los materiales de till, aumentando ligeramente la concentración de algunos minerales de mayor densidad y estabilidad. Como minerales pesados se reconocieron principalmente un clinopiroxeno (diópsido) y clinoanfíboles. En menor medida se reportaron óxidos de $\mathrm{Fe} \mathrm{y} \mathrm{Ti}$, ortopiroxenos (enstatita rica en $\mathrm{Fe}$ ), granates (almandino), magnetitas y minerales del grupo del epidoto (epidoto s.s. > clinozoisita). Como fases accesorias se identificaron andalucita, circón, estaurolita, minerales del grupo de la apatita, goethita y titanita. En relación a los minerales livianos, se identificó principalmente cuarzo y en menor medida plagioclasa sódica y feldespato potásico (ortosa).

\subsection{Subambiente marino costero}

Los yacimientos de tipo placer de playa generados en la costa noreste de la Isla Grande de Tierra del Fuego se explotaron principalmente desde fines del siglo XIX y principios del siglo XX para la recuperación de oro. Como ya se mencionó anteriormente, el oro, junto con el resto de los minerales pesados que aparece en las playas, proviene esencialmente de la erosión de los sedimentos de origen glacigénico presentes en este sector, tanto en los acantilados activos como en la Plataforma Continental Argentina. Durante eventos de fuertes tormentas o mareas de sicigia, el mar puede alcanzar los acantilados, erosionando la base de los mismos o directamente retrabajando el material proveniente de los desprendimientos que se acumulan por caída gravitacional sobre la zona supramareal. En dichos eventos de alta energía los sedimentos de la cubierta superficial y/o los depósitos glacigénicos de la plataforma más somera fueron retrabajados, transportando el oleaje minerales pesados hacia el sector costero.

El proceso de concentrado generó (y genera) niveles anómalos en minerales pesados localizados principalmente en la zona supramareal. Para los formación de estos depósitos los agentes dinámicos que intervienen se pueden agrupar en marinos, como el oleaje, la deriva litoral y las mareas, y eólicos. 
En este sector costero, las acumulaciones de minerales pesados presentan un tamaño de grano principalmente de arena media a fina. Se localizan tanto en la superficie de la playa como en profundidad, constituyendo capas discontinuas lenticulares que se intercalan entre las gravas y arenas constituidas principalmente por minerales livianos (Fig.8.1A).

Que la acumulación de minerales pesados se produzca en la parte alta del perfil de la playa es debido a que la velocidad y energía de las olas de rompiente son mayores que en las olas en retroceso. Por este motivo, las primeras pueden movilizar tanto minerales pesados como livianos, pero las aguas que vuelven al mar, y que pueden generar corrientes de resaca locales, solamente pueden levantar o arrastrar a los minerales livianos o de menor tamaño, generando de esta manera una fina capa en la superficie (Fig.8.1C). Este transporte, reiterado en el tiempo innumerables veces, provoca la clasificación vertical en niveles profundos de mayor espesor como respuesta al cizallamiento entre los granos (shear sorting). El principal aporte de material para el crecimiento del yacimiento se produce durante el oleaje de tormenta. La acción de las mareas puede intensificar este proceso ya que, debido al importante rango de amplitud mareal, se expone una mayor extensión del perfil de la playa para la acción del oleaje. La corriente de deriva litoral paralela a la costa provoca el trasporte en zig-zag de las partículas, distribuyéndolas a lo largo de la línea de costa.

En la zona supramareal e intermareal durante la marea baja, cuando el viento es lo suficientemente fuerte y constante, se puede producir el levantamiento de los minerales pesados presentes en la superficie, acumulándose en las dunas costeras fuera del alcance de las olas. Sin embargo, este proceso en la zona de investigación muestra escaso desarrollo (Fig. 8.1B).

Durante la bajamar, el drenaje de la zona intermareal hacia el mar genera múltiples canales mareales en los cuales se transportan minerales pesados de tamaños principalmente muy finos. Este proceso genera unos depósitos superficiales de pequeño espesor y de escasa durabilidad temporal, ya que cuando sube la marea son retrabajados y disipados.

Debido a los cambios del nivel de mar sucedidos como consecuencia de las glaciaciones cuaternarias, la línea de costa fluctuó dejando su impronta en el registro sedimentario de la actual Plataforma Continental Argentina. Por ello, es altamente probable 
que se hayan generado concentraciones anómalas de minerales pesados en zonas actualmente sumergidas (Fig. 8.2c).
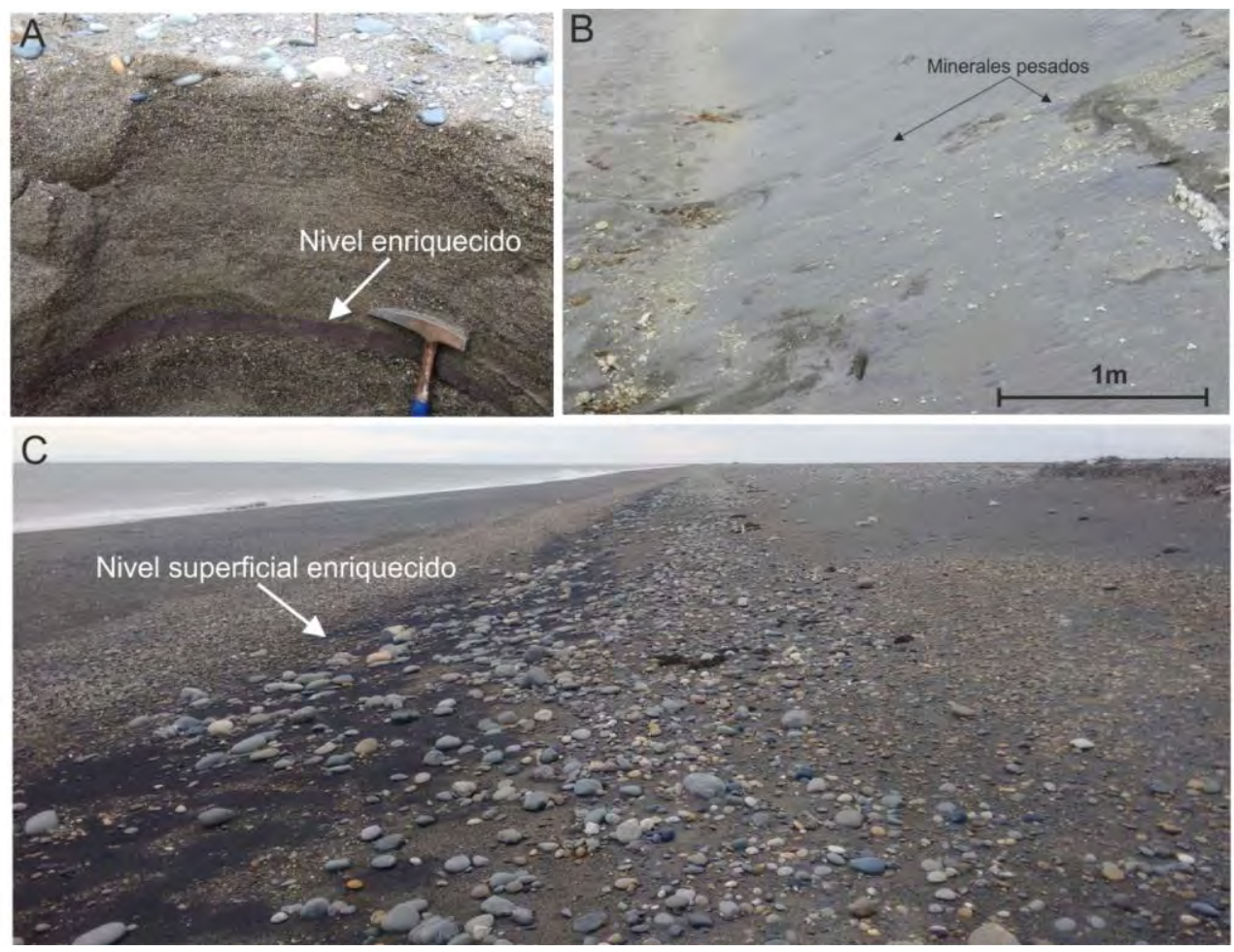

Fig. 8.1. Depósitos de minerales pesados en la playa del cañadón Beta (A y B) y El Páramo (C). A) Nivel enriquecido en minerales pesados en la zona supramareal B) acumulación de minerales pesados a barlovento en una duna remontante y C) acumulación de minerales pesados en la superficie.

Estudios analíticos sobre contenidos auríferos de algunos depósitos detríticos de Tierra del Fuego fueron realizados por R.D. Acevedo (com. pers.) en las playas de los cañadones Beta y Tortuga a partir de muestras tomadas por un lado mediante un muestreo sistemático de los diferentes sectores de la playa y por otro lado de niveles enriquecidos. Las muestras fueron sometidas a concentración con un concentrador centrífugo Knelson y los análisis químicos de $\mathrm{Au}$ y $\mathrm{Ag}$ se realizaron mediante el proceso de fusión en retalla. A partir de estos análisis se determinó que el sector donde se observan las mayores leyes de oro corresponden con la zona de tormenta, llegando a obtener en cañadón Beta 0,2402 $\mathrm{g} / \mathrm{m}^{3}$ y en cañadón Tortuga $0,8040 \mathrm{~g} / \mathrm{m}^{3}$. En las zonas intermareal alta e intermareal baja disminuyen progresivamente los valores hasta alcanzarse las leyes más bajas en esta última (Tabla 8.2). Las muestras de los niveles enriquecidos de la zona supramareal presentaron la máxima ley de oro, alcanzando un valor de $6,5336 \mathrm{~g} / \mathrm{m}^{3}$ en una muestra correspondiente a la playa del cañadón Beta (Tabla 8.3). 


\begin{tabular}{|c|c|c|c|c|c|c|c|c|c|}
\hline \multirow[b]{2}{*}{ Muestra } & \multirow[b]{2}{*}{ Ambiente } & \multirow[b]{2}{*}{ Peso (g)* } & \multirow[b]{2}{*}{ Peso $(\mathrm{g})^{* *}$} & \multirow[b]{2}{*}{$\mathrm{Au}(\mathrm{g})$} & \multirow[b]{2}{*}{$\mathrm{Ag}(\mathrm{g})$} & \multicolumn{4}{|l|}{ Leyes } \\
\hline & & & & & & $A u(g / t)$ & $\mathrm{Ag}(\mathrm{g} / \mathrm{t})$ & $\mathrm{Au}\left(\mathrm{g} / \mathrm{m}^{3}\right)$ & $\mathrm{Ag}\left(\mathrm{g} / \mathrm{m}^{3}\right)$ \\
\hline \multirow[t]{3}{*}{ Beta } & Sup. & 108020 & 1238,7 & 0,0138546 & 0,00017342 & 0,1283 & 0,0016 & 0,2402 & 0,0030 \\
\hline & I.A. & 92740 & 1235,5 & 0,00159666 & 0,00008649 & 0,0172 & 0,0009 & 0,0322 & 0,0017 \\
\hline & I.B. & 42850 & 1013,7 & 0,00020052 & 0,00006082 & 0,0047 & 0,0014 & 0,0088 & 0,0027 \\
\hline \multirow[t]{3}{*}{ Tortuga } & Sup. & 12105 & 1447,7 & 0,00519619 & 0,00017336 & 0,4293 & 0,0143 & 0,8040 & 0,0268 \\
\hline & I.A. & 14360 & 1189,3 & 0,00013965 & 0,00004757 & 0,0097 & 0,0033 & 0,0182 & 0,0062 \\
\hline & I.B. & 11620 & 1029,3 & 0,00000416 & 0,00004117 & 0,0004 & 0,0035 & 0,0007 & 0,0066 \\
\hline
\end{tabular}

Tabla 8.2. Análisis químicos de concentrados efectuados en el campo mediante concentrador Knelson. Muestras sin seleccionar obtenidas en tres puntos del perfil de la playa. Ley calculada a partir del peso inicial. Sup. Supramareal, I.A, intermareal alta, I.B, intermareal baja* peso total de la muestra** peso concentrado.

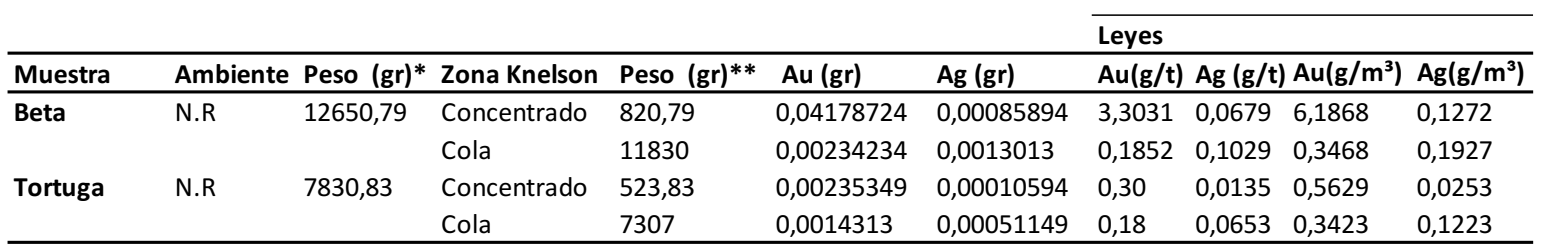

Tabla 8.3. Análisis químicos de concentrados obtenidos mediante concentrador Knelson en laboratorio. Muestras obtenidas de los niveles enriquecidos (N.R) presentes en la zona supramareal o de tormenta. Análisis del concentrado y de la muestra que termina en la cola del concentrador Knelson como consecuencia del pequeño tamaño. Ley calculada a partir del peso inicial. *peso total de la muestra**peso concentrado.

Leyes de oro similares fueron obtenidas por otros investigadores como Sister (1948) y Maleville (1998) en las playas del cañadón Tortuga, la desembocadura del río Cullen, el sector de El Páramo y al sur de la bahía San Sebastián, en la zona comprendida entre punta Basílica y cabo San Sebastián. En estos sectores de playas se reportaron valores entre $0,6 \mathrm{~g} / \mathrm{m}^{3}$ y $1 \mathrm{~g} / \mathrm{m}^{3}$.

En la provincia de Santa Cruz, en el sector litoral desde el sur de la localidad de Río Gallegos hasta el Cabo Vírgenes, Beros y Prez (1987) obtuvieron en las playas una ley promedio de $0,09 \mathrm{~g} / \mathrm{m}^{3}$ en el material "estéril" y $5,5 \mathrm{~g} / \mathrm{m}^{3}$ en los niveles enriquecidos. En este mismo sector, Codignotto et al. (1992) a partir de una muestreo sistemático obtuvieron leyes de oro que fluctuaron entre 0 y $1,7 \mathrm{~g} / \mathrm{m}^{3}$, alcanzando los valores más altos en sectores puntuales de la costa sur limitada por acantilados activos compuestos por depósitos glacigénicos.

En resumen, la mayor riqueza aurífera del yacimiento de tipo placer está limitada a niveles enriquecidos en minerales pesados presentes en la zona supramareal. Sin embargo, la ley del resto de los sectores costeros es muy superior a la presente en los diferentes materiales glacigénicos y fluviales. Este hecho es reflejo de un transporte y selección mucho más intenso y de dimensiones regionales, que se está produciendo en todo el sector litoral de la costa sur de la provincia de Santa Cruz y del noreste de Tierra del Fuego. 


\subsubsection{Asociación mineral}

En este punto hay que diferenciar entre las arenas de las playas en las cuales se realizó un muestreo sistemático sin selección y los niveles enriquecidos en minerales pesados:

En las arenas de las playas, donde la concentración de minerales junto con fragmentos líticos pesados fluctuó entre $4 \%$ y 33\%, la asociación de fases pesadas está constituida principalmente por clinopiroxenos (diópsido y augita), ortopiroxenos (enstatita rica en $\mathrm{Fe}$ ), minerales del grupo del epidoto (epidoto s.s. >clinozoisita) y clinoanfíboles (pargasita y tschermakita). En menor medida se identificaron granates (almandino), óxidos de $\mathrm{Fe}$ y $\mathrm{Ti}$ (óxidos intermedios de $\mathrm{Fe}-\mathrm{Ti}>$ ilmenita), magnetitas y estaurolita. Como minerales accesorios se encontraron circón, pirita, andalucita, goethita y calcopirita. Por su parte, las fases de minerales livianos correspondieron mayoritariamente a cuarzo y en menor medida plagioclasa (oligoclasa-labradorita), feldespato potásico (ortosa>>microclino) y carbonato (calcita).

En los niveles de minerales pesados concentrados de manera natural hay un dominio de los granates (almandino > espessartina), óxidos de Fe y Ti (óxidos intermedios de $\mathrm{Fe}-\mathrm{Ti}>$ hematita titanífera e ilmenita) y minerales del grupo de las espinelas (magnetita titanífera y magnetita s.s > magnetita rica en Al, espinela ferrosa y espinela cromífera). En menor medida se identificaron clinopiroxenos (diópsido y augita), ortopiroxenos (enstatita rica en $\mathrm{Fe}$ ), minerales del grupo del epidoto (epidoto s.s > clinozoisita) y estaurolita. Como minerales accesorios se reportaron clinoanfíboles (magnesiohastingsita, magnesiohornblenda > pargasita, ferropargasita), circón, titanita, pirita, goethita, rutilo, leucoxeno, apatita y minerales del grupo del oro (oro y electrum). En los niveles enriquecidos del sector norte de la isla hay un mayor predominio de granates y en los del sur de óxidos de Fe y $\mathrm{Ti}$ y magnetitas. Las fases livianas quedaron reducidas a granos de cuarzo y plagioclasa (andesina y oligoclasa).

\subsection{Subambiente marino de Plataforma Continental Argentina}

La Plataforma Continental corresponde a sectores continentales actualmente cubiertos por aguas oceánicas, por lo tanto, presenta características físicas similares a las del continente adyacente. Durante el Pleistoceno, el recubrimiento de buena parte de la plataforma por los glaciares moldeó el lecho marino con diversas geoformas y depósitos asociados a la actividad glacial (Mouzo, 2005a). El retroceso de los hielos en las etapas 
interglaciales generó ríos de deshielo que transportaron y depositaron en la Plataforma material glacifluvial que posteriormente sería cubierto por el agua como consecuencia del ascenso del nivel del mar. De esta manera, quedó registro del pasado glacial en los fondos marinos mediante depósitos glacifluviales, till y bloques erráticos (Mouzo, 2005b). La cubierta sedimentaria superficial que recubre estos materiales deriva fundamentalmente de su erosión, presentando por lo tanto una composición mineralógica similar.

Los sedimentos de la plataforma más somera pueden estar afectados por las condiciones hidrodinámicas del sector litoral, especialmente durante temporales donde el nivel de base del oleaje es más profundo y permite la removilización de los depósitos del fondo. En el resto de la plataforma, salvo la más próxima al talud donde hay corrientes de borde y procesos gravitacionales, los depósitos presentes en el fondo marino no sufren prácticamente movimiento, quedando como relictos de la actividad glacial cuaternaria. Siguiendo la clasificación para la dinámica sedimentaria de la Plataforma utilizada por Violante et al. (2017b) la porción más somera correspondería a la zona interna y la más profunda abarcaría a la media y externa.

\subsubsection{Asociación mineral}

En la fracción arenosa pesada presente en las arenas del lecho de la Plataforma Continental la asociación de minerales y fragmentos líticos pesados varió entre 0,25 y $8,7 \%$. Los minerales pesados están constituidos principalmente por clinopiroxenos (diópsido y augita), ortopiroxenos (enstatita rica en $\mathrm{Fe}$ ) y clinoanfíboles (magnesiohastingsita y magnesiohornblenda). En menor proporción se identificaron minerales del grupo del epidoto (epidoto s.s. > clinozoisita), óxidos de Fe y Ti (ilmenita, óxidos intermedios de $\mathrm{Fe}-\mathrm{Ti}>$ hematita titanífera), magnetita titanífera, andalucita y granate. Como minerales accesorios también se reconocieron circón y titanita. Hacia la Plataforma más profunda aumenta el contenido de los ortopiroxenos en detrimento de los clinopiroxenos.

Entre los minerales livianos se identificaron principalmente cuarzo, en menor medida plagioclasa (albita a oligoclasa) y feldespato potásico (ortosa y microclino). 
a)

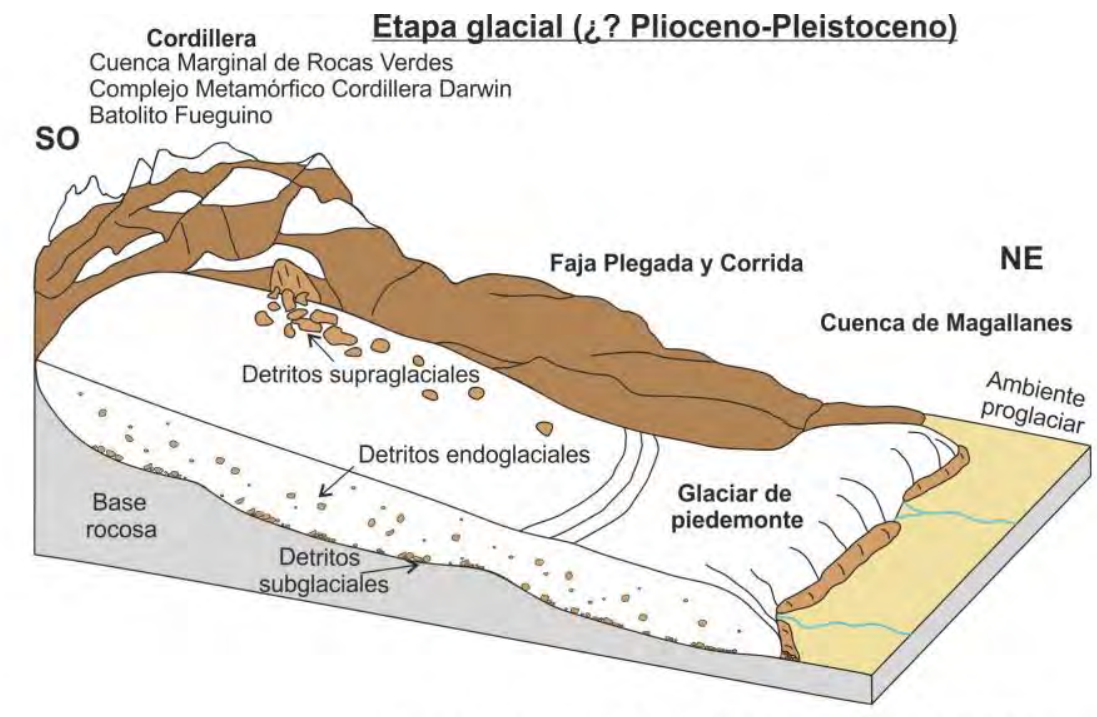

b)

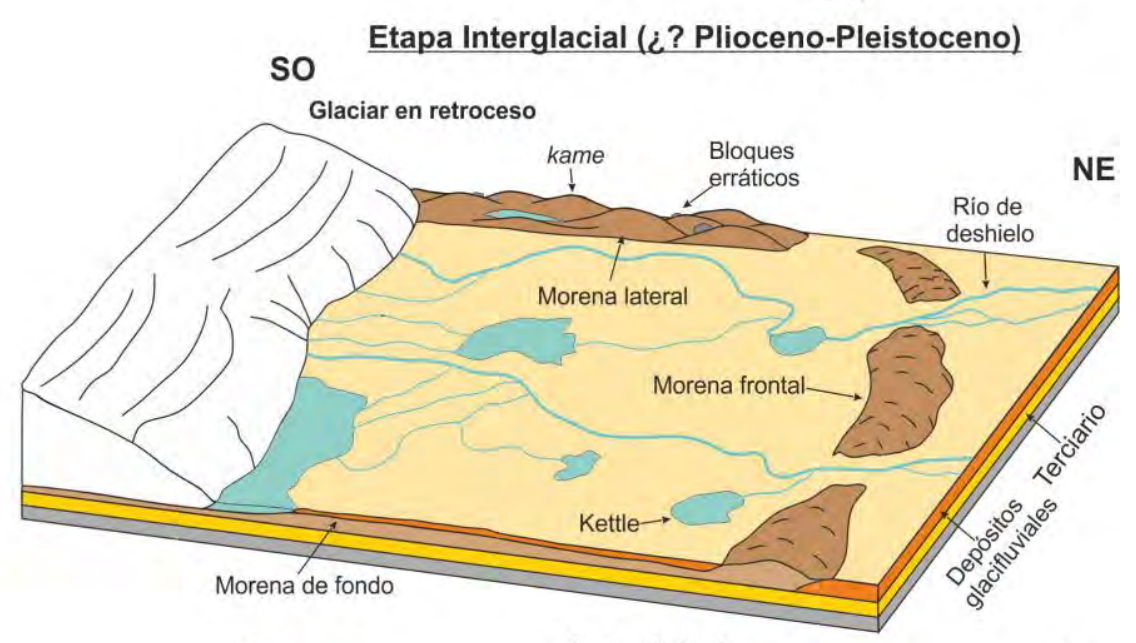

c)

Actualidad

NE

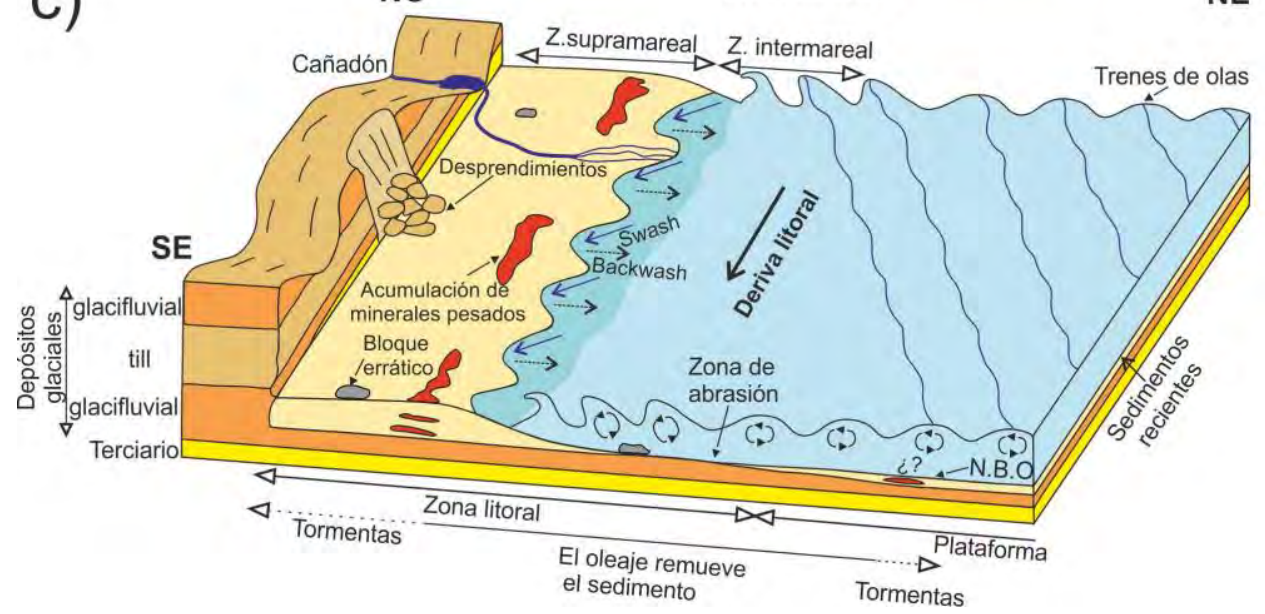

Fig. 8.2. Block diagramas de las diferentes subambientes glacial (a), interglacial (b) y litoral junto con la Plataforma Continental en el sector al $N$ del río Cullen, desde el Plioceno (?) hasta la actualidad. N.B.O. nivel base del oleaje. 


\subsection{Concentración de minerales pesados según el subambiente de muestreo}

A medida que los minerales son sometidos a diferentes procesos exógenos de transporte se produce un aumento de la concentración de los minerales más estables, así como una mejor selección entre los minerales más pesados (mayor madurez composicional). Esto se refleja principalmente en aquellos subambientes donde los efectos del agua han tenido una mayor intensidad, como en los depósitos glacifluviales a partir del agua de deshielo glacial o en las arenas de las playas afectadas principalmente por efectos del oleaje. En los depósitos de till no se produjo ninguna selección ya que el hielo no actuó, lógicamente, como agente concentrador. Los sedimentos del lecho de la Plataforma Continental analizados se localizan principalmente en la plataforma media o muy próxima a ella, por lo que los sedimentos superficiales actualmente presentan escasa movilidad debido al nulo efecto del oleaje (salvo tormentas), las mareas o las corrientes de deriva litoral, por lo tanto, en estos sectores no se está generando una selección de minerales pesados y livianos (Fig.8.3).

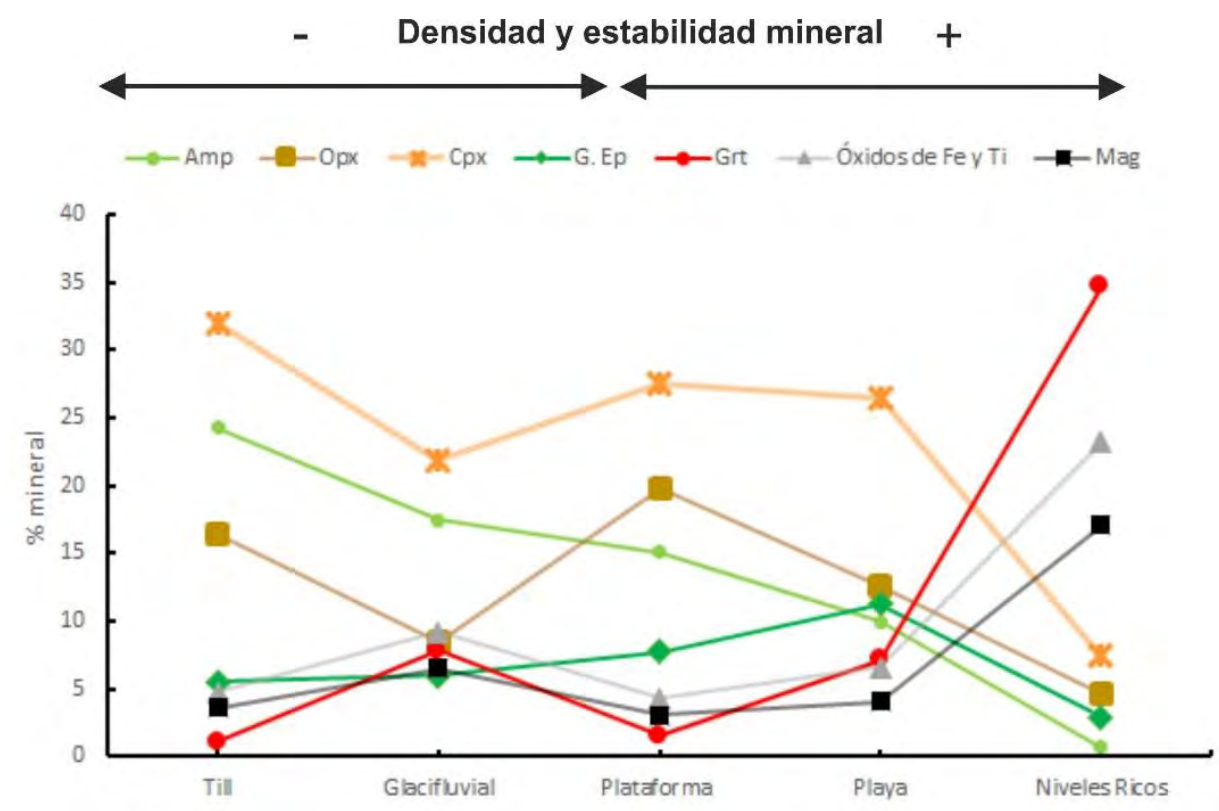

Fig. 8.3. Contenido en los principales minerales pesados presentes en los diferentes depósitos/subambientes.

El oro, como consecuencia de la erosión y el transporte, termina concentrándose junto con aquellos minerales que tienen mayor estabilidad geoquímica y densidad, tales como los granates, óxidos de Fe y Ti y magnetitas. Es por ello que los niveles con mayor ley de oro, presentes en la zona supramareal de la playa, están compuestos principalmente por estos grupos minerales. 


\subsection{Discusión}

El sector septentrional de la isla Grande de Tierra del Fuego está cubierto por grandes acumulaciones de origen glacigénico. En el área más al norte (DPB) se observa una alternancia de depósitos estratificados glacifluviales y till, a diferencia de los depósitos localizados al sur del río Cullen (DRC y DSS) donde mayoritariamente corresponden a depósitos tillíticos, presentando bloques erráticos de naturaleza granodiorítica y tonalítica en la superficie. Coincidiendo con las conclusiones de Díaz Balocchi et al. (2018b), los depósitos del DPB reflejarían avances glaciales con intercalaciones de depósitos glacifluviales proglaciales asociados a la glaciación Pampa de Beta. Los del DRC y DSS corresponderían mayoritariamente con depósitos transportados y depositados por el hielo, constituyendo las morenas latero-frontales de las glaciaciones Río Cullen y San Sebastián.

Los glaciares que afectaron este sector se corresponden a los lóbulos del Estrecho de Magallanes al norte y bahía Inútil-bahía San Sebastián al sur, partiendo ambos del manto de hielo de montaña de la Cordillera Darwin. Estos glaciares de piedemonte trasportaron gran cantidad de material desde la cordillera, incluyendo grandes bloques arrastrados de manera supraglacial como consecuencia de desprendimientos ocurridos en el sector cordillerano (Coronato et al. 1999, Coronato et al. 2004b, Darvill et al. 2015a). Por lo tanto, se puede inferir por la litología de las rocas y minerales como por la dirección de flujo de los glaciares que el área fuente se localiza en las rocas presentes en la Cordillera Darwin y zonas aledañas.

Los depósitos de la Plataforma Continental al NE de la Isla Grande de Tierra del Fuego están directamente ligados con la historia glacial que afectó a todo este sector durante las glaciaciones ocurridas en el Plioceno y el Pleistoceno, cuyos límites se sitúan mar adentro de la actual línea de costa (Caldenius 1932, Isla y Schnack 1995, Mouzo 2005c). Debido a ello, el nivel del mar sufrió grandes fluctuaciones glacioeustáticas dejando en varios períodos una gran extensión de la Plataforma Continental expuesta (Rabassa 2008, Ponce et al. 2011) donde se desarrollaron redes fluviales y geoformas y depósitos de origen glacial (Violante et al. 2014).

La asociación de minerales reconocida en los sedimentos de fondo de la Plataforma Continental es de gran similitud con la presente en las unidades glacígenas del área continental y en los sedimentos de las playas. Asimismo, es análoga a la encontrada en el sedimento superficial a lo largo del Estrecho de Magallanes, asociada también con el retrabajo de los depósitos glacifluviales y morénicos (Brambati et al. 1991). Debido a ello, 
se puede confirmar a partir de los análisis químicos de las diferentes fases minerales que estos minerales provendrían de la erosión y retrabajo de los depósitos de origen glacial.

En relación a los sedimentos de las playas, coincidiendo con Vilas el al. (1987), Bujalesky (1990), Isla et al. (1991) y Bujalesky (2007), el principal aporte sedimentario procede de los depósitos glacigénicos presentes tanto en los acantilados activos como sumergidos en la Plataforma Continental.

En el perfil transversal de la playa se pudieron diferenciar a grandes rasgos tres zonas principales: supramareal, intermareal alta y baja, a excepción del sector comprendido desde el sur del cañadón Tortuga hasta la zona de cabo Nombre donde no se llega a desarrollar una zona intermareal baja. Como indica Bujalesky (2007), la morfología de la playa está ligada a la paleotopografía de la plataforma de abrasión, constituida por sedimentitas cenozoicas. La plataforma de abrasión se localiza a muy poca profundidad llegando a aflorar en la zona intermareal baja de algunas de las playas, por lo que cualquier cambio que se produjera en ella condicionaría la acumulación de sedimentos en este sector. Desde el cabo Espíritu Santo hasta el sur del cañadón Tortuga las sedimentitas de la Fm. Cullen buzan suavemente hasta desaparecer por debajo de los acantilados, debido a ello, la plataforma de abrasión se debe localizar a una profundidad mayor. Esta zona, según Meglioli (1992), estuvo sometida a procesos de erosión como consecuencia de corrientes con agua de deshielo provenientes de glaciaciones posteriores a la del Río Cullen (Pleistoceno medio). Por ello, los depósitos correspondientes a esta glaciación no afloran en la costa Atlántica de este sector. Este hecho permite suponer que la zona abarcada por el actual río Cullen, sufrió una erosión mayor que el resto de la costa, afectando a la plataforma de abrasión y por lo tanto a la morfología de la playa. Futuros estudios geofísicos a realizar en la zona intermareal baja, como por ejemplo geoeléctrica o sísmica, podrán aportar mayores datos a esta consideración.

De acuerdo con los resultados obtenidos por Bujalesky (1990) en la espiga de El Páramo, los perfiles de estas playas suelen permanecer estables en el tiempo como consecuencia de la alta energía que se necesita para poner en movimiento los sedimentos gruesos que conforman el perfil superior de la playa.

La asociación mineral identificada en las arenas de las playas es muy similar en todo el sector litoral comprendido desde el sur de Río Gallegos (Santa Cruz) hasta el cabo Domingo, caracterizada por la presencia de depósitos glacigénicos (Codignotto et al. 1992, Gómez Peral y Martínez 1997). Si bien Acevedo et al. (2007) reportaron también la presencia de dravita y corindón en las playas de los cañadones Beta y Tortuga, en la presente investigación no se identificaron estos minerales. 
Las mayores acumulaciones de minerales pesados se localizan en la zona supramareal y en la zona de batida del oleaje, siendo especialmente abundantes después de un evento de oleaje de alta energía (tormenta). Esta consideración es coincidente con lo indicado por Etchichury y Tófalo (1981) para la zona comprendida entre cabo Espíritu Santo y cabo Nombre, con lo señalado por Gagliardo (1994) en la playa de la espiga del Páramo y por Codignotto et al. (1992) en el área del cabo Vírgenes.

Gómez Peral y Martínez (1997) en un estudio sobre la distribución de minerales pesados entre el cabo San Sebastián y el cabo Domingo asociaron las mayores concentraciones de minerales pesados con las antiguas desembocaduras de los ríos anteriores a la trasgresión post-glacial. Por otro lado, Codignotto et al. (1992) en un estudio mineralógico realizado entre punta Loyola y punta Dungeness asociaron la mayor concentración de minerales pesados a la desembocadura de los cañadones ya que consideran que los cursos de agua actúan como agentes disipadores de energía, favoreciendo su depositación. A partir de los resultados obtenidos en esta investigación, se observó que la concentración anómala de minerales pesados se da a lo largo de todo el sector costero, no solamente donde los cursos fluviales cortan el acantilado. Que históricamente se eligieran ciertos sectores para instalar las plantas de tratamiento y la explotación de oro se debe por un lado a la mejor accesibilidad a la zona de playa y por el otro, a la disponibilidad de agua dulce empleada para el lavado y concentración del oro.

La mayor concentración de granates y minerales opacos en los niveles glacifluviales del Drift Pampa de Beta permite relacionar las áreas más enriquecidas en minerales pesados de las playas al norte del río Cullen con su proximidad a estos depósitos. El sector comprendido desde el sur del cañadón Beta al sur del cañadón Tortuga corresponde a un área donde los espesores del Drift Pampa de Beta son más potentes y los desprendimientos frecuentes, como consecuencia del retroceso de los acantilados, por lo tanto, hay un mayor aporte de material detrítico. La presencia de niveles ricos en minerales pesados al norte del cañadón Beta y sur del cañadón Alfa, donde los acantilados están constituidos principalmente por sedimentitas de la Formación Cullen, se debe a la acción del oleaje de dirección S-SE (contrario al oleaje NE que genera la deriva litoral dominante) indicado por (Bujalesky 1990). La escasez de minerales pesados en el punto más septentrional, correspondiente con el sector del cabo Espíritu Santo, se debe a la baja frecuencia y persistencia de estos vientos que por lo tanto generan un oleaje de menor capacidad de transporte. En cambio, hacia el sur, la fuerte deriva litoral dominante distribuye los minerales pesados por todo el litoral, generando zonas de acumulación en sectores donde la costa rectilínea sufre una inflexión (cabo Nombre o punta Sinaí) (Fig.8.4). 


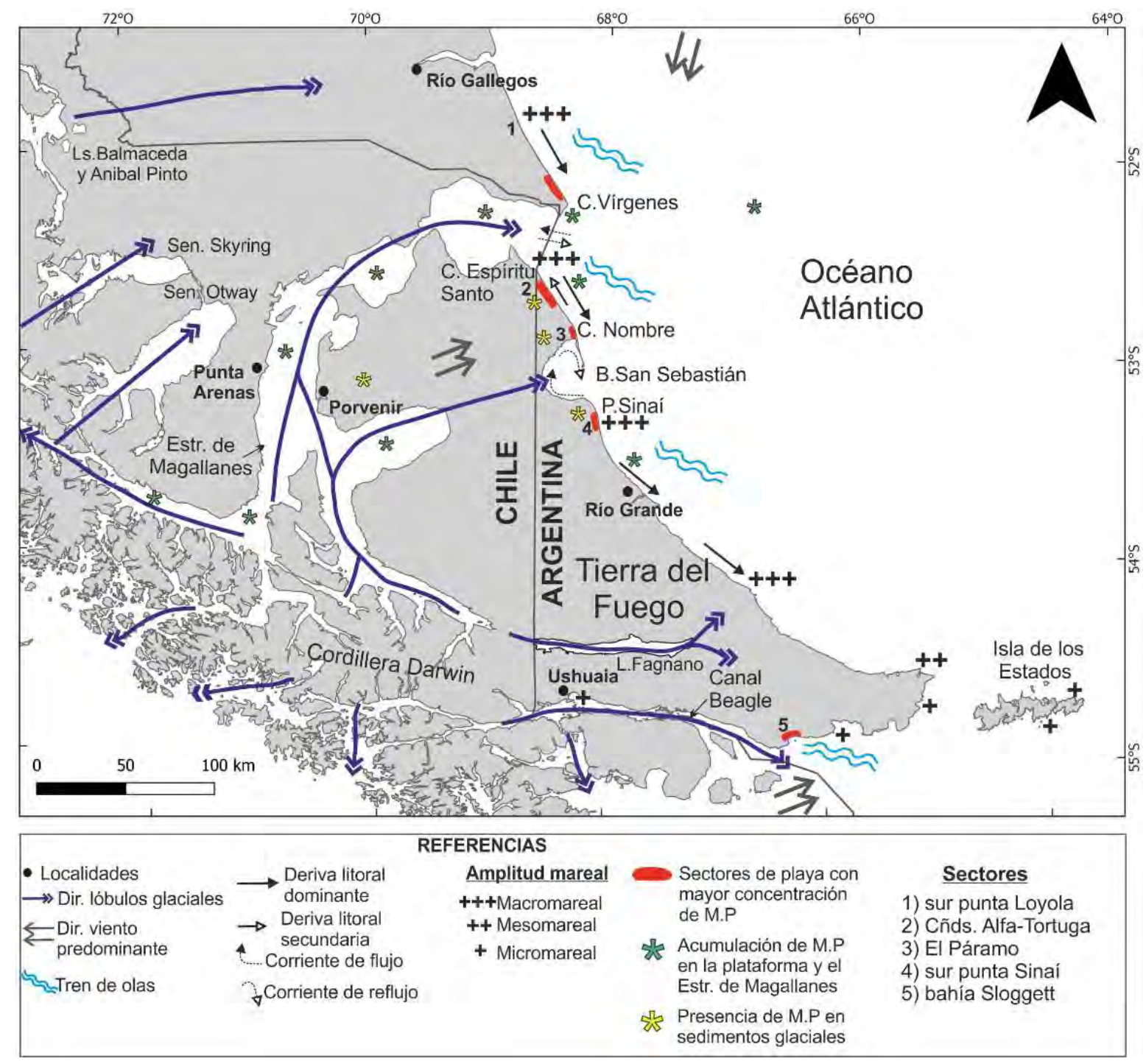

Fig. 8.4. Mapa esquemático regional de distribución de los principales factores y procesos morfodinámicos actuantes en la concentración de minerales pesados del sector oriental de la Isla Grande de Tierra del Fuego y sector austral de la provincia de Santa Cruz. La dirección de los lóbulos glaciales durante el Pleistoceno fue tomado de Meglioli (1992) y Coronato et al. (2004b). Abreviaturas: B bahía, C cabo, L y Ls lago/os, M.P minerales pesados, Sen Seno

Respecto al oro, las partículas con morfologías planas, plegadas y arriñonadas son indicativas de un intenso transporte, como consecuencia de los impactos entre cantos duros y la fricción (Viladevall et al. 1991, Townley et al. 2003). El martilleo ("hammering") provoca el aplastamiento de los granos durante el transporte y según Knight et al. (1999) es la principal causa que produce el cambio de forma durante el transporte fluvial de las partículas, que junto con la abrasión provocan su disminución y aumento de la redondez. Según Hérail et al. (1990) los granos de oro transportados por un río más de $60 \mathrm{~km}$ desde el área fuente se aplanan y pliegan, generando "estructuras en sandwich". En este sector, el oro sufrió diferentes procesos de transporte como glacial, glacifluvial, fluvial y finalmente marino, por lo que precisar la distancia del área fuente a partir de la morfometría es muy 
complicado. Sin embargo, sí se pueden expresar algunas consideraciones preliminares de las características físicas de los granos de oro. Presentan rasgos de un intenso y extenso transporte. La reducción del tamaño de grano y aumento de la alteración de los bordes en los granos de oro presentes en las playas más meridionales (El Páramo) indican que han sufrido una mayor exposición y transporte como consecuencia de la deriva litoral, localizándose por lo tanto la zona de aporte de este mineral en el sector norte de la zona de trabajo, correspondiente con los sedimentos del Drift Pampa de Beta.

En lo que respecta al sector de la bahía Sloggett, Carrillo et al. (1989) confirmaron la presencia de oro en los depósitos aluvionales del río López y en la misma bahía. Estos investigadores concluyen que el aumento de la concentración de minerales pesados en la bahía estaría asociado a la dinámica marina local. La presencia de oro junto con otros minerales pesados en la zona próxima al bed rock del sector supramareal de la playa, responde a la selección que se produce por cizalla ("shear sorting") como consecuencia del efecto del oleaje. Las características morfométricas de estos granos sugieren un menor transporte que los granos presentes en las playas del norte de la isla como consecuencia del reparo que ofrece la bahía frente a las corrientes marinas, restringiendo el efecto de la deriva litoral.

Según Methol y Sister (1949) el oro se asocia al sedimento transportado por el glaciar desde Cordillera Darwin. Sin embargo, la presencia de este mineral aguas arriba del río López podría indicar una procedencia más próxima, en las cabeceras de la cuenca hidrográfica del río. A pesar de ello, los datos son insuficientes ya que los depósitos glacigénicos del valle, presentes en las zonas más proximales a la bahía, podrían corresponder a planicies glacifluviales de la glaciación Lennox (Rabassa et al. 2003) y constituir la fuente de procedencia del metal precioso.

En el Canal Beagle hay registro histórico de explotación de placeres de playa tanto en las playas de la bahía Sloggett como en las islas localizadas en el extremo oriental del canal: Picton, Lennox y Nueva, coincidiendo todo este sector con la máxima extensión del glaciar Beagle durante la Glaciación Lennox. Este hecho indicaría la asociación de depósitos enriquecidos en oro con los depósitos glacigénicos frontales de la anteúltima glaciación. La presencia de oro únicamente en estos sectores puede ser explicada por la preservación de los sedimentos de la glaciación Lennox, ya que, como indican Rabassa et al. (2003), la siguiente glaciación, Moat, tuvo una extensión más reducida. En el caso de la bahía Sloggett, el glaciar tributario del valle del río López no alcanzó la bahía, quedando restos de sus morenas a los pies del frente montañoso. Por lo tanto, estos depósitos no fueron cubiertos por glaciaciones posteriores por lo que no sufrieron procesos de erosión 
glacial que los desmantelaran. Pero sí fueron afectados por corrientes glacifluviales durante su retroceso, hecho que permitió el retrabajo y concentrado del oro en algunos sectores. La presencia de depósitos detríticos ricos en oro con esta génesis está documentada en el sector chileno septentrional de la isla Grande de Tierra del Fuego, en el área del Cordón Baquedano (Greiner 1991).

\subsection{Consideraciones finales}

El modelo genético de los depósitos detríticos del litoral atlántico fueguino implica una secuencia concatenada de subambientes con muy variados procesos geológicos y condiciones geodinámicas que se han interrelacionado en el tiempo desde los sectores cordilleranos hasta las profundidades de la Plataforma Continental.

La combinación de esos procesos geológicos, desde la formación de las rocas ígneo-metamórficas durante el Mesozoico hasta la acción modeladora y de transporte de las masas glaciales durante el Cuaternario, ha permitido la generación de depósitos glacígenos a partir de los cuales la acción erosiva y seleccionadora de los agentes fluviales y marinos someros han llevado a la concentración de depósitos detríticos en el sector marino costero de la porción austral patagónico-fueguina (sector sur de Santa Cruz y el litoral atlántico fueguino). Estos depósitos detríticos, que contienen asociaciones de minerales pesados de una potencialidad económica todavía no suficientemente evaluada, presentan una magnitud y distribución regional en distancias que superan varios centenares de kilómetros y que han sido objeto, desde hace más de 130 años, de la explotación del mineral más buscado a través de la historia de la humanidad. 


\section{CONCLUSIONES GENERALES}

$>\quad$ Los estudios geológicos, mineralógicos y mineraloquímicos realizados en la presente investigación han abarcado las acumulaciones sedimentarias que se han desarrollado en tres grandes y distintas áreas del noreste de la isla Grande de Tierra del Fuego y regiones adyacentes, que de oeste a este son: a) Sector continental, dominado por la presencia de depósitos glacígenos de edad pleistocena, b) Sector costero, con los depósitos detríticos auríferos actuales del litoral atlántico y c) Sector de la Plataforma Continental Argentina, con los depósitos detríticos actuales del fondo marino.

$>\quad$ En los depósitos glacigénicos del sector continental, la fracción psefítica es muy variada, reconociéndose individuos de muy dispar granulometría y de naturaleza metamórfica (metacuarcitas, metapelitas, anfibolitas, milonitas, pizarras, filitas y esquistos, gneises y migmatitas), plutónica (dioritas, microdioritas, granodioritas, tonalitas, gabros, microgabros y rocas ultramáficas) volcánica (basaltos, pórfidos riolíticas, riodacíticas y andesíticas) y sedimentaria (grauvacas, cherts y ftanitas). Cabe agregar también la presencia frecuente de clastos de cuarzo de veta y variedades de la sílice como jaspe, calcedonia y ópalo.

En la fracción arenosa de los diferentes depósitos glacigénicos (till y glacifluviales), los minerales pesados identificados fueron esencialmente clinopiroxenos (augita+diópsido), ortopiroxenos (enstatita rica en $\mathrm{Fe}$ ) y clinoanfíboles (magnesiohastingsita+tschermakita+magnesiohornblenda). En menor medida se reportaron óxidos de $\mathrm{Fe} \mathrm{y} \mathrm{Ti}$ (óxidos intermedios de $\mathrm{Fe}-\mathrm{Ti}>$ hematita titanífera+ilmenita) y minerales de los grupos del epidoto (epidoto > clinozoisita), de la espinela (magnetita titanífera+magnetita s.s.) y del granate (almandino). Como minerales accesorios se identificaron andalucita, circón, estaurolita, minerales del grupo de la apatita (flúorapatita+hidroxiapatita), pirita, goethita y titanita. En la fracción liviana se identificaron principalmente cuarzo, plagioclasa (andesina-labradorita) y ortosa. En la fracción arenosa de los depósitos glacifluviales se reconoció un mayor contenido de óxidos de Fe y Ti y minerales de los grupos del granate y espinela respecto de los minerales identificados en los depósitos de till, reflejando por lo tanto, una mayor madurez composicional como consecuencia del mayor retrabajo de los materiales glacifluviales. 
En los sectores de playa la fracción psefítica presenta una marcada continuidad a lo largo de decenas de kilómetros y está compuesta por rocas volcánicas (riolitas, andesitas y basaltos), rocas metamórficas (metapelitas, migmatitas y metacuarcitas), rocas plutónicas (dioritas, granodioritas, monzonitas, tonalitas, microgabros, aplitas y rocas ultramáficas como hornblenditas y piroxenitas) y rocas sedimentarias (ftanitas y fragmentos de lutitas de la Formación Cullen en el sector norte de la zona de trabajo). También, se encontraron con frecuencia fragmentos de cuarzo de veta y distintas variedades silíceas.

En las fracciones arenosas de los sectores de playa, la asociación de minerales pesados está conformada principalmente por clinopiroxeno (augita y diópsido), ortopiroxeno (enstatita rica en $\mathrm{Fe}$ ), minerales del grupo del epidoto (epidoto > clinozoisita) y anfíbol (magnesiohastingsita+magnesiohornblenda+pargasita $>$ tschermakita+ ferropargasita). En menor medida se identificaron minerales del grupo del granate (almandino > espessartina), óxidos de Fe y $\mathrm{Ti}$ (óxidos intermedios de $\mathrm{Fe}-\mathrm{Ti}>$ hematita titanífera+ilmenita), minerales del grupo de la espinela (magnetita titanífera+magnetita s.s. >magnetita rica en Al+espinela s.s. ferrosa+espinela s.s. cromífera) y estaurolita. Como fases accesorias se reconocieron circón, andalucita, pirita, goethita, titanita, rutilo, minerales del grupo de la apatita, calcopirita y minerales del grupo del oro (oro+electrum). Completan la composición las fases dravita y el corindón. La fracción liviana, ampliamente mayoritaria en las playas, está constituida principalmente por cuarzo, plagioclasa (andesina hasta labradorita), feldespato potásico (ortosa>>microclino) y carbonatos correspondientes a fragmentos de conchillas.

En los sedimentos de fondo localizados en la Plataforma Continental Argentina se logró determinar un predominio de clastos psefíticos de naturaleza volcánica (basaltos, espilitas, riolitas, ignimbritas riolíticas y andesíticas), y en menor proporción individuos de rocas plutónicas (microdioritas, granodioritas y microgabros) y rocas metamórficas (metapelitas y anfibolitas), además de escasos fragmentos de rocas sedimentarias (grauvacas) y cuarzo de veta.

La asociación de minerales pesados presente en la fracción arenosa de los sedimentos de fondo de la Plataforma Continental está constituida principalmente por clinopiroxenos (diópsido+augita), ortopiroxenos (enstatita rica en $\mathrm{Fe}$ ), clinoanfíboles (magnesiohastingsita+magnesiohornblenda) y minerales del grupo del epidoto (epidoto > 
clinozoisita). En menor proporción se identificaron minerales agrupados dentro de los óxidos de $\mathrm{Fe}$ y $\mathrm{Ti}$ (ilmenita+óxidos intermedios de $\mathrm{Fe}$-Ti>hematita titanífera), magnetita titanífera, andalucita y minerales del grupo del granate. Circón y titanita también se reconocieron como minerales accesorios. En la fracción liviana los minerales principales que se identificaron fueron cuarzo, plagioclasa (albita hasta oligoclasa) y en menor proporción feldespato potásico (ortosa+microclino). Hacia la plataforma externa aumentó el contenido de los ortopiroxenos en detrimento de los clinopiroxenos.

Respecto de los sectores considerados más propicios para albergar importantes acumulaciones de minerales pesados en la costa noreste de Tierra del Fuego se destacan la zona supramareal y la zona de batida del oleaje, alcanzándose los volúmenes más significativos en las playas del sector al norte del río Cullen. Las capas de minerales pesados presentan morfología desde tabular hasta lenticular, alcanzan máximos de $7 \mathrm{~cm}$ de espesor con longitudes laterales parciales de hasta aproximadamente $3 \mathrm{~m}$ y se repiten innumerables veces a lo largo de toda la costa. Están constituidas principalmente por minerales del grupo del granate y minerales opacos (óxidos de Fe y $\mathrm{Ti}$ y magnetitas). La concentración de estos minerales va acompañada por el aumento del contenido de oro el cual se visualiza rápidamente con lupa de mano como pequeñas chispas (de tamaños $<1 \mathrm{~mm}$ ).

$>\quad$ Los estudios mineralógicos y petrográficos llevados a cabo en los tres ambientes geológicos identificados permitieron reconocer similares asociaciones de minerales pesados indicando que los materiales provienen de una misma región de procedencia. La proporción de los minerales pesados varía en cada uno de los ambientes como consecuencia de los diferentes procesos de transporte o intensidades de estos. Por una parte, los depósitos glaciales tanto continentales como sumergidos en la actual plataforma fueron transportados por el hielo y/o las aguas de deshielo, y, por otra parte, los depósitos litorales y los sedimentos de la cubierta superficial de la plataforma, procedentes del retrabajo de los depósitos anteriormente citados, fueron afectados por procesos de la acción marina.

La procedencia de los minerales pesados de los sectores de playa se encuentra fundamentalmente relacionada, en última instancia, a los cercanos sedimentos glacigénicos constituyentes de los acantilados activos. A esta situación debe agregarse la 
incidencia de los sedimentos glacigénicos del fondo de la Plataforma Continental, los cuales aportan material en ocasiones de fuertes tormentas y borrascas.

$>\quad$ Los depósitos glacifluviales, al haber sufrido procesos de selección y concentración de minerales pesados mucho mayores que los de los depósitos de till, aportan la mayor cantidad de material seleccionado a los niveles enriquecidos de las playas. No es casualidad que estos depósitos sean los que presentan una mayor distribución y espesor en el sector al norte del río Cullen, correspondiente al Drift Pampa de Beta. De acuerdo a los análisis mineralógicos efectuados estos depósitos constituyen el área de aporte más significativa del yacimiento.

$>\quad$ La acción erosiva y de transporte de las olas, la deriva litoral (dominante hacia el sur), las mareas y los fuertes vientos se conjugan para generar un sistema complejo de retrabajo y redistribución de los minerales detríticos, acumulándolos en los sectores geodinámicamente favorables del litoral costero.

Por su parte, los enormes volúmenes de rocas que han arrastrado los cuerpos glaciales provienen esencialmente del sector cordillerano (Cordillera Darwin y zonas adyacentes, Chile) donde existen variados ambientes geológicos desarrollados durante gran parte del Mesozoico.

$>\quad$ Los minerales del grupo del granate, ilmenita, rutilo, estaurolita y minerales del grupo del epidoto provendrían de las metapelitas y metabasitas del Complejo Metamórfico Cordillera Darwin. Los minerales del supergrupo del anfíbol, del grupo de la apatita y la titanita podrían tener su área fuente en la región de los granitoides del Batolito Fueguino. Por su parte, el circón podría derivar de ambas unidades morfoestructurales o también de las riolitas de la Fm. Tobífera o Lemaire. Los sulfuros (pirita y calcopirita), el resto de los óxidos de Fe y Ti y los minerales del grupo del piroxeno y la espinela, derivarían mayormente de los basaltos, gabros y diabasas del Complejo Ofiolítico Tortuga. La andalucita se relacionaría a aureolas de contacto producto de los intrusivos del Batolito Fueguino mientras que, finalmente, los minerales del grupo del oro se asociarían a posibles sistemas epitermales o porfídicos asociados a esta unidad morfoestructural. 
El inicio del ciclo de formación de los yacimientos auríferos de tipo placer de playa del litoral fueguino atlántico se remonta entonces a la actividad ígnea desarrollada en ambiente de arco magmático durante el Jurásico en la región cordillerana. Como consecuencia de los esfuerzos compresivos desarrollados entre el Cretácico superior y el Paleógeno se generó el levantamiento principal de la actual cordillera, acompañado por episodios de procesos metamórficos de características regionales. Durante el Cuaternario los glaciares discurrieron desde el sector cordillerano arrastrando consigo una enorme cantidad de material sin seleccionar. A partir de los ríos de deshielo desarrollados durante el retroceso de las lenguas glaciales se inició la selección por tamaño y densidad de los diferentes minerales disgregados de las rocas. Posteriormente, el aumento progresivo del nivel del mar en los períodos interglaciales cubrió buena parte de los depósitos más orientales generados por el avance de los hielos en los períodos glaciales. Finalmente, se produjo el desplazamiento de la línea de costa hacia el oeste hasta su posición actual. Con posterioridad llegó a la zona litoral el aporte procedente del material glacial retrabajado de los acantilados y de la Plataforma Continental más somera durante eventos de fuertes tormentas. Es en esta zona donde se produjo y se produce una mayor removilización, selección y concentración de minerales pesados como consecuencia de los efectos del oleaje, corrientes de deriva litoral y mareas. Este transporte marino junto con la acción el viento que puede incrementar el proceso de concentrado en la playa, genera en la zona supramareal niveles discontinuos constituidos prácticamente por minerales pesados donde se concentró y se concentra actualmente el oro que ha evolucionado bajo condiciones de un Megamodelo genético.

Debido a que el oro abunda casi exclusivamente en los delgados niveles enriquecidos en minerales pesados, la ley general del yacimiento es baja. Pero involucra un enorme volumen y una extensión de escala regional ya que se extiende como mínimo desde el sector austral de la costa de la provincia de Santa Cruz por el norte hasta el sur de Punta Sinaí, incluyendo en el sur de la Isla Grande de Tierra del Fuego el sector oriental del Canal Beagle. Su extensión longitudinal involucra el recorrido de los glaciares que afectaron a esta región, desde el sector cordillerano hasta la actual Plataforma Continental Argentina, alcanzando regiones próximas a las Islas Malvinas.

El yacimiento de tipo placer de playa de la costa atlántica nororiental de la Isla Grande de Tierra del Fuego está en constante evolución y cambio, las 24 horas del día y los 365 días del año. 


\section{BIBLIOGRAFÍA}

Acevedo, R.D. 1988. Estudios geológicos areales y petroestructurales en el Complejo Deformado de los Andes Fueguinos. Tesis Doctoral, Universidad de Buenos Aires, 233 p., Buenos Aires.

Acevedo, R.D. 1996. Los mecanismos sustitutivos y los factores de evolución en los anfíboles de la Hornblendita Ushuaia,Tierra del Fuego. Revista de la Asociación Geológica Argentina 51(1): 69-77, Buenos Aires.

Acevedo, R.D. 2016. Alkali basalts and enclosed ultramafic xenoliths near Ushuaia, Tierra del Fuego, Argentina. SpringerPlus 5: 1-5.

Acevedo, R.D. 2019. Geological Records of the Fuegian Andes Deformed Complex Framed in a Patagonian Orogenic Belt Regional Context. Springer, 113p.

Acevedo, R.D., Linares, E., Ostera, H.A. y Valín-Alberdi, M. L. 2002. La Hornblendita Ushuaia (Tierra del Fuego): Geoquímica y Geocronología. Asociación Geológica Argentina 57(2): 133-142, Buenos Aires.

Acevedo, R.D., Quartino, G.P. y Coto, C.D. 1989. La intrusión ultramáfica de Estancia Túnel, y el significado de la presencia de granates y biotita en el Complejo Deformado de la Isla Grande de Tierra del Fuego. Acta Geologica Lilloana XVII, 1: 21-36, San Miguel de Tucumán.

Acevedo, R.D, Valin-Alberdi, C., Subías, I. y Villar, L. 2007. First gold and other heavy minerals microprobe analysis from Cañanon Beta deposits in the north part of Tierra del Fuego. GeoSur, Santiago de Chile.

Agüero, R., Danza, R., Martinioni, D. y Fernández, J. 2003. Mapa geológico de la Isla Grande de Tierra del Fuego e Isla de los Estados, Provincia de Tierra del Fuego, República Argentina. Laboratorio de Geología Andina (CADIC-CONICET) y Laboratorio de Micropaleontología (SEGEMAR-CONICET).

Andò, S., Garzanti, E., Padoan, M. y Limonta, M. 2012. Corrosion of heavy minerals during weathering and diagenesis: A catalog for optical analysis. Sedimentary Geology 280: 165-19.

Anthony, J.W., Bideaux, R.A, Bladh, K.W. y Nichols, M.C. (eds) 1990. Handbook of Mineralogy. Mineralogical Society of America, Chantilly, VA 20151-1110, USA. http://www.handbookofmineralogy.org/.

Armbruster, T., Bonazzi, P., Akasaka, M., Bermanec, V., Chopin, C., Gieré, R., HeussAssbichler, S., Liebscher, A., Menchetti, S., Pan, Y. y Pasero, M. 2006. Recommended nomenclature of epidote-group minerals. European Journal of Mineralogy 18: 551-567.

Aubrecht, R., Š,M., Sýkora, M. y Mikuš, T. 2009. Provenance of the detrital garnets and spinels from the Albian sediments of the Czorsztyn Unit (Pieniny Klippen Belt, Western Carpathians, Slovakia). Geologica Carpathica 60: 463-483.

Avendaño, V. 2008. Petrología del Complejo Ofiolítico Tortuga, Magallanes Chile: Evidencias de un metamorfismo Cretácico inferior. Memoria de título geólogo, Universidad de Chile, 128 p., Santiago. 
Bagnold, R. A. 1954. Experiments on a gravity-free dispersion of large solid spheres in a Newtonian fluid under shear. Proceedings of the Royal Society of London, A 225: 49-63.

Baker, P.E., Rea, W.J., Skarmeta, J., Caminos, R. y Rex, D.C. 1981. Igneous history of the Andean Cordillera and Patagonian plateau around latitude $46^{\circ} \mathrm{S}$. Philosophical Transaction of the Royal Society of London 300: 105-149.

Barbeau, D.L, Olivero, E.B., Swanson-Hysell, N.L.,Zahid, K.M., Murray, K.E. y Gehrels, G.E. 2009. Detrital-zircon geochronology of the eastern Magallanes foreland basin: Implications for Eocene kinematics of the northern Scotia Arc and Drake Passage. Earth and Planetary Science Letters 284: 489-503.

Barker, P.F. y Burrel, J. 1977. The opening of Drake Passage. Marine Geology 25(1-3): 1534.

Basu, A. y Molinaroli, E. 1989. Provenance characteristics of detritital opaque Fe-Ti oxide minerals. Journal of Sedimentary Petrology 59(6): 922-934.

Beros, C. y Prez, H. 1987. Geomorfología y oro entre Punta Dungeness y Cabo Buen Tiempo, Santa Cruz. Secretaría de Minería de la Nación. Informe Inédito, 73p., Comodoro Rivadavia.

Biel, C. 2011. El depósito de Sulfuros Masivos Polimetálicos de Arroyo Rojo, Tierra del Fuego (Argentina). Mineralogía, Geoquímica y Metalogenia. Tesis Doctoral, Universidad de Zaragoza, 394p., Zaragoza.

Biel, C., Subías, I., Fanlo, I., Mateo, E. y Acevedo, R.D. 2010. The Arroyo Rojo volcanichosted massive sulphide deposit (Tierra del Fuego, southernmost Argentina): geology, mineralogy, petrography and mineral chemistry. Revista Mexicana de Ciencias Geológicas 27(1): 84-96.

Blott, S. y Pye, K. 2001. GRADISTAT: a grain size distribution and statistics package for the analysis of unconsolidated sediments. Earth Surface Processes and Landforms 26:1237-1248.

Borrello, A., 1969. Los geosinclinales de la Argentina. Anales 14, Dirección Nacional de Geología y Minería, Dirección Nacional de Minería, 188 p., Buenos Aires

Bowles, J.F.K., Howie, R.A., Vaughan, D.J. y Zussman, J. 2011. Rock-Forming Minerals. Non-Silicates. Segunda ed., The Geological Society, 90 p., Londres.

Brambati, A., Fontolan, G. y Simeoni, U. 1991. Recent sediments and sedimentalogical processes in the Strait of Magellan. Bollettino di Oceanologia Teorica ed Applicata 9(2-3): 217-259.

Buddington, A. y Lindsley, D. 1964. Iron-Titanium oxide minerals and synthetic equivalents. Journal of Petrology 5: 310-357.

Bujalesky , G., Coronato, A. e Isla, F. 2001. Ambientes glacifluviales y litorales cuaternarios de la región del río Chico, Tierra del Fuego, Argentina. Revista de la Asociación Geológica Argentina 51(1): 73-90, Buenos Aires.

Bujalesky, G. 1990. Morfología y Dinámica de la Sedimentación Costera en la Península El Páramo, Bahía San Sebastián, Isla Grande de la Tierra del Fuego. Tesis Doctoral, Facultad de Ciencias Naturales y Museo, Universidad Nacional de La Pata, 188 p., La Plata. 
Bujalesky, G. 1997. Patrón espacial y dinámica de canales de sobrelavado de la costa de Tierra del Fuego. Revista de la Asociación Geológica Argentina 52(3): 257-274, Buenos Aires.

Bujalesky, G. 2007. Coastal geomorphology and evolution of Tierra del Fuego (Southern Argentina). Geológica Acta 5(4): 337-362.

Caldenius, C. 1932. Las glaciaciones cuaternarias en la Patagonia y Tierra del Fuego. Geografiska Annaler, 1-164 p., Stockholm.

Camacho, H. H. 1948. Geología de la cuenca del lago Fagnano o Cami, Gobernación Marítima de Tierra del Fuego. Tesis Doctoral, Universidad de Buenos Aires, 543 p., Buenos Aires.

Caminos, R. 1980. Cordillera Fueguina. En Geología Regional Argentina. Academia Nacional de Ciencias: 1463-1501, Córdoba, Argentina.

Caminos, R., Haller, M., Lapido, O., Lizuain, A., Page, R. y Ramos, V. 1981. Reconocimiento geológico de los Andes Fueguinos. Territorio Nacional de Tierra del Fuego. $8^{\circ}$ Congreso Geológico Argentino, Actas 3: 754-786, San Luis.

Caminos, R. y Nullo, F. 1979. Descripción geológica de la Hoja 67e, Isla de los Estados. Servicio Geológico Nacional, Boletín 175, Buenos aires.

Carrillo Rasúa, F., Morales Ruano, S. y Fenoll Hach-Ali, P. 2002. The three generations of gold in the Palai-Islica epithermal deposit, southeastern Spain. The Canadian Mineralogist 40: 1465-1481.

Carrillo, R., Hurtado, A. y Tassone, A. 1989. Prospección aurífera de depósitos aluvionales del Río López-Bahía Sloggett. PEOF N5, Proyecto Extremo Oriental de Tierra del Fuego.

Cavallotto, J., Violante, R. y Hernádez-Molina, F. 2011. Geological aspects and evolution of the Patagonian continental margin. Biological Journal of the Linnean Society 103: 346-362.

Chapman, R.J., Leake, R.C., Moles, N.R., Earls, G., Cooper, C., Harrington, K. y Berzins, R. 2000. The Application of Microchemical Analysis of Alluvial Gold Grains to the Understanding of Complex Local and Regional Gold Mineralization: A Case Study in the Irish and Scottish Caledonides. Economic Geology 95(8):1753-1773.

Chapman, R.J., Leake, R.C. y Styles, M. 2002. Microchemical Characterization of Alluvial Gold Grains as an Exploration Tool. Gold Bulletin 35(2): 53-65.

Codignotto, J. 1979. Hojas geológicas 63a Cullen, 64a Bahía San Sebastián y 65b Río Grande. Servicio Geológico Nacional, 71 p., Buenos Aires.

Codignotto, J. y Malumián, N. 1981. Geología de la región al norte del paralelo $54^{\circ} \mathrm{S}$ de la isla Grande de la Tierra del Fuego. Revista de la Asociación Geológica Argentina 36(1): 44-88, Buenos Aires.

Codignotto, J., Marcomini, S. y Kokot, R. 1992. Concentración aurífera en el área del Cabo Vírgenes. Revista de la Asociación Geológica Argentina 47(4): 408-415, Buenos Aires.

Cogliati, M. y Cuello, M. 2007. El clima de la Patagonia. En: C. Godoy Martínez, (ed.), Patagonia Total, Antártida e Islas Malvinas. Barcel Baires Ediciones: 618-642. 
Collado, L. 2007. La vegetación de Tierra del Fuego: de la estepa a la selva. En: C. Godoy Martínez, (ed.), Patagonia Total, Antártida e Islas Malvinas. Barcel Baires Ediciones: 755-772.

Coloma, F. 2010. Mineralogía y propiedades magnéticas del Complejo Ofiolítico Tortuga, Tierra del Fuego, Chile. Memoria Titulo de Geólogo, Universidad de Chile, 95 p., Santiago.

Compagnie de Recherches et d'Études Oceanographiques y Geomatter, 1985. Campagne meteo-oceanographique, site Río Cullen/Hydra, periode de Fevrier 1984 a Fevrier 1985, Informe Técnico CREO/1249 realizado para Total Austral, 399 p., Buenos Aires.

Corbella, H. 2002. El campo Volcano-Tectónico de Pali Aike. En: M. J. Haller, ed. Geología y Recursos Naturales de Santa Cruz. XV Congreso Geológico Argentino, Relatorio: 285-301, Buenos Aires.

Corbella, H., Chelotti, L. y Pomposiello, C. 1996. Neotectónica del Rift Jurásico Austral en Pali Aike, Patagonia extrandina, Santa Cruz, Argentina. XIII Congreso Geológico Argentino y III Congreso de Exploracion de Hidrocarburos, Actas: 383-393, Buenos Aires.

Coronato, A., Martínez, O. y Rabassa, J. 2004a. Glaciations in Argentine Patagonia, southern South America. En: J. Ehlers \& P. Gibbard (eds.), Quaternary Glaciations - Extent and Chronology. Quaternary Book Series, Part III, Elsevier:49-67.

Coronato, A., Meglioli, A. y Rabassa, J. 2004b. Glaciations in the Magellan Straits and Tierra del Fuego, southernmost South America. En: J. Ehlers y P. L. Gibbard (eds.), Quaternary Glaciations - Extent and Chronology. Quaternary Book Series, Part III, Elsevier: 45-48.

Coronato, A., Borromei, A. y Rabassa, J. 2007. Paleoclimas y paleoescenarios en la Patagonia Austral y en Tierra del Fuego durante el Cuaternario. Boletín Geográfico de la Universidad Nacional del Comahue, Número Especial Jornadas sobre Calentamiento Global: 18-28.

Coronato, A., Mazzoni, E., Vázquez, M. y Coronato, F. 2017. En Patagonia: Una síntesis de su geografía física. Ediciones Universidad Nacional de la Patagonia Austral, 217 p., Río Gallegos.

Coronato, A. y Rabassa, J. 2011. Pleistocene Glaciations in Southern Patagonia and Tierra del Fuego. En: J. Ehlers, P. D. Hughes y P. L. Gibbard (eds.). Quaternary glaciations - extent and chronology, Elsevier: 715-727, Amsterdam.

Coronato, A., Roig, C., Rabassa, J. y Meglioli, A. 1999. Erratic boulder field of pre-Illinoian age at Punta Sinaí, Tierra del Fuego, Southernmost South America. XV INQUA Congress: 47-48, Durban, South Africa.

Cunningham, W.D. 1993. Strike-slip faults in the southernmost Andes and the development of the Patagonian orocline. Tectonics 12(1): 169-186.

Cunningham, W.D., Dalziel, I.A.W., Tung-Yi, L. and Lawver, L.A. 1995. Southernmost South America-Antarctic Peninsula relative plate motions since $84 \mathrm{Ma}$ : implications for the tectonic evolution of the Scotia Arc region. Journal of Geophysical Research 100 (B5): 8257-8266. 
Cunningham, W.D. 1995. Orogenesis at the southern tip of the Americas: the structural evolution of the Cordillera Darwin metamorphic complex, southernmost Chile. Tectonophysics 244: 197-229.

Dabrio, D. 2010. Playas. En: A. Arche, (ed.), Sedimentología del proceso físico a la cuenca sedimentaria. Consejo Superior de Investigaciones Científicas: 441-502, Madrid.

Dahlquist, J., Alasino, P., Galindo, C. y Casquet, C. 2006. Diferencias entre granates de rocas ígneas y metamórficas de edad Famatiniana (Ordovícico), en las Sierras Pampeanas (Argentina). XXVI Reunión (SEM), MACLA: 155-158, Oviedo.

Dalziel, I.W., De Wit, M.J. y Palmer, K. F. 1974. Fossil marginal basin in the southern Andes. Nature 250: 291-294.

Darvill , C.M., Bentley, M.J. y Stokes, C. R. 2015a. Geomorphology and weathering characteristics of erratic boulder trains on Tierra del Fuego, southernmost South America: Implications for dating of glacial deposits. Geomorphology 228: 382-397.

Darvill, C.M., Bentley, M.J., Stokes, C.R. y Hein, A. 2015b. Extensive MIS 3 glaciation in southermost Patagonia revealed by cosmogenic nuclide datin of outhwash sediments. Earth and Planetary Science Letters 429: 157-169.

Deer, W.A., Howie, R.A. y Zussman, J. 1992. An Introduction to the Rock-Forming Minerals. Longman Group, 696p., Londres.

Deer, W.A., Howie, R.A. y Zussman, J. 1997a. Rock-Forming Minerals. Volumen 1B: Disilicates and Ring Silicates. The Geological Society, Segunda ed., 912 p., Londres.

Deer, W.A., Howie, R.A. y Zussman, J. 1997b. Rock-Forming Minerals. Volumen 2A: Single Chain Silicates. The Geological Society, Segunda ed., 668 p., Londres.

Deer, W.A., Howie, R.A. y Zussman, J. 2013. An Introduction to the Rock-Forming Minerals. Mineralogical Society of Great Britain and Ireland, Tercera ed., 498 p.

Desborugh, G., Raymond, W. y lagmin, P. 1970. Distribution of silver and copper in placer gold derived from the northeastern part of the Colorado mineral belt. Economic Geology 65(8): 937-944.

Díaz Balocchi, L., Ponce, J.,Tripaldi, A. y Magneres, I. 2018a. Asociaciones de geoformas y depósitos del sector norte del lóbulo Bahía Inútil-Bahía San Sebastián, Tierra del Fuego. $7^{\circ}$ Congreso Argentino de Cuaternario y Geomorfología, Puerto Madryn.

Díaz Balocchi, L., Ponce, J., Tripaldi, A. y Magneres, I. 2018b. Caracterización geomorfológica y sedimentológica de la planicie glacigénica del extremo norte del sector argentino de la isla Grande de Tierra del Fuego. $7^{\circ}$ Congreso Argentino de Cuaternario y Geomorfología, Puerto Madryn.

Díaz Balocchi, L., Ponce, J., Tripaldi, A. y Magneres, I. 2020. Geomorphology of the northeastern extreme of Isla Grande de Tierra del Fuego, Argentina. Journal of Maps 16(2): 512-523.

Dill, H. 2010. The "chessboard" classification scheme of mineral deposits: Mineralogy and geology from aluminum to zirconium. Earth-Science Reviews 100: 1-420.

Dill, H., Goldmann, S. y Cravero, F. 2018. Zr-Ti-Fe placers along the coast of NE Argentina: Provenance analysis and ore guide for the metallogenesis in the South Atlantic Ocean. Ore Geology Reviews 95: 131-160. 
Diraison, M., Cobbold, P.R., Gapais, D., Rossello, E.A. y LeCorre, C. 2000. Cenozoic crustal thickening, wrenching and rifting in the foothills of the southernmost Andes. Tectonophysics 316: 91-119.

Diraison, M., Cobbold, P.R., Gapais, D. y Rossello, E.A. 1997. Magellan Strait: Part of a Neogene rift system. Geology 25: 703-706.

Dott, R.H., Winn, R.D., de Wit, M.J. y Bruhn, L.R. 1977. Tectonic and sedimentary significance of Cretaceous Tekenika Beds of Tierra del Fuego. Nature 266: 620-622.

Droop, G.T. 1987. A general equation for estimating $\mathrm{Fe}^{3+}$ concentrations in ferromagnesian silicates and oxides from microprobe analyses, using stoichiometric criteria. Mineralogical Magazine 51: 431-435.

Dzogolyk, E. 2007. Termobarometría de aluminio en hornblenda en el batolito sur patagónico. Memoria Título de Geólogo, Universidad de Chile, 80 p., Santiago.

Elthon, D. 1979. High magnesia liquids as the parental magma for ocean floor basalts. Nature 278: 514-517.

Etchichury, M. y Tófalo, O. 1981. Sedimentología de muestras litorales de Tierra del Fuego, entre Cabo Espíritu Santo y Mina María. Revista de la Asociación Geológica Argentina 36(4): 333-357, Buenos Aires.

Flor, G., 2004. Geología Marina. Universidad de Oviedo, 617 p., Oviedo.

Folk, R. y Ward, W. 1957. Brazos River Bar: A Study in the Significance of Grain Size Parameters. Journal of Sedimentary Petrology 27(1): 3-26.

Freyssinet, P., Zeegers, H. y Tardy, Y. 1989. Morphology and geochemistry of gold grains in lateritic profiles of southern Mali. Journal of Geochemical Exploration 32: 17-31.

Frost, M.T., Grey, I.E., Harrowfield, I.R. y Mason, K. 1983. The dependence of alumina and silica contents on the extent of alteration of weathered ilmenites from Western Australia. Mineralogical Magazine 47: 201-208.

Furque, G. 1966. Algunos aspectos de la geología de bahía Aguirre, Tierra del Fuego. Revista de la Asociación Geológica Argentina 21: 61-66.

Gagliardo, M.L. 1994. Minerales pesados en la playa de la espiga de San Sebastián, Tierra del Fuego. II Reunión de Mineralogía y Metalogenia, Actas №3: 101-108, La Plata.

Ghiglione, M.C. 2002. Diques clásticos asociados a deformación transcurrente en depósitos sinorogénicos del Mioceno inferior de la Cuenca Austral. Revista de la Asociación Geológica Argentina 57(2): 103-118, Bueno Aires.

Ghiglione, M., 2003. Estructura y evolución tectónica del cretácico-terciario de la Costa Atlántica de Tierra del Fuego. Tesis Doctoral, Universidad de Buenos Aires, 183 p., Buenos Aires.

Ghiglione, M., Navarrete-Rodríguez, A.T., González-Guillot, M. y Bujalesky, G. 2012. The opening of the Magellan Strait and its geodynamic implications. Terra Nova 25(1): 13-20.

Ghiglione, M. y Ramos, V. 2005. Progression of deformation and sedimentation in the southernmost Andes.. Tectonophysics 405: 25-46. 
Gómez Peral, M.A. y Martínez, D.A. 1997. Distribución de los minerales pesados en playas del litoral atlántico de la Tierra del Fuego, entre cabo San Sebastián y cabo Domingo. Revista de la Asociación Geológica Argentina 52(4): 504-514.

González de Vallejo, L.I., Ferrer, M., Ortuño, L. y Oteo, C. 2004. Movimientos de ladera. En: Capella I (ed), Igeniería Geológica. Pearson Educación, S.A: 622-638, Madrid.

González Guillot, M. 2009. Estudio petrogenético de plutones de la cordillera fueguina entre el lago fagnano y el canal beagle, y algunas consideraciones sobre las mineralizaciones asociadas.Tesis Doctoral, Facultad de Ciencias Naturales y Museo, Universidad Nacional de la Plata, 329 p., La Plata.

González Guillot, M. 2016. Magmatic Evolution of the Southernmost Andes and Its Relation with Subduction Processes. En: M.C. Ghiglione (ed.), Geodynamic Evolution of the Southernmost Andes. Springer International Publishing: 37-74, Switzerland.

González Guillot, M. y Acevedo, R.D. 2009. Facies con biotita y granate en plutones de los Andes Fueguinos de Argentina. XII Congreso Geológico Chileno, Santiago.

González Guillot, M., Ghiglione, M., Escayola, M., Pimentel, M.M., Mortensen, J. y Acevedo, R.D. 2018. Ushuaia pluton: Magma diversification, emplacement and relation with regional tectonics in the southernmost Andes. Journal of South American Earth Sciences 88: 497-519.

González Guillot, M., González, M., Prezzi, C,. Acevedo, R.D. y Escayola, M. 2012. A comparative study of two rear-arc plutons and implications for the Fuegian Andes tectonic evolution: Mount Kranck Pluton and Jeu-Jepén Monzonite, Argentina. Journal of South American Earth Sciences 38:71-88.

González Guillot, M. y Schalamuk, I., 2009. Mineralizaciones metalíferas en rocas ultramáficas de Tierra del Fuego, Argentina. IX Congreso de Geología Económica, Actas:19-24, Catamarca.

González Guillot, M., Urraza, I., Acevedo, R.D. y Escayola, M. 2016. Magmatismo básico jurásico-cretácico en los Andes Fueguinos y su relación con la cuenca marginal de rocas verdes. Revista de la Asociacion Geologica Argentina 73(1): 1-22. Buenos Aires.

González, G., Acevedo, R.D. y Escayola, M., 2007. The monte Kranck pluton: a new evidence of magmatic activity in the Fuegian Andes of Argentina. GeoSur, Libro de Resúmenes: 67, Santiago.

González-Guillot, M. y Acevedo, R.D. 2009. Facies con biotita y granate en plutones de los Andes Fueguinos de Argentina. XII Congreso Geológico Chileno: 1-4, Santiago.

Greiner, G.A. 1991. Características y distribución de los placeres auríferos de Chile. Symposium International Sur les Gisements Alluviaux d'Or, Resúmenes: 39-52, La Paz.

Guevara, D. 2004. Tierra del Fuego. En: E. Lavandaio y E. Catalano, (eds.), Historia de la Minería Argentina. Instituto de Geología y Recursos Minerales-SEGEMAR, Tomo 2: 271-292, Buenos Aires.

Guevara, D. 2016. Julio Popper, el alquimista de El Páramo. Talleres Gráficos del Instituto Geográfico Nacional, 510 p., Buenos Aires. 
Gutiérrez, M. 2008. Geomorfología Glaciar II. En: M. Martín-Romo (ed.), Geomofología. Pearson Prentice Hall: 485-514, Madrid.

Hanson, R. y Wilson, T. 1991. Submarine rhyolitic volcanism in a Jurassic proto-marginal basin; southern Andes, Chile and Argentina. Geological Society of America, Special Paper 265: 13-27.

Hawthorne, F.C., Oberti, R., Harlow, G,E., Maresch, W.V., Martin, R.F., Schumacher, J.C. y Welch, M.D. 2012. Nomenclature of the amphibole supergroup. American Mineralogist 97 (11-12): 2031-2048.

Hérail, G., Fornari, M., Viscarra, G. y Miranda, V. 1990. Morphological and chemical evolution of gold grains during the formation of a polygenic fluviatile placer. The MioPleistocene Tipuani placer example (Andes, Bolivia). Chronique de la Recherche Minière 500: 41-49.

Hervé, F., Calderón, M. y Faúndez, V. 2008. The metamorphic complexes of the Patagonian and Fuegian Andes. Geologica Acta 6: 43-53.

Hervé, F., Fanning, C. M., Pankhurst, R.J., Mpodozis, C., Klepeis, K., Calderón, M. y Thompson, S.N. 2010. Detrital zircon SHRIMP U-Pb age study of the Cordillera Darwin Metamorphic Complex of Tierra del Fuego: sedimentary sources and implications for the evolution of the Pacific margin of Gondwana. Journal of the Geological Society 167: 555-568, London.

Hervé, F., Nelson, E., Kawashita, K. y Suárez, M. 1981. New isotopic ages and the timing of orogenic events in the Cordillera Darwin, southernmost Chilean Andes. Earth and Planetary Science Letters 55: 257-265.

Hervé, F., Pankhurst, R.J., Fanning, C.M., Calderón, M. y Yaxley G.M. 2007. The South Patagonian batholith: 150 my of granite magmatism on a plate margin. Lithos 97:373-394.

Hervé, M., Suárez, M. y Puig, A. 1984. The Patagonian Batholith south of Tierra del Fuego, Chile. Timing and tectonic implications. Geological Society of London Bulletin 141(5): 909-917.

Hough, R., Butt, R. y Fischer-Bühner, J. 2009. The Crystallography, Metallography and Composition of Gold. Elements 5(5): 297-302.

IMCOS Marine Limited, 1978. Meteorological and Oceanographic Study: Offshore Tierra del Fuego. Informe Técnico 78/111 (inédito) realizado para Total Austral, 17 p., Buenos Aires.

Isla , F.I., Vilas , F.E., Bujalesky, G.G., Ferrero, M., Gonzalez Bonorino, G. y Arche Miralles, A. 1991. Gravel drift and wind effects on the macrotidal San Sebastian Bay, Tierra del Fuego, Argentina. Marine Geology 97: 211-224.

Isla, F.I., Spagnuolo, J. O. y Gelós, E. M. 2000. Sedimentología y mineralogía de las playas de Tierra del Fuego y Sector Antártico Argentino (Arco de Scotia e islas asociadas). Revista de la Asociación Geológica Argentina 55(3): 216-228, Buenos Aires.

Isla, F. y Schnack, E. 1995. Submerged moraines offshore northern Tierra del Fuego, Argentina. Quaternary of South America and the Antarctic Peninsula 9: 205-222. 
Iturraspe, R. y Urciuolo, A. 2007. Los recursos hídricos de Tierra del Fuego. En: C. Godoy Martínez (ed.), Patagonia Total, Antártida e Islas Malvinas. Barcel Baires Ediciones: 733-754.

Kerr, P. 1972. Mineralogía Óptica. Ediciones del Castillo S.A., 3 ed, 433 p., Madrid

Klein, C. y Hurlbut, C. 1997. Manual de Mineralogía. Volumen 2. Reverté, 21 ed. 396p., Barcelona.

Klepeis, K. 1994. Relationship between uplift of the metamorphic core of the southernmost Andes and shortening in the Magallanes foreland fold and thrust belt, Tierra del Fuego,Chile. Tectonics 13: 882-904.

Klepeis, K.A. y Austin, J.A. 1997. Contrasting styles of superposed deformation in the southernmost Andes. Tectonics 16(5): 755-776.

Knight, J., Morison, S. y Mortensen, J. 1999. The relationship between placer gold particle shape, rimming, and distance of fluvial transport as exemplified by gold from the Klondike District, Yukon Territory, Canada. Economic Geology 94(5): 635-648.

Kohn, M.J., Spear, F.S. y Dalziel, I. 1993. Metamorphic P-T Paths from Cordillera Darwin, a Core Complex in Tierra del Fuego, Chile. Journal of Petrology 34(3): 519-542.

Komar, P.D. 2007. Chapter 1: The Entrainment, Transport and Sorting of Heavy Minerals by Waves and Currents. En: M. A. Mange y D. T. Wright (eds), Heavy Minerals in Use. Elsevier: 3-48, Amsterdam.

Kowallis, B.J., Christiansen, E. H., Dorais, M. J., Winkel, T., Henze, P., Franzen, L., Mosher, $\mathrm{H}$. y Young, U. B. 2018. Compositional Variation of $\mathrm{Fe}, \mathrm{Al}, \mathrm{y} \mathrm{F}$ in Titanite. Indianapolis. GSA Annual Meeting: Indianápolis.

Kranck, E. 1932. Geological investigations in the Cordillera of Tierra del Fuego. Acta Geographica 4(2): 231.

Kreps, G., Peri, P. y Martínez Pastur, G. 2012. Cambio climático en Patagonia Sur: Escenarios futuros en el manejo de los recursos naturales. INTA, 100p., Buenos Aires.

Kudrass, H., 2016. Formation of placer deposits. Reference Module in Earth Systems and Environmental Sciences, Elsevier Inc: 1-5.

Kudrass, H. R. 1987. Sedimentary Models to Estimate the Heavy-Mineral Potential of Shelf Sediments. En: P. G. Teleki, M. R. Dobson, J. R. Moore y U. von Stackelberg (eds), Marine Minerales. NATO ASI Series, Springer 194: 39-56, Dordrecht.

Kyle, J. 1890. El platino nativo de la Tierra del Fuego. Anales de la Sociedad Científica Argentina 29: 51-52.

Lameyre, J. y Bowden, P. 1982. Plutonic rock types series: discrimination of various granitoid series and related rocks. Journal of Volcanology and Geothermal Research 14: 169-186.

Leake, B.E. 1965. The relationship between tetrahedral aluminum and the maximum possible octohedral aluminum in natural calciferous and subcalciferous amphiboles. American Mineralogist 50: 843-851.

Leake, B. E. y otros 21 autores. 1997. Nomenclature of amphiboles: report of the subcommittee on amphiboles of the International Mineralogical Association, 
commission on new minerals and mineral names. American Mineralogist 35: 219246.

Leterrier, J., Maury, R.C., Thonon, P., Girad, D. y Marchal, M. 1982. Clinopyroxene composition as a method of identification of the magmatic affinities of paleo-volcanic series. Earth and Planetary Science Letters 59: 139-154.

Locock, A. 2008. An Excel spreadsheet to recast analyses of garnet into end-member components, and a synopsis of the crystal chemistry of natural. Computers y Geosciences 34: 1769-1780.

Loekemeyer, N., Hlopec, R.,Bianciotto, O.,Valdéz, G. y Ortiz, G. 2005. El sistema de áreas naturales protegidas de la provincia de Tierra del fuego, Antártida e Islas del Atlántico Sur. Ministerio de La Producción, Provincia de Tierra del Fuego, Argentina. https://wwfar.awsassets.panda.org/downloads/ap_de_tierra_del_fuego.pdf

Macdonald, E. 2007. Handbook of gold exploration and evaluation. Woodhead Publishing and Maney Publishing on behalf of The Institute of Materials, Minerals and Mining, 647 p., Cambridge.

Macellari, C. 1979. La presencia del género Aucellina (Bivalvia, Cretácico) en la Formación Hito XIX (Tierra del Fuego, Argentina). Ameghiniana 16: 143-172, Buenos Aires.

Maleville, H. 1998. Informe Proyecto aluvional Río Cullen. Informe (inédito), Inversora y Minera Rio Grande S.A.,17p., Río Grande.

Maloney, K.T., Clarke, G.L., Klepeis, K.A., Fanning, C.M. y Wang, W. 2011. Crustal growth during back-arc closure: Cretaceous exhumation history of Cordillera Darwin, southern Patagonia. Journal of Metamorphic Geology 29: 649-672.

Malumián, N. 1999. La sedimentación en la Patagonia extrandina. En: R. Caminos, (ed.), Geología Argentina. Servicio Geológico Minero Argentino, Anales, 29: 557-612.

Malumián, N., Hromic, T. y Ñanez, C. 2013. El Paleógeno de la cuenca de Magallanes: bioestratigrafía y discontinuidades. Anales Instituto Patagonia 41(1): 29-52.

Mange, M.A. y Maurer, H.F. 1992. Heavy Minerals in Colour. Chapman y Hall, 147 p., Londres.

Mange, M.A. y Morton, A. C. 2007. Chapter 13 Geochemistry of Heavy Minerals Capítulo. Developments in Sedimentology 58: 345-391.

Manso Galván, F. 2001. Exploración de placeres costeros de minerales pesados y su génesis en la costa de Galicia. Tesis Doctoral, Universidad de Vigo, 265 p., Vigo.

Martín Ramos, J.D. (2007). Using XPowder: A software package for powder X-ray diffraction analysis. http://www.xpowder.com.

Masselink, G. y Short, A.D. 1993. The Effect of Tide Range on Beach Morphodynamics and Morphology: A Conceptual Beach Model. Journal of Coastal Research 9: 785-800.

Mazzarini, F. y D'Orazio, M. 2003. Spatial distribution of cones and satellite-detected lineaments in the Pali Aike Volcanic Field (southernmost Patagonia): insights into the tectonic setting of a Neogene rift system. Journal of Volcanology and Geothermal Research 125: 291-305.

Meglioli, A., 1992. Glacial geology and chronology of Southernmost Patagonia and Tierra del Fuego.Tesis Doctoral, Lehig University (inédita), 216p., Bethlehem, EEUU. 
Meinhold, G., 2010. Rutile and its applications in earth sciences. Earth-Science Reviews 102: 1-28.

Méres, Š. 2008. Garnets-important information resource about source area and parental rocks of the siliciclastic sedimentary rocks. In Cambelove DNI 2008: 37-43

Methol, E. y Sister, R. 1949. Informe sobre los aluviones auríferos del Depto. de San Sebastián entre Río Gamma y Cabo Espíritu Santo, Tierra del Fuego. Informe (inédito), Dirección General de Industria Minera, 42 p., Buenos Aires.

Middleton, G.V. 1970. Experimental studies related to problems of flysch sedimentation. En: J. Lajoie (ed.), Flysch Sedimentology in North America. Geologic Association of Canada, Special Paper N07: 253-272.

Miller, C., Barton, M., Hanson, R. y Fleming, T. 1994. An Early Cretaceous volcanic arcmarginal basin transition zone, Peninsula Hardy, southernmost Chile. Journal of Volcanology and Geothermal Research 63: 33-58.

Mills, S., Hatert, F., Nickel, E.H. y Ferraris, G. 2009. The standardisation of mineral group hierarchies: application to recent nomenclature proposals. European Journal of Mineralogy 21: 1073-1080.

Molina , J.F., Scarrow, J. H., Montero, P. G. y Bea, F. 2009. High-Ti amphibole as a petrogenetic indicator of magma chemistry: evidence for mildly alkalic-hybrid melts during evolution of Variscan basic-ultrabasic magmatism of Central Iberia. Contributions to Mineralogy and Petrology 158: 69-98.

Montes, M. 2013. Evolución magmática del Batolito Fueguino, XII Región de Magallanes y de la Antártida Chilena, Chile. Memoria de Título Geólogo, Universidad de Chile, 98 p., Santiago.

Montes, A. 2015. Morfología y evolución de depósitos litorales del Holoceno en la zona del río Chico, Tierra del Fuego. Tesis Doctoral, Universidad Nacional de la Patagonia San Juan Bosco, 306 p., Comodoro Rivadavia.

Morimoto, N.C., Fabries, J., Ferguson A.K., Ginzburg, I.V., Ross, M., Seifert, F.A., Zussman, J., Aoki, K. y Gottardi, G. 1988. Nomenclature of pyroxenes. American Mineralogist 73: 1123-1133.

Morrison, G.W., Rose, W. J. y Jaireth, S. 1990. Geological and geochemical controls on the silver content (fineness) of gold in gold-silver deposits. Ore Geology Reviews 6: 333364.

Morton, A.C. y Hallsworth, C., 2007. Stability of detrital heavy minerals during burial diagéneis. En: M. A. Mange y D. T. Wrigth(eds.), Heavy Minerals in use. ELSEVIER: 215-246, Amsterdam.

Mouzo, F. 2005a. Batimetría y morfología submarina al noreste de la Tierra del Fuego. XVI Congreso Geológico Argentino, Actas 3: 771-778, La Plata.

Mouzo, F. 2005b. Estructura somera y cubierta sedimentaria Plio-Plesitoceno en la plataforma continenta al noreste de la Tierra del Fuego. XVI Congreso Geológico Argentino, Actas 3: 779-786, La Plata.

Mouzo, F. 2005c. Límites de las glaciaciones plio-pleistocenas en la plataforma continental al noreste de la Tierra del Fuego. XVI Congreso Geológico Argentino, Actas 3: 787794, La Plata. 
Mpodozis, C., Mella, P. y Padva, D. 2011. Estratigrafía y megasecuencias sedimentarias en la Cuenca Austral-Magallanes, Argentina y Chile. VIII Congreso de Exploración y Desarrollo de Hidrocarburos: 97-137, Mar del Plata.

Mücke, A. y Bhadra Chaudhuri, J.N. 1991. The continuous alteration of ilmenite through pseudorutile to leucoxene. Ore Geology Reviews 6: 25-44.

Mukasa, S.B. y Daziel, I.W.D. 1996. Southernmost Andes and South Georgia Island, North Scotia Ridge: Zircon U-Pb and muscovite 40Ar/39Ar age constraints on tectonic evolution of Southwestern Gondwanaland. Journal of South American Earth Sciences 9: 349-365.

Natland, M., González, E., Cañón, A. y Ernst, M. 1974. A system of stages for correlation of Magallanes Basin sediments. Geological Society of America Memoirs 139: 126.

Nelson, E., Bruce, B., Elthon, D., Kammer, D. y Weaver, S. 1988. Regional lithologic variations in the Patagonian batholith. Journal of South American Earth Sciences 1(3): $239-247$.

Nelson, E.P. 1982. Post-tectonic uplift of the Cordillera Darwin orogenic core complex: evidence from fission track geochronology and closing temperature-time relationships. Journal of Geological Society of London 139: 755-761.

Nelson, E.P., Dalziel, I.W.D. y Milnes, A. G. 1980. Structural geology of the Cordillera Darwin-collision style orogenesis in the Southernmost Andes. Eclogae Geologicae Helvetiae 73: 727-751.

Nisbet, E. y Pearce, J. 1977. Clinopyroxene composition in mafic lavas from different tectonic settings. Contributions to Mineralogy and Petrology 63(2): 149-160.

Nordenskjöld, O. 1905. Die krystallinischen Gesteine der Magellansländer. Svenska expeditionen till Magellansländerna 1(6): 175-240, Estocolmo.

Olivero, E.B., Acevedo, R.D. y Martinioni, D. 1997. Geología del Mesozoico de bahía Ensenada, Tierra del Fuego. Revista de la Asociación Geológica Argentina 52(2): 169-179, Buenos Aires.

Olivero, E.B. y Malumián, N. 2008. Mesozoic-Cenozoic stratigraphy of the Fuegian Andes, Argentina. Geologica Acta 6(1): 5-18.

Olivero, E.B., Malumián, N. y Martinioni, D. 2006. Mapa geológico de la Isla Grande de Tierra del Fuego e Isla de los Estados. Escala 1:500.000. Servicio Geológico Minero Argentino (SEGEMAR), Buenos Aires.

Olivero, E.B. y Martinioni, D. 1996. Sedimentología de las Formaciones Lemaire y Yahgán (Jurásico-Cretácico) en Tierra del Fuego. $13^{\circ}$ Congreso Geológico Argentino y $3^{\circ}$ Congreso de Exploración de Hidrocarburos, Actas 2: 45-59.

Olivero, E.B. y Martinioni, D. 2001. A review of the geology of the Argentinian Fuegian Andes. Journal of South American Earth Sciences 14: 175-188.

Olivero, E.B., Martinioni, D., Malumián, N. y Palamarczuk, S. 1999. Bosquejo geológico de la Isla Grande de Tierra del Fuego, Argentina. XIV Congreso Geológico Argentino, Salta.

Parfenoff, A., Pomerol, C. y Tourenq, J. 1970. Les minéraux en grains Méthodes d'études et détermination. Masson et Cie, Paris, $578 \mathrm{p}$. 
Parker, G., Paterlini, C. y Violante, R. 1997. El Fondo Marino. En: E. Boschi (ed.), El Mar Argentino y sus recursos pesqueros. Secretaría de Agricultura, Ganadería, Pesca y Alimentación: 65-87, Mar del Plata.

Parker, G., Violante, R. y Paterlini, M., 1996. Fisiografía de la Plataforma Continental. En: V. Ramos y M. Turic (eds.), Geología y Recursos Naturales de la Plataforma Continental Argentina. XIII Congreso Geológico Argentino y III Congreso de Exploración de Hidrocarburos, Actas: 1-16, Buenos Aires.

Paterlini, C.M., Armas Pfirter, F., Abraham, D., Allegrino, J.B., Ancarola, M., Areco, A. y Berbeglia, Y. 2017. El Margen Continental Argentino: entre los $35^{\circ}$ y $55^{\circ}$ de latitud sur en el contexto del artículo 76 de la convención de las Naciones Unidas sobre el derecho del mar. COPLA, 453p., Buenos Arires.

Penrose, R., 1908. The gold regions of the Strait of Magellan and Tierra del Fuego. The Journal of Geology 16(8): 683-697.

Pérez Mateos, J. 1965. Análisis mineralógico de arenas. Método de estudio. C.S.I.C., Patronato Alonso de Herrera. 266p., Madrid.

Petersen, C. 1949. Informe sobre los trabajos de relevamiento geológico efectuados en Tierra del Fuego entre 1945 y 1948. Informe (inédito), Buenos Aires.

Petersen, C. y Methol, E. 1948. Nota preliminar sobre rasgos geológicos generales de la porción septentrional de Tierra del Fuego. Revista de la Asociación Geológica Argentina 3: 279-292, Buenos Aires.

Piccoli, P.M. y Candela, P.A. 2002. Apatite in Igneous Systems. Reviews in Mineralogy and Geochemistry 48(1): 255-292.

Ponce, J., Rabassa, J., Coronato, A. y Borromei, A. 2011. Palaeogeographical evolution of the Atlantic coast of Pampa and Patagonia from the last glacial maximum to the Middle Holocene. Biological Journal of the Linnean Society 103: 363-379.

Powers, M. 1953. A new roundness scale for sedimentary particles. Journal of Sedimentary Petrology 23(2): 117-119.

Puig, A., Hervé, M. y Suárez, M. 1984. Milonitas en el Batolito Patagónico y en su roca de caja al sur de tierra del Fuego. Coloquio sobre megafallas 34: 121-124.

Quartino, B.J., Acevedo, R.D. y Scalabrini Ortiz, J. 1989. Rocas eruptivas volcanógenas entre Monte Olivia y Paso Garibaldi, Isla Grande de Tierra del Fuego. Asociación Geológica Argentina 44: 328-335., Buenos Aires.

Rabassa, J. 2008. Late Cenozoic Glaciations in Patagonia and Tierra del Fuego. En: J. Rabassa (ed.) Late Cenozoic of Patagonia and Tierra del Fuego. Elsevier, Developments in Quaternary Sciences: 151-204, Amsterdam.

Rabassa, J. y Coronato, A. 2007. Glaciaciones del Cenozoico tardío en los Andes Patagónicos-Fueguinos. En: C. Godoy Martínez (ed.), Patagonia Total, Antártida e Islas Malvinas. Barcel Baires Ediciones: 644-663.

Rabassa, J., Coronato, A. y Martínez, O. 2011. Late Cenozoic glaciations in Patagonia and Tierra del Fuego: an updated review. Biological Journal of the Linnean Society 103: 316-335.

Rabassa, J.,Coronato, A., Roig, C., Martínez, O. y Serrat, D. 2003. Un bosque sumergido en Bahía Sloggett, Tierra del Fuego, Argentina: Evidencias de comportamiento 
tectónico diferencial en el Holoceno tardío. Procesos geomorfológicos y evolución costera. Reunión Geomorfológica Litoral 2: 333-354, Santiago de Compostela.

Ramos, V.A., Haller, M.J. y Butrón, F. 1986. Geología y Evolución tectónica de las Islas Barnevelt: Atlántico Sur. Revista de la Asociación Geológica Argentina 15(3-4): 137154. Buenos Aires.

Ramos, V. 1996. Evolución Tectónica de la plataforma continental. En: Turic, V. A. y Ramos, M. A. (eds.), Geología y Recursos Naturales de la Plataforma Continental Argentina. XIII ${ }^{\circ}$ Congreso Geológico Argentino y $\mathrm{III}^{\circ}$ Congreso de Exploración de Hidrocarburos, Actas: 385-404, Buenos Aires.

Reyneke, L. y Wallmach, T. 2007. Characterization of FeTi-oxide species occuring in the Ranobe heavy mineral deposit, Madagascar. The 6th International Heavy Minerals Conference 'Back to Basics', The Southern African Institute of Mining and Metallurgy: 151-158.

Rittenhouse, G. 1943. Transportation and deposition of heavy minerals. Bulletin of the Geological Society of América 54: 1725-1780.

Rodríguez, M.P., Lincoñir, L.P. y Encinas, A. 2012. Cenozoic erosion in the Andean forearc in Central Chile $\left(33^{\circ}-34^{\circ} \mathrm{S}\right)$ : Sediment provenance inferred by heavy mineral studies. The Geological Society of America Special Paper 487: 141-162.

Rosenblum, S. y Brownfield, I. K. 2000. Magnetic susceptibilities of minerals. U.S. Department of the Interior, U.S. Geological Survey, Open-File Report 99-529.

Rubey, W. W. 1933. The size distribution of heavy minerals within a water-laid sandstone. Journal of Sedimentary Research 3(1): 3-29.

Schalamuk, I., de Barrio, R., Zubia, M., Genini, A. y Valvano, J. 2002. Mineralizaciones auro-argentíferas del Macizo del Deseado y su encuadre metalogénico. En: Haller, M.J. (Ed.), Geología y Recursos Naturales de Santa Cruz, XV Congreso Geológico Argentino, Relatorio: 679-713, Buenos Aires.

Schalamuk, I., Zubia, M., Genini, A. y Fernández, R. 1997. Jurassic epithermal Au-Ag deposits of Patagonia, Argentina. Ore Geology Reviews 12:173-186.

Schumacher, J.C 1997. Appendix 2. The estimation of the proportion of ferric iron in the electron-microprobe analysis of amphiboles. The Canadian Mineralogist 35: 238246.

Seibold, E. y Berger, W. 1982. The Sea Floor: an introduction to marine geology. 3rd ed., Springer, New York.

Señoret, M. 1893. La región aurífera en la Tierra del Fuego. Anales de la Sociedad Científica Argentina 35: 243-252.

Servicio de Hidrografía Naval, 2019. Predicciones corrientes de marea. Bahía San Sebastián.http://www.hidro.gov.ar/oceanografia/tmareas/form_tcorrientes.asp

Servicio Meteorológico Nacional, 2018. Estadísticas climáticas normales período 19812010, Río Grande B.A.

Sister, R. 1948. Contribución al conocimiento de los aluviones del Departamento San Sebastián, Tierra del Fuego. Tesis Doctoral, Museo de La Plata, Universidad Nacional de La Plata (inédita), 69 p., La Plata. 
Skewes, M.A. 1978. Geología, petrología, quimismo y origen de los volcanes del área de Pali-Aike, Magallanes, Chile. ANS. INST. PAT 9: 96-106.

Skewes, M.A. y Stern, C.R. 1979. Petrology and geochemistry of alkali basalts and ultramafic inclusions from the Pali-Aike volcanic field in southern Chile and the origin of the Patagonian plateau lavas. J. Volcanol. Geotherm. Res. 6: 3-25.

Slingerland, R. 1984. Role of hidraulic sorting in the origin of fluvial placers. Journal of sedimentary petrology 54:137-150.

Slingerland, R. y Smith, N.D. 1986. Occurence and formation of water-laid placers. Annual Review of Earth and Planetary Sciences 14: 113-47.

Smirnov, V.I. 1982. Geología de Yacimientos Minerales. Mir Moscú, 654 p.

Stappenbeck, R. 1918. Los yacimientos de minerales y rocas de aplicación en la República Argentina. Boletín 19 (serie B), Dirección General de Minas, Geología e Hidrología, Buenos Aires.

Steidtmann, J.R. 1982. Size-density sorting of sand-size spheres during deposition from bedload transport and implications concerning hydraulics equivalence. Sedimentology 22: 877-883.

Stern, C. y Elthon, D. 1979. Vertical variations in the effect of hydrothermal metamorphism in Chilean ophiolites: their implications for ocean floor metamorphism. Tectonophysics 55: 179-213.

Stern, C.R., Futa, K., Saul, S. y Skewes, M.A. 1986. Nature and evolution of the subcontinental mantle lithosphere below southern South America and implications for Andean magma genesis. Revista Geológica de Chile 27: 41-53.

Stern, C.R., Saul, S., Skewes, M.A. y Futa, K. 1989. Garnet peridotite xenoliths from PaliAike basalts of southernmost South America. Kimberlites and related rocks. Geological Society of Australia Special Publication 14: 735-744.

Stern, C. y Wit, M. 2003. Rocas Verdes ophiolites, southernmost South America: remnants of progressive stages of development of oceanic-type crust in a continental margin back-arc basin. En: Dilek, Y. y Robinson, P. T. (eds.), Ophiolites in Earth History. Geological Society, Special Publications: 665-683, London.

Suárez, M. 1976. The geology of the southern Andes. Tesis de doctorado, Universidad de Birmingham, 222 p., Birmingham.

Suárez, M. 1977a. Aspectos geoquímicos del Complejo Ofiolítico Tortuga en la Cordillera Patagónica del sur de Chile. Revista Geológica de Chile 4: 3-14.

Suárez, M. 1977b. Notas geoquímicas preliminares del Batolito Patagónico al sur de Tierra del Fuego, Chile. Revista Geológica de Chile 4: 15-33.

Suárez, M. 1979. A late Mesozoic island arc in the southern Andes, Chile. Geological Magazine 116(3): 181-190.

Suárez, M., Hervé, M. y Puig, A. 1985. Hoja Isla Hoste e islas adyacentes, XII Región. Servicio Nacional de Geología y Minería, 133 p., Chile.

Suárez, M., Naranjo, J. A. y Puig, A. 1990. Mesozoic "S-like" granites of the central and southern Andes; A review. Geological Society of America 241: 27-32. 
Suárez, M. y Pettigrew, T. 1976. An upper Mesozoic island-arc back-arc system in the southern Andes and South Georgia. Geological Magazine 113: 305-400.

Suh, C.E. y Lehmann, B. 2003. Morphology and electron-probe microanalysis of residual gold-grains at Dimako, Southeast Cameroon. Neues Jahrbuch für Mineralogie 6: 255-275.

Svetlitskaya, T., Nevolko, P., Kolpakov, V. y Tolstykh, N. 2018. Native gold from the Inagli Pt-Au placer deposit (the Aldan Shield, Russia): geochemical characteristics and implications for possible bedrock sources. Mineralium Deposita 53: 323-338.

Torres Carbonell, P.J., Malumián, N. y Olivero, E.B. 2009. El Paleoceno-Mioceno de Península Mitre: antefosa y depocentro de techo de cuña de la cuenca Austral, Tierra del Fuego, Argentina. Andean Geology 36(2): 197-235.

Townley, B.K.,Hérail, G., Maksaev, V., Palacios, C., de Parseval, P., Sepulveda, F., Orellana, R., Rivas, P. y Ulloa, C. 2003. Gold grain morphology and composition as an exploration tool: application to gold exploration in covered areas. Geochemistry: Exploration, Environment, Analysis 3: 29-38.

Udden, J. 1914. Mechanical Composition of Clastic Sediments. Geological Society of America Bulletin 25: 655-744.

Vairo, C. y Gatti, F. 2000. Oro en Tierra del Fuego: La carrera del oro en el extremo del mundo. Publicaciones Zaigier y Urruty Pubns, 194 p., Ushuaia.

Viladevall, M. 2005. La prospección de placeres de oro y otros minerales densos. Publicacions i Edicions de la Universitat de Barcelona, Barcelona. http://www.publicacions.ub.es/refs/pub_dig/pros_aluv.pdf

Viladevall, M., Camacho, G., Morturia, J. y Ponce, J. 1991. Los placeres auriferos de la llanura aluvial del río Segre y delta del río Ebro: NE de la Peninsula Ibérica. Symposium International sur les Gisements Alluviaux d'Or: 187-215, La Paz.

Vilas, F., Arche, A., González Bonorino, G., Isla, F. y Herrero, H. 1987. Sedimentación intermareal en la bahía de San Sebastián, Tierra del Fuego, Argentina. Acta Geológica Hispánica 21-22: 253-260.

Villar, L.M., Acevedo, R.D. y Lagorio, S.L. 2007. The Puente Quemado gabbro, to the west of Ushuaia, Tierra del Fuego, Argentina. International Congress on the Geology and Geophysics of the Southern Hemisphere (GeoSur), Actas 1: 172, Santiago de Chile.

Violante, R.A. 2005. Submerged terraces in the Continental Shelf of Argentina: its significance as paleo sea-levels indicators. 5th. Annual Conference Project IGCP 464, Continental Shelves during the Last Glacial Cycle, Abstracts volume: 97-99, San Petesburgo.

Violante, R.A., Costa, I.P., Cavallotto, J.L., Paterlini, C.M., Marcolini, S. y Bozzano, G. 2014. Rasgos morfosedimentarios, procesos y evolución de la Plataforma Continental Argentina desde el último máximo glacial. Revista de la Asociación Geológica Argentina 71(2): 292-310, Buenos Aires.

Violante, R.A, Cavallotto, J.L., Bozzano, G. y Spoltore, D. 2017a. Sedimentación marina profunda en el margen Continental Argentino: revisión y estado de conocimiento. Latin American Journal of Sedimentology and Basin Analysis 24(1): 7-29. 
Violante, R.A., Laprida, C. y García Chapori, N. 2017b. The Argentina Continental: A Potential Paleoclimatic-Paleoceanographic Archive for the Southern Ocean. Springer.

Vishiti, A., Suh, C.E., Lehmann, B., Egbe, J.A. y Shemang, E.M. 2015. Gold grade variation and particle microchemistry in exploration pits of the Batouri gold district, SE Cameroon. Journal of African Earth Sciences 111: 1-13.

Weibel, R. y Friis, H. 2007. Chapter 10 Alteration of Opaque Heavy Minerals as a Reflection of the Geochemical Conditions in Depositional and Diagenetic Environments. En: Mange, M. A. y Wrigth, D. T. (eds.), Developments in Sedimentology. Elsevier 58: 277-303.

Wentworth, C. 1922. A scale of grade and class terms for clastic sediments. The Journal of Geology 30(5): 377-392.

Whitney, D.L. y Evans, B.W. 2010. Abbreviations for names of rock-forming minerals. American Mineralogist 95:185-187.

Winn, R.D. 1978. Upper Mesozoic flysch of Tierra del Fuego and South Georgia Island. A sedimentologic approach to lithosphere restoration. Geological Society of America Bulletin 89: 553-547.

Zappettini, E.,Villar, L., Segal, S.,Celeda, A., Romano, A. y Acevedo, R.D. 2004. The origin of platinum in Tierra del Fuego: Geological evidence. Bolletino di Geofisica teorica ed applicata. Instituto Nazionale di Oceanografia e di Geofisica Sperimenta 45(2): 129-132. 


\section{Anexo. TABLAS DE ANÁLISIS POR MICROSONDA ELECTRÓNICA.}




\section{Supergrupo del anfíbol}

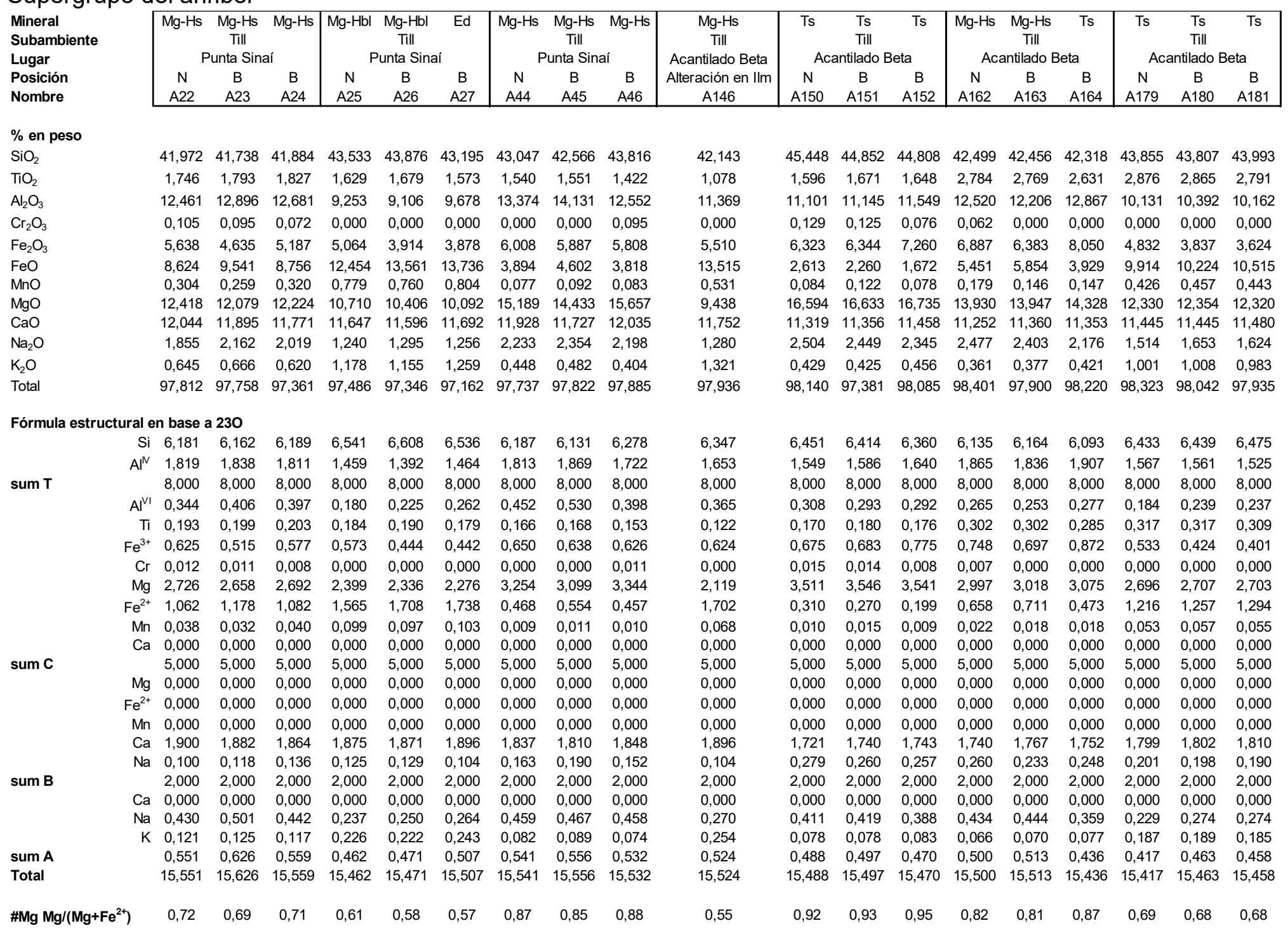

A.1. Análisis con microsonda electrónica efectuados en anfíboles presentes en los sedimentos glacigénicos continentales. La fórmula estructural se calculó en base a 23 y y el contenido de Fe2+ y Fe3+ según la máxima estimación de Fe3+ (Leake et al 1997). 


Mineral
Subambiente
Lugar
Posición
Nombre

$\%$ en peso

$\mathrm{SiO}_{2}$

$\mathrm{TiO}_{2}$

$\mathrm{Al}_{2} \mathrm{O}_{3}$

$\mathrm{Cr}_{2} \mathrm{O}_{3}$

$\mathrm{Fe}_{2} \mathrm{O}_{3}$

$\mathrm{FeO}$

$\mathrm{MnO}$

$\mathrm{MgO}$

$\mathrm{CaO}$

$\mathrm{Na}_{2} \mathrm{O}$

$\mathrm{K}_{2} \mathrm{O}$

Total

\begin{tabular}{|c|c|c|c|c|c|c|c|c|c|c|c|}
\hline \multicolumn{3}{|c|}{$\begin{array}{c}\mathrm{Mg}-\mathrm{Hs} \quad \mathrm{Mg}-\mathrm{Hs} \mathrm{Mg}-\mathrm{Hs} \\
\text { Plataforma } \\
\text { Externa }\end{array}$} & \multicolumn{3}{|c|}{$\begin{array}{c}\text { Mg-Hs } \mathrm{Mg}-\mathrm{Hs} \mathrm{Mg}-\mathrm{Hs} \\
\text { Plataforma } \\
\text { Externa }\end{array}$} & \multicolumn{3}{|c|}{$\begin{array}{c}\mathrm{Mg}-\mathrm{Hbl} \text { Mg-Hbl } \mathrm{Mg}-\mathrm{Hbl} \\
\text { Plataforma } \\
\text { Media }\end{array}$} & \multicolumn{3}{|c|}{$\begin{array}{c}\text { Mg-Hs } \mathrm{Mg}-\mathrm{Hs} \text { Mg-Hs } \\
\text { Plataforma } \\
\text { Media }\end{array}$} \\
\hline$N$ & B & B & $N$ & B & B & $\mathrm{N}$ & B & B & $\mathrm{N}$ & B & B \\
\hline A350 & A351 & A352 & A380 & A381 & A382 & A423 & A424 & A425 & A427 & A428 & A429 \\
\hline
\end{tabular}

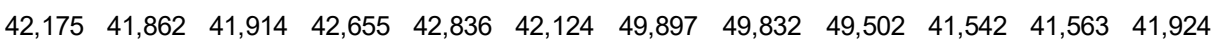

$\begin{array}{llllllllllll}1,620 & 1,636 & 1,751 & 1,187 & 1,369 & 1,087 & 1,248 & 1,272 & 1,350 & 3,955 & 4,007 & 3,967\end{array}$

$\begin{array}{llllllllllll}14,096 & 13,873 & 13,712 & 10,884 & 9,840 & 11,038 & 5,881 & 6,055 & 6,445 & 11,952 & 11,919 & 11,817\end{array}$

$\begin{array}{llllllllllll}0,070 & 0,061 & 0,123 & 0,000 & 0,000 & 0,000 & 0,000 & 0,000 & 0,000 & 0,000 & 0,000 & 0,000\end{array}$

$\begin{array}{lllllllllllll}7,808 & 6,833 & 5,567 & 5,127 & 5,600 & 6,211 & 8,770 & 8,299 & 7,766 & 4,782 & 3,135 & 3,134\end{array}$

$\begin{array}{lllllllllllll}2,042 & 2,741 & 3,685 & 13,409 & 12,383 & 12,901 & 3,459 & 3,952 & 4,558 & 7,371 & 8,750 & 8,831\end{array}$

$\begin{array}{llllllllllll}0,085 & 0,072 & 0,103 & 0,738 & 0,924 & 0,796 & 0,448 & 0,467 & 0,404 & 0,210 & 0,142 & 0,171\end{array}$

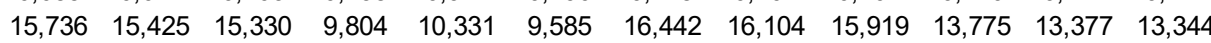

$\begin{array}{llllllllllll}11,954 & 11,849 & 11,978 & 11,850 & 11,647 & 11,623 & 11,276 & 11,108 & 11,273 & 11,611 & 11,638 & 11,464\end{array}$

$\begin{array}{llllllllllll}2,435 & 2,426 & 2,478 & 1,273 & 1,313 & 1,320 & 1,145 & 1,237 & 1,292 & 2,119 & 2,133 & 2,227\end{array}$

$\begin{array}{llllllllllll}0,468 & 0,477 & 0,482 & 1,349 & 1,246 & 1,452 & 0,141 & 0,147 & 0,125 & 1,045 & 1,025 & 1,054\end{array}$

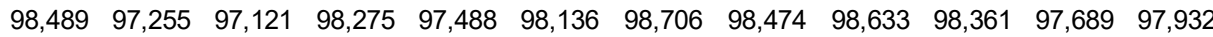

Fórmula estructural en base a 230

\begin{tabular}{|c|c|c|c|c|c|c|c|c|c|c|c|c|c|}
\hline & $\mathrm{Si}$ & 6,013 & 6,048 & 6,075 & 6,397 & 6,459 & 6,340 & 7,039 & 7,051 & 7,007 & 6,063 & 6,115 & 6,150 \\
\hline & $A l^{N}$ & 1,987 & 1,952 & 1,925 & 1,603 & 1,541 & 1,660 & 0,961 & 0,949 & 0,993 & 1,937 & 1,885 & 1,850 \\
\hline \multirow[t]{9}{*}{ sum $T$} & & 8,000 & 8,000 & 8,000 & 8,000 & 8,000 & 8,000 & 8,000 & 8,000 & 8,000 & 8,000 & 8,000 & 8,000 \\
\hline & $A l^{V I}$ & 0,382 & 0,410 & 0,417 & 0,321 & 0,208 & 0,298 & 0,017 & 0,061 & 0,082 & 0,119 & 0,182 & 0,194 \\
\hline & $\mathrm{Ti}$ & 0,174 & 0,178 & 0,191 & 0,134 & 0,155 & 0,123 & 0,132 & 0,135 & 0,144 & 0,434 & 0,443 & 0,438 \\
\hline & $\mathrm{Fe}^{3+}$ & 0,838 & 0,743 & 0,607 & 0,579 & 0,636 & 0,704 & 0,931 & 0,884 & 0,827 & 0,525 & 0,347 & 0,346 \\
\hline & $\mathrm{Cr}$ & 0,008 & 0,007 & 0,014 & 0,000 & 0,000 & 0,000 & 0,000 & 0,000 & 0,000 & 0,000 & 0,000 & 0,000 \\
\hline & $\mathrm{Mg}$ & 3,344 & 3,322 & 3,312 & 2,191 & 2,322 & 2,150 & 3,458 & 3,397 & 3,359 & 2,997 & 2,934 & 2,918 \\
\hline & $\mathrm{Fe}^{2+}$ & 0,243 & 0,331 & 0,447 & 1,682 & 1,562 & 1,624 & 0,408 & 0,468 & 0,540 & 0,900 & 1,077 & 1,084 \\
\hline & $\mathrm{Mn}$ & 0,010 & 0,009 & 0,013 & 0,094 & 0,118 & 0,101 & 0,054 & 0,056 & 0,048 & 0,026 & 0,018 & 0,021 \\
\hline & $\mathrm{Ca}$ & 0,000 & 0,000 & 0,000 & 0,000 & 0,000 & 0,000 & 0,000 & 0,000 & 0,000 & 0,000 & 0,000 & 0,000 \\
\hline \multirow[t]{6}{*}{ sum C } & & 5,000 & 5,000 & 5,000 & 5,000 & 5,000 & 5,000 & 5,000 & 5,000 & 5,000 & 5,000 & 5,000 & 5,000 \\
\hline & $\mathrm{Mg}$ & 0,000 & 0,000 & 0,000 & 0,000 & 0,000 & 0,000 & 0,000 & 0,000 & 0,000 & 0,000 & 0,000 & 0,000 \\
\hline & $\mathrm{Fe}^{2+}$ & 0,000 & 0,000 & 0,000 & 0,000 & 0,000 & 0,000 & 0,000 & 0,000 & 0,000 & 0,000 & 0,000 & 0,000 \\
\hline & $\mathrm{Mn}$ & 0,000 & 0,000 & 0,000 & 0,000 & 0,000 & 0,000 & 0,000 & 0,000 & 0,000 & 0,000 & 0,000 & 0,000 \\
\hline & $\mathrm{Ca}$ & 1,826 & 1,834 & 1,860 & 1,904 & 1,882 & 1,874 & 1,705 & 1,684 & 1,710 & 1,816 & 1,835 & 1,802 \\
\hline & $\mathrm{Na}$ & 0,174 & 0,166 & 0,140 & 0,096 & 0,118 & 0,126 & 0,295 & 0,316 & 0,290 & 0,184 & 0,165 & 0,198 \\
\hline \multirow[t]{4}{*}{ sum $B$} & & 2,000 & 2,000 & 2,000 & 2,000 & 2,000 & 2,000 & 2,000 & 2,000 & 2,000 & 2,000 & 2,000 & 2,000 \\
\hline & $\mathrm{Ca}$ & 0,000 & 0,000 & 0,000 & 0,000 & 0,000 & 0,000 & 0,000 & 0,000 & 0,000 & 0,000 & 0,000 & 0,000 \\
\hline & $\mathrm{Na}$ & 0,499 & 0,514 & 0,557 & 0,274 & 0,266 & 0,260 & 0,018 & 0,023 & 0,064 & 0,415 & 0,443 & 0,435 \\
\hline & K & 0,085 & 0,088 & 0,089 & 0,258 & 0,240 & 0,279 & 0,025 & 0,027 & 0,022 & 0,195 & 0,192 & 0,197 \\
\hline & & 0,585 & 0,602 & 0,646 & 0,532 & 0,505 & 0,538 & 0,043 & 0,050 & 0,087 & 0,610 & 0,635 & 0,633 \\
\hline & & 15,585 & 15,602 & 15,646 & 15,532 & 15,505 & 15,538 & 15,043 & 15,050 & 15,087 & 15,610 & 15,635 & 15,63 \\
\hline
\end{tabular}

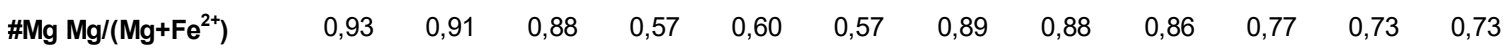

A.2. Análisis con microsonda electrónica efectuados en anfíboles presentes en la cubierta superficial de la Plataforma Continental. 


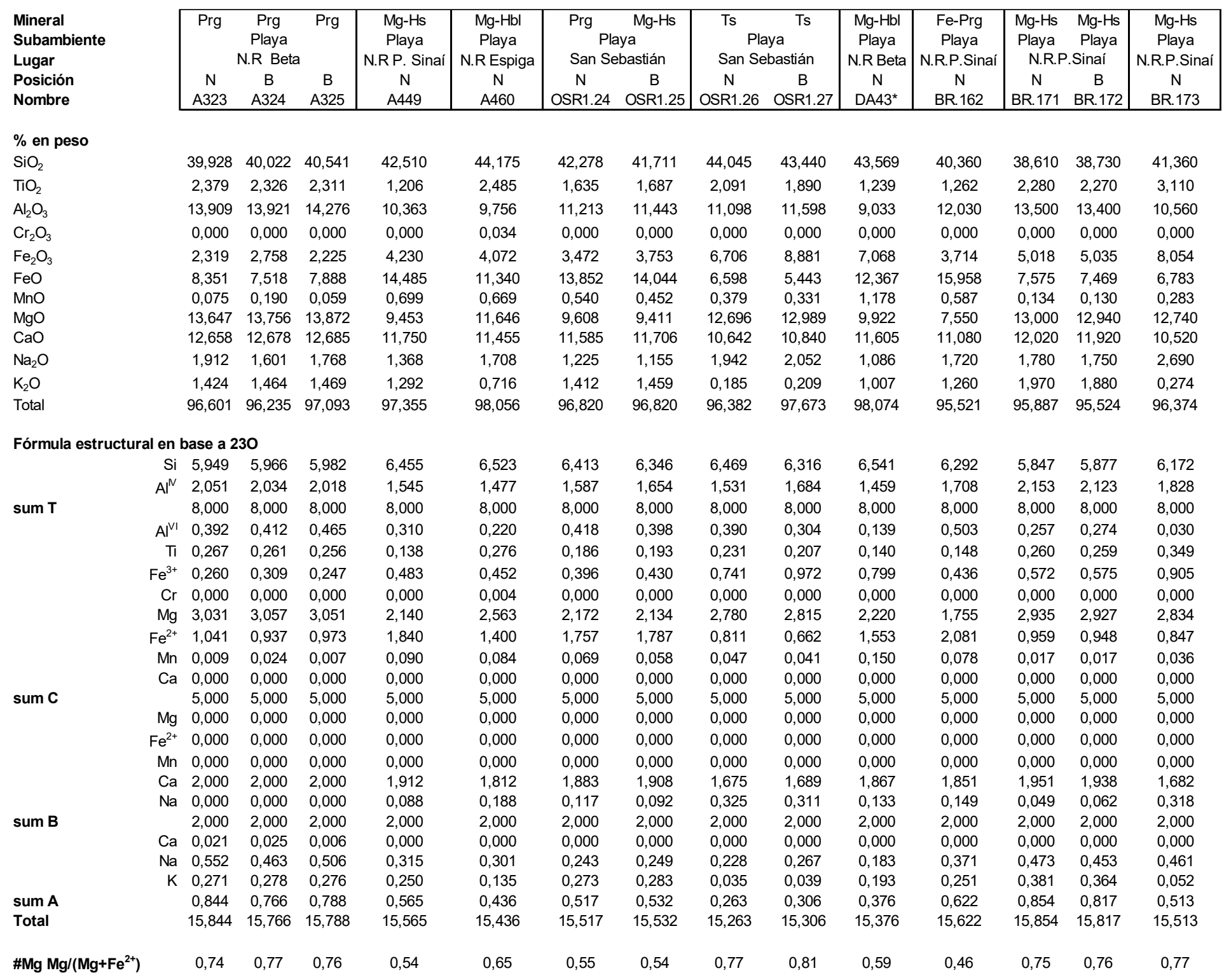

A.3. Análisis con microsonda electrónica efectuados en anfíboles presentes en las arenas de las playas. 


\section{Grupo del piroxeno}

\begin{tabular}{|c|c|c|c|c|c|c|c|c|c|c|c|c|c|c|c|c|c|c|c|c|c|c|}
\hline \multirow{4}{*}{$\begin{array}{l}\text { Mineral } \\
\text { Subambiente } \\
\text { Localización } \\
\text { No Análsiis } \\
\text { Posición } \\
\text { Nombre }\end{array}$} & \multirow{2}{*}{\multicolumn{2}{|c|}{$\begin{array}{l}\text { Aug } \quad \text { Aug } \\
\text { Till } \\
\text { P.Sinaí }\end{array}$}} & \multicolumn{2}{|c|}{$\begin{array}{c}\text { En- }(\mathrm{Fe}) \quad \text { En- }(\mathrm{Fe}) \\
\text { T.ill } \\
\text { P.Sinaí }\end{array}$} & \multicolumn{2}{|c|}{$\begin{array}{cc}\mathrm{Di} & \mathrm{Di} \\
\text { Till } \\
\text { P.Sinai }\end{array}$} & \multirow{2}{*}{\multicolumn{2}{|c|}{$\begin{array}{c}\text { Aug } \\
\text { Till } \\
\text { P.Sinai } \\
\text { Punal }\end{array}$}} & \multicolumn{2}{|c|}{$\begin{array}{c}\text { Aug } \\
\substack{\text { Till } \\
\text { P.Sinaí }} \\
\text { Aug } \\
\end{array}$} & \multicolumn{2}{|c|}{$\begin{array}{c}\text { Aug } \\
\text { Till } \\
\text { P.Sinai }\end{array}$} & \multicolumn{2}{|c|}{$\begin{array}{c}\text { Aug } \\
\substack{\text { Till } \\
\text { P.Sinai }}\end{array}$} & \multicolumn{2}{|c|}{$\begin{array}{c}\text { En- }(\mathrm{Fe}) \quad \text { En- }(\mathrm{Fe}) \\
\text { T.lil } \\
\text { P.Sinaí }\end{array}$} & \multicolumn{2}{|c|}{$\begin{array}{c}\text { En- }(\mathrm{Fe}) \underset{\text { Till }}{E n-(\mathrm{Fe})} \\
\text { P.Sinai }\end{array}$} & \multicolumn{2}{|c|}{$\begin{array}{c}\text { En-(Fe) } \quad \text { En- }(\mathrm{Fe}) \\
\text { Till } \\
\text { P.Sinaí }\end{array}$} & \multicolumn{2}{|c|}{$\begin{array}{c}\text { Aug } \\
\text { Till } \\
\text { P.Sinai } \\
\text { Pug } \\
\end{array}$} \\
\hline & & 2 & 1 & 2 & 2 & 2 & & 2 & 1 & 2 & 1 & 2 & 1 & 2 & 1 & 2 & 1 & 2 & 1 & 2 & & \\
\hline & $\mathrm{N}$ & B & $\mathrm{N}$ & B & $\mathrm{N}$ & B & $\mathrm{N}$ & B & $\mathrm{N}$ & B & B & $\mathrm{N}$ & $\mathrm{N}$ & B & N & B & $\mathrm{N}$ & B & $\mathrm{N}$ & B & $\mathrm{N}$ & B \\
\hline & \begin{tabular}{|l}
$9 A C 1.6$ \\
\end{tabular} & 9AC1.6 & 9AC1.12 & 9AC1.12 & $9 A C 1.1 .4$ & 9AC1.1.4 & 9AC2.5.1 & $9 A C 2.5 .2$ & $9 \mathrm{AC2} 2.7 .1$ & 9AC2.7.2 & 9AC3.4.2 & 9AC3.4.1 & 9AC3.5.1 & 9AС3.5.2 & 9AC3.6.1 & 9AC3.6.2 & 9AC4.13.1 & 9AC4.13.2 & 9AC4.8.1 & 9AC4.8.2 & 9AC4.20.1 & $9 \mathrm{AC} 4.20 .2$ \\
\hline \multicolumn{23}{|l|}{$\%$ en peso } \\
\hline $\mathrm{SiO}_{2}$ & 52,733 & 51,313 & 55,070 & 53,922 & 52,913 & 52,581 & 51,060 & 50,927 & 52,232 & 52,888 & 50,975 & 51,112 & 51,284 & 51,930 & 53,400 & 54,927 & 53,490 & 53,500 & 52,704 & 52,627 & 52,951 & 53,152 \\
\hline $\mathrm{TiO}_{2}$ & 0,468 & 0,585 & 0,245 & 0,343 & 0,299 & 0,362 & 0,671 & 0,630 & 0,403 & 0,388 & 0,669 & 0,674 & 0,668 & 0,713 & 0,246 & 0,243 & 0,264 & 0,302 & 0,301 & 0,280 & 0,245 & 0,256 \\
\hline $\mathrm{A}_{2} \mathrm{O}_{3}$ & 2,510 & 2,481 & 1,286 & 2,363 & 2,399 & 2,527 & 2,567 & 2,555 & 1,778 & 1,603 & 2,859 & 2,950 & 2,655 & 2,647 & 1,406 & 1,208 & 1,373 & 1,944 & 0,817 & 0,749 & 3,213 & 3,125 \\
\hline $\mathrm{Cr}_{2} \mathrm{O}_{3}$ & L.D & 0,066 & L.D & 0,034 & 0,251 & 0,256 & L.D & L.D & L.D & L.D & L.D & L.D & L.D & 0,061 & L.D & L.D & L.D & L.D & L.D & L.D & 0,248 & 0,223 \\
\hline $\mathrm{Fe}_{2} \mathrm{O}_{3}$ & 0,548 & 2,957 & 0,000 & 0,000 & 0,418 & 1,291 & 1,710 & 2,083 & 1,609 & 0,933 & 2,090 & 1,238 & 1,608 & 0,625 & 2,836 & 0,000 & 0,000 & 0,000 & 0,000 & 0,000 & 0,401 & 0,000 \\
\hline $\mathrm{FeO}$ & 8,354 & 6,718 & 15,429 & 15,572 & 4,620 & 3,973 & 8,687 & 8,878 & 7,663 & 8,130 & 7,605 & 8,297 & 8,268 & 8,092 & 12,990 & 14,863 & 18,476 & 17,233 & 23,215 & 23,958 & 4,157 & 4,585 \\
\hline $\begin{array}{l}\mathrm{MnO} \\
\mathrm{MaO}\end{array}$ & $\begin{array}{c}0,266 \\
16449\end{array}$ & $\begin{array}{r}0,269 \\
1524\end{array}$ & $\begin{array}{c}0,394 \\
26658\end{array}$ & $\begin{array}{r}0,364 \\
26001\end{array}$ & $\begin{array}{c}0,134 \\
15110\end{array}$ & $\begin{array}{c}0,140 \\
15233\end{array}$ & $\begin{array}{c}0,371 \\
14,043\end{array}$ & $\begin{array}{c}0,445 \\
13804\end{array}$ & $\begin{array}{r}0,283 \\
114952\end{array}$ & $\begin{array}{c}0,334 \\
15243\end{array}$ & $\begin{array}{c}0,312 \\
14,189\end{array}$ & $\begin{array}{c}0,293 \\
14016\end{array}$ & $\begin{array}{c}0,318 \\
14284\end{array}$ & $\begin{array}{c}0,237 \\
1476\end{array}$ & $\begin{array}{c}0,387 \\
27162\end{array}$ & $\begin{array}{r}0,336 \\
27,288\end{array}$ & $\begin{array}{l}0,628 \\
24058\end{array}$ & $\begin{array}{r}0,473 \\
24686\end{array}$ & $\begin{array}{l}1,221 \\
20444\end{array}$ & $\begin{array}{l}1,298 \\
19602\end{array}$ & $\begin{array}{l}0,173 \\
1696\end{array}$ & $\begin{array}{l}0,118 \\
16915\end{array}$ \\
\hline $\mathrm{CaO}$ & 19,124 & 20,257 & 1,645 & $\begin{array}{c}20,001 \\
1,600\end{array}$ & $\begin{array}{l}153,740 \\
23,441\end{array}$ & $\begin{array}{l}15,23 \\
23,741\end{array}$ & 20,131 & 19,813 & 20,980 & 20,779 & 21,198 & 20,933 & 20,737 & 20,980 & 1,776 & 1,744 & $\begin{array}{c}24,058 \\
1,674\end{array}$ & $\begin{array}{r}24,686 \\
1,639\end{array}$ & $\begin{array}{c}20,444 \\
1,457\end{array}$ & $\begin{array}{c}19,602 \\
1,489\end{array}$ & $\begin{array}{l}16,966 \\
21,367\end{array}$ & $\begin{array}{l}16,915 \\
21,175\end{array}$ \\
\hline $\mathrm{Na}_{2} \mathrm{O}$ & 0,222 & 0,312 & 0,000 & 0,063 & 0,309 & 0,330 & 0,382 & 0,462 & 0,288 & 0,286 & 0,255 & 0,286 & 0,281 & 0,260 & L.D & L.D & L.D & L.D & L.D & L.D & 0,342 & 0,250 \\
\hline $\mathrm{K}_{2} \mathrm{O}$ & L.D & L.D & L.D & L.D & L.D & L.D & L.D & L.D & L.D & L.D & L.D & L.D & L.D & L.D & L.D & L.D & L.D & L.D & L.D & L.D & L.D & L.D \\
\hline $\mathrm{NiO}$ & L.D & L.D & L.D & L.D & L.D & L.D & L.D & L.D & L.D & L.D & L.D & L.D & L.D & L.D & L.D & L.D & L.D & L.D & L.D & L.D & L.D & L.D \\
\hline $\mathrm{ZnO}$ & L.D & L.D & L.D & L.D & L.D & L.D & L.D & L.D & L.D & L.D & L.D & L.D & L.D & L.D & L.D & L.D & L.D & L.D & L.D & L.D & L.D & L.D \\
\hline $\mathrm{V}_{2} \mathrm{O}_{3}$ & L.D & L.D & L.D & L.D & L.D & L.D & L.D & L.D & L.D & L.D & L.D & L.D & L.D & L.D & L.D & L.D & L.D & L.D & L.D & L.D & L.D & L.D \\
\hline $\mathrm{Zr}_{2} \mathrm{O}$ & N.D & N.D & N.D & N.D & N.D & N.D & N.D & N.D & N.D & N.D & N.D & N.D & N.D & N.D & N.D & N.D & N.D & N.D & N.D & N.D & N.D & N.D \\
\hline Total & 100,674 & 100,381 & 100,725 & 100,262 & 100,193 & 100,426 & 99,621 & 99,597 & 100,188 & 100,585 & 100,153 & 99,799 & 100,103 & 100,313 & 100,203 & 100,448 & 99,963 & 99,777 & 100,159 & 100,001 & 100,065 & 99,800 \\
\hline $\mathrm{P}_{2} \mathrm{O}_{5}$ & N.D & N.D & N.D & N.D & N.D & N.D & N.D & N.D & N.D & N.D & N.D & N.D & N.D & N.D & N.D & N.D & N.D & N.D & N.D & N.D & N.D & N.D \\
\hline $\mathrm{Ta}_{2} \mathrm{O}_{5}$ & N.D & N.D & N.D & N.D & N.D & N.D & N.D & N.D & N.D & N.D & N.D & N.D & N.D & N.D & N.D & N.D & N.D & N.D & N.D & N.D & N.D & N.D \\
\hline \multicolumn{23}{|c|}{ Fórmula estructural ( 6 O y 4 Cationes) } \\
\hline $\mathrm{Si}$ & 1,933 & 1,899 & 1,975 & 1,945 & 1,941 & 1,926 & 1,914 & 1,913 & 1,938 & 1,9 & 1,898 & 1,909 & 1,911 & 1,92 & 1,9 & 1,969 & & 1,956 & 1,982 & 1,992 & 1,927 & 1,941 \\
\hline $\mathrm{Ti}$ & & & & & & & & & & & & & & 020 & 0,007 & & & & & 0,008 & 0,007 & 0,007 \\
\hline $\mathrm{Al}$ & 0 & 0,1 & 0,054 & 0,100 & 0,104 & 0,1 & & & $0, \mathrm{C}$ & & & & & 0 & $0, \mathrm{C}$ & 0,0 & & & & 0,033 & 0,138 & 0,135 \\
\hline $\mathrm{Cr}$ & & 0,0 & 0,000 & 0,001 & 0,007 & $0, \mathrm{C}$ & & & $0, \mathrm{C}$ & 0,0 & & & & & 0,0 & & & & & 0,000 & 0,007 & 0,006 \\
\hline $\mathrm{Fe}^{3+}$ & 0,015 & 0,082 & 0,000 & 0,000 & 0,012 & 0,036 & 0,048 & 0,059 & 0,045 & 0,026 & 0,059 & 0,035 & 0,045 & 0,017 & 0,077 & 0,000 & 0,000 & 0,000 & 0,000 & 0,000 & 0,011 & 0,000 \\
\hline $\mathrm{Fe}^{2+}$ & 0,256 & 0,208 & 0,463 & 0,470 & 0,142 & 0,122 & 0,272 & 0,279 & 0,238 & 0,251 & 0,237 & 0,259 & 0,258 & 0,250 & 0,392 & 0,446 & 0,567 & 0,527 & 0,730 & 0,758 & 0,127 & 0,140 \\
\hline $\mathrm{Mn}$ & 0,008 & 0,008 & 0,012 & 0,011 & 0,004 & 0,004 & 0,012 & 0,014 & 0,009 & 0,010 & 0,010 & & & 0,007 & 0,0 & 0,0 & & & & 0,0 & 0,005 & \\
\hline $\mathrm{Mg}$ & 0,89 & & & & & & & & & & & & & & & & & & & & & \\
\hline $\mathrm{Ca}$ & 0,7 & & & 0,0 & & & & & 0, & & & & & & 0 , & & & & & & 0,8 & \\
\hline $\mathrm{Na}$ & & & & & & & & & & & & & & & & & & & & & & 0.018 \\
\hline$k$ & 0,0 & 0,0 & & & & & & & & & & & & & & & & & & & & 0,000 \\
\hline $\mathrm{Ni}$ & & 0,0 & & & & & & & & & & & & & & & & & & & & 00 \\
\hline $\mathrm{Zn}$ & & & & & & & & & & & & & & & & & & & & & & 00 \\
\hline $\mathrm{V}$ & & & & & & & & & & & & & & & & & & & & & & 00 \\
\hline 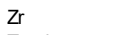 & & & & & & & & & & & & & & & & & & & & & & 00 \\
\hline Total & & & & & & & & & & & & & & & & & & & & & & 4,000 \\
\hline En & 46 & 43,574 & 72 & 72, & & & & & & & & & & & & & & & & & 48 & 48,643 \\
\hline rs & & & & 24 & & & & & & & & & & & & & & & & & & 7,590 \\
\hline Wo & 38,928 & 41, & & 3,186 & 48,681 & 48, & & & & & & & & & 3, & & & 3, & 2, & 3, & 43,933 & 43,767 \\
\hline \#Mg & 0,778 & 0,755 & 0,854 & 0,742 & 0,777 & 0,751 & 0,755 & 0,788 & 0,699 & 0,611 & 0,879 & 0,754 & 0,607 & 0,765 & 0,838 & 0,837 & 0,912 & 0,773 & 0,869 & 0,703 & 0,849 & 0,727 \\
\hline
\end{tabular}

A.4. Análisis con microsonda electrónica efectuados en piroxenos presentes en los sedimentos glacigénicos. La medida del FeO y Fe $2 \mathrm{O}_{3}$ se realizó siguiendo el método de Droop (1987). Abreviaturas: L.D límite de detección, N.D elemento no analizado. 
Tesis Doctoral Luis Santamaría Torres

\begin{tabular}{|c|c|c|c|c|c|c|c|c|c|c|c|c|c|c|c|c|c|c|}
\hline \multirow[t]{2}{*}{$\begin{array}{l}\text { Mineral } \\
\text { Subambiente } \\
\text { Localización } \\
\mathbf{N}^{\circ} \text { Análsiis }\end{array}$} & \multicolumn{2}{|c|}{$\begin{array}{l}\text { Aug } \text { Till }^{\text {Aug }} \\
\text { P.Sinaí }\end{array}$} & \multicolumn{2}{|c|}{$\begin{array}{c}\text { Till } \\
\text { P.Sinaí }\end{array}$} & \multicolumn{2}{|c|}{$\begin{array}{c}\text { Till } \\
\text { P.Sinai }\end{array}$} & \multicolumn{2}{|c|}{$\begin{array}{c}\text { Till } \\
\text { A.C.Beta }\end{array}$} & \multicolumn{2}{|c|}{$\begin{array}{c}\mathrm{Di} \quad \underset{\text { Till }}{ } \mathrm{Di} \\
\text { A.C.Beta }\end{array}$} & \multicolumn{2}{|c|}{$\begin{array}{c}\mathrm{Di}{ }_{\text {Till }} \mathrm{Di} \\
\text { A.C.Beta }\end{array}$} & \multicolumn{2}{|c|}{$\begin{array}{c}\mathrm{Di}{ }_{\text {Till }} \mathrm{Di} \\
\text { A.C.Beta }\end{array}$} & \multicolumn{2}{|c|}{$\begin{array}{l}\text { Till } \\
\text { A.C.Beta }\end{array}$} & \multirow{4}{*}{\begin{tabular}{|c|} 
En-(Fe) \\
Glacifluvial \\
A.C.Tortuga \\
2 \\
$\mathrm{~N}$ \\
7AC2.1
\end{tabular}} & \multirow{4}{*}{$\begin{array}{c}\mathrm{Di} \\
\text { Glacifluvial } \\
\text { A.C.Tortuga } \\
1 \\
\mathrm{~N} \\
7 \mathrm{AC} 2.1 \\
\end{array}$} \\
\hline & 1 & 2 & 1 & 2 & 1 & 2 & 1 & 2 & 1 & 2 & 1 & 2 & 1 & 2 & 1 & 3 & & \\
\hline Posición & $\mathrm{N}$ & B & $\mathrm{N}$ & B & $\mathrm{N}$ & B & $\mathrm{N}$ & B & $\mathrm{N}$ & B & $\mathrm{N}$ & B & $\mathrm{N}$ & B & $\mathrm{N}$ & B & & \\
\hline Nombre & 9AC4.16.1 & 9AC4.16.2 & 9AC5.4.1 & 9AC5.4.2 & 9AC5.2.1 & 9AC5.2.2 & $9 \mathrm{BC} 1.20 .1$ & $9 B C 1.20 .2$ & 9BC1.18.1 & $9 \mathrm{BC} 1.18 .2$ & $9 \mathrm{BC} 1.9 .1$ & $9 B C 1.9 .2$ & $9 B C 2.9 .1$ & $9 \mathrm{BC} 2.9 .2$ & $9 \mathrm{BC} 2.3 .1$ & $9 \mathrm{BC} 2.3 .1$ & & \\
\hline \multicolumn{19}{|l|}{$\%$ en peso } \\
\hline $\mathrm{SiO}_{2}$ & 52,450 & 51,512 & 53,069 & 52,072 & 50,120 & 51,479 & 52,141 & 53,165 & 52,925 & 52,661 & 53,391 & 53,616 & 53,042 & 53,116 & 52,627 & 52,171 & 53,577 & 50,739 \\
\hline $\mathrm{TiO}_{2}$ & 0,607 & 0,711 & 0,231 & 0,336 & 0,935 & 0,506 & 0,453 & 0,356 & 0,380 & 0,328 & 0,119 & 0,130 & 0,330 & 0,324 & 0,379 & 0,548 & 0,313 & 0,556 \\
\hline $\mathrm{Al}_{2} \mathrm{O}_{3}$ & 2,243 & 2,800 & 0,473 & 0,769 & 4,636 & 4,034 & 2,748 & 2,012 & 2,601 & 2,250 & 1,896 & 1,888 & 1,529 & 1,530 & 2,752 & 2,718 & 1,361 & 3,432 \\
\hline $\mathrm{Cr}_{2} \mathrm{O}_{3}$ & 0,068 & L.D & L.D & L.D & L.D & 0,275 & 0,316 & 0,153 & 0,084 & 0,149 & 0,605 & 0,728 & L.D & L.D & 0,438 & 0,038 & L.D & L.D \\
\hline $\mathrm{Fe}_{2} \mathrm{O}_{3}$ & 0,359 & 0,991 & 0,000 & 0,000 & 2,629 & 1,125 & 0,669 & 0,331 & 0,378 & 0,903 & 0,000 & 0,000 & 1,026 & 0,000 & 0,723 & 0,000 & 0,000 & 1,690 \\
\hline $\mathrm{FeO}$ & 8,609 & 8,194 & 23,637 & 23,382 & 7,532 & 5,879 & 5,034 & 4,839 & 5,175 & 4,431 & 2,884 & 2,872 & 7,291 & 7,975 & 4,465 & 7,658 & 18,017 & 4,481 \\
\hline $\mathrm{MnO}$ & 0,308 & 0,244 & 1,026 & 1,015 & 0,267 & 0,203 & 0,144 & 0,164 & 0,145 & 0,111 & 0,098 & 0,041 & 0,790 & 0,745 & 0,072 & 0,219 & 0,866 & 0,169 \\
\hline $\mathrm{MgO}$ & 14,795 & 14,721 & 20,442 & 20,480 & 13,767 & 15,502 & 14,563 & 15,175 & 14,881 & 14,893 & 16,736 & 17,036 & 13,942 & 14,076 & 16,559 & 15,304 & 23,918 & 14,131 \\
\hline $\mathrm{CaO}$ & 20,503 & 20,667 & 1,741 & 1,947 & 20,232 & 20,757 & 23,845 & 24,256 & 24,036 & 24,356 & 23,461 & 23,332 & 22,358 & 22,359 & 21,920 & 21,189 & 1,501 & 23,654 \\
\hline $\mathrm{Na}_{2} \mathrm{O}$ & 0,367 & 0,232 & L.D & L.D & 0,541 & 0,366 & 0,230 & 0,164 & 0,212 & 0,209 & 0,187 & 0,205 & 0,460 & 0,382 & 0,244 & 0,250 & L.D & 0,221 \\
\hline $\mathrm{K}_{2} \mathrm{O}$ & L.D & L.D & L.D & L.D & L.D & L.D & L.D & L.D & L.D & L.D & L.D & L.D & L.D & L.D & L.D & L.D & L.D & L.D \\
\hline $\begin{array}{l}\mathrm{NiO} \\
\mathrm{ZnO}\end{array}$ & $\begin{array}{l}\text { L.D } \\
\text { L.D }\end{array}$ & $\begin{array}{l}\text { L.D } \\
\text { L.D }\end{array}$ & $\begin{array}{l}\text { L.D } \\
\text { L.D }\end{array}$ & $\begin{array}{l}\text { L.D } \\
\text { L.D }\end{array}$ & $\begin{array}{l}\text { L.D } \\
\text { L.D }\end{array}$ & $\begin{array}{l}\text { L.D } \\
\text { L.D }\end{array}$ & $\begin{array}{l}\text { L.D } \\
\text { L.D }\end{array}$ & $\begin{array}{l}\text { L.D } \\
\text { L.D }\end{array}$ & $\begin{array}{l}\text { L.D } \\
\text { L.D }\end{array}$ & $\begin{array}{l}\text { L.D } \\
\text { L.D }\end{array}$ & $\begin{array}{l}\text { L.D } \\
\text { L.D }\end{array}$ & $\begin{array}{l}0,090 \\
\text { L.D }\end{array}$ & $\begin{array}{l}\text { L.D } \\
\text { L.D }\end{array}$ & $\begin{array}{l}\text { L.D } \\
\text { L.D }\end{array}$ & $\begin{array}{l}\text { L.D } \\
\text { L.D }\end{array}$ & $\begin{array}{l}\text { L.D } \\
\text { L.D }\end{array}$ & $\begin{array}{l}\text { L.D } \\
\text { L.D }\end{array}$ & $\begin{array}{l}\text { L.D } \\
\text { L.D }\end{array}$ \\
\hline $\mathrm{V}_{2} \mathrm{O}_{3}$ & L.D & L.D & L.D & L.D & L.D & L.D & L.D & L.D & L.D & L.D & 0,334 & 0,374 & L.D & L.D & L.D & L.D & L.D & L.D \\
\hline $\mathrm{Zr}_{2} \mathrm{O}$ & N.D & N.D & N.D & N.D & N.D & N.D & N.D & N.D & N.D & N.D & N.D & N.D & N.D & N.D & N.D & N.D & L.D & L.D \\
\hline Total & 100,309 & 100,071 & 100,619 & 100,000 & 100,659 & 100,126 & 100,141 & 100,614 & 100,819 & 100,291 & 99,710 & 100,312 & 100,768 & 100,508 & 100,178 & 100,094 & 99,554 & 99,074 \\
\hline $\mathrm{P}_{2} \mathrm{O}_{5}$ & N.D & N.D & N.D & N.D & N.D & N.D & N.D & N.D & N.D & N.D & N.D & N.D & N.D & N.D & N.D & N.D & L.D & 0,238 \\
\hline $\mathrm{Ta}_{2} \mathrm{O}_{5}$ & N.D & N.D & N.D & N.D & N.D & N.D & N.D & N.D & N.D & N.D & N.D & N.D & N.D & N.D & N.D & N.D & 0,326 & 0,394 \\
\hline \multicolumn{19}{|c|}{ Fórmula estructural ( 6 O y 4 Cationes) } \\
\hline $\mathrm{Si}$ & 1,941 & 1,913 & 1,988 & 1,960 & 1,856 & 1,892 & 1,922 & 1,946 & 1,935 & 1,935 & 1,952 & 1,948 & 1,960 & 1,965 & 1,923 & 1,925 & 1,976 & 1,893 \\
\hline $\mathrm{Ti}$ & 0,017 & 0,020 & 0,007 & 0,010 & 0,026 & 0,014 & 0,013 & 0,010 & 0,010 & 0,009 & 0,003 & 0,004 & 0,009 & 0,009 & 0,010 & 0,015 & 0,009 & 0,016 \\
\hline Al & 0,098 & 0,123 & 0,021 & 0,034 & 0,202 & 0,175 & 0,119 & 0,087 & 0,112 & 0,097 & 0,082 & 0,081 & 0,067 & 0,067 & 0,119 & 0,118 & 0,059 & 0,151 \\
\hline $\mathrm{Cr}$ & 0,002 & 0,000 & 0,000 & 0,000 & 0,000 & 0,008 & 0,009 & 0,004 & 0,002 & 0,004 & 0,017 & 0,021 & 0,000 & 0,000 & 0,013 & 0,001 & 0,000 & 0,000 \\
\hline $\mathrm{Fe}^{3+}$ & 0,010 & 0,028 & 0,000 & 0,000 & 0,073 & 0,031 & 0,019 & 0,009 & 0,010 & 0,025 & 0,000 & 0,000 & 0,029 & 0,000 & 0,020 & 0,000 & 0,000 & 0,047 \\
\hline $\mathrm{Fe}^{2+}$ & 0,266 & 0,255 & 0,741 & 0,736 & 0,233 & 0,181 & 0,155 & 0,148 & 0,158 & 0,136 & 0,088 & 0,087 & 0,225 & 0,247 & 0,136 & 0,236 & 0,556 & 0,140 \\
\hline $\mathrm{Mn}$ & 0,010 & 0,008 & 0,033 & 0,032 & 0,008 & 0,006 & 0,005 & 0,005 & 0,004 & 0,003 & 0,003 & 0,001 & 0,025 & 0,023 & 0,002 & 0,007 & 0,027 & 0,005 \\
\hline $\mathrm{Mg}$ & 0,816 & 0,815 & 1,142 & 1,149 & 0,760 & 0,849 & 0,800 & 0,828 & 0,811 & 0,816 & 0,912 & 0,923 & 0,768 & 0,776 & 0,902 & 0,842 & 1,315 & 0,786 \\
\hline $\mathrm{Ca}$ & 0,813 & 0,822 & 0,070 & 0,079 & 0,803 & 0,817 & 0,942 & 0,951 & 0,941 & 0,959 & 0,919 & 0,908 & 0,885 & 0,886 & 0,858 & 0,838 & 0,059 & 0,946 \\
\hline $\mathrm{Na}$ & 0,026 & 0,017 & 0,000 & 0,000 & 0,039 & 0,026 & 0,016 & 0,012 & 0,015 & 0,015 & 0,013 & 0,014 & 0,033 & 0,027 & 0,017 & 0,018 & 0,000 & 0,016 \\
\hline K & 0,000 & 0,000 & 0,000 & 0,000 & 0,000 & 0,000 & 0,000 & 0,000 & 0,000 & 0,000 & 0,000 & 0,000 & 0,000 & 0,000 & 0,000 & 0,000 & 0,000 & 0,000 \\
\hline $\mathrm{Ni}$ & 0,000 & 0,000 & 0,000 & 0,000 & 0,000 & 0,000 & 0,000 & 0,000 & 0,000 & 0,000 & 0,000 & 0,003 & 0,000 & 0,000 & 0,000 & 0,000 & 0,000 & 0,000 \\
\hline $\mathrm{Zn}$ & 0,000 & 0,000 & 0,000 & 0,000 & 0,000 & 0,000 & 0,000 & 0,000 & 0,000 & 0,000 & 0,000 & 0,000 & 0,000 & 0,000 & 0,000 & 0,000 & 0,000 & 0,000 \\
\hline V & 0,000 & 0,000 & 0,000 & 0,000 & 0,000 & 0,000 & 0,000 & 0,000 & 0,000 & 0,000 & 0,010 & 0,011 & 0,000 & 0,000 & 0,000 & 0,000 & 0,000 & 0,000 \\
\hline Zr & 0,000 & 0,000 & 0,000 & 0,000 & 0,000 & 0,000 & 0,000 & 0,000 & 0,000 & 0,000 & 0,000 & 0,000 & 0,000 & 0,000 & 0,000 & 0,000 & 0,000 & 0,000 \\
\hline Total & 4,000 & 4,000 & 4,000 & 4,000 & 4,000 & 4,000 & 4,000 & 4,000 & 4,000 & 4,000 & 4,000 & 4,000 & 4,000 & 4,000 & 4,000 & 4,000 & 4,000 & 4,000 \\
\hline En & 42,615 & 42,289 & 57,524 & 57,572 & 40,477 & 45,062 & 41,675 & 42,646 & 42,117 & 42,068 & 47,448 & 48,070 & 39,757 & 40,168 & 47,010 & 43,784 & 67,193 & 40,847 \\
\hline Fs & 14,938 & 15,040 & 38,955 & 38,494 & 16,770 & 11,573 & 9,282 & 8,360 & 8,989 & 8,486 & 4,744 & 4,612 & 14,421 & 13,974 & 8,264 & 12,647 & 29,776 & 10,011 \\
\hline Wo & 42,447 & 42,671 & 3,521 & 3,934 & 42,753 & 43,365 & 49,044 & 48,993 & 48,894 & 49,446 & 47,808 & 47,318 & 45,822 & 45,858 & 44,726 & 43,569 & 3,031 & 49,142 \\
\hline$\#$ Mg & 0,532 & 0,708 & 0,648 & 0,656 & 0,876 & 0,658 & 0,573 & 0,900 & 0,751 & 0,821 & 0,724 & 0,735 & 0,848 & 0,847 & 0,619 & 0,811 & 0,831 & 0,745 \\
\hline
\end{tabular}

A.5. Continuación. 


\begin{tabular}{|c|c|c|c|c|c|c|c|c|c|c|c|c|c|c|c|c|c|c|c|c|c|c|c|c|}
\hline \multirow{3}{*}{$\begin{array}{l}\text { Mineral } \\
\text { Subambiente } \\
\text { Localización } \\
\text { No Análsiis } \\
\text { Posición } \\
\text { Nombre }\end{array}$} & \multicolumn{2}{|c|}{ 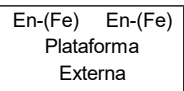 } & \multicolumn{2}{|c|}{$\begin{array}{l}\text { En-(Fe) En- }(\mathrm{Fe}) \\
\text { Plataforma } \\
\text { Externa }\end{array}$} & \multicolumn{2}{|c|}{$\begin{array}{l}\text { En- }(\mathrm{Fe}) \quad \text { En- }(\mathrm{Fe}) \\
\text { Platatorma } \\
\text { Externa }\end{array}$} & \multicolumn{2}{|c|}{$\begin{array}{l}\text { En- }(\mathrm{Fe}) \quad \text { En- }(\mathrm{Fe}) \\
\text { Platatorma } \\
\text { Externa }\end{array}$} & \multicolumn{2}{|c|}{$\begin{array}{l}\text { En- }(\mathrm{Fe}) \quad \text { En- }(\mathrm{Fe}) \\
\text { Platatorma } \\
\text { Externa }\end{array}$} & \multicolumn{2}{|c|}{$\begin{array}{l}\mathrm{Di} \quad \mathrm{Di} \\
\text { Plataforma } \\
\text { Externa }\end{array}$} & \multicolumn{2}{|c|}{$\begin{array}{c}\text { En-(Fe) } \quad \text { En-(Fe) } \\
\text { Plataforma } \\
\text { Externa }\end{array}$} & \multicolumn{2}{|c|}{$\begin{array}{l}\text { Pgt } \quad \text { En-(Fe) } \\
\text { Plataforma } \\
\text { Externa }\end{array}$} & \multicolumn{2}{|c|}{$\begin{array}{l}\mathrm{Di} \quad \mathrm{Di} \\
\text { Plataforma } \\
\text { Media }\end{array}$} & \multicolumn{2}{|c|}{$\begin{array}{c}\text { En- }(\mathrm{Fe}) \\
\text { Plan- }(\mathrm{Fe}) \\
\text { Plataforma } \\
\text { Media }\end{array}$} & \multirow{3}{*}{\begin{tabular}{|c|} 
Aug \\
Plataforma \\
Media \\
1 \\
$\mathrm{~N}$ \\
5BC5.10.1
\end{tabular}} & \multirow{3}{*}{$\begin{array}{c}\text { En-(Fe) } \\
\text { Plataforma } \\
\text { Interna } \\
2 \\
\mathrm{~N} \\
\text { GAC3.1 } \\
\end{array}$} & \multicolumn{2}{|c|}{ 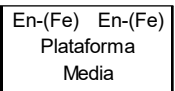 } \\
\hline & 1 & 2 & 1 & 2 & 1 & 2 & & 2 & 1 & 2 & & & & & & & & & 1 & & & & & \\
\hline & $\begin{array}{c}N \\
5 A C 111\end{array}$ & $\begin{array}{r}B \\
5 A C 1\end{array}$ & $\stackrel{N}{N}$ & B & $\begin{array}{c}N \\
5 A C 271\end{array}$ & B & $\begin{array}{c}B \\
B C 293\end{array}$ & $\begin{array}{r}\mathrm{N} \\
5 \mathrm{AC} 2 \mathrm{C}\end{array}$ & $\begin{array}{c}\mathrm{N} \\
\mathrm{AC2} 281\end{array}$ & $\begin{array}{c}\mathrm{B} \\
5 \mathrm{AC} 28\end{array}$ & $\mathrm{~N}$ & B & $\begin{array}{l}\mathrm{N} \\
\mathrm{C} 38\end{array}$ & B & $\mathrm{N}$ & $\begin{array}{c}\text { B } \\
C 31\end{array}$ & $\begin{array}{l}\mathrm{N} \\
\mathrm{C} 561\end{array}$ & B & $\begin{array}{l}\mathrm{N} \\
\mathrm{C} 54.1\end{array}$ & B & & & B & $\begin{array}{l}N \\
\text { C11 }\end{array}$ \\
\hline \\
\hline $\mathrm{SiO}_{2}$ & 53,647 & 53,326 & 51,823 & 51,136 & 54,097 & 53,567 & 53,454 & 53,082 & 54,183 & 53,252 & 48,814 & 48,265 & 53,557 & 53,838 & 52,497 & 52,288 & 53,232 & 51,148 & 53,252 & 54,006 & 51,266 & 53,689 & 54,551 & 53,786 \\
\hline $\mathrm{TiO}_{2}$ & 0,187 & 0,192 & 0,133 & 0,200 & 0,285 & 0,248 & 0,118 & 0,121 & 0,086 & 0,130 & 0,838 & 0,819 & 0,133 & 0,119 & 0,425 & 0,386 & 0,272 & 0,511 & 0,289 & 0,239 & 0,752 & 0,234 & 0,150 & 0,221 \\
\hline $\mathrm{A}_{2} \mathrm{O}_{3}$ & 0,974 & 1,379 & 0,522 & 0,767 & 0,866 & 1,281 & 0,624 & 0,600 & 0,326 & 0,715 & 6,158 & 5,850 & 0,840 & 0,596 & 3,033 & 2,946 & 2,009 & 2,944 & 2,434 & 2,142 & 2,511 & 1,030 & 0,689 & 1,298 \\
\hline $\mathrm{Cr}_{2} \mathrm{O}_{3}$ & L.D & L.D & L.D & L.D & L.D & 0,064 & L.D & L.D & L.D & L.D & 0,105 & L.D & L.D & L.D & L.D & L.D & 0,291 & 0,499 & 0,072 & 0,099 & L.D & L.D & L.D & L.D \\
\hline $\mathrm{Fe}_{2} \mathrm{O}_{3}$ & 0,689 & 0,962 & 0,130 & 0,607 & 0,000 & 1,639 & 0,000 & 0,000 & 0,000 & 0,769 & 3,759 & 3,977 & 0,000 & 0,199 & 0,000 & 0,000 & 0,906 & 2,833 & 0,807 & 0,000 & 3,428 & 0,000 & 0,000 & 0,000 \\
\hline $\mathrm{FeO}$ & $\begin{array}{l}16,934 \\
\end{array}$ & 17,727 & 27,455 & 27,081 & 18,002 & 14,891 & 21,787 & 21,823 & 21,661 & 20,607 & 3,518 & 3,227 & 21,381 & 20,807 & 21,968 & 22,291 & 3,212 & 3,228 & 15,270 & 14,920 & 5,996 & 17,022 & 17,055 & $\begin{array}{l}16,398 \\
0907\end{array}$ \\
\hline $\begin{array}{l}\mathrm{MnO} \\
\mathrm{MgO}\end{array}$ & $\begin{array}{r}0,359 \\
25,328\end{array}$ & $\begin{array}{r}0,459 \\
24,662\end{array}$ & $\begin{array}{l}1,637 \\
17,540\end{array}$ & $\begin{array}{r}1,631 \\
17,246\end{array}$ & $\begin{array}{c}0,540 \\
24,462\end{array}$ & $\begin{array}{l}0,422 \\
26,235\end{array}$ & $\begin{array}{c}0,767 \\
22,213\end{array}$ & $\begin{array}{c}0,845 \\
22,554\end{array}$ & $\begin{array}{c}0,873 \\
23,201\end{array}$ & $\begin{array}{c}0,666 \\
23,161\end{array}$ & $\begin{array}{c}0,151 \\
13,923\end{array}$ & $\begin{array}{c}0,156 \\
13,738\end{array}$ & $\begin{array}{c}0,726 \\
23,046\end{array}$ & $\begin{array}{c}0,835 \\
23,505\end{array}$ & $\begin{array}{c}0,713 \\
16,530\end{array}$ & $\begin{array}{l}840 \\
6,603\end{array}$ & $\begin{array}{c}0,088 \\
16,167\end{array}$ & $\begin{array}{c}0,186 \\
15,575\end{array}$ & $\begin{array}{r}0,328 \\
25,776\end{array}$ & $\begin{array}{c}0,316 \\
26,604\end{array}$ & $\begin{array}{c}0,298 \\
15,451\end{array}$ & $\begin{array}{c}0,538 \\
25,079\end{array}$ & $\begin{array}{l}1,092 \\
24,875\end{array}$ & $\begin{array}{c}0,907 \\
25,482\end{array}$ \\
\hline $\mathrm{CaO}$ & $\begin{array}{l}2,0000 \\
1,460\end{array}$ & $\begin{array}{l}44,002 \\
1,392\end{array}$ & 1,333 & $\begin{array}{l}1,446 \\
1,446\end{array}$ & $\begin{array}{r}24,402 \\
1,582\end{array}$ & 1,709 & 0,935 & 0,981 & 0,642 & 0,956 & 23,165 & 22,887 & 0,701 & 0,727 & 2,182 & 075 & 24,044 & 22,897 & 1,517 & 1,382 & 20,835 & 1,576 & 1,262 & 1,303 \\
\hline $\mathrm{Na}_{2} \mathrm{O}$ & L.D & L.D & L.D & L.D & L.D & L.D & L.D & L.D & L.D & L.D & 0,206 & 0,270 & L.D & L.D & 0,540 & 0,468 & 0,210 & 0,238 & 0,096 & L.D & 0,311 & L.D & L.D & L.D \\
\hline $\mathrm{K}_{2} \mathrm{O}$ & L.D & L.D & L.D & L.D & L.D & L.D & L.D & L.D & L.D & L.D & L.D & L.D & L.D & L.D & L.D & L.D & L.D & L.D & L.D & L.D & L.D & L.D & L.D & L.D \\
\hline o & L.D & L.D & L.D & L.D & L.D & L.D & L.D & R & L.D & O & L.D & L.D & D & L.D & L.D & L.D & D & L.D & D & त & & & L.D & L.D \\
\hline $\mathrm{ZnO}$ & L.D & L.D & L.D & L.V & L.D & L.V & L.D & & L.D & & L.D & L.D & L.E & L. & L.D & L.L & 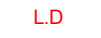 & L.D & 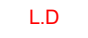 & L.D & & & D & D \\
\hline $\mathrm{V}_{2} \mathrm{O}_{3}$ & L.D & L.D & L.D & L.D & L.D & L.D & L.D & L.D & L.D & L.D & L.D & L.D & L.D & L.D & L.D & L.D & L.D & L.D & L.D & L.D & L.D & L.D & L.D & L.D \\
\hline $\mathrm{Zr}_{2} \mathrm{O}$ & N.D & N.D & N.D & N.D & N.D & N.D & N.D & N.D & N.D & N.D & N.D & N.D & N.D & N.D & N.D & N.D & N.D & N.D & N.D & N.D & N.D & L.D & L.D & L.D \\
\hline Total & 99,579 & 100,098 & 100,574 & 100,114 & 99,834 & 100,056 & 99,898 & 100,005 & 100,972 & 100,257 & 100,636 & 99,189 & 100,384 & 100,626 & 97,887 & 97,897 & 100,432 & 100,057 & 99,840 & 99,708 & 100,849 & 99,169 & 99,674 & 99,396 \\
\hline $\mathrm{P}_{2} \mathrm{O}_{5}$ & N.D & N.D & N.D & N.D & N.D & N.D & N.D & N.D & N.D & N.D & N.D & N.D & N.D & N.D & N.D & N.D & N.D & N.D & N.D & N.D & N.D & L.D & L.D & L.D \\
\hline $\mathrm{Ta}_{2} \mathrm{O}_{5}$ & N.D & N.D & N.D & N.D & N.D & N.D & N.D & N.D & N.D & N.D & N.D & N.D & N.D & N.D & N.D & N.D & N.D & N.D & N.D & N.D & N.D & 0,340 & 0,418 & 0,430 \\
\hline \multicolumn{25}{|c|}{ Fórmula estructural ( 6 O y 4 Cationes) } \\
\hline $\mathrm{Si}$ & & & & & & & & & & & & & & & & & & & & & & & & \\
\hline & & & & & & & & & & & & & & & & & & & & & & & & \\
\hline & & & & & & & & & & & & & & & & & & & & & & & & \\
\hline & & & & & & & & & & & & & & & & & & & & & & & & \\
\hline $\mathrm{Fe}^{3+}$ & & & & & & & & & & & & & & & & & & 0,0 & & & & & 0,000 & 0,000 \\
\hline & & & & & & & & & & & & & & & & & & 0,0 & & & & & 0,523 & 0,502 \\
\hline & & & & & & & & & & & & & & & & & & & & & & & & \\
\hline & & & & & & & & & & & & & & & & & & & & & & & & \\
\hline & & & & & & & & & & & & & & & & & & & & & & & & \\
\hline & & & & & & & & & & & & & & & & & & & & & & & & \\
\hline & & & & & & & & & & & & & & & & & & & & & & & & \\
\hline & & & & & & & & & & & & & & & & & & & & & & & & \\
\hline & & & & & & & & & & & & & & & & & & & & & & & & \\
\hline & & & & & & & & & & & & & & & & & & & & & & & & \\
\hline & & & & & & & & & & & & & & & & & & & & & & & & \\
\hline & & & & & & & & & & & & & & & & & & & & & & & & \\
\hline $\mathrm{E}$ & & & & & & & & & & & & & & & & & & & & & & & & \\
\hline $\mathrm{F}$ & & & & & & & & & & & & & & & & & & & & & & & 28,323 & 26,885 \\
\hline Wo & & & & & & & & & & & 48,219 & 48,2 & & & & 4,8 & 48,328 & 46,516 & 3,026 & 2,7 & 41,959 & 3,1 & 2,522 & 2,593 \\
\hline \#Mg & 0,517 & 0,676 & 0,759 & 0,786 & 0,864 & 0,732 & 0,687 & 0,843 & 0,937 & 0,702 & 0,861 & 0,689 & 0,762 & 0,541 & 0,805 & 0,780 & 0,634 & 0,895 & 0,821 & 0,855 & 0,831 & 0,853 & 0,853 & 0,817 \\
\hline
\end{tabular}

A.6. Análisis con microsonda electrónica efectuados en piroxenos presentes en los sedimentos de la cubierta superficial de la Plataforma Continental. 


\begin{tabular}{|c|c|c|c|c|c|c|c|c|c|c|c|c|c|c|c|c|c|c|c|c|c|}
\hline \multirow{4}{*}{$\begin{array}{l}\text { Mineral } \\
\text { Subambiente } \\
\text { Localización } \\
\mathrm{N}^{\circ} \text { Análsiis } \\
\text { Posición } \\
\text { Nombre }\end{array}$} & \multirow{4}{*}{\begin{tabular}{|c|} 
Aug \\
Playa \\
*P Sinai \\
1 \\
$\mathrm{~N}$ \\
$1 \mathrm{BC} 1.5 .1$ \\
\end{tabular}} & \multirow{4}{*}{\begin{tabular}{|c|} 
Aug \\
Playa \\
*P Sinai \\
1 \\
$N$ \\
1BC1.1.1. \\
\end{tabular}} & \multirow{4}{*}{\begin{tabular}{|c|} 
En- $(\mathrm{Fe})$ \\
Playa \\
${ }^{*} \mathrm{P}$ Sinai \\
1 \\
$\mathrm{~N}$ \\
$\mathrm{~N}$ \\
$1 \mathrm{BC} 3.11 .1$ \\
\end{tabular}} & \multirow{4}{*}{\begin{tabular}{|c|} 
Aug \\
Playa \\
*La Espiga \\
1 \\
$N$ \\
1AC3.1.1. \\
\end{tabular}} & \multirow{4}{*}{\begin{tabular}{|c|} 
Di \\
Playa \\
*La Espiga \\
1 \\
$\mathrm{~N}$ \\
1AC5.6.1 \\
\end{tabular}} & \multirow{4}{*}{\begin{tabular}{|c|} 
En-(Fe) \\
Playa \\
*La Espiga \\
1 \\
$\mathrm{~N}$ \\
1AC5.2.1 \\
\end{tabular}} & \multirow{4}{*}{\begin{tabular}{|c|} 
En-(Fe) \\
Playa \\
*La Espiga \\
1 \\
$\mathrm{~N}$ \\
1AC5.1.1 \\
\end{tabular}} & \multicolumn{2}{|c|}{$\begin{array}{c}\text { En- }(\mathrm{Fe}) \quad \text { En- }(\mathrm{Fe}) \\
\text { Playa } \\
{ }^{*} \text { EI Páramo }\end{array}$} & \multicolumn{2}{|c|}{$\begin{array}{c}\text { En- }(\mathrm{Fe}) \quad \text { En- }(\mathrm{Fe}) \\
\text { Playa } \\
{ }^{*} \text { El Páramo }\end{array}$} & \multicolumn{2}{|c|}{$\begin{array}{l}\text { Aug Pug } \\
\text { Playa } \\
{ }^{*} \text { El Páramo }\end{array}$} & \multicolumn{2}{|c|}{$\begin{array}{l}\mathrm{Di} \quad \mathrm{Di} \\
\quad \text { Playa } \\
{ }^{* E} \text { El Páramo }\end{array}$} & \multicolumn{2}{|c|}{$\begin{array}{c}\text { En- }(\mathrm{Fe}) \quad \text { En- }(\mathrm{Fe}) \\
\text { Playa } \\
{ }^{*} \text { El Páramo }\end{array}$} & \multicolumn{2}{|c|}{$\begin{array}{c}\text { En- }(\mathrm{Fe}) \quad \text { En- }(\mathrm{Fe}) \\
{ }^{2} \text { Playa } \\
{ }^{*} \text { El Páramo }\end{array}$} & \multicolumn{2}{|c|}{$\begin{array}{l}\mathrm{Di} \quad \mathrm{Di} \\
\quad \text { Playa } \\
{ }^{*} \text { El Páramo }\end{array}$} \\
\hline & & & & & & & & 1 & 2 & & 2 & 1 & 2 & & & & 2 & & 2 & & 2 \\
\hline & & & & & & & & B & $\mathrm{N}$ & B & $\mathrm{N}$ & $\mathrm{N}$ & B & B & $\mathrm{N}$ & B & $\mathrm{N}$ & $\mathrm{N}$ & B & $\mathrm{N}$ & B \\
\hline & & & & & & & & CPC3.01 & CPC 3.25 & CPC11.05 & CPC11.06 & CPC11.09 & CPC11.08 & CPC1.11 & $\mathrm{CPC1} 112$ & CPC6.14 & CPC6.15 & CPC6.18 & CPC6.17 & CPC4.20 & $\mathrm{CPC} 4.21$ \\
\hline \multicolumn{22}{|l|}{$\%$ en peso } \\
\hline $\mathrm{SiO}_{2}$ & 53,214 & 51,887 & 53,254 & 52,303 & 49,338 & 54,638 & 52,189 & 51,984 & 53,042 & 53,160 & 53,286 & 50,897 & 50,505 & 51,308 & 51,141 & 53,604 & 53,033 & 52,002 & 52,961 & 49,950 & 50,219 \\
\hline $\mathrm{TiO}_{2}$ & 0,342 & 0,504 & 0,199 & 0,496 & 0,664 & 0,355 & 0,130 & 0,325 & 0,130 & 0,437 & 0,241 & 0,495 & 0,315 & 0,204 & 0,250 & 0,415 & 0,447 & 0,303 & 0,218 & 0,498 & 0,554 \\
\hline $\mathrm{Al}_{2} \mathrm{O}_{3}$ & 2,028 & 2,199 & 0,373 & 2,222 & 4,166 & 1,212 & 0,370 & 1,699 & 1,219 & 1,692 & 1,179 & 2,190 & 2,207 & 1,722 & 1,717 & 0,859 & 0,824 & 1,242 & 1,432 & 3,561 & 3,847 \\
\hline $\mathrm{Cr}_{2} \mathrm{O}_{3}$ & 0,336 & 0,086 & L.D & 0,079 & L.D & 0,175 & L.D & 0,038 & L.D & 0,039 & 0,039 & L.D & L.D & 0,081 & 0,051 & 0,116 & 0,029 & L.D & L.D & 0,050 & L.D \\
\hline $\mathrm{Fe}_{2} \mathrm{O}_{3}$ & 0,227 & 2,494 & 0,000 & 2,030 & 2,611 & 0,000 & 0,000 & 1,897 & 0,000 & 1,378 & 2,151 & 2,758 & 3,799 & 4,176 & 4,112 & 2,261 & 1,127 & 2,307 & 1,730 & 3,120 & 4,655 \\
\hline $\mathrm{FeO}$ & 5,352 & 5,276 & 22,757 & 6,648 & 4,755 & 15,697 & 28,153 & 18,260 & 20,109 & 14,937 & 14,612 & 7,235 & 6,481 & 3,550 & 3,952 & 15,205 & 16,269 & 18,839 & 18,240 & 4,672 & 4,204 \\
\hline $\mathrm{MnO}$ & 0,180 & 0,210 & 1,389 & 0,241 & 0,207 & 0,379 & 1,603 & 1,010 & 1,174 & 0,353 & 0,402 & 0,425 & 0,353 & 0,312 & 0,316 & 0,488 & 0,596 & 0,620 & 0,569 & 0,243 & 0,316 \\
\hline $\mathrm{MgO}$ & 16,758 & 16,388 & 20,735 & 16,007 & 13,153 & 25,777 & 16,907 & 23,835 & 23,513 & 25,759 & 25,772 & 14,929 & 14,751 & 14,383 & 14,077 & 25,962 & 24,939 & 23,181 & 23,973 & 14,106 & 14,446 \\
\hline $\mathrm{CaO}$ & 21,504 & 20,844 & 1,506 & 20,637 & 23,291 & 1,972 & 1,271 & 0,532 & 0,547 & 2,042 & 2,084 & 20,162 & 20,238 & 23,531 & 23,625 & 1,809 & 1,918 & 1,113 & 1,346 & 22,380 & 22,377 \\
\hline $\mathrm{Na}_{2} \mathrm{O}$ & 0,211 & 0,235 & L.D & 0,242 & 0,290 & L.D & L.D & L.D & 0,044 & 0,023 & 0,057 & 0,258 & 0,337 & 0,397 & 0,369 & 0,021 & L.D & 0,045 & 0,054 & 0,296 & 0,342 \\
\hline $\mathrm{K}_{2} \mathrm{O}$ & L.D & L.D & L.D & L.D & L.D & L.D & L.D & L.D & L.D & 0,008 & 0,013 & L.D & 0,010 & L.D & 0,012 & 0,025 & 0,010 & L.D & L.D & 0,022 & L.D \\
\hline $\mathrm{NiO}$ & L.D & L.D & L.D & L.D & L.D & L.D & L.D & L.D & 0,046 & L.D & L.D & L.D & 0,022 & 0,043 & L.D & L.D & L.D & 0,032 & L.D & L.D & 0,019 \\
\hline $\mathrm{ZnO}$ & L.D & L.D & L.D & L.D & L.D & L.D & L.D & N.D & N.D & N.D & N.D & N.D & N.D & N.D & N.D & N.D & N.D & N.D & N.D & N.D & N.D \\
\hline $\mathrm{V}_{2} \mathrm{O}_{3}$ & L.D & L.D & L.D & L.D & L.D & L.D & L.D & N.D & N.D & N.D & N.D & N.D & N.D & N.D & N.D & N.D & N.D & N.D & N.D & N.D & N.D \\
\hline $\mathrm{Zr}_{2} \mathrm{O}$ & N.D & N.D & N.D & N.D & N.D & N.D & N.D & N.D & N.D & N.D & N.D & N.D & N.D & N.D & N.D & N.D & N.D & N.D & N.D & N.D & N.D \\
\hline Total & 100,153 & 100,123 & 100,212 & 100,905 & 98,475 & 100,205 & 100,622 & 99,580 & 99,822 & 99,828 & 99,834 & 99,349 & 99,016 & 99,707 & 99,619 & 100,765 & 99,191 & 99,684 & 100,522 & 98,897 & 100,978 \\
\hline $\mathrm{P}_{2} \mathrm{O}_{5}$ & N.D & N.D & N.D & N.D & N.D & N.D & N.D & N.D & N.D & N.D & N.D & N.D & N.D & N.D & N.D & N.D & N.D & N.D & N.D & N.D & N.D \\
\hline $\mathrm{Ta}_{2} \mathrm{O}_{5}$ & N.D & N.D & N.D & N.D & N.D & N.D & N.D & N.D & N.D & N.D & N.D & N.D & N.D & N.D & N.D & N.D & N.D & N.D & N.D & N.D & N.D \\
\hline Fórmula estru & $\mathrm{ral}(60 \mathrm{O}$ y 4 & Cationes) & & & & & & & & & & & & & & & & & & & \\
\hline $\mathrm{Si}$ & 1,946 & 1, & 1, & 18 & 1,862 & 1,979 & 004 & 27 & 1,962 & 1,933 & 94 & 1,908 & 1,9 & 1,911 & 1,9 & 1,939 & 1,954 & 1,934 & 1,941 & 1,874 & 1,849 \\
\hline $\mathrm{Ti}$ & & & & & & & & & & & & & & & & & & & & & \\
\hline Al & & & & & & & & & & & & & & & & & & & & & 0,167 \\
\hline $\mathrm{Cr}$ & & & & & & & & & 0,00 & 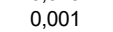 & 0,00 & 0,000 & 0,0 & 0,002 & 0,001 & 0,003 & 0,001 & 0,000 & 0,000 & 0,001 & 0,000 \\
\hline $\mathrm{Fe}^{3+}$ & 0,006 & 0,069 & 0 & 0,056 & 0,074 & 0,000 & 0,000 & 0,053 & 0,000 & 0,038 & 0,059 & 0,078 & 0,108 & 0,117 & 0,116 & 0,062 & 0,031 & 0,065 & 0,048 & 0,088 & 0,129 \\
\hline $\mathrm{Fe}^{2+}$ & 0,164 & 0,163 & 0,714 & 0,204 & 0,150 & 0,475 & 0,904 & 0,566 & 0,622 & 0,454 & 0,445 & 0,227 & 0,204 & 0,111 & 0,123 & 0,460 & 0,501 & 0,586 & 0,559 & 0,147 & 0,129 \\
\hline $\mathrm{Mn}$ & & & & & & & & & & & & & & 0,010 & 0,0 & $0, \mathrm{C}$ & & 0,020 & 0,018 & 0,008 & 0,010 \\
\hline $\mathrm{Mg}$ & & & & & & & & & & & & & & 0,799 & 0,7 & 1,400 & & 1,285 & 1,310 & 0,789 & 0,793 \\
\hline $\mathrm{Ca}$ & & & & & & & & & 0,0 & 0,0 & 0,0 & 0,8 & 0,8 & 0,939 & 0,9 & 0,070 & 0,076 & 0,044 & 0,053 & 0,900 & 0,883 \\
\hline $\mathrm{Na}$ & & & & & & & & & 0,0 & & & & 0,0 & 0,029 & 0,0 & 0,001 & & 0,003 & 0,004 & 0,022 & $\begin{array}{l}0,003 \\
0,024\end{array}$ \\
\hline $\mathrm{K}$ & & & & & & & & & & & & & 0,0 & 0, & 0,0 & & & & & & 0,000 \\
\hline TNI & & & & & & & & & & & & & & & & & & & & & \\
\hline $\mathrm{Zn}$ & & & & & & & & & & & & & & & & & & & & & \\
\hline $\mathrm{v}$ & & & & & & & & & & & & & & & & & & & & & 0,000 \\
\hline$\Delta r$ & & & & & & & & & & & & & 0,0 & 0,000 & 0,0 & 0,000 & 0,000 & 0,000 & 0,000 & 0,000 & 0,000 \\
\hline Total & & 4,000 & & & 4,000 & 4,000 & 4,000 & 4,0 & 4,000 & 4,0 & 4,0 & 4,00 & 4,0 & 4,000 & 4,000 & 4,000 & 4,000 & 4,000 & 4,000 & 4,000 & 4,000 \\
\hline En & $\begin{array}{l}4,07,296 \\
47\end{array}$ & $\begin{array}{r}4,000 \\
45,896\end{array}$ & $\begin{array}{c}4,000 \\
58,619\end{array}$ & $\begin{array}{r}44,7909 \\
44,\end{array}$ & $\begin{array}{r}38,000 \\
38,689\end{array}$ & $\begin{array}{l}4,000 \\
71,176\end{array}$ & $\begin{array}{r}4,000 \\
48,971\end{array}$ & $\begin{array}{l}\text {, } 66,2220 \\
66,22\end{array}$ & $\begin{array}{l}6,05,581 \\
65\end{array}$ & $\begin{array}{l}70,568 \\
70\end{array}$ & $\begin{array}{l}4,000 \\
70,068\end{array}$ & $\begin{array}{r}4,000 \\
42,518\end{array}$ & $\begin{array}{r}42,080 \\
42,\end{array}$ & $\begin{array}{r}40,433 \\
40\end{array}$ & $\begin{array}{r}4,000 \\
39,620\end{array}$ & $\begin{array}{l}\text { i, } 69,770 \\
6\end{array}$ & $\begin{array}{l}4,000 \\
68,606\end{array}$ & $\begin{array}{l}4,000 \\
64,274\end{array}$ & $\begin{array}{l}4,05015 \\
65,915\end{array}$ & $\begin{array}{l}4,000 \\
40,858\end{array}$ & $\begin{array}{c}4,000 \\
40,789\end{array}$ \\
\hline $\mathrm{Fs}$ & 9,085 & 12,1 & 38,3 & & & 24,9 & 48,3 & 32,715 & 33,3 & 25,411 & $25, \varepsilon$ & 16,212 & 16,416 & 12,023 & 12,588 & 26,736 & 27,602 & 33,508 & 31,425 & 12,552 & 13,800 \\
\hline Wo & 43,6 & 41, & & & 49 , & 3 & & 1,062 & & 4,0 & & 41 & 41,499 & 47,544 & 47,792 & 3,494 & 3,792 & 2,218 & 2,660 & 46,590 & 45,410 \\
\hline$\# M g$ & 0,838 & 0,806 & 0,824 & 0,920 & 0,909 & 0,667 & 0,768 & 0,801 & 0,793 & 0,878 & 0,817 & 0,984 & 0,685 & 0,630 & 0,665 & 0,864 & 0,949 & 0,825 & 0,720 & 0,636 & 0,620 \\
\hline
\end{tabular}

A.7. Análisis con microsonda electrónica efectuados en piroxenos presentes en los depósitos de las playas. * Muestra proveniente de un nivel enriquecido. 


\begin{tabular}{|c|c|c|c|c|c|c|c|c|c|c|c|c|c|c|c|c|c|c|c|c|c|c|}
\hline $\begin{array}{l}\text { Mineral } \\
\text { Subambiente } \\
\text { Localización } \\
\text { N}^{\circ} \text { Análsiis } \\
\text { Posición } \\
\text { Nombre }\end{array}$ & \begin{tabular}{|c|c}
$\mathrm{Di}$ \\
$\mathrm{Pl}$ \\
${ }^{*} \mathrm{El} \mathrm{Pc}$ \\
1 \\
$\mathrm{~B}$ \\
$\mathrm{CPC} 4.23$ \\
\end{tabular} & \begin{tabular}{|c|}
\multicolumn{1}{|c|}{$\mathrm{Di}$} \\
aya \\
1 \\
$\mathrm{~N}$ \\
$\mathrm{CPC} 4.24$ \\
\end{tabular} & \begin{tabular}{|c|} 
En-(Fe) \\
Playa \\
*El Páramo \\
1 \\
$\mathrm{~N}$ \\
BR.16 \\
\end{tabular} & \begin{tabular}{|c|} 
Aug \\
Playa \\
*El Páramo \\
1 \\
$\mathrm{~N}$ \\
BR.26 \\
\end{tabular} & \begin{tabular}{|c|} 
En-(Fe) \\
Playa \\
*EI Páramo \\
1 \\
$\mathrm{~N}$ \\
BR.27 \\
\end{tabular} & \begin{tabular}{|c} 
En-(Fe) \\
Playa \\
${ }^{*}$ EI Pá \\
1 \\
$\mathrm{~N}$ \\
BR.38 \\
\end{tabular} & $\begin{array}{c}\text { En-(Fe) } \\
\text { Playa } \\
\text { áramo } \\
1 \\
\text { B } \\
\text { BR.39 } \\
\end{array}$ & \begin{tabular}{|c|} 
En- $(\mathrm{Fe})$ \\
Playa \\
*El Páramo \\
2 \\
$\mathrm{~N}$ \\
BR.41 \\
\end{tabular} & \begin{tabular}{|c|} 
Aug \\
Playa \\
*El Páramo \\
1 \\
$\mathrm{~N}$ \\
$\mathrm{BR} .47$ \\
\end{tabular} & \begin{tabular}{|c} 
En-(Fe) \\
Playa \\
*La E \\
2 \\
$\mathrm{~N}$ \\
BR.117 \\
\end{tabular} & $\begin{array}{c}\text { En-(Fe) } \\
\text { Playa } \\
\text { Espiga } \\
2 \\
\text { B } \\
\text { BR.119 } \\
\end{array}$ & \begin{tabular}{|c|} 
En-(Fe) \\
Playa \\
*La Espiga \\
1 \\
$\mathrm{~N}$ \\
BR.159 \\
\end{tabular} & \begin{tabular}{|c|} 
Aug \\
Playa \\
*P Sinai \\
1 \\
$\mathrm{~N}$ \\
BR.164 \\
\end{tabular} & $\begin{array}{c}\text { Aug } \\
\text { Playa } \\
\text { *P Sinaí } \\
1 \\
\mathrm{~N} \\
\text { BR.165 } \\
\end{array}$ & \begin{tabular}{|c|} 
Aug \\
Playa \\
*P Sinaí \\
1 \\
$\mathrm{~N}$ \\
BR.166 \\
\end{tabular} & \begin{tabular}{|c|} 
Aug \\
Playa \\
*P Sinaí \\
1 \\
$\mathrm{~N}$ \\
BR.167 \\
\end{tabular} & \begin{tabular}{|c|} 
Aug \\
Playa \\
*P Sinai \\
2 \\
$\mathrm{~N}$ \\
BR.169 \\
\end{tabular} & \begin{tabular}{|c|} 
Aug \\
Playa \\
*P Sinai \\
1 \\
$\mathrm{~N}$ \\
BR.182 \\
\end{tabular} & \begin{tabular}{|c|} 
En- $(\mathrm{Fe})$ \\
Playa \\
*P Sinai \\
1 \\
$\mathrm{~N}$ \\
BR.184 \\
\end{tabular} & \begin{tabular}{|c|} 
Aug \\
Playa \\
*P Sinaí \\
1 \\
$\mathrm{~N}$ \\
BR.185 \\
\end{tabular} & \begin{tabular}{|c|} 
Aug \\
Playa \\
*P Sinai \\
1 \\
$\mathrm{~N}$ \\
BR.190 \\
\end{tabular} & \begin{tabular}{|c} 
Aug \\
Playa \\
*P Sinai \\
1 \\
$\mathrm{~N}$ \\
BR.191 \\
\end{tabular} \\
\hline \multicolumn{23}{|l|}{$\%$ en peso } \\
\hline $\mathrm{SiO}_{2}$ & 51,863 & 51,978 & 51,890 & 50,550 & 52,330 & 51,970 & 53,840 & 50,275 & 52,800 & 52,640 & 52,900 & 50,400 & 50,750 & 49,750 & 50,000 & 48,060 & 50,240 & 49,320 & 53,000 & 48,490 & 50,260 & 50,200 \\
\hline $\mathrm{TiO}_{2}$ & 0,228 & 0,433 & 0,144 & 0,528 & 0,124 & 0,348 & 0,193 & 0,225 & 0,530 & 0,251 & 0,240 & 0,183 & 0,620 & 0,734 & 0,585 & 1,001 & 0,570 & 0,787 & 0,148 & 0,558 & 0,457 & 0,602 \\
\hline $\mathrm{A}_{2} \mathrm{O}_{3}$ & 1,904 & 1,960 & 0,936 & 4,630 & 1,071 & 3,140 & 1,436 & 0,539 & 2,590 & 1,523 & 1,346 & 0,384 & 2,530 & 2,580 & 2,330 & 4,110 & 2,405 & 2,880 & 0,864 & 3,750 & 2,710 & 2,340 \\
\hline $\mathrm{Cr}_{2} \mathrm{O}_{3}$ & 0,163 & 0,509 & L.D & 0,404 & L.D & L.D & L.D & L.D & L.D & L.D & 0,029 & L.D & L.D & 0,075 & L.D & L.D & 0,129 & L.D & L.D & 0,089 & L.D & L.D \\
\hline $\mathrm{Fe}_{2} \mathrm{O}_{3}$ & 2,685 & 2,461 & 2,730 & 2,871 & 1,406 & 2,591 & 0,409 & 0,000 & 1,499 & 3,400 & 3,141 & 4,434 & 5,817 & 3,799 & 4,331 & 4,726 & 3,178 & 3,716 & 4,517 & 3,441 & 4,042 & 2,993 \\
\hline $\mathrm{FeO}$ & 1,721 & 1,929 & 17,933 & 4,456 & 18,884 & 14,268 & 15,712 & 25,890 & 7,031 & 13,326 & 13,304 & 20,790 & 3,465 & 5,842 & 4,663 & 5,257 & 4,835 & 4,766 & 11,246 & 5,084 & 6,293 & 5,937 \\
\hline $\begin{array}{l}\mathrm{MnO} \\
\mathrm{MgO}\end{array}$ & $\begin{array}{c}0,115 \\
16,088\end{array}$ & $\begin{array}{c}0,046 \\
16,089\end{array}$ & & & & $\begin{array}{c}0,412 \\
25\end{array}$ & $\begin{array}{c}0,369 \\
260200\end{array}$ & $\begin{array}{r}1,291 \\
17,095\end{array}$ & $\begin{array}{l}77 \\
50\end{array}$ & $\begin{array}{c}0,418 \\
26.455\end{array}$ & $\begin{array}{c}0,427 \\
26,720\end{array}$ & $\begin{array}{r}1,530 \\
20,200\end{array}$ & $\begin{array}{c}0,269 \\
16,550\end{array}$ & $\begin{array}{l}0,254 \\
1521\end{array}$ & $\begin{array}{c}0,216 \\
15550\end{array}$ & $\begin{array}{c}0,181 \\
14540\end{array}$ & $\begin{array}{c}0,210 \\
15,780\end{array}$ & $\begin{array}{c}0,225 \\
15,520\end{array}$ & $\begin{array}{c}0,467 \\
286150\end{array}$ & $\begin{array}{l}0,205 \\
14800\end{array}$ & $\begin{array}{c}0,372 \\
14660\end{array}$ & 0,222 \\
\hline $\begin{array}{l}\mathrm{MgO} \\
\mathrm{CaO}\end{array}$ & $\begin{array}{l}16,088 \\
24,240\end{array}$ & $\begin{array}{l}16,089 \\
24,258\end{array}$ & $\begin{array}{c}23,700 \\
0,829\end{array}$ & $\begin{array}{l}15,500 \\
21,370\end{array}$ & $\begin{array}{c}23,490 \\
0,798\end{array}$ & $\begin{array}{c}25,600 \\
1,590\end{array}$ & $\begin{array}{c}26,020 \\
1,560\end{array}$ & $\begin{array}{c}17,095 \\
1,565\end{array}$ & $\begin{array}{l}16,250 \\
20,100\end{array}$ & $\begin{array}{c}26,455 \\
1,540\end{array}$ & $\begin{array}{c}26,720 \\
1,500\end{array}$ & $\begin{array}{c}20,200 \\
1,238\end{array}$ & $\begin{array}{l}16,550 \\
20,520\end{array}$ & $\begin{array}{l}15,210 \\
19,550\end{array}$ & $\begin{array}{l}15,550 \\
20,250\end{array}$ & $\begin{array}{l}14,540 \\
19,450\end{array}$ & $\begin{array}{l}15,780 \\
20,410\end{array}$ & $\begin{array}{l}15,520 \\
20,140\end{array}$ & $\begin{array}{r}28,150 \\
1,257\end{array}$ & $\begin{array}{l}14,800 \\
19,410\end{array}$ & $\begin{array}{l}14,660 \\
20,080\end{array}$ & $\begin{array}{l}15,560 \\
19,780\end{array}$ \\
\hline $\mathrm{Na}_{2} \mathrm{O}$ & 0,132 & 0,153 & L.D & 0,283 & L.D & 0,022 & 0,019 & 0,062 & 0,331 & 0,063 & 0,039 & 0,107 & 0,364 & 0,344 & 0,345 & 0,442 & 0,272 & 0,263 & L.D & 0,415 & 0,427 & 0,286 \\
\hline $\mathrm{K}_{2} \mathrm{O}$ & L.D & 0,032 & 0,016 & L.D & 0,010 & L.D & L.D & L.D & L.D & L.D & L.D & L.D & L.D & L.D & L.D & L.D & L.D & L.D & L.D & L.D & L.D & L.D \\
\hline $\mathrm{NiO}$ & 0,038 & L.D & 0,026 & L.D & L.D & L.D & L.D & L.D & 0,020 & L.D & L.D & L.D & 0,026 & L.D & 0,043 & 0,041 & L.D & L.D & L.D & 0,021 & L.D & L.D \\
\hline $\mathrm{ZnO}$ & N.D & N.D & N.D & & & $N$ & N.D & & N.D & NR & N.D & & N.D & N.D & N.D & N.D & N.D & & . & N.D & L & 5 \\
\hline $\mathrm{V}_{2} \mathrm{O}_{3}$ & N.D & N.D & L.D & 0,022 & L.D & 0,039 & L.D & L.D & 0,022 & 0,023 & 0,026 & L.D & 0,065 & 0,081 & 0,044 & 0,096 & 0,043 & 0,086 & L.D & 0,045 & 0,035 & 0,069 \\
\hline $\mathrm{Zr}_{2} \mathrm{O}$ & N.D & N.D & L.D & L.D & L.D & L.D & L.D & 0,041 & L.D & L.D & L.D & L.D & L.D & 0,097 & 0,042 & L.D & L.D & L.D & L.D & L.D & L.D & L.D \\
\hline Total & 99,177 & 99,848 & 99,055 & 100,755 & 98,978 & 99,980 & 99,558 & 96,983 & 101,479 & 99,638 & 99,672 & 99,266 & 100,976 & 98,315 & 98,398 & 97,904 & 98,072 & 97,703 & 99,647 & 96,307 & 99,335 & 97,990 \\
\hline $\mathrm{P}_{2} \mathrm{O}_{5}$ & N.D & N.D & N.D & N.D & N.D & N.D & N.D & N.D & N.D & N.D & N.D & N.D & N.D & N.D & N.D & N.D & N.D & N.D & N.D & N.D & N.D & N.D \\
\hline $\mathrm{Ta}_{2} \mathrm{O}_{5}$ & N.D & N.D & N.D & N.D & N.D & N.D & N.D & N.D & N.D & N.D & N.D & N.D & N.D & N.D & N.D & N.D & N.D & N.D & N.D & N.D & N.D & N.D \\
\hline \multicolumn{23}{|c|}{ Fórmula estructural ( 60 y 4 Cationes) } \\
\hline $\mathrm{Si}$ & 1,917 & & & & & & & & & & & & 1,4 & & & & 1802 & , & 1,916 & 1,863 & 35 & 88 \\
\hline $\mathrm{Ti}$ & 0,006 & 0,012 & & & & 0 & 0,00 & & & 007 & 0,0 & & 0,017 & 1 & $0, \mathrm{C}$ & 0,029 & 0 & 0,022 &, 004 & 0,016 & 0,013 & 0,017 \\
\hline Al & & 0,085 & & & & & 0,06 & & & 0,065 & 0,0 & & 0,109 & & & 0,184 & 7 & 0,129 & 0,037 & 0,170 & 0,120 & 0,104 \\
\hline $\mathrm{Cr}$ & & & & & & & & & & & 0,0 & & 0,000 & & & 0,0 & 4 & 0,000 & 0,000 & 0,003 & 0,000 & 0,000 \\
\hline $\mathrm{Fe}^{3+}$ & 0,075 & 0,068 & 0,077 & 0,079 & 0,040 & 0,071 & 0,011 & 0,000 & 0,041 & 0,093 & 0,086 & 0,128 & 0,160 & 0,108 & 0,123 & 0,135 & 0,090 & 0,106 & 0,123 & 0,099 & 0,114 & 0,085 \\
\hline $\mathrm{Fe}^{2+}$ & 0,053 & 0,059 & 0,560 & 0,136 & 0,590 & 0,433 & 0,478 & 0,856 & 0,214 & 0,406 & 0,404 & 0,665 & 0,106 & 0,185 & 0,147 & 0,167 & 0,152 & 0,151 & 0,340 & 0,163 & 0,197 & 0,188 \\
\hline $\mathrm{Mn}$ & & $0, \mathrm{C}$ & & & & & 0,01 & & & & 0,0 & & 0,008 & . & & 0,0 & & 0,007 & 0,014 & 0,007 & 0,012 & 0,007 \\
\hline $\mathrm{Mg}$ & & & & & & & & & & & & & & & & & & & & & & \\
\hline $\mathrm{Ca}$ & & 0 , & & & & & & & & & 0 & & 0 , & & & 0 , & & 0, & 9 & 9 & 0,807 & 0,801 \\
\hline $\mathrm{Na}$ & & & & & & & & & & & & & 0,0 & & & & & 0,019 & 0,000 & & 0,031 & 0,021 \\
\hline K & 0,000 & 0,002 & & & 0,000 & 0,000 & 0,000 & 0,000 & 0,000 & 0,000 & 0,000 & 0,000 & 0,000 & 0,000 & 0,000 & 0,000 & 0,000 & 0,000 & 0,000 & 0,000 & 0,000 & 0,000 \\
\hline $\mathrm{Ni}$ & 0,001 & 0,000 & & & & & 0,000 & 0,000 & & 0,000 & 0,000 & & 0,001 & 0,000 & 0,001 & 0,001 & 0 & 0,000 & 0,000 & 0,001 & 0,000 &, 000 \\
\hline $\mathrm{Zn}$ & & & & & & & & & & & & & & & & & & & & & & \\
\hline v & & & & & & & & & & & & & & & & & & & & & & \\
\hline $\mathrm{Zr}$ & & & & & & & & & & & & & & & & & & & & & 0,000 & 0,000 \\
\hline Total & 4,000 & 4,000 & 4,000 & 4,000 & 4,000 & 4,000 & 4,000 & 4,000 & 4,000 & 4,000 & 4,000 & 4,000 & 4,000 & 4,000 & 4,000 & 4,000 & 4,000 & 4,000 & 4,000 & 4,000 & 4,000 & 4,000 \\
\hline En & 44,818 & 44,848 & 65,438 & 44,428 & 65,507 & 70,545 & 71,540 & 51,065 & 45,682 & 71,518 & 72,042 & 56,330 & 45,553 & 43,960 & 44,392 & 42,819 & 45,234 & 44,761 & 74,261 & 44,237 & 42,037 & 44,785 \\
\hline Fs & 6,647 & 6,553 & 32,9 & & 32,8 & 26,306 & 25,37 & 45,5 & , & 25,490 & 25,051 & w & 13,854 & 15 & 110 & 1604 & 127 & 13,491 & 23,356 & 14,064 & 16,579 & 14,298 \\
\hline Wo & 48,534 & 48,59 & & 44,024 & & 3,149 & 3,083 & 3,360 & 40,612 & 2,992 & 2,907 & 2,482 & 40,594 & 40,610 & 41,549 & 41,167 & 42,050 & 41,748 & 2,383 & 41,698 & 41,384 & 40,918 \\
\hline$\# \mathrm{Mg}$ & 0,729 & 0,788 & 0,687 & 0,619 & 0,805 & 0,732 & 0,802 & 0,733 & 0,856 & 0,786 & 0,812 & 0,772 & 0,908 & 0,669 & 0,854 & 0,839 & 0,708 & 0,718 & 0,886 & 0,673 & 0,819 & 0,792 \\
\hline
\end{tabular}

A.8. Continuación 


\begin{tabular}{|c|c|c|c|c|c|c|c|c|c|c|c|c|c|c|c|c|c|c|c|c|c|c|c|}
\hline $\begin{array}{l}\text { Mineral } \\
\text { Subambiente }\end{array}$ & \begin{tabular}{|c|} 
Di \\
Playa
\end{tabular} & \begin{tabular}{|c|} 
Aug \\
Playa
\end{tabular} & \begin{tabular}{|c|} 
En- $(\mathrm{Fe})$ \\
Playa
\end{tabular} & \begin{tabular}{|l|} 
Aug \\
Playa
\end{tabular} & \begin{tabular}{c|} 
Aug \\
Playa
\end{tabular} & \begin{tabular}{|l|} 
Aug \\
Playa
\end{tabular} & \begin{tabular}{|c|} 
Aug \\
Playa
\end{tabular} & \begin{tabular}{|c|} 
En-(Fe) \\
Playa
\end{tabular} & \begin{tabular}{|c|}
$\mathrm{Di}$ \\
Playa
\end{tabular} & \begin{tabular}{|c|} 
En-(Fe) \\
Playa
\end{tabular} & \begin{tabular}{|c|} 
En-(Fe) \\
Playa
\end{tabular} & $\begin{array}{c}\text { Aug } \\
\text { Playa }\end{array}$ & $\begin{array}{c}\mathrm{Di} \\
\text { Playa }\end{array}$ & $\begin{array}{c}\mathrm{Di} \\
\text { Playa }\end{array}$ & $\begin{array}{c}\mathrm{Di} \\
\text { Playa }\end{array}$ & $\begin{array}{c}\mathrm{Di} \\
\text { Playa }\end{array}$ & $\begin{array}{c}\text { En-(Fe) } \\
\text { Playa }\end{array}$ & \begin{tabular}{|c|} 
En-(Fe) \\
Playa
\end{tabular} & $\begin{array}{c}\text { En-(Fe) } \\
\text { Playa }\end{array}$ & \begin{tabular}{|l} 
En-(Fe) \\
Playa
\end{tabular} & $\begin{array}{c}\text { En-(Fe) } \\
\text { Playa }\end{array}$ & \begin{tabular}{|l} 
En-(Fe) \\
Playa
\end{tabular} & $\begin{array}{c}\text { En-(Fe) } \\
\text { Playa }\end{array}$ \\
\hline Localización & *P Sinai & *P S Sinai & *P Sinai & *P Sinai & *P Sinai & *P Sinai & *P Sinai & ${ }^{*}$ C.Beta & ${ }^{*}$ C. Beta & ${ }^{*}$ C.Beta & ${ }^{*}$ C.Beta & ${ }^{*}$ C. Tortuga & ${ }^{*}$ C. Tortuga & ${ }^{*}$ C. Tortuga & \multicolumn{2}{|c|}{ B.S.Sebastián } & B.S.Sebastián & \multicolumn{2}{|c|}{$\begin{array}{l}\text { Playa Paya Playa } \\
\text { BS S Sebastian }\end{array}$} & \multicolumn{2}{|c|}{ B.S.Sebastián } & \multicolumn{2}{|c|}{ B.S.Sebastián } \\
\hline Análsiis & 1 & 1 & 1 & 1 & 1 & 1 & 1 & 1 & 1 & 1 & 1 & 1 & 1 & 1 & 0.00 & 1 & 2 & 0.0 & nats & 1 & & 1 & 1 \\
\hline Posición & $\mathrm{N}$ & $\mathrm{N}$ & $\mathrm{N}$ & $\mathrm{N}$ & $\mathrm{N}$ & $\mathrm{N}$ & $\mathrm{N}$ & $\mathrm{N}$ & $\mathrm{N}$ & $\mathrm{N}$ & $\mathrm{N}$ & $\mathrm{N}$ & $\mathrm{N}$ & $\mathrm{N}$ & 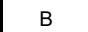 & $B(N)$ & $\mathrm{N}$ & $\mathrm{N}$ & B & B & $\mathrm{N}$ & B & $\mathrm{N}$ \\
\hline Nombre & BR.196 & \begin{tabular}{|l|} 
BR.197 \\
\end{tabular} & \begin{tabular}{|l|} 
BR.198 \\
\end{tabular} & BR.199 & BR.201 & BR.211 & \begin{tabular}{|l|} 
BR. 225 \\
\end{tabular} & B.1.22 & B. $2.6^{*}$ & B. $2.7^{\star}$ & B. $2.20^{*}$ & T. $3.8^{*}$ & T. $3.5^{*}$ & T.2.1 & 3AC2.1 & $3 \mathrm{AC2} .2$ & $3 \mathrm{AC} 3.1$ & OSR1.17 & OSR1.18 & OSR1.28 & OSR1.29 & OSR1.30 & OSR1.31 \\
\hline \multicolumn{24}{|l|}{$\%$ en peso } \\
\hline $\mathrm{SiO}_{2}$ & 52,680 & 50,110 & 50,470 & 49,780 & 52,640 & 49,940 & 51,030 & 55,602 & 51,852 & 54,575 & 52,321 & 52,122 & 50,509 & 51,698 & 49,916 & 49,144 & 53,145 & 52,354 & 52,694 & 52,839 & 52,452 & 53,441 & 54,690 \\
\hline $\mathrm{TiO}_{2}$ & 0,095 & 0,490 & 0,447 & 0,571 & 0,519 & 0,711 & 0,335 & 0,118 & 0,202 & 0,177 & 0,132 & 0,609 & 0,487 & 0,357 & 0,614 & 0,771 & 0,170 & 0,247 & 0,271 & 0,185 & 0,209 & 0,236 & 0,167 \\
\hline $\mathrm{Al}_{2} \mathrm{O}_{3}$ & 1,018 & 2,620 & 1,237 & 2,300 & 2,430 & 2,080 & 2,150 & 1,927 & 1,971 & 0,744 & 0,423 & 1,324 & 3,771 & 2,479 & 4,823 & 5,152 & 1,758 & 1,068 & 1,589 & 0,477 & 0,515 & 1,942 & 0,838 \\
\hline $\mathrm{Cr}_{2} \mathrm{O}_{3}$ & L.D & 0,121 & L.D & 0,049 & L.D & L.D & L.D & 0,168 & 0,462 & L.D & L.D & L.D & L.D & 0,247 & 0,821 & 0,558 & L.D & L.D & L.D & L.D & L.D & L.D & L.D \\
\hline $\mathrm{Fe}_{2} \mathrm{O}_{3}$ & 1,513 & 4,200 & 2,868 & 1,801 & 2,044 & 3,545 & 3,973 & 0,000 & 3,549 & 0,000 & 1,680 & 0,000 & 3,095 & 2,985 & 1,970 & 1,521 & 0,000 & 0,000 & 0,000 & 0,000 & 0,000 & 0,000 & 0,000 \\
\hline $\mathrm{FeO}$ & 2,518 & 2,821 & 19,049 & 7,789 & 6,951 & 6,950 & 4,115 & 11,540 & 0,500 & 19,904 & 22,491 & 12,328 & 4,271 & 1,549 & 3,701 & 5,441 & 17,148 & 21,580 & 20,847 & 22,853 & 22,555 & 16,987 & 16,765 \\
\hline $\mathrm{MnO}$ & 0,138 & 0,185 & 0,530 & 0,271 & 0,341 & 0,421 & 0,240 & 0,223 & 0,071 & 0,749 & 1,092 & 0,562 & 0,134 & 0,000 & 0,124 & 0,149 & 0,541 & 0,791 & 0,615 & 1,400 & 1,491 & 0,524 & 0,534 \\
\hline $\mathrm{MgO}$ & 16,180 & 16,000 & 21,480 & 14,460 & 15,870 & 14,890 & 16,680 & 28,932 & 16,798 & 24,272 & 21,442 & $\begin{array}{l}13,721 \\
\end{array}$ & 15,261 & $\begin{array}{l}16,204 \\
16\end{array}$ & 14,847 & 14,341 & 24,702 & 21,191 & 22,122 & 20,222 & 20,662 & 24,906 & 25,256 \\
\hline $\mathrm{CaO}$ & 24,000 & 21,410 & 2,030 & 19,170 & 20,120 & 19,430 & 19,960 & 0,912 & 24,059 & 0,971 & 0,673 & 18,595 & 22,006 & 24,008 & 22,197 & 21,139 & 1,260 & 1,583 & 1,384 & 1,494 & 1,448 & 1,484 & 1,587 \\
\hline $\mathrm{Na}_{2} \mathrm{O}$ & 0,172 & 0,273 & 0,027 & 0,337 & 0,400 & 0,328 & 0,357 & 0,071 & 0,163 & L.D & L.D & 0,286 & 0,222 & 0,204 & 0,325 & 0,263 & L.D & L.D & L.D & L.D & L.D & L.D & L.D \\
\hline $\mathrm{K}_{2} \mathrm{O}$ & 0,011 & L.D & L.D & 0,011 & L.D & L.D & L.D & L.D & L.D & L.D & L.D & L.D & L.D & L.D & L.D & L.D & L.D & L.D & L.D & L.D & L.D & L.D & L.D \\
\hline $\mathrm{NiO}$ & L.D & L.D & L.D & 0,041 & L.D & 0,026 & L.D & L.D & 0,092 & L.D & L.D & L.D & L.D & L.D & L.D & L.D & L.D & L.D & L.D & L.D & L.D & L.D & L.D \\
\hline $\mathrm{ZnO}$ & N.D & N.D & N.D & N.D & N.D & N.D & N.D & N.D & N.D & N.D & N.D & N.D & N.D & N.D & L.D & L.D & L.D & L.D & L.D & L.D & L.D & L.D & L.D \\
\hline $\mathrm{V}_{2} \mathrm{O}_{3}$ & 0,032 & 0,031 & L.D & 0,052 & 0,054 & 0,035 & 0,028 & N.D & N.D & N.D & N.D & N.D & N.D & N.D & L.D & L.D & L.D & L.D & L.D & L.D & L.D & 0,385 & 0,114 \\
\hline $\mathrm{Zr}_{2} \mathrm{O}$ & L.D & 0,044 & 0,050 & L.D & 0,064 & L.D & L.D & N.D & N.D & N.D & N.D & N.D & N.D & N.D & L.D & L.D & L.D & L.D & L.D & L.D & L.D & L.D & L.D \\
\hline Total & 98,356 & 98,305 & 98,188 & 96,632 & 101,431 & 98,354 & 98,868 & 99,493 & 99,718 & 101,392 & 100,254 & 99,547 & 99,756 & 99,731 & 99,338 & 98,478 & 98,724 & 98,814 & 99,521 & 99,470 & 99,332 & 99,905 & 99,950 \\
\hline $\mathrm{P}_{2} \mathrm{O}_{5}$ & N.D & N.D & N.D & N.D & N.D & N.D & N.D & L.D & 0,367 & L.D & L.D & 0,254 & 0,252 & 0,337 & 0,233 & 0,188 & L.D & L.D & L.D & L.D & L.D & L.D & L.D \\
\hline $\mathrm{Ta}_{2} \mathrm{O}_{5}$ & N.D & N.D & N.D & N.D & N.D & N.D & N.D & N.D & N.D & N.D & N.D & N.D & N.D & N.D & 0,297 & 0,367 & 0,494 & 0,392 & 0,442 & 0,462 & 0,419 & 0,487 & 0,434 \\
\hline \multicolumn{24}{|c|}{ Fórmula estructural ( 6 O y 4 Cationes) } \\
\hline $\mathrm{Si}$ & 1,960 & 1,878 & 1,921 & 1,917 & 1,920 & 1,894 & 1,900 & 1,983 & 1,902 & 1,983 & 1,963 & 1,969 & 1,869 & 1,899 & 1,850 & 1,844 & 1,963 & 1,979 & 1,966 & 2,002 & 1,985 & 1,951 & 1,994 \\
\hline $\mathrm{Ti}$ & 0,003 & 0,014 & & 0,017 & 0,014 & & 0,009 & & 0,006 & 0,005 & 0,004 & & 0,014 & 0,010 & 0,017 & & $0, \mathrm{c}$ & 0,007 & & 0,005 & 0,006 & 0,006 & 0,005 \\
\hline 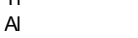 & 0,045 & 0,116 & & & & & & & 0,085 & & & & 0,1 & 0,6 & 0,211 & & $0, c$ &,$c$ & & $0, \mathrm{C}$ & 0,023 & 0,084 & 0,036 \\
\hline $\mathrm{Cr}$ & $\begin{array}{l}0,045 \\
0,000\end{array}$ & & & & & & & & 0, & 0, & 0,0 & & 0,0 & 0,0 & 0,024 & & $0, \mathrm{C}$ & 0 & & & $\begin{array}{l}0,000 \\
0,000\end{array}$ & 000 & $\begin{array}{l}0,000 \\
0,000\end{array}$ \\
\hline $\mathrm{Fe}^{3+}$ & 0,042 & 0,118 & 0,082 & 0,052 & 0,056 & 0,101 & 0,111 & 0,000 & 0,098 & 0,000 & 0,047 & 0,000 & 0,086 & 0,082 & 0,055 & 0,04 & 0,000 & 0,000 & 0,000 & 0,000 & 0,000 & 0,000 & 0,000 \\
\hline $\mathrm{Fe}^{2+}$ & 0,078 & 0,088 & 0,606 & 0,251 & 0,212 & 0,220 & 0,128 & & 0,015 & 0,605 & 0,706 & & 0,132 & 0,048 & 0,115 & 0,17 & 0,530 & 0,682 & 0,651 & 0,724 & 0,714 & 0,519 & 0,511 \\
\hline $\mathrm{Mn}$ & & 0,006 & & & & 0,014 & & & 0,002 & & $0, \mathrm{c}$ & & 0,0 & 0, & 0,004 & & 0,0 & 0,025 & 0,019 & 0,0 & 0,048 & 0,016 & 0,016 \\
\hline $\mathrm{Mg}$ & 0,897 & 0,894 & & & & 0,8 & & & & & 1,1 & & 0,8 & 0,8 & 0, & & 1,3 & 1,1 & & & & 5 & 1,373 \\
\hline $\begin{array}{l}\mathrm{Nug} \\
\mathrm{Ca}\end{array}$ & $\begin{array}{l}0,897 \\
0,957\end{array}$ & 0,8 & o, & 0,7 & 0, & 0,6 & 0 , & 5 & 0, & 0, & 0,0 & 0, & 0,8 & $\begin{array}{l}0,0 \mathrm{c} \\
0,96\end{array}$ & 0, & 0 & $0, c$ & $0, \mathrm{C}$ & 0 & o, & o, & $\begin{array}{l}1,030 \\
0,058\end{array}$ & $\begin{array}{l}0,062 \\
0,02\end{array}$ \\
\hline $\mathrm{Na}$ & & 0, & & & & & & & & & 0, & & & & & & & & & & & & 00 \\
\hline $\mathrm{K}$ & & & & & & 0, & & & & & & & & 0,0 & & & & & & & & & 00 \\
\hline $\mathrm{NI}$ & $\begin{array}{l}0,000 \\
0,000\end{array}$ & & & & & & & & & & & & & & & & & & & & & & 000 \\
\hline $\mathrm{Zn}$ & 0,000 & & & & & & & & & & & & & & & & & & & & & & \\
\hline V & & & & & & & & & & & & & & & & & & & & & & & \\
\hline$\Delta$ & & & & & & & & & & & & & & & & & & & & & & & 0,000 \\
\hline Tota & & & & & & & & & & & & & & & 4,000 & & $4, C$ & & & & & 4,000 & 4,000 \\
\hline En & 45,342 & 45,460 & 60,723 & 42,946 & 44,760 & 42,809 & 47,018 & 79,949 & 46,401 & 66,387 & 59,542 & 39,979 & 43,464 & 45,218 & 43,742 & 42,888 & 69,515 & 60,746 & 62,916 & 57,923 & 58,694 & 69,570 & 69,951 \\
\hline $\mathrm{Fs}$ & 6,319 & 10,818 & 35,153 & 16,134 & 14,454 & 17,041 & 12,544 & 18,239 & 5,834 & 31,704 & 39,114 & 21,081 & 11,490 & 6,630 & 9,256 & 11,676 & 27,937 & 35,992 & 34,255 & 39,001 & 38,350 & 27,451 & 26,889 \\
\hline Wo & 48,339 & 43,721 & 4,125 & 40,920 & 40,786 & 40,150 & 40,438 & 1,8 & 47,765 & 1,909 & 1,3 & & 45,046 & 48,152 & 47,002 & & 2,548 & 3,262 & 2,829 & 3,076 & 2,956 & 2,980 & 3,160 \\
\hline$\# \mathrm{Mg}$ & 0,819 & 0,664 & 0,758 & 0,782 & $\begin{array}{l}0,729 \\
0,10\end{array}$ & 0,793 & 0,878 & 0,817 & 0,984 & 0,685 & 0,630 & 0,665 & 0,864 & 0,949 & 0,877 & 0,825 & 0,720 & 0,636 & 0,654 & 0,612 & 0,620 & 0,723 & 0,729 \\
\hline
\end{tabular}

A.9. Continuación. 
Tesis Doctoral Luis Santamaría Torres

\begin{tabular}{|c|c|c|c|c|c|c|c|c|c|c|c|c|c|c|c|c|c|}
\hline $\begin{array}{l}\text { Mineral } \\
\text { Subambiente }\end{array}$ & \begin{tabular}{|c|} 
Aug \\
Playa \\
\end{tabular} & \begin{tabular}{|c|} 
En- $(\mathrm{Fe})$ \\
Playa
\end{tabular} & $\begin{array}{c}\text { En-(Fe) } \\
\text { Playa }\end{array}$ & \begin{tabular}{|c|} 
Aug \\
Playa
\end{tabular} & $\begin{array}{c}\text { En-(Fe) } \\
\text { Playa }\end{array}$ & $\begin{array}{l}\text { Aug } \\
\text { Playa }\end{array}$ & \begin{tabular}{|c|} 
En- $(\mathrm{Fe})$ \\
Playa
\end{tabular} & $\begin{array}{c}\mathrm{Di} \\
\text { Playa }\end{array}$ & $\begin{array}{l}\text { Aug } \\
\text { Playa }\end{array}$ & $\begin{array}{c}\text { Aug } \\
\text { Playa }\end{array}$ & $\begin{array}{c}\mathrm{Di} \\
\text { Playa }\end{array}$ & $\begin{array}{c}\mathrm{Di} \\
\text { Playa }\end{array}$ & $\begin{array}{c}\text { En-(Fe) } \\
\text { Playa }\end{array}$ & $\begin{array}{c}\mathrm{Di} \\
\text { Playa }\end{array}$ & $\begin{array}{c}\text { Di } \\
\text { Playa }\end{array}$ & \begin{tabular}{|l|} 
Aug \\
Playa
\end{tabular} & $\begin{array}{l}\text { Aug } \\
\text { Playa }\end{array}$ \\
\hline Localización & ${ }^{*}$ C.Beta & ${ }^{*}$ C. Beta & ${ }^{*}$ C.Beta & *C.Beta & ${ }^{*}$ C.Beta & ${ }^{*}$ C.Beta & *C.Beta & ${ }^{*}$ C.Beta & ${ }^{*} \mathrm{C}$. Tortuga & *C.Tortuga & ${ }^{*}$ C.Tortuga & ${ }^{*} \mathrm{C}$. Tortuga & ${ }^{*}$ C.Tortuga & ${ }^{*}$ C.Beta & ${ }^{*}$ C.Beta & ${ }^{*}$ C.Beta & ${ }^{*}$ C.Beta \\
\hline № Análsiis & 1 & 1 & 1 & 1 & 1 & 1 & 1 & 1 & 1 & 1 & 1 & 1 & 1 & 1 & 1 & 1 & 1 \\
\hline Posición & $\mathrm{N}$ & $\mathrm{N}$ & $\mathrm{N}$ & $\mathrm{N}$ & $\mathrm{N}$ & $\mathrm{N}$ & $\mathrm{N}$ & $\mathrm{N}$ & $\mathrm{N}$ & $\mathrm{N}$ & $\mathrm{N}$ & $\mathrm{N}$ & $\mathrm{N}$ & $\mathrm{N}$ & $\mathrm{N}$ & $\mathrm{N}$ & $\mathrm{N}$ \\
\hline Nombre & OSR3.8 & OSR3.9 & OSR3.20 & OSR3.21 & OSR3.29 & OSR3.30 & OSR3.31 & OSR3.32 & OSR3.34 & OSR3.35 & OSR3.58 & OSR3.60 & OSR3.67 & OSR3.69 & OSR3.70 & OSR3.71 & OSR3.79 \\
\hline \multicolumn{18}{|l|}{$\%$ en peso } \\
\hline $\mathrm{SiO}_{2}$ & 50,931 & 52,824 & 52,980 & 49,480 & 53,543 & 50,984 & 54,063 & 48,979 & 48,589 & 51,091 & 49,616 & 52,173 & 52,921 & 51,752 & 49,223 & 52,699 & 51,648 \\
\hline $\mathrm{TiO}_{2}$ & 0,669 & 0,190 & 0,062 & 0,932 & 0,235 & 0,794 & 0,257 & 0,830 & 1,187 & 0,564 & 0,658 & 0,345 & 0,132 & 0,444 & 0,431 & 0,553 & 0,708 \\
\hline $\mathrm{Al}_{2} \mathrm{O}_{3}$ & 2,529 & 0,891 & 0,481 & 3,584 & 0,892 & 2,430 & 0,948 & 5,326 & 4,077 & 2,318 & 4,725 & 2,091 & 0,400 & 3,158 & 4,414 & 1,947 & 3,143 \\
\hline $\mathrm{Cr}_{2} \mathrm{O}_{3}$ & L.D & L.D & L.D & 0,019 & L.D & L.D & L.D & 0,129 & L.D & L.D & L.D & 0,298 & L.D & 0,089 & 0,311 & L.D & L.D \\
\hline $\mathrm{Fe}_{2} \mathrm{O}_{3}$ & 1,685 & 0,000 & 0,000 & 3,219 & 0,000 & 2,163 & 0,000 & 2,591 & 3,534 & 2,585 & 0,594 & 1,695 & 0,000 & 0,760 & 0,957 & 0,000 & 0,000 \\
\hline $\mathrm{FeO}$ & 7,122 & 18,974 & 23,139 & 6,339 & 16,319 & 6,572 & 16,462 & 4,180 & 6,492 & 6,171 & 6,483 & 2,855 & 20,025 & 4,503 & 4,755 & 10,112 & 9,747 \\
\hline $\mathrm{MnO}$ & 0,288 & 0,579 & 0,984 & 0,278 & 0,409 & 0,296 & 0,500 & 0,109 & 0,302 & 0,383 & 0,203 & 0,096 & 0,627 & 0,150 & 0,120 & 0,355 & 0,320 \\
\hline $\mathrm{MgO}$ & 14,855 & 23,335 & 21,107 & 14,726 & 25,021 & 14,973 & 25,334 & 13,962 & 13,400 & 14,931 & 12,348 & 15,817 & 22,691 & 14,765 & 13,921 & 13,736 & 13,948 \\
\hline $\mathrm{CaO}$ & 20,287 & 1,628 & 0,546 & 20,066 & 1,609 & 20,604 & 1,635 & 22,749 & 20,739 & 20,855 & 23,048 & 23,674 & 1,212 & 23,497 & 22,335 & 19,837 & 20,306 \\
\hline $\mathrm{Na}_{2} \mathrm{O}$ & 0,349 & L.D & L.D & 0,307 & 0,043 & 0,371 & L.D & 0,213 & 0,412 & 0,368 & 0,365 & 0,263 & L.D & 0,259 & 0,203 & 0,230 & 0,288 \\
\hline $\mathrm{K}_{2} \mathrm{O}$ & L.D & L.D & L.D & L.D & L.D & L.D & L.D & L.D & L.D & L.D & L.D & L.D & L.D & L.D & L.D & L.D & L.D \\
\hline $\mathrm{NiO}$ & L.D & L.D & L.D & L.D & L.D & L.D & L.D & L.D & L.D & L.D & L.D & L.D & L.D & L.D & L.D & L.D & L.D \\
\hline $\mathrm{ZnO}$ & L.D & L.D & L.D & L.D & L.D & L.D & L.D & L.D & L.D & L.D & L.D & L.D & L.D & L.D & L.D & L.D & L.D \\
\hline $\mathrm{V}_{2} \mathrm{O}_{3}$ & L.D & L.D & L.D & L.D & L.D & L.D & L.D & L.D & L.D & L.D & L.D & L.D & L.D & L.D & L.D & L.D & L.D \\
\hline $\mathrm{Zr}_{2} \mathrm{O}$ & L.D & L.D & L.D & L.D & L.D & L.D & L.D & L.D & L.D & L.D & L.D & L.D & L.D & L.D & L.D & L.D & L.D \\
\hline Total & 98,714 & 98,422 & 99,300 & 98,950 & 98,070 & 99,185 & 99,199 & 99,067 & 98,732 & 99,266 & 98,038 & 99,307 & 98,008 & 99,377 & 96,670 & 99,469 & 100,107 \\
\hline $\mathrm{P}_{2} \mathrm{O}_{5}$ & 0,246 & L.D & L.D & 0,277 & L.D & 0,175 & L.D & 0,246 & 0,197 & 0,266 & 0,240 & 0,296 & L.D & 0,216 & 0,241 & 0,148 & 0,231 \\
\hline $\mathrm{Ta}_{2} \mathrm{O}_{5}$ & 0,393 & 0,429 & 0,493 & 0,314 & 0,438 & 0,415 & 0,386 & 0,341 & 0,237 & 0,515 & 0,465 & 0,483 & 0,409 & 0,418 & 0,479 & 0,417 & 0,293 \\
\hline \multicolumn{18}{|c|}{ Fórmula estructural ( 60 y 4 Cationes) } \\
\hline $\mathrm{Si}$ & 1,914 & 1,976 & 2,002 & 1,860 & 1,985 & 1,907 & 1,982 & 1,829 & 1,840 & 1,910 & 1,881 & 1,926 & 1,999 & 1,916 & 1,877 & 1,982 & 1,923 \\
\hline $\mathrm{Ti}$ & 0,019 & 0,005 & 0,002 & 0,026 & 0,007 & 0,022 & 0,007 & 0,023 & 0,034 & 0,016 & 0,019 & 0,010 & 0,004 & 0,012 & 0,012 & 0,016 & 0,020 \\
\hline Al & 0,112 & 0,039 & 0,021 & 0,159 & 0,039 & 0,107 & 0,041 & 0,234 & 0,182 & 0,102 & 0,211 & 0,091 & 0,018 & 0,138 & 0,198 & 0,086 & 0,138 \\
\hline $\mathrm{Cr}$ & 0,000 & 0,000 & 0,000 & 0,001 & 0,000 & 0,000 & 0,000 & 0,004 & 0,000 & 0,000 & 0,000 & 0,009 & 0,000 & 0,003 & 0,009 & 0,000 & 0,000 \\
\hline $\mathrm{Fe}^{3+}$ & 0,048 & 0,000 & 0,000 & 0,091 & 0,000 & 0,061 & 0,000 & 0,073 & 0,101 & 0,073 & 0,017 & 0,047 & 0,000 & 0,021 & 0,027 & 0,000 & 0,000 \\
\hline $\mathrm{Fe}^{2+}$ & 0,224 & 0,594 & 0,731 & 0,199 & 0,506 & 0,206 & 0,505 & 0,131 & 0,206 & 0,193 & 0,206 & 0,088 & 0,633 & 0,139 & 0,152 & 0,318 & 0,304 \\
\hline $\mathrm{Mn}$ & 0,009 & 0,018 & 0,032 & 0,009 & 0,013 & 0,009 & 0,016 & 0,003 & 0,010 & 0,012 & 0,007 & 0,003 & 0,020 & 0,005 & 0,004 & 0,011 & 0,010 \\
\hline $\mathrm{Mg}$ & 0,832 & 1,302 & 1,189 & 0,825 & 1,383 & 0,835 & 1,385 & 0,777 & 0,756 & 0,832 & 0,698 & 0,871 & 1,278 & 0,815 & 0,792 & 0,770 & 0,774 \\
\hline $\mathrm{Ca}$ & 0,817 & 0,065 & 0,022 & 0,808 & 0,064 & 0,826 & 0,064 & 0,910 & 0,841 & 0,835 & 0,936 & 0,937 & 0,049 & 0,932 & 0,913 & 0,799 & 0,810 \\
\hline $\mathrm{Na}$ & 0,025 & 0,000 & 0,000 & 0,022 & 0,003 & 0,027 & 0,000 & 0,015 & 0,030 & 0,027 & 0,027 & 0,019 & 0,000 & 0,019 & 0,015 & 0,017 & 0,021 \\
\hline K & 0,000 & 0,000 & 0,000 & 0,000 & 0,000 & 0,000 & 0,000 & 0,000 & 0,000 & 0,000 & 0,000 & 0,000 & 0,000 & 0,000 & 0,000 & 0,000 & 0,000 \\
\hline $\mathrm{Ni}$ & 0,000 & 0,000 & 0,000 & 0,000 & 0,000 & 0,000 & 0,000 & 0,000 & 0,000 & 0,000 & 0,000 & 0,000 & 0,000 & 0,000 & 0,000 & 0,000 & 0,000 \\
\hline $\mathrm{Zn}$ & 0,000 & 0,000 & 0,000 & 0,000 & 0,000 & 0,000 & 0,000 & 0,000 & 0,000 & 0,000 & 0,000 & 0,000 & 0,000 & 0,000 & 0,000 & 0,000 & 0,000 \\
\hline v & 0,000 & 0,000 & 0,000 & 0,000 & 0,000 & 0,000 & 0,000 & 0,000 & 0,000 & 0,000 & 0,000 & 0,000 & 0,000 & 0,000 & 0,000 & 0,000 & 0,000 \\
\hline $\mathrm{Zr}$ & 0,000 & 0,000 & 0,000 & 0,000 & 0,000 & 0,000 & 0,000 & 0,000 & 0,000 & 0,000 & 0,000 & 0,000 & 0,000 & 0,000 & 0,000 & 0,000 & 0,000 \\
\hline Total & 4,000 & 4,000 & 4,000 & 4,000 & 4,000 & 4,000 & 4,000 & 4,000 & 4,000 & 4,000 & 4,000 & 4,000 & 4,000 & 4,000 & 4,000 & 4,000 & 4,000 \\
\hline En & 43,127 & 65,773 & 60,239 & 42,699 & 70,354 & 43,116 & 70,318 & 41,031 & 39,525 & 42,777 & 37,457 & 44,751 & 64,551 & 42,615 & 41,941 & 40,559 & 40,793 \\
\hline Fs & 14,543 & 30,929 & 38,641 & 15,482 & 26,394 & 14,243 & 26,421 & 10,917 & 16,510 & 14,279 & 12,292 & 7,108 & 32,970 & 8,644 & 9,697 & 17,345 & 16,523 \\
\hline Wo & 42,329 & 3,299 & 1,120 & 41,819 & 3,252 & 42,641 & 3,262 & 48,051 & 43,965 & 42,943 & 50,251 & 48,141 & 2,479 & 48,741 & 48,361 & 42,096 & 42,684 \\
\hline \#Mg & 0,788 & 0,687 & 0,619 & 0,805 & 0,732 & 0,802 & 0,733 & 0,856 & 0,786 & 0,812 & 0,772 & 0,908 & 0,669 & 0,854 & 0,839 & 0,708 & 0,718 \\
\hline
\end{tabular}

A.10. Continuación. 
Tesis Doctoral Luis Santamaría Torres

\begin{tabular}{|c|c|c|c|c|c|c|c|c|c|c|c|c|c|c|c|}
\hline \multirow{5}{*}{$\begin{array}{l}\text { Mineral } \\
\text { Subambiente } \\
\text { Localización } \\
\mathrm{N}^{\circ} \text { Análsiis } \\
\text { Posición } \\
\text { Nombre }\end{array}$} & \multirow{5}{*}{$\begin{array}{c}\text { Di } \\
\text { Playa } \\
{ }^{*} \text { C.Beta } \\
1 \\
\mathrm{~N} \\
\text { OSR3.100 } \\
\end{array}$} & \multirow{5}{*}{\begin{tabular}{|c|} 
En- $(\mathrm{Fe})$ \\
Playa \\
${ }^{*}$ C.Beta \\
1 \\
$\mathrm{~N}$ \\
OSR3.108 \\
\end{tabular}} & \multirow{5}{*}{\begin{tabular}{|c|}
$\mathrm{Di}$ \\
Playa \\
${ }^{*}$ C.Beta \\
1 \\
$\mathrm{~N}$ \\
OSR3.113 \\
\end{tabular}} & $\begin{array}{l}\text { Aug } \\
\text { Playa }\end{array}$ & \multirow{2}{*}{$\begin{array}{c}\text { Aug } \\
\text { Playa } \\
\text { Affa }\end{array}$} & \multirow{2}{*}{\multicolumn{2}{|c|}{$\begin{array}{cc}\mathrm{Di} & \mathrm{Di} \\
\text { Playa }^{*} & \text { Playa } \\
\end{array}$}} & $\begin{array}{c}\text { En-(Fe) } \\
\text { Playa }\end{array}$ & \multirow{2}{*}{$\begin{array}{l}\text { En-(Fe) } \\
\text { Playa } \\
\text { Alfa }\end{array}$} & \multirow{2}{*}{\multicolumn{2}{|c|}{$\begin{array}{lc}\text { Aug } & \text { Aug } \\
\text { Playa } & \text { Playa } \\
\end{array}$}} & \multicolumn{2}{|c|}{$\begin{array}{cc}\text { Aug } & \text { Aug } \\
\text { Playa } & \text { Playa }\end{array}$} & \multicolumn{2}{|c|}{$\begin{array}{cc}\text { En-(Fe) } & \text { En-(Fe) } \\
\text { Playa } & \text { Playa }\end{array}$} \\
\hline & & & & ${ }^{*}$ C.Alfa & & & & ${ }^{*}$ C.Alfa & & & & & \multicolumn{2}{|c|}{${ }^{*}$ C.Beta } \\
\hline & & & & 1 & 2 & \multicolumn{2}{|c|}{1 C.Alra } & 1 & 2 & 1 & 2 & 1 & 2 & 1 & 2 \\
\hline & & & & $\mathrm{N}$ & B & $\mathrm{N}$ & B & $\mathrm{N}$ & B & $\mathrm{N}$ & B & $\mathrm{N}$ & B & $\mathrm{N}$ & B \\
\hline & & & & 4AC3.3.1 & 4AC3.3.2 & $4 \mathrm{AC} 2.9 .1$ & 4AC2.9.2 & $4 \mathrm{AC2} 2.7 .1$ & $4 \mathrm{AC2} 2.7 .2$ & $4 \mathrm{BC} 3.8 .1$ & $4 \mathrm{BC} 3.8 .2$ & 4BC7.6.1 & $4 \mathrm{BC} 7.6 .2$ & 4BC2.1.1 & $4 \mathrm{BC} 2.1 .2$ \\
\hline \multicolumn{16}{|l|}{$\%$ en peso } \\
\hline $\mathrm{SiO}_{2}$ & 52,686 & 52,775 & 49,730 & 51,386 & 50,981 & 48,738 & 48,576 & 52,727 & 52,152 & 50,488 & 50,994 & 51,290 & 50,875 & 53,354 & 53,072 \\
\hline $\mathrm{TiO}_{2}$ & 0,296 & 0,342 & 0,659 & 0,587 & 0,727 & 0,784 & 0,727 & 0,251 & 0,227 & 0,673 & 0,722 & 0,779 & 0,766 & 0,329 & 0,368 \\
\hline $\mathrm{Al}_{2} \mathrm{O}_{3}$ & 2,135 & 0,838 & 5,784 & 1,865 & 2,200 & 6,849 & 6,382 & 1,162 & 1,084 & 1,850 & 1,863 & 2,544 & 2,632 & 1,018 & 1,175 \\
\hline $\mathrm{Cr}_{2} \mathrm{O}_{3}$ & 0,170 & L.D & 0,153 & L.D & L.D & 0,068 & L.D & L.D & L.D & L.D & L.D & L.D & L.D & 0,073 & 0,061 \\
\hline $\mathrm{Fe}_{2} \mathrm{O}_{3}$ & 0,978 & 0,000 & 1,176 & 3,011 & 3,138 & 2,492 & 4,145 & 0,691 & 2,844 & 2,762 & 2,539 & 2,421 & 3,895 & 0,657 & 0,996 \\
\hline $\mathrm{FeO}$ & 3,581 & 19,810 & 5,612 & 6,967 & 6,202 & 5,063 & 3,404 & 20,510 & 18,930 & 8,409 & 8,723 & 7,390 & 4,894 & 16,646 & 16,159 \\
\hline $\mathrm{MnO}$ & 0,104 & 0,640 & 0,124 & 0,356 & 0,408 & 0,157 & 0,066 & 0,552 & 0,640 & 0,395 & 0,425 & 0,359 & 0,277 & 0,554 & 0,504 \\
\hline $\mathrm{MgO}$ & 15,556 & 22,827 & 14,244 & 14,901 & 15,267 & 12,873 & 13,368 & 22,760 & 23,170 & 14,786 & 14,727 & 14,860 & 15,186 & 25,110 & 25,161 \\
\hline $\mathrm{CaO}$ & 23,982 & 1,743 & 21,584 & 20,764 & 20,436 & 23,208 & 23,422 & 1,275 & 1,314 & 19,109 & 19,455 & 20,441 & 21,270 & 1,659 & 1,772 \\
\hline $\mathrm{Na}_{2} \mathrm{O}$ & 0,242 & L.D & 0,275 & 0,319 & 0,345 & 0,233 & 0,309 & L.D & L.D & 0,286 & 0,279 & 0,345 & 0,437 & L.D & L.D \\
\hline $\mathrm{K}_{2} \mathrm{O}$ & L.D & L.D & L.D & L.D & L.D & L.D & L.D & L.D & L.D & L.D & L.D & L.D & L.D & L.D & L.D \\
\hline $\mathrm{NiO}$ & L.D & L.D & L.D & L.D & L.D & L.D & L.D & L.D & L.D & L.D & L.D & L.D & L.D & L.D & L.D \\
\hline $\mathrm{ZnO}$ & L.D & L.D & L.D & L.D & L.D & L.D & L.D & L.D & L.D & L.D & L.D & L.D & L.D & L.D & L.D \\
\hline $\mathrm{V}_{2} \mathrm{O}_{3}$ & L.D & L.D & L.D & L.D & L.D & L.D & L.D & L.D & L.D & L.D & L.D & L.D & L.D & L.D & L.D \\
\hline $\mathrm{Zr}_{2} \mathrm{O}$ & L.D & L.D & L.D & N.D & N.D & N.D & N.D & N.D & N.D & N.D & N.D & N.D & N.D & N.D & N.D \\
\hline Total & 99,729 & 98,974 & 99,340 & 100,156 & 99,706 & 100,465 & 100,398 & 99,928 & 100,360 & 98,758 & 99,727 & 100,431 & 100,230 & 99,401 & 99,267 \\
\hline $\mathrm{P}_{2} \mathrm{O}_{5}$ & 0,226 & L.D & 0,173 & N.D & N.D & N.D & N.D & N.D & N.D & N.D & N.D & N.D & N.D & N.D & N.D \\
\hline $\mathrm{Ta}_{2} \mathrm{O}_{5}$ & 0,320 & 0,422 & 0,449 & N.D & N.D & N.D & N.D & N.D & N.D & N.D & N.D & N.D & N.D & N.D & N.D \\
\hline \multicolumn{16}{|c|}{ Fórmula estructural ( 60 y 4 Cationes) } \\
\hline $\mathrm{Si}$ & 1,938 & 1,972 & 1,846 & 1,912 & 1,900 & 1,802 & 1,794 & 1,958 & 1,930 & 1,911 & 1,913 & 1,901 & 1,883 & 1,959 & 1,950 \\
\hline $\mathrm{Ti}$ & 0,008 & 0,010 & 0,018 & 0,016 & 0,020 & 0,022 & 0,020 & 0,007 & 0,006 & 0,019 & 0,020 & 0,022 & 0,021 & 0,009 & 0,010 \\
\hline Al & 0,093 & 0,037 & 0,253 & 0,082 & 0,097 & 0,298 & 0,278 & 0,051 & 0,047 & 0,083 & 0,082 & 0,111 & 0,115 & 0,044 & 0,051 \\
\hline $\mathrm{Cr}$ & 0,005 & 0,000 & 0,004 & 0,000 & 0,000 & 0,002 & 0,000 & 0,000 & 0,000 & 0,000 & 0,000 & 0,000 & 0,000 & 0,002 & 0,002 \\
\hline $\mathrm{Fe}^{3+}$ & 0,027 & 0,000 & 0,033 & 0,084 & 0,088 & 0,069 & 0,115 & 0,019 & 0,079 & 0,079 & 0,072 & 0,068 & 0,108 & 0,018 & 0,028 \\
\hline $\mathrm{Fe}^{2+}$ & 0,110 & 0,619 & 0,174 & 0,217 & 0,193 & 0,157 & 0,105 & 0,637 & 0,586 & 0,266 & 0,274 & 0,229 & 0,151 & 0,511 & 0,496 \\
\hline $\mathrm{Mn}$ & 0,003 & 0,020 & 0,004 & 0,011 & 0,013 & 0,005 & 0,002 & 0,017 & 0,020 & 0,013 & 0,013 & 0,011 & 0,009 & 0,017 & 0,016 \\
\hline $\mathrm{Mg}$ & 0,853 & 1,272 & 0,788 & 0,827 & 0,848 & 0,709 & 0,736 & 1,260 & 1,279 & 0,834 & 0,823 & 0,821 & 0,838 & 1,374 & 1,378 \\
\hline $\mathrm{Ca}$ & 0,945 & 0,070 & 0,859 & 0,828 & 0,816 & 0,919 & 0,927 & 0,051 & 0,052 & 0,775 & 0,782 & 0,812 & 0,843 & 0,065 & 0,070 \\
\hline $\mathrm{Na}$ & 0,017 & 0,000 & 0,020 & 0,023 & 0,025 & 0,017 & 0,022 & 0,000 & 0,000 & 0,021 & 0,020 & 0,025 & 0,031 & 0,000 & 0,000 \\
\hline $\mathrm{K}$ & 0,000 & 0,000 & 0,000 & 0,000 & 0,000 & 0,000 & 0,000 & 0,000 & 0,000 & 0,000 & 0,000 & 0,000 & 0,000 & 0,000 & 0,000 \\
\hline $\mathrm{Ni}$ & 0,000 & 0,000 & 0,000 & 0,000 & 0,000 & 0,000 & 0,000 & 0,000 & 0,000 & 0,000 & 0,000 & 0,000 & 0,000 & 0,000 & 0,000 \\
\hline $\mathrm{Zn}$ & 0,000 & 0,000 & 0,000 & 0,000 & 0,000 & 0,000 & 0,000 & 0,000 & 0,000 & 0,000 & 0,000 & 0,000 & 0,000 & 0,000 & 0,000 \\
\hline V & 0,000 & 0,000 & 0,000 & 0,000 & 0,000 & 0,000 & 0,000 & 0,000 & 0,000 & 0,000 & 0,000 & 0,000 & 0,000 & 0,000 & 0,000 \\
\hline Zr & 0,000 & 0,000 & 0,000 & 0,000 & 0,000 & 0,000 & 0,000 & 0,000 & 0,000 & 0,000 & 0,000 & 0,000 & 0,000 & 0,000 & 0,000 \\
\hline Total & 4,000 & 4,000 & 4,000 & 4,000 & 4,000 & 4,000 & 4,000 & 4,000 & 4,000 & 4,000 & 4,000 & 4,000 & 4,000 & 4,000 & 4,000 \\
\hline En & 44,000 & 64,201 & 42,432 & 42,028 & 43,309 & 38,153 & 39,040 & 63,496 & 63,422 & 42,421 & 41,926 & 42,308 & 42,970 & 69,198 & 69,335 \\
\hline Fs & 7,246 & 32,277 & 11,356 & 15,880 & 15,023 & 12,410 & 11,797 & 33,948 & 33,993 & 18,177 & 18,267 & 15,864 & 13,776 & 27,515 & 27,155 \\
\hline Wo & 48,755 & 3,522 & 46,212 & 42,092 & 41,668 & 49,437 & 49,163 & 2,556 & 2,585 & 39,402 & 39,807 & 41,828 & 43,255 & 3,287 & 3,509 \\
\hline$\# \mathrm{Mg}$ & 0,886 & 0,673 & 0,819 & 0,792 & 0,814 & 0,819 & 0,875 & 0,664 & 0,686 & 0,758 & 0,751 & 0,782 & 0,847 & 0,729 & 0,735 \\
\hline
\end{tabular}

A.11. Continuación. 


\section{Grupo del granate}

\begin{tabular}{|c|c|c|c|c|c|c|c|c|c|c|c|c|c|c|c|c|c|c|c|c|c|}
\hline $\begin{array}{l}\text { no análisis } \\
\text { Subambiente } \\
\text { Localización }\end{array}$ & 1 & $\begin{array}{c}2 \\
\text { Playa } \\
\text { *C.Alfa }\end{array}$ & 2 & 1 & $\begin{array}{c}4 \\
\begin{array}{c}4 \\
\text { Playa } \\
\text { *C.Alfa }\end{array}\end{array}$ & 3 & 1 & $\begin{array}{c}1 \\
\text { Playa } \\
{ }^{*} \text { C.Alfa }\end{array}$ & 2 & 1 & $\begin{array}{c}1 \\
\text { Playa } \\
\text { *C.Alfa }\end{array}$ & 2 & 1 & $\begin{array}{c}1 \\
\text { Playa } \\
\text { *C.Alfa }^{-}\end{array}$ & 2 & 1 & $\begin{array}{c}1 \\
\text { Playa } \\
\text { *C.Alfa }\end{array}$ & 3 & 1 & $\begin{array}{c}1 \\
\text { Playa } \\
\text { *C.Alfa }^{2}\end{array}$ & 2 \\
\hline $\begin{array}{l}\text { Posición } \\
\text { Nombre }\end{array}$ & $\begin{array}{c}\text { N } \\
\text { A207 }\end{array}$ & $\begin{array}{c}1 \\
\text { A208-210 }\end{array}$ & $\begin{array}{c}\text { B } \\
\text { A209-211 }\end{array}$ & $\begin{array}{c}\text { N } \\
\text { A212 }\end{array}$ & $\begin{array}{c}1 \\
\text { A213 }\end{array}$ & $\begin{array}{c}\text { B } \\
\text { A216 }\end{array}$ & $\begin{array}{c}N \\
\text { A232 }\end{array}$ & $\begin{array}{c}1 \\
\text { A234 }\end{array}$ & $\begin{array}{c}\text { B } \\
\text { A233-235 }\end{array}$ & $\underset{A 236}{N}$ & $\begin{array}{c}1 \\
\text { A239 }\end{array}$ & $\begin{array}{c}\text { B } \\
\text { A237-238 }\end{array}$ & $\begin{array}{c}\mathrm{N} \\
\text { A240 }\end{array}$ & $\begin{array}{c}1 \\
\text { A243 }\end{array}$ & $\begin{array}{c}\text { B } \\
\text { A241-242 }\end{array}$ & $\begin{array}{c}\text { N } \\
\text { A244 }\end{array}$ & $\begin{array}{c}1 \\
\text { A246 }\end{array}$ & $\begin{array}{c}\text { B } \\
\text { 245-247-24 }\end{array}$ & $\begin{array}{c}N \\
\text { A249 }\end{array}$ & $\begin{array}{c}1 \\
\text { A251 }\end{array}$ & $\begin{array}{c}\text { B } \\
\text { A250-252 }\end{array}$ \\
\hline \multicolumn{22}{|l|}{ \%wt } \\
\hline $\mathrm{SiO} 2$ & ,321 & ,945 & 36,312 & 37,981 & 37,181 & 36,762 & 35,096 & 36,047 & 35,286 & 35,288 & 35,682 & 36,193 & 36,526 & 36,861 & 36,331 & 36,490 & 36,145 & 6,313 & 35,754 & 36,130 & 36,369 \\
\hline $\mathrm{TiO} 2$ & 228 & 31 & L.D & 0,074 & L.D & 0,034 & ,040 & L.D & 0,041 & 0,038 & L.D & L.D & L.D & L.D & L.D & 0,441 & 0,402 & 0,404 & 0,139 & 0,159 & 0,133 \\
\hline 1203 & 20,201 & 20,064 & 20,835 & 20,974 & 20,970 & 21,029 & 21,435 & 21,204 & 21,319 & 20,857 & 20,572 & 20,444 & 21,313 & 20,794 & 21,587 & 20,501 & 20,488 & 20,800 & 20,967 & 20,839 & 20,895 \\
\hline $\mathrm{Cr} 2 \mathrm{O} 3$ & L.D & L.D & L.D & L.D & L.D & L.D & L.D & L.D & L.D & L.D & L.D & L.D & L.D & L.D & L.D & L.D & L.D & L.D & L.D & L.D & L.D \\
\hline $\mathrm{Fe} 2 \mathrm{O} 3$ & 3,300 & 4,032 & 2,813 & 0,000 & 0,627 & 1,902 & 3,671 & 3,297 & 3,791 & 4,035 & 2,513 & 1,771 & 2,444 & 0,743 & 2,482 & 2,356 & 3,062 & 2,566 & 3,356 & 2,486 & 2,375 \\
\hline 0 & 57 & 17,142 & 17,736 & 30,550 & 33,073 & 32,435 & 26,013 & 28,240 & 27,473 & 23,997 & 24,016 & 24,887 & 30,645 & 31,527 & 30,846 & 31,318 & 31,305 & 30,862 & 27,988 & 28,945 & 30,231 \\
\hline $\mathrm{MnO}$ & 601 & 19,209 & 19,621 & 2,836 & 1,790 & 0,972 & 10,875 & 8,795 & 9,169 & 13,969 & 14,762 & 14,326 & 5,637 & 5,353 & 5,463 & 1,605 & 1,620 & 1,621 & 8,615 & 7,654 & 6,516 \\
\hline $\mathrm{MgO}$ & 554 & 3,005 & 2,705 & 2,529 & 3,080 & 2,826 & 1,733 & 2,129 & 2,075 & 0,898 & 0,742 & 0,806 & 3,095 & 3,153 & 3,206 & 1,898 & 1,835 & 2,015 & 1,564 & 1,681 & 1,553 \\
\hline $\mathrm{CaO}$ & 0,933 & 0,895 & 0,773 & 5,428 & 3,185 & 4,316 & 1,472 & 1,274 & 1,382 & 1,939 & 1,855 & 1,906 & 1,408 & 1,176 & 1,052 & 012 & 5,748 & 6,001 & 2,635 & 2,850 & 3,129 \\
\hline V2O3 & L.D & L.D & L.D & L.D & L.D & L.D & L.D & L.D & L.D & 0,344 & L.D & L.D & L.D & L.D & L.D & L.D & L.D & L.D & L.D & L.D & L.D \\
\hline $\mathrm{ZrO2}$ & $\mathrm{N}$ & & $\mathrm{N}$ & $\mathrm{N}$ & & N.M & & & N.M & N.M & N & & & & N. & & & & & & \\
\hline $\mathrm{Na} 2 \mathrm{O}$ & L.D & L.D & L.D & 0,088 & L.D & L.D & L.D & 0,114 & L.D & L.D & L.D & L.D & L.D & L.U & L.D & L.U & L.D & L.D & L.D & L.D & L.D \\
\hline Total & 100,794 & 100,422 & 100,794 & 100,460 & 99,907 & 100,277 & 100,335 & 101,100 & 100,537 & 101,365 & 100,141 & 1 100,334 & 101,068 & 99,607 & 100,967 & 100,621 & 100,605 & 100,582 & 101,017 & 100,744 & 101,200 \\
\hline \multicolumn{22}{|l|}{ Min } \\
\hline $\mathrm{Nb} 2 \mathrm{O} 5$ & V.M & N.M & N.M & N.M & N.M & N.M & N.M & N.M & N.M & N.M & N.M & N.M & N.M & N.M & N.M & N.M & N.M & N.M & N.M & N.M & N.M \\
\hline a2O5 & N.M & N.M & N.M & N.M & N.M & N.M & N.M & N.M & N.M & N.M & N.M & $\mathrm{M}$ & $M$ & N.M & N.M & N.M & I.M & N.M & N.M & N.M & N.M \\
\hline $\mathrm{NiO}$ & L.D & L.D & L. & L.D & L. & L.D & L.D & L.D & L.D & L.D & L.D & L.D & L.D & L.D & L.D & L.D & L.D & L.D & L.D & D & L.D \\
\hline no & L.L & L. & L. & L.D & 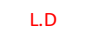 & L.D & L. & L.D & L. & 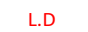 & L. & L.D & 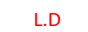 & L. & D & L.D & D & L.D & L.D & D & D \\
\hline $\mathrm{K} 2 \mathrm{O}$ & L & L & L & & & L.I & & & & & & & & & & & & & & & \\
\hline P2O5 & N.M & N.N & N. & N.M & $\mathrm{N}$ & N.M & N.M & N.M & & M & $\mathrm{N}$ & & N.M & N.M & N.M & I.M & & & $M$ & M & N.M \\
\hline \multicolumn{22}{|c|}{ APFU (12 Oxígnos y 8 Cationes) } \\
\hline $\mathrm{Si}$ & (20) & 2,911 & & & & & & & & & & & & & 9 & & & & & 22 & 929 \\
\hline $\mathrm{Ti}$ & 0,014 & 0,008 & 0 & 0,004 & 0,000 & 0,002 & 02 & 0,000 & 0,003 & 0,002 & 000 & 00 & 0,000 & 0,000 & 0,000 & 027 & 0,024 & 0,024 & 0,008 & 3,010 & 008 \\
\hline Al & & & & & & 1,987 & & 2,012 & & & & & & & 2,036 & & & & & 986 & 883 \\
\hline $\mathrm{Cr}$ & 000 & 0,000 & ро & 0,000 & 000 & 0,000 & 00 & 000 & 0,000 & 0,000 & 000 & 00 & 0,000 & 000 & 0,000 & 000 & 0,000 & 0,000 & 0,000 & , 000 & 000 \\
\hline $\mathrm{Fe} 3+$ & & 0,246 & & 0,000 & 0,038 & 0,115 & & 0,200 & & 0,247 & 155 & & 0,147 & 045 & 0,149 & 142 & 0,186 & 0,155 & 0,204 & 0,151 & 144 \\
\hline $\mathrm{Fe} 2+$ & & 1,161 & 1 & 2,034 & 2 & 2,175 & 1,771 & 902 & 1,864 & 1,630 & 648 & 702 & 50 & 135 & 2,064 & 104 & 2,108 & 2,072 & 92 & 57 & 036 \\
\hline $\mathrm{Mn}$ & 1 & 1,318 & & 0,191 & 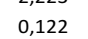 & 0,066 & 0,750 & 0,600 & 0,630 & 51 & 026 & 992 & 0,382 & 367 & 0,370 & 109 & 0,111 & 0,1 & 0,590 & ,524 & 444 \\
\hline $\mathrm{Mg}$ & & & & 0,300 & 0,369 & 0,338 & 0 & 0,256 & 0,251 & 0,109 & 0,091 & 88 & 0,369 & 81 & 0,382 & 227 & 0,220 & 0,241 & 0,188 & 0,203 & 186 \\
\hline $\mathrm{Ca}$ & & 0 & & & & & & & & & & & & & 0,090 & & & & & , 247 & 7 \\
\hline . & & 0, & & & & 0, & & & 0 , & & & & 0 , & & 0,000 & 00 & 0,000 & 0,000 & 0,000 & 0,000 & 00 \\
\hline $\mathrm{Zr}$ & 0,000 & 0,000 & 0,000 & 0,000 & 0,000 & 0,000 & 0,000 & 0,000 & 0,000 & 0,000 & 0,000 & 000 & 0,000 & 000 & 0,000 & 000 & 0,000 & 0,000 & 0,000 &, 000 & 000 \\
\hline $\mathrm{Na}$ & & & & & & & & & & & & & & & , & & & & 0,000 & 000 & 000 \\
\hline Sum & 8,000 & 00 & 00 & 8,000 & 000 & 8,000 & 8,000 & 8,000 & 8, & 8,000 & 8,0 & 000 & 8,000 & 000 & 8,0 & 000 & 8,000 & 8,000 & 8,00 & 8,000 & 000 \\
\hline \multicolumn{22}{|l|}{ Miemb } \\
\hline Sps & $42,32 \%$ & ,93\% & & $\%$ & 4 & 6 & 2 & $20,00 \%$ & 21 & 32 & 34 & 33 & 12 & 12 & 1 & $3,64 \%$ & & 3, & &, $47 \%$ & 1 \\
\hline 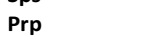 & $23 \%$ & $12,09 \%$ & $10,83 \%$ & $9,65 \%$ & $12,30 \%$ & $11,26 \%$ & 7,01\% & $8,52 \%$ & $8,37 \%$ & $3,62 \%$ & $3,02 \%$ & $3,28 \%$ & $12,30 \%$ & $12,69 \%$ & $12,75 \%$ & $7,58 \%$ & $7,34 \%$ & $8,03 \%$ & $6,28 \%$ & $6,75 \%$ & $6,21 \%$ \\
\hline Alm & & $35,32 \%$ & 39 , & $67,82 \%$ & $74,09 \%$ & $72,49 \%$ & $59, \mathrm{C}$ & $63,39 \%$ & & $54,32 \%$ & $54,93 \%$ & & & $71,17 \%$ & $68,81 \%$ & $70,14 \%$ & 70,2 & 69,0 & $63,08 \%$ & $65,25 \%$ & \\
\hline Grs & 0,0 & 0,00 & $0,00 \%$ & $14,58 \%$ & $8,25 \%$ & $10,75 \%$ & $4,16 \%$ & $3,66 \%$ & $3,55 \%$ & $3,09 \%$ & $3,70 \%$ & $3,44 \%$ & $3,18 \%$ & $2,38 \%$ & $3,01 \%$ & $12,27 \%$ & $11,45 \%$ & $13,33 \%$ & $5,39 \%$ & $5,91 \%$ & $6,69 \%$ \\
\hline Adr & 1,9 & 2,1 & 2,2 & $0,00 \%$ & 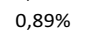 & & 0,0 & $0,00 \%$ & & $1,29 \%$ & & & & $2 \%$ & $0,00 \%$ & $4 \% \%$ & $3,86 \%$ & $2,65 \%$ & $1,79 \%$ & $84 \%$ & $91 \%$ \\
\hline Otr & & & & $0,49 \%$ & $0,00 \%$ & $0,10 \%$ & $0,12 \%$ & $0,00 \%$ & $0,13 \%$ & $1,24 \%$ & $0,00 \%$ & $0,00 \%$ & 0,00\% & $0,00 \%$ & $0,00 \%$ & $1,33 \%$ & $1,22 \%$ & $1,22 \%$ & $0,42 \%$ & $0,48 \%$ & $0,40 \%$ \\
\hline Resto & $1,98 \%$ & $2,69 \%$ & $2,48 \%$ & $1,09 \%$ & $0,40 \%$ & $1,69 \%$ & $4,69 \%$ & $4,42 \%$ & $4,50 \%$ & $4,41 \%$ & $2,41 \%$ & $1,33 \%$ & $2,61 \%$ & $0,50 \%$ & $3,09 \%$ & $1,39 \%$ & $2,17 \%$ & $2,04 \%$ & $3,37 \%$ & $2,29 \%$ & $2,11 \%$ \\
\hline
\end{tabular}

A.12. Análisis con microsonda electrónica efectuados en granates presentes en los depósitos de las playas. * Muestra proveniente de un nivel enriquecido. Fe $\mathrm{O}_{3}$ y FeO calculados según el método de Droop (1987). Miembros finales calculados mediante la planilla de Locock (2008). N, Núcleo: Borde; I, Intermedio. 


\begin{tabular}{|c|c|c|c|c|c|c|c|c|c|c|c|c|c|c|c|c|c|c|c|c|}
\hline $\begin{array}{l}\text { no análisis } \\
\text { Subambiente } \\
\text { Localización }\end{array}$ & 1 & $\begin{array}{c}1 \\
\text { Playa } \\
\text { *C.Bet }\end{array}$ & 1 & & $\begin{array}{l}{ }^{2} \\
\text { aya } \\
\text { Beta }\end{array}$ & 1 & $\begin{array}{c}1 \\
\text { Playa } \\
{ }^{*} \text { C.Bet }\end{array}$ & 1 & 1 & $\begin{array}{c}1 \\
\text { Playa } \\
{ }^{* \text { C.Betz }}\end{array}$ & 1 & 1 & $\begin{array}{c}1 \\
\text { Playa } \\
\text { *C.Beta }^{2}\end{array}$ & 1 & 1 & $\begin{array}{c}1 \\
\text { Playa } \\
\text { *P. Sianí }\end{array}$ & 1 & \begin{tabular}{|c|}
1 \\
Playa \\
*P. Sinaí
\end{tabular} & \begin{tabular}{|c|}
1 \\
Playa \\
*P. Sinaí
\end{tabular} & \begin{tabular}{|c|} 
\\
Playa \\
*P. Sinaí
\end{tabular} \\
\hline Posición & $\mathrm{N}$ & I & B & $\mathrm{N}$ & B & $\mathrm{N}$ & 1 & B & $\mathrm{N}$ & 1 & B & $\mathrm{N}$ & 1 & B & $\mathrm{N}$ & 1 & B & $\mathrm{N}$ & $\mathrm{N}$ & N \\
\hline
\end{tabular}

\%wt

$\mathrm{TiO} 2$

$\mathrm{Al} 2 \mathrm{O} 3$

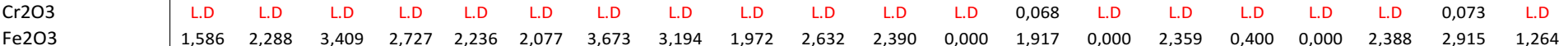

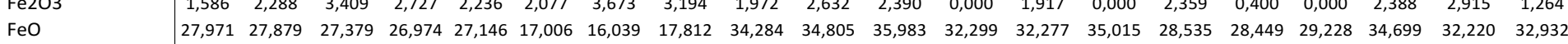

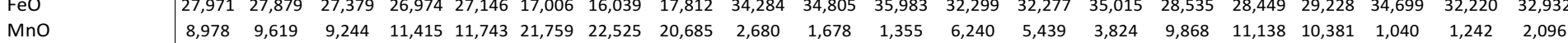

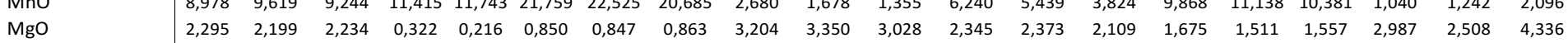

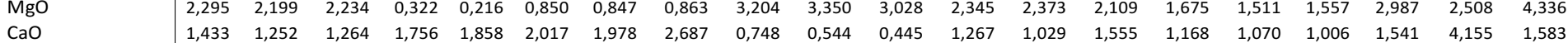

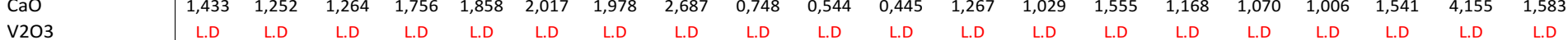

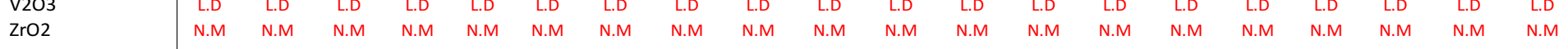

$\begin{array}{lllllllllllllllllllll}\text { L.D } & \text { L.D } & 0,113 & 0,086 & \text { L.D } & \text { L.D } & \text { L.D } & \text { L.D } & \text { L.D } & \text { L.D } & \text { L.D } & \text { L.D } & \text { L.D } & \text { L.D } & \text { L.D } & \text { L.D } & \text { L.D } & 0,131 & \text { L.D } & 0,088\end{array}$

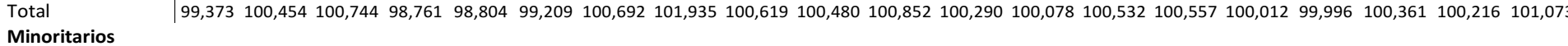

\begin{tabular}{l|llllllllllllllllllll} 
Nb205 & N.M & N.M & N.M & N.M & N.M & N.M & N.M & N.M & N.M & N.M & N.M & N.M & N.M & N.M & N.M & N.M & N.M & N.M & N.M & N.M
\end{tabular}

\begin{tabular}{l|llllllllllllllllllll} 
Ta205 & N.M & N.M & N.M & N.M & N.M & N.M & N.M & N.M & N.M & N.M & N.M & N.M & N.M & N.M & N.M & N.M & N.M & N.M & N.M & N.M
\end{tabular}

\begin{tabular}{l|llllllllllllllllllll}
$\mathrm{NiO}$ & L.D & L.D & L.D & L.D & L.D & L.D & L.D & L.D & L.D & L.D & L.D & L.D & L.D & L.D & L.D & L.D & L.D & L.D & L.D & L.D \\
LnO & L.D & L.D & L.D & L.D & L. & L.D & L.D & L.D & L.D & L.D & L.D & L.D & L.D & L.D & L.D & L.D & L.D & L.D & L.D & L.D
\end{tabular}

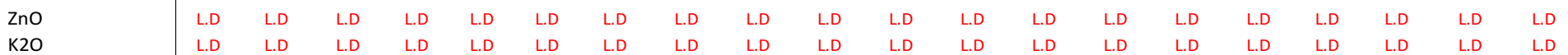

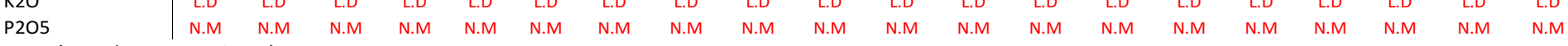

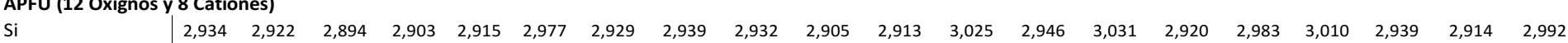

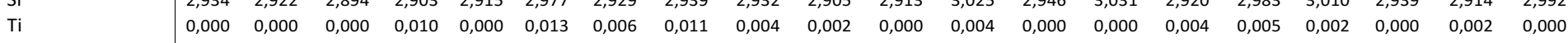
\begin{tabular}{l|llllllllllllllllllll} 
Al & 2,035 & 2,017 & 2,022 & 2,017 & 2,029 & 1,891 & 1,903 & 1,907 & 2,009 & 2,026 & 2,030 & 1,968 & 1,986 & 1,953 & 2,008 & 1,999 & 2,002 & 1,998 & 1,986 & 1,954
\end{tabular}

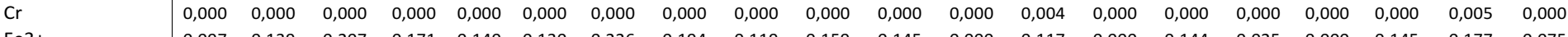
\begin{tabular}{l|lllllllllllllllllllll} 
Fe3+ & 0,097 & 0,139 & 0,207 & 0,171 & 0,140 & 0,130 & 0,226 & 0,194 & 0,119 & 0,159 & 0,145 & 0,000 & 0,117 & 0,000 & 0,144 & 0,025 & 0,000 & 0,145 & 0,177 & 0,075 \\
\hline
\end{tabular}

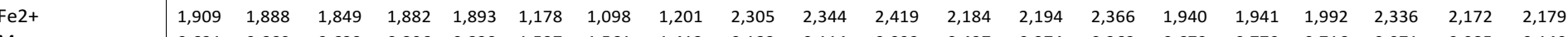
\begin{tabular}{l|llllllllllllllllllll}
$M n$ & 0,621 & 0,660 & 0,632 & 0,806 & 0,829 & 1,527 & 1,561 & 1,413 & 0,183 & 0,114 & 0,092 & 0,427 & 0,374 & 0,262 & 0,679 & 0,770 & 0,716 & 0,071 & 0,085 & 0,140 \\
\hline
\end{tabular} \begin{tabular}{l|lllllllllllllllllllllll}
$\mathrm{Mg}$ & 0,279 & 0,265 & 0,269 & 0,040 & 0,027 & 0,105 & 0,103 & 0,104 & 0,384 & 0,402 & 0,363 & 0,283 & 0,288 & 0,254 & 0,203 & 0,184 & 0,189 & 0,358 & 0,301 & 0,511 \\
$\mathrm{Ca}$ & 0,125 & 0,109 & 0,109 & 0,157 & 0,166 & 0,179 & 0,173 & 0,232 & 0,064 & 0,047 & 0,038 & 0,110 & 0,090 & 0,135 & 0,102 & 0,094 & 0,088 & 0,133 & 0,359 & 0,134
\end{tabular} $\begin{array}{llllllllllllllllllllllllll}\mathrm{Ca} & & 0,125 & 0,109 & 0,109 & 0,157 & 0,166 & 0,179 & 0,173 & 0,232 & 0,064 & 0,047 & 0,038 & 0,110 & 0,090 & 0,135 & 0,102 & 0,094 & 0,088 & 0,133 & 0,359 & 0,134 \\ \mathrm{~V} & 0,00 & 0,000 & 0,000 & 0,00 & 0,00 & 0,00 & 0,00 & 0,000 & 0,000 & 0,000 & 0,000 & 0,000 & 0,000 & 0,000 & 0,000 & 0,000 & 0,000 & 0,000 & 0,000 & 0,000\end{array}$

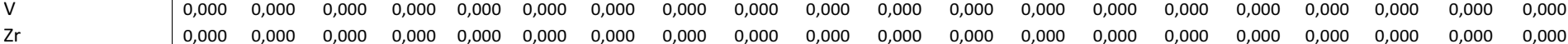

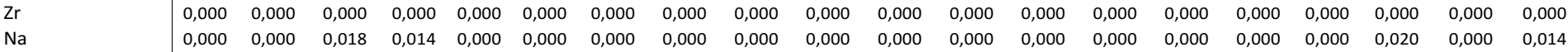
$\begin{array}{llllllllllllllllllll}0,000 & 0,000 & 0,018 & 0,014 & 0,000 & 0,000 & 0,000 & 0,000 & 0,000 & 0,000 & 0,000 & 0,000 & 0,000 & 0,000 & 0,000 & 0,000 & 0,000 & 0,020 & 0,000 & 0,014 \\ 8,000 & 8,000 & 8,000 & 8,000 & 8,000 & 8,000 & 8,000 & 8,000 & 8,000 & 8,000 & 8,000 & 8,000 & 8,000 & 8,000 & 8,000 & 8,000 & 8,000 & 8,000 & 8,000 & 8,000\end{array}$ Miembros extremos

Sps

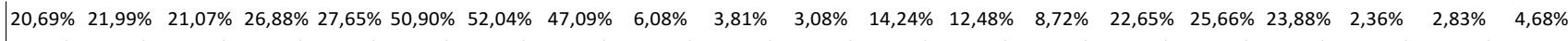

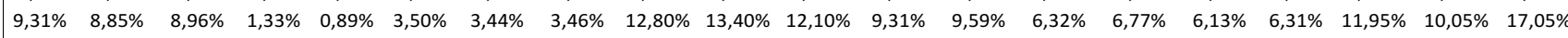
$\begin{array}{llllllllllllllllllll}63,63 \% & 62,93 \% & 61,62 \% & 62,72 \% & 63,10 \% & 39,01 \% & 36,12 \% & 40,04 \% & 76,84 \% & 78,12 \% & 80,65 \% & 72,79 \% & 73,14 \% & 78,86 \% & 64,66 \% & 64,70 \% & 66,40 \% & 77,86 \% & 72,39 \% & 72,63 \%\end{array}$

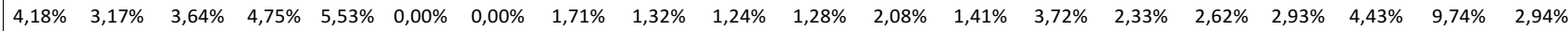

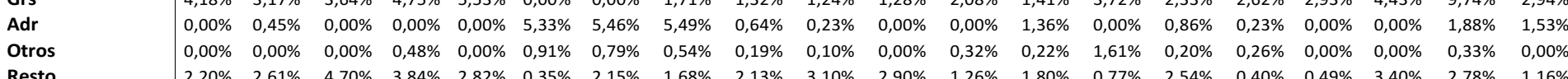

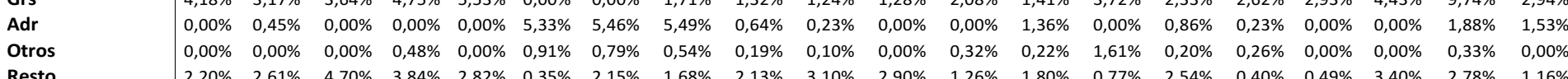




\begin{tabular}{|c|c|c|c|c|c|c|c|c|c|c|c|c|c|c|c|c|c|c|c|}
\hline \multirow{2}{*}{$\begin{array}{l}\text { no análisis } \\
\text { Subambiente } \\
\text { Localización } \\
\text { Posición }\end{array}$} & \multirow{2}{*}{\begin{tabular}{|c|}
1 \\
Playa \\
*La Espiga \\
N \\
A450 \\
\end{tabular}} & \multirow{2}{*}{\begin{tabular}{|c|}
1 \\
Playa \\
*La Espiga \\
N \\
A451 \\
\end{tabular}} & \multicolumn{3}{|c|}{$\begin{array}{c}1 \\
\text { Playa } \\
\text { *La Espiga }\end{array}$} & \multirow{2}{*}{\begin{tabular}{|c|}
1 \\
Playa \\
*La Espiga \\
N \\
A455 \\
\end{tabular}} & \multicolumn{2}{|c|}{\begin{tabular}{|cc}
1 & 2 \\
Playa & Playa \\
*La Espiga
\end{tabular}} & \multicolumn{3}{|c|}{$\begin{array}{cc}1 & 1 \\
& \text { Playa } \\
& \text { *El Páramo }\end{array}$} & \multirow{2}{*}{\begin{tabular}{|c|c|}
1 \\
Playa \\
*EI Páramo \\
$\mathrm{N}$ \\
$\mathrm{CG4}$ \\
\end{tabular}} & \multicolumn{2}{|c|}{$\begin{array}{l}1 \text { Playa } \\
\text { *El Páramo } \\
{ }^{2}\end{array}$} & \multicolumn{2}{|c|}{\begin{tabular}{l}
1 \\
\multicolumn{1}{c}{ Playa } \\
${ }_{*}$ El Páramo
\end{tabular}} & \multicolumn{3}{|c|}{$\begin{array}{cc}1 & 1 \\
& \text { Playa } \\
& * E \mid\end{array}$} \\
\hline & & & $\underset{A 452}{N}$ & $\begin{array}{c}1 \\
\text { A453 }\end{array}$ & $\begin{array}{c}\text { B } \\
\text { A454 }\end{array}$ & & $\begin{array}{c}N \\
\text { A461 }\end{array}$ & $\begin{array}{c}\text { B } \\
\text { A462-63 }\end{array}$ & $\begin{array}{c}\text { B } \\
\text { CG1 }\end{array}$ & $\begin{array}{l}1 \\
\text { CG2 }\end{array}$ & $\begin{array}{c}\mathrm{N} \\
\mathrm{CG3}\end{array}$ & & $\stackrel{N}{\mathrm{~N}}$ & $\begin{array}{c}\text { B } \\
\text { CG2 }\end{array}$ & $\begin{array}{c}\text { B } \\
\text { CG3 }\end{array}$ & $\begin{array}{c}N \\
\text { CG8 }\end{array}$ & $\begin{array}{c}\text { B } \\
\text { CG11 }\end{array}$ & $\begin{array}{c}\mathrm{N} \\
\mathrm{CG} 12\end{array}$ & $\begin{array}{c}1 \\
\text { CG13 }\end{array}$ \\
\hline \multicolumn{20}{|l|}{ \%wt } \\
\hline $\mathrm{SiO} 2$ & 5,610 & 36,767 & 36,149 & 36,197 & 36,395 & 37,355 & 36,866 & 36,990 & 36,110 & 36,292 & 36,557 & 36,013 & 6,422 & 36,614 & 36,412 & 36,526 & 37,171 & 36,876 & 36,544 \\
\hline TiO2 & & 0,038 & L.D & L.D & L.D & 049 & 0,298 & 0,320 & 0,040 & L.D & L.D & 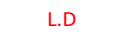 & 0,045 & 0,042 & 0,010 & L.D & L.D & L.D & L.D \\
\hline $\mathrm{Al} 2 \mathrm{O} 3$ & 21,177 & 20,843 & 21,308 & 21,430 & 20,874 & 20,646 & 20,497 & 20,535 & 19,629 & 19,657 & 19,870 & 20,688 & 21,081 & 21,054 & 20,883 & 21,205 & 21,576 & 20,988 & 21,142 \\
\hline r203 & 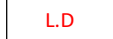 & L.D & L.D & L.D & L.D & L.D & L.D & L.D & L.D & 0,014 & 0,024 & L.D & 0,042 & 0,035 & 0,021 & L.D & L.D & 0,017 & L.D \\
\hline $\mathrm{Fe} 2 \mathrm{O} 3$ & 0,646 & 2,820 & 2,353 & 2,736 & 2,727 & 0,000 & 1,864 & 1,823 & 3,748 & 3,080 & 2,011 & 1,844 & 1,170 & 1,914 & 1,483 & 0,608 & 1,583 & 1,554 & 2,030 \\
\hline $\mathrm{FeO}$ & 27,445 & 35,819 & 29,898 & 30,228 & 30,877 & 32,575 & 30,801 & 30,862 & 18,950 & 18,841 & 19,143 & 22,812 & 29,556 & 29,636 & 30,651 & 29,251 & 33,741 & 33,173 & 32,753 \\
\hline $\mathrm{MnO}$ & 11,917 & 0,452 & 5,645 & 5,798 & 5,840 & 6,263 & 3,350 & 3,329 & 11,206 & 11,719 & 12,818 & 13,211 & 9,520 & 9,637 & 7,963 & 10,191 & 4,067 & 4,540 & 4,387 \\
\hline $\mathrm{MgO}$ & 1,724 & 2,298 & 3,063 & 3,171 & 2,982 & 2,448 & 3,216 & 3,235 & 0,516 & 0,583 & 0,532 & 0,438 & 1,531 & 1,543 & 1,903 & 1,222 & 2,368 & 2,402 & 2,412 \\
\hline $\mathrm{CaO}$ & & 2,299 & 1,677 & 1,193 & 1,101 & 1,051 & 3,454 & 3,525 & 9,362 & 9,090 & 8,304 & ,753 & 1,299 & 1,305 & 1,124 & 1,502 & 1,846 & 1,593 & 1,718 \\
\hline 203 & & 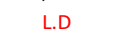 & 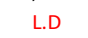 & L.D & L.D & L.D & L.D & L.D & N.M & N.M & N.M & N.M & N.M & N.M & N.M & N.M & N.M & N.M & N.M \\
\hline $\mathrm{ZrO2}$ & & & & N.M & N.M & N.I & N.M & & & N.M & & & M & M & M & N.M & M & M & M \\
\hline $\mathrm{Na} 2 \mathrm{O}$ & L.D & 0,147 & L.D & L.D & D & L.D & L.D & L.D & $M$ & N.M & $\mathrm{M}$ & & N.M & N.M & N.M & N.M & I.M & N.M & $M$ \\
\hline Tota & 00,59 & 101,482 & 100,093 & 100,753 & 100,795 & 100,387 & 100,345 & 100,618 & 99,561 & 99,276 & 99,259 & 99,759 & 100,666 & 101,780 & 100,449 & 100,505 & 02,353 & 01,143 & 80 \\
\hline \multicolumn{20}{|l|}{ Minoritarios } \\
\hline $\mathrm{Nb205}$ & $\mathrm{N}$ & N.M & N.M & N.M & N.M & N.M & N.M & N.M & M & N.M & N.M & N.M & N.M & N.M & N.M & N.M & N.M & N.M & N.M \\
\hline Ta20 & & & $N$ & $N$ & & & & & & & & & & & & & & & M \\
\hline $\mathrm{NiO}$ & & L.D & L.D & L.C & L.D & & L.D & & M & M & & & M & M & M & M & M & M & M \\
\hline $\mathrm{ZnO}$ & & & L. & L.D & & & & & & & & & & & & & M & M & M \\
\hline $\mathrm{K} 2 \mathrm{O}$ & & L. & 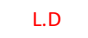 & L.D & & & L.D & & & N.M & & & M & 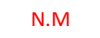 & M & M & M & M & M \\
\hline P2O5 & & & & & & & & & & N.M & & & n. & 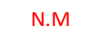 & M & M & M & M & M \\
\hline \multicolumn{20}{|l|}{ APFU (12 Oxígn } \\
\hline $\mathrm{Si}$ & 2,964 & 2,942 & & 2,904 & & & 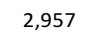 & & 41 & 60 & 2,982 & 946 & 953 & 2,942 & 2,955 & 2,967 & ,945 & ,960 & 2,937 \\
\hline & & & & & & & & & & 0,000 & & & & 0,003 & 001 & 0,000 & 000 & 00 & 0,000 \\
\hline $\mathrm{Al}$ & 2 & 65 & 2,026 & 2,026 & 1 & 1, & 38 & 55 & 84 & 1,890 & 1,910 & 1,995 & 014 & 1,994 & 1,997 & 2,030 & 2,015 & 1,985 & 2,003 \\
\hline & & & & & & & & & & 0,001 & & & 03 & 0,002 & 01 & 0,000 & 000 & 01 & 0,000 \\
\hline $\mathrm{Fe} 3$ & & & & & & & 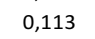 & & & 0 , & 0,1 & & 71 & 0,116 & 91 & 0,037 & 094 & 94 & 0,123 \\
\hline $\mathrm{Fe} 2+$ & & 2 & & & & & 56 & & & 1,285 & 1, & & 04 & 1, & 080 & 1,987 & 36 & 27 & 2,202 \\
\hline $\mathrm{Mn}$ & & & & & & & 28 & & & $0, \varepsilon$ & 0,8 & & 54 & 0,656 & 0,547 & 0,701 & 0,273 & 0,309 & 0,299 \\
\hline $\mathrm{Mg}$ & & & & & & & 84 & & 53 & 0,071 & 0,0 & 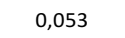 & 35 & 0,185 & 0,230 & 0 &, 280 & 87 & 0,289 \\
\hline $\mathrm{Ca}$ & & & & & & & & & & 0,7 & & & 3 & 0,112 & 0,098 & 0,1 & (1) & 37 & 0,148 \\
\hline $\mathrm{v}$ & & & & & & & & & & 0,000 & & & ,000 & 0,000 & 0,000 & , ,000 & , ,000 & 0,000 & 0,000 \\
\hline z & & & & & & & & & & & & & & & & 0,000 & 0,000 & 0,000 & 0,000 \\
\hline $\mathrm{Na}$ & & & & & & & & & & & & & & 0,000 & 0,000 & 0,000 & ,000 & 0,000 & 0,000 \\
\hline Sum & 8,000 & 8,000 & 8,000 & 8,000 & 8,000 & & 000 & 8,000 & 8,000 & 8,000 & 8,000 & 000 & 8,000 & 8,000 & 8,000 & 8,000 & 8,000 & 8,000 & 8,000 \\
\hline \multicolumn{20}{|l|}{ Miembros extr } \\
\hline Sps & 27,24 & $1,02 \%$ & $86 \%$ & $13,13 \%$ & $13,27 \%$ & 17 & to & & $25,77 \%$ & $26,99 \%$ & $29,52 \%$ & $30,51 \%$ & $21,79 \%$ & $86 \%$ & $18,24 \%$ & ,37\% & $9,10 \%$ & $10,29 \%$ &, $96 \%$ \\
\hline Prp & & & $12,28 \%$ & $12,64 \%$ & $11,92 \%$ & & & & $2,09 \%$ & $2,36 \%$ & $2,16 \%$ & 1,78 & $6,17 \%$ & $6,16 \%$ & $7,67 \%$ & $4,93 \%$ & $9,32 \%$ & $9,58 \%$ & $9,63 \%$ \\
\hline Alm & $61,95 \%$ & $79,89 \%$ & $67,23 \%$ & $67,61 \%$ & $69,25 \%$ & $73,34 \%$ & $68,87 \%$ & $68,80 \%$ & $43,02 \%$ & $42,84 \%$ & $43,53 \%$ & $52,02 \%$ & $66,80 \%$ & $66,38 \%$ & $69,34 \%$ & $66,23 \%$ & $74,53 \%$ & $74,23 \%$ & $73,39 \%$ \\
\hline Grs & $2,59 \%$ & $5,30 \%$ & $4,71 \%$ & $3,14 \%$ & $0,92 \%$ & $2,45 \%$ & $5,46 \%$ & $5,50 \%$ & $20,36 \%$ & $20,30 \%$ & $19,42 \%$ & 12 & $3,49 \%$ & $2,37 \%$ & $2,35 \%$ & $4,36 \%$ & $5,06 \%$ & $3,17 \%$ & $4,02 \%$ \\
\hline Adr & & $1,15 \%$ & $0,12 \%$ & $0,28 \%$ & $2,25 \%$ & & $3,54 \%$ & $3,60 \%$ & $6,75 \%$ & $6,14 \%$ & $4,70 \%$ & 1,17 & $0,00 \%$ & $1,14 \%$ & $0,81 \%$ &, $00 \%$ & $17 \%$ & ,34\% & $91 \%$ \\
\hline Otra & $0,26 \%$ & $0,11 \%$ & 0,00\% & 0,00\% & 0,00\% & $1,40 \%$ & 0,90\% & 0,96\% & $0,12 \%$ & $0,05 \%$ & $0,08 \%$ & $00 \%$ &, $27 \%$ & $0,24 \%$ & $0,10 \%$ & $0,00 \%$ & ,00\% & $05 \%$ & $00 \%$ \\
\hline Resto & $1,01 \%$ & $3,39 \%$ & $2,81 \%$ & $3,19 \%$ & $2,40 \%$ & $0,28 \%$ & $0,84 \%$ & $0,75 \%$ & $1,89 \%$ & $1,33 \%$ & $0,59 \%$ & $1,80 \%$ & $1,47 \%$ & $1,86 \%$ & $1,49 \%$ & $1,11 \%$ & $1,82 \%$ & $1,34 \%$ & $2,09 \%$ \\
\hline
\end{tabular}

A. 14. Continuación. 
Tesis Doctoral Luis Santamaría Torres

\begin{tabular}{|c|c|c|c|c|c|c|c|c|c|c|c|c|c|c|c|c|c|}
\hline \multirow{2}{*}{$\begin{array}{l}\text { no análisis } \\
\text { Subambiente } \\
\text { Localización } \\
\text { Posición }\end{array}$} & \multicolumn{3}{|c|}{$\begin{array}{ccc}1 & 1 & 1 \\
& \text { Playa } \\
& \text { *El Páramo } & \end{array}$} & \multicolumn{3}{|c|}{$\begin{array}{ccc}1 & 1 \\
& 1 & 1 \\
& \text { Playa } \\
& \text { *El Páramo } & \end{array}$} & \multicolumn{2}{|c|}{$\begin{array}{l}1 \text { Playa } \\
\text { PEl Páramo } \\
*^{2}\end{array}$} & \multirow{2}{*}{\begin{tabular}{|c|c|}
1 \\
Playa \\
*El Páramo \\
N \\
BR.1
\end{tabular}} & \multirow{2}{*}{$\begin{array}{c}1 \\
\text { Playa } \\
\text { *El Páramo } \\
\text { N } \\
\text { BR.2 } \\
\end{array}$} & \multirow{2}{*}{\begin{tabular}{|c|}
1 \\
Playa \\
*El Páramo \\
N \\
BR.3 \\
\end{tabular}} & \multirow{2}{*}{\begin{tabular}{|c|}
1 \\
Playa \\
*EI Páramo \\
N \\
BR.5 \\
\end{tabular}} & \multirow{2}{*}{\begin{tabular}{|c|}
1 \\
Playa \\
*El Páramo \\
N \\
BR.28 \\
\end{tabular}} & \multirow{2}{*}{$\begin{array}{c}2 \\
\text { Playa } \\
\text { *El Páramo } \\
\mathrm{N} \\
\text { BR29 } \\
\end{array}$} & \multirow{2}{*}{$\begin{array}{c}1 \\
\text { Playa } \\
\text { *El Páramo } \\
\text { N } \\
\text { BR.46 } \\
\end{array}$} & \multirow{2}{*}{\begin{tabular}{|c|}
1 \\
Playa \\
*El Páramo \\
N \\
BR.48 \\
\end{tabular}} & \multirow{2}{*}{$\begin{array}{c}1 \\
\text { Playa } \\
\text { *El Páramo } \\
\text { N } \\
\text { BR.52 }\end{array}$} \\
\hline & $\underset{\mathrm{CG} 14}{\mathrm{~N}}$ & $\begin{array}{c}\text { I } \\
\text { CG15 }\end{array}$ & $\begin{array}{c}\text { B } \\
\text { CG16 }\end{array}$ & $\begin{array}{c}1 \\
\text { CG17 }\end{array}$ & $\begin{array}{c}\text { B } \\
\text { CG18 }\end{array}$ & $\begin{array}{c}\mathrm{N} \\
\text { CG19 }\end{array}$ & $\begin{array}{c}\text { B } \\
\text { CG20 }\end{array}$ & $\begin{array}{c}\mathrm{N} \\
\mathrm{CG} 21\end{array}$ & & & & & & & & & \\
\hline \multicolumn{18}{|l|}{ \%wt } \\
\hline $\mathrm{SiO} 2$ & | 36,172 & 36,699 & 36,534 & 36,737 & 36,359 & 36,678 & 36,501 & 36,502 & 36,120 & 36,460 & 35,660 & 37,130 & 36,070 & 36,395 & 35,720 & 36,790 & 36,870 \\
\hline TiO2 & L.D & L.D & L.D & L.D & L.D & L.D & L.D & 0,016 & 0,056 & L.D & 0,094 & 0,204 & L.D & L.D & 0,043 & 0,060 & 0,036 \\
\hline $\mathrm{Al} 2 \mathrm{O} 3$ & 20,815 & 21,129 & 21,099 & 20,891 & 20,905 & 21,111 & 20,928 & 20,818 & 20,270 & 20,180 & 20,050 & 20,820 & 20,400 & 20,680 & 20,890 & 20,840 & 20,880 \\
\hline $\mathrm{Cr} 2 \mathrm{O} 3$ & 0,023 & L.D & L.D & 0,058 & 0,041 & 0,102 & L.D & L.D & L.D & L.D & L.D & L.D & L.D & L.D & L.D & L.D & L.D \\
\hline $\mathrm{Fe} 2 \mathrm{O} 3$ & 2,128 & 1,251 & 1,576 & 1,242 & 2,411 & 2,771 & 1,352 & 1,550 & 2,851 & 1,904 & 3,394 & 0,869 & 2,606 & 1,875 & 2,664 & 1,332 & 1,429 \\
\hline $\mathrm{FeO}$ & 29,794 & 30,564 & 30,136 & 28,813 & 28,128 & 28,633 & 28,363 & 28,613 & 32,574 & 33,377 & 26,366 & 33,148 & 29,615 & 30,613 & 31,753 & 33,972 & 31,674 \\
\hline $\mathrm{MnO}$ & 8,612 & 8,245 & 8,560 & 8,529 & 8,733 & 8,901 & 10,881 & 10,620 & 3,100 & 3,080 & 10,070 & 3,500 & 7,640 & 7,290 & 6,290 & 3,540 & 4,040 \\
\hline $\mathrm{MgO}$ & 1,656 & 1,719 & 1,718 & 2,932 & 2,904 & 2,801 & 1,527 & 1,525 & 3,420 & 3,270 & 2,190 & 3,520 & 1,382 & 1,890 & 2,070 & 2,680 & 2,750 \\
\hline $\mathrm{CaO}$ & 1,392 & 1,486 & 1,418 & 0,976 & 1,035 & 0,949 & 1,202 & 1,228 & 0,990 & 0,992 & 1,650 & 1,261 & 2,460 & 1,560 & 0,731 & 1,335 & 2,530 \\
\hline V2O3 & N.M & N.M & N.M & N.M & N.M & N.M & N.M & N.M & L.D & L.D & 0,034 & L.D & L.D & L.D & L.D & L.D & L.D \\
\hline $\mathrm{ZrO2}$ & N.M & N.M & N.M & N.M & N.M & N.M & N.M & N.M & L.D & L.D & 0,059 & L.D & 0,061 & L.D & L.D & L.D & L.D \\
\hline $\mathrm{Na} 2 \mathrm{O}$ & N.M & N.M & N.M & N.M & N.M & N.M & N.M & N.M & 0,035 & L.D & 0,038 & L.D & 0,043 & 0,033 & L.D & L.D & 0,045 \\
\hline Total & 100,592 & 101,092 & 101,041 & 100,177 & 100,516 & 101,947 & 100,754 & 100,872 & 99,416 & 99,263 & 99,604 & 100,455 & 100,277 & 100,336 & 100,161 & 100,549 & 100,255 \\
\hline \multicolumn{18}{|c|}{ 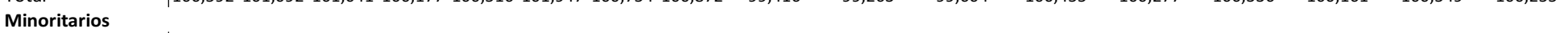 } \\
\hline $\mathrm{Nb} 2 \mathrm{O} 5$ & N.M & N.M & N.M & N.M & N.M & N.M & N.M & N.M & N.M & N.M & N.M & N.M & N.M & N.M & N.M & N.M & N.M \\
\hline Ta2O5 & N.M & N.M & N.M & N.M & N.M & N.M & N.M & N.M & N.M & N.M & N.M & N.M & N.M & N.M & N.M & N.M & N.M \\
\hline $\mathrm{NiO}$ & N.M & N.M & N.M & N.M & N.M & N.M & N.M & N.M & L.D & L.D & L.D & L.D & L.D & L.D & 0,03 & L.D & L.D \\
\hline $\mathrm{ZnO}$ & N.M & N.M & N.M & N.M & N.M & N.M & N.M & N.M & N.M & N.M & N.M & N.M & N.M & N.M & N.M & N.M & N.M \\
\hline K2O & N.M & N.M & N.M & N.M & N.M & N.M & N.M & N.M & L.D & L.D & L.D & L.D & L.D & 0,01 & 0,01 & 0,01 & 0,01 \\
\hline P2O5 & N.M & N.M & N.M & N.M & N.M & N.M & N.M & N.M & N.M & N.M & N.M & N.M & N.M & N.M & N.M & N.M & N.M \\
\hline \multicolumn{18}{|c|}{ APFU (12 Oxígnos y 8 Cationes) } \\
\hline $\mathrm{Si}$ & $\mid 2,938$ & 2,958 & 2,949 & 2,966 & 2,932 & 2,922 & 2,959 & 2,958 & 2,940 & 2,972 & 2,921 & 2,977 & 2,941 & 2,956 & 2,912 & 2,966 & 2,968 \\
\hline $\mathrm{Ti}$ & 0,000 & 0,000 & 0,000 & 0,000 & 0,000 & 0,000 & 0,000 & 0,001 & 0,003 & 0,000 & 0,006 & 0,012 & 0,000 & 0,000 & 0,003 & 0,004 & 0,002 \\
\hline Al & 1,993 & 2,007 & 2,007 & 1,988 & 1,987 & 1,982 & 2,000 & 1,988 & 1,944 & 1,939 & 1,936 & 1,968 & 1,960 & 1,979 & 2,007 & 1,980 & 1,981 \\
\hline $\mathrm{Cr}$ & 0,001 & 0,000 & 0,000 & 0,004 & 0,003 & 0,006 & 0,000 & 0,000 & 0,000 & 0,000 & 0,000 & 0,000 & 0,000 & 0,000 & 0,000 & 0,000 & 0,000 \\
\hline $\mathrm{Fe} 3+$ & 0,130 & 0,076 & 0,096 & 0,075 & 0,146 & 0,166 & 0,082 & 0,095 & 0,175 & 0,117 & 0,209 & 0,052 & 0,160 & 0,115 & 0,163 & 0,081 & 0,087 \\
\hline $\mathrm{Fe} 2+$ & 2,024 & 2,060 & 2,034 & 1,946 & 1,897 & 1,908 & 1,923 & 1,939 & 2,217 & 2,275 & 1,806 & 2,223 & 2,019 & 2,079 & 2,165 & 2,290 & 2,132 \\
\hline $\mathrm{Mn}$ & 0,592 & 0,563 & 0,585 & 0,583 & 0,597 & 0,601 & 0,747 & 0,729 & 0,214 & 0,213 & 0,699 & 0,238 & 0,528 & 0,501 & 0,434 & 0,242 & 0,275 \\
\hline $\mathrm{Mg}$ & 0,201 & 0,207 & 0,207 & 0,353 & 0,349 & 0,333 & 0,185 & 0,184 & 0,415 & 0,397 & 0,267 & 0,421 & 0,168 & 0,229 & 0,252 & 0,322 & 0,330 \\
\hline $\mathrm{Ca}$ & 0,121 & 0,128 & 0,123 & 0,084 & 0,089 & 0,081 & 0,104 & 0,107 & 0,086 & 0,087 & 0,145 & 0,108 & 0,215 & 0,136 & 0,064 & 0,115 & 0,218 \\
\hline $\mathrm{v}$ & 0,000 & 0,000 & 0,000 & 0,000 & 0,000 & 0,000 & 0,000 & 0,000 & 0,000 & 0,000 & 0,002 & 0,000 & 0,000 & 0,000 & 0,000 & 0,000 & 0,000 \\
\hline $\mathrm{zr}$ & 0,000 & 0,000 & 0,000 & 0,000 & 0,000 & 0,000 & 0,000 & 0,000 & 0,000 & 0,000 & 0,002 & 0,000 & 0,002 & 0,000 & 0,000 & 0,000 & 0,000 \\
\hline $\mathrm{Na}$ & 0,000 & 0,000 & 0,000 & 0,000 & 0,000 & 0,000 & 0,000 & 0,000 & 0,006 & 0,000 & 0,006 & 0,000 & 0,007 & 0,005 & 0,000 & 0,000 & 0,007 \\
\hline Suma & 8,000 & 8,000 & 8,000 & 8,000 & 8,000 & 8,000 & 8,000 & 8,000 & 8,000 & 8,000 & 8,000 & 8,000 & 8,000 & 8,000 & 8,000 & 8,000 & 8,000 \\
\hline \multicolumn{18}{|l|}{ Miembros extre } \\
\hline Sps & $\mid 19,75 \%$ & $18,77 \%$ & $19,51 \%$ & $19,44 \%$ & $19,88 \%$ & $20,02 \%$ & $24,90 \%$ & $24,30 \%$ & $7,12 \%$ & $7,09 \%$ & $23,29 \%$ & $7,92 \%$ & $17,59 \%$ & $16,71 \%$ & $14,48 \%$ & $8,06 \%$ & $9,18 \%$ \\
\hline Prp & 6,68\% & $6,89 \%$ & $6,89 \%$ & $11,76 \%$ & $11,64 \%$ & $11,09 \%$ & $6,15 \%$ & $6,14 \%$ & $13,83 \%$ & $13,25 \%$ & $8,91 \%$ & $14,03 \%$ & $5,60 \%$ & $7,63 \%$ & $8,39 \%$ & $10,74 \%$ & $11,00 \%$ \\
\hline Alm & $67,46 \%$ & $68,68 \%$ & $67,80 \%$ & $64,86 \%$ & $63,23 \%$ & $63,60 \%$ & $64,10 \%$ & $64,63 \%$ & $73,25 \%$ & $75,22 \%$ & $60,21 \%$ & $74,10 \%$ & $67,31 \%$ & $69,30 \%$ & $72,16 \%$ & $76,35 \%$ & $71,07 \%$ \\
\hline Grs & $2,63 \%$ & $3,95 \%$ & $3,58 \%$ & $1,66 \%$ & $1,19 \%$ & $0,53 \%$ & $2,77 \%$ & $2,22 \%$ & $0,00 \%$ & $0,00 \%$ & $0,44 \%$ & $1,21 \%$ & $4,56 \%$ & $3,10 \%$ & $0,93 \%$ & $2,16 \%$ & $6,17 \%$ \\
\hline Adr & $1,33 \%$ & $0,32 \%$ & $0,51 \%$ & $0,97 \%$ & $1,66 \%$ & $1,85 \%$ & $0,71 \%$ & $1,28 \%$ & $2,71 \%$ & $2,89 \%$ & $3,87 \%$ & $1,78 \%$ & $2,48 \%$ & $1,42 \%$ & $1,06 \%$ & $1,50 \%$ & $0,99 \%$ \\
\hline Otros & $0,07 \%$ & $0,00 \%$ & $0,00 \%$ & $0,19 \%$ & $0,13 \%$ & $0,32 \%$ & $0,00 \%$ & $0,05 \%$ & $0,82 \%$ & $0,63 \%$ & $0,52 \%$ & $0,62 \%$ & $0,12 \%$ & $0,00 \%$ & $0,13 \%$ & $0,18 \%$ & $0,11 \%$ \\
\hline Resto & $\%$ & $1,39 \%$ & $1,71 \%$ & 1,12\% & 2,26\% & $2,58 \%$ & $1,37 \%$ & $1,38 \%$ & $2,26 \%$ & $\%$ & $2,75 \%$ & 0,34\% & $2,34 \%$ & $\%$ & $2,84 \%$ & $1,01 \%$ & $1,48 \%$ \\
\hline
\end{tabular}

A.15. Continuación. 
Tesis Doctoral Luis Santamaría Torres

\begin{tabular}{|c|c|c|c|c|c|c|c|c|c|c|c|c|c|c|c|c|c|}
\hline $\begin{array}{l}\text { no análisis } \\
\text { Subambiente } \\
\text { Localización } \\
\text { Posición } \\
\text { Nombre }\end{array}$ & \begin{tabular}{|c|}
$\mathbf{1}$ \\
Playa \\
*El Páramo \\
$\mathbf{N}$ \\
BR.53 \\
\end{tabular} & \begin{tabular}{|c|}
1 \\
Playa \\
*El Páramo \\
N \\
BR.60 \\
\end{tabular} & \begin{tabular}{|c|}
1 \\
Playa \\
*EI Páramo \\
N \\
BR.68 \\
\end{tabular} & \begin{tabular}{|c|}
1 \\
Playa \\
*EI Páramo \\
$\mathrm{N}$ \\
BR.73 \\
\end{tabular} & \begin{tabular}{|c|}
1 \\
Playa \\
* La Espiga \\
$\mathrm{N}$ \\
$\mathrm{BR} .83$ \\
\end{tabular} & \begin{tabular}{|c|}
1 \\
Playa \\
*La Espiga \\
$\mathrm{N}$ \\
BR.86 \\
\end{tabular} & \begin{tabular}{|c} 
\\
Playa \\
*La Es \\
N \\
BR.95 \\
\end{tabular} & \begin{tabular}{|c|}
2 \\
Playa \\
Espiga \\
B \\
BR.96 \\
\end{tabular} & \begin{tabular}{|c|}
1 \\
Playa \\
*La Espiga \\
N \\
BR.107 \\
\end{tabular} & \begin{tabular}{|c|}
1 \\
Playa \\
*La Espiga \\
$\mathrm{N}$ \\
BR.108 \\
\end{tabular} & \begin{tabular}{|c|}
1 \\
Playa \\
*La Espiga \\
N \\
BR.110 \\
\end{tabular} & \begin{tabular}{|c|}
1 \\
Playa \\
*La Espiga \\
N \\
BR.115 \\
\end{tabular} & \begin{tabular}{|c|}
1 \\
Playa \\
*La Espiga \\
N \\
BR.116 \\
\end{tabular} & \begin{tabular}{|c|}
1 \\
Playa \\
*La Espiga \\
$\mathrm{N}$ \\
BR.130 \\
\end{tabular} & \begin{tabular}{|c|}
1 \\
Playa \\
*La Espiga \\
N \\
BR.146 \\
\end{tabular} & \begin{tabular}{|c|}
1 \\
Playa \\
*La Espiga \\
N \\
BR.147 \\
\end{tabular} & \begin{tabular}{|c}
1 \\
Playa \\
*La Espiga \\
N \\
BR.149 \\
\end{tabular} \\
\hline $\mathrm{SiO} 2$ & 35,210 & 37,080 & 36,790 & 36,450 & 35,460 & 35,790 & 36,440 & 36,490 & 35,590 & 35,460 & 35,610 & 35,040 & 36,160 & 36,060 & 35,970 & 35,990 & 33,870 \\
\hline TiO2 & L.D & L.D & L.D & 0,126 & 0,040 & 0,093 & 0,152 & 0,095 & 0,100 & 0,108 & L.D & L.D & 0,128 & 0,052 & L.D & 0,109 & 0,027 \\
\hline Al2O3 & 19,880 & 21,040 & 20,830 & 20,460 & 20,910 & 20,330 & 20,500 & 20,710 & 20,290 & 20,040 & 20,200 & 19,720 & 20,450 & 20,650 & 20,380 & 20,100 & 19,190 \\
\hline $\mathrm{Cr} 2 \mathrm{O} 3$ & L.D & L.D & L.D & L.D & L.D & L.D & L.D & L.D & L.D & L.D & L.D & L.D & L.D & L.D & L.D & L.D & L.D \\
\hline $\mathrm{MgO}$ & 173 & 1,613 & 2,940 & 1,750 & 3,050 & 2,040 & 1,466 & 1,940 & 1,970 & 1,627 & 2,100 & 0,391 & 3,280 & 2,570 & 2,360 & 2,050 & 1,870 \\
\hline $\mathrm{CaO}$ & 2,210 & 1,290 & 3,100 & 4,030 & 1,172 & 1,400 & 6,830 & 5,950 & 1,304 & 4,690 & 1,328 & 3,910 & 0,849 & 1,358 & 1,540 & 2,000 & 3,050 \\
\hline V2O3 & L.D & L.D & L.D & 0,059 & L.D & 0,032 & L.D & L.D & L.D & L.D & 0,031 & L.D & L.D & L.D & L.D & 0,032 & L.D \\
\hline $\mathrm{ZrO2}$ & 0,055 & L.D & 0,098 & L.D & L.D & L.D & L.D & L.D & 0,154 & L.D & L.D & L.D & L.D & 0,042 & L.D & L.D & L.D \\
\hline $\mathrm{Na} 2 \mathrm{O}$ & 0,056 & L.D & 0,061 & L.D & 0,018 & 0,043 & L.D & 0,025 & L.D & 0,064 & 0,054 & 0,105 & L.D & 0,047 & L.D & 0,024 & 0,023 \\
\hline Total & 99,332 & 100,979 & 100,104 & 99,794 & 100,423 & 99,686 & 99,710 & 99,810 & 100,121 & 98,750 & 99,582 & 98,749 & 99,891 & 100,500 & 99,827 & 99,793 & 96,366 \\
\hline Minc & & & & & & & & & & & & & & & & & \\
\hline APFU & 8 Cationes) & & & & & & & & & & & & & & & & \\
\hline $\mathrm{Si}$ & 2,928 & 2,992 & 2,961 & 2,962 & 2,868 & 2,930 & 2,951 & 2,947 & 2,911 & 2,918 & 2,920 & 2,916 & 2,932 & 2,919 & 2,934 & 2,941 & 2,875 \\
\hline $\mathrm{Ti}$ & & 0,000 & 0,000 & 0,008 & 0,002 & 0,006 & 0,009 & 0,006 & 0,006 & 0,007 & 0,000 & 0,000 & 0,008 & 0,003 & 0,000 & 0,007 & 0,002 \\
\hline Al & 1,949 & 2,001 & 1,976 & 1,960 & 1,993 & 1,962 & 1,957 & 1,971 & 1,956 & 1,944 & 1,952 & 1,934 & 1,955 & 1,970 & 1,959 & 1,936 & 1,920 \\
\hline $\mathrm{Cr}$ & 00 & 0,000 & 0,000 & 0,000 & 0,000 & 0,000 & 0,000 & 0,000 & 0,000 & 0,000 & 0,000 & 0,000 & 0,000 & 0,000 & 0,000 & 0,000 & 0,000 \\
\hline Fe3+ & 99 & 0,014 & 0,105 & 0,097 & 0,269 & 0,171 & 0,123 & 0,125 & 0,199 & 0,217 & 0,215 & 0,252 & 0,165 & 0,189 & 0,173 & 0,171 & 0,331 \\
\hline $\mathrm{Fe} 2+$ & & 2,018 & 2,2 & 1,955 & 2,087 & 2,187 & 1,980 & 2,1 & 2, & 2,105 & 1, & 1,681 & 1,936 & 2,2 & 2,081 & 1,990 & ,273 \\
\hline $\mathrm{Mn}$ & & & & & & & 0,210 & 0,061 & & & 0 & 0,8 & 534 & 0,1 & 1 & 0,525 & 0,082 \\
\hline $\mathrm{Mg}$ & 11 & 0,194 & 0,353 & 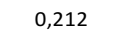 & th & 19 & 0,177 & 0 , & 0,240 & 0,200 & 0, & 0,049 & 77 & 0, & 37 & 0,250 & ,237 \\
\hline $\mathrm{Ca}$ & & & & & & & 0,593 & 0,515 & 0 & & & 0349 & & 0 & 0,135 & 0,175 & 0,277 \\
\hline v & 0,000 & 0,000 & 0, & 0,004 & 0,000 & 0,002 & 0,000 & 0,000 & 0,000 & 000 & 0,002 & 00 & 000 & 0,000 & 000 & 0,002 & 0,000 \\
\hline $\mathrm{Zr}$ & & & & & & 000 & 0,000 & 0,001 & 0,006 & 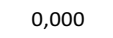 & & 0,0 & 0,000 & 0,0 & 0 & 0,000 & 0,000 \\
\hline $\mathrm{Na}$ & 09 & 0, & & 0,000 & & 007 & 0,000 & & 0,000 & & & & 0,000 & 0,007 & ,000 & 0,004 & 0,004 \\
\hline Suma & 8,000 & 8,000 & & 8,000 & 8,000 & 8,000 & 8,000 & 8,000 & 8,000 & 8,000 & 8,000 & 8,000 & 8,000 & 8,000 & 8,000 & 8,000 & 8,000 \\
\hline Miembros & & & & & & & & & & & & & & & & & \\
\hline
\end{tabular}

A.16. Continuación. 


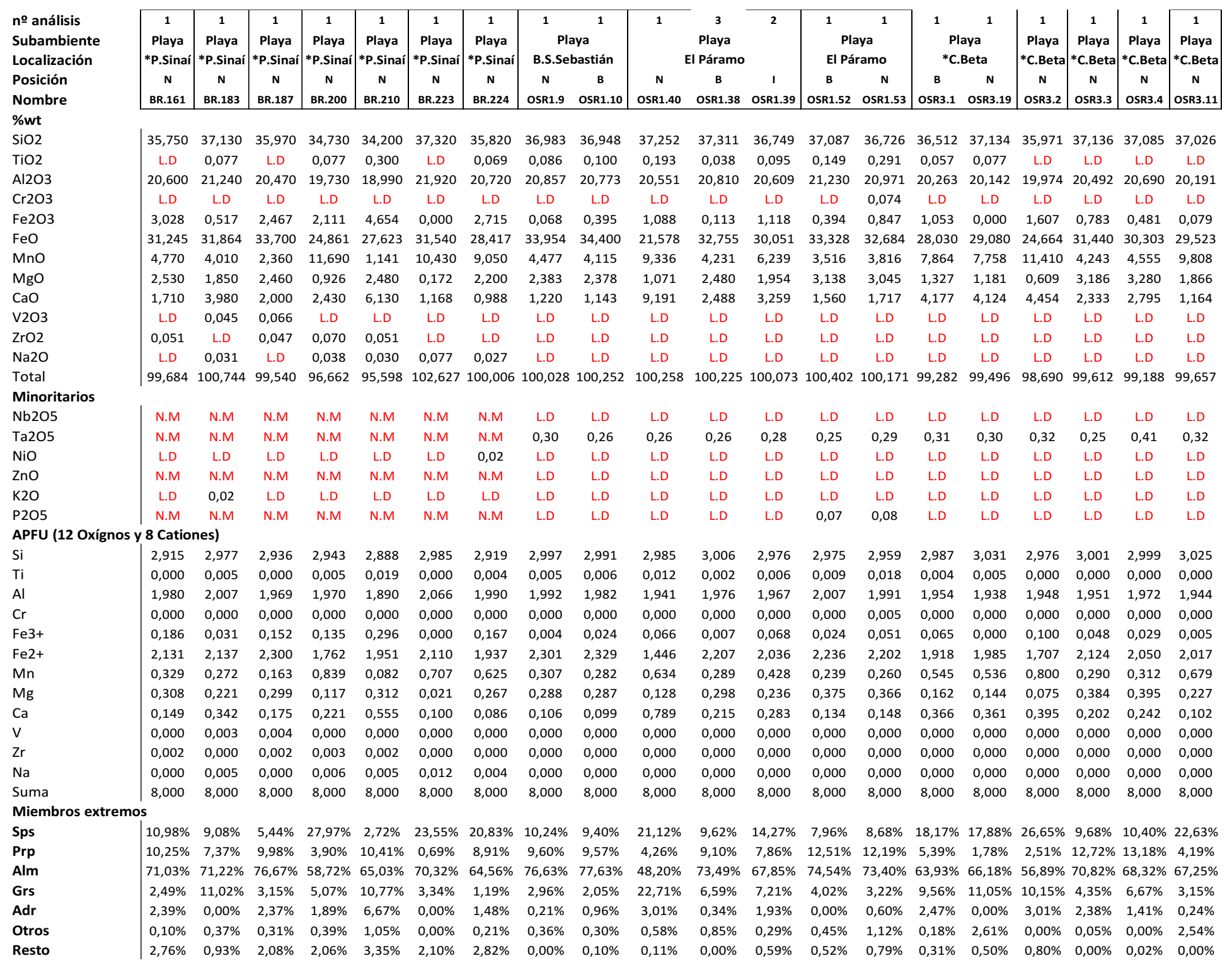

A. 17. Continuación. 


\begin{tabular}{|c|c|c|c|c|c|c|c|c|c|c|c|c|c|c|c|c|}
\hline $\begin{array}{l}\text { no análisis } \\
\text { Subambiente } \\
\text { Localización } \\
\text { Posición } \\
\text { Nombre }\end{array}$ & \begin{tabular}{|c|}
1 \\
Playa \\
*C.Beta \\
N \\
OSR3.12
\end{tabular} & $\begin{array}{c}1 \\
\text { Playa } \\
\text { *C.Beta } \\
\text { N } \\
\text { OSR3.13 }\end{array}$ & $\left|\begin{array}{c}1 \\
\text { Playa } \\
\text { *C.Beta } \\
\text { N } \\
\text { OSR3.14 }\end{array}\right|$ & $\left|\begin{array}{c}1 \\
\text { Playa } \\
\text { *C.Beta } \\
\text { N } \\
\text { OSR3.22 }\end{array}\right|$ & $\mid \begin{array}{c}1 \\
\text { Playa } \\
\text { *C.Beta } \\
\mathbf{N} \\
\text { OSR3.33 }\end{array}$ & \begin{tabular}{|c|}
1 \\
Playa \\
*C.Tortuga \\
$\mathbf{N}$ \\
OSR3.65
\end{tabular} & $\left|\begin{array}{c}1 \\
\text { Playa } \\
* \text { C.Beta } \\
\text { N } \\
\text { OSR3.68 }\end{array}\right|$ & \begin{tabular}{|c|}
1 \\
Playa \\
*C.Beta \\
N \\
OSR3.77
\end{tabular} & $\mid \begin{array}{c}1 \\
\text { Playa } \\
\text { *C.Beta } \\
\text { N } \\
\text { OSR3.78 }\end{array}$ & $\mid \begin{array}{c}1 \\
\text { Playa } \\
\text { *C.Beta } \\
\text { N } \\
\text { OSR3.80 }\end{array}$ & $\mid \begin{array}{c}1 \\
\text { Playa } \\
{ }^{*} \text { C.Beta } \\
\text { N } \\
\text { OSR3.81 }\end{array}$ & \begin{tabular}{|c|}
1 \\
Playa \\
*C.Beta \\
N \\
OSR3.82
\end{tabular} & \begin{tabular}{|c}
1 \\
Playa \\
${ }^{*}$ C.Beta \\
N \\
OSR3.83
\end{tabular} & \begin{tabular}{|c|}
1 \\
Playa \\
*C.Beta \\
N \\
OSR3.84
\end{tabular} & \begin{tabular}{|c|}
1 \\
Playa \\
*C.Beta \\
N \\
OSR3.92
\end{tabular} & \begin{tabular}{|c|} 
\\
Playa \\
${ }^{*}$ C.Beta \\
N \\
OSR3.93
\end{tabular} \\
\hline \multicolumn{17}{|l|}{$\% w t$} \\
\hline $\mathrm{SiO} 2$ & $\mid 37,065$ & 37,320 & 36,534 & 36,755 & 36,783 & 36,266 & 39,016 & 36,363 & 36,970 & 35,641 & 36,955 & 37,675 & 36,363 & 36,838 & 36,815 & 36,963 \\
\hline TiO2 & L.D & L.D & 0,154 & 0,034 & 0,076 & L.D & 0,074 & L.D & 0,100 & 0,050 & 0,051 & 0,044 & 0,190 & 0,038 & 0,093 & 0,114 \\
\hline $\mathrm{Al} 2 \mathrm{O} 3$ & 20,200 & 20,311 & 20,103 & 20,451 & 20,944 & 19,894 & 21,952 & 20,499 & 21,084 & 19,683 & 20,751 & 21,296 & 20,332 & 20,424 & 20,663 & 20,703 \\
\hline $\mathrm{Cr} 2 \mathrm{O} 3$ & L.D & L.D & L.D & L.D & L.D & L.D & L.D & L.D & L.D & L.D & L.D & L.D & L.D & L.D & L.D & L.D \\
\hline $\mathrm{Fe} 2 \mathrm{O} 3$ & 0,274 & 0,089 & 1,290 & 0,801 & 0,692 & 0,948 & 0,000 & 0,900 & 0,645 & 2,196 & 0,588 & 0,000 & 0,891 & 1,140 & 1,380 & 0,222 \\
\hline $\mathrm{FeO}$ & 30,590 & 32,405 & 26,116 & 30,940 & 30,649 & 30,818 & 28,606 & 29,315 & 27,475 & 32,973 & 29,351 & 34,356 & 26,675 & 28,405 & 34,028 & 30,846 \\
\hline $\mathrm{MnO}$ & 4,715 & 1,881 & 11,894 & 6,298 & 7,372 & 7,070 & 11,194 & 11,575 & 8,664 & 3,016 & 7,061 & 2,084 & 11,137 & 6,497 & 3,204 & 6,959 \\
\hline MgO & 2,983 & 3,160 & 1,414 & 2,445 & 2,826 & 1,783 & 1,781 & 0,272 & 2,147 & 2,706 & 1,203 & 3,428 & 1,662 & 1,574 & 2,094 & 2,053 \\
\hline $\mathrm{CaO}$ & 2,839 & 3,655 & 2,451 & 1,796 & 0,702 & 1,724 & 0,989 & 1,529 & 3,293 & 1,413 & 4,361 & 1,750 & 2,134 & 4,910 & 2,418 & 2,145 \\
\hline V2O3 & L.D & L.D & L.D & L.D & L.D & L.D & L.D & L.D & L.D & L.D & L.D & L.D & L.D & L.D & L.D & L.D \\
\hline $\mathrm{ZrO} 2$ & L.D & L.D & L.D & L.D & L.D & L.D & L.D & L.D & L.D & L.D & L.D & L.D & L.D & L.D & L.D & L.D \\
\hline $\mathrm{Na} 2 \mathrm{O}$ & L.D & L.D & L.D & L.D & L.D & L.D & L.D & L.D & L.D & L.D & L.D & L.D & L.D & L.D & L.D & L.D \\
\hline Total & 98,666 & 98,820 & 99,956 & 99,519 & 100,044 & 98,502 & 103,612 & 100,452 & 100,378 & 97,679 & 100,320 & 100,634 & 99,383 & 99,827 & 100,695 & 100,004 \\
\hline \multicolumn{17}{|l|}{ Minoritarios } \\
\hline $\mathrm{Nb} 2 \mathrm{O} 5$ & L.D & L.D & L.D & L.D & L.D & L.D & L.D & L.D & L.D & L.D & L.D & L.D & L.D & L.D & L.D & L.D \\
\hline Ta2O5 & 0,28 & 0,26 & 0,30 & 0,26 & 0,27 & 0,31 & L.D & L.D & 0,32 & 0,42 & 0,27 & 0,28 & 0,44 & 0,36 & 0,37 & 0,25 \\
\hline $\mathrm{NiO}$ & L.D & L.D & L.D & L.D & L.D & L.D & L.D & L.D & L.D & L.D & L.D & L.D & L.D & L.D & L.D & L.D \\
\hline $\mathrm{ZnO}$ & L.D & L.D & L.D & L.D & L.D & L.D & L.D & L.D & L.D & L.D & L.D & L.D & L.D & L.D & L.D & L.D \\
\hline $\mathrm{K} 2 \mathrm{O}$ & L.D & L.D & L.D & L.D & L.D & L.D & L.D & L.D & L.D & L.D & L.D & L.D & L.D & L.D & L.D & L.D \\
\hline P2O5 & L.D & L.D & L.D & L.D & L.D & L.D & L.D & L.D & L.D & L.D & L.D & L.D & L.D & L.D & L.D & L.D \\
\hline \multicolumn{17}{|c|}{ APFU (12 Oxígnos y 8 Cationes) } \\
\hline $\mathrm{Si}$ & 3,021 & 3,027 & 2,983 & 2,992 & 2,976 & 3,001 & 3,058 & 2,982 & 2,975 & 2,964 & 2,990 & 3,005 & 2,979 & 2,987 & 2,970 & 2,997 \\
\hline $\mathrm{Ti}$ & 0,000 & 0,000 & 0,009 & 0,002 & 0,005 & 0,000 & 0,004 & 0,000 & 0,006 & 0,003 & 0,003 & 0,003 & 0,012 & 0,002 & 0,006 & 0,007 \\
\hline Al & 1,941 & 1,941 & 1,935 & 1,962 & 1,997 & 1,940 & 2,028 & 1,981 & 1,999 & 1,929 & 1,979 & 2,002 & 1,963 & 1,952 & 1,965 & 1,978 \\
\hline $\mathrm{Cr}$ & 0,000 & 0,000 & 0,000 & 0,000 & 0,000 & 0,000 & 0,000 & 0,000 & 0,000 & 0,000 & 0,000 & 0,000 & 0,000 & 0,000 & 0,000 & 0,000 \\
\hline Fe3+ & 0,017 & 0,005 & 0,079 & 0,049 & 0,042 & 0,059 & 0,000 & 0,056 & 0,039 & 0,137 & 0,036 & 0,000 & 0,055 & 0,070 & 0,084 & 0,014 \\
\hline $\mathrm{Fe} 2+$ & 2,085 & 2,198 & 1,784 & 2,107 & 2,074 & 2,132 & 1,875 & 2,010 & 1,849 & 2,293 & 1,986 & 2,292 & 1,828 & 1,926 & 2,296 & 2,092 \\
\hline $\mathrm{Mn}$ & 0,326 & 0,129 & 0,823 & 0,434 & 0,505 & 0,495 & 0,743 & 0,804 & 0,590 & 0,212 & 0,484 & 0,141 & 0,773 & 0,446 & 0,219 & 0,478 \\
\hline $\mathrm{Mg}$ & 0,363 & 0,382 & 0,172 & 0,297 & 0,341 & 0,220 & 0,208 & 0,033 & 0,257 & 0,335 & 0,145 & 0,408 & 0,203 & 0,190 & 0,252 & 0,248 \\
\hline $\mathrm{Ca}$ & 0,248 & 0,318 & 0,214 & 0,157 & 0,061 & 0,153 & 0,083 & 0,134 & 0,284 & 0,126 & 0,378 & 0,150 & 0,187 & 0,427 & 0,209 & 0,186 \\
\hline V & 0,000 & 0,000 & 0,000 & 0,000 & 0,000 & 0,000 & 0,000 & 0,000 & 0,000 & 0,000 & 0,000 & 0,000 & 0,000 & 0,000 & 0,000 & 0,000 \\
\hline $\mathrm{Zr}$ & 0,000 & 0,000 & 0,000 & 0,000 & 0,000 & 0,000 & 0,000 & 0,000 & 0,000 & 0,000 & 0,000 & 0,000 & 0,000 & 0,000 & 0,000 & 0,000 \\
\hline $\mathrm{Na}$ & 0,000 & 0,000 & 0,000 & 0,000 & 0,000 & 0,000 & 0,000 & 0,000 & 0,000 & 0,000 & 0,000 & 0,000 & 0,000 & 0,000 & 0,000 & 0,000 \\
\hline Suma & 8,000 & 8,000 & 8,000 & 8,000 & 8,000 & 8,000 & 8,000 & 8,000 & 8,000 & 8,000 & 8,000 & 8,000 & 8,000 & 8,000 & 8,000 & 8,000 \\
\hline \multicolumn{17}{|c|}{ Miembros extremos } \\
\hline Sps & $10,85 \%$ & $4,31 \%$ & $27,42 \%$ & $14,48 \%$ & $16,84 \%$ & $16,51 \%$ & $24,77 \%$ & $26,80 \%$ & $19,68 \%$ & $7,08 \%$ & $16,13 \%$ & $4,69 \%$ & $25,76 \%$ & $14,87 \%$ & $7,30 \%$ & $15,93 \%$ \\
\hline Prp & $9,24 \%$ & $9,19 \%$ & $5,74 \%$ & $9,89 \%$ & $11,36 \%$ & $7,26 \%$ & $6,94 \%$ & $1,11 \%$ & $8,58 \%$ & $11,18 \%$ & $4,84 \%$ & $13,59 \%$ & $6,76 \%$ & $6,34 \%$ & $8,40 \%$ & $8,27 \%$ \\
\hline Alm & $69,51 \%$ & $73,26 \%$ & $59,46 \%$ & $70,22 \%$ & $69,12 \%$ & $71,08 \%$ & $62,51 \%$ & $67,01 \%$ & $61,63 \%$ & $76,37 \%$ & $66,20 \%$ & $76,40 \%$ & $60,92 \%$ & $64,21 \%$ & $76,53 \%$ & $69,59 \%$ \\
\hline Grs & $7,42 \%$ & $10,31 \%$ & $3,30 \%$ & $3,14 \%$ & $1,32 \%$ & $2,14 \%$ & $2,77 \%$ & $3,22 \%$ & $8,82 \%$ & $0,00 \%$ & $11,26 \%$ & $4,99 \%$ & $3,67 \%$ & $11,52 \%$ & $4,52 \%$ & $4,99 \%$ \\
\hline Adr & $0,84 \%$ & $0,27 \%$ & $3,38 \%$ & $1,98 \%$ & $0,48 \%$ & $2,95 \%$ & $0,00 \%$ & $1,25 \%$ & $0,35 \%$ & $4,04 \%$ & $1,19 \%$ & $0,00 \%$ & $1,99 \%$ & $2,59 \%$ & $2,17 \%$ & $0,68 \%$ \\
\hline Otros & $2,13 \%$ & $2,66 \%$ & $0,47 \%$ & $0,10 \%$ & $0,23 \%$ & $0,05 \%$ & $0,00 \%$ & $0,00 \%$ & $0,30 \%$ & $0,23 \%$ & $0,16 \%$ & $0,00 \%$ & $0,58 \%$ & $0,12 \%$ & $0,28 \%$ & $0,55 \%$ \\
\hline Resto & $0,00 \%$ & $0,00 \%$ & $0,24 \%$ & $0,19 \%$ & $0,65 \%$ & $0,00 \%$ & $3,01 \%$ & $0,61 \%$ & $0,64 \%$ & $1,11 \%$ & $0,24 \%$ & $0,33 \%$ & $0,30 \%$ & $0,36 \%$ & $0,81 \%$ & $0,00 \%$ \\
\hline
\end{tabular}

A. 18. Continuación. 


\begin{tabular}{|c|c|c|c|c|c|c|c|c|c|c|c|c|c|c|c|c|}
\hline $\begin{array}{l}\text { no análisis } \\
\text { Subambiente } \\
\text { Localización } \\
\text { Posición } \\
\text { Nombre }\end{array}$ & \begin{tabular}{|c|}
1 \\
Playa \\
*C.Beta \\
N \\
OSR3.94 \\
\end{tabular} & \begin{tabular}{|c|}
1 \\
Playa \\
${ }^{*}$ C.Beta \\
N \\
OSR3.96 \\
\end{tabular} & \begin{tabular}{|c|}
1 \\
Playa \\
*C.Beta \\
N \\
OSR3.97 \\
\end{tabular} & \begin{tabular}{|c|} 
\\
Playa \\
${ }^{*}$ C.Beta \\
N \\
OSR3.98 \\
\end{tabular} & \begin{tabular}{|c|}
1 \\
Playa \\
${ }^{*}$ C.Beta \\
N \\
OSR3.99 \\
\end{tabular} & \begin{tabular}{|c|} 
\\
Playa \\
*C.Beta \\
N \\
OSR3.101 \\
\end{tabular} & $\begin{array}{c}1 \\
\text { Playa } \\
\text { *C.Beta } \\
\text { N } \\
\text { OSR3.106 }\end{array}$ & \begin{tabular}{|c}
1 \\
Playa \\
*C.Beta \\
N \\
OSR3.110
\end{tabular} & \begin{tabular}{|c|}
1 \\
Playa \\
${ }^{*}$ C.Beta \\
N \\
OSR3.112 \\
\end{tabular} & \begin{tabular}{|c|} 
\\
Playa \\
${ }^{*}$ C.Beta \\
N \\
OSR3.114 \\
\end{tabular} & \begin{tabular}{|c|}
1 \\
Playa \\
*C.Beta \\
N \\
OSR3.115
\end{tabular} & \begin{tabular}{|c|}
1 \\
Playa \\
*C.Beta \\
N \\
OSR3.116 \\
\end{tabular} & \begin{tabular}{|c|}
1 \\
Playa \\
*C.Beta \\
N \\
OSR3.117
\end{tabular} & \begin{tabular}{|c|}
1 \\
Playa \\
${ }^{*}$ C.Beta \\
N \\
OSR3.118
\end{tabular} & \begin{tabular}{|c|} 
\\
Playa \\
${ }^{*}$ C.Beta \\
N \\
OSR3.119 \\
\end{tabular} & \begin{tabular}{|c|}
1 \\
Playa \\
${ }^{*}$ C.Beta \\
N \\
OR3.123 \\
\end{tabular} \\
\hline \multicolumn{17}{|l|}{ \%wt } \\
\hline $\mathrm{SiO} 2$ & 37,091 & 37,434 & 37,434 & 37,421 & 37,160 & 36,810 & 36,628 & 36,931 & 35,555 & 37,311 & 36,919 & 36,534 & 37,429 & 37,065 & 35,979 & 36,754 \\
\hline TiO2 & 0,099 & 0,061 & 0,080 & 0,239 & 0,050 & L.D & 0,034 & 0,075 & L.D & 0,104 & 0,177 & 0,070 & 0,050 & 0,297 & L.D & L.D \\
\hline $\mathrm{Al} 2 \mathrm{O} 3$ & 20,696 & 20,552 & 20,548 & 20,639 & 20,717 & 20,868 & 20,261 & 20,296 & 20,179 & 20,678 & 20,350 & 20,270 & 20,393 & 20,128 & 19,671 & 20,497 \\
\hline Cr2O3 & L.D & L.D & L.D & L.D & L.D & L.D & L.D & L.D & L.D & L.D & L.D & 0,075 & L.D & L.D & L.D & L.D \\
\hline $\mathrm{Fe} 2 \mathrm{O} 3$ & 0,739 & 0,755 & 0,136 & 0,000 & 0,000 & 0,765 & 1,237 & 1,004 & 1,614 & 0,000 & 0,968 & 1,651 & 0,000 & 0,830 & 1,950 & 0,919 \\
\hline $\mathrm{FeO}$ & 30,642 & 29,637 & 32,855 & 31,375 & 33,295 & 35,439 & 35,191 & 28,968 & 26,131 & 31,820 & 22,857 & 28,407 & 29,384 & 31,256 & 28,175 & 33,074 \\
\hline $\mathrm{MnO}$ & 7,115 & 6,494 & 2,054 & 5,442 & 5,595 & 1,977 & 3,476 & 6,692 & 14,262 & 3,959 & 10,940 & 8,146 & 7,750 & 3,348 & 9,780 & 4,873 \\
\hline MgO & 2,108 & 3,119 & 1,897 & 2,373 & 2,216 & 3,002 & 1,866 & 1,084 & 0,119 & 3,371 & 0,819 & 2,906 & 2,551 & 3,164 & 0,461 & 2,573 \\
\hline $\mathrm{CaO}$ & 2,212 & 2,374 & 5,086 & 2,459 & 1,217 & 0,953 & 1,397 & 5,111 & 1,016 & 2,185 & 6,952 & 1,092 & 1,750 & 3,356 & 2,884 & 1,056 \\
\hline V2O3 & L.D & L.D & L.D & L.D & L.D & L.D & L.D & L.D & L.D & L.D & L.D & L.D & L.D & L.D & L.D & L.D \\
\hline $\mathrm{ZrO} 2$ & L.D & L.D & L.D & L.D & L.D & L.D & L.D & L.D & L.D & L.D & L.D & L.D & L.D & L.D & L.D & L.D \\
\hline $\mathrm{Na} 2 \mathrm{O}$ & L.D & L.D & L.D & L.D & L.D & L.D & L.D & L.D & 0,092 & L.D & & 0,110 & 0,113 & . D & 0,091 & L.D \\
\hline Total & 100,702 & 100,425 & 100,091 & 99,947 & 100,250 & 99,815 & 100,091 & 100,160 & 98,967 & 99,428 & 99,983 & 99,259 & 99,418 & 99,444 & 98,992 & 99,745 \\
\hline \multicolumn{17}{|l|}{ Minoritarios } \\
\hline $\mathrm{Nb} 2 \mathrm{O} 5$ & L.D & L.D & L.D & L.D & L.D & L.D & L.D & L.D & L.D & L.V & L.D & L.V & L.D & L.D & L.D & L.D \\
\hline Ta2O & 0,31 & 0,32 & 0,35 & 0,28 & 0,22 & 0,29 & 0,23 & 0,44 & 0,30 & 0,35 & 0,32 & 0,39 & 0,23 & 0,45 & 0,29 & 0,31 \\
\hline $\mathrm{NiO}$ & L.D & L.D & L.D & L.D & L.D & L.D & & & & L.D & & & & & L.D & L.D \\
\hline ZnO & L.D & L.D & L.D & L.D & L.D & L.D & L.D & L.D & L.D & L.D & L.D & L.D & L.D & L.D & L.D & L.D \\
\hline $\mathrm{K} 2 \mathrm{O}$ & L.D & L.D & L.D & L.D & L.D & L.D & L.D & L.D & L.D & L.D & L.D & L.D & L.D & L.D & L.D & L.D \\
\hline P2O5 & L.D & L.D & 0,05 & L.D & $D$ & $1 D$ & L.D & $D$ & & 18 & $D$ & $D$ & LD & 0,05 & D & L.D \\
\hline \multicolumn{17}{|c|}{ APFU (12 Oxígnos y 8 Cationes) } \\
\hline $\mathrm{Si}$ & 2,989 & 3,002 & 3,016 & 3,026 & 3,009 & 2,981 & 2,986 & 2,995 & 2,965 & 3,012 & 2,989 & 2,978 & 3,039 & 2,997 & 2,985 & 2,989 \\
\hline $\mathrm{Ti}$ & 0,006 & 0,004 & 0,005 & 0,015 & 0,003 & 0,000 & 0,002 & 0,005 & 0,000 & 0,006 & 0,011 & 0,004 & 0,003 & 0,018 & 0,000 & 0,000 \\
\hline $\mathrm{Al}$ & 1,966 & 1,943 & 1,951 & 1,967 & 1,977 & 1,992 & 1,947 & 1,940 & 1,983 & 1,968 & 1,942 & 1,947 & 1,951 & 1,918 & 1,923 & 1,965 \\
\hline $\mathrm{Cr}$ & 0,000 & 0,000 & 0,000 & 0,000 & 0,000 & 0,000 & 0,000 & 0,000 & 00 & 0,000 & 0,000 & 0,005 & 0,000 & 0,000 & 0,000 & 0,000 \\
\hline $\mathrm{Fe} 3+$ & 0,045 & 0,046 & 0,008 & 0,000 & 0,000 & 0,047 & 0,076 & 0,061 & 0,101 & 0,000 & 0,059 & 0,101 & 0,000 & 0,051 & 0,122 & 0,056 \\
\hline $\mathrm{Fe} 2+$ & 2,065 & 1,988 & 2,213 & 2,121 & 2,255 & 2,400 & 2,400 & 1,965 & 1,822 & 2,148 & 1,548 & 1,936 & 1,995 & 2,114 & 1,955 & 2,250 \\
\hline $\mathrm{Mn}$ & 0,486 & 0,441 & 0,140 & 0,373 & 0,384 & 0,136 & 0,240 & 0,460 & 1,007 & 0,271 & 0,750 & 0,562 & 0,533 & 0,229 & 0,687 & 0,336 \\
\hline $\mathrm{Mg}$ & 0,253 & 0,373 & 0,228 & 0,286 & 0,267 & 0,362 & 0,227 & 0,131 & 0,015 & 0,406 & 0,099 & 0,353 & 0,309 & 0,381 & 0,057 & 0,312 \\
\hline $\mathrm{Ca}$ & 0,191 & 0,204 & 0,439 & 0,213 & 0,106 & 0,083 & 0,122 & 0,444 & 0,091 & 0,189 & 0,603 & 0,095 & 0,152 & 0,291 & 0,256 & 0,092 \\
\hline V & 0,000 & 0,000 & 0,000 & 0,000 & 0,000 & 0,000 & 0,000 & 0,000 & 0,000 & 0,000 & 0,000 & 0,000 & 0,000 & 0,000 & 0,000 & 0,000 \\
\hline $\mathrm{Zr}$ & 0,000 & 0,000 & 0,000 & 0,000 & 0,000 & 0,000 & 0,000 & 0,000 & 0,000 & 0,000 & 0,000 & 0,000 & 0,000 & 0,000 & 0,000 & 0,000 \\
\hline $\mathrm{Na}$ & 0,000 & 0,000 & 0,000 & 0,000 & 0,000 & 0,000 & 0,000 & 0,000 & 0,015 & 0,000 & 0,000 & 0,017 & 0,018 & 0,000 & 0,015 & 0,000 \\
\hline Suma & 8,000 & 8,000 & 8,000 & 8,000 & 8,000 & 8,000 & 8,000 & 8,000 & 8,000 & 8,000 & 8,000 & 8,000 & 8,000 & 8,000 & 8,000 & 8,000 \\
\hline \multicolumn{17}{|c|}{ Miembros extremos } \\
\hline Sps & $16,19 \%$ & $14,70 \%$ & $4,67 \%$ & $12,42 \%$ & $12,79 \%$ & $4,52 \%$ & $8,00 \%$ & $15,32 \%$ & $33,58 \%$ & $9,02 \%$ & $25,01 \%$ & $18,75 \%$ & $17,76 \%$ & $7,65 \%$ & $22,91 \%$ & $11,19 \%$ \\
\hline Prp & $8,44 \%$ & $12,13 \%$ & $5,52 \%$ & $9,53 \%$ & $7,80 \%$ & $12,08 \%$ & $7,56 \%$ & $4,37 \%$ & $0,49 \%$ & $12,35 \%$ & $3,30 \%$ & $11,77 \%$ & $9,39 \%$ & $12,71 \%$ & $1,90 \%$ & $10,40 \%$ \\
\hline Alm & $68,83 \%$ & $66,14 \%$ & $73,62 \%$ & $70,72 \%$ & $75,07 \%$ & $80,00 \%$ & $79,99 \%$ & $65,49 \%$ & $60,75 \%$ & $71,56 \%$ & $51,59 \%$ & $64,55 \%$ & $66,51 \%$ & $69,95 \%$ & $65,16 \%$ & $74,99 \%$ \\
\hline Grs & $4,26 \%$ & $4,15 \%$ & $13,73 \%$ & $5,66 \%$ & $3,19 \%$ & $2,02 \%$ & $1,12 \%$ & $11,56 \%$ & $2,60 \%$ & $5,44 \%$ & $16,64 \%$ & $1,19 \%$ & $3,91 \%$ & $5,49 \%$ & $5,43 \%$ & $1,13 \%$ \\
\hline Adr & $1,81 \%$ & $2,28 \%$ & $0,41 \%$ & $0,00 \%$ & $0,00 \%$ & $0,74 \%$ & $2,84 \%$ & $3,02 \%$ & $0,43 \%$ & $0,00 \%$ & $2,92 \%$ & $1,54 \%$ & $0,00 \%$ & $2,53 \%$ & $3,11 \%$ & $1,93 \%$ \\
\hline Otros & $0,30 \%$ & $0,59 \%$ & $2,05 \%$ & $0,00 \%$ & $1,12 \%$ & $0,00 \%$ & $0,10 \%$ & $0,23 \%$ & $0,00 \%$ & $1,39 \%$ & $0,54 \%$ & $0,45 \%$ & $0,83 \%$ & $1,68 \%$ & $0,00 \%$ & $0,00 \%$ \\
\hline Resto & $0,17 \%$ & $0,00 \%$ & $0,00 \%$ & $1,66 \%$ & $0,03 \%$ & $0,64 \%$ & $0,38 \%$ & $0,02 \%$ & $2,15 \%$ & $0,23 \%$ & $0,01 \%$ & $1,76 \%$ & $1,60 \%$ & $0,00 \%$ & $1,48 \%$ & $0,35 \%$ \\
\hline
\end{tabular}

A. 19. Continuación. 


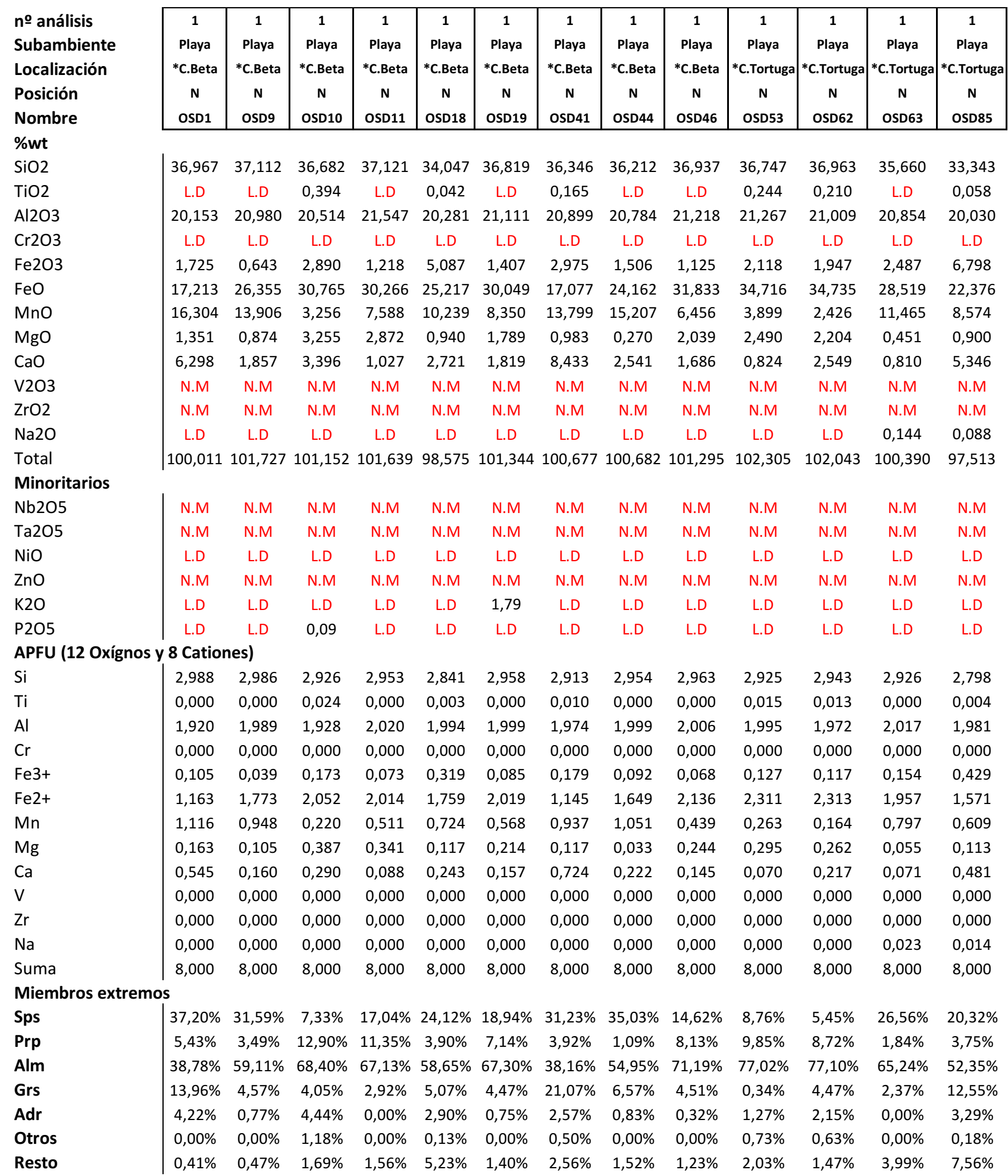

A.20. Continuación. 


\begin{tabular}{|c|c|c|c|c|c|c|c|c|c|c|c|c|}
\hline $\begin{array}{l}\text { no análisis } \\
\text { Subambiente } \\
\text { Localización }\end{array}$ & \multicolumn{2}{|c|}{$\begin{array}{c}\text { Till } \\
\text { A.P.Sinaí }\end{array}$} & \multicolumn{2}{|c|}{$\begin{array}{c}\text { Till } \\
\text { A.P.Sinaí }\end{array}$} & \multicolumn{2}{|c|}{$\begin{array}{c}\text { Till } \\
\text { A.P.Sinaí }\end{array}$} & \multicolumn{2}{|c|}{$\begin{array}{c}\text { Till } \\
\text { A.P.Sinaí }\end{array}$} & \multicolumn{2}{|c|}{$\begin{array}{c}\text { Till } \\
\text { A.P.Sinaí }\end{array}$} & \multicolumn{2}{|c|}{$\begin{array}{c}\text { Till } \\
\text { A.P.Sinaí }\end{array}$} \\
\hline Posición & N & B & N & B & N & B & N & B & N & B & N & B \\
\hline Nombre & A7-A10 & A8-A9-A11 & A16 & A17-18 & A19 & A20-21 & A31 & A32-33 & A37 & A38-39-40 & A41 & A42-43 \\
\hline \multicolumn{13}{|l|}{$\% w t$} \\
\hline $\mathrm{SiO} 2$ & 36,508 & 36,193 & 36,530 & 36,303 & 37,411 & 37,405 & 37,297 & 36,887 & 37,174 & 36,535 & 36,209 & 36,334 \\
\hline $\mathrm{TiO} 2$ & 0,026 & 0,030 & L.D & 0,056 & 0,207 & 0,221 & 0,036 & L.D & L.D & 0,042 & 0,033 & 0,067 \\
\hline Al2O3 & 20,790 & 20,765 & 20,592 & 20,619 & 20,645 & 20,767 & 21,227 & 21,112 & 21,012 & 20,907 & 20,995 & 20,813 \\
\hline Cr2O3 & L.D & L.D & L.D & L.D & L.D & L.D & L.D & L.D & L.D & L.D & L.D & L.D \\
\hline $\mathrm{Fe} 2 \mathrm{O} 3$ & 1,768 & 2,510 & 1,488 & 1,450 & 0,833 & 0,487 & 1,181 & 1,853 & 0,200 & 1,121 & 1,433 & 1,578 \\
\hline $\mathrm{FeO}$ & 31,979 & 30,906 & 36,372 & 36,351 & 32,219 & 32,031 & 32,424 & 31,492 & 32,112 & 31,259 & 35,188 & 33,522 \\
\hline $\mathrm{MnO}$ & 5,440 & 5,212 & 2,192 & 2,337 & 1,502 & 1,380 & 2,766 & 2,736 & 6,685 & 7,164 & 3,685 & 5,269 \\
\hline $\mathrm{MgO}$ & 2,338 & 2,319 & 1,088 & 0,961 & 1,686 & 1,725 & 3,698 & 3,772 & 2,479 & 2,019 & 0,833 & 0,704 \\
\hline $\mathrm{CaO}$ & 1,577 & 2,331 & 2,458 & 2,364 & 6,381 & 6,573 & 2,195 & 2,435 & 0,897 & 1,256 & 2,280 & 2,648 \\
\hline V2O3 & L.D & L.D & L.D & L.D & L.D & L.D & L.D & L.D & L.D & L.D & L.D & L.D \\
\hline ZrO2 & N.M & N.M & N.M & N.M & N.M & N.M & N.M & N.M & N.M & N.M & N.M & N.M \\
\hline $\mathrm{Na} 2 \mathrm{O}$ & L.D & L.D & L.D & L.D & L.D & L.D & L.D & L.D & L.D & L.D & L.D & L.D \\
\hline Total & |\#\#\#\#\# & 100,266 & 100,720 & 100,441 & 100,884 & 100,589 & 100,823 & 100,286 & 100,522 & 100,304 & 100,657 & 100,934 \\
\hline \multicolumn{13}{|l|}{ Minoritarios } \\
\hline $\mathrm{Nb} 2 \mathrm{O} 5$ & N.M & N.M & N.M & N.M & N.M & N.M & N.M & N.M & N.M & N.M & N.M & N.M \\
\hline Ta2O5 & N.M & N.M & N.M & N.M & N.M & N.M & N.M & N.M & N.M & N.M & N.M & N.M \\
\hline $\mathrm{NiO}$ & L.D & L.D & L.D & L.D & L.D & L.D & L.D & L.D & L.D & L.D & L.D & L.D \\
\hline $\mathrm{ZnO}$ & L.D & L.D & L.D & L.D & L.D & L.D & L.D & L.D & L.D & L.D & L.D & L.D \\
\hline K2O & L.D & L.D & L.D & L.D & L.D & L.D & L.D & L.D & L.D & L.D & L.D & L.D \\
\hline P2O5 & N.M & N.M & N.M & N.M & N.M & N.M & N.M & N.M & N.M & N.M & N.M & N.M \\
\hline \multicolumn{13}{|c|}{ APFU (12 Oxígnos y 8 Cationes) } \\
\hline $\mathrm{Si}$ & 2,953 & 2,931 & 2,968 & 2,961 & 2,990 & 2,993 & 2,967 & 2,949 & 2,997 & 2,964 & 2,947 & 2,951 \\
\hline $\mathrm{Ti}$ & 0,002 & 0,002 & 0,000 & 0,003 & 0,012 & 0,013 & 0,002 & 0,000 & 0,000 & 0,003 & 0,002 & 0,004 \\
\hline Al & 1,982 & 1,982 & 1,972 & 1,982 & 1,945 & 1,958 & 1,990 & 1,990 & 1,995 & 1,999 & 2,014 & 1,993 \\
\hline $\mathrm{Cr}$ & 0,000 & 0,000 & 0,000 & 0,000 & 0,000 & 0,000 & 0,000 & 0,000 & 0,000 & 0,000 & 0,000 & 0,000 \\
\hline Fe3+ & 0,108 & 0,153 & 0,091 & 0,089 & 0,050 & 0,029 & 0,071 & 0,111 & 0,012 & 0,068 & 0,088 & 0,096 \\
\hline $\mathrm{Fe} 2+$ & 2,164 & 2,093 & 2,472 & 2,480 & 2,154 & 2,143 & 2,157 & 2,106 & 2,165 & 2,121 & 2,395 & 2,277 \\
\hline $\mathrm{Mn}$ & 0,373 & 0,357 & 0,151 & 0,161 & 0,102 & 0,093 & 0,186 & 0,185 & 0,456 & 0,492 & 0,254 & 0,363 \\
\hline $\mathrm{Mg}$ & 0,282 & 0,280 & 0,132 & 0,117 & 0,201 & 0,206 & 0,439 & 0,450 & 0,298 & 0,244 & 0,101 & 0,085 \\
\hline $\mathrm{Ca}$ & 0,137 & 0,202 & 0,214 & 0,207 & 0,546 & 0,564 & 0,187 & 0,209 & 0,077 & 0,109 & 0,199 & 0,231 \\
\hline V & 0,000 & 0,000 & 0,000 & 0,000 & 0,000 & 0,000 & 0,000 & 0,000 & 0,000 & 0,000 & 0,000 & 0,000 \\
\hline $\mathrm{Zr}$ & 0,000 & 0,000 & 0,000 & 0,000 & 0,000 & 0,000 & 0,000 & 0,000 & 0,000 & 0,000 & 0,000 & 0,000 \\
\hline $\mathrm{Na}$ & 0,000 & 0,000 & 0,000 & 0,000 & 0,000 & 0,000 & 0,000 & 0,000 & 0,000 & 0,000 & 0,000 & 0,000 \\
\hline Suma & 8,000 & 8,000 & 8,000 & 8,000 & 8,000 & 8,000 & 8,000 & 8,000 & 8,000 & 8,000 & 8,000 & 8,000 \\
\hline \multicolumn{13}{|c|}{ Miembros extremos } \\
\hline Sps & $12,43 \%$ & $11,92 \%$ & $5,03 \%$ & $5,38 \%$ & $3,39 \%$ & $3,12 \%$ & $6,21 \%$ & $6,18 \%$ & $15,21 \%$ & $16,41 \%$ & $8,47 \%$ & $12,08 \%$ \\
\hline Prp & $9,40 \%$ & $9,33 \%$ & $4,39 \%$ & $3,90 \%$ & $6,70 \%$ & $6,86 \%$ & $14,62 \%$ & $14,99 \%$ & $9,93 \%$ & $8,14 \%$ & $3,37 \%$ & $2,84 \%$ \\
\hline Alm & $72,12 \%$ & $69,77 \%$ & $82,39 \%$ & $82,65 \%$ & $71,70 \%$ & $71,24 \%$ & $71,91 \%$ & $70,20 \%$ & $72,15 \%$ & $70,69 \%$ & $79,84 \%$ & $75,91 \%$ \\
\hline Grs & $2,84 \%$ & $4,61 \%$ & $5,21 \%$ & $5,23 \%$ & $14,96 \%$ & $16,34 \%$ & $5,14 \%$ & $5,59 \%$ & $2,31 \%$ & $2,89 \%$ & $6,38 \%$ & $6,36 \%$ \\
\hline Adr & $1,64 \%$ & $2,03 \%$ & $1,92 \%$ & $1,49 \%$ & $2,51 \%$ & $1,47 \%$ & $0,99 \%$ & $1,36 \%$ & $0,28 \%$ & $0,62 \%$ & $0,15 \%$ & $1,12 \%$ \\
\hline Otros & $0,08 \%$ & $0,09 \%$ & $0,00 \%$ & $0,17 \%$ & $0,75 \%$ & $0,98 \%$ & $0,11 \%$ & $0,00 \%$ & $0,00 \%$ & $0,13 \%$ & $0,10 \%$ & $0,20 \%$ \\
\hline Resto & $1,50 \%$ & $2,25 \%$ & $1,05 \%$ & $1,18 \%$ & $0,00 \%$ & $0,00 \%$ & $1,02 \%$ & $1,68 \%$ & $0,13 \%$ & $1,12 \%$ & $1,70 \%$ & $1,48 \%$ \\
\hline
\end{tabular}

A.21. Análisis con microsonda electrónica efectuados en granates presentes en los sedimentos glacigénicos. 


\begin{tabular}{|c|c|c|c|c|c|c|c|c|c|c|c|c|c|}
\hline $\begin{array}{l}\text { no análisis } \\
\text { Subambiente } \\
\text { Localización }\end{array}$ & \multicolumn{3}{|c|}{$\begin{array}{c}\text { Till } \\
\text { A.C.Beta }\end{array}$} & \multicolumn{3}{|c|}{$\begin{array}{c}\text { Till } \\
\text { A.C.Beta }\end{array}$} & \multicolumn{2}{|c|}{$\begin{array}{l}\text { Glacifluvial } \\
\text { A.C.Tortuaga }\end{array}$} & \multicolumn{3}{|c|}{$\begin{array}{l}\text { Glacifluvial } \\
\text { A.C.Tortuaga }\end{array}$} & \multicolumn{2}{|c|}{$\begin{array}{l}\text { Glacifluvial } \\
\text { A.C.Tortuaga }\end{array}$} \\
\hline Posición & $N$ & 1 & B & $\mathbf{N}$ & 1 & B & $N$ & B & $N$ & B & $N$ & $N$ & B \\
\hline Nombre & A165 & A166 & A167 & A168 & A171 & A169-170 & OSR2.19 & OSR2.20 & OSR2.21 & OSR2.22 & OSR2.31 & OSR2.33 & OSR2.34 \\
\hline \multicolumn{14}{|l|}{$\% w t$} \\
\hline $\mathrm{SiO} 2$ & 38,018 & 37,673 & 37,587 & 38,578 & 37,573 & 37,848 & 37,124 & 37,699 & 36,983 & 36,640 & 36,409 & 37,142 & 36,667 \\
\hline $\mathrm{TiO} 2$ & 0,120 & 0,104 & 0,162 & 0,067 & 0,060 & 0,062 & 0,081 & 0,092 & 0,081 & 0,072 & 0,079 & 0,101 & 0,111 \\
\hline $\mathrm{Al} 2 \mathrm{O} 3$ & 20,808 & 20,606 & 20,580 & 21,789 & 21,606 & 21,465 & 20,303 & 19,798 & 20,984 & 21,103 & 20,213 & 20,201 & 20,106 \\
\hline $\mathrm{Cr} 2 \mathrm{O} 3$ & L.D & L.D & L.D & L.D & L.D & L.D & L.D & L.D & L.D & L.D & L.D & L.D & L.D \\
\hline $\mathrm{Fe} 2 \mathrm{O} 3$ & 0,062 & 0,752 & 0,517 & 0,000 & 1,966 & 1,392 & 2,547 & 1,813 & 0,000 & 0,601 & 0,767 & 0,123 & 1,120 \\
\hline $\mathrm{FeO}$ & 28,146 & 26,660 & 28,326 & 30,517 & 29,453 & 29,780 & 21,894 & 22,106 & 31,740 & 30,843 & 27,079 & 30,437 & 27,609 \\
\hline $\mathrm{MnO}$ & 4,183 & 4,804 & 3,497 & 0,921 & 0,976 & 0,952 & 7,008 & 6,822 & 6,413 & 7,120 & 12,073 & 5,977 & 7,394 \\
\hline MgO & 1,001 & 1,031 & 1,107 & 6,891 & 6,953 & 6,959 & 0,892 & 0,873 & 2,194 & 2,112 & 1,972 & 1,692 & 1,258 \\
\hline $\mathrm{CaO}$ & 8,897 & 9,192 & 8,780 & 1,706 & 1,674 & 1,687 & 10,835 & 11,387 & 1,606 & 1,606 & 0,613 & 3,899 & 5,154 \\
\hline V2O3 & L.D & L.D & L.D & L.D & L.D & L.D & L.D & L.D & L.D & L.D & L.D & L.D & L.D \\
\hline $\mathrm{ZrO} 2$ & N.M & N.M & N.M & N.M & N.M & N.M & L.D & L.D & L.D & L.D & L.D & L.D & L.D \\
\hline $\mathrm{Na} 2 \mathrm{O}$ & L.D & L.D & L.D & L.D & L.D & L.D & L.D & L.D & L.D & L.D & L.D & L.D & L.D \\
\hline Total & 101,235 & 100,821 & 100,556 & 100,468 & 100,261 & 100,145 & 100,684 & 100,591 & 100,001 & 100,098 & 99,205 & 99,572 & 99,419 \\
\hline \multicolumn{14}{|l|}{ Minoritarios } \\
\hline $\mathrm{Nb} 2 \mathrm{O} 5$ & N.M & N.M & N.M & N.M & N.M & N.M & L.D & L.D & L.D & L.D & L.D & L.D & L.D \\
\hline Ta2O5 & N.M & N.M & N.M & N.M & N.M & N.M & 0,311 & 0,227 & 0,212 & 0,290 & 0,313 & 0,312 & 0,223 \\
\hline $\mathrm{NiO}$ & L.D & L.D & L.D & L.D & L.D & L.D & L.D & L.D & L.D & L.D & L.D & L.D & L.D \\
\hline $\mathrm{ZnO}$ & L.D & L.D & L.D & L.D & L.D & L.D & L.D & L.D & L.D & L.D & L.D & L.D & L.D \\
\hline $\mathrm{K} 2 \mathrm{O}$ & L.D & L.D & L.D & L.D & L.D & L.D & L.D & L.D & L.D & L.D & L.D & L.D & L.D \\
\hline P2O5 & N.M & N.M & N.M & N.M & N.M & N.M & 0,083 & L.D & L.D & L.D & L.D & L.D & L.D \\
\hline \multicolumn{14}{|c|}{ APFU (12 Oxígnos y 8 Cationes) } \\
\hline $\mathrm{Si}$ & 3,018 & 3,003 & 3,005 & 3,005 & 2,942 & 2,965 & 2,964 & 3,009 & 2,996 & 2,969 & 2,992 & 3,022 & 2,992 \\
\hline $\mathrm{Ti}$ & 0,007 & 0,006 & 0,010 & 0,004 & 0,004 & 0,004 & 0,005 & 0,006 & 0,005 & 0,004 & 0,005 & 0,006 & 0,007 \\
\hline $\mathrm{Al}$ & 1,947 & 1,936 & 1,939 & 2,000 & 1,994 & 1,982 & 1,910 & 1,862 & 2,004 & 2,016 & 1,958 & 1,937 & 1,934 \\
\hline $\mathrm{Cr}$ & 0,000 & 0,000 & 0,000 & 0,000 & 0,000 & 0,000 & 0,000 & 0,000 & 0,000 & 0,000 & 0,000 & 0,000 & 0,000 \\
\hline Fe3+ & 0,004 & 0,045 & 0,031 & 0,000 & 0,116 & 0,082 & 0,153 & 0,109 & 0,000 & 0,037 & 0,047 & 0,008 & 0,069 \\
\hline $\mathrm{Fe} 2+$ & 1,868 & 1,777 & 1,894 & 1,988 & 1,929 & 1,951 & 1,462 & 1,476 & 2,151 & 2,090 & 1,861 & 2,071 & 1,884 \\
\hline $\mathrm{Mn}$ & 0,281 & 0,324 & 0,237 & 0,061 & 0,065 & 0,063 & 0,474 & 0,461 & 0,440 & 0,489 & 0,840 & 0,412 & 0,511 \\
\hline $\mathrm{Mg}$ & 0,118 & 0,123 & 0,132 & 0,800 & 0,812 & 0,813 & 0,106 & 0,104 & 0,265 & 0,255 & 0,242 & 0,205 & 0,153 \\
\hline $\mathrm{Ca}$ & 0,757 & 0,785 & 0,752 & 0,142 & 0,140 & 0,142 & 0,927 & 0,974 & 0,139 & 0,139 & 0,054 & 0,340 & 0,451 \\
\hline V & 0,000 & 0,000 & 0,000 & 0,000 & 0,000 & 0,000 & 0,000 & 0,000 & 0,000 & 0,000 & 0,000 & 0,000 & 0,000 \\
\hline $\mathrm{Zr}$ & 0,000 & 0,000 & 0,000 & 0,000 & 0,000 & 0,000 & 0,000 & 0,000 & 0,000 & 0,000 & 0,000 & 0,000 & 0,000 \\
\hline $\mathrm{Na}$ & 0,000 & 0,000 & 0,000 & 0,000 & 0,000 & 0,000 & 0,000 & 0,000 & 0,000 & 0,000 & 0,000 & 0,000 & 0,000 \\
\hline Suma & 8,000 & 8,000 & 8,000 & 8,000 & 8,000 & 8,000 & 8,000 & 8,000 & 8,000 & 8,000 & 8,000 & 8,000 & 8,000 \\
\hline \multicolumn{14}{|c|}{ Miembros extremos } \\
\hline Sps & $9,38 \%$ & $10,81 \%$ & $7,89 \%$ & $2,03 \%$ & $2,16 \%$ & $2,10 \%$ & $15,80 \%$ & $15,37 \%$ & $14,67 \%$ & $16,29 \%$ & $28,02 \%$ & $13,73 \%$ & $17,03 \%$ \\
\hline Prp & $1,59 \%$ & $3,66 \%$ & $3,72 \%$ & $26,67 \%$ & $27,05 \%$ & $27,09 \%$ & $3,54 \%$ & $2,28 \%$ & $8,83 \%$ & $8,51 \%$ & $8,05 \%$ & $3,96 \%$ & $5,10 \%$ \\
\hline Alm & $62,04 \%$ & $59,04 \%$ & $62,81 \%$ & $66,26 \%$ & $64,28 \%$ & $65,03 \%$ & $48,72 \%$ & $49,00 \%$ & $71,69 \%$ & $69,68 \%$ & $61,45 \%$ & $68,82 \%$ & $62,80 \%$ \\
\hline Grs & $24,32 \%$ & $23,29 \%$ & $22,54 \%$ & $4,75 \%$ & $3,27 \%$ & $3,09 \%$ & $25,63 \%$ & $26,46 \%$ & $4,46 \%$ & $4,43 \%$ & & $10,34 \%$ & $11,34 \%$ \\
\hline Adr & $0,18 \%$ & $2,26 \%$ & $1,56 \%$ & & $1,23 \%$ & $1,45 \%$ & $5,02 \%$ & $5,45 \%$ & & & $1,56 \%$ & $0,38 \%$ & $3,34 \%$ \\
\hline Otros & $2,49 \%$ & $0,94 \%$ & $1,49 \%$ & $0,00 \%$ & $0,18 \%$ & $0,18 \%$ & $0,24 \%$ & $1,44 \%$ & $0,18 \%$ & $0,22 \%$ & $0,83 \%$ & $2,78 \%$ & $0,34 \%$ \\
\hline Resto & $0,00 \%$ & $0,00 \%$ & $0,00 \%$ & $0,30 \%$ & $1,82 \%$ & $1,06 \%$ & $1,05 \%$ & $0,00 \%$ & $0,17 \%$ & $0,87 \%$ & $0,09 \%$ & $0,00 \%$ & $0,04 \%$ \\
\hline
\end{tabular}

A.22. Continuación. 


\begin{tabular}{|c|c|c|c|c|c|c|c|c|c|c|c|c|c|c|c|c|c|c|c|c|c|c|}
\hline \multirow{2}{*}{$\begin{array}{l}\text { no análisis } \\
\text { Subambiente } \\
\text { Localización } \\
\text { Posición }\end{array}$} & \multicolumn{3}{|c|}{$\begin{array}{c}1 \\
\text { Plat. } \\
\text { Externa }\end{array}$} & \multirow{2}{*}{\multicolumn{2}{|c|}{$\begin{array}{cc}1 & 2 \\
& \text { Plat. } \\
& \text { Externa } \\
\text { N } & 1\end{array}$}} & 2 & \multicolumn{3}{|c|}{$\begin{array}{ccc}1 & 1 & 1 \\
& \begin{array}{c}\text { Plat. } \\
\text { Externa }\end{array} & \\
\end{array}$} & \multicolumn{3}{|c|}{\begin{tabular}{|cc}
1 & 1 \\
& Plat. \\
& Externa
\end{tabular}} & \multicolumn{2}{|c|}{$\begin{array}{l}1{ }^{1}{ }^{1} \\
\text { Plat. } \\
\text { Interna }\end{array}$} & \multirow{3}{*}{\begin{tabular}{|c|}
2 \\
Plat. \\
Interna \\
N \\
OSR1.60 \\
\end{tabular}} & \multicolumn{2}{|c|}{$\begin{array}{l}1 \\
1 \\
\text { Plat. } \\
\text { Interna }\end{array}$} & \multirow{3}{*}{\begin{tabular}{|c|}
2 \\
Plat. \\
Interna \\
$N$ \\
OSR1.69 \\
\end{tabular}} & \multicolumn{2}{|c|}{$\begin{array}{l}1{ }^{1}{ }^{1} \\
\text { Plat. } \\
\text { Media }\end{array}$} & \multicolumn{2}{|c|}{ 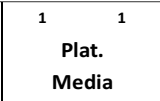 } \\
\hline & $\mathrm{N}$ & 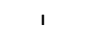 & 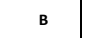 & & & в & 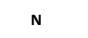 & I & B & N & 1 & B & N & . & & , & 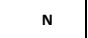 & & 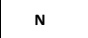 & . & B & N \\
\hline Nombre & A353 & A355 & A356 & A357 & A358-360 & A359-361 & A374 & A375 & A376 & A383 & A384 & A385 & OSR1.54 & OSR1.55 & & 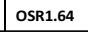 & OSR1.65 & & \begin{tabular}{|l|l|} 
OSR2.1 \\
\end{tabular} & OSR2.2 & \begin{tabular}{|l|} 
OSR2.9. \\
\end{tabular} & OSR2.10 \\
\hline \multicolumn{23}{|l|}{ \%wt } \\
\hline $\mathrm{SiO} 2$ & $\mid 36,22$ & 37,02 & 37,47 & 35,87 & 36,14 & 36,56 & 35,52 & 35,69 & 36,03 & 36,41 & 36,47 & 36,28 & 36,50 & 35,93 & 36,63 & 36,58 & 36,31 & 37,46 & 37,05 & 36,97 & 36,85 & 36,87 \\
\hline TiO2 & 0,05 & L.D & 0,00 & 0,22 & 0,08 & L.D & L.D & L.D & L.D & L.D & 0,04 & L.D & 0,04 & L.D & 0,34 & 0,03 & L.D & 0,18 & 0,00 & L.D & 0,12 & 0,12 \\
\hline Al2O3 & 21,53 & 21,60 & 21,42 & 21,01 & 21,05 & 21,00 & 21,35 & 21,63 & 21,48 & 21,02 & 21,01 & 21,45 & 20,24 & 19,92 & 20,67 & 21,03 & 20,89 & 20,74 & 21,12 & 20,55 & 20,59 & 20,55 \\
\hline $\mathrm{Cr} 2 \mathrm{O} 3$ & L.D & L.D & L.D & L.D & L.D & L.D & 0,06 & L.D & L.D & L.D & L.D & L.D & L.D & L.D & L.D & L.D & L.D & L.D & L.D & L.D & L.D & L.D \\
\hline $\mathrm{Fe} 2 \mathrm{O} 3$ & 2,91 & 1,81 & 0,29 & 2,27 & 2,37 & 1,38 & 3,51 & 3,60 & 2,56 & 1,98 & 1,84 & 2,80 & 0,19 & 1,17 & 0,77 & 0,48 & 1,38 & 0,12 & 0,71 & 0,25 & 0,51 & 0,81 \\
\hline $\mathrm{FeO}$ & 28,14 & 31,28 & 34,04 & 26,11 & 27,85 & 31,90 & 30,16 & 30,71 & 30,85 & 32,73 & 32,65 & 33,14 & 32,82 & 32,49 & 34,16 & 35,57 & 34,55 & 18,12 & 36,43 & 35,16 & 30,19 & 27,99 \\
\hline $\mathrm{MnO}$ & 3,70 & 1,41 & 1,34 & 12,28 & 10,47 & 6,35 & 5,62 & 5,75 & 5,67 & 4,25 & 4,34 & 3,30 & 6,10 & 5,95 & 1,50 & 3,45 & 4,14 & 13,43 & 0,77 & 2,60 & 4,58 & 5,65 \\
\hline $\mathrm{MgO}$ & 2,47 & 3,97 & 3,86 & 1,56 & 1,83 & 1,72 & 3,10 & 2,77 & 2,98 & 2,95 & 2,96 & 2,94 & 00 & 1,83 & 68 & 2,00 & 1,92 & 1,20 & 2,73 & 2,14 & 1,26 & 1,16 \\
\hline $\mathrm{CaO}$ & 5,51 & 3,50 & 1,97 & 1,38 & 1,22 & 1,80 & 0,85 & 0,93 & 0,93 & 0,98 & 1,03 & 0,97 & 0,87 & 0,92 & 4,24 & 0,88 & 0,98 & 8,66 & 1,73 & 2,03 & 5,53 & 6,57 \\
\hline V2O3 & L.D & L.D & L.D & L.D & L.D & L.D & L.D & L.D & L.D & L.D & L.D & L.D & L.D & L.D & L.D & L.D & L.D & L.D & L.D & L.D & L.D & L.D \\
\hline $\mathrm{ZrO} 2$ & N.M & N.M & N.M & N.M & N.M & N.M & N.M & N.M & N.M & N.M & N.M & N.M & L.D & L.D & L.D & L.D & L.D & L.D & L.D & L.D & L.D & L.D \\
\hline $\mathrm{Na} 2 \mathrm{O}$ & L.D & L.D & L.D & L.D & L.D & L.D & L.D & L.D & L.D & L.D & L.D & 0,09 & L.D & L.D & L.D & L.D & L.D & L.D & L.D & L.D & L.D & L.D \\
\hline Total & 100,52 & 100,58 & 100,40 & 100,69 & 101,02 & 100,71 & 100,17 & 101,09 & 100,50 & 100,31 & 100,34 & 100,96 & 98,76 & 98,22 & 99,99 & 100,03 & 100,16 & 99,90 & 100,54 & 99,71 & 99,63 & 99,72 \\
\hline \multicolumn{23}{|l|}{ Minoritarios } \\
\hline $\mathrm{Nb} 2 \mathrm{O} 5$ & N.M & N.M & N.M & N.M & N.M & N.M & N.M & N.M & N.M & N.M & N.M & N.M & L.D & L.D & L.D & L.D & L.D & L.D & L.D & L.D & L.D & L.D \\
\hline $\mathrm{Ta} 2 \mathrm{O} 5$ & N.M & N.M & N.M & N.M & N.M & N.M & N.M & N.M & N.M & N.M & N.M & N.M & 0,21 & 0,25 & L.D & 0,36 & 0,29 & 0,29 & 0,27 & 0,26 & 0,23 & 0,26 \\
\hline $\mathrm{NiO}$ & L.V & L.D & L.D & L.D & L.D & L.D & L.D & L.D & L.D & L.D & L.D & L.D & L.D & L.D & L.D & L.D & L.D & 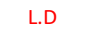 & L.D & L.D & L.D & L.D \\
\hline $\mathrm{ZnO}$ & L.D & L.D & L.D & L.D & L.D & L.D & L.D & L.D & L.D & L.D & L.D & L.D & L.D & L.D & L.D & L.D & L.D & L.D & L.D & L.D & L.D & L.D \\
\hline K2O & L.D & L.D & L.D & L.D & L.D & L.D & L.D & L.D & L.D & L.D & L.D & L.D & L.D & L.D & L.D & L.D & L.D & L.D & L.D & L.D & L.D & L.D \\
\hline P2O5 & N.M & N.M & N.M & N.M & N.M & N.M & N.M & N.M & N.M & N.M & N.M & N.M & L. & L.D & 05 & L.D & L.D & L.D & .D & L.D & D & L.D \\
\hline \multicolumn{23}{|c|}{ APFU (12 Oxígnos y 8 Cationes) } \\
\hline $\mathrm{Si}$ & 2,90 & 2,94 & 2,99 & 2,91 & 2,92 & 2,96 & 2,87 & 2,87 & 2,90 & 2,94 & 2,94 & 2,91 & 3,01 & 2,99 & 2,97 & 2,98 & 2,96 & 3,01 & 2,98 & 3,01 & 2,99 & 2,99 \\
\hline$T$ & 0,00 & 0,00 & 0,00 & 0, & 0,00 & 0,00 & 0,00 & 0,00 & 0,00 & 000 & 0,00 & 0 & 00 & 0,00 & 02 & 0,00 & 0,00 & 0,01 & 0,00 & 0,00 & 0,01 & 0,01 \\
\hline Al & 2,03 & 2,02 & 2,01 & 2, & 2,01 & 2,00 & 2,04 & 2,05 & $2, c$ & 2,00 & 2,00 & 2 & 1,97 & 1,95 & 97 & 2,02 & 2,00 & 1,96 & 00 & 97 & 1,97 & 1,96 \\
\hline $\mathrm{Cr}$ & 0,00 & 0,00 & 0,00 & 0 , & 0,0 & 0,00 & 0,00 & 0,00 & $0, c$ & 0 , & $0, c$ & 0 , & 0,00 & 0,0 & 00 & 0,00 & 00 & 00 & 00 & 00 & 0,00 & 0,00 \\
\hline $\mathrm{Fe} 3+$ & 0,17 & 0,11 & 0,02 & 0,14 & 0,14 & 0,08 & 0,21 & 0,22 & 0,16 & 0,12 & 0,11 & 0,17 & 0,01 & 0,07 & 05 & 0,03 & 08 & 0,01 & 0,04 & 02 & 0,03 & 0,05 \\
\hline $\mathrm{Fe} 2+$ & 1,88 & 2,07 & 2,27 & 1,77 & 1,88 & 2,16 & 2,04 & 2,06 & 2,08 & 2,21 & 2,20 & 2,22 & 2,26 & 2,26 & 32 & 2,42 & 2,35 & 1,22 & 2,45 & 2,39 & 2,05 & 1,90 \\
\hline $\mathrm{Mn}$ & 0,25 & 0,09 & 0,09 & 0, & 0,72 & 0,44 & 0 , & 20 & 0 , & 0 & 0,3 & 0 & 43 & 0,42 & 10 & 0,24 & 29 & 0,91 & 0,05 & ,18 & 0,32 & 0,39 \\
\hline $\mathrm{Mg}$ & 0,29 & 0,47 & 0,46 & 0 , & 0,22 & 0,2 & 0,37 & 0,33 & 0 , & 0 & 0,36 & 0 & 0,25 & 0,2 & 0,20 & 0,24 & 0,23 & 0,14 & 33 & ,26 & 0,15 & 0,14 \\
\hline Ca & 0,47 & 0,30 & 0,17 & 0 , & 0,1 & 0 & 0,0 & 0 & 0 , & & 0,09 & & 08 & 0,0 & 37 & 0,08 & 09 & ,74 & 15 & 18 & 0,48 & 0,57 \\
\hline 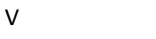 & 0,00 & 0,00 & 0,00 & 0,00 & 0,00 & 0,00 & 0,00 & 0,00 & 0,00 & 0,00 & 0,00 & 0,00 & 0,00 & 0,00 & 0,00 & 0,00 & 0,00 & 0,00 & 0,00 & 0,00 & 0,00 & 0,00 \\
\hline $\mathrm{Zr}$ & 0,00 & 0,00 & 0,00 & & 0,00 & & & & 0, & & 0,00 & & 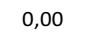 & 0,00 & & 0,00 & 00 & 0,0 & 00 & 00 & 0,00 & 0,00 \\
\hline $\mathrm{Na}$ & 0,00 & 0,00 & 0,00 & 0,00 & 0,00 & 0,00 & 0,00 & 0,00 & 0,00 & 0,00 & 0,00 & 0,01 & 0,00 & 0,00 & 00 & 0,00 & 00 & 0,00 & 0,00 & , 00 & 0,00 & 0,00 \\
\hline Sum & 8,00 & 8,00 & 8,00 & & 8,00 & 8,00 & 8,00 & 8,00 & 8,00 & 8,00 & 8,00 & 8,00 & 8,00 & 8,00 & 8,00 & 8,00 & 8,00 & 8,00 & 8,00 & 8,00 & 8,00 & 8,00 \\
\hline Miembros & remos & & & & & & & & & & & & & & & & & & & & & \\
\hline Sps & | 8,35\% & $3,15 \%$ & $3,02 \%$ & $28,16 \%$ & $23,90 \%$ & $14,51 \%$ & $12,83 \%$ & $13,05 \%$ & $12,90 \%$ & $9,68 \%$ & $9,89 \%$ & $7,48 \%$ & $14,19 \%$ & $13,98 \%$ & $3,44 \%$ & $7,93 \%$ & $9,52 \%$ & $30,42 \%$ & $1,75 \%$ & $5,98 \%$ & $10,50 \%$ & $12,92 \%$ \\
\hline Prp & $9,82 \%$ & $15,64 \%$ & $15,29 \%$ & $6,29 \%$ & $7,35 \%$ & $6,92 \%$ & $12,47 \%$ & $11,05 \%$ & $11,91 \%$ & $11,83 \%$ & $11,88 \%$ & $11,70 \%$ & $7,04 \%$ & $7,57 \%$ & $6,76 \%$ & $8,09 \%$ & $7,75 \%$ & $4,08 \%$ & $10,90 \%$ & $7,66 \%$ & $5,10 \%$ & $4,68 \%$ \\
\hline Alm & $62,72 \%$ & $69,16 \%$ & $75,60 \%$ & $59,09 \%$ & $62,75 \%$ & $71,93 \%$ & $68,02 \%$ & $68,79 \%$ & $69,28 \%$ & $73,66 \%$ & $73,43 \%$ & $74,08 \%$ & $75,35 \%$ & $75,31 \%$ & $77,18 \%$ & $80,66 \%$ & $78,40 \%$ & $40,16 \%$ & $81,64 \%$ & $79,73 \%$ & $68,34 \%$ & $63,20 \%$ \\
\hline Grs & $15,31 \%$ & $9,82 \%$ & $5,60 \%$ & $2,59 \%$ & $2,28 \%$ & $4,61 \%$ & $2,13 \%$ & $2,68 \%$ & $2,65 \%$ & $1,82 \%$ & $1,83 \%$ & $2,79 \%$ & $1,75 \%$ & $0,12 \%$ & $9,78 \%$ & $2,47 \%$ & $2,32 \%$ & $23,37 \%$ & $4,66 \%$ & $5,13 \%$ & $14,19 \%$ & $16,65 \%$ \\
\hline Adr & $0,27 \%$ & $0,11 \%$ & & $0,74 \%$ & $0,99 \%$ & $0,60 \%$ & $0,14 \%$ & & & $1,00 \%$ & $1,03 \%$ & & $0,60 \%$ & $2,60 \%$ & $1,48 \%$ & & $0,52 \%$ & $0,36 \%$ & $0,32 \%$ & $0,77 \%$ & $1,49 \%$ & $1,99 \%$ \\
\hline Otro & $0,15 \%$ & $0,00 \%$ & $0,00 \%$ & $0,66 \%$ & $0,24 \%$ & $0,00 \%$ & $0,20 \%$ & $0,00 \%$ & $0,01 \%$ & $0,00 \%$ & $0,12 \%$ & $0,00 \%$ & $1,07 \%$ & $0,00 \%$ & $1,03 \%$ & $0,10 \%$ & $0,00 \%$ & $1,61 \%$ & $0,00 \%$ & $0,73 \%$ & $0,35 \%$ & $0,36 \%$ \\
\hline Resto & $3,39 \%$ & $2,12 \%$ & $0,48 \%$ & $2,48 \%$ & $2,49 \%$ & $1,44 \%$ & $4,22 \%$ & $4,43 \%$ & $3,24 \%$ & $2,01 \%$ & $1,82 \%$ & $3,95 \%$ & $0,00 \%$ & $0,43 \%$ & $0,35 \%$ & $0,75 \%$ & $1,48 \%$ & $0,00 \%$ & $0,73 \%$ & $0,00 \%$ & $0,03 \%$ & $0,19 \%$ \\
\hline
\end{tabular}

A.23. Análisis con microsonda electrónica efectuados en granates presentes en la cubierta superficial de la Plataforma Continental. 
Óxidos de Fe y Ti

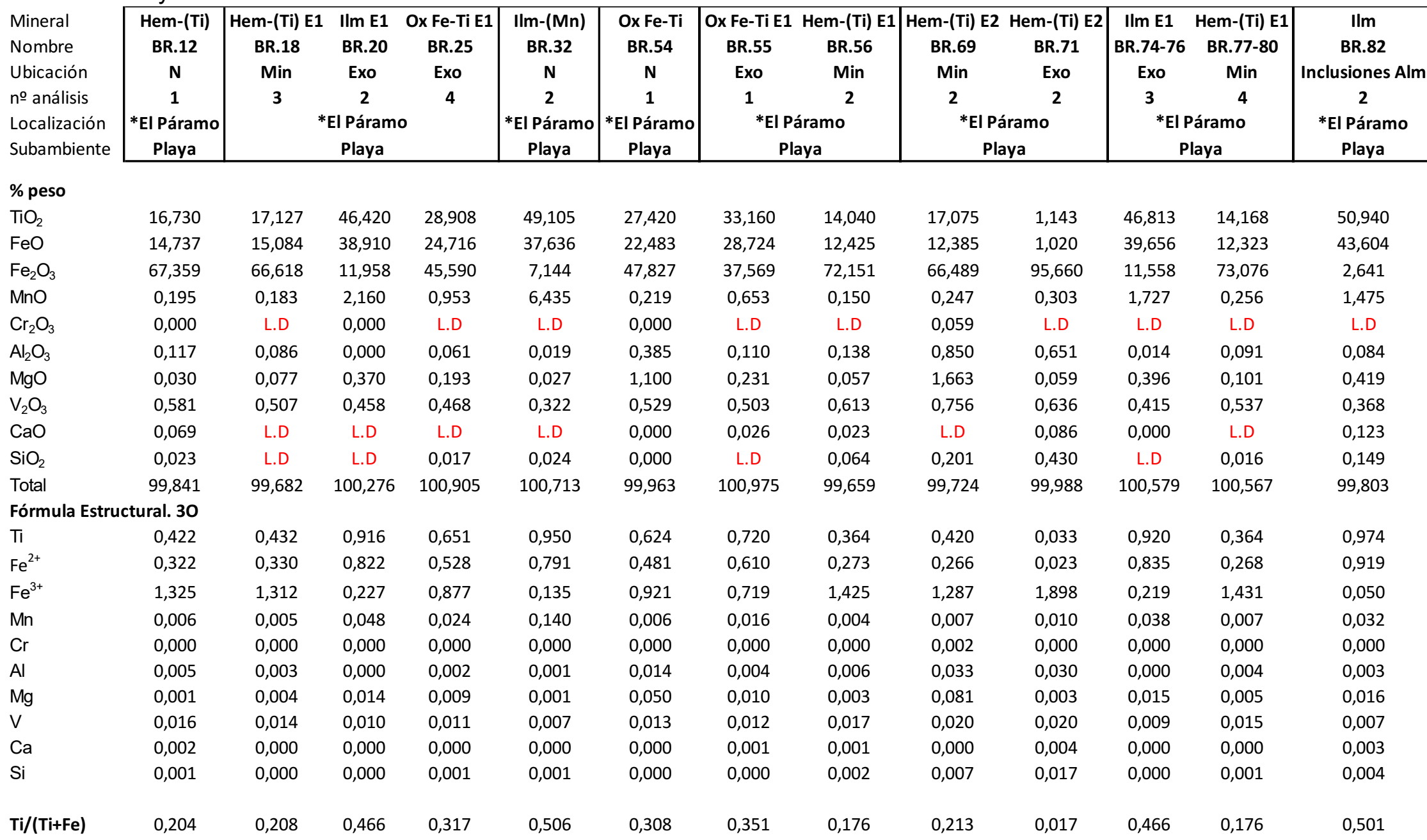

A. 24. Análisis con microsonda electrónica efectuados en los minerales agrupados como óxidos de Fe y Ti de los sedimentos de las playas. Fe $\mathrm{O}_{3}$ calculado por Droop (1987). Abreviaturas: Hem-(Ti), hematita titanífera; Ox Fe-Ti, óxidos intermedios de Fe y Ti; Ilm, ilmenita; Mag-(Ti), magnetita titanífera; Alm, almandino; E1, Hem-Ti u Ox Fe-Ti con exsolución a ilmenita u Ox FeTi (mayor contenido de Ti en las exsoluciones); E2, Hem-(Ti) con exsolución a Hem-(Ti) (exsoluciones con mayor o menor contenido de Ti); E3, IIm con exsoluciones de magnetita titanifera. Min= mineral y Exo= exsolución. 


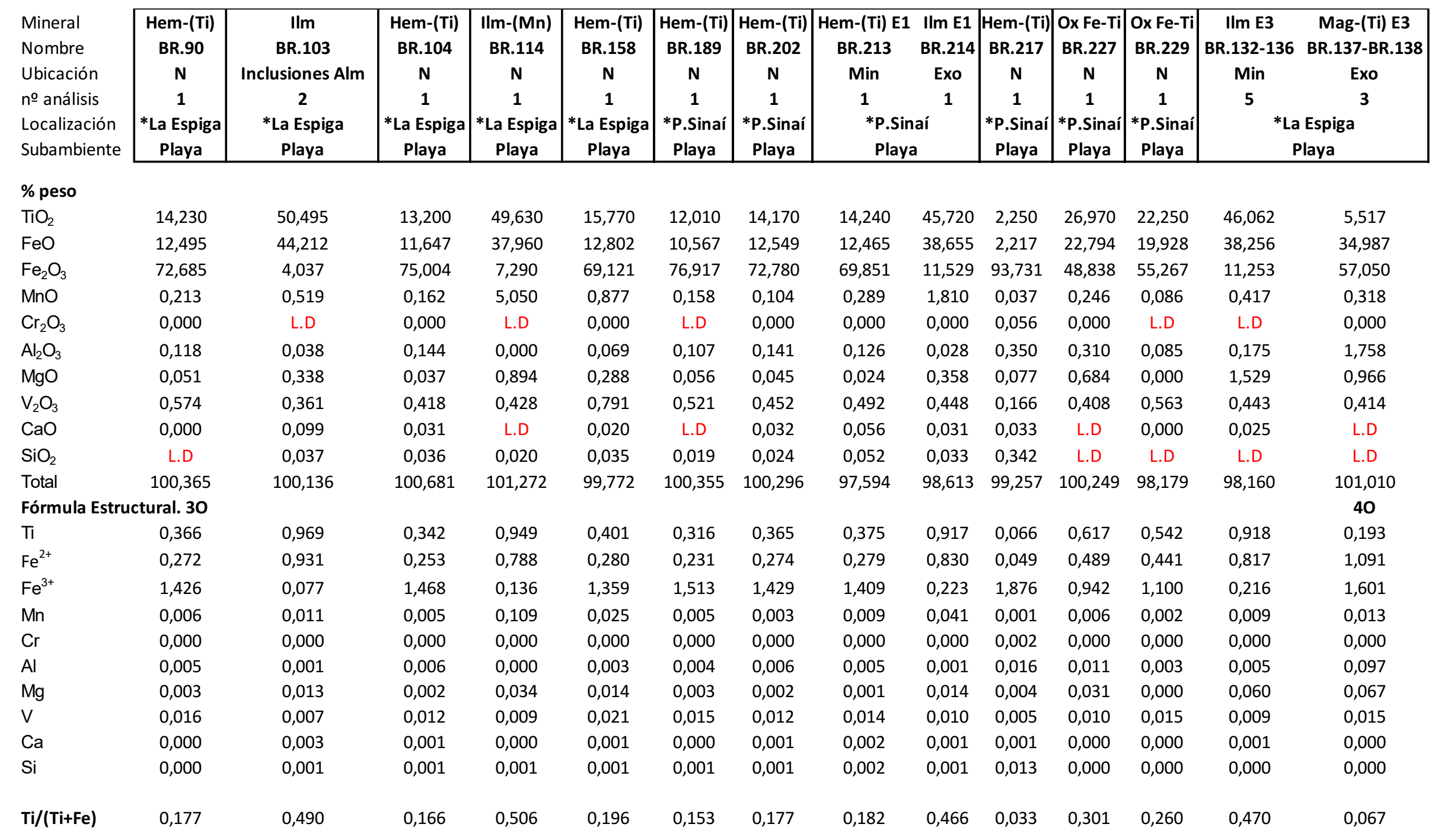

A.25. Continuación. 


\begin{tabular}{|c|c|c|c|c|c|c|c|c|c|c|c|c|}
\hline Mineral & Ox Fe-Ti & Ilm-(Mg) & Ox Fe-Ti & Ox Fe-Ti & Ox Fe-Ti & Ox Fe-Ti & Ox Fe-Ti & Ox Fe-Ti & Ox Fe-Ti & $\mathrm{IIm}$ & $\mathrm{Ilm}$ & Ox Fe-Ti \\
\hline Nombre & OOR1.12 & OOR1.14 & OOR1.20 & OOR1.45 & OOR1.49 & OOR3.7 & OOR3.16 & OOR3.17 & OOR3.23 & OOR3.24 & OOR3.25 & OOR3.26 \\
\hline Ubicación & $\mathbf{N}$ & $\mathbf{N}$ & $\mathbf{N}$ & $\mathbf{N}$ & $\mathbf{N}$ & $\mathbf{N}$ & $\mathbf{N}$ & $\mathbf{N}$ & $\mathbf{N}$ & $\mathbf{N}$ & $\mathbf{N}$ & $\mathbf{N}$ \\
\hline no a aálisis & 2 & 2 & 2 & 2 & 2 & 1 & 1 & 1 & 1 & 1 & 1 & 1 \\
\hline Localización & B.S.Sebastián & B.S.Sebastián & B.S.Sebastián & El Páramo & El Páramo & *C.Beta & *C.Beta & $*$ C.Beta & ${ }^{*}$ C.Beta & ${ }^{*}$ C.Beta & $*$ C.Beta & *C.Beta \\
\hline Subambiente & Playa & Playa & Playa & Playa & Playa & Playa & Playa & Playa & Playa & Playa & Playa & Playa \\
\hline \multicolumn{13}{|l|}{$\%$ peso } \\
\hline $\mathrm{TiO}_{2}$ & 29,762 & 48,864 & 29,859 & 27,472 & 35,654 & 30,194 & 28,765 & 28,605 & 29,473 & 42,072 & 39,794 & 27,848 \\
\hline $\mathrm{FeO}$ & 24,217 & 37,581 & 24,587 & 22,935 & 28,901 & 25,036 & 23,640 & 23,616 & 24,440 & 36,010 & 34,558 & 22,712 \\
\hline $\mathrm{Fe}_{2} \mathrm{O}_{3}$ & 43,910 & 9,355 & 42,754 & 48,332 & 33,316 & 44,489 & 45,685 & 46,722 & 45,311 & 16,091 & 22,652 & 47,910 \\
\hline $\mathrm{MnO}$ & 0,309 & 0,912 & 0,235 & 0,261 & 0,309 & 0,208 & 0,255 & 0,248 & 0,235 & 1,887 & 0,791 & 0,195 \\
\hline $\mathrm{Cr}_{2} \mathrm{O}_{3}$ & L.D & L.D & L.D & L.D & 0,060 & L.D & L.D & L.D & L.D & L.D & 0,000 & 0,000 \\
\hline $\mathrm{Al}_{2} \mathrm{O}_{3}$ & 0,271 & 0,206 & 0,412 & 0,348 & 0,314 & 0,324 & 0,394 & 0,348 & 0,375 & 0,003 & 0,037 & 0,389 \\
\hline $\mathrm{MgO}$ & 1,258 & 3,019 & 1,098 & 0,849 & 1,604 & 1,074 & 1,079 & 1,046 & 1,029 & 0,031 & 0,246 & 1,201 \\
\hline $\mathrm{V}_{2} \mathrm{O}_{3}$ & 0,200 & 0,021 & 0,199 & 0,291 & 0,419 & 0,096 & 0,256 & 0,315 & 0,322 & 0,016 & 0,228 & 0,115 \\
\hline $\mathrm{CaO}$ & L.D & 0,054 & 0,060 & L.D & L.D & L.D & 0,042 & L.D & 0,000 & L.D & 0,000 & 0,000 \\
\hline $\mathrm{SiO}_{2}$ & L.D & L.D & 0,000 & L.D & L.D & L.D & 0,000 & L.D & L.D & 0,109 & L.D & L.D \\
\hline Total & 99,926 & 100,013 & 99,204 & 100,487 & 100,577 & 101,420 & 100,115 & 100,900 & 101,184 & 96,218 & 98,305 & 100,369 \\
\hline \multicolumn{13}{|c|}{ Fórmula Estructural. 30} \\
\hline $\mathrm{Ti}$ & 0,665 & 0,937 & 0,670 & 0,624 & 0,754 & 0,666 & 0,647 & 0,641 & 0,654 & 0,884 & 0,838 & 0,630 \\
\hline $\mathrm{Fe}^{2+}$ & 0,517 & 0,778 & 0,529 & 0,490 & 0,608 & 0,528 & 0,505 & 0,501 & 0,517 & 0,796 & 0,749 & 0,484 \\
\hline $\mathrm{Fe}^{3+}$ & 0,844 & 0,174 & 0,828 & 0,928 & 0,631 & 0,844 & 0,878 & 0,892 & 0,862 & 0,320 & 0,442 & 0,919 \\
\hline $\mathrm{Mn}$ & 0,008 & 0,020 & 0,006 & 0,007 & 0,007 & 0,005 & 0,006 & 0,006 & 0,006 & 0,045 & 0,019 & 0,005 \\
\hline $\mathrm{Cr}$ & 0,000 & 0,000 & 0,000 & 0,000 & 0,001 & 0,000 & 0,000 & 0,000 & 0,000 & 0,000 & 0,000 & 0,000 \\
\hline $\mathrm{Al}$ & 0,009 & 0,006 & 0,014 & 0,012 & 0,010 & 0,011 & 0,014 & 0,012 & 0,013 & 0,000 & 0,001 & 0,014 \\
\hline $\mathrm{Mg}$ & 0,056 & 0,115 & 0,049 & 0,038 & 0,067 & 0,047 & 0,048 & 0,046 & 0,045 & 0,001 & 0,010 & 0,054 \\
\hline V & 0,005 & 0,000 & 0,005 & 0,007 & 0,009 & 0,002 & 0,006 & 0,008 & 0,008 & 0,000 & 0,005 & 0,003 \\
\hline $\mathrm{Ca}$ & 0,000 & 0,001 & 0,002 & 0,000 & 0,000 & 0,000 & 0,001 & 0,000 & 0,000 & 0,000 & 0,000 & 0,000 \\
\hline Si & 0,000 & 0,000 & 0,000 & 0,000 & 0,000 & 0,000 & 0,000 & 0,000 & 0,000 & 0,003 & 0,000 & 0,000 \\
\hline $\mathrm{Ti} /(\mathrm{Ti}+\mathrm{Fe})$ & 0,328 & 0,496 & 0,331 & 0,306 & 0,378 & 0,327 & 0,319 & 0,315 & 0,322 & 0,442 & 0,413 & 0,310 \\
\hline
\end{tabular}




\begin{tabular}{|c|c|c|c|c|c|c|c|c|c|c|c|c|c|c|c|c|}
\hline Mineral & Hem-(Ti) & Ox Fe-Ti & Ox Fe-Ti & Ox Fe-Ti & Hem-(Ti) & Ox Fe-Ti & Hem-(Ti) & IIm-(Mg) & Ox Fe-Ti & Ox Fe-Ti & Ox Fe-Ti & Hem-(Ti) & Ox Fe-Ti & Ox Fe-Ti & Ox Fe-Ti & Ox Fe-Ti \\
\hline Nombre & OOR3.27 & OOR3.28 & OOR3.37 & OOR3.38 & OOR3.43 & OOR3.44 & OOR3.45 & OOR3.48 & OOR3.63 & OOR3.72 & OOR3.74 & OOR3.75 & OOR3.76 & OOR3.85 & OOR3.88 & OOR3.89 \\
\hline $\begin{array}{l}\text { Ubicación } \\
\text { no análisis }\end{array}$ & $\begin{array}{c}N \\
1\end{array}$ & $\begin{array}{l}N \\
1\end{array}$ & $\begin{array}{l}N \\
1\end{array}$ & $\begin{array}{l}N \\
1\end{array}$ & $\begin{array}{l}N \\
1\end{array}$ & $\begin{array}{c}N \\
1\end{array}$ & $\begin{array}{l}N \\
1\end{array}$ & $\begin{array}{l}N \\
1\end{array}$ & $\begin{array}{c}N \\
1\end{array}$ & \begin{tabular}{l|}
$N$ \\
1
\end{tabular} & $\begin{array}{l}N \\
1\end{array}$ & $\begin{array}{l}N \\
1\end{array}$ & $\begin{array}{l}N \\
1\end{array}$ & $\begin{array}{l}N \\
1\end{array}$ & $\begin{array}{l}N \\
1\end{array}$ & $\begin{array}{l}N \\
1\end{array}$ \\
\hline $\begin{array}{l}\text { Localización } \\
\text { Subambiente }\end{array}$ & $\begin{array}{c}* \text { C.Tortuga } \\
\text { Playa }\end{array}$ & $\begin{array}{c}* \text { C.Tortuga } \\
\text { Playa }\end{array}$ & $\begin{array}{c}{ }^{*} \text { C.Tortuga } \\
\text { Playa }\end{array}$ & $\begin{array}{c}{ }^{*} \text { C. Tortuga } \\
\text { Playa }\end{array}$ & $\begin{array}{c}{ }^{*} \text { C.Tortuga } \\
\text { Playa }\end{array}$ & $\begin{array}{c}{ }^{*} \text { C.Tortuga } \\
\text { Playa }\end{array}$ & $\begin{array}{c}{ }^{*} \text { C.Tortuga } \\
\text { Playa }\end{array}$ & $\begin{array}{c}* \text { C.Tortuga } \\
\text { Playa }\end{array}$ & $\begin{array}{c}{ }^{*} \text { C.Tortuga } \\
\text { Playa }\end{array}$ & $\begin{array}{c}{ }^{*} \text { C.Beta } \\
\text { Playa }\end{array}$ & $\begin{array}{c}\text { *C.Beta } \\
\text { Playa }\end{array}$ & $\begin{array}{c}{ }^{*} \text { C.Beta } \\
\text { Playa }\end{array}$ & $\begin{array}{c}{ }^{*} \text { C.Beta } \\
\text { Playa }\end{array}$ & $\begin{array}{c}{ }^{*} \text { C.Beta } \\
\text { Playa }\end{array}$ & $\begin{array}{c}{ }^{*} \text { C.Beta } \\
\text { Playa }\end{array}$ & $\begin{array}{c}{ }^{*} \text { C.Beta } \\
\text { Playa }\end{array}$ \\
\hline \multicolumn{17}{|l|}{$\%$ peso } \\
\hline $\mathrm{TiO}_{2}$ & 12,843 & 27,972 & 29,820 & 28,202 & 17,510 & 28,213 & 12,871 & 41,986 & 35,041 & 30,984 & 28,884 & 0,070 & 29,607 & 28,723 & 27,351 & 27,408 \\
\hline $\mathrm{FeO}$ & 11,389 & 22,933 & 24,615 & 23,797 & 15,325 & 22,986 & 11,150 & 31,384 & 27,986 & 25,552 & 24,042 & 0,545 & 23,728 & 24,118 & 23,490 & 23,354 \\
\hline $\mathrm{Fe}_{2} \mathrm{O}_{3}$ & 76,884 & 48,073 & 44,315 & 46,976 & 67,420 & 47,393 & 76,277 & 22,243 & 34,093 & 40,897 & 45,815 & 94,808 & 45,606 & 45,843 & 48,420 & 48,615 \\
\hline $\mathrm{MnO}$ & 0,162 & 0,284 & 0,131 & 0,117 & 0,268 & 0,130 & 0,352 & 0,859 & 0,299 & 0,218 & 0,224 & 0,009 & 0,233 & 0,131 & 0,066 & 0,099 \\
\hline $\mathrm{Cr}_{2} \mathrm{O}_{3}$ & L.D & L.D & 0,064 & L.D & L.D & L.D & L.D & L.D & L.D & L.D & 0,000 & 0,000 & L.D & L.D & L.D & L.D \\
\hline $\mathrm{Al}_{2} \mathrm{O}_{3}$ & 0,108 & 0,337 & 0,382 & 0,290 & 0,145 & 0,428 & 0,048 & 0,296 & 0,352 & 0,347 & 0,539 & 0,482 & 0,378 & 0,288 & 0,313 & 0,322 \\
\hline $\mathrm{MgO}$ & 0,000 & 1,089 & 1,165 & 0,816 & 0,087 & 1,269 & 0,041 & 3,067 & 1,813 & 1,144 & 0,962 & 0,029 & 1,497 & 0,891 & 0,587 & 0,674 \\
\hline $\mathrm{V}_{2} \mathrm{O}_{3}$ & 0,519 & 0,195 & 0,511 & 0,544 & 0,303 & 0,279 & 0,449 & 0,000 & 0,249 & 0,208 & 0,285 & 0,496 & 0,275 & 0,260 & 0,216 & 0,286 \\
\hline $\mathrm{CaO}$ & L.D & L.D & L.D & L.D & L.D & L.D & L.D & 0,038 & L.D & 0,046 & L.D & 0,129 & 0,000 & L.D & L.D & L.D \\
\hline $\mathrm{SiO}_{2}$ & L.D & L.D & 0,000 & L.D & L.D & 0,000 & L.D & L.D & L.D & L.D & L.D & 0,592 & L.D & L.D & L.D & L.D \\
\hline Total & 101,905 & 100,883 & 101,002 & 100,741 & 101,057 & 100,699 & 101,187 & 99,872 & 99,833 & 99,397 & 100,751 & 97,160 & 101,325 & 100,253 & 100,442 & 100,758 \\
\hline \multicolumn{17}{|c|}{ Fórmula Estructural. 30} \\
\hline Ti & 0,331 & 0,630 & 0,660 & 0,635 & 0,435 & 0,634 & 0,334 & 0,846 & 0,748 & 0,688 & 0,646 & 0,002 & 0,654 & 0,647 & 0,624 & 0,623 \\
\hline $\mathrm{Fe}^{2+}$ & 0,245 & 0,487 & 0,520 & 0,507 & 0,331 & 0,488 & 0,242 & 0,654 & 0,593 & 0,548 & 0,510 & 0,012 & 0,499 & 0,515 & 0,503 & 0,498 \\
\hline $\mathrm{Fe}^{3+}$ & 1,489 & 0,918 & 0,843 & 0,900 & 1,309 & 0,905 & 1,487 & 0,417 & 0,650 & 0,789 & 0,875 & 1,939 & 0,863 & 0,882 & 0,933 & 0,933 \\
\hline Mn & 0,005 & 0,007 & 0,003 & 0,003 & 0,007 & 0,003 & 0,010 & 0,019 & 0,007 & 0,005 & 0,006 & 0,000 & 0,006 & 0,003 & 0,002 & 0,003 \\
\hline $\mathrm{Cr}$ & 0,000 & 0,000 & 0,001 & 0,000 & 0,000 & 0,000 & 0,000 & 0,000 & 0,000 & 0,000 & 0,000 & 0,000 & 0,000 & 0,000 & 0,000 & 0,000 \\
\hline $\mathrm{Al}$ & 0,004 & 0,012 & 0,013 & 0,010 & 0,006 & 0,015 & 0,002 & 0,009 & 0,012 & 0,012 & 0,019 & 0,023 & 0,013 & 0,010 & 0,011 & 0,011 \\
\hline Mg & 0,000 & 0,049 & 0,051 & 0,036 & 0,004 & 0,056 & 0,002 & 0,122 & 0,077 & 0,050 & 0,043 & 0,002 & 0,066 & 0,040 & 0,027 & 0,030 \\
\hline $\mathrm{v}$ & 0,014 & 0,005 & 0,012 & 0,013 & 0,008 & 0,007 & 0,012 & 0,000 & 0,006 & 0,005 & 0,007 & 0,016 & 0,006 & 0,006 & 0,005 & 0,007 \\
\hline $\mathrm{Ca}$ & 0,000 & 0,000 & 0,000 & 0,000 & 0,000 & 0,000 & 0,000 & 0,001 & 0,000 & 0,001 & 0,000 & 0,006 & 0,000 & 0,000 & 0,000 & 0,000 \\
\hline $\mathrm{Si}$ & 0,000 & 0,000 & 0,000 & 0,000 & 0,000 & 0,000 & 0,000 & 0,000 & 0,000 & 0,000 & 0,000 & 0,024 & 0,000 & 0,000 & 0,000 & 0,000 \\
\hline $\mathrm{Ti} /(\mathrm{Ti}+\mathrm{Fe})$ & 0,160 & 0,310 & 0,326 & 0,311 & 0,210 & 0,313 & 0,162 & 0,441 & 0,376 & 0,340 & 0,318 & 0,001 & 0,324 & 0,317 & 0,303 & 0,303 \\
\hline
\end{tabular}




\begin{tabular}{|c|c|c|c|c|c|c|c|c|c|c|c|}
\hline Mineral & Hem-(Ti) & Ox Fe-Ti & Hem-(Ti) E1 & Ox Fe-Ti & Ox Fe-Ti & Ox Fe-Ti & Ox Fe-Ti & Ox Fe-Ti & IIm-(Mg) & Ox Fe-Ti & $\mathrm{IIm}$ \\
\hline Nombre & OOR3.91 & OOR3.102 & OOR3.107 & OOR3.120 & OOR3.122 & OOR3.124 & OOR3.125 & OOR3.126 & OOR3.127 & $\mathrm{CO} 2$ & $\mathrm{CO4}$ \\
\hline Ubicación & $\mathbf{N}$ & $\mathbf{N}$ & Caja & $\mathbf{N}$ & $\mathbf{N}$ & $\mathbf{N}$ & $\mathbf{N}$ & $\mathbf{N}$ & $\mathbf{N}$ & $\mathbf{N}$ & $\mathbf{N}$ \\
\hline no a nálisis & 1 & 1 & 1 & 1 & 1 & 1 & 1 & 1 & 1 & 2 & 2 \\
\hline Localización & $*$ C.Beta & $*$ C.Beta & ${ }^{*}$ C.Beta & $*$ C.Beta & ${ }^{*}$ C.Beta & *C.Beta & *C.Beta & ${ }^{*}$ C.Beta & ${ }^{*}$ C.Beta & *El Páramo & *El Páramo \\
\hline Subambiente & Playa & Playa & Playa & Playa & Playa & Playa & Playa & Playa & Playa & Playa & Playa \\
\hline \multicolumn{12}{|l|}{$\%$ peso } \\
\hline $\mathrm{TiO}_{2}$ & 18,280 & 27,934 & 20,659 & 26,809 & 28,565 & 28,506 & 27,532 & 27,876 & 43,070 & 27,867 & 53,097 \\
\hline $\mathrm{FeO}$ & 16,006 & 22,767 & 17,943 & 22,475 & 23,193 & 23,385 & 22,462 & 23,163 & 31,628 & 23,276 & 45,913 \\
\hline $\mathrm{Fe}_{2} \mathrm{O}_{3}$ & 65,180 & 48,625 & 63,252 & 47,333 & 44,936 & 44,886 & 46,793 & 46,118 & 19,175 & 47,035 & 0,432 \\
\hline $\mathrm{MnO}$ & 0,275 & 0,215 & 0,449 & 0,258 & 0,214 & 0,166 & 0,207 & 0,180 & 0,747 & 0,220 & 1,726 \\
\hline $\mathrm{Cr}_{2} \mathrm{O}_{3}$ & L.D & 0,000 & L.D & L.D & 0,000 & L.D & 0,000 & L.D & L.D & L.D & 0,000 \\
\hline $\mathrm{Al}_{2} \mathrm{O}_{3}$ & 0,101 & 0,378 & 0,119 & 0,365 & 0,386 & 0,386 & 0,355 & 0,412 & 0,354 & 0,327 & 0,004 \\
\hline $\mathrm{MgO}$ & 0,089 & 1,203 & 0,105 & 0,772 & 1,283 & 1,172 & 1,175 & 0,971 & 3,567 & 0,881 & 0,062 \\
\hline $\mathrm{V}_{2} \mathrm{O}_{3}$ & 0,323 & 0,351 & 0,605 & 0,328 & 0,305 & 0,341 & 0,390 & 0,404 & 0,167 & 0,600 & 0,495 \\
\hline $\mathrm{CaO}$ & L.D & L.D & L.D & 0,041 & L.D & L.D & L.D & L.D & L.D & 0,011 & 0,014 \\
\hline $\mathrm{SiO}_{2}$ & L.D & L.D & L.D & 0,040 & L.D & 0,000 & L.D & L.D & L.D & 0,012 & 0,021 \\
\hline Total & 100,255 & 101,473 & 103,132 & 98,421 & 98,882 & 98,841 & 98,913 & 99,124 & 98,709 & 100,227 & 101,762 \\
\hline \multicolumn{12}{|c|}{ Fórmula Estructural. 30} \\
\hline $\mathrm{Ti}$ & 0,454 & 0,626 & 0,490 & 0,622 & 0,649 & 0,648 & 0,631 & 0,637 & 0,864 & 0,631 & 0,992 \\
\hline $\mathrm{Fe}^{2+}$ & 0,348 & 0,480 & 0,378 & 0,490 & 0,501 & 0,505 & 0,486 & 0,500 & 0,663 & 0,498 & 0,952 \\
\hline $\mathrm{Fe}^{3+}$ & 1,275 & 0,922 & 1,200 & 0,928 & 0,873 & 0,873 & 0,910 & 0,896 & 0,362 & 0,905 & 0,008 \\
\hline $\mathrm{Mn}$ & 0,008 & 0,005 & 0,012 & 0,007 & 0,005 & 0,004 & 0,005 & 0,005 & 0,017 & 0,006 & 0,036 \\
\hline $\mathrm{Cr}$ & 0,000 & 0,000 & 0,000 & 0,000 & 0,000 & 0,000 & 0,000 & 0,000 & 0,000 & 0,000 & 0,000 \\
\hline $\mathrm{Al}$ & 0,004 & 0,013 & 0,004 & 0,013 & 0,014 & 0,014 & 0,013 & 0,015 & 0,011 & 0,012 & 0,000 \\
\hline $\mathrm{Mg}$ & 0,004 & 0,053 & 0,005 & 0,035 & 0,058 & 0,053 & 0,053 & 0,044 & 0,142 & 0,040 & 0,002 \\
\hline V & 0,009 & 0,008 & 0,015 & 0,008 & 0,007 & 0,008 & 0,010 & 0,010 & 0,004 & 0,014 & 0,010 \\
\hline $\mathrm{Ca}$ & 0,000 & 0,000 & 0,000 & 0,001 & 0,000 & 0,000 & 0,000 & 0,000 & 0,000 & 0,000 & 0,000 \\
\hline Si & 0,000 & 0,000 & 0,000 & 0,001 & 0,000 & 0,000 & 0,000 & 0,000 & 0,000 & 0,000 & 0,001 \\
\hline $\mathrm{Ti} /(\mathrm{Ti}+\mathrm{Fe})$ & 0,219 & 0,309 & 0,237 & 0,305 & 0,321 & 0,320 & 0,311 & 0,313 & 0,458 & 0,310 & 0,508 \\
\hline
\end{tabular}

A. 28. Continuación. 


\begin{tabular}{|c|c|c|c|c|c|c|c|c|c|c|c|c|c|}
\hline Mineral & Ox Fe-Ti & Ox Fe-Ti & Ox Fe-Ti & Ox Fe-Ti & Ox Fe-Ti & Hem-(Ti) & Hem-(Ti) & $\mathrm{IIm}$ & $\mathrm{Ilm}$ & $\mathrm{IIm}$ & $\mathrm{IIm}$ & IIm-(Mn) & $\mathrm{Ilm}$ \\
\hline Nombre & OOD32 & OOD40 & OOD45 & OOD47 & OOD48 & OOD57 & OOD60 & OOD27 & OOD61 & OOD66 & OOD67 & OOD73 & OOD86 \\
\hline Ubicación & $\mathbf{N}$ & $\mathbf{N}$ & $\mathbf{N}$ & $\mathbf{N}$ & $\mathbf{N}$ & $\mathbf{N}$ & $\mathbf{N}$ & $\mathbf{N}$ & $\mathbf{N}$ & $\mathbf{N}$ & $\mathbf{N}$ & $\mathbf{N}$ & $\mathbf{N}$ \\
\hline no análisis & 1 & 1 & 1 & 1 & 1 & 1 & 1 & 1 & 1 & 1 & 1 & 1 & 1 \\
\hline Localización & *C.Beta & *C.Beta & *C.Beta & *C.Beta & *C.Beta & *C.Tortuga & *C.Tortuga & *C.Beta & *C.Tortuga & *C.Tortuga & *C.Tortuga & ${ }^{*}$ C.Tortuga & *C.Tortuga \\
\hline Subambiente & \begin{tabular}{|l} 
Playa \\
\end{tabular} & Playa & Playa & Playa & Playa & Playa & Playa & Playa & Playa & Playa & Playa & Playa & Playa \\
\hline \multicolumn{14}{|l|}{$\%$ peso } \\
\hline $\mathrm{TiO}_{2}$ & 29,641 & 30,365 & 32,723 & 30,128 & 29,752 & 12,864 & 19,059 & 54,369 & 51,342 & 54,512 & 53,483 & 54,588 & 56,788 \\
\hline $\mathrm{FeO}$ & 24,321 & 25,458 & 26,979 & 24,596 & 24,380 & 11,269 & 16,413 & 47,200 & 42,112 & 46,560 & 46,671 & 39,403 & 44,957 \\
\hline $\mathrm{Fe}_{2} \mathrm{O}_{3}$ & 45,113 & 44,569 & 41,231 & 46,007 & 45,715 & 77,555 & 64,818 & 0,000 & 6,118 & 0,000 & 0,000 & 0,470 & 0,000 \\
\hline $\mathrm{MnO}$ & 0,261 & 0,132 & 0,151 & 0,328 & 0,212 & 0,000 & 0,536 & 0,812 & 3,032 & 0,724 & 0,861 & 8,263 & 1,801 \\
\hline $\mathrm{Cr}_{2} \mathrm{O}_{3}$ & L.D & 0,000 & L.D & 0,000 & L.D & L.D & L.D & 0,000 & 0,000 & 0,000 & L.D & L.D & 0,000 \\
\hline $\mathrm{Al}_{2} \mathrm{O}_{3}$ & 0,487 & 0,418 & 0,385 & 0,336 & 0,367 & 0,051 & 0,064 & 0,034 & 0,015 & 0,076 & 0,096 & 0,008 & 0,013 \\
\hline $\mathrm{MgO}$ & 1,166 & 0,967 & 1,323 & 1,245 & 1,244 & 0,030 & 0,106 & 0,240 & 0,562 & 0,363 & 0,381 & 0,748 & 0,081 \\
\hline $\mathrm{V}_{2} \mathrm{O}_{3}$ & N.M & N.M & N.M & N.M & N.M & N.M & N.M & N.M & N.M & N.M & N.M & N.M & N.M \\
\hline $\mathrm{CaO}$ & 0,000 & 0,000 & 0,000 & 0,003 & 0,000 & 0,344 & 0,000 & 0,167 & L.D & 0,084 & 0,049 & 0,000 & 0,000 \\
\hline $\mathrm{SiO}_{2}$ & L.D & L.D & 0,045 & 0,041 & 0,041 & 0,160 & 0,000 & 0,056 & 0,000 & 0,075 & 0,860 & L.D & L.D \\
\hline Total & 100,989 & 101,909 & 102,836 & 102,684 & 101,712 & 102,273 & 100,996 & 102,878 & 103,182 & 102,394 & 102,401 & 103,480 & 103,640 \\
\hline \multicolumn{14}{|c|}{ Fórmula Estructural. 30} \\
\hline $\mathrm{Ti}$ & 0,658 & 0,667 & 0,699 & 0,658 & 0,656 & 0,330 & 0,468 & 1,000 & 0,962 & 1,004 & 0,983 & 0,997 & 1,028 \\
\hline $\mathrm{Fe}^{2+}$ & 0,514 & 0,534 & 0,558 & 0,511 & 0,512 & 0,241 & 0,354 & 0,966 & 0,860 & 0,957 & 0,957 & 0,799 & 0,917 \\
\hline $\mathrm{Fe}^{3+}$ & 0,858 & 0,841 & 0,768 & 0,861 & 0,863 & 1,495 & 1,258 & 0,000 & 0,112 & 0,000 & 0,000 & 0,009 & 0,000 \\
\hline $\mathrm{Mn}$ & 0,007 & 0,003 & 0,004 & 0,008 & 0,005 & 0,000 & 0,015 & 0,017 & 0,064 & 0,015 & 0,018 & 0,170 & 0,037 \\
\hline $\mathrm{Cr}$ & 0,000 & 0,000 & 0,000 & 0,000 & 0,000 & 0,000 & 0,000 & 0,000 & 0,000 & 0,000 & 0,000 & 0,000 & 0,000 \\
\hline $\mathrm{Al}$ & 0,017 & 0,014 & 0,013 & 0,011 & 0,013 & 0,002 & 0,002 & 0,001 & 0,000 & 0,002 & 0,003 & 0,000 & 0,000 \\
\hline $\mathrm{Mg}$ & 0,051 & 0,042 & 0,056 & 0,054 & 0,054 & 0,002 & 0,005 & 0,009 & 0,021 & 0,013 & 0,014 & 0,027 & 0,003 \\
\hline V & 0,000 & 0,000 & 0,000 & 0,000 & 0,000 & 0,000 & 0,000 & 0,000 & 0,000 & 0,000 & 0,000 & 0,000 & 0,000 \\
\hline $\mathrm{Ca}$ & 0,000 & 0,000 & 0,000 & 0,000 & 0,000 & 0,013 & 0,000 & 0,004 & 0,000 & 0,002 & 0,001 & 0,000 & 0,000 \\
\hline $\mathrm{Si}$ & 0,000 & 0,000 & 0,001 & 0,001 & 0,001 & 0,005 & 0,000 & 0,001 & 0,000 & 0,002 & 0,021 & 0,000 & 0,000 \\
\hline $\mathrm{Ti} /(\mathrm{Ti}+\mathrm{Fe})$ & 0,324 & 0,326 & 0,345 & 0,324 & 0,323 & 0,160 & 0,225 & 0,509 & 0,497 & 0,512 & 0,507 & 0,553 & 0,528 \\
\hline
\end{tabular}




\begin{tabular}{|c|c|c|c|c|c|c|c|c|c|c|c|c|c|}
\hline Mineral & Ox Fe-Ti & Ox Fe-Ti & Ox Fe-Ti & Ox Fe-Ti & Hem-(Ti) E2 & Hem-(Ti) E2 & Ox Fe-Ti & Ox Fe-Ti & Ox Fe-Ti & Ox Fe-Ti & Hem-(Ti) & Ox Fe-Ti & Ox Fe-Ti \\
\hline Nombre & B11 & B15 & B18 & B21 & B22 & B23 & B26 & B29 & B38 & B43 & B48 & B49 & B50 \\
\hline Ubicación & $\mathbf{N}$ & $\mathbf{N}$ & $\mathbf{N}$ & $\mathbf{N}$ & Exo & Min & $\mathbf{N}$ & $\mathbf{N}$ & $\mathbf{N}$ & $\mathbf{N}$ & $\mathbf{N}$ & $\mathbf{N}$ & $\mathbf{N}$ \\
\hline no análisis & 3 & 2 & 3 & 3 & 1 & 1 & 3 & 3 & 3 & 3 & 1 & 1 & 1 \\
\hline Localización & *C.Alfa & *C.Alfa & *C.Alfa & $*$ C.Alfa & \multicolumn{2}{|c|}{${ }^{*}$ C.Alfa } & $*$ C.Beta & *C.Beta & *C.Beta & ${ }^{*}$ C.Beta & *P.Sinaí & *P.Sinaí & *P.Sinaí \\
\hline Subambiente & Playa & Playa & Playa & Playa & Playa & Playa & Playa & Playa & Playa & Playa & Playa & Playa & Playa \\
\hline \multicolumn{14}{|l|}{$\%$ peso } \\
\hline $\mathrm{TiO}_{2}$ & 26,545 & 30,114 & 28,100 & 31,105 & 13,939 & 10,759 & 33,552 & 28,276 & 27,587 & 28,101 & 11,636 & 27,506 & 27,744 \\
\hline $\mathrm{FeO}$ & 21,838 & 24,719 & 22,982 & 25,623 & 12,285 & 9,526 & 26,862 & 23,826 & 22,573 & 22,763 & 10,306 & 22,707 & 22,580 \\
\hline $\mathrm{Fe}_{2} \mathrm{O}_{3}$ & 49,956 & 44,404 & 47,374 & 41,473 & 72,708 & 79,208 & 36,591 & 46,252 & 47,605 & 46,706 & 77,531 & 46,876 & 46,381 \\
\hline $\mathrm{MnO}$ & 0,194 & 0,149 & 0,303 & 0,261 & 0,162 & 0,150 & 0,195 & 0,131 & 0,238 & 0,248 & 0,095 & 0,230 & 0,153 \\
\hline $\mathrm{Cr}_{2} \mathrm{O}_{3}$ & L.D & L.D & L.D & L.D & L.D & L.D & 0,064 & L.D & L.D & L.D & L.D & L.D & 0,125 \\
\hline $\mathrm{Al}_{2} \mathrm{O}_{3}$ & 0,406 & 0,418 & 0,363 & 0,327 & 0,050 & 0,078 & 0,351 & 0,300 & 0,354 & 0,364 & 0,099 & 0,462 & 0,325 \\
\hline $\mathrm{MgO}$ & 1,034 & 1,245 & 1,116 & 1,174 & 0,050 & 0,000 & 1,751 & 0,828 & 1,123 & 1,270 & 0,036 & 1,011 & 1,247 \\
\hline $\mathrm{V}_{2} \mathrm{O}_{3}$ & 0,359 & 0,239 & 0,268 & 0,253 & 0,303 & 0,301 & 0,628 & 0,181 & 0,304 & 0,340 & 0,379 & 0,099 & 0,446 \\
\hline $\mathrm{CaO}$ & N.M & N.M & N.M & N.M & N.M & N.M & N.M & N.M & N.M & N.M & N.M & N.M & N.M \\
\hline $\mathrm{SiO}_{2}$ & N.M & N.M & N.M & N.M & N.M & N.M & N.M & N.M & N.M & N.M & N.M & N.M & N.M \\
\hline Total & 100,332 & 101,289 & 100,507 & 100,216 & 99,498 & 100,022 & 99,994 & 99,794 & 99,784 & 99,793 & 100,083 & 98,891 & 99,001 \\
\hline \multicolumn{14}{|c|}{ Fórmula Estructural. 30} \\
\hline $\mathrm{Ti}$ & 0,607 & 0,664 & 0,634 & 0,686 & 0,363 & 0,288 & 0,723 & 0,642 & 0,628 & 0,637 & 0,308 & 0,632 & 0,634 \\
\hline $\mathrm{Fe}^{2+}$ & 0,466 & 0,521 & 0,489 & 0,545 & 0,270 & 0,209 & 0,569 & 0,512 & 0,484 & 0,487 & 0,226 & 0,491 & 0,487 \\
\hline $\mathrm{Fe}^{3+}$ & 0,960 & 0,842 & 0,907 & 0,794 & 1,440 & 1,566 & 0,697 & 0,894 & 0,919 & 0,900 & 1,530 & 0,913 & 0,901 \\
\hline $\mathrm{Mn}$ & 0,005 & 0,004 & 0,008 & 0,006 & 0,005 & 0,005 & 0,005 & 0,003 & 0,006 & 0,006 & 0,003 & 0,006 & 0,004 \\
\hline $\mathrm{Cr}$ & 0,000 & 0,000 & 0,000 & 0,000 & 0,000 & 0,000 & 0,001 & 0,000 & 0,000 & 0,000 & 0,000 & 0,000 & 0,003 \\
\hline $\mathrm{Al}$ & 0,015 & 0,014 & 0,013 & 0,011 & 0,002 & 0,003 & 0,012 & 0,011 & 0,013 & 0,013 & 0,004 & 0,017 & 0,012 \\
\hline $\mathrm{Mg}$ & 0,047 & 0,054 & 0,050 & 0,051 & 0,003 & 0,000 & 0,075 & 0,037 & 0,051 & 0,057 & 0,002 & 0,046 & 0,056 \\
\hline V & 0,009 & 0,006 & 0,006 & 0,006 & 0,008 & 0,009 & 0,014 & 0,004 & 0,007 & 0,008 & 0,011 & 0,002 & 0,011 \\
\hline $\mathrm{Ca}$ & 0,000 & 0,000 & 0,000 & 0,000 & 0,000 & 0,000 & 0,000 & 0,000 & 0,000 & 0,000 & 0,000 & 0,000 & 0,000 \\
\hline $\mathrm{Si}$ & 0,000 & 0,000 & 0,000 & 0,000 & 0,000 & 0,000 & 0,000 & 0,000 & 0,000 & 0,000 & 0,000 & 0,000 & 0,000 \\
\hline $\mathrm{Ti} /(\mathrm{Ti}+\mathrm{Fe})$ & 0,299 & 0,328 & 0,312 & 0,339 & 0,175 & 0,139 & 0,364 & 0,314 & 0,309 & 0,315 & 0,149 & 0,310 & 0,313 \\
\hline
\end{tabular}




\begin{tabular}{|c|c|c|c|c|c|c|c|c|c|c|c|}
\hline $\begin{array}{l}\text { Mineral } \\
\text { Nombre }\end{array}$ & $\begin{array}{c}\text { Ox Fe-Ti } \\
\text { B51 }\end{array}$ & $\begin{array}{c}\text { Ox Fe-Ti } \\
\text { B52 }\end{array}$ & $\begin{array}{c}\text { Ox Fe-Ti } \\
\text { B53 }\end{array}$ & $\begin{array}{c}\text { Hem-(Ti) } \\
\text { B57 }\end{array}$ & $\begin{array}{c}\text { Ox Fe-Ti E1 } \\
\text { A39 }\end{array}$ & $\begin{array}{c}\text { Hem-(Ti) E1 } \\
\text { A40 }\end{array}$ & $\begin{array}{c}\text { Hem-(Ti) E1 } \\
\text { A46 }\end{array}$ & $\begin{array}{c}\text { IIm E1 } \\
\text { A47 }\end{array}$ & $\begin{array}{c}\text { Ox Fe-Ti E1 } \\
\text { A53 }\end{array}$ & $\begin{array}{c}\text { IIm E1 } \\
\text { A54 }\end{array}$ & $\begin{array}{c}11 \mathrm{~m}-(\mathrm{Mg}) \\
\text { B45 }\end{array}$ \\
\hline Ubicación & $\mathbf{N}$ & $\mathbf{N}$ & $\mathbf{N}$ & $\mathbf{N}$ & Exo & Min & Min & Exo & Min & Exo & $\mathbf{N}$ \\
\hline no a análisis & 1 & 1 & 1 & 1 & 1 & 1 & & 1 & & 1 & 1 \\
\hline Localización & *La Espiga & *La Espiga & *La Espiga & *La Espiga & \multicolumn{2}{|c|}{ *C.Beta } & \multirow{2}{*}{\multicolumn{2}{|c|}{$\begin{array}{c}\text { *P.Sinaí } \\
\text { Playa } \\
\end{array}$}} & \multirow{2}{*}{\multicolumn{2}{|c|}{$\begin{array}{c}\text { *a Espiga } \\
\text { Playa } \\
\end{array}$}} & *P.Sinaí \\
\hline Subambiente & Playa & Playa & Playa & Playa & & aya & & & & & Playa \\
\hline \multicolumn{12}{|l|}{$\%$ peso } \\
\hline $\mathrm{TiO}_{2}$ & 25,451 & 27,077 & 26,350 & 13,170 & 31,958 & 16,848 & 18,354 & 46,992 & 26,350 & 45,976 & 46,214 \\
\hline $\mathrm{FeO}$ & 21,831 & 22,251 & 22,550 & 11,525 & 27,688 & 14,762 & 15,923 & 40,091 & 22,550 & 38,673 & 35,515 \\
\hline $\mathrm{Fe}_{2} \mathrm{O}_{3}$ & 50,897 & 48,814 & 48,838 & 74,202 & 37,931 & 67,724 & 63,715 & 11,820 & 48,838 & 13,857 & 12,694 \\
\hline $\mathrm{MnO}$ & 0,285 & 0,316 & 0,841 & 0,250 & 0,757 & 0,242 & 0,360 & 1,478 & 0,841 & 2,076 & 0,513 \\
\hline $\mathrm{Cr}_{2} \mathrm{O}_{3}$ & L.D & L.D & L.D & L.D & L.D & L.D & 0,000 & L.D & L.D & L.D & 0,000 \\
\hline $\mathrm{Al}_{2} \mathrm{O}_{3}$ & 0,331 & 0,336 & 0,084 & 0,172 & 0,023 & 0,063 & 0,123 & 0,012 & 0,084 & 0,000 & 0,317 \\
\hline $\mathrm{MgO}$ & 0,435 & 1,002 & 0,170 & 0,038 & 0,164 & 0,083 & 0,125 & 0,384 & 0,170 & 0,327 & 3,106 \\
\hline $\mathrm{V}_{2} \mathrm{O}_{3}$ & 0,270 & 0,260 & 0,264 & 0,575 & 0,275 & 0,459 & 0,250 & 0,066 & 0,264 & 0,035 & 0,206 \\
\hline $\mathrm{CaO}$ & N.M & N.M & N.M & N.M & N.M & N.M & N.M & N.M & N.M & N.M & N.M \\
\hline $\mathrm{SiO}_{2}$ & N.M & N.M & N.M & N.M & N.M & N.M & N.M & N.M & N.M & N.M & N.M \\
\hline Total & 99,499 & 100,055 & 99,096 & 99,932 & 98,795 & 100,181 & 98,850 & 100,843 & 99,096 & 100,944 & 98,566 \\
\hline \multicolumn{12}{|c|}{ Fórmula Estructural. 30} \\
\hline $\mathrm{Ti}$ & 0,594 & 0,619 & 0,615 & 0,343 & 0,714 & 0,424 & 0,461 & 0,922 & 0,615 & 0,908 & 0,910 \\
\hline $\mathrm{Fe}^{2+}$ & 0,473 & 0,477 & 0,492 & 0,253 & 0,602 & 0,322 & 0,351 & 0,842 & 0,492 & 0,812 & 0,746 \\
\hline $\mathrm{Fe}^{3+}$ & 0,992 & 0,941 & 0,958 & 1,463 & 0,743 & 1,328 & 1,263 & 0,223 & 0,958 & 0,262 & 0,240 \\
\hline $\mathrm{Mn}$ & 0,007 & 0,008 & 0,022 & 0,007 & 0,019 & 0,007 & 0,010 & 0,033 & 0,022 & 0,046 & 0,011 \\
\hline $\mathrm{Cr}$ & 0,000 & 0,000 & 0,000 & 0,000 & 0,000 & 0,000 & 0,000 & 0,000 & 0,000 & 0,000 & 0,000 \\
\hline $\mathrm{Al}$ & 0,012 & 0,012 & 0,003 & 0,007 & 0,001 & 0,002 & 0,005 & 0,000 & 0,003 & 0,000 & 0,010 \\
\hline $\mathrm{Mg}$ & 0,020 & 0,045 & 0,008 & 0,002 & 0,007 & 0,004 & 0,006 & 0,015 & 0,008 & 0,013 & 0,121 \\
\hline V & 0,007 & 0,006 & 0,007 & 0,016 & 0,007 & 0,012 & 0,007 & 0,001 & 0,007 & 0,001 & 0,004 \\
\hline $\mathrm{Ca}$ & 0,000 & 0,000 & 0,000 & 0,000 & 0,000 & 0,000 & 0,000 & 0,000 & 0,000 & 0,000 & 0,000 \\
\hline Si & 0,000 & 0,000 & 0,000 & 0,000 & 0,000 & 0,000 & 0,000 & 0,000 & 0,000 & 0,000 & 0,000 \\
\hline $\mathrm{Ti} /(\mathrm{Ti}+\mathrm{Fe})$ & 0,289 & 0,304 & 0,298 & 0,167 & 0,347 & 0,205 & 0,222 & 0,464 & 0,298 & 0,458 & 0,480 \\
\hline
\end{tabular}

A 31 Análisis con microsonda electrónica realizados por R.D. Acevedo en los minerales agrupados como óxidos de Fe y Ti de los sedimentos de las playas. 


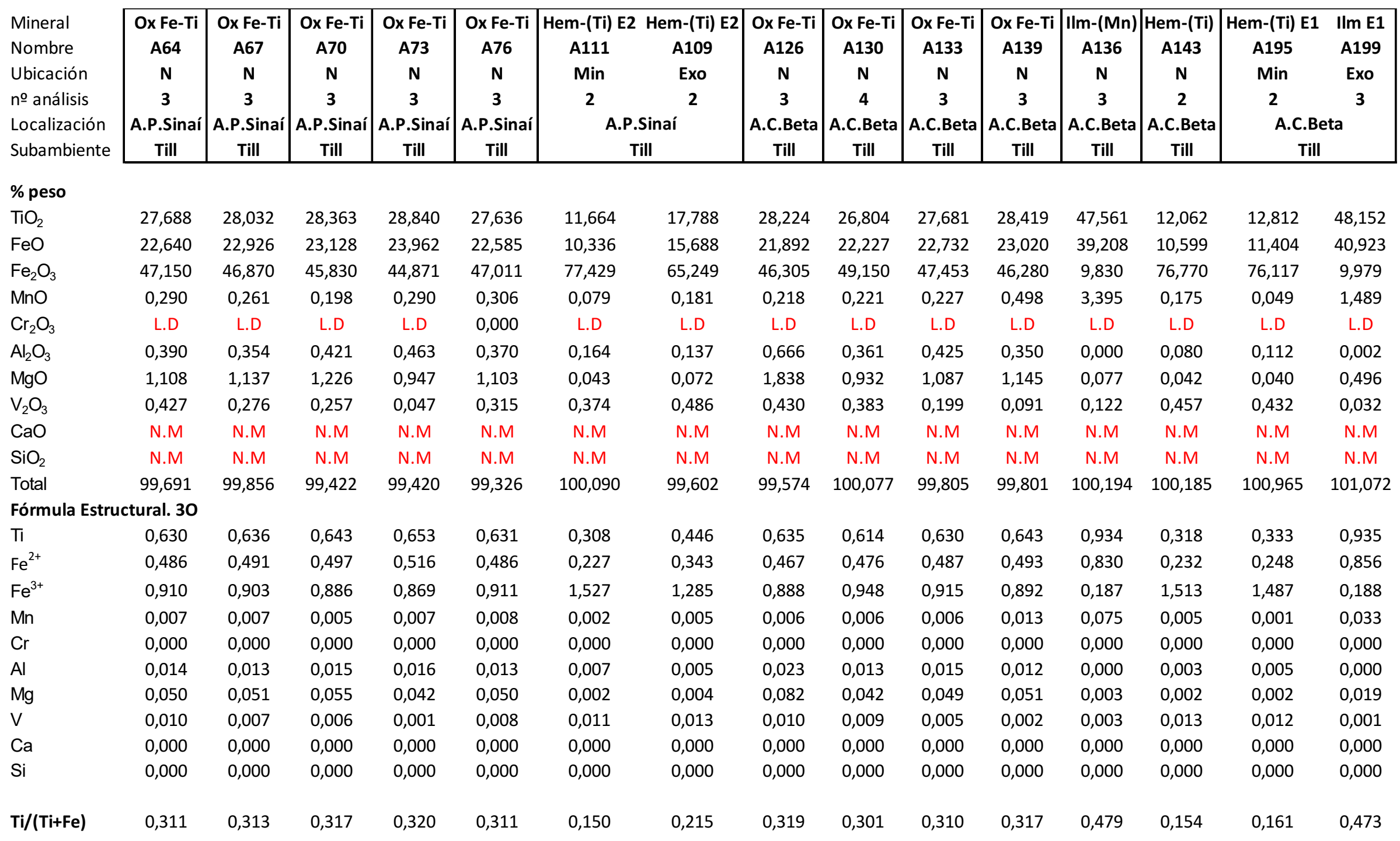

A.32. Análisis con microsonda electrónica efectuados en los minerales agrupados como óxidos de Fe y Ti de los sedimentos glacigénicos continentales. 


\begin{tabular}{|c|c|c|c|c|c|c|c|c|c|c|c|c|c|c|c|c|c|}
\hline $\begin{array}{l}\text { Mineral } \\
\text { Nombre } \\
\text { Ubicación } \\
\text { no análisis } \\
\text { Localización } \\
\text { Subambiente }\end{array}$ & \begin{tabular}{|c|} 
Ilm \\
OOR1.59 \\
$\mathrm{N}$ \\
2 \\
Interna \\
Plat \\
\end{tabular} & 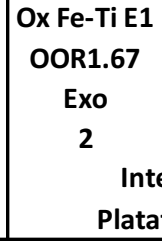 & $\begin{array}{l}\text { Hem-(Ti) E1 } \\
\text { OOR1.68 } \\
\quad \begin{array}{l}\text { Min } \\
1\end{array} \\
\text { erna } \\
\text { forma }\end{array}$ & \begin{tabular}{|c|} 
IIm \\
OOR1.72 \\
$\mathbf{N}$ \\
2 \\
Interna \\
Plat \\
\end{tabular} & \begin{tabular}{|c|} 
Hem-(Ti) \\
OOR1.76 \\
$\mathbf{N}$ \\
2 \\
Interna \\
Plat \\
\end{tabular} & $\mid \begin{array}{c}\text { Ox Fe-Ti } \\
\text { OOR2.4 } \\
\text { N } \\
2 \\
\text { Media } \\
\text { Plat }\end{array}$ & $\mid \begin{array}{c}\text { Ox Fe-Ti } \\
\text { OOR2.6 } \\
\mathbf{N} \\
2 \\
\text { Media } \\
\text { Plat } \\
\end{array}$ & \begin{tabular}{|c} 
Ox Fe-Ti \\
A393 \\
$\mathbf{N}$ \\
$\mathbf{3}$ \\
Externa \\
Plat \\
\end{tabular} & \begin{tabular}{|c} 
Ox Fe-Ti \\
A402 \\
$\mathbf{N}$ \\
1 \\
Externa \\
Plat \\
\end{tabular} & \begin{tabular}{|c} 
Ox Fe-Ti \\
A411 \\
N \\
3 \\
Media \\
Plat \\
\end{tabular} & \begin{tabular}{|c} 
IIm \\
A414 \\
$\mathbf{N}$ \\
3 \\
Media \\
Plat \\
\end{tabular} & $\begin{array}{c}\text { Hem-(Ti) E1 } \\
\text { A415 } \\
\text { Min } \\
1 \\
\text { Medi } \\
\text { Platafor }\end{array}$ & $\begin{array}{l}\text { IIm E1 } \\
\text { A416 } \\
\text { Exo } \\
\quad 1 \\
\text { ia } \\
\text { rma } \\
\end{array}$ & $\begin{array}{c}\text { IIm-(Mg) } \\
\text { A396 } \\
\mathbf{N} \\
\mathbf{3} \\
\text { Externa } \\
\text { Plat } \\
\end{array}$ & $\begin{array}{c}\text { IIm-(Mg) } \\
\text { A398 } \\
\mathbf{N} \\
2 \\
\text { Externa } \\
\text { Plat }\end{array}$ & \begin{tabular}{|c} 
IIm-(Mg) \\
A401 \\
$\mathbf{N}$ \\
$\mathbf{3}$ \\
Externa \\
Plat \\
\end{tabular} & \begin{tabular}{|c} 
IIm-(Mg) \\
A405 \\
$\mathbf{N}$ \\
$\mathbf{3}$ \\
Media \\
Plat \\
\end{tabular} \\
\hline \multicolumn{18}{|l|}{$\%$ peso } \\
\hline $\mathrm{TiO}_{2}$ & 50,009 & 35,981 & 14,974 & 43,891 & 4,295 & 30,657 & 29,120 & 28,244 & 32,582 & 27,539 & 38,102 & 13,765 & 47,349 & 45,713 & 42,343 & 47,079 & 44,287 \\
\hline $\mathrm{FeO}$ & 42,483 & 30,020 & 13,024 & 35,482 & 0,216 & 24,693 & 23,653 & 23,110 & 26,516 & 22,781 & 31,086 & 12,079 & 39,922 & 35,863 & 33,059 & 34,742 & 33,779 \\
\hline $\mathrm{Fe}_{2} \mathrm{O}_{3}$ & 5,373 & 32,957 & 70,345 & 17,839 & 89,805 & 41,677 & 44,388 & 45,995 & 38,992 & 48,081 & 28,821 & 73,140 & 10,823 & 15,711 & 22,549 & 13,802 & 19,309 \\
\hline $\mathrm{MnO}$ & 1,247 & 1,718 & 0,279 & 0,704 & 0,534 & 0,294 & 0,237 & 0,259 & 0,207 & 0,245 & 0,770 & 0,155 & 1,798 & 0,500 & 0,472 & 0,417 & 0,819 \\
\hline $\mathrm{Cr}_{2} \mathrm{O}_{3}$ & L.D & L.D & L.D & L.D & 0,189 & L.D & L.D & L.D & L.D & L.D & L.D & L.D & 0,000 & L.D & 0,000 & 0,075 & L.D \\
\hline $\mathrm{Al}_{2} \mathrm{O}_{3}$ & 0,026 & 0,050 & 0,073 & 0,150 & 2,106 & 0,449 & 0,386 & 0,341 & 0,301 & 0,390 & 0,172 & 0,097 & 0,011 & 0,218 & 0,207 & 0,397 & 0,201 \\
\hline $\mathrm{MgO}$ & 0,696 & 0,340 & 0,092 & 1,844 & 1,741 & 1,451 & 1,292 & 1,142 & 1,449 & 0,978 & 1,351 & 0,082 & 0,476 & 2,666 & 2,554 & 4,031 & 2,935 \\
\hline $\mathrm{V}_{2} \mathrm{O}_{3}$ & 0,051 & 0,228 & 0,594 & 0,039 & 0,066 & 0,292 & 0,268 & 0,344 & 0,112 & 0,378 & 0,223 & 0,333 & 0,263 & 0,211 & 0,255 & 0,557 & 0,184 \\
\hline $\mathrm{CaO}$ & L.D & L.D & L.D & L.D & 0,065 & L.D & L.D & N.M & N.M & N.M & N.M & N.M & N.M & N.M & N.M & N.M & N.M \\
\hline $\mathrm{SiO}_{2}$ & L.D & L.D & 0,000 & L.D & 0,066 & L.D & L.D & N.M & N.M & N.M & N.M & N.M & N.M & N.M & N.M & N.M & N.M \\
\hline Total & 99,884 & 101,295 & 99,381 & 99,948 & 99,083 & 99,514 & 99,344 & 99,436 & 100,159 & 100,393 & 100,526 & 99,650 & 100,642 & 100,881 & 101,440 & 101,101 & 101,513 \\
\hline \multicolumn{18}{|c|}{ Fórmula Estructural. 30} \\
\hline $\mathrm{Ti}$ & 0,965 & 0,763 & 0,386 & 0,878 & 0,119 & 0,680 & 0,656 & 0,641 & 0,710 & 0,625 & 0,794 & 0,358 & 0,926 & 0,892 & 0,844 & 0,900 & 0,869 \\
\hline $\mathrm{Fe}^{2+}$ & 0,895 & 0,634 & 0,287 & 0,745 & 0,005 & 0,528 & 0,508 & 0,497 & 0,563 & 0,486 & 0,655 & 0,265 & 0,839 & 0,740 & 0,682 & 0,707 & 0,693 \\
\hline $\mathrm{Fe}^{3+}$ & 0,102 & 0,626 & 1,393 & 0,337 & 1,759 & 0,802 & 0,858 & 0,890 & 0,745 & 0,923 & 0,546 & 1,446 & 0,205 & 0,292 & 0,418 & 0,253 & 0,356 \\
\hline $\mathrm{Mn}$ & 0,027 & 0,041 & 0,008 & 0,016 & 0,017 & 0,007 & 0,006 & 0,007 & 0,005 & 0,006 & 0,018 & 0,005 & 0,040 & 0,011 & 0,011 & 0,009 & 0,018 \\
\hline $\mathrm{Cr}$ & 0,000 & 0,000 & 0,000 & 0,000 & 0,006 & 0,000 & 0,000 & 0,000 & 0,000 & 0,000 & 0,000 & 0,000 & 0,000 & 0,000 & 0,000 & 0,002 & 0,000 \\
\hline $\mathrm{Al}$ & 0,001 & 0,002 & 0,003 & 0,005 & 0,091 & 0,016 & 0,014 & 0,012 & 0,010 & 0,014 & 0,006 & 0,004 & 0,000 & 0,007 & 0,006 & 0,012 & 0,006 \\
\hline $\mathrm{Mg}$ & 0,027 & 0,014 & 0,005 & 0,073 & 0,096 & 0,064 & 0,058 & 0,051 & 0,063 & 0,044 & 0,056 & 0,004 & 0,018 & 0,103 & 0,101 & 0,153 & 0,114 \\
\hline V & 0,001 & 0,005 & 0,016 & 0,001 & 0,002 & 0,007 & 0,006 & 0,008 & 0,003 & 0,009 & 0,005 & 0,009 & 0,005 & 0,004 & 0,005 & 0,011 & 0,004 \\
\hline $\mathrm{Ca}$ & 0,000 & 0,000 & 0,000 & 0,000 & 0,003 & 0,000 & 0,000 & 0,000 & 0,000 & 0,000 & 0,000 & 0,000 & 0,000 & 0,000 & 0,000 & 0,000 & 0,000 \\
\hline $\mathrm{Si}$ & 0,000 & 0,000 & 0,000 & 0,000 & 0,002 & 0,000 & 0,000 & 0,000 & 0,000 & 0,000 & 0,000 & 0,000 & 0,000 & 0,000 & 0,000 & 0,000 & 0,000 \\
\hline $\mathrm{Ti} /(\mathrm{Ti}+\mathrm{Fe})$ & 0,492 & 0,377 & 0,187 & 0,448 & 0,063 & 0,339 & 0,325 & 0,316 & 0,352 & 0,307 & 0,398 & 0,173 & 0,470 & 0,464 & 0,434 & 0,484 & 0,453 \\
\hline
\end{tabular}

A.33. Análisis con microsonda electrónica efectuados en los minerales agrupados como óxidos de Fe y Ti de los sedimentos presentes en la Plataforma Continental interna, media y externa. 


\section{Magnetita}

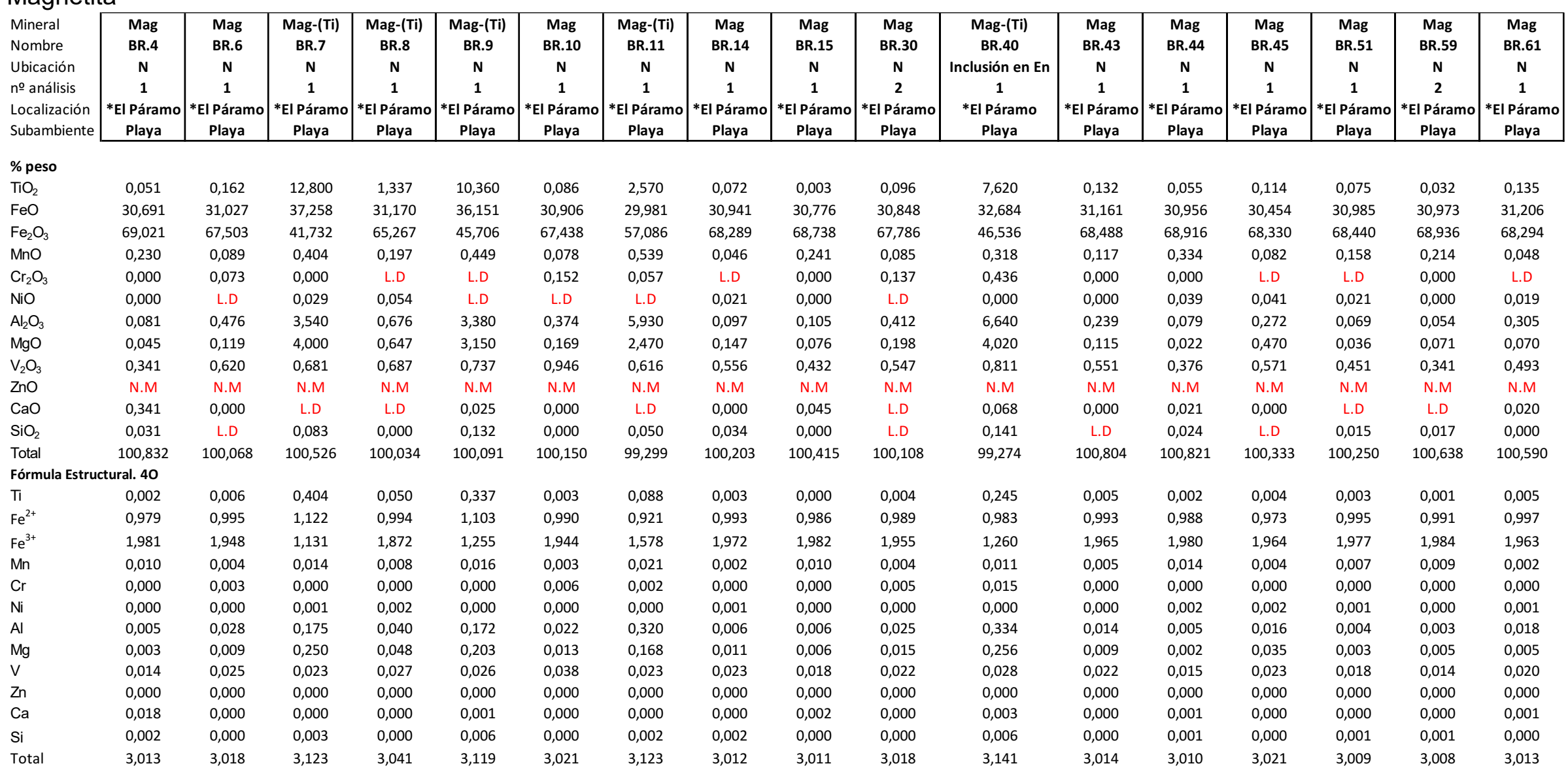

A.34. Análisis con microsonda electrónica efectuados en las magnetitas de los sedimentos de las playas. $\mathrm{Fe}_{2} \mathrm{O}_{3}$ calculado por Droop (1987). *Niveles enriquecidos. Abreviaturas: Mag, magnetita s.S.; Mag-(Ti), magnetita titanífera; Hem-(Ti), hematita titanífera; En, enstatita rica en Fe; Aug, augita; PI, plagioclasa; E4, Mag-(Ti) con exsoluciones más ricas en Ti; E5, Mag(Ti) con exsoluciones más ricas en Ti correspondientes con la fase Hem-(Ti); Min, minerales; Exo, exolución. 


\begin{tabular}{|c|c|c|c|c|c|c|c|c|c|c|c|c|c|c|c|c|}
\hline $\begin{array}{l}\text { Mineral } \\
\text { Nombre }\end{array}$ & $\begin{array}{l}\text { Mag } \\
\text { BR.62 }\end{array}$ & $\begin{array}{c}\text { Mag } \\
\text { BR.66 }\end{array}$ & $\begin{array}{l}\text { Mag } \\
\text { BR. } 88\end{array}$ & $\begin{array}{c}\text { Mag } \\
\text { BR.89 }\end{array}$ & $\begin{array}{l}\text { Mag } \\
\text { BR.91 }\end{array}$ & $\begin{array}{l}\text { Mag } \\
\text { BR.92 }\end{array}$ & $\begin{array}{l}\text { Mag } \\
\text { BR.94 }\end{array}$ & $\begin{array}{c}\text { Mag } \\
\text { BR.111 }\end{array}$ & $\begin{array}{c}\text { Mag } \\
\text { BR.112 }\end{array}$ & $\begin{array}{c}\text { Mag } \\
\text { BR.113 }\end{array}$ & $\begin{array}{c}\text { Mag-(Ti) } \\
\text { BR.124 }\end{array}$ & $\begin{array}{c}\text { Mag } \\
\text { BR.128 }\end{array}$ & $\begin{array}{c}\text { Mag } \\
\text { BR.160 }\end{array}$ & $\begin{array}{c}\text { Mag } \\
\text { BR.151 }\end{array}$ & $\begin{array}{c}\text { Mag } \\
\text { BR.152 }\end{array}$ & $\begin{array}{c}\text { Mag-(Ti) } \\
\text { BR.155 }\end{array}$ \\
\hline Ubicación & $\mathrm{N}$ & $\mathrm{N}$ & N & $\mathrm{N}$ & $\mathrm{N}$ & $\begin{array}{c}\text { D.je } \\
\mathrm{N}\end{array}$ & N & $\mathrm{N}$ & $\mathrm{N}$ & $\mathrm{N}$ & Inclusiónes en En & $\mathbf{N}$ & $\mathrm{N}$ & N & N & $\mathbf{N}$ \\
\hline № análisis & 1 & 1 & 1 & 1 & 1 & 1 & 2 & 1 & 1 & 1 & 3 & 2 & 2 & 1 & 1 & 1 \\
\hline $\begin{array}{l}\text { Localización } \\
\text { Subambiente }\end{array}$ & $\begin{array}{c}\text { *La Espiga } \\
\text { Playa }\end{array}$ & $\begin{array}{c}* \text { La Espiga } \\
\text { Playa }\end{array}$ & $\begin{array}{c}{ }^{*} \text { La Espiga } \\
\text { Playa }\end{array}$ & $\begin{array}{c}{ }^{*} \text { La Espiga } \\
\text { Playa }\end{array}$ & $\begin{array}{c}\text { *La Espiga } \\
\text { Playa }\end{array}$ & $\begin{array}{c}\text { *La Espiga } \\
\text { Playa }\end{array}$ & $\begin{array}{c}* \text { La Espiga } \\
\text { Playa }\end{array}$ & $\begin{array}{c}\text { *La Espiga } \\
\text { Playa }\end{array}$ & $\begin{array}{c}\text { *La Espiga } \\
\text { Playa }\end{array}$ & $\begin{array}{c}{ }^{*} \text { La Espiga } \\
\text { Playa }\end{array}$ & $\begin{array}{l}\text { *La Espiga } \\
\text { Playa }\end{array}$ & $\begin{array}{c}{ }^{*} \text { La Espiga } \\
\text { Playa }\end{array}$ & $\begin{array}{c}\text { *La Espiga } \\
\text { Playa }\end{array}$ & $\begin{array}{c}\text { *La Espiga } \\
\text { Playa }\end{array}$ & $\begin{array}{c}* \text { La Espiga } \\
\text { Playa }\end{array}$ & $\begin{array}{c}\text { *La Espiga } \\
\text { Playa }\end{array}$ \\
\hline \multicolumn{17}{|l|}{$\%$ peso } \\
\hline $\mathrm{TiO}_{2}$ & 0,033 & 0,132 & 0,081 & 0,079 & 0,143 & 0,000 & 0,013 & 0,109 & 0,000 & 0,052 & 7,613 & 0,280 & 0,041 & 0,311 & 0,375 & 12,380 \\
\hline $\mathrm{FeO}$ & 30,814 & 30,180 & 30,273 & 31,182 & 31,398 & 31,022 & 31,370 & 30,828 & 30,794 & 31,212 & 33,489 & 31,107 & 30,982 & 31,116 & 31,415 & 37,662 \\
\hline $\mathrm{Fe}_{2} \mathrm{O}_{3}$ & 68,574 & 65,811 & 65,996 & 68,754 & 68,670 & 69,065 & 68,911 & 68,514 & 68,351 & 68,620 & 48,009 & 68,337 & 68,476 & 68,038 & 67,662 & 42,939 \\
\hline $\mathrm{MnO}$ & 0,122 & 0,083 & 0,082 & 0,086 & 0,064 & 0,312 & 0,037 & 0,447 & 0,263 & 0,055 & 0,324 & 0,091 & 0,095 & 0,038 & 0,071 & 0,626 \\
\hline $\mathrm{Cr}_{2} \mathrm{O}_{3}$ & L.D & L.D & 0,000 & L.D & 0,091 & 0,000 & L.D & L.D & 0,000 & 0,120 & L.D & 0,000 & 0,000 & 0,000 & 0,003 & 0,000 \\
\hline $\mathrm{NiO}$ & L.D & 0,000 & 0,000 & 0,000 & 0,020 & 0,000 & L.D & 0,000 & L.D & L.D & L.D & L.D & 0,000 & 0,027 & 0,063 & 0,018 \\
\hline $\mathrm{Al}_{2} \mathrm{O}_{3}$ & 0,195 & 0,287 & 3,190 & 0,228 & 0,276 & 0,046 & 0,023 & 0,367 & 0,071 & 0,254 & 6,233 & 0,209 & 0,175 & 0,246 & 0,588 & 2,660 \\
\hline $\mathrm{MgO}$ & 0,198 & 0,165 & 1,194 & 0,160 & 0,151 & 0,000 & 0,028 & 0,132 & 0,042 & 0,061 & 3,630 & 0,256 & 0,099 & 0,324 & 0,147 & 3,120 \\
\hline $\mathrm{V}_{2} \mathrm{O}_{3}$ & 0,504 & 0,515 & 0,594 & 0,664 & 0,559 & 0,306 & 0,033 & 0,490 & 0,289 & 0,329 & 0,636 & 0,515 & 0,519 & 0,581 & 0,635 & 0,541 \\
\hline $\mathrm{ZnO}$ & N.M & N.M & N.M & N.M & N.M & N.M & N.M & N.M & N.M & N.M & N.M & N.M & N.M & N.M & N.M & N.M \\
\hline $\mathrm{CaO}$ & L.D & 0,032 & 0,030 & 0,000 & L.D & 0,000 & 0,024 & 0,000 & 0,042 & 0,045 & L.D & 0,021 & 0,000 & 0,000 & 0,021 & 0,029 \\
\hline $\mathrm{SiO}_{2}$ & L.D & 0,126 & 0,063 & L.D & 0,039 & 0,035 & 0,179 & L.D & 0,103 & 0,031 & 0,123 & 0,016 & L.D & 0,056 & L.D & 0,078 \\
\hline Total & 100,439 & 97,331 & 101,502 & 101,152 & 101,410 & 100,787 & 100,618 & 100,887 & 99,957 & 100,780 & 100,058 & 100,832 & 100,387 & 100,737 & 100,979 & 100,052 \\
\hline \multicolumn{17}{|c|}{ Fórmula Estructural. 40} \\
\hline Ti & 0,001 & 0,005 & 0,003 & 0,003 & 0,005 & 0,000 & 0,001 & 0,004 & 0,000 & 0,002 & 0,246 & 0,011 & 0,002 & 0,012 & 0,014 & 0,400 \\
\hline $\mathrm{Fe}^{2+}$ & 0,986 & 0,995 & 0,935 & 0,990 & 0,994 & 0,991 & 1,003 & 0,981 & 0,991 & 0,996 & 1,006 & 0,990 & 0,992 & 0,991 & 0,997 & 1,152 \\
\hline $\mathrm{Fe}^{3+}$ & 1,974 & 1,953 & 1,834 & 1,965 & 1,957 & 1,986 & 1,984 & 1,962 & 1,980 & 1,970 & 1,298 & 1,958 & 1,974 & 1,949 & 1,933 & 1,182 \\
\hline $\mathrm{Mn}$ & 0,005 & 0,004 & 0,003 & 0,004 & 0,003 & 0,013 & 0,002 & 0,019 & 0,011 & 0,002 & 0,012 & 0,004 & 0,004 & 0,002 & 0,003 & 0,023 \\
\hline $\mathrm{Cr}$ & 0,000 & 0,000 & 0,000 & 0,000 & 0,004 & 0,000 & 0,000 & 0,000 & 0,000 & 0,005 & 0,000 & 0,000 & 0,000 & 0,000 & 0,000 & 0,000 \\
\hline $\mathrm{Ni}$ & 0,000 & 0,000 & 0,000 & 0,000 & 0,001 & 0,000 & 0,000 & 0,000 & 0,000 & 0,000 & 0,000 & 0,000 & 0,000 & 0,001 & 0,003 & 0,001 \\
\hline Al & 0,012 & 0,018 & 0,180 & 0,013 & 0,016 & 0,003 & 0,001 & 0,022 & 0,004 & 0,015 & 0,315 & 0,012 & 0,010 & 0,015 & 0,035 & 0,135 \\
\hline $\mathrm{Mg}$ & 0,015 & 0,013 & 0,085 & 0,012 & 0,011 & 0,000 & 0,002 & 0,010 & 0,003 & 0,005 & 0,232 & 0,019 & 0,008 & 0,024 & 0,011 & 0,200 \\
\hline $\mathrm{V}$ & 0,021 & 0,022 & 0,023 & 0,027 & 0,022 & 0,012 & 0,001 & 0,020 & 0,012 & 0,013 & 0,022 & 0,021 & 0,021 & 0,023 & 0,025 & 0,019 \\
\hline $\mathrm{Zn}$ & 0,000 & 0,000 & 0,000 & 0,000 & 0,000 & 0,000 & 0,000 & 0,000 & 0,000 & 0,000 & 0,000 & 0,000 & 0,000 & 0,000 & 0,000 & 0,000 \\
\hline $\mathrm{Ca}$ & 0,000 & 0,002 & 0,002 & 0,000 & 0,000 & 0,000 & 0,001 & 0,000 & 0,002 & 0,002 & 0,000 & 0,001 & 0,000 & 0,000 & 0,001 & 0,001 \\
\hline $\mathrm{Si}$ & 0,000 & 0,007 & 0,003 & 0,000 & 0,002 & 0,002 & 0,009 & 0,000 & 0,005 & 0,002 & 0,005 & 0,001 & 0,000 & 0,003 & 0,000 & 0,003 \\
\hline Total & 3,013 & 3,017 & 3,069 & 3,014 & 3,016 & 3,008 & 3,004 & 3,018 & 3,009 & 3,011 & 3,135 & 3,017 & 3,011 & 3,019 & 3,022 & 3,115 \\
\hline
\end{tabular}




\begin{tabular}{|c|c|c|c|c|c|c|c|c|c|c|c|c|c|c|c|}
\hline Mineral & Mag-(Ti) & Mag-(Ti) & Mag-(Ti) & Mag & Mag & Mag & Mag-(Ti) & Mag-(Ti) & Mag & Mag & Mag & Mag & Mag & Mag & Mag \\
\hline Nombre & BR.179 & BR.188 & BR.192 & BR.203 & BR.204 & BR.205 & BR.206 & BR.212 & BR.220 & BR.221 & BR.222 & BR.226 & BR.228 & BR.230 & OOR1.51 \\
\hline Ubicación & $\mathbf{N}$ & $\mathbf{N}$ & Inclusion Aug & $\mathbf{N}$ & $\mathbf{N}$ & $\mathbf{N}$ & $\mathbf{N}$ & $\mathbf{N}$ & $\mathbf{N}$ & $\mathbf{N}$ & $\mathbf{N}$ & $\mathbf{N}$ & $\mathbf{N}$ & $\mathbf{N}$ & $\mathbf{N}$ \\
\hline no análisis & 2 & 1 & 1 & 1 & 1 & 1 & 1 & 1 & 1 & 1 & 1 & 1 & 1 & 1 & 2 \\
\hline Localización & *P.Sinaí & *P.Sinaí & *P.Sinaí & *C.Beta & *C.Beta & *C.Beta & ${ }^{*}$ C.Beta & ${ }^{*}$ C.Beta & $*$ C.Beta & $*$ C.Beta & $*$ C.Beta & $*$ C.Beta & *C.Beta & *C.Beta & El Páramo \\
\hline ubambiente & Playa & Playa & Playa & Playa & Playa & Playa & Playa & Playa & Playa & Playa & Playa & Playa & Playa & Playa & Playa \\
\hline
\end{tabular}

\begin{tabular}{|c|c|c|c|c|c|c|c|c|c|c|c|c|c|c|c|}
\hline \multicolumn{16}{|c|}{$\%$ peso } \\
\hline $\mathrm{TiO}_{2}$ & 14,125 & 13,240 & 10,490 & 0,420 & 0,000 & 0,000 & 15,210 & 13,380 & 0,345 & 0,048 & 0,381 & 0,042 & 0,268 & 0,127 & 0,003 \\
\hline $\mathrm{FeO}$ & 39,639 & 39,069 & 34,234 & 30,693 & 30,764 & 31,010 & 39,664 & 35,262 & 31,234 & 30,608 & 30,784 & 31,163 & 28,738 & 30,855 & 30,355 \\
\hline $\mathrm{Fe}_{2} \mathrm{O}_{3}$ & 39,174 & 41,641 & 43,847 & 67,241 & 68,996 & 68,767 & 36,480 & 40,650 & 66,441 & 68,780 & 67,885 & 69,076 & 66,680 & 68,729 & 67,990 \\
\hline $\mathrm{MnO}$ & 0,490 & 0,695 & 0,359 & 0,115 & 0,276 & 0,224 & 0,548 & 0,401 & 0,118 & 0,525 & 0,136 & 0,222 & 0,055 & 0,076 & 0,414 \\
\hline $\mathrm{Cr}_{2} \mathrm{O}_{3}$ & L.D & L.D & 0,775 & 0,000 & L.D & 0,000 & 0,000 & L.D & 0,133 & 0,000 & L.D & 0,000 & 0,000 & 0,000 & L.D \\
\hline $\mathrm{NiO}$ & 0,000 & L.D & 0,048 & 0,043 & 0,000 & L.D & L.D & 0,000 & 0,057 & 0,000 & 0,000 & 0,000 & 0,000 & 0,035 & L.D \\
\hline $\mathrm{Al}_{2} \mathrm{O}_{3}$ & 2,760 & 2,370 & 4,010 & 0,437 & 0,042 & 0,038 & 3,300 & 3,830 & 1,150 & 0,071 & 0,510 & 0,014 & 2,580 & 0,262 & 0,029 \\
\hline $\mathrm{MgO}$ & 3,015 & 2,720 & 4,190 & 0,417 & 0,135 & 0,011 & 3,510 & 5,580 & 0,153 & 0,041 & 0,541 & 0,000 & 2,140 & 0,386 & 0,001 \\
\hline $\mathrm{V}_{2} \mathrm{O}_{3}$ & 0,759 & 0,460 & 0,923 & 0,487 & 0,296 & 0,323 & 0,591 & 0,637 & 0,610 & 0,276 & 0,621 & 0,293 & 0,558 & 0,580 & 0,334 \\
\hline $\mathrm{ZnO}$ & N.M & N.M & N.M & N.M & N.M & N.M & N.M & N.M & N.M & N.M & N.M & N.M & N.M & N.M & L.D \\
\hline $\mathrm{CaO}$ & 0,039 & 0,036 & 0,235 & 0,000 & L.D & L.D & 0,023 & 0,063 & 0,000 & L.D & 0,000 & L.D & 0,031 & 0,000 & L.D \\
\hline $\mathrm{SiO}_{2}$ & 0,090 & 0,093 & 0,075 & 0,019 & 0,030 & 0,057 & 0,049 & 0,138 & L.D & L.D & L.D & 0,035 & 0,033 & 0,017 & L.D \\
\hline Total & 100,092 & 100,324 & 99,187 & 99,873 & 100,539 & 100,430 & 99,374 & 99,940 & 100,240 & 100,349 & 100,857 & 100,844 & 101,083 & 101,065 & 99,127 \\
\hline \multicolumn{16}{|c|}{ ctural. 40} \\
\hline $\mathrm{Ti}$ & 0,448 & 0,426 & 0,338 & 0,016 & 0,000 & 0,000 & 0,477 & 0,416 & 0,013 & 0,002 & 0,014 & 0,002 & 0,010 & 0,005 & 0,000 \\
\hline $\mathrm{Fe}^{2+}$ & 1,210 & 1,197 & 1,041 & 0,984 & 0,984 & 0,994 & 1,211 & 1,053 & 0,996 & 0,982 & 0,976 & 0,995 & 0,888 & 0,979 & 0,986 \\
\hline $\mathrm{Fe}^{3+}$ & 1,076 & 1,148 & 1,200 & 1,940 & 1,987 & 1,984 & 1,002 & 1,092 & 1,906 & 1,986 & 1,937 & 1,985 & 1,854 & 1,962 & 1,988 \\
\hline $\mathrm{Mn}$ & 0,018 & 0,025 & 0,013 & 0,005 & 0,012 & 0,010 & 0,019 & 0,014 & 0,005 & 0,023 & 0,006 & 0,010 & 0,002 & 0,003 & 0,018 \\
\hline $\mathrm{Cr}$ & 0,000 & 0,000 & 0,026 & 0,000 & 0,000 & 0,000 & 0,000 & 0,000 & 0,005 & 0,000 & 0,000 & 0,000 & 0,000 & 0,000 & 0,000 \\
\hline $\mathrm{Ni}$ & 0,000 & 0,000 & 0,002 & 0,002 & 0,000 & 0,000 & 0,000 & 0,000 & 0,002 & 0,000 & 0,000 & 0,000 & 0,000 & 0,001 & 0,000 \\
\hline $\mathrm{Al}$ & 0,137 & 0,119 & 0,202 & 0,026 & 0,003 & 0,002 & 0,162 & 0,187 & 0,068 & 0,004 & 0,030 & 0,001 & 0,146 & 0,016 & 0,002 \\
\hline Mg & 0,190 & 0,173 & 0,267 & 0,031 & 0,010 & 0,001 & 0,218 & 0,344 & 0,011 & 0,003 & 0,040 & 0,000 & 0,153 & 0,029 & 0,000 \\
\hline V & 0,026 & 0,016 & 0,032 & 0,020 & 0,012 & 0,013 & 0,020 & 0,021 & 0,024 & 0,011 & 0,025 & 0,012 & 0,022 & 0,023 & 0,014 \\
\hline Zn & 0,000 & 0,000 & 0,000 & 0,000 & 0,000 & 0,000 & 0,000 & 0,000 & 0,000 & 0,000 & 0,000 & 0,000 & 0,000 & 0,000 & 0,000 \\
\hline $\mathrm{Ca}$ & 0,002 & 0,002 & 0,011 & 0,000 & 0,000 & 0,000 & 0,001 & 0,003 & 0,000 & 0,000 & 0,000 & 0,000 & 0,002 & 0,000 & 0,000 \\
\hline $\mathrm{Si}$ & 0,004 & 0,004 & 0,003 & 0,001 & 0,002 & 0,003 & 0,002 & 0,006 & 0,000 & 0,000 & 0,000 & 0,002 & 0,002 & 0,001 & 0,000 \\
\hline Total & 3,111 & 3,110 & 3,134 & 3,024 & 3,010 & 3,007 & 3,113 & 3,135 & 3,031 & 3,011 & 3,028 & 3,006 & 3,078 & 3,019 & 3,008 \\
\hline
\end{tabular}

A.36. Continuación. 


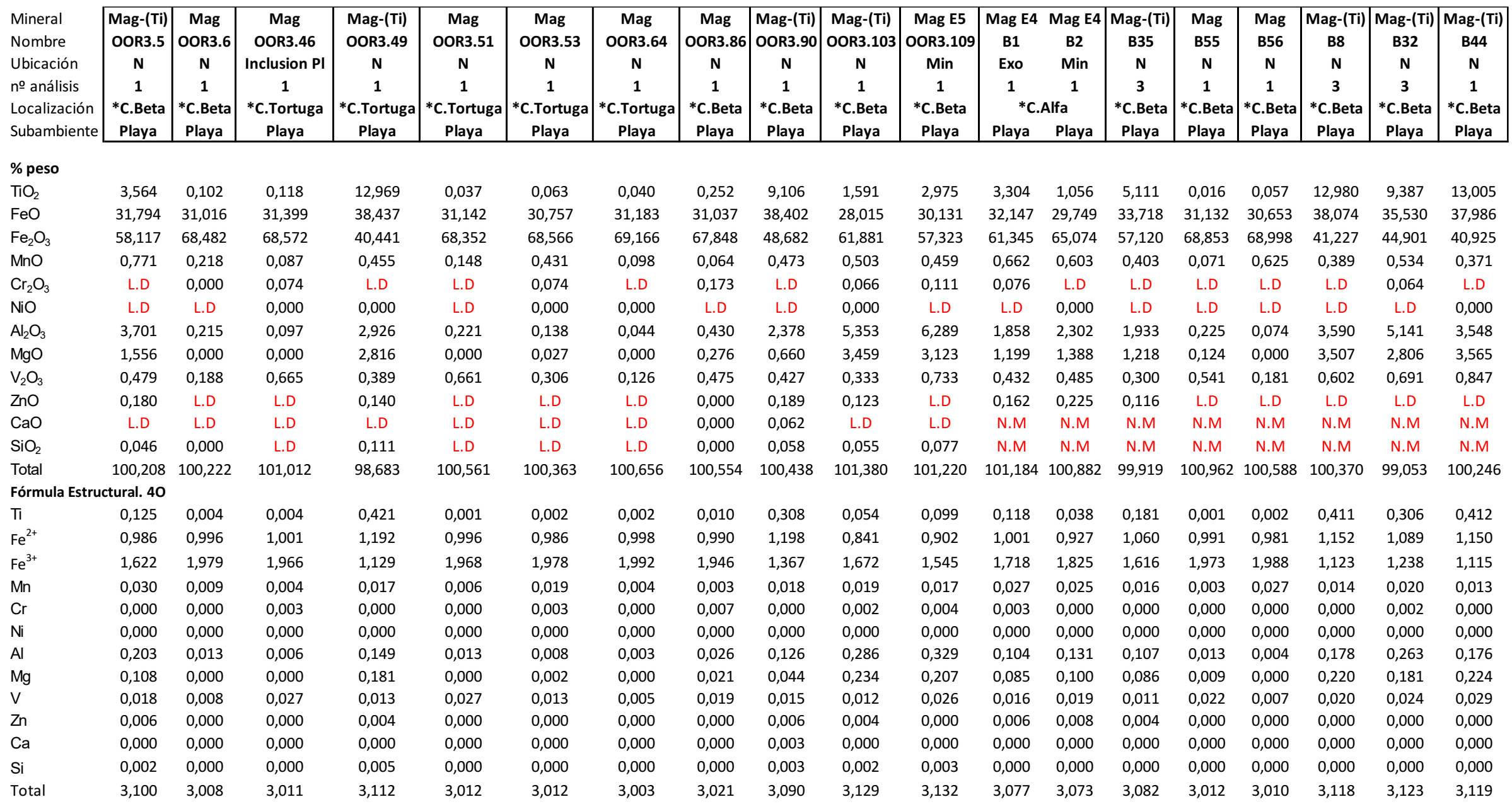

A.37. Continuación. 


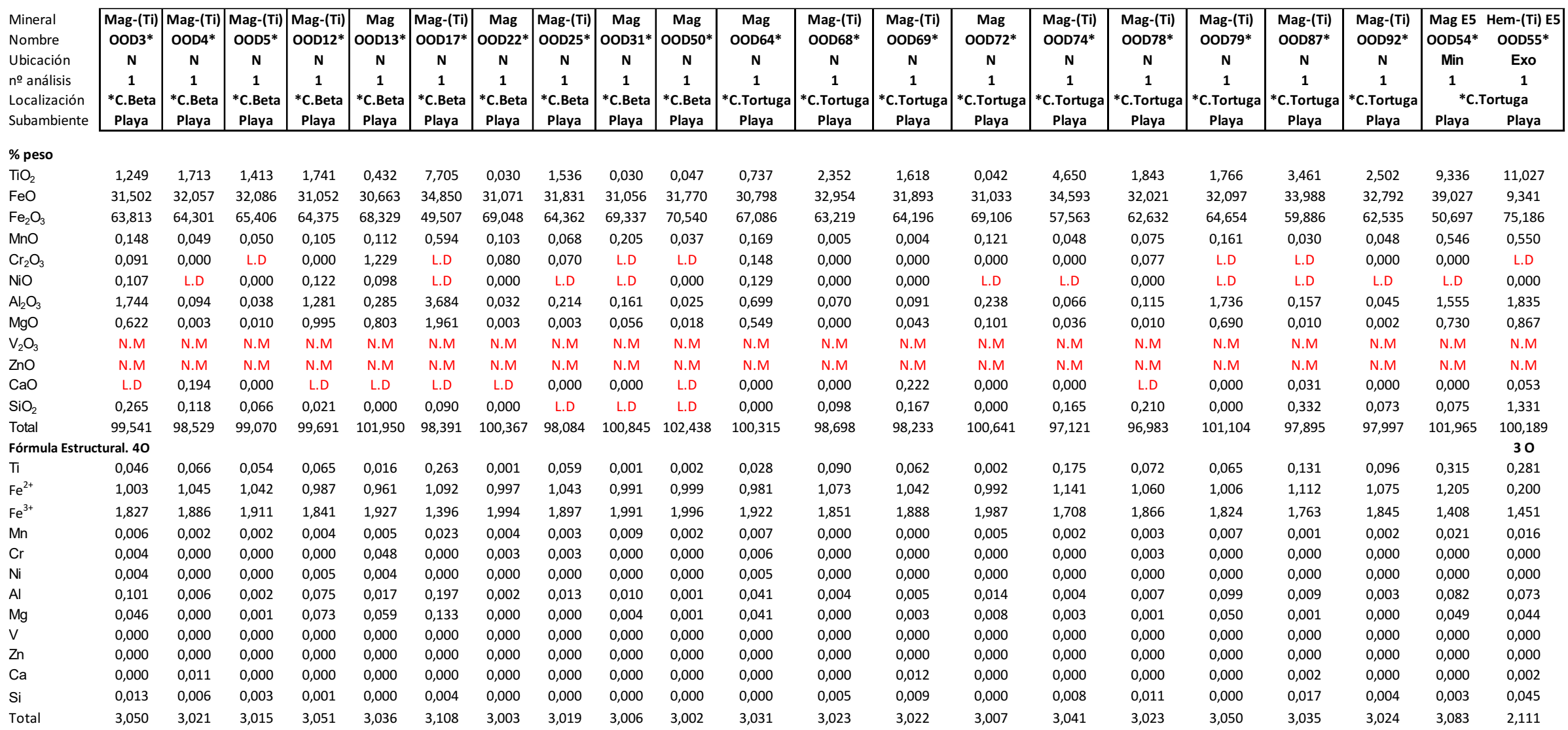

A.38. Análisis con microsonda electrónica realizados por R.D. Acevedo en las magnetitas de los sedimentos de las playas. 


\begin{tabular}{|c|c|c|c|c|c|}
\hline Mineral & Mag-(Ti) & Mag & Mag-(Ti) & Mag-(Ti) & Mag-(Ti) \\
\hline Nombre & A120 & A61 & OOR1.74 & OOR2.12 & OOR2.14 \\
\hline Ubicación & $\mathbf{N}$ & $\mathbf{N}$ & $\mathbf{N}$ & $\mathbf{N}$ & $\mathbf{N}$ \\
\hline $\mathrm{n}$ o análisis & 5 & 3 & 2 & 2 & 2 \\
\hline Localización & A.C.Beta & A.P.Sinaí & Interna & Media & Media \\
\hline Subambiente & Till & Till & Plataforma & Plataforma & Plataforma \\
\hline \multicolumn{6}{|l|}{$\%$ peso } \\
\hline $\mathrm{TiO}_{2}$ & 11,881 & 0,072 & 8,996 & 8,595 & 5,930 \\
\hline $\mathrm{FeO}$ & 36,524 & 31,186 & 36,289 & 34,730 & 35,620 \\
\hline $\mathrm{Fe}_{2} \mathrm{O}_{3}$ & 42,383 & 68,085 & 42,448 & 47,865 & 55,874 \\
\hline $\mathrm{MnO}$ & 0,470 & 0,062 & 0,879 & 0,330 & 0,944 \\
\hline $\mathrm{Cr}_{2} \mathrm{O}_{3}$ & 0,091 & L.D & 0,095 & 0,242 & 0,126 \\
\hline $\mathrm{NiO}$ & L.D & L.D & L.D & L.D & L.D \\
\hline $\mathrm{Al}_{2} \mathrm{O}_{3}$ & 3,061 & 0,279 & 6,092 & 4,144 & 1,109 \\
\hline $\mathrm{MgO}$ & 3,325 & 0,010 & 1,645 & 3,097 & 0,175 \\
\hline $\mathrm{V}_{2} \mathrm{O}_{3}$ & 0,592 & 0,639 & 0,564 & 0,751 & 0,460 \\
\hline $\mathrm{ZnO}$ & L.D & L.D & 0,136 & L.D & 0,133 \\
\hline $\mathrm{CaO}$ & N.M & N.M & L.D & L.D & L.D \\
\hline $\mathrm{SiO}_{2}$ & N.M & N.M & 0,142 & 0,080 & 0,057 \\
\hline Total & 98,326 & 100,333 & 97,286 & 99,834 & 100,427 \\
\hline \multicolumn{6}{|c|}{ Fórmula Estructural. 40} \\
\hline $\mathrm{Ti}$ & 0,389 & 0,003 & 0,298 & 0,282 & 0,211 \\
\hline $\mathrm{Fe}^{2+}$ & 1,133 & 1,000 & 1,135 & 1,060 & 1,127 \\
\hline $\mathrm{Fe}^{3+}$ & 1,183 & 1,964 & 1,195 & 1,315 & 1,591 \\
\hline $\mathrm{Mn}$ & 0,017 & 0,003 & 0,033 & 0,012 & 0,038 \\
\hline $\mathrm{Cr}$ & 0,003 & 0,000 & 0,003 & 0,008 & 0,005 \\
\hline $\mathrm{Ni}$ & 0,000 & 0,000 & 0,000 & 0,000 & 0,000 \\
\hline $\mathrm{Al}$ & 0,157 & 0,017 & 0,316 & 0,213 & 0,062 \\
\hline$M g$ & 0,216 & 0,001 & 0,108 & 0,202 & 0,012 \\
\hline V & 0,021 & 0,026 & 0,020 & 0,026 & 0,017 \\
\hline $\mathrm{Zn}$ & 0,000 & 0,000 & 0,004 & 0,000 & 0,005 \\
\hline $\mathrm{Ca}$ & 0,000 & 0,000 & 0,000 & 0,000 & 0,000 \\
\hline $\mathrm{Si}$ & 0,000 & 0,000 & 0,006 & 0,004 & 0,003 \\
\hline Total & 3,119 & 3,012 & 3,118 & 3,123 & 3,070 \\
\hline
\end{tabular}


Sulfuros y Oxihidróxidos

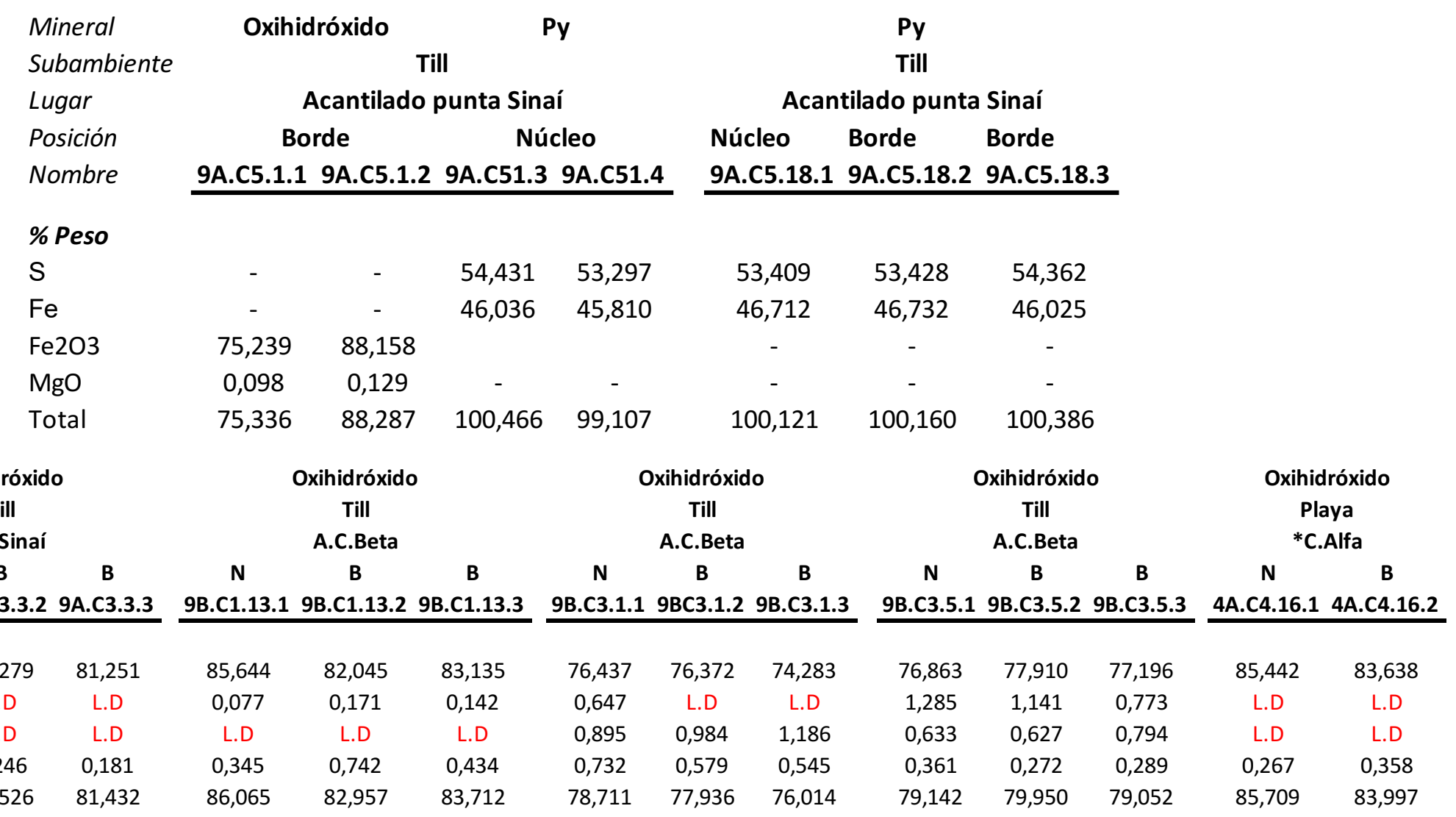

A.40. Análisis con microsonda electrónica efectuados en piritas y oxihidróxidos presentes en las arenas del sedimento glacial (till) y en niveles enriquecidos de la playa. En los oxihidróxidos no se calculó el contenido de agua. *Nivel enriquecido. 
Grupo del epidoto

\begin{tabular}{|c|c|c|c|c|c|c|c|c|c|c|c|c|c|c|c|c|}
\hline Mineral & \multicolumn{2}{|c|}{ Ep } & Ep & \multicolumn{2}{|c|}{ Ep } & \multirow{6}{*}{\begin{tabular}{|c|} 
Ep \\
2 \\
Playa \\
*El Páramo \\
Núcleo \\
BR.64 \\
\end{tabular}} & \multirow{6}{*}{\begin{tabular}{|c|} 
Ep \\
1 \\
Playa \\
*P.Sinaí \\
Núcleo \\
BR.193 \\
\end{tabular}} & \multirow{6}{*}{\begin{tabular}{|c|} 
Ep \\
1 \\
Playa \\
*P.Sinaí \\
Núcleo \\
BR.186 \\
\end{tabular}} & \multirow{6}{*}{\begin{tabular}{|c|} 
Ep \\
1 \\
Playa \\
*C.Beta \\
Núcleo \\
OSD.2b.1.2
\end{tabular}} & \multirow{6}{*}{\begin{tabular}{|c|} 
Ep \\
1 \\
Playa \\
*C.Beta \\
Núcleo \\
OSD.16b.1.13 \\
\end{tabular}} & \multirow{6}{*}{\begin{tabular}{|c|} 
Czo \\
1 \\
Playa \\
${ }^{*}$ C.Beta \\
Núcleo \\
OSD.30b.2.1 \\
\end{tabular}} & \multirow{6}{*}{\begin{tabular}{|c|} 
Czo \\
1 \\
Playa \\
*C.Beta \\
Núcleo \\
OSD.33b.2.4 \\
\end{tabular}} & \multirow{6}{*}{\begin{tabular}{|c|} 
Ep \\
1 \\
Playa \\
*C.Beta \\
Núcleo \\
OSD.51b.2.19 \\
\end{tabular}} & \multirow{6}{*}{\begin{tabular}{|c|} 
Ep \\
1 \\
Playa \\
*C.Tortuga \\
Núcleo \\
OSD.84t.2.2
\end{tabular}} & \multirow{6}{*}{\begin{tabular}{|c|} 
Ep \\
1 \\
Playa \\
*C.Tortuga \\
Núcleo \\
OSD.90t.2.7 \\
\end{tabular}} & \multirow{6}{*}{\begin{tabular}{|c|} 
Ep \\
1 \\
Playa \\
*C.Tortuga \\
Núcleo \\
OSD.91t.2.8 \\
\end{tabular}} \\
\hline № análisis & 1 & 2 & 1 & 1 & 1 & & & & & & & & & & & \\
\hline Subambiente & Til & & Playa & & laya & & & & & & & & & & & \\
\hline Localización & A.P.S & Sinaí & ${ }^{*}$ C.Beta & B.S.Sek & ebastián & & & & & & & & & & & \\
\hline Posición análisis & Núcleo & Borde & Núcleo & Núcleo & Borde & & & & & & & & & & & \\
\hline Nombre & A77 & A79 & OSR3.18 & OSR1.32 & OSR1.33 & & & & & & & & & & & \\
\hline \multicolumn{17}{|l|}{$\% w t$} \\
\hline $\mathrm{SiO}_{2}$ & | 38,195 & 38,062 & 37,015 & 37,258 & 37,132 & 38,100 & 37,240 & 37,300 & 37,352 & 37,679 & 37,626 & 38,982 & 36,819 & 36,774 & 37,361 & 37,643 \\
\hline $\mathrm{TiO}_{2}$ & 0,027 & 0,047 & 0,022 & 0,203 & 0,150 & 0,093 & 0,113 & 0,032 & 0,193 & 0,083 & 0,035 & 0,260 & 0,687 & 0,075 & 0,015 & 0,175 \\
\hline $\mathrm{V}_{2} \mathrm{O}_{3}$ & L.D & L.D & L.D & L.D & L.D & 0,040 & L.D & 0,172 & N.M & N.M & N.M & N.M & N.M & N.M & N.M & N.M \\
\hline $\mathrm{Al}_{2} \mathrm{O}_{3}$ & 24,280 & 23,117 & 24,359 & 21,249 & 21,252 & 24,250 & 24,280 & 23,070 & 23,450 & 22,142 & 25,318 & 21,237 & 20,362 & 23,482 & 22,892 & 24,175 \\
\hline $\mathrm{Cr}_{2} \mathrm{O}_{3}$ & L.D & L.D & L.D & L.D & L.D & L.D & L.D & L.D & L.D & L.D & L.D & L.D & L.D & L.D & L.D & L.D \\
\hline $\mathrm{Fe}_{2} \mathrm{O}_{3}$ & 12,529 & 13,560 & 10,530 & 15,377 & 15,087 & 12,124 & 12,113 & 13,291 & 14,159 & 15,306 & 5,470 & 5,395 & 17,114 & 14,547 & 14,730 & 12,940 \\
\hline MnO & 0,101 & 0,128 & 0,087 & 0,352 & 0,279 & 0,133 & 1,091 & 0,283 & 0,360 & 0,411 & 0,176 & 0,751 & 0,195 & 0,203 & 0,300 & 0,480 \\
\hline MgO & 0,032 & 0,025 & 0,274 & 0,041 & 0,090 & 0,018 & 0,000 & 0,301 & 0,051 & 0,023 & 2,505 & 0,073 & 0,030 & 0,000 & 0,032 & 0,022 \\
\hline $\mathrm{CaO}$ & 23,536 & 23,330 & 23,424 & 22,879 & 22,925 & 23,220 & 21,360 & 21,370 & 23,421 & 22,995 & 23,163 & 34,336 & 23,286 & 23,086 & 22,654 & 23,169 \\
\hline $\mathrm{P}_{2} \mathrm{O}_{5}$ & N.M & N.M & 0,265 & 0,262 & 0,292 & N.M & N.M & N.M & 0,380 & 0,376 & 0,360 & 0,442 & 0,337 & 0,234 & 0,321 & 0,330 \\
\hline Total & 98,700 & 98,270 & 95,977 & 97,620 & 97,206 & 97,978 & 96,197 & 95,819 & 99,366 & 99,015 & 94,653 & 101,476 & 98,830 & 98,401 & 98,305 & 98,934 \\
\hline \multicolumn{17}{|l|}{$\operatorname{APFU}(12,50)$} \\
\hline Si & 3,006 & 3,021 & 2,982 & 3,001 & 3,002 & 3,015 & 3,002 & 3,023 & 2,942 & 2,986 & 3,021 & 3,037 & 2,953 & 2,928 & 2,973 & 2,962 \\
\hline $\mathrm{Ti}$ & 0,002 & 0,003 & 0,001 & 0,012 & 0,009 & 0,006 & 0,007 & 0,002 & 0,011 & 0,005 & 0,002 & 0,015 & 0,041 & 0,004 & 0,001 & 0,010 \\
\hline v & 0,000 & 0,000 & 0,000 & 0,000 & 0,000 & 0,003 & 0,000 & 0,011 & 0,000 & 0,000 & 0,000 & 0,000 & 0,000 & 0,000 & 0,000 & 0,000 \\
\hline Al & 2,252 & 2,162 & 2,313 & 2,017 & 2,025 & 2,262 & 2,307 & 2,204 & 2,177 & 2,068 & 2,396 & 1,950 & 1,925 & 2,203 & 2,147 & 2,242 \\
\hline $\mathrm{Cr}$ & 0,000 & 0,000 & 0,000 & 0,000 & 0,000 & 0,000 & 0,000 & 0,000 & 0,000 & 0,000 & 0,000 & 0,000 & 0,000 & 0,000 & 0,000 & 0,000 \\
\hline $\mathrm{Fe}^{3+}$ & 0,742 & 0,810 & 0,638 & 0,932 & 0,918 & 0,722 & 0,735 & 0,811 & 0,839 & 0,913 & 0,330 & 0,316 & 1,033 & 0,872 & 0,882 & 0,766 \\
\hline$M n$ & 0,007 & 0,009 & 0,006 & 0,024 & 0,019 & 0,009 & 0,075 & 0,019 & 0,024 & 0,028 & 0,012 & 0,050 & 0,013 & 0,014 & 0,020 & 0,032 \\
\hline Mg & 0,004 & 0,003 & 0,033 & 0,005 & 0,011 & 0,002 & 0,000 & 0,036 & 0,006 & 0,003 & 0,300 & 0,008 & 0,004 & 0,000 & 0,004 & 0,003 \\
\hline $\mathrm{Ca}$ & 1,984 & 1,984 & 2,022 & 1,975 & 1,985 & 1,969 & 1,845 & 1,856 & 1,976 & 1,953 & 1,992 & 2,866 & 2,001 & 1,969 & 1,931 & 1,953 \\
\hline $\mathbf{P}$ & 0,000 & 0,000 & 0,018 & 0,018 & 0,020 & 0,000 & 0,000 & 0,000 & 0,025 & 0,025 & 0,024 & 0,029 & 0,023 & 0,016 & 0,022 & 0,022 \\
\hline Suma & 7,996 & 7,991 & 8,014 & 7,985 & 7,988 & 7,986 & 7,970 & 7,962 & 8,001 & 7,980 & 8,077 & 8,271 & 7,993 & 8,006 & 7,979 & 7,991 \\
\hline XEp & 25 & 27 & 22 & 32 & 31 & 24 & 24 & 27 & 28 & 31 & 12 & 14 & 35 & 29 & 29 & 26 \\
\hline
\end{tabular}

A.41.. Análisis con microsonda electrónica efectuados en minerales del grupo del epidoto. Los análisis con nombre OSD fueron realizados por R.G. Acevedo. XEp=Fe ${ }^{3+} /\left(F^{3+}+A l\right)$. $H_{2} O$ no calculado. Todo el Fe se considera como $\mathrm{Fe}^{3+}\left(\mathrm{Fe}_{2} \mathrm{O}_{3}=\mathrm{FeO} \times 1\right.$ 1,113). 
Estaurolita

\begin{tabular}{|c|c|c|c|c|c|c|c|c|c|c|c|c|c|c|}
\hline Análisis & 2 & 2 & 1 & 2 & 1 & 2 & 1 & 1 & 1 & 1 & 1 & 1 & 1 & 1 \\
\hline Subambiente & \multicolumn{2}{|c|}{ Playa } & \multicolumn{2}{|c|}{ Playa } & \multicolumn{2}{|c|}{ Playa } & Playa & Playa & Playa & Playa & Playa & Playa & Playa & Playa \\
\hline Localización & \multicolumn{2}{|c|}{${ }^{*}$ C.Alfa } & \multicolumn{2}{|c|}{ *C.Alfa } & \multicolumn{2}{|c|}{${ }^{*}$ C.Beta } & *P Sinaí & ${ }^{*}$ C.Beta & *C.Tortuga & *C.Tortuga & B.S.Sebastián & B.S.Sebastián & $*$ C.Beta & ${ }^{*}$ C.Beta \\
\hline Posición & $\mathbf{N}$ & B & $\mathbf{N}$ & B & $\mathbf{N}$ & B & $\mathrm{N}$ & $\mathbf{N}$ & $\mathbf{N}$ & $\mathbf{N}$ & $\mathbf{N}$ & $\mathbf{N}$ & $\mathbf{N}$ & $\mathbf{N}$ \\
\hline Nombre & P205 & P206 & P253 & P255 & P326 & P328 & P444 & OSD6* & OSD77* & OSD82* & OSR1.36 & OSR1.37 & OSR3.95 & OSR3.111 \\
\hline
\end{tabular}

\begin{tabular}{|c|c|c|c|c|c|c|c|c|c|c|c|c|c|c|}
\hline \multicolumn{15}{|c|}{$\%$ en peso } \\
\hline $\mathrm{K}_{2} \mathrm{O}$ & L.D & L.D & L.D & L.D & L.D & L.D & L.D & L.D & L.D & L.D & L.D & L.D & L.D & L.D \\
\hline $\mathrm{CaO}$ & L.D & L.D & L.D & L.D & L.D & L.D & L.D & L.D & L.D & L.D & L.D & L.D & L.D & L.D \\
\hline $\mathrm{TiO}_{2}$ & 0,366 & 0,404 & 0,396 & 0,450 & 0,570 & 0,582 & 0,422 & 0,370 & 0,699 & 0,232 & 0,434 & 0,405 & 0,492 & 0,564 \\
\hline $\mathrm{FeO}$ & 13,784 & 14,112 & 14,695 & 14,728 & 13,365 & 13,595 & 13,930 & 14,293 & 13,826 & 14,576 & 14,209 & 14,117 & 13,480 & 14,634 \\
\hline $\mathrm{MnO}$ & 0,557 & 0,627 & 0,378 & 0,492 & 0,427 & 0,450 & 0,425 & 0,527 & 0,613 & 0,505 & 0,568 & 0,489 & 0,404 & 0,311 \\
\hline $\mathrm{Na}_{2} \mathrm{O}$ & L.D & L.D & L.D & L.D & L.D & L.D & L.D & L.D & L.D & L.D & L.D & L.D & L.D & L.D \\
\hline $\mathrm{Cr}_{2} \mathrm{O}_{3}$ & L.D & L.D & L.D & L.D & L.D & L.D & L.D & L.D & 0,085 & L.D & L.D & L.D & L.D & L.D \\
\hline $\mathrm{NiO}$ & L.D & L.D & L.D & L.D & L.D & L.D & L.D & L.D & L.D & L.D & L.D & L.D & L.D & L.D \\
\hline $\mathrm{SiO}_{2}$ & 26,860 & 27,556 & 27,000 & 26,978 & 26,586 & 27,105 & 27,248 & 26,611 & 26,777 & 26,373 & 27,212 & 26,040 & 27,974 & 27,141 \\
\hline $\mathrm{Al}_{2} \mathrm{O}_{3}$ & 54,787 & 54,826 & 54,736 & 54,640 & 54,882 & 54,463 & 54,131 & 56,481 & 55,103 & 56,467 & 54,346 & 56,325 & 53,596 & 53,963 \\
\hline $\mathrm{MgO}$ & 1,208 & 1,178 & 1,331 & 1,300 & 1,765 & 1,811 & 1,490 & 1,398 & 1,496 & 1,114 & 1,793 & 1,652 & 1,811 & 1,269 \\
\hline $\mathrm{V}_{2} \mathrm{O}_{3}$ & L.D & L.D & L.D & L.D & L.D & L.D & L.D & L.D & L.D & L.D & L.D & L.D & L.D & L.D \\
\hline $\mathrm{ZnO}$ & 0,106 & 0,199 & 0,245 & 0,272 & 0,467 & 0,380 & 0,219 & N.M & N.M & N.M & 0,089 & 0,186 & 0,493 & 0,175 \\
\hline Total & 97,667 & 98,903 & 98,779 & 98,860 & 98,062 & 98,386 & 97,865 & 99,680 & 98,599 & 99,267 & 98,651 & 99,214 & 98,249 & 98,057 \\
\hline \multicolumn{15}{|c|}{ Fórmula Estructural en base a 230} \\
\hline Ti & 0,038 & 0,042 & 0,041 & 0,047 & 0,060 & 0,061 & 0,044 & 0,038 & 0,073 & 0,024 & 0,045 & 0,042 & 0,051 & 0,059 \\
\hline $\mathrm{Fe}^{2+}$ & 1,608 & 1,627 & 1,701 & 1,706 & 1,553 & 1,574 & 1,622 & 1,635 & 1,598 & 1,677 & 1,645 & 1,625 & 1,561 & 1,705 \\
\hline $\mathrm{Mn}$ & 0,066 & 0,073 & 0,044 & 0,058 & 0,050 & 0,053 & 0,050 & 0,061 & 0,072 & 0,059 & 0,067 & 0,057 & 0,047 & 0,037 \\
\hline $\mathrm{Cr}$ & 0,000 & 0,000 & 0,000 & 0,000 & 0,000 & 0,000 & 0,000 & 0,000 & 0,009 & 0,000 & 0,000 & 0,000 & 0,000 & 0,000 \\
\hline $\mathrm{Si}$ & 3,746 & 3,798 & 3,738 & 3,736 & 3,693 & 3,753 & 3,793 & 3,641 & 3,700 & 3,628 & 3,766 & 3,585 & 3,873 & 3,782 \\
\hline Al & 9,005 & 8,906 & 8,931 & 8,917 & 8,985 & 8,888 & 8,881 & 9,107 & 8,975 & 9,155 & 8,864 & 9,138 & 8,746 & 8,863 \\
\hline $\mathrm{Mg}$ & 0,251 & 0,242 & 0,275 & 0,268 & 0,365 & 0,374 & 0,309 & 0,285 & 0,308 & 0,228 & 0,370 & 0,339 & 0,374 & 0,264 \\
\hline $\mathrm{Zn}$ & 0,000 & 0,020 & 0,025 & 0,028 & 0,048 & 0,039 & 0,022 & 0,000 & 0,000 & 0,000 & 0,000 & 0,019 & 0,050 & 0,018 \\
\hline Total & 14,713 & 14,707 & 14,755 & 14,759 & 14,755 & 14,742 & 14,722 & 14,768 & 14,735 & 14,771 & 14,757 & 14,805 & 14,703 & 14,728 \\
\hline XMg & 0,14 & 0,13 & 0,14 & 0,14 & 0,19 & 0,19 & 0,16 & 0,15 & 0,16 & 0,12 & 0,18 & 0,17 & 0,19 & 0,13 \\
\hline $\mathrm{XFe}$ & 0,86 & 0,87 & 0,86 & 0,86 & 0,81 & 0,81 & 0,84 & 0,85 & 0,84 & 0,88 & 0,82 & 0,83 & 0,81 & 0,87 \\
\hline
\end{tabular}

A.42. Análisis con microsonda electrónica efectuados en estaurolitas presentes en las arenas de las playas. *Nivel enriquecido. Los análisis OSD77 y OSD82 fueron realizados por R.D. Acevedo. $X M g=M g /(M g+F e), X F e=F e /(F e+M g)$. 
Circón

\begin{tabular}{|c|c|c|c|c|c|c|c|c|c|c|c|c|c|c|c|}
\hline Mineral & \multicolumn{5}{|c|}{ Zrn } & \multicolumn{4}{|c|}{ Zrn } & \multicolumn{3}{|c|}{$\mathrm{Zrn}$} & \multicolumn{3}{|c|}{ Zrn } \\
\hline Nombre & A220 & A221 & A222 & A223 & A224 & A225 & A226 & A227 & A228 & A305 & A306 & A307 & A308 & A309 & A310 \\
\hline Ubicación & $\mathbf{N}$ & Int & Int & Int & B & $\mathbf{N}$ & Int & B & Int & $\mathbf{N}$ & B & Int & $\mathbf{N}$ & B & Int \\
\hline Subambiente & & & Playa & & & & & & & & Playa & & & Playa & \\
\hline Localización & & & ${ }^{*}$ C. Alfa & & & & & & & & ${ }^{*}$ C.Beta & & & ${ }^{*}$ C.Beta & \\
\hline
\end{tabular}

$\%$ Peso

$\mathrm{SiO}_{2}$

$\mathrm{ZrO}_{2}$

$\mathrm{HfO}_{2}$

$\mathrm{P}_{2} \mathrm{O}_{5}$

$\mathrm{ThO}_{2}$

$\mathrm{Nd}_{2} \mathrm{O}_{3}$

$\mathrm{Dy}_{2} \mathrm{O}_{3}$

$\mathrm{Yb}_{2} \mathrm{O}_{3}$

$\mathrm{Er}_{2} \mathrm{O}_{3}$

$\mathrm{Y}_{2} \mathrm{O}_{3}$

Total

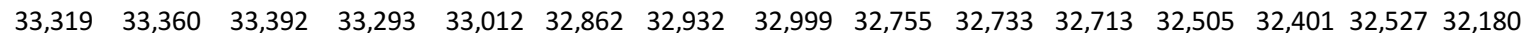
$\begin{array}{lllllllllllllll}64,987 & 65,599 & 65,429 & 65,379 & 64,501 & 64,980 & 65,567 & 65,413 & 65,301 & 66,154 & 65,334 & 66,191 & 65,555 & 64,876 & 65,323\end{array}$ $\begin{array}{lllllllllllllll}1,233 & 1,518 & 1,464 & 1,526 & 1,889 & 1,452 & 1,509 & 1,357 & 1,454 & 1,144 & 1,500 & 1,452 & 1,439 & 1,774 & 1,486\end{array}$ $\begin{array}{lllllllllllllll}0,292 & 0,226 & 0,237 & 0,181 & 0,182 & 0,178 & 0,189 & 0,170 & 0,190 & 0,236 & 0,218 & 0,348 & 0,197 & 0,235 & 0,223\end{array}$

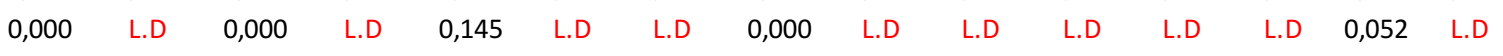

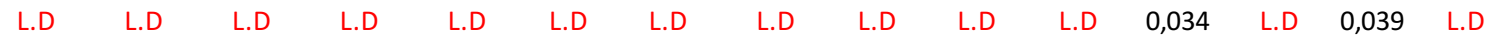
$\begin{array}{lllllllllllllll}\text { L.D } & 0,000 & 0,000 & 0,000 & 0,000 & 0,000 & 0,010 & 0,000 & 0,000 & 0,000 & 0,000 & \text { L.D } & \text { L.D } & 0,000 & \text { L.D }\end{array}$ $\begin{array}{lllllllllllllll}0,054 & \text { L.D } & \text { L.D } & \text { L.D } & 0,067 & 0,000 & \text { L.D } & \text { L.D } & \text { L.D } & \text { L.D } & \text { L.D } & \text { L.D } & 0,000 & \text { L.D } & \text { L.D }\end{array}$

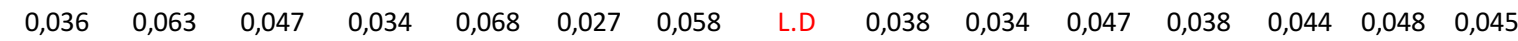

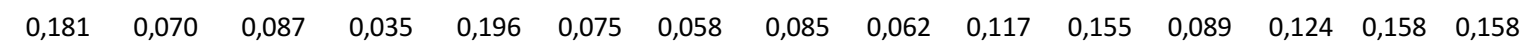

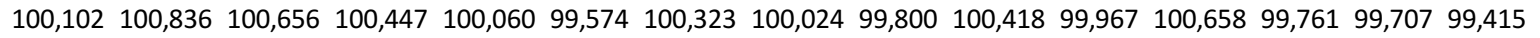

\begin{tabular}{|c|c|c|c|c|c|c|c|c|c|c|c|c|c|c|c|}
\hline & \multicolumn{3}{|c|}{ Zrn } & \multicolumn{3}{|c|}{ Zrn } & \multirow{2}{*}{\begin{tabular}{|c|c} 
Zrn \\
A464 \\
$\mathrm{N}$ \\
Playa \\
*La Espiga
\end{tabular}} & \multirow[b]{2}{*}{\begin{tabular}{|c|} 
Zrn \\
A465 \\
N \\
Playa \\
* La Espiga \\
\end{tabular}} & \multicolumn{3}{|c|}{ Zrn } & \multirow[b]{2}{*}{\begin{tabular}{|c|} 
Zrn \\
A469 \\
$\mathbf{N}$ \\
Playa \\
* La Espiga \\
\end{tabular}} & \multicolumn{2}{|c|}{ Zrn } & \multirow{2}{*}{\begin{tabular}{|c} 
Zrn \\
A472 \\
N \\
Playa \\
*P.Sinaí
\end{tabular}} \\
\hline $\begin{array}{l}\text { Nombre } \\
\text { Ubicación } \\
\text { Subambiente } \\
\text { Localización }\end{array}$ & $\begin{array}{c}\text { A311 } \\
\mathrm{N}\end{array}$ & $\begin{array}{c}\text { A312 } \\
\text { B } \\
\text { Playa } \\
\text { * }^{\text {C.Beta }} \\
\end{array}$ & $\begin{array}{c}\text { A313 } \\
\text { Int }\end{array}$ & $\begin{array}{c}\text { A314 } \\
\text { N }\end{array}$ & $\begin{array}{c}\text { A315 } \\
\text { Int } \\
\text { Playa } \\
{ }^{*} \text { C.Beta } \\
\end{array}$ & $\begin{array}{c}\text { A316 } \\
\text { B }\end{array}$ & & & $\begin{array}{c}\text { A466 } \\
\mathrm{N}\end{array}$ & $\begin{array}{c}\text { A467 } \\
\text { B } \\
\text { Playa } \\
\text { *La Espig } \\
\end{array}$ & $\begin{array}{c}\text { A468 } \\
\text { Int }\end{array}$ & & $\begin{array}{l}\text { A470 } \\
\quad \text { N } \\
\text { Play } \\
{ }^{*} \text { P.Si }\end{array}$ & $\begin{array}{l}\text { A471 } \\
\text { B } \\
\text { yanaí } \\
\end{array}$ & \\
\hline \multicolumn{16}{|l|}{$\%$ Peso } \\
\hline $\mathrm{SiO}_{2}$ & 32,557 & 32,359 & 32,279 & ,043 & & 31,843 & & & 33,012 & 33,066 & 32,780 & & 32,728 & 32,644 & 32,781 \\
\hline $\mathrm{O}_{2}$ & 65,018 & 64,673 & 64,526 & 65,897 & 65,794 & 65,455 & 65,935 & 64,829 & 65,118 & 8 64,625 & 66,019 & 66,074 & 66,219 & 64,860 & 65,304 \\
\hline مी & 819 & 1952 & 1,921 & 918 & & 2.000 & & & 103 & 1645 & 1537 & & 1,345 & 1,658 & 1,379 \\
\hline $\mathrm{O}_{5}$ & 3 & 7 & 02 & 0,250 & & 208 & & $\angle E$ & ,223 & 0,204 & 0,189 & 316 & 0,216 & 0,248 & ,225 \\
\hline 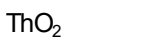 & & 72 & 5 & & 0,05 & & U, & & LD & & L. & & 0,000 & L.D & 0,000 \\
\hline $\mathrm{H}_{2} \mathrm{O}_{3}$ & 0,036 & 1 & D & U & & D & & & 0,047 & & L.D & & 0,039 & L.D &.$D$ \\
\hline $\mathrm{y}_{2} \mathrm{O}_{3}$ & 0 & & 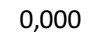 & & & 000 & & 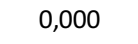 & 1 & 0,000 & 0,000 & & L.D & 0,000 & 0,000 \\
\hline 0 & & & \pm & & & 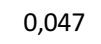 & & & 0,000 & & 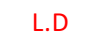 & 37 & L.D & 0,000 & 0,000 \\
\hline $\mathrm{r}_{2} \mathrm{O}_{3}$ & & & 053 & $0,04 J$ & & 0,028 & & & L.U & 0,048 & 0,035 & & 0,044 & 0,038 & L.D \\
\hline 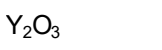 & & 0,120 & 0,222 & 0,118 & 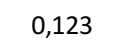 & 0,091 & & & 0,079 & 0,143 & 0,040 & 0,106 & 0,066 & 0,109 & 0,049 \\
\hline tal & 99,819 & 99,417 & 99,349 & 100,270 & 100,197 & 99,672 & 00,690 & 99,948 & 99,581 & 199,729 & 100,600 & 00,670 & 100,657 & 99,556 & 99,737 \\
\hline
\end{tabular}

A.43. Análisis con microsonda electrónica efectuados en circones presentes en las arenas de las playas. *Nivel enriquecido. 


\begin{tabular}{|c|c|c|c|c|c|c|c|c|c|c|c|c|c|}
\hline Mineral & & $2 \mathrm{rn}$ & $\mathrm{z}$ & & Zrn & Zrn & Zrn & Zrn & Zrn & Zrn & Zrn & $\mathrm{Zr}$ & \\
\hline Nombre & ORZ.7 & ORZ.8 & ORZ.46 & ORZ.47 & OSD.100 & OSD.101 & OSD.102 & BR.37 & BR.50 & BR.65 & BR.156 & BR.208 & BR.209 \\
\hline Ubicación & & $\mathbf{N}$ & & $\mathbf{N}$ & $\mathbf{N}$ & $\mathbf{N}$ & $\mathbf{N}$ & Inclusión en Mn-Ilm & $\mathbf{N}$ & & & $\mathbf{N}$ & B \\
\hline Subambiente & & laya & $\mathrm{Pl}_{\mathbf{a}}$ & yу & Playa & Playa & Playa & Playa & Playa & Playa & Playa & Pla & aya \\
\hline Localización & B.S.Se & bastián & El Pá & ramo & *C.Tortuga & *C.Tortuga & *C.Tortuga & *La Espiga & *La Espiga & *La Espiga & *La Espiga & * La E & Espiga \\
\hline$\%$ Peso & & & & & & & & & & & & & \\
\hline $\mathrm{SiO}_{2}$ & 32,340 & 32,480 & 32,810 & 33,051 & 33,270 & 33,506 & 33,251 & 32,370 & 31,800 & 31,870 & 30,070 & 30,650 & 30,920 \\
\hline $\mathrm{ZrO}_{2}$ & 65,652 & 65,972 & 65,254 & 65,171 & 64,585 & 64,829 & 65,532 & 64,820 & 66,540 & 65,780 & 66,120 & 66,880 & 64,930 \\
\hline $\mathrm{HfO}_{2}$ & 1,414 & 1,214 & 1,407 & 1,245 & 1,290 & 1,275 & 1,512 & N.M & N.M & N.M & N.M & N.M & N.M \\
\hline $\mathrm{P}_{2} \mathrm{O}_{5}$ & 0,166 & 0,160 & 0,170 & 0,235 & L.D & L.D & L.D & N.M & N.M & N.M & N.M & N.M & N.M \\
\hline $\mathrm{ThO}_{2}$ & L.D & 0,055 & 0,000 & 0,000 & N.M & N.M & N.M & N.M & N.M & N.M & N.M & N.M & N.M \\
\hline $\mathrm{Nd}_{2} \mathrm{O}_{3}$ & 0,034 & L.D & L.D & L.D & N.M & N.M & N.M & N.M & N.M & N.M & N.M & N.M & N.M \\
\hline $\mathrm{Dy}_{2} \mathrm{O}_{3}$ & 0,000 & 0,000 & 0,000 & 0,000 & N.M & N.M & N.M & N.M & N.M & N.M & N.M & N.M & N.M \\
\hline $\mathrm{Yb}_{2} \mathrm{O}_{3}$ & L.D & 0,000 & 0,000 & 0,000 & N.M & N.M & N.M & N.M & N.M & N.M & N.M & N.M & N.M \\
\hline $\mathrm{Er}_{2} \mathrm{O}_{3}$ & L.D & 0,041 & 0,026 & L.D & N.M & N.M & N.M & N.M & N.M & N.M & N.M & N.M & N.M \\
\hline $\mathrm{Y}_{2} \mathrm{O}_{3}$ & 0,054 & 0,082 & 0,092 & 0,064 & N.M & N.M & N.M & N.M & N.M & N.M & N.M & N.M & N.M \\
\hline Total & 99,660 & 100,004 & 99,759 & 99,767 & 99,145 & 99,610 & 100,295 & 97,190 & 98,340 & 97,650 & 96,190 & 97,530 & 95,850 \\
\hline
\end{tabular}

A.44. Continuación. Los análisis con nombre OSD. 100, 101 y 102 fueron realizados por R.D. Acevedo.

\begin{tabular}{|c|c|c|c|}
\hline Mineral & \multicolumn{3}{|c|}{ Zrn } \\
\hline Nombre & ORZ.77 & ORZ.78 & ORZ.79 \\
\hline Ubicación & Int & $\mathbf{N}$ & B \\
\hline Subambiente & \multicolumn{3}{|c|}{ Plataforma } \\
\hline Localización & \multicolumn{3}{|c|}{ Media } \\
\hline \multicolumn{4}{|l|}{$\%$ Peso } \\
\hline $\mathrm{SiO}_{2}$ & 32,493 & 32,815 & 32,681 \\
\hline $\mathrm{ZrO}_{2}$ & 65,125 & 65,089 & 64,728 \\
\hline $\mathrm{HfO}_{2}$ & 1,322 & 1,252 & 1,519 \\
\hline $\mathrm{P}_{2} \mathrm{O}_{5}$ & 0,146 & 0,201 & 0,190 \\
\hline $\mathrm{ThO}_{2}$ & L.D & 0,053 & 0,045 \\
\hline $\mathrm{Nd}_{2} \mathrm{O}_{3}$ & 0,033 & L.D & 0,035 \\
\hline $\mathrm{Dy}_{2} \mathrm{O}_{3}$ & 0,061 & 0,000 & 0,087 \\
\hline $\mathrm{Yb}_{2} \mathrm{O}_{3}$ & L.D & L.D & 0,000 \\
\hline $\mathrm{Er}_{2} \mathrm{O}_{3}$ & 0,032 & 0,058 & 0,038 \\
\hline $\mathrm{Y}_{2} \mathrm{O}_{3}$ & 0,127 & 0,085 & 0,109 \\
\hline 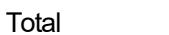 & 99,33 & 99,552 & 99,43 \\
\hline
\end{tabular}

\begin{tabular}{|ccccc|cc|cc|}
\hline \multicolumn{5}{|c|}{ Zrn } & \multicolumn{2}{c|}{ Zrn } & \multicolumn{2}{c|}{ Zrn } \\
A182 & A183 & A184 & A185 & A186 & ORZ.71 & ORZ.72 & OSR2.27 & OSR2.28 \\
N & Int & Int & Int & B & B & N & N & B \\
& & Till & & & Glacifluvial & Glacifluvial \\
& \multicolumn{3}{|c}{ A.C.Beta } & & & A.C.Tortuga & A.C.Tortuga \\
\hline
\end{tabular}

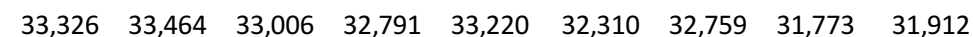

$\begin{array}{llllllllll}65,147 & 65,274 & 65,600 & 65,772 & 64,680 & 64,763 & 64,495 & 64,514 & 64,235\end{array}$

$\begin{array}{llllllllll}1,332 & 1,385 & 1,472 & 1,332 & 2,006 & 1,542 & 1,730 & \text { N.M } & \text { N.M }\end{array}$

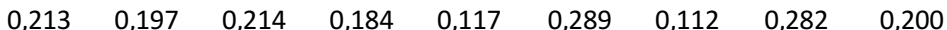

$\begin{array}{lllllllll}0,000 & 0,000 & 0,000 & 0,000 & \text { L.D } & \text { L.D } & \text { L.D } & \text { N.M } & \text { N.M }\end{array}$

$\begin{array}{lllllllllll}0,034 & \text { L.D } & 0,047 & \text { L.D } & 0,032 & \text { L.D } & \text { L.D } & \text { N.M } & \text { N.M }\end{array}$

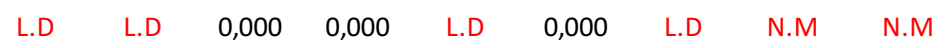

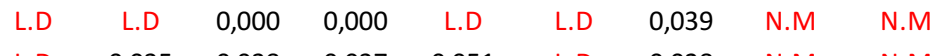

$\begin{array}{llllllllllll}0,035 & 0,038 & 0,037 & 0,051 & \text { L.D } & 0,028 & \text { N.M } & \text { N.M }\end{array}$

$\begin{array}{lllllllll}0,094 & 0,100 & 0,027 & 0,045 & 0,124 & 0,000 & 0,083 & \text { N.M } & \text { N.M }\end{array}$

$100,146 \quad 100,454 \quad 100,404 \quad 100,160 \quad 100,229 \quad 98,905 \quad 99,246 \quad 96,569 \quad 96,346$

A.45. Análisis realizados en circones de los sedimentos de la cubierta superficial de la Plataforma Continental media y en los depósitos glacigénicos continentales. 
Grupo del oro

\begin{tabular}{|c|c|c|c|c|c|c|c|c|c|c|c|c|c|}
\hline Nombre & Loc. & $\mathrm{Cu}$ & $\mathrm{Ag}$ & $\mathrm{Au}$ & $\mathrm{Hg}$ & $\mathrm{Fe}$ & $\mathrm{Bi}$ & $\mathrm{Pt}$ & Total & Posición & Pureza & Obs. & $\mathrm{N}^{\circ}$ análisis \\
\hline OAU.3 & \multirow{2}{*}{ Cñd.Alfa } & 0,017 & 27,254 & 72,738 & 0,000 & - & - & - & 100,008 & $\mathrm{~N}$ & 727 & \multirow{2}{*}{ Z } & 2 \\
\hline OAU.4 & & 0,027 & 24,724 & 74,411 & 0,000 & - & - & - & 99,162 & $\mathrm{~B}, \mathrm{Au}$ & 751 & & 1 \\
\hline OAU.9 & \multirow{2}{*}{ Cñd.Alfa } & 0,027 & 8,513 & 90,942 & 0,000 & - & - & - & 99,482 & $\mathrm{~N}$ & 914 & \multirow{2}{*}{ Z } & 3 \\
\hline OAU.10 & & 0,013 & 1,885 & 97,976 & 0,000 & - & - & - & 99,874 & $\mathrm{~B}, \mathrm{Au}$ & 981 & & 1 \\
\hline OAU.12 & \multirow{2}{*}{ Cñd.Alfa } & 0,017 & 0,211 & 99,737 & 0,000 & - & - & - & 99,965 & $\mathrm{~N}$ & 998 & \multirow{2}{*}{$\mathrm{H}$} & 1 \\
\hline OAU.13 & & 0,035 & 0,878 & 99,344 & 0,000 & - & - & - & 100,257 & B & 991 & & 2 \\
\hline OAU.17 & \multirow{2}{*}{ Cñd.Alfa } & 0,013 & 13,079 & 87,189 & 0,000 & - & - & - & 100,281 & $\mathrm{~N}$ & 870 & \multirow{2}{*}{ Z } & 3 \\
\hline OAU.18 & & 0,010 & 1,825 & 97,794 & 0,000 & - & - & - & 99,629 & $\mathrm{~B}, \mathrm{Au}$ & 982 & & 1 \\
\hline OAU.20 & \multirow{2}{*}{ Cñd.Alfa } & 0,016 & 15,630 & 83,907 & 0,000 & - & - & - & 99,553 & $\mathrm{~N}$ & 843 & \multirow{2}{*}{$\mathrm{H}$} & 1 \\
\hline OAU.21 & & 0,009 & 15,568 & 84,419 & 0,000 & - & - & - & 99,996 & $\mathrm{~B}$ & 844 & & 2 \\
\hline OAU.24 & \multirow{2}{*}{ Cñd.Alfa } & 0,012 & 28,112 & 71,360 & 0,000 & - & - & - & 99,484 & $\mathrm{~N}$ & 717 & \multirow{2}{*}{ z } & 2 \\
\hline OAU.25 & & 0,001 & 1,923 & 97,768 & 0,000 & - & - & - & 99,692 & $\mathrm{~B}, \mathrm{Au}$ & 981 & & 2 \\
\hline OAU.26 & \multirow{2}{*}{ Cñd.Alfa } & 0,026 & 18,971 & 80,903 & 0,000 & - & - & - & 99,900 & $\mathrm{~N}$ & 810 & \multirow{2}{*}{$\mathrm{H}$} & 1 \\
\hline OAU.27 & & 0,019 & 18,540 & 81,598 & 0,000 & - & - & - & 100,156 & $\mathrm{~B}$ & 815 & & 1 \\
\hline OAU.28 & \multirow{2}{*}{ Cñd.Alfa } & 0,020 & 0,076 & 100,830 & 0,000 & - & - & - & 100,926 & $\mathrm{~N}$ & 999 & \multirow{2}{*}{$\mathrm{H}$} & 1 \\
\hline OAU.29 & & 0,017 & 0,470 & 99,094 & 0,000 & - & - & - & 99,581 & B & 995 & & 1 \\
\hline OAU. 30 & Cñd.Alfa & 0,076 & 8,194 & 91,103 & 0,000 & - & - & - & 99,373 & $\mathrm{~N}$ & 917 & $\mathrm{H}$, Incl. Bi & 1 \\
\hline OAU.31 & Cñd lffa & 0,006 & 12,449 & 86,747 & 0,000 & - & - & - & 99,203 & $\mathrm{~N}$ & 874 & $\mathrm{H}$ & 1 \\
\hline OAU.32 & Cna.Alld & 0,011 & 13,063 & 85,986 & 0,000 & - & - & - & 99,059 & B & 868 & $\mathrm{H}$ & 1 \\
\hline OAU.39 & & 0,007 & 22,196 & 77,784 & 0,000 & - & - & - & 99,987 & $\mathrm{~N}$ & 778 & & 6 \\
\hline OAU.40 & El Páramo & 0,000 & 1,474 & 98,575 & 0,000 & - & - & - & 100,050 & $\mathrm{~B}, \mathrm{Au}$ & 985 & Z & 2 \\
\hline OAU.44 & Fl Páramo & 0,007 & 15,951 & 84,293 & 0,000 & - & - & - & 100,251 & $\mathrm{~N}$ & 841 & 7 & 4 \\
\hline OAU.45 & El Paramo & 0,018 & 0,544 & 100,398 & 0,000 & - & - & - & 100,960 & $\mathrm{~B}, \mathrm{Au}$ & 995 & 2 & 1 \\
\hline OAU.48 & El Páramo & 0,002 & 21,773 & 77,434 & 0,000 & - & - & - & 99,209 & $\mathrm{~N}$ & 781 & 7 & 1 \\
\hline OAU.47 & El Paramo & 0,002 & 1,503 & 97,958 & 0,000 & - & - & - & 99,463 & $\mathrm{~B}, \mathrm{Au}$ & 985 & 2 & 1 \\
\hline OAU.52 & & 0,005 & 30,637 & 69,191 & 0,000 & - & - & - & 99,833 & $\mathrm{~N}$ & 693 & $\mathrm{H}$ & 4 \\
\hline OAU. 53 & El Pàramo & 0,008 & 29,755 & 69,465 & 0,000 & - & - & - & 99,228 & $\mathrm{~B}$ & 700 & $\mathrm{H}$ & 1 \\
\hline OAU.55 & El Páramo & 0,030 & 7,106 & 93,153 & 0,000 & - & - & - & 100,288 & $\mathrm{~N}$ & 929 & $\mathrm{H}$ & 2 \\
\hline OAU.56 & EI Paramo & 0,048 & 6,993 & 92,473 & 0,000 & - & - & - & 99,513 & B & 930 & $\mathrm{H}$ & 1 \\
\hline OAU.59 & & 0,003 & 41,903 & 57,144 & 0,000 & - & - & - & 99,050 & $\mathrm{~N}$ & 577 & 7 & 3 \\
\hline OAU.60 & El Páramo & 0,005 & 26,780 & 72,412 & 0,000 & - & - & - & 99,197 & $\mathrm{~B}, \mathrm{Au}$ & 730 & 2 & 1 \\
\hline OAU.64 & Fl Páramo & 0,012 & 12,833 & 86,391 & 0,000 & - & - & - & 99,236 & $\mathrm{~N}$ & 871 & 7 & 2 \\
\hline OAU.65 & El Paramo & 0,007 & 0,801 & 98,747 & 0,000 & - & - & - & 99,555 & $\mathrm{~B}, \mathrm{Au}$ & 992 & 2 & 1 \\
\hline OAU.67 & El Páramo & 0,013 & 28,028 & 71,684 & 0,000 & - & - & - & 99,725 & $\mathrm{~N}$ & 719 & $\mathrm{H}$ & 2 \\
\hline OAU.68 & El Paramo & 0,005 & 28,836 & 70,882 & 0,000 & - & - & - & 99,723 & $\mathrm{~B}$ & 711 & $\mathrm{H}$ & 1 \\
\hline OAU.70 & Fl Dóramo & 0,057 & 9,844 & 89,973 & 0,000 & - & - & - & 99,875 & $\mathrm{~N}$ & 901 & & 2 \\
\hline OAU.71 & El Páramo & 0,048 & 9,995 & 89,067 & 0,000 & - & - & - & 99,110 & $\mathrm{~B}$ & 899 & $\mathrm{H}$ & 1 \\
\hline OAU.76 & Cñd Reta & 0,010 & 23,975 & 75,641 & 0,000 & - & - & - & 99,627 & $\mathrm{~N}$ & 759 & $\mathrm{H}$ & 4 \\
\hline OAU.77 & Cna. Beta & 0,009 & 23,820 & 76,094 & 0,000 & - & - & - & 99,922 & B & 762 & $\mathrm{H}$ & 2 \\
\hline OAU.79 & Cñd Reta & 0,004 & 16,445 & 83,426 & 0,000 & - & - & - & 99,875 & $\mathrm{~N}$ & 835 & & 1 \\
\hline OAU.80 & Cna. Beta & 0,014 & 12,407 & 87,953 & 0,000 & - & - & - & 100,374 & $\mathrm{~B}, \mathrm{Au}$ & 876 & Z & 2 \\
\hline OAU. 82 & & 0,022 & 14,719 & 85,555 & 0,000 & - & - & - & 100,296 & $\mathrm{~N}$ & 853 & 7 & 1 \\
\hline OAU.83 & Cñd. Beta & 0,007 & 1,041 & 99,262 & 0,000 & - & - & - & 100,310 & $\mathrm{~B}, \mathrm{Au}$ & 990 & 2 & 2 \\
\hline OAU.85 & Cñd Reta & 0,025 & 0,529 & 99,741 & 0,000 & - & - & - & 100,295 & $\mathrm{~N}$ & 995 & 7 & 2 \\
\hline OAU.86 & $\mathrm{Cr}$ & 0,059 & 6,043 & 93,283 & 0,000 & - & - & - & 99,385 & $\mathrm{~B}, \mathrm{Ag}$ & 939 & 2 & 1 \\
\hline OAU.89 & 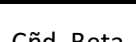 & 0,005 & 19,377 & 81,380 & 0,000 & - & - & - & 100,762 & $\mathrm{~N}$ & 808 & & 2 \\
\hline OAU.90 & Cñd. Beta & 0,007 & 19,368 & 81,340 & 0,000 & - & - & - & 100,715 & B & 808 & $\mathrm{H}$ & 1 \\
\hline OAU.92 & Cñd Beta & 0,005 & 27,635 & 71,406 & 0,000 & - & - & - & 99,046 & $\mathrm{~N}$ & 721 & $\mathrm{H}$ & 1 \\
\hline OAU.93 & Cna. Beta & 0,003 & 27,338 & 72,946 & 0,000 & - & - & - & 100,286 & B & 727 & $\mathrm{H}$ & 2 \\
\hline OAU.96 & & 0,007 & 3,563 & 96,370 & 0,000 & - & - & - & 99,939 & $\mathrm{~N}$ & 964 & & 1 \\
\hline OAU.97 & Cñd. Beta & 0,010 & 4,544 & 94,955 & 0,000 & - & - & - & 99,509 & $\mathrm{~B}, \mathrm{Ag}$ & 954 & Z & 1 \\
\hline OAU.98 & & 0,019 & 2,100 & 97,468 & 0,000 & - & - & - & 99,586 & $\mathrm{~B}, \mathrm{Au}$ & 979 & & 1 \\
\hline
\end{tabular}

A.46. Promedios de los análisis realizados mediante microsonda electrónica en los granos de Au. Pureza, $A u^{*} 1000 /(A u+A g)$. Abreviaturas: $N$, núcleo; B, borde; Z zonados; H, homogéneo; Incl, inclusión 


\begin{tabular}{|c|c|c|c|c|c|c|c|c|c|c|c|c|c|}
\hline $\begin{array}{l}\text { OAU.100 } \\
\text { OAU.101 }\end{array}$ & Cñd. Beta & $\begin{array}{l}0,005 \\
0,016\end{array}$ & $\begin{array}{c}14,209 \\
0,345\end{array}$ & $\begin{array}{c}85,127 \\
100,511\end{array}$ & $\begin{array}{l}0,000 \\
0,000\end{array}$ & - & - & - & $\begin{array}{c}99,341 \\
100,872\end{array}$ & $\begin{array}{c}\mathrm{N} \\
\mathrm{B}, \mathrm{Au}\end{array}$ & $\begin{array}{l}857 \\
997\end{array}$ & Z & $\begin{array}{l}1 \\
1\end{array}$ \\
\hline OAU.103 & ta & 0,013 & 17,817 & 78,810 & 0,000 & - & - & - & 96,640 & $\mathrm{~N}$ & 816 & $\mathrm{H}$ & 1 \\
\hline OAU.104 & ta & 0,008 & 18,390 & 80,821 & 0,000 & - & - & - & 99,219 & B & 815 & $\mathrm{H}$ & 2 \\
\hline OAU.106 & & 0,018 & 0,095 & 99,436 & 0,000 & - & - & - & 99,549 & $\mathrm{~N}$ & 999 & 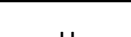 & 1 \\
\hline OAU.107 & Cnd. & 0,009 & 0,074 & 99,723 & 0,000 & - & - & - & 99,806 & $\mathrm{~B}$ & 999 & $\mathrm{H}$ & 2 \\
\hline OAU.110 & Cñd Ret? & 0,008 & 20,911 & 79,068 & 0,000 & - & - & - & 99,988 & $\mathrm{~N}$ & 791 & $H$ & 2 \\
\hline OAU.111 & & 0,008 & 20,980 & 79,927 & 0,000 & - & - & - & 100,915 & $\mathrm{~B}$ & 792 & $\mathrm{H}$ & 2 \\
\hline OAU.114 & & 0,003 & 31,255 & 69,615 & 0,000 & - & - & - & 100,873 & $\mathrm{~N}$ & 690 & 7 & 2 \\
\hline OAU.115 & El Páramo & 0,000 & 36,062 & 63,044 & 0,000 & - & - & - & 99,105 & $\mathrm{~B}, \mathrm{Ag}$ & 636 & $\angle$ & 1 \\
\hline OAU.117 & $1 P_{2}-2$ & 0,070 & 5,535 & 93,879 & 0,000 & - & - & - & 99,484 & $\mathrm{~N}$ & 944 & $\mathrm{H}$ & 2 \\
\hline OAU.118 & EI Paramo & 0,079 & 5,515 & 94,315 & 0,000 & - & - & - & 99,909 & B & 945 & $\mathrm{H}$ & 1 \\
\hline OAU.121 & & 0,015 & 4,960 & 94,667 & 0,000 & - & - & - & 99,642 & $\mathrm{~N}$ & 950 & & 1 \\
\hline OAU.122 & Páramo & 0,029 & 4,809 & 95,112 & 0,000 & - & - & - & 99,950 & B & 952 & $\mathrm{H}$ & 2 \\
\hline OAU.124 & Fl Páramo & 0,019 & 8,318 & 90,919 & 0,000 & - & - & - & 99,256 & $\mathrm{~N}$ & 916 & $H$ & 1 \\
\hline OAU.125 & El Paramo & 0,013 & 8,217 & 91,509 & 0,000 & - & - & - & 99,738 & B & 918 & $\mathrm{H}$ & 2 \\
\hline OAU.127 & $\Gamma \tilde{n} \gamma_{\lambda}$ & 0,013 & 18,658 & 82,012 & 0,000 & - & - & - & 100,684 & $\mathrm{~N}$ & 815 & $H$ & 1 \\
\hline OAU.128 & $c$ & 0,018 & 18,742 & 80,560 & 0,000 & - & - & - & 99,320 & B & 811 & $\mathrm{H}$ & 2 \\
\hline BAu.17.1 & & 0,002 & 0,394 & 98,113 & 0,067 & 0,003 & 0,000 & - & 98,580 & $\mathrm{~N}$ & 996 & & 13 \\
\hline BAu.17.2 & Alfa & 0,005 & 0,218 & 97,005 & 0,144 & 0,010 & 0,000 & - & 97,382 & B & 998 & $H$ & 2 \\
\hline BAu.30.1 & & 0,035 & 5,078 & 92,404 & 0,516 & 0,003 & 0,072 & - & 98,107 & $\mathrm{~N}$ & 948 & 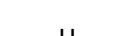 & 5 \\
\hline BAu. 30.2 & Alfa & 0,029 & 4,940 & 92,475 & 0,473 & 0,006 & 0,000 & - & 97,922 & B & 949 & $\mathrm{H}$ & 4 \\
\hline BAu.45.1 & Ifa & 0,051 & 11,586 & 86,383 & 0,095 & 0,003 & 0,000 & - & 98,118 & $\mathrm{~N}$ & 882 & $\mathrm{H}$ & 7 \\
\hline BAu. 45.2 & (T⿰亻 & 0,039 & 11,775 & 85,340 & 0,057 & 0,007 & 0,187 & - & 97,405 & B & 879 & $\mathrm{H}$ & 4 \\
\hline BAu. 65.1 & & 0,023 & 16,856 & 81,442 & 0,111 & 0,004 & 0,000 & - & 98,435 & $\mathrm{~N}$ & 829 & & 14 \\
\hline BAu. 65.2 & Páramo & 0,013 & 16,957 & 81,223 & 0,103 & 0,001 & 0,134 & - & 98,431 & $\mathrm{~B}$ & 827 & $\mathrm{H}$ & 3 \\
\hline BAu. 82.1 & & 0,012 & 15,488 & 82,766 & 0,159 & 0,005 & 0,000 & - & 98,430 & $\mathrm{~N}$ & 842 & 7 & 8 \\
\hline BAu. 82.2 & 10 & 0,006 & 5,520 & 92,235 & 0,031 & 0,049 & 0,000 & - & 97,841 & $\mathrm{~B}, \mathrm{Au}$ & 944 & 2 & 2 \\
\hline BAu.103.1 & & 0,020 & 15,714 & 81,897 & 0,289 & 0,008 & 0,175 & - & 98,103 & $\mathrm{~N}$ & 839 & & 13 \\
\hline BAu.103.2 & El Páramo & 0,005 & 5,405 & 86,263 & 3,488 & 0,066 & 0,000 & - & 95,226 & $\mathrm{~B}, \mathrm{Au}$ & 941 & Z & 4 \\
\hline BAu.103.3 & & 0,000 & 18,540 & 76,850 & 1,610 & 0,080 & 0,341 & - & 97,421 & $\mathrm{~B}, \mathrm{Ag}$ & 806 & & 1 \\
\hline BAu.118.1 & Páramo & 0,020 & 6,496 & 91,414 & 0,084 & 0,000 & 0,000 & - & 98,015 & $\mathrm{~N}$ & 934 & & 9 \\
\hline BAu.118.2 & Páramo & 0,003 & 6,380 & 91,665 & 0,032 & 0,000 & 0,000 & - & 98,081 & $\mathrm{~B}$ & 935 & $\mathrm{Bi}$ & 2 \\
\hline BAu.129.1 & & 0,008 & 3,709 & 94,007 & 0,080 & 0,005 & 0,000 & - & 97,808 & $\mathrm{~N}$ & 962 & & 7 \\
\hline BAu.129.2 & aramo & 0,016 & 2,410 & 95,290 & 0,132 & 0,016 & 0,000 & - & 97,864 & $\mathrm{~B}, \mathrm{Au}$ & 975 & L & 2 \\
\hline BAu.137.1 & El Páramo & 0,050 & 1,943 & 95,503 & 0,187 & 0,003 & 0,170 & - & 97,856 & $\mathrm{~N}$ & 980 & t & 3 \\
\hline BAu.137.2 & & 0,030 & 1,870 & 95,710 & 0,189 & 0,000 & 0,000 & - & 97,798 & B & 981 & $\mathrm{H}$ & 1 \\
\hline OAuD.1 & Cñd. Beta & 0,037 & 24,298 & 75,612 & 0,000 & 0,005 & 0,512 & 0,000 & 100,464 & $\mathrm{~N}$ & 757 & $\mathrm{H}$ & 1 \\
\hline OAuD. 3 & Cñd. Beta & 0,140 & 12,531 & 87,386 & 0,000 & 0,005 & 0,591 & 0,002 & 101,418 & $\mathrm{~N}$ & 875 & $\mathrm{H}$ & 3 \\
\hline OAuD. 6 & Cñd. Beta & 0,328 & 9,112 & 91,170 & 0,000 & 0,005 & 0,616 & 0,000 & 101,232 & $\mathrm{~N}$ & 909 & $\mathrm{H}$ & 2 \\
\hline OAuD.8 & Cñd. Tortuga & 0,124 & 12,384 & 88,657 & 0,000 & 0,004 & 0,609 & 0,003 & 101,780 & $\mathrm{~N}$ & 877 & $\mathrm{H}$ & 2 \\
\hline OAuD.10 & Cñd. Tortuga & 0,164 & 2,748 & 97,160 & 0,000 & 0,003 & 0,672 & 0,000 & 100,747 & $\mathrm{~N}$ & 972 & $\mathrm{H}$ & 2 \\
\hline
\end{tabular}

A.47. Continuación. 